\author{
European Languages and Studies (Italian Studies) \\ School of Humanities \\ University of Western Australia \\ 2011
}

\title{
Catholic Women's Movements in Liberal and Fascist Italy
}

This thesis is presented in fulfilment of the requirements for the degree of

Doctor of Philosophy of the University of Western Australia.

Helena Aulikki Dawes BA (Hons) ANU, MA Monash, BEc UWA,

GradDipA (Adv) UWA 


\section{CONTENTS}

$\begin{array}{lll}\text { Abbreviations } & \text { ii }\end{array}$

Note on Citations $\quad$ iii

Preface $\quad$ iv

$\begin{array}{lr}\text { Introduction } & 1\end{array}$

$\begin{array}{lll}\text { Chapter One } & \text { The Italian State, the Catholic Church and Women } & 7\end{array}$

Chapter Two The Cultural, Political and Ideological Context

of femminismo cristiano 56

$\begin{array}{lll}\text { Chapter Three } & \text { Femminismo cristiano } & 88\end{array}$

Chapter Four $\quad$ Elisa Salerno’s Contribution to femminismo cristiano 174

Chapter Five $\quad$ The Conservative Catholic Women’s Movements $\quad 237$

$\begin{array}{ll}\text { Conclusion } & 333\end{array}$

$\begin{array}{ll}\text { Bibliography } & 337\end{array}$ 


\section{ABBREVIATIONS}

ACV

AEP

AGOP

ARM

$\mathrm{BCB}$

FAC

FES
Archivi ecclesiastici della diocesi (Curia vescovile),

Vicenza

Archivio Elena da Persico (Fondazione Elena da Persico), Affi, Verona

Fondo Giustiniani Bandini (Archivum generale Ordinis praedicatorum), Rome

Archivio Romolo Murri (Fondazione Romolo Murri), Urbino

Biblioteca civica bertoliana, Vicenza

Fondo Adelaide Coari (Fondazione per le scienze religiose Giovanni XXIII), Bologna

Fondo Elisa Salerno (Centro documentazione e studi "Presenza Donna”), Vicenza 


\section{NOTE ON CITATIONS}

All citations are presented respecting the original spelling, accentuation, capitalization, punctuation and typefaces. Occasionally changes have been made to paragraphing. 


\section{PREFACE}

The writing of this thesis has depended on access to published documents and archival material in Italy and Australia. I have been able to rely on the excellent interlibrary loans and reader services of the Reid Library of the University of Western Australia, and I am most grateful to its staff for the assistance and courtesy they have shown to me. I would also like to express my gratitude to the various libraries, archives and research centres in Italy which have permitted me to access their facilities and resources during my visits. They include: Biblioteca nazionale centrale, Florence; Fondo Adelaide Coari (Fondazione per le scienze religiose Giovanni XXIII), Bologna; Biblioteca “Giuseppe Dossetti”, Bologna; Biblioteca delle donne italiane, Bologna; Biblioteca nazionale braidense, Milan; Biblioteca ambrosiana, Milan; Biblioteca dell’Università cattolica del Sacro Cuore, Milan; Biblioteca dell’Università degli studi di Milano, Milan; Centro documentazione dell’Unione femminile nazionale, Milan; Fondazione Romolo Murri, Urbino; Centro studi Romolo Murri, Gualdo, Macerata; Centro documentazione e studi "Presenza Donna”, Vicenza; Archivi ecclesiastici della diocesi, Vicenza; Biblioteca civica bertoliana, Vicenza; Fondazione Elena da Persico, Affi, Verona; Biblioteca comunale, Verona; Biblioteca nazionale centrale, Rome; Istituto per la storia dell'Azione cattolica e del movimento cattolico in Italia Paolo VI, Rome; Fondo Cristina Giustiniani Bandini (Archivum generale Ordinis praedicatorum), Rome; and Istituto Luigi Sturzo, Rome.

In conducting my research I have received support and useful advice from a number of scholars, academics, librarians and archivists, many of whom are associated with the above-listed institutions. To some of them I am particularly indebted. On my visits to Bologna I was fortunate to meet Professor Gabriella Zarri whom I thank for kindly drawing my attention to various publications related to my research topic. I would also like to express my gratitude to Dr. Fabio Nardelli of the Istituto delle scienze religiose for enabling me to consult the resources of the Fondo Adelaide Coari. My research was significantly facilitated by access to the early issues of L'Azione muliebre at Villa Elena at Affi, Verona, and I would like to thank Signora Mariuccia Besesti for her courteous hospitality and Professor Dora Castenetto for her generous gift of books. 
Many scholars have also given me assistance in relation to my studies on Romolo Murri. In particular I would like to thank Professor Alfonso Botti and Dr. Ilaria Biagioli for access to the manuscript holdings of the Fondazione Romolo Murri, Urbino, and Professor Anna Maria Massucci for access to the Centro studi Romolo Murri, Gualdo. I also wish to thank Professor Rocco Cerrato and Dr. Fabrizio Chiappetti for sharing with me their expert knowledge in this subject area. Discussions with Dr. Roberta Fossati in Milan have been invaluable for my attempts to grasp the complex phenomenon of femminismo cristiano, and I would like to express to her my sincere thanks for the interest she has shown in my work and for the historical material which she has kindly donated to me. I am grateful to Dr. Eleonora Cirant for access to the resources of the Centro documentazione dell'Unione femminile nazionale and for providing me with precious material on the Unione femminile and on early Italian feminist movements.

My research on Elisa Salerno would not have been possible without the help which I have received from the members of the Centro documentazione e studi "Presenza Donna”, through consultation of their archives, gifts of their publications, and invitations to their functions. My special thanks go to Suor Maria Grazia Piazza for her continuous support. I acknowledge with gratitude Monsignor Antonio Marangoni’s permission to access the Archivi ecclesiastici della diocesi in Vicenza. I also wish to thank Dr. Sonia Residori and Dr. Silvia Calamati for facilitating my perusal of early periodical publications in the Biblioteca civica bertoliana in Vicenza.

Consultation of the Archives of the Istituto Paolo VI of Azione cattolica in Rome has been essential for my study of the Unione donne and of the Gioventù femminile. I am grateful to Professor Cecilia Dau Novelli for facilitating my access to the Archives. I would also like to thank Dr. Simona Ferrantin for permitting me to use the resources of the Istituto Paolo VI and Mr. Alessandro Romano for ensuring that all my requests were fulfilled. I wish to express my gratitude to Fr. Wilmer Rojas Crespo, O.P., for providing me with copies of letters and other documents held in the Fondo Giustiniani Bandini, and to Dr. Concetta Argiolas for allowing me to consult the Archivio Luigi Sturzo.

Parts of Chapter Three of the thesis have been accepted for publication in The Catholic Historical Review. I greatly appreciate the practical advice I received from Dr. Nelson $\mathrm{H}$. Minnich in preparing the manuscript for publication. 
In particular I would like to thank my supervisor, Professor Lorenzo Polizzotto, for his enduring support during the writing of the thesis, first in the selection of the topic and then in the provision of meticulous feedback on the individual chapters as they evolved. While I appreciate the freedom he has given me to develop the topic according to my own perception of the subject matter, I also acknowledge his generosity in allowing me to draw, as often has been the case, on his vast knowledge of Italian history and culture.

Finally, the thesis would not have been finished without the constant encouragement of my husband, Walter Dawes, whose good-humoured and intelligent criticism has at times helped me to look at my writing from a different perspective. His patience has been tested innumerable times by proof-reading the thesis in its different versions. 


\section{INTRODUCTION}

In the early 1900s Italy was a battlefield of diverse intellectual, cultural and political forces with different ideologies competing for hegemony. For the first time in its history the Catholic Church appealed directly to women, asking for their help in reinforcing Catholic values in society. As a result, various Catholic women's associations came into being with the aim of assisting the Church in its mission by disseminating religious propaganda and alleviating serious social problems. By this time Italy had already seen the emergence of the first secular feminist movements which had their origins in the Enlightenment, the French Revolution, the intellectual currents of the nineteenth century and socialist doctrine. Two important national feminist organizations, the Consiglio nazionale delle donne italiane and the Unione femminile nazionale, had come into existence in 1899, with the objective of pursuing philanthropic and women's rights issues.

Little is known outside Italy of the rise and development of Italian women's movements, either Catholic or secular. Yet Italy was in the forefront of writing on women's issues. In fact, John Stuart Mill's seminal treatise, The Subjection of Women (1869), was preceded by two Italian publications on the woman question. The first, Woman and Science (1861), was written by the Neapolitan politician Salvatore Morelli (1824-1880), ${ }^{1}$ while the author of the second, Woman and Her Social Relationships (1864), was a young Lombard woman Anna Maria Mozzoni (1837-1920). ${ }^{2}$ Published in Italian, these books failed to gain attention abroad. Nevertheless, in their own country, not only Mozzoni but several other middle-class women became famous - or infamous - for their feminist demands and campaigns. This group of pioneers includes Maria Montessori (1870-1952) who is better remembered for her achievements as an educator, as well as the dazzling and flamboyant Sibilla Aleramo (1876-1960) who, for her part, embraced feminism not only in her writings but also in her personal life, being the quintessential embodiment of the adventurous and self-reliant donna nuova. Another notable figure was the colourful and fascinating Russian-born socialist Anna Kuliscioff (1854-1925) who through her intellect and personal charisma left an indelible

\footnotetext{
${ }^{1}$ Salvatore Morelli, La donna e la scienza considerate come soli mezzi atti a risolvere il problema dell'avvenire, Napoli, Stab. Tip. delle Belle Arti, 1861.

${ }^{2}$ Anna Maria Mozzoni, La donna e i suoi rapporti sociali, Milano, Tipografia Sociale, 1864.
} 
mark on early Italian feminism. Many others made a reputation as indefatigable fighters for women’s suffrage; among them Ersilia Majno Bronzini (1859-1933), also known as manager of a rehabilitation home for "fallen" girls and for girls "at risk", Asilo Mariuccia, which was the first of its kind in Europe. ${ }^{3}$

While secular women's movements are widely known, women's organizations within the Catholic system in Italy during the Liberal and Fascist periods require further attention. In this field, too, one comes across women of great determination, dedication and talent, such as the young school teacher Adelaide Coari (1881-1966). In a period when women were not expected to move about unaccompanied let alone assume any kind of public role, Coari, after finishing her day's work at school, would go to meetings to unionize women and even to organize factory strikes. The name of Armida Barelli (1882-1952) still resonates in Catholic circles because of her role as a brilliant organizer of young Catholic women and girls. Similarly, Countess Elena da Persico (1869-1948), editor of the first Catholic women's journal, L'Azione muliebre, and Princess Cristina Giustiniani Bandini (1866-1959), founder of the Unione fra le donne cattoliche d'Italia, have an assured place in the history of the Italian Catholic women's movements for the pivotal role they played in them. The poetess Luisa Anzoletti (18631925) and the feminist journalist Antonietta Giacomelli (1857-1949), though less wellknown, were in their time significant participants in feminist debate. So was the belligerent Vicenza feminist Elisa Salerno (1873-1957) whose contribution to Catholic feminism has been brought to our attention in recent times by the efforts of the Suore orsoline del Sacro Cuore di Maria who, after receiving her library and personal papers in the late 1970s, have revived the memory of this remarkable woman. In seeking to ameliorate the condition and the role of women in society, Salerno did not hesitate to question the Church's stand on many issues, both social and doctrinal.

The earliest Catholic women's movement was promoted by progressive members of the clergy who recognized the vital role which women could play in maintaining the Catholic presence in Italian society in the face of the secularizing tendencies which Unification had set in train. Until then, the involvement of Catholic laywomen in Church-sponsored activities had typically been of a charitable nature. Now they were called on to operate in an entirely new context and to tackle various religious and social

\footnotetext{
${ }^{3}$ See Annarita Buttafuoco, Le Mariuccine. Storia di un'istituzione laica: l'Asilo Mariuccia, Milano, Franco Angeli, 1998.
} 
issues which had emerged in the wake of rapid industrialization and urbanization. Often in rivalry with leftist agitators, they would deal with problems which stemmed from abject working conditions, long working hours, low rates of pay, and social dislocations caused by migration.

At the same time, the Catholic women's movements had to take cognizance of developments in the wider world. With the women's campaign for emancipation gaining momentum in Europe and the United States, the question of women's civil and political rights became topical and pressing also in Italy. Since the vote for women was widely debated in Italy and in other Catholic countries, the Italian Catholic women's movements, too, had to take a stand on the issue. As a consequence there would be a clash between the patriarchal religious values underpinning the attitudes of Catholic society and women's claims for individual rights which were requisite for their entry into modern society.

Among Italian Catholic women, therefore, women's suffrage and women's rights in general would be divisive issues. In fact, it is not possible to speak of a single, continuous Catholic women's movement, since the earliest current, femminismo cristiano, explicitly differed in its goals from the subsequent, more conservative movements, the Unione fra le donne cattoliche d'Italia and the Gioventù femminile cattolica italiana, precisely on these issues. This discontinuity in orientation resulted from the firm line adopted by the ecclesiastical hierarchies against women's rights, while they at the same time followed the dual policy of conditioning women to the acceptance of traditional Catholic values and of mobilizing them in the defence of the Church.

Due to differences in social status and political orientation, the fragmentation of the Catholic women's movement was, indeed, inevitable. The exponents of femminismo cristiano came from humble social backgrounds and often personally shared the concerns of their working-class constituency. The Unione donne and the Gioventù femminile, on the other hand, were led by women from the aristocracy or the upper middle class, and inevitably reflected the cultural, social and political attitudes of these classes on a range of issues. 
Since the concept of the family and the role of woman as mother and educator were central to Catholic teachings, the Church could not ignore developments which could have been considered as inhibiting women from performing their primary function. The Church leaders, including Popes Pius X, Benedict XV and Pius XI, took a close interest in the Catholic women's movements, both to guide and to control them. One of the objectives of this thesis is to analyse the complex attitude of the ecclesiastical hierarchy to the Catholic women's movements to ascertain whether it was able or willing to accommodate any degree of feminism. This, in turn, will involve examining the nature and aspirations of femminismo cristiano which flourished in the first decade of the twentieth century. At the centre of this enquiry will also be the two long-surviving Catholic women's organizations, the Unione fra le donne cattoliche d'Italia and the Gioventù femminile cattolica italiana, and their attitudes to the woman question. Considering the social spread of the memberships of these organizations and, therefore, the potential conflicts of interest, another objective of the enquiry is to gauge the manner in which the Catholic women's movements dealt with class related issues. An example of this is found in the attitudes which their leadership adopted towards trade unions and industrial issues. Further, it is essential to explore how Catholic teachings had influenced, not only general attitudes to women, but also, and especially, women's own perceptions of themselves, their social roles and their capabilities. To appreciate the range of views in this respect, the conventional submissiveness expected of women at the time needs to be seen in juxtaposition with Elisa Salerno's study of Catholic dogma for signs of antifeminism in it and for reasons why in contemporary society women were accorded a lesser status than men. In addition, it is important to ascertain whether the Catholic women's movements could satisfy both women's interests and the interests of the Catholic hierarchy; and, how, indeed, “women's interests” were perceived by the Catholic women leaders. Since the Church wanted to enlist women's help in re-Christianizing society and in combating its liberal, socialist and fascist rivals, it is important to know what kinds of social roles it, in turn, envisaged for women, both laywomen and women religious, in the contemporary environment. Moreover, the examination of the nature of the Catholic women's movements, their aims and accomplishments will enable us to determine whether their leaders were true “protagonists" setting their agenda or whether they instead took their cue from the clergy. 
Largely chronologically structured, the thesis relies on analytical narrative. The subject matter is organized into five chapters. The first two chapters set the context of the Catholic women's movements. In Chapter One the historical background to ChurchState relations and the condition of Italian women in the Liberal and Fascist periods are examined. Chapter Two deals more specifically with the cultural, political, and ideological context of Catholic feminism. Chapter Three follows the evolution of Catholic feminism from the early Christian democratic movement, discussing the impetus given to the feminist movement by two women's periodicals, L'Azione muliebre and Pensiero e azione. It also explores the reasons for the suppression of Catholic feminism, and highlights the attitude of the early Christian democratic leader, Romolo Murri, to the woman question. Chapter Four examines Elisa Salerno’s contribution to Catholic feminism, concentrating in particular on her journalism, her doctrinal studies and her relations with the Catholic women's movements as well as with the ecclesiastical and secular authorities. Chapter Five traces the developments of the Unione fra le donne cattoliche d'Italia and the Gioventù femminile cattolica italiana, analysing their social role and relations with the ecclesiastical hierarchy, while also drawing comparisons with the contemporary Fascist women's movement.

Some of these issues have already been addressed by historians. Paola Gaiotti de Biase has been the most prolific writer on the matter of the Catholic women's movements, especially on Catholic feminism, commencing with her book, Le origini del movimento cattolico femminile, ${ }^{4}$ while several other writers have contributed biographies on leading figures in the Catholic women's movements. Cecilia Dau Novelli has dealt comprehensively with the Unione fra le donne cattoliche d'Italia in a series of articles and in her book Società, chiesa e associazionismo femminile. L'Unione fra le donne cattoliche d'Italia (1902-1919), ${ }^{5}$ but has limited her enquiry to the first ten years of the existence of the Unione donne. No analysis has been made of this organization in the succeeding decades. There is, furthermore, a paucity of secondary literature even on the Gioventù femminile, an organization for young women and girls. The thesis will seek to study these areas which, until now, have been largely unexplored.

\footnotetext{
${ }^{4}$ Paola Gaiotti de Biase, Le origini del movimento cattolico femminile, Nuova edizione, Brescia, Morcelliana, 2002.

${ }^{5}$ Cecilia Dau Novelli, Società, chiesa e associazionismo femminile. L'Unione fra le donne cattoliche d'Italia (1902-1919), Roma, A.V.E., 1988.
} 
The primary sources used in this thesis can be broadly classified into four groups. The first relates to the correspondence of the personalities around the Catholic women's movements, including Maria Baldo, Adelaide Coari, Elena da Persico, Giacomo Radini Tedeschi, Giuseppe Toniolo, Elisa Salerno, Ferdinando Rodolfi and Cristina Giustiniani Bandini. The second group consists of works on those movements and related issues, originally published in the period under discussion or earlier, such as, for example, Atti del primo Congresso cattolico italiano tenutosi in Venezia dal 12 al 16 giugno 1874 (1874), Atti del Convegno femminile, Milano, 25-26-27-28 aprile 1907 (1907), Elisa Salerno's Per la riabilitazione della donna (1917), and Armida Barelli’s La sorella maggiore racconta (1948). The third group is made up of articles in contemporary periodicals, especially those produced by women themselves, such as L'Azione muliebre, Pensiero e azione, La Donna e il lavoro, Problemi femminili, Bollettino dell'Unione femminile cattolica italiana, In Alto! and Fiamma viva. The final group includes doctrinal and papal documents, primarily encyclicals ranging from Pius IX's Ubi primum (1849) to Pius XII’s Divino afflante spiritu (1943).

The Italian Catholic women's movements form an important part of the history of not only Catholic women but of all Italian women and thus of the history of the Italian nation. The intention of this thesis is to show the roles of these movements in Italian society from the early 1900 s to the late 1930 s. 


\section{CHAPTER ONE: THE ITALIAN STATE, THE CATHOLIC CHURCH AND WOMEN}

During the first three decades of the twentieth century, when Italy was undergoing immense social, economic, and political transformations, women's organizations underpinned the Catholic Church's strategy in responding to the challenges of modern society, fighting the State for political survival, and withstanding the influences of the political left. The nature and the aims of the Catholic women's movements cannot, therefore, be properly understood without reference to the environment from which they emanated. This necessitates examining the broad setting of post-Unification Italy, Church-State relations, and women's position in Italian society.

\section{The Italian State}

Modern Italy has its roots in the nineteenth-century Risorgimento which aimed at liberating Italy from foreign domination and unifying the various political entities on the Italian peninsula under one government. Unification was preceded by decades of both overt and clandestine revolutionary activity against the Austrians in the north, the Bourbon dynasty in the south, and the administrative system of the Papal States. It involved three Wars of Independence against Austria (in 1848-49, 1859, and 1866) under the political and military leadership of Piedmont and the expedition of Giuseppe Garibaldi and his "Thousand” to Sicily. A united kingdom, headed by the Piedmontese monarch, was formally established in March 1861. The process of Unification continued with the acquisition of the Veneto in 1866 and Rome in 1870, and with further territorial additions including Alto-Adige, Trentino, Trieste and Istria after World War I. The annexation of Rome and the Papal States meant that the Pope lost his temporal power. Among the higher echelons of the Church this created an aura of almost visceral animosity towards the State.

None of the heroes of the Risorgimento - neither its theoretical champion Giuseppe Mazzini, nor its revolutionary activist Giuseppe Garibaldi, nor its political tactician Count Camillo Benso di Cavour - showed any affection toward the Catholic Church, or envisaged the Church as playing an important part in unified Italy. Although some exponents, like Mazzini, were republicans, the Risorgimento did not seek to overturn 
the existing social order, as did the French Revolution, and there was no evidence to suggest that it was a broad-based popular movement. The forces behind the thrust for Unification were the members of the modernizing agricultural and industrial bourgeoisie and aristocracy in the north, who saw in the existence of trade barriers between the states on the peninsula a hindrance to further economic development. ${ }^{1}$ It was, in the first instance, this group which would become the new ruling élite of unified Italy. As they would soon find out, their task of creating a nation from the diverse elements of the new political entity would prove even more demanding than the process of Unification itself, and, as Krystyna von Henneberg and Albert Russell Ascoli observe, "even the most persuasive images of Italy as a unitary nation were not always sufficient to transcend class, regional or gender inequalities". ${ }^{2}$

Arguably, many social and economic problems, instead of being redressed, intensified under the successive Liberal governments after Unification. The administration of the country was hampered by the absence of a common language; a case in point being that even the King "never felt comfortable" speaking Italian. ${ }^{3}$ Communication was also rendered difficult by the high illiteracy rate, approximately 68.8 per cent for the total population above the age of six, as revealed by the 1871 census. ${ }^{4}$ Moreover, although schooling was made compulsory for two years in 1877, and increased to three years in 1888, it was not strictly enforced, so illiteracy and dialects persisted to underline regional and class differences. ${ }^{5}$ Conscription, on the other hand, brought together men from different parts of the country, and recruits were taught to read and write, but in return they would often to be deployed to fight a colonial war or fellow Italians during political unrest. For the most part, the country was economically backward possessing relatively few natural resources, and for the majority of people the only route to escape from poverty, or to improve their station in life, was by way of emigration. By the outbreak of World War I millions of Italians had permanently shifted overseas, mainly to North and South America. New infrastructure and industrial projects tended to benefit northerners while, with the removal of internal tariffs, the southern markets were suddenly flooded with imports from other parts of the country to the detriment of local

\footnotetext{
${ }^{1}$ Denis Mack Smith, The Making of Italy 1796-1866, $2^{\text {nd }}$ ed., Basingstoke, Hampshire, Macmillan, 1992, pp. 84-110.

${ }^{2}$ Krystyna von Henneberg and Albert Russell Ascoli, "Introduction: Nationalism and the Uses of Risorgimento Culture”, in Albert Russell Ascoli and Krystyna von Henneberg (eds.), Making and Remaking Italy, Oxford, Berg, 2001, p. 7.

${ }^{3}$ David I. Kertzer, Prisoner of the Vatican, Boston, Houghton Mifflin, 2004, p. 73.

${ }^{4}$ Martin Clark, Modern Italy 1871-1995, $2^{\text {nd }}$ ed., London, Longman, 1997, p. 35.

${ }^{5}$ Ibid., p. 37.
} 
industry. Thus, in the eyes of many southerners, who were crippled by new heavy taxes, the Risorgimento represented another form of colonization rather than deliverance from foreign domination. Owing to the lack of resources and foresight, the central government failed to commit sufficient funds for the maintenance of law and order in the south, which in turn led to brigandage and the emergence of the criminal mafia organization. ${ }^{6}$ No lasting benefits would subsequently be derived from Italy's military forays into Africa or World War I in terms of expanding markets, reduced population pressures, or enhanced international prestige. Nor would the Risorgimento bring emancipation to Italian women, who, on the contrary, "in Lombardy, Venetia, and Tuscany lost political rights and in some instances private authority previously exercised". 7

Nineteenth-century liberalism and Catholicism embodied different ideologies, and these differences played no small part in the development of Church-State relations after Unification. Liberalism sees the abuse of power, and therefore the freedom of the individual, as the central problem of government. Various nineteenth-century theorists, such as François Guizot, Pierre Paul Royer-Collard and Benjamin Constant, rejected the unlimited sovereignty of any power. ${ }^{8}$ While, as a political doctrine, liberalism emphasizes the importance of limited government; as a philosophy of life it calls for individual freedom, imagination and self-fulfilment. It acknowledges particular natural rights as universal and inalienable, and various definitions exist of the concept: the English philosopher John Locke, for instance, seeing man's natural rights as consisting of his right to life, liberty and property. ${ }^{9}$ Further notions of liberalism include the idea of the state's positive role in ensuring all citizens equal protection under the law, equal opportunity to exercise the privileges of citizenship, and to participate fully in national life, regardless of race, religion or sex. While the advance of democracy was regarded

\footnotetext{
${ }^{6}$ In his article "Enforcers, Entrepreneurs, and Survivors: How the Mafia Has Adapted to Change", The British Journal of Sociology, v. 36, no. 1, Mar. 1985, p. 35, Raimondo Catanzaro describes the emergence of the mafia in the aftermath of the peasant revolts in the 1860 s as a consequence of three aspects of the process of creating the Italian State: "the communication gap between centre and periphery and the consequent delegation to the local ruling class of social control over the peasants; the diffuse nature of the Italian public administration system of the periphery; and the patronage system of local government”.

${ }^{7}$ Judith Jeffrey Howard, "Patriot Mothers in the Post-Risorgimento: Women after the Italian Revolution", in Carol R. Berkin and Clara M. Lovett (eds.), Women, War, and Revolution, New York, Holmes \& Meier, 1980, p. 238.

${ }^{8}$ E.K.. Bramsted and K..J. Melhuish, “Aspects of Liberalism and Radicalism in France”, in E.K.. Bramsted and K.J. Melhuish (eds.), Western Liberalism: A History in Documents from Locke to Croce, London, Longman, 1978, p. 55.

9 John Locke, "Second Treatise”, in Two Treatises of Government, ed. with introd. by P. Laslett, Cambridge, Cambridge University Press, 1967, pp. 283-446.
} 
by Alexis de Tocqueville and John Stuart Mill as inevitable, and in the case of Mill even desirable, they both envisaged the tyranny of the majority as a potential threat to the rights of the minorities and the quality of government. ${ }^{10}$ In nineteenth-century Europe, the middle classes therefore feared the potential consequences of the extension of democratic rights to all classes of people. "Liberal” principles continued to be applied selectively, excluding wide sections of the population from its covenant, as demonstrated by Liberal Italy with the sole recognition of men as "citizens" and with the treatment of women as minors under their family's or husband's tutelage. Full participation in national life was out of the question for most people, male or female, under a system which kept them disenfranchised. The interests of the propertied classes, by contrast, were vehemently protected, leading to the concentration of economic wealth in the hands of a relatively small number of citizens, and leaving the problem of the landless peasantry unresolved. ${ }^{11}$

The Catholic Church was opposed to liberalism because it saw it as having negative effects on society for religious, ethical, political, and economic reasons. As regards religion, comments “Antonietta” in the women’s magazine L'Azione muliebre in March 1901, the harmful repercussions included the separation of State from Church, and the secularization of schools, the family, and society. Ethically, the objectionable characteristics of liberalism included the independence of reason, the laws and government, and morals without God. Politically, liberalism elevated popular sovereignty to a divine role, since it viewed social power as deriving from the people to be exercised in its name. Economically, the principle of laissez-faire had legitimized the prevalence of ever increasing competition, monopoly, usury, and social injustice. Liberalism had not only given rise to capitalism but had also led to the enslavement of the proletariat. Moreover, with the disappearance of the ancient guilds for arts and crafts, which had evolved within Christian society to protect the spiritual and material interests of workers, the latter were now left alone and defenceless at the mercy of fluctuations in industry and in the labour market. ${ }^{12}$

\footnotetext{
${ }^{10}$ E.K. Bramsted and K.J. Melhuish, "The Tyranny of the Majority and the Right to Non-conformity: Introduction”, in Bramsted and Melhuish, Western Liberalism, cit., pp. 578-581.

${ }^{11}$ In southern Italy, the demesne and ecclesiastical lands sold upon Unification at public auctions were acquired by the wealthy middle classes rather than the peasants who as a result were worse-off since they lost their ancient grazing, pasturage and wood gathering rights. In northern Italy the disposal of the ecclesiastical lands was handled more equitably. See Clark, Modern Italy 1871-1995, pp. 16-17.

12 “Antonietta”, “L’enciclica sulla Democrazia cristiana”, L’Azione muliebre, a. I, fasc. 3, marzo 1901, p. 15.
} 
In post-Unification Italy the propertied classes, with their narrow interests, continued to dominate most sectors of parliament and public opinion, agreeing "on the main lines of financial, religious and foreign policy, and on the need for prudent restrictions on freedom in the interests of public order" ${ }^{13}$ In the absence of a genuine opposition party, the task of government gradually became that of patronage and pork-barrelling in the electorate, and trasformismo in parliament, "by which government ministers brokered individual and collective favours in exchange for votes”. ${ }^{14}$ Prime Minister Depretis is credited with having coined the term trasformismo, under which the system came to be known, when he said in 1882:

We are a progressive government, and if anyone wishes to transform himself and become progressive, if he wishes to accept my very moderate programme, can I reject him? ${ }^{15}$

Maurice F. Neufeld observes how Prime Ministers Agostino Depretis, Francesco Crispi and Giovanni Giolitti, each of whom enjoyed long periods in office, successively “devised, improved, and perfected” the system, and goes on to say:

The shrewd and complex system of political deals, favors, accommodation, bribery, electoral corruption, and violence at the polls changed clashing parliamentary groups with paltry sense of country or democracy into workable legislative majorities. ${ }^{16}$

Trasformismo reached its utmost perfection with Giovanni Giolitti who dominated Italian politics from 1900 to 1914 either as Prime Minister of Minister for the Interior.

Capitalist forces, frequently under tariff shelter, ruled the economy. With agriculture constituting a substantial part of the Italian economy, ${ }^{17}$ John Pollard notes the dualism which persisted between small-scale subsistence and large-scale capitalist farming as well as the emergence of a rural, agrarian proletariat. ${ }^{18}$ Various forms of dualism also accompanied the development of a large-scale manufacturing industry in the last two decades of the nineteenth and the early twentieth century. This became evident from

${ }^{13}$ Christopher Seton-Watson, Italy from Liberalism to Fascism: 1870-1925, London, Methuen, 1967, p. 16.

14 John A. Davis, “Introduction: Italy’s Difficult Modernization”, in John A. Davis (ed.), Italy in the Nineteenth Century, Oxford, Oxford University Press, 2000, p. 20.

${ }^{15}$ Quoted in Seton-Watson, Italy from Liberalism to Fascism, cit., p. 51.

${ }^{16}$ Maurice F. Neufeld, Italy: School for Awakening Countries, Westport, Conn., Greenwood, 1974, pp. 3, 82.

${ }^{17}$ On p. 255 of "Economy, Society, and the State”, in Davis (ed.), Italy in the Nineteenth Century, cit., John A. Davis writes: "By the close of the nineteenth century Italy was the only Mediterranean country to have acquired an industrial base, but it was still far from an industrial society. Nearly $40 \%$ of the active population was still engaged in agriculture, which contributed more than $50 \%$ of gross national product.”

18 John Pollard, Catholicism in Modern Italy, London, Routledge, 2008, p. 50. 
the coexistence of a modern industrial sector alongside "backward" forms of production, and from the development of the industrial triangle of Milan, Turin and Genoa which contrasted with the underdeveloped south. ${ }^{19}$ In the early stages of industrialization the textile industry, especially silk production, was the leading sector of Italy's economic development. ${ }^{20}$ The "second wind" of industrialization in the years 1897-1913 featured the large-scale use of new materials (steel and chemical products), the introduction of new sources of energy (hydroelectric power), the expansion of assemblage industries, the development of steel machine tools, and the manufacture of new consumer goods such as typewriters, bicycles and automobiles. ${ }^{21}$ But the traditional industries still employed 60 per cent of the 1.5 million workers in manufacturing (1911 census). ${ }^{22}$ The continuing importance of the textile industry is highlighted by the fact that in the pre-World War I period it was the country's sole big exporting industry, making up some 40 per cent of the total value of the credit side of Italy's trade balance, and was the source of employment for approximately a third of workers in the manufacturing sector (1911 census). ${ }^{23}$ According to official statistics, textiles, together with foodstuffs and other agricultural-manufacturing industries, in 1913 still accounted for 60 per cent of the total added value of the manufacturing industries. ${ }^{24}$ Because of various forms of industrialization, the northern cities had a huge demand for labour, resulting in big population movements from rural to urban areas, and from the south to the north of Italy. The census data for 1911 shows, however, that the percentage of the total population employed in secondary industry did not constitute more than 4.7 per cent for Italy as a whole, and only 9.6 per cent for the industrial triangle. $^{25}$

While economic transformation was underway, the Liberal governments - as was the case with nineteenth century liberalism in general - intervened minimally to correct the operation of market forces in the workplace to protect weaker members of society. ${ }^{26}$

19 Ibid.

${ }^{20}$ Luciano Cafagna, “The Industrial Revolution in Italy 1830-1914”, in Carlo M. Cipolla (ed.), The Fontana Economic History of Europe: The Emergence of Industrial Societies: Part One, London, Collins/Fontana, 1973, p. 281.

${ }^{21}$ Ibid., pp. 304, 315.

${ }^{22}$ Ibid., p. 309

${ }^{23}$ Ibid., p. 305.

${ }^{24}$ Ibid., p. 309.

${ }^{25}$ Ibid., p. 324.

${ }^{26}$ On p. 68 of From Wealth to Welfare: The Evolution of Liberalism, Stanford, Calif., Stanford University Press, 1950, Harry K. Girvetz writes: "In principle, classical liberalism rejects all attempts by government to do for the welfare of individuals who are sane and adult what they would not do for themselves. It reserves the name of 'paternalism' for government intervention of this kind. It rejects paternalism, not 
New jobs were filled not only by male workers, but in large numbers also by women and children with minimal government control. Some social legislation was eventually passed. It included the introduction, in 1883, of a voluntary “industrial workmen's compensation scheme", and in 1886 "parliament limited the working day of children under twelve to eight hours, and forbade the employment of children less than nine years of age in industry, less than ten years underground and less than fifteen years in dangerous or unhealthy occupations". ${ }^{27}$ In 1898 the legislation related to workers compensation was amended to make it the employer's responsibility to bear full costs, and a voluntary disability and old age pension scheme was introduced. ${ }^{28}$ In 1902 the Giolitti government passed laws specifically aimed at the protection of female and child labour. Enacted at the behest of the Socialist Party, this minimal welfare legislation did not extend to agricultural workers. ${ }^{29}$ Further social legislation included the enactment of a compulsory rest-day in 1907, the prohibition of night work in bakeries in 1908, and the setting up of a State-subsidized sickness and old-age fund for the merchant navy in $1913 .^{30}$

Since, under a liberal system, government is based on the rule exercised at the will of the majority, analysis of the composition of the electorate is a key to understanding the nature of government. In most countries in the nineteenth century franchise was restricted to a small section of the adult population, mirroring the fears harboured by the middle classes of the repercussions which the broadening of the electorate would have on their private property rights. In Italy the middle classes were numerically small, and so correspondingly was the electoral base. Thus in 1870 only 529,000 adult males, less than two per cent of the total population, could meet the necessary property and literacy qualifications for eligibility. ${ }^{31}$ The demographic data obtained some ten years later gives an idea of how the electorate was made up. While the total population at the 1881 census numbered almost 30,000,000 people ${ }^{32}$, there were only “about 200,000 'independent' landowners, rentiers and entrepreneurs, and about another 100,000

only because of misgivings about government, but ... because paternalism is said to sap initiative and self-reliance and because, in general, rational adults are said to know their own interests better than any government could know them.”

${ }^{27}$ Seton-Watson, Italy from Liberalism to Fascism, cit., p. 90.

${ }^{28}$ Ibid., p. 186.

${ }^{29}$ Elda Gentili Zappi, If Eight Hours Seem Too Few: Mobilization of Women Workers in the Italian Rice Fields, Albany, N.Y., State University of New York, 1991, p. 125.

${ }^{30}$ Clark, Modern Italy 1871-1995, cit., p. 137.

${ }^{31}$ Seton-Watson, Italy from Liberalism to Fascism, cit., p. 16.

${ }^{32}$ Neufeld, Italy, cit., p. 520. 
'professional' men”, 33 and these two groups formed the élite of Italian society. There were additionally " 100,000 Italians holding respectable white-collar jobs in the private sector" and "250,000 in non-manual public employment”. ${ }^{34}$ At the 1882 elections, with an extended franchise, the number of eligible voters rose to 2,018,000 adult males, which still represented less than 7 per cent of the total population. By the 1913 elections the eligibility rate had reached 23.2 per cent, almost one quarter of the total population, reflecting the full voting rights of adult males, but with the exclusion of women it still fell far short of full adult suffrage. ${ }^{35}$

Yet it is difficult to disagree with Raffaella Gherardi who in her book L'arte del compromesso suggests that "restricting political representation" was necessary to enable “a gradual process of political change” and that far from being “weak” Italian liberalism was "flexible" and "pragmatic", “incorporating different tendencies" held together by the "art of compromise". ${ }^{36}$ Admittedly the political system was complex, and in the early 1900s the gradualist approach to extending the suffrage was preferred even by the Socialist Right. Along with the industrialists profiting from the tariffs on manufactured goods, the Socialists in the north favoured gradual introduction of universal suffrage and, as late as 1908, their leader, Filippo Turati held the view that even the existing system was too advanced for the South. ${ }^{37}$ As Raffaele Romanelli points out, the Liberals, for their part, kept a wary eye on the Catholics, whose religious ideology and call for social renewal cemented cohesion between the classes. ${ }^{38}$ But the Liberals also envisaged that Catholicism, despite its anti-capitalist mantra, would one day provide a basis for an autonomous class organization and would, as such, be ultimately destined to become the ideology of the ruling groups. Nevertheless, in the final decade of the nineteenth century, the Liberal rulers continued to regard Catholic organizations as their political adversaries since the latter aimed to transform radically the entire system. Thus, writes Romanelli, the Liberal government was almost as suspicious of the "Blacks" as it was of the "Reds" and, by its repeated efforts to defend its institutions

\footnotetext{
${ }^{33}$ Clark, Modern Italy 1871-1995, cit., p. 29.

${ }^{34}$ Ibid.

${ }^{35}$ Statistics obtained from Neufeld, Italy, cit., pp. 520, 524.

${ }^{36}$ Lucy Riall, "Progress and Compromise in Liberal Italy”, The Historical Journal, v. 38, no. 1, Mar. 1995, p. 209. Commentary on Raffaella Gherardi’s book L'arte del compromesso. La politica della mediazione nell'Italia liberale, Bologna, Il Mulino, 1988.

37 Spencer Di Scala, Dilemmas of Italian Socialism: The Politcs of Filippo Turati, Amherst, Mass., University of Massachusetts Press, 1980, p.116.

${ }^{38}$ Raffaele Romanelli, L'Italia liberale 1861-1900, Bologna, Il Mulino, 1990, p.322.
} 
from both, it reversed the process of increasing the size of the electorate, which by then had become inevitable. ${ }^{39}$

The Liberals' fear was justified, even though the ultimate threat did not come from either source. When universal male suffrage was finally introduced, the Liberals had no longer the capacity to orchestrate smoothly the ascendant parliamentary forces which included the numerically strong Socialist, Popular and Nationalist Parties. Nor were they able to contain subversive extra-parliamentary elements from either Left or Right. By the time Giolitti was inaugurated as Prime Minister for the fifth time in 1920, the Liberal system could not guarantee civic order, and in a matter of only a couple of years the "benevolent autocracy" of Liberal Italy was substituted by the "fascist totalitarianism” of Benito Mussolini. ${ }^{40}$

\section{Church-State Relations}

Church-State relations unfolded against the backdrop of Liberal and, later, Fascist Italy. The central issue was the political controversy between the papacy and the Italian State: the papacy's loss of the temporal power and the Popes' refusal to recognize the Italian State. It is noteworthy that the Risorgimento had received support, as Martin Papenheim comments, from "a substantial sector of the Catholic population, and even of the clergy" who especially in Lombardy had taken part in "nationalist conspiracies". ${ }^{4}$ "Partly as a consequence of developments in Rome”, he argues, "an intransigent Catholicism” won the upper hand by suppressing these Catholic traditions and imposing "uniformity upon the Church". ${ }^{2}$ Judging by the inflammatory rhetoric from both sides at the time, the annexation of the Papal States, and Rome in particular, had led to a total breakdown in relations between Church and State but, despite hostile slogans, pragmatism would ultimately prevail to enable continued coexistence of these two entities.

With its territorial base on Italian soil, the Catholic Church had by necessity a unique relationship with the Italian State, for "although the struggle between Church and state

\footnotetext{
39 Ibid.

${ }^{40}$ Riall, "Progress and Compromise in Liberal Italy", cit., p. 6.

${ }^{41}$ Martin Papenheim, "Roma o morte: Culture Wars in Italy”, in Christopher Clark and Wolfram Kaiser (eds.), Culture Wars: Secular-Catholic Conflict in Nineteenth-Century Europe, Cambridge, Cambridge University Press, 2003, p. 203.

${ }^{42}$ Ibid., p. 204.
} 
was a prominent feature of nation-state formation in France and Germany, only in Italy was the Church's temporal power under threat". ${ }^{43}$ The question arose whether the Church should be subject to the laws of the Italian government, or whether the State should allow religion and religious jurisdiction to infiltrate the system of government. Guido de Ruggiero accredits Cavour, the Piedmontese statesman behind Unification, with finding a solution to the problem, captured in the phrase "a free Church in a free State". This entailed the separation of the respective spheres of influence of the two institutions so that, while the State had the right to insist that those living within its boundaries respected its laws, the Church enjoyed freedom of association and full freedom in doctrinal and practical matters. ${ }^{44}$

Foreshadowing the future problematic coexistence with the Italian State but also bemusing public opinion abroad, the autocratic rulings listed in The Syllabus of Errors Condemned by Pius IX which accompanied the encyclical Quanta cura (1864) set the intransigent tone of the papacy of Pius IX, the occupant of St Peter's throne at the time of Unification. ${ }^{45}$ Calling into question the sovereignty of the Liberal State, the Syllabus banned liberalism together with socialism, communism, pantheism, naturalism, rationalism, Protestantism, and modern science, and listed the Church’s exclusion from wielding the temporal power among the errors to be condemned.

The loss of the temporal power forced the Catholic Church to redefine its political and social role. In 1869-70, coinciding with the takeover of Rome by the Italian army, Pius IX convened a general council of Church dignitaries, subsequently known as Vatican I, which was the first general ecclesiastical meeting held since the Council of Trent from 1545 to 1563 . As with the publication of the Syllabus, the Pope’s proclamation at the

${ }^{43}$ Lucy Riall, The Italian Risorgimento: State, Society and National Unification, London, Routledge, 1994, p. 79.

${ }^{44}$ On p. 335 of The History of European Liberalism, Boston, Beacon, 1959, Guido De Ruggiero writes: "From the unitarists he accepted the idea of State sovereignty; but instead of understanding by that an absorption of the religious content of the Church into the State, he confined it within its own juridical limits, and interpreted it as the right of the State to insist that all who lived within its boundaries should respect its laws. The right, therefore, to demand that the Church, as an association for purposes of worship, should enter into the sphere of common rights. But within these juridical limits, he left to the Church full doctrinal and practical freedom, simply because the State, granted its liberal character, not only had no right to invade the conscience of the individual and to encroach upon the autonomy of associations, but actually rested upon this conscience and this autonomy. Thus arose the famous formula, 'A free Church in a free State'."

45 Among those who expressed their dismay at the Syllabus were the British envoy Odo Russell, numerous American prelates as well as the German Church historian and theologian Ignaz von Döllinger. See Kertzer, Prisoner of the Vatican, cit., pp. 23-26. 
council of his own infallibility elicited ridicule in Italy and dismay abroad. ${ }^{46}$ Nonetheless, the overall result of this meeting was greater centralization and more effective organization of the Church, with a new breed of "intransigent" bishops regrouping under the Pope's leadership. ${ }^{47}$ Carefully crafted papal encyclicals became an important instrument in expressing the Church's position not only on the political issues stemming from the unification of Italy but also on the social and economic problems caused by modernization in the latter half of the nineteenth and the early twentieth century.

In the years 1860-1870, in an attempt to cling to the temporal power, the papacy turned for help to "every enemy of Italy, both internal and external". ${ }^{48}$ In the south it supported the Bourbons; in Emilia it stirred up peasants who were infuriated by tax levies; and in Milan and Florence the extreme revolutionary slogans of ecclesiastical agitators and journalists led frightened Liberals to suspect a secret alliance between socialists and the Vatican. ${ }^{49}$ Pius IX ultimately lost his hold on Rome on 2 October 1870, after the French garrison, which had protected the Pope, departed in August on the eve of the Franco-Prussian War. From then on the papal territory would be confined to the narrow strip of land in Rome constituting the Vatican City where the Pope would live in self-imposed exile as "the prisoner of the Vatican”. As Benedetto Croce points out, this damaged the image of the Italian State among Catholics abroad, "but it also troubled many Italians, liberal Catholics and moderate, conciliatory, or far-sighted liberals". 50

The Church's grievances were not limited to its loss of territory. Between 1850 and 1859 Piedmont enacted a number of secularist laws, whereby "the clergy lost most of their ancient privileges; religious orders were suppressed or deprived of their property;

\footnotetext{
${ }^{46}$ On p. 32 of ibid. Kertzer comments: “Throughout Europe, emperors, kings, and prime ministers voiced their anger. If the pope was now infallible, where did this leave their authority when the pope's conflicted with their own? Within days of the decision, the Austrian government voted to abrogate its concordat with the Vatican; within months the Swiss government, citing the new proclamation, unleashed a campaign against the Catholic clergy. Bismarck was reported to have been delighted at the infallibility proclamation, believing that the negative popular reaction to it in Germany would undercut the pope's influence there. Odo Russell's remarks in his report to the British foreign minister, written on the very day of the vote, were typical. That the final version of infallibility was substantially toned down from the original was lost on Russell, as it was on other political leaders in Europe. 'The independence of the Roman Catholic hierarchy has thus been destroyed', he wrote, 'and the supreme absolutism of Rome at last been obtained'."

${ }^{47}$ Clark, Modern Italy 1871-1995, cit., p. 86.

${ }^{48}$ Seton-Watson, Italy from Liberalism to Fascism, cit., p. 11.

${ }^{49}$ Ibid.

${ }^{50}$ Benedetto Croce, A History of Italy 1871-1915, Oxford, Clarendon, 1929, p. 32.
} 
monasteries and convents were closed; civil marriage was introduced; and church schools subjected to State control". ${ }^{51}$ These laws were extended to the rest of Italy in $1860 .^{52}$ Further measures taken by the Italian government included the ceasing, in 1866, of the payment of a direct subsidy to the Church and the setting up, instead, of a special Ecclesiastical Fund, which received part of the revenue from the confiscated church property to be used for the payment of clerical stipends. ${ }^{53}$ This was followed by the suppression, in 1872, of theological faculties in all universities and the subjection of seminaries to government inspection. ${ }^{54}$ In 1873 the existing legislation related to the suppression of religious corporations and confiscation of their property was extended to include Rome, and soon afterwards priests were made liable to military conscription. ${ }^{55}$ Moreover, religious orders were forbidden to acquire real property - it was surely not coincidental that the ban imposed on the Church to acquire property was listed among the “modern sins” in Pius IX's Syllabus of Errors. Italy, however, still remained a Catholic country, and there were limits to how far the State could go in curbing the Church's influence. It is illuminating that in 1867, when attempting to move towards the separation of Church and State with the introduction of a Free Church Bill, Bettino Ricasoli caused such indignation that he consequently lost office. ${ }^{56}$

Church-State relations were set on a legal footing with the Law of Guarantees (Legge delle Guarentigie) which was passed by the Italian Parliament in 1871 but was never ratified by the Vatican. The first part of the document related to the papacy, and deprived the Pope of the temporal power leaving to him only the Vatican, the Lateran Palaces and the villa at Castel Gandolfo; notwithstanding that, the Pope was to be accorded all the honours of a sovereign, and the diplomatic corps at the Vatican would enjoy the same immunities and privileges as those accredited to the King. Furthermore, the Law of Guarantees permitted the Pope to maintain his traditional armed guards, granted freedom to all cardinals to participate in conclaves, and undertook on the part of the State not to expel from Rome any ecclesiastic who worked there. The Pope would be able to set up his own telegraph office, make use of the "diplomatic bag”, and would

\footnotetext{
${ }^{51}$ Seton-Watson, Italy from Liberalism to Fascism, cit., p. 10.

52 Ibid.

${ }^{53}$ Ibid.

${ }^{54}$ Ibid., p. 56.

${ }^{55}$ Ibid., pp. 56-57.

${ }^{56}$ Ibid., p. 10.
} 
be paid an annual allowance. ${ }^{57}$ The second part of the Law of Guarantees dealt specifically with the relations between Church and State, seeking very cautiously to put the principles of separation into practice and leaving the Catholics considerable latitude to perform their religious activities. The State would no longer exercise control over the promulgation of new ecclesiastical laws, nor would bishops be required to take an oath of allegiance to the Italian State. Some measure of government oversight over ecclesiastical matters was still retained through the control over nominations to ecclesiastical benefices and over property transactions of ecclesiastical organizations. ${ }^{58}$ While Pius IX and his successors refused to sign the Law of Guarantees offered by the Italian government, their repeated efforts towards an international Law of Guarantees with foreign governments as signatories proved fruitless.

One of the most unsettling consequences of the Pope's refusal to recognize the existence of the Italian State was his proscription banning Catholics from participating in national politics. So while the Roman question remained unresolved, Catholics were officially prevented from standing as candidates or voting at national elections, first by Don Giacomo Margotti's dictum, in 1861, Nè eletti, nè elettori ${ }^{59}$, and then by the 1871 declaration of the Holy Penitentiary, confirmed by Pius IX in 1874, that voting was "not expedient”. (No such proscription existed with regard to local politics in which Catholics participated fully and actively.) The initial formula non expedit was in fact made a categorical non licet in $1877 .{ }^{60}$ Even with the electoral reform of 1882, which not only increased the size of the electorate but also strengthened the anti-clerical Left in parliament, the new Pope, Leo XIII, retained the prohibition, reaffirming it with Non expedit prohibitionem importat in $1886 .{ }^{61}$ In 1895, the unveiling of a Garibaldi monument in Rome, with the King in attendance, to mark the twenty-fifth anniversary

\footnotetext{
${ }^{57}$ A.C. Jemolo, Church and State in Italy 1850-1950, Oxford, Basil Blackwell, 1960, pp. 49-50. The annual sum was never accepted by the Holy See.

${ }^{58}$ On p. 83 of Modern Italy 1871-1995, cit., Clark writes: "The Law of Guarantees laid down that, although the Church was normally free to make her own appointments, the income (benefices and ecclesiastical goods) associated with episcopal sees or parishes could not be enjoyed without a royal decree of exequatur or placet. This was more important than it sounds, for it was difficult for a bishop to carry out his duties without access to the bishop's palace. Refusing the royal exequatur for episcopal benefices meant a de facto veto on episcopal appointments; and, of course, it was an easy way of increasing the State's revenues."

${ }^{59}$ Ronald S. Cunsolo, "Nationalists and Catholics in Giolittian Italy: An Uneasy Collaboration", The Catholic Historical Review, v. 79, 1993, p. 23.

${ }^{60}$ Seton-Watson, Italy from Liberalism to Fascism, cit., p. 59.

${ }^{61}$ Ibid., p. 219.
} 
of the occupation of the city, caused the Pope to proclaim the non expedit even more categorically than before. ${ }^{62}$

The most significant outcome of the non expedit was, in fact, the absence of a conservative Catholic party in Italian politics, which would have absorbed a significant proportion of the Catholic vote and would have effectively represented Catholic interests at the national level. This does not mean that Catholics did not vote at national elections. Of course they did. Here distinction must be drawn between Liberal Catholics who were willing to participate in national politics and "intransigent" Catholics who strictly adhered to papal policy directives. ${ }^{63}$ The participation rate at the elections between 1861 and 1921 fluctuated between 45.5 per cent (November 1870, just before the proclamation of the non expedit) to 65.0 per cent in March 1909. For most of the period, the participation percentages were in the high fifties. On the relaxation of the non expedit in 1904 there was a 4.4 per cent increase in voting over the previous election, and surprisingly the rate dropped by 3.8 per cent in 1919 when the Catholic-aligned Partito popolare italiano made its debut at the elections. ${ }^{64}$ While the direct electoral impact of the non expedit cannot be accurately gauged, it provided a powerful symbol of the impasse of Church-State relations.

By the time Pius $\mathrm{X}$ ascended to the papacy in 1903 the Roman question was becoming irrelevant with the realization that Rome would never be restored to the papacy. By then Church and State had found a form of modus vivendi, which allowed them to coexist with some concessions being made on both sides, but many disagreements still remaining on matters of social policy. ${ }^{65}$ The differences included issues such as provision of religious instruction in State schools; government recognition and inspection of Catholic schools; guaranteeing the legality of endowments to religious

${ }^{62}$ Ibid., p. 223.

63 On pp. 15-16 of his Il movimento sociale nell'Opera dei congressi (1874-1904), Roma, Editrice Università Gregoriana, 1958, Angelo Gambasin writes: “Anche i cattolici d’Italia ... si organizzarono ed agirono, formando varie correnti cattoliche che andavano dai cattolici liberali, transigenti - i quali più of meno scendevano a qualche patto con i principi del liberalismo -, fino ai cattolici puri, intransigenti - i quali non ammettevano nessuna intesa, sia pur minima, con la rivoluzione -’.

${ }^{64}$ For participation rates in Italian national elections, see Neufeld, Italy, cit., p. 524.

65 On p. 85 of Church and State in Italy 1850-1950, cit., Jemolo writes: "The abolition of the temporal power and the Law of Guarantees, the formal suppression of the monasteries and the tolerance that enabled them to survive in the form of free associations and to continue their religious, scholastic and philanthropic activities, the substantial secularization of State institutions and in particular the nonrecognition by the State of religious marriages - these things were regarded by nearly everyone as established and irremovable features of the Italian scene ... within the limits defined by these landmarks there was still room for a great number of divergences of opinion, less clamorous, less substantial than those which had arisen in the nineteenth century”. 
communities not recognized by the State; the State's continuation of the policy of secularization of confraternities, some of them still holding considerable assets; the status to be assigned under the new social legislation to confessional bodies, such as cooperative societies, banks, friendly societies or workers' associations, in comparison with secular organizations; and the precedence of civil marriage over religious marriage. ${ }^{66}$ Giovanni Giolitti, Prime Minister at the time, while cautious not to alienate the Socialist Left, enjoyed good relations with the Catholic leaders. On two occasions, in 1901 and 1903, he withheld his support for the passage of a divorce bill. ${ }^{67}$ Pius X, on the other hand, "animated by a profound love of his patria ... refused to name the Francophile, anti-Italian Rampolla as his Secretary of State”. ${ }^{68}$ More importantly, during Pius X's papacy, the process of gradual reconciliation with the State brought about a discretionary lifting of the non expedit, starting with the November 1904 national elections in order to preclude a Socialist victory. Again, the organized Catholic vote proved crucial in 1913 when the national elections took place for the first time under full adult male franchise. Prior to the poll Count Vincenzo Gentiloni, president of the Catholic Electoral Union, had requested certain undertakings on the part of Liberal candidates in exchange for Catholic votes. Religious instruction in schools and opposition to the legalization of divorce were the key items in the seven-point programme which the candidates had to sign to secure Catholic support. ${ }^{69}$

While certain prickly sensitivities still disturbed Church-State relations, both had discovered common ground in a fight against new hostile forces, that is, the socialists and communists who had started to spread their doctrines among the working classes. Catholic attitudes toward socialism were succinctly summarized by a contributor to the Catholic women's magazine, L'Azione muliebre, in May 1905. According to the writer, socialism represented the natural consequence of liberalism. Eliminating existing hardships simply by making everyone materially equal through a class struggle would ultimately bring about the abolition of private property and the public ownership of the land. Such a system was harmful, moreover, because instead of solving the problem of poverty, it aggravated the condition of the worker. By forbidding him to use his savings to acquire land, it deprived him of a hope of improving his situation. Besides, the writer maintains, by violating the legitimate proprietors' rights which were derived from and

\footnotetext{
${ }^{66}$ Ibid., p. 86.

${ }^{67}$ Frank J. Coppa, The Modern Papacy since 1789, London, Longman, 1998, p. 149.

${ }^{68}$ Ibid.

${ }^{69}$ Clark, Modern Italy 1871-1995, cit., p. 157.
} 
willed by nature itself, the socialist system was unjust, since by tampering with existing property rights it upset the social order and was therefore subversive. ${ }^{70}$

In the early years, the working classes had staged social protest either in response to new tax levies or in a quest for higher wages. It had usually been spontaneous, unorganized, and mostly "local, Northern, short-lived and unsuccessful". ${ }^{71}$ After the government crackdown on the anarchists in 1878, however, rival socialist organizations began to gain ground, and various bodies came into existence. Up to the 1890s organized working-class movements operated independently, pursued their different ideologies, and were looked upon with suspicion by the rulers. Frequently the government responded to strikes and demonstrations by resorting to harsh and repressive measures. In the 1890s the Milanese lawyer Filippo Turati set himself the task of founding a socialist party which would be legal and reformist, and would also have an extensive working-class base. In 1895 he changed the name of his organization from the Party of Workers to the Italian Socialist Party. After it had suffered periods of official persecution in the 1890s, ${ }^{72}$ the Italian Socialist Party would later become a functional element of the Giolittian system, even though it would never be fully absorbed into it. By the early 1900s Turati and Giolitti had reached a tacit understanding that government would intervene as little as possible in labour disputes. ${ }^{73}$

With the potential to alienate working-class believers, socialism posed a threat also to the Catholic Church, which responded to this challenge on 15 May 1891 by issuing Rerum novarum: Encyclical of Pope Leo XIII on Capital and Labour. ${ }^{74}$ In composing the encyclical, Leo XIII enlisted the cooperation of the Jesuit Matteo Liberatore, who in 1889 had published a book entitled Principi di economia politica. ${ }^{75}$ An appeal to devout Catholics to transform society "at a time of agricultural crisis, industrial depression, and high emigration”, ${ }^{76}$ the encyclical positioned the Church ideologically against the Liberal system which since Unification had operated in the interests of the middle and upper classes, widening the gap between the rich and the poor and leaving

\footnotetext{
70 “Fmm.”, “Quindici maggio”, L’Azione muliebre, a. V, fasc. 5, maggio 1905, p. 294.

${ }^{71}$ Clark, Modern Italy 1871-1995, cit., p.72.

${ }^{72}$ Ibid., pp.110-112.

${ }^{73}$ Ibid., p.137.

${ }^{74}$ Leo XIII, Rerum novarum: Encyclical of Pope Leo XIII on Capital and Labour (15 May 1891). http://www.vatican.va/holy_father/leo_xiii/encyclicals/documents/hf_l-xiii_enc_15051891_rerumnovarum_enc.html (11/12/2007)

${ }^{75}$ Silvio Fantoni, Breve storia del movimento cattolico italiano (1870-1920), n.p., Santi Quaranta, n.d., p. 53.

${ }^{76}$ Clark, Modern Italy 1871-1995, cit., p. 106.
} 
the lower classes to fend for themselves. Since the Church was often the only source of assistance for people living in indigent circumstances, the broad masses had continued to identify politically and socially with the clergy. Sixteen years earlier, in a speech to the Chamber of Deputies on 6 May 1875, the historian and politician Pasquale Villari, a sagacious observer of the contemporary situation, had commented on the hold which the Catholic Church continued to have on Italian society:

È il nostro scetticismo che dà la maggior forza al clero, perché noi non possiamo mai dire al popolo una parola di quella religione di cui ha bisogno, perché noi non abbiamo con esso un principio che ci ravvicini! Il popolo sente la voce del clero e si abbandona ad esso, appunto perché non crede al nostro scetticismo, al nostro razionalismo. Quello che a noi fa supporre che la Chiesa non abbia la forza immensa che ha, è appunto il non osservarla, il non studiarla, e ciò accade per la natura stessa e l'indirizzo del nostro spirito. ${ }^{77}$

The Church now felt that its grip had begun to loosen on the masses through the workings of a new type of "crafty agitators stirring up people to revolt",78 and called on the State to "intervene to put restraint upon such firebrands, to save the working classes from being led astray by their manoeuvres, and to protect lawful owners from spoliation". ${ }^{79}$ To prevent strikes, laws should be enacted to regulate the working day, working conditions, and the rates of pay. ${ }^{80}$ The encyclical specifically stated that that women and children should not be expected to perform to the same physical standards as men. ${ }^{81}$ Although it spoke against blatant exploitation of workers due to "the hardheartedness of employers", "unchecked competition" and "rapacious usury”, 82 it essentially endorsed capitalism and workers' right to acquire property, seeing it as a means of achieving a more equitable distribution of wealth, ${ }^{83}$ whereas it utterly rejected "the main tenet of socialism, community of goods", regarding it as "directly contrary to the natural rights of mankind”. ${ }^{4}$ Rather than joining non-religious unions, Catholic workers were encouraged to set up associations either jointly with employers ${ }^{85}$ or among themselves. ${ }^{86}$ The idea of mixed unions of employers and workers - which would prove unsuccessful in practice - characterized the theories of the Pisan

${ }^{77}$ Camera dei Deputati, Discorso del deputato Villari sulle relazioni dello Stato colla Chiesa pronunciato nella seduta del 6 maggio 1875, Roma, 1875, pp. 10-13. Quoted in Storia d'Italia, Volume quarto: Dall'Unità a oggi, 3, Torino, Einaudi, 1976, p. 1712.

${ }^{78}$ Leo XIII, Rerum novarum, cit., para 2.

${ }^{79}$ Ibid., para 38.

${ }^{80}$ Ibid., para 39.

${ }^{81}$ Ibid., para 42.

${ }^{82}$ Ibid., para 3.

${ }^{83}$ Ibid., para 47.

${ }^{84}$ Ibid., para 15.

${ }^{85}$ Ibid., para 48.

${ }^{86}$ Ibid., para 54. 
sociologist Giuseppe Toniolo ${ }^{87}$ who, by idealizing the rural life and corporatism of the Middle Ages, tried to find Christian solutions to contemporary problems without duly considering factors governing the operation of modern economies. Nevertheless, Rerum novarum, which condemned both laissez-faire liberalism and the revolutionary belligerence of socialism, represented the first positive move by the Catholic Church towards staking out a social and political role in modern Italy.

In Liberal Italy the working classes and the left-wing parties were not the only threat to political stability. Especially in the first two decades of the twentieth century the Nationalists became an increasingly destabilizing element. They drew support from various sections of society and, as Ronald S. Cunsolo observes, from a significant Catholic faction, known as the Clerical-Moderates, ${ }^{88}$ who "privately... judged the end of the temporal power to be a blessing for Church and state", 89 and "believed that the Liberal, monarchical state was under siege by Socialists, Republicans, and Radicals”. ${ }^{90}$ The Clerical-Moderates, and many other Catholics, warmly supported the Libyan war in 1911-12, which enhanced contact between the Nationalists and the Clerical-Moderates. Ideologically these groups had a lot in common:

Neither was the kind of society willed by the Nationalists to be identified exclusively with civil rights, or with inter-class rivalry, redistribution of wealth, egocentric individualism, labor-management animosity, but by duties, patriotic service, gerarchia (rank), institutional reverence, respect for family and national traditions. The highly admired thinker Toniolo and [politicians] Meda, Cornaggia, and other notable conservative Catholic personalities shared a paternalistic outlook toward government and society strikingly akin to that of the Nationalists. $^{91}$

The Nationalists and the Clerical-Moderates cooperated to mutual advantage at the 1913 elections, and both saw the brutal violence of the Red Week (6-11 June 1914) ${ }^{92}$ as "an indictment of Giolitti, the ruling classes, and the Liberal regime”. ${ }^{93}$ Finally the Catholic

87 Paolo Pecorari, “Toniolo, Giuseppe”, in Francesco Traniello e Giorgio Campanini (a cura di), Dizionario storico del movimento cattolico in Italia 1860-1980, II: I protagonisti, Torino, Marietti, 1982, pp.636-644.

${ }^{88}$ Cunsolo, "Nationalists and Catholics in Giolittian Italy”, cit., p. 25.

${ }^{89}$ Ibid., p. 26.

${ }^{90}$ Ibid.

${ }^{91}$ Ibid., p. 34.

92 On p. 180 of Modern Italy 1871-1995, cit., Clark writes that in early June 1914 "there was yet another 'proletarian massacre', when three anti-militarist demonstrators were killed at Ancona ... The syndicalists, Republicans and anarchists protested furiously; the Directorate of the Socialist Party proclaimed a general strike ... There were riots and demonstrations in most major cities, and some small towns in Romagna and the Marches were taken over by insurgents. Railway stations were seized, telephone wires cut, taxregisters burned, and trees of liberty planted."

${ }^{93}$ Cunsolo, "Nationalists and Catholics in Giolittian Italy, cit., p. 48. 
politician Filippo Meda's endorsement of World War I as “our war” vindicated the Nationalist view "that Italian Catholics had become a constituent element of the kingdom”.94

It was these Catholic elements with Nationalist affinities which would be drawn to fascism when Benito Mussolini came into power in 1922. Yet, "fascism was instinctively anti-clerical”, and its intellectual ancestry - the Futurists, Friedrich Nietzsche and Georges Sorel - was "implacably hostile to the Church". ${ }^{95}$ Although imbued with anti-clericalist values from birth, Mussolini must have realized that he would not be able to crush the Catholic Church and consequently "became attracted to the idea of a Church that would be gradually, almost imperceptibly transformed into an instrumentum regni". ${ }^{96}$ Accordingly, just a few months into his Prime Ministership, Mussolini not only asserted that he was a Catholic but also declared that the Catholic faith must stay the State religion. ${ }^{97}$

The Catholics themselves were by no means a single, monolithic block with the same set of values and aspirations. To the right stood those middle-class Catholics who detested violence and were frightened of the working-class militancy experienced especially during the Biennio rosso (1918-1920). Wanting to have law and order maintained and their own property protected, they were ready to join the fascist ranks. At the opposite end - as will be discussed in a later section - there were the remnants of the Christian democratic movement who at no point were attracted to fascism. The majority of Catholics occupied the middle ground, "substantially lacking any political orientation". 98 While in the provinces Catholic societies were disbanded and priests were subjected to beatings by fascist thugs, at an official level the fascist government made a number of conciliatory gestures which included compulsory religious teaching at schools, restoration of churches damaged in the war, restitution of crucifixes in the Rome General Hospital, broadening the ambit of clerical stipends, and exemption of ecclesiastics from military service. ${ }^{99}$ Friendly overtures were not lacking from the Catholic side either. As early as March 1923 Monsignor Paino, Archbishop of Messina, apparently with the blessing of the Pope, paid homage to Mussolini:

\footnotetext{
${ }^{94}$ Ibid., p. 52.

${ }^{95}$ Jemolo, Church and State in Italy 1850-1950, cit., p. 184.

${ }^{96}$ Ibid., p. 187.

${ }^{97}$ R.J.B. Bosworth, Mussolini's Italy, London, Penguin Books, 2006, p. 187.

98 Jemolo, Church and State in Italy 1850-1950, cit., pp. 188-189.

${ }^{99}$ Ibid., pp. 204-205.
} 
I feel it my duty to send my greeting also to him who is leading Italy along the right road, to him who is imbuing the Nation with new vigour - I mean, to the Head of the Government. ${ }^{100}$

The Catholic Church would have proved a formidable opponent, had Mussolini not chosen the path of rapprochement. Mussolini's readiness to compromise was made easier by the willingness of the Church to meet him halfway. Even with the excesses of the squadristi against Catholic institutions in the 1924-6 period, official denunciations were muted compared with the outbursts of anger over property confiscations after 1861. After three years of negotiations, the Papal Secretary of State, Cardinal Pietro Gasparri, and Mussolini ultimately signed, on 11 February 1929, three documents known as the Lateran Pacts (a treaty, a financial convention and a concordat) which for the first time since Unification regularized the relations between Church and State. ${ }^{101}$ The substantive issues on which agreement was reached included: the abrogation by Italy of the Law of Guarantees and the recognition of the temporal power of the papacy in the form of a miniature, neutral Vatican City State; the declaration of the Roman Catholic religion as the "sole religion of the State"; ${ }^{102}$ the definite and irrevocable resolution of the Roman Question; the recognition by the Church of the Kingdom of Italy; financial compensation to the Church for its losses after 1861; regulation of relations between Church and State; the Pope's prerogative to veto political and religious activities of which he disapproved; removal of apostate or censured priests from positions "in immediate contact with the public"; ${ }^{103}$ and recognition of "the sacrament of marriage as regulated by canon law”, whereby legalization of divorce was ruled out. ${ }^{104}$ As Martin Clark correctly observes, the most important provision of the agreements was the guarantee that the lay Catholic organizations, known as Catholic Action, would be permitted to continue their existence, since this ensured the Church's continued social - and political - influence on the Italian population. ${ }^{105}$ The Lateran Pacts were undoubtedly one of Mussolini's greatest victories, enhancing his prestige

\footnotetext{
${ }^{100}$ Ibid., p. 204.

${ }^{101}$ Seton-Watson, Italy from Liberalism to Fascism, cit., p. 704.

102 On p. 36 of "Church and State in Italy: The Constitutional Issues”, International Affairs, v.35, no. 1, Jan. 1959, Guido Calogero observes that, although the Roman Catholic religion was recognized by the Kingdom of Italy as the sole religion of the State, "this principle had been tacitly recognized as no longer valid throughout the whole history of liberal Italy after the unification".

103 On p. 37 of ibid. Calogero mentions that "this article was adopted in order to oust Professor Ernesto Buonaiuti, a priest who had been excommunicated for his 'modernistic' views, from his Chair of History of Christendom at Rome University”. Soon Mussolini was "terrified” to find out that very many teachers and professors in Italy were in fact defrocked priests. He then stated that the article would not be applied retrospectively. The only person affected by it was Buonaiuti.

${ }^{104}$ Seton-Watson Italy from Liberalism to Fascism, cit., pp., 704-705.

${ }^{105}$ Clark, Modern Italy 1871-1995, cit., p. 255.
} 
abroad and his political stature at home. For the Catholic Church the outcome was more ambiguous. Although it gained the assurances it had sought since Unification, they came at the price of tighter government control over its senior ecclesiastical appointments. $^{106}$

\section{$\underline{\text { The Catholic System }}$}

The official policy of the Catholic Church reflected the background of its leaders in the Vatican. In post-Unification Italy positions in the upper echelons of the Church continued to be held by clerics originating from the aristocracy or the upper middle classes and, with one exception, the incumbent popes in the first half of the twentieth century fitted this bill. Leo XIII (1878-1903), or Vincenzo Gioacchino Pecci, was born in Carpineto Romano, Lazio, to Count Lodovico Pecci; Benedict XV (1914-1922), or Giacomo Della Chiesa, who prior to his elevation to the papacy had acquired a doctorate in law, was the son of the Genoese Marquis Giuseppe Della Chiesa; and Pius XI (1922-1939), or Achille Ratti born in Desio, Alta Brianza, was the son of Francesco Ratti, manager and, later, co-owner of two spinning factories. The exception was Pius X (1903-1914), or Giuseppe Melchiorre Sarto, who was the son of postman Giovanni Battista Sarto from Riese, Treviso. ${ }^{107}$

Socially and politically the popes were conservative, and in matters of dogma they could hardly be regarded as innovative, looking back to the Middle Ages as they were with Leo XIII's reaffirmation of Thomas Aquinas as doctrinal authority and with Pius X's subsequent confirmation of this act on the occasion of the six hundredth anniversary of Aquinas's canonization. Leo XIII recognized that the papacy no longer carried the political clout which had underpinned its relations with absolute monarchs, but he also understood that there was a need for an active involvement of the Catholic laity in the vast processes of change in civil society and the economy. ${ }^{108}$ Pius X carried out a series of substantial internal reforms in the Church and took steps towards a rapprochement

\footnotetext{
106 On p. 36 of "Church and State in Italy", cit., Calogero writes: “According to Article 19 of the Concordat, the Church cannot appoint a bishop or an archbishop without previously asking for the agreement of the State; according to Article 20, bishops, before taking over their dioceses, must take an oath of allegiance to the Head of the State; and according to Article 21, even the bestowal of ecclesiastical benefices is something which the Church cannot do without previous agreement with the State”.

${ }^{107}$ Francesco Malgeri, "Leone XIII", in Enciclopedia dei papi, v. 3, Roma, Enciclopedia Italiana, 2000, pp. 575-593; Maurilio Guasco, “Pio X, santo”, in ibid., pp. 593-608; Gabriele De Rosa, "Benedetto XV”, in ibid., pp. 608-617; Francesco Margiotta Broglio, "Pio XI”, in ibid., pp. 617-632.

${ }^{108}$ Malgeri, “Leone”, cit., p. 584.
} 
with the State by relaxing, in 1904, the application of the non expedit in some electorates to prevent a socialist victory. He is best known, however, for his condemnation of the modernist movement which endeavoured to interpret the teachings of the Church in the light of contemporary philosophy and science. ${ }^{109}$ Benedict XV, on the other hand, tried, unsuccessfully, to mediate between the world powers to avert the outbreak of World War I, and condemned, in his encyclical Ad beatissimi (1914), nationalistic egoism, racist hatred and class struggle. ${ }^{110}$ He put an end to modernist controversies, and abolished the non expedit, which led to the establishment, in 1919, of a party with strong Catholic sympathies, the Partito popolare italiano. ${ }^{111}$ The great achievement of Benedict's successor, Pius XI, was the resolution of the Roman Question in 1929, which gave the Church an enhanced presence in Italian society. However, commonality of interests with the totalitarian states Germany, Italy and Spain led the Vatican to consider them as mutual allies against liberalism, rationalism, atheism, socialism and communism and to close its eyes to the injustices endemic to totalitarianism. $^{112}$

Outside the ecclesiastical hierarchy, the faithful adhered to a Catholic lay movement, known as Catholic Action, which the Church endeavoured to retain untainted by liberal ideas. Despite its "unquestioning devotion to the Pope" and "total submission to ecclesiastical authority”, Catholic Action was essentially a forward looking organization aiming to reconquer Italy for Christianity. ${ }^{113}$ The first nationwide organization for the Catholic laity - as will be discussed in greater detail in Chapter Two - was established at a congress in Venice in 1874, and it came to be known as the Opera dei congressi $e$ dei comitati cattolici in Italia. Under Leo's papacy the Opera enjoyed relative freedom, which led to the development, under its umbrella, of a Christian democratic movement. Pius $\mathrm{X}$, on the other hand, regarded the lay movement in its existing form as a threat to his own authority and to the Church's unity, disbanding it in June 1904, which also spelled an end to Christian democracy. ${ }^{114}$ He re-established Catholic Action the following year in a new format under tighter ecclesiastical control.

\footnotetext{
109 Guasco, “Pio X, Santo”, cit., p. 598.

${ }^{110}$ De Rosa, “Benedetto XV”, cit., p. 609.

111 Ibid., p. 615.

112 Margiotta Broglio, “Pio XI”, cit., p. 625.

113 Seton-Watson, Italy from Liberalism to Fascism, cit., p. 60.

114 On p. 147 of Modern Italy 1871-1995, cit., Clark writes: "The Vatican worried that if lay Catholics were too successful in political and social affairs, they might be less willing to accept Papal directives, and above all might begin to regard the Roman question as irrelevant. In July 1904 Count Grosoli, president of the Opera dei congressi, annoyed the new Pope, Pius X, intensely by claiming that the
} 
These developments left the supporters of the Christian democratic movement in disarray. Some, like Filippo Meda, seized the opportunity to enter politics and urged others to take full advantage of the relaxation of the non expedit. ${ }^{115}$ Among the very few former Christian democratic leaders to rebel against the Pope's directives was Romolo Murri who - as will be discussed later - went on to set up his own organization, the Lega democratica nazionale, in the hope of laying the foundations of a mass Catholic party. The Church's response to Murri's action was to forbid priests to join the Lega, and some time later Murri himself was defrocked. ${ }^{116}$ Another dissenting leader was Luigi Sturzo who, on the one hand, "foresaw that the consequences of the ClericalModerate policy would be to dilute and distort the Catholic political programme and turn Catholic deputies into Giolittian askaris” but who, on the other, had no sympathy with Murri's “theocratic aim of committing a 'modernised' church to a particular political and social programme". ${ }^{117}$ After World War I Sturzo would gather the remaining strands of Christian democracy into his Partito popolare italiano which, while based on Christian principles, was an autonomous, non-confessional, lay party. For these very reasons as well as its leftist orientation, the Partito popolare never enjoyed the full blessing of the official hierarchy of the Church, and after 1922 it began to appear to the ecclesiastical hierarchy as merely a hindrance to good relations between Church and State. ${ }^{118}$

\section{$\underline{\text { Women and the Risorgimento }}$}

In the period up to World War II Italian women did not play any significant part in national politics and had only a limited role in society. Yet, earlier on, unlike most of his contemporaries, Giuseppe Mazzini had recognized women's potential, dealing with the role of women in society, albeit briefly, in Chapter VI, "Doveri verso la famiglia” of his treatise Dei doveri dell'uomo. ${ }^{119}$ The family is at the heart of the nation - says

Catholics were 'anxious that the work of the living should not be impeded by dead issues'. Pius dissolved the Opera dei congressi two weeks after Grosoli's blunder."

${ }^{115}$ Ibid., pp. 275-276.

${ }^{116}$ Ibid., p. 276.

${ }^{117}$ Ibid., pp. 276-277.

118 On pp. 187-188 of Mussolini's Italy, cit., Bosworth writes: "Early in the new year Mussolini met secretly with Cardinal Pietro Gasparri, the Papal Secretary of State... and, by July 1923, Vatican pressure had persuaded the priest Luigi Sturzo to retire from the leadership of the PPI. Then and thereafter, nothing was done by the Church to save this party from dissolution".

${ }^{119}$ Giuseppe Mazzini, Dei doveri dell'uomo/Fede e avvenire, a cura di Paolo Rossi, 2. edizione, Milano, Mursia, 1972, pp. 66-72. 
Mazzini - and in the family woman has a special role as an angel who infuses life with grace, sweetness and love, and alleviates pain and the burden of duties. Before God - it is stressed - men and women are equal, and while the Old Testament says that God created man, and from man a woman, the Bible will say in future: God created mankind, manifested in woman and man. Mazzini emphasizes the equality of the two sexes urging his readers to respect woman, not merely seeking in her consolation, but also seeing in her a source of inspiration as well as of moral and intellectual energy. Importantly, Mazzini tells his readers to abandon any notion of their own superiority regarding women. Women's alleged intellectual inferiority, due to poor education and perpetual oppression by law, he claims, cannot be used as an argument to keep them permanently oppressed. Oppressors, after all, always base their argument on conditions which they have created themselves. Men and women are not unequal, states Mazzini, but, as often is the case with two men, there are differences in inclinations and special vocations.

“During Italy's century of political upheaval, women's roles expanded in both theory and practice” - observes Judith Jeffrey Howard - and through Mazzini the traditional female image was politicized:

Giuseppe Mazzini’s revolutionary republicanism ... placed women at the center of a most radical vision for a new society. Essentially, Mazzini contributed to the feminist version of the patriot mother ideal by politicizing the "angel of the hearth”, transforming the passive, domestic paragon of traditional religion and morality into a maternal anticlerical revolutionary in her own right, companion and mother to men and women who shared her ideals. ${ }^{120}$

Both Mazzini and Garibaldi valued women for their patriotic contributions in their roles as "fundraisers, nurses, couriers, confidants, soldiers, and martyrs". ${ }^{121}$ Garibaldi would be able to remember his Brazilian-born wife Anita as a fellow combatant who died in the cause of the Risorgimento ${ }^{122}$ while Mazzini and Cavour received their first patriotic lessons from their own mothers. ${ }^{123}$ The most prized position among the patriot mothers went to Adelaide Cairoli who lost four sons as fighters for the Risorgimento, with her fifth son Benedetto, later to become Prime Minister, remaining crippled for life.

\footnotetext{
${ }^{120}$ Jeffrey Howard, “Patriot Mothers in the Post-Risorgimento”, cit., p. 239.

121 Ibid.

${ }^{122}$ Anthony Valerio, Anita Garibaldi, Westport, Conn., Praeger, 2001.

${ }^{123}$ Ginevra Conti Odorisio, Storia dell'idea femminista in Italia, Torino, ERI, 1980, p. 106.
} 
Garibaldi likened Adelaide's sacrifice to the heroic feats of the past: "La Grecia ebbe $i$ suoi Leonida, Roma antica i suoi Fabii e l'Italia moderna i suoi Cairoli”. ${ }^{124}$

The effect of women's participation in revolutionary activities was to lift them from their domestic role as "angels of the hearth" and to engage them in the political issues of the day. This also enabled them to come into contact with other women. "The boundaries between political activity and private life blurred”, argues Judith Jeffrey Howard, and

After Unification, many women participants turned the political networks they had developed and the political experiences they had gained toward raising Italian women's status in both public and private life. ${ }^{125}$

Jeffrey Howard demonstrates the extent of this contribution by following the careers of four women, Erminia Fuà Fusinato, Aurelia Cimino Folliero de Luna, Sara Nathan, and Gualberta Alaide Beccari. ${ }^{126}$ After active participation in the Risorgimento, these women were able to forge post-Risorgimento careers, but they were admirable exceptions, and their overall impact on women's status in post-Unification Italy may not have been quite as significant as Jeffrey Howard implies.

With their emphasis on the need to improve women's education and to grant women political rights to enable them to better discharge their function as mothers, the four women advocated many of the issues later taken up by feminists, while Beccari herself belonged to the first generation of feminists. So did Anna Maria Mozzoni, another Mazzinian, and a contributor to Beccari's periodical, La Donna. Originating from a wealthy upper middle-class family, Mozzoni was the most important Italian feminist in the nineteenth century, deriving her feminist ideas from a variety of contemporary cultural influences which included the writings of Claude Henri Comte de Saint-Simon,

\footnotetext{
${ }^{124}$ Antonio Spinosa, Italiane: il lato segreto del Risorgimento, Milano, Arnoldo Mondadori, 1994, p. 118.

125 Jeffrey Howard, "Patriot Mothers in the Post-Risorgimento", cit., p. 237.

${ }^{126}$ See ibid., pp. 244-252, for biographies of these four women.

Erminia Fuà Fusinato, after Unification, was appointed to the post of school inspector for Rome and Naples, and also worked as a professor of literature at the women's normal school in Rome, as director of the women's college (Scuola Superiore) there, and as founder of the Society for Women's Higher Education.

Aurelia Cimino Folliero endeavoured, among other things, to introduce agricultural education for women, including a school for orphan girls at Cesena.

Sara Nathan, on her return from exile in London, set up a Mazzinian school, which excluded religious instruction, for working-class girls in Rome with the aim of making the girls self-supporting workers. Gualberta Alaide Beccari is known above all as founder and editor of the important women's journal $\mathrm{La}$ Donna, which commenced publication in 1868 and drew contributions exclusively from women. See also Beatrice Pisa, Venticinque anni di emancipazionismo femminile in Italia: Gualberta Alaide Beccari e la rivista “La Donna” (1868-1890), Roma “Elengraf”, n.d.
} 
François Marie Charles Fourier, John Stuart Mill, and Karl Marx. Mozzoni’s feminist career started in 1864 with the publication of the treatise La donna e $i$ suoi rapporti sociali (Woman and Her Social Relations), which was followed by her translation into Italian, in 1870, of John Stuart Mill's The Subjection of Women.

These educated Mazzinian women came from the Risorgimento élite, and their lives and careers cannot be regarded as being representative of those of the majority of Italian women at the time. As Ginevra Conti Odorisio points out, the unification of Italy was the overriding and exclusive preoccupation of the cultural Risorgimento élite in the Restoration period ${ }^{127}$, and this would have precluded any thought being given to women's emancipation. The restoration of the ancient monarchical institutions after the Congress of Vienna in 1814-15 brought in its wake the reinstatement of administrative rules and practices which severely restricted women's juridical capacity, totally eliminated their economic independence, and created a cultural climate hostile to even the slightest improvement or reform. ${ }^{128}$ In the Romantic literature woman was accorded the inspirational function of a muse, but in the philosophical writings of Antonio Rosmini and Vincenzo Gioberti, more prosaically, that of the good mother of a family. Rosmini, a priest, philosopher and religious reformer, writes in his Filosofia del diritto that the dependent condition of a woman with respect to her husband is a natural situation, and therefore it would be absurd to speak of parity, or to try to introduce democratic principles into the ambit of the family. While man has the qualities of vigour, energy and rationality which make him suited to take the lead, woman has the necessary timidity and docility to obey man and to satisfy his inclinations. Accordingly, her existence should be confined to seclusion within the family, and her external activities should be limited in order not to arouse in other men illicit desires and in her husband justified jealousy. ${ }^{129}$ A similar attitude to women was also professed by the above-mentioned Vincenzo Gioberti, a neo-Guelph priest who became a deputy, senator and, ultimately, Prime Minister of Piedmont. Gioberti's position did not diverge from the traditional Catholic view of women as being complementary to men, which, although conceding in theory moral parity to women, stressed the difference in their roles and functions. The "Jacobinism" of Gioberti towards women, writes Conti Odorisio, was "nothing but the umpteenth version of [their] dependence and inferiority

\footnotetext{
${ }^{127}$ Conti Odorisio, Storia dell'idea femminista in Italia, cit., p. 101.

${ }^{128}$ Ibid., p. 113.

${ }^{129}$ Ibid., p. 115.
} 
...perhaps without misogyny, if this can be seen as progress”. ${ }^{130}$ There can be no doubt, however, about Gioberti’s underlying sentiments about women as parasites:

La femminilità... risiede per contro in una natura incoata e confusa che non erompe in riflessione, e non si estrinseca che sotto la forma istintiva del sentimento; onde la donna si sente debole, bisognosa di appoggio e di aiuto: il suo amore è un abbandono, che ella fa di se medesima a un essere più forte che la protegge [...] per cui alcuni antichi chiamarono la donna un uomo dimezzato ... La donna, insomma, è in certo modo verso l'uomo ciò che è il vegetabile verso l'animale, o la pianta parassita verso quella che si regge e sostenta da sé. $^{131}$

As a counterpoint to the previously discussed Mazzinian women, Caterina Franceschi Ferrucci provides an example of a woman who came from the Giobertian Catholic environment. Far from being oppressed, according to Franceschi Ferrucci, women in civil society had the post that was their due. Moreover, it was pointless to speak of emancipation because the gospel had bestowed equal dignity on all human beings. While men went about their public and private business, women managed the home in order to provide good and useful citizens to the State. ${ }^{132}$ The merit of the works of Franceschi Ferrucci, writes Conti Odorisio, is to highlight the nineteenth century bourgeois ideal of the buona madre di famiglia:

... donna operosa e saggia, sufficientemente istruita, ma con il pensiero mai teso agli studi, ciò che genera pedanteria e superbia, ma all'educazione dei figli e all'andamento della casa, costante ispiratrice di nobili azioni, esempio vivente di ogni virtù, prima fra tutte della rinuncia. ${ }^{133}$

An interesting corollary to this is that even Franceschi Ferrucci managed to incur the censure of the Jesuits by suggesting in her books Della educazione morale della donna italiana and Degli studi delle donne italiane that it was necessary for women to receive some education in order to participate in their husbands' lives. In the eyes of La Civiltà cattolica, teaching girls to read set a dangerous precedent and was to be condemned. ${ }^{134}$

The acquiescent Caterina Franceschi Ferrucci did not see any need for improving women's social position. Neither she nor the politically more aware Mazzinian women were called on to contribute to the drafting of the 1865 Italian Civil Code which defined

\footnotetext{
${ }^{130}$ On p. 114 of ibid. Conti Odorisio writes: 'Il 'giacobinismo' di Gioberti nei confronti della donna non è che l'ennesima versione della dipendenza e dell'inferiorità della donna, forse senza misoginia, se questo può costituire un progresso".

${ }^{131}$ Quoted in ibid., p. 115.

${ }^{132}$ Ibid., p. 116.

${ }^{133}$ Ibid., p. 117.

${ }^{134}$ Ibid., pp. 117-118.
} 
the social status of women. ${ }^{135}$ Emilia Sarogni sees in the code the influence of two discrepant perceptions of woman and family; on the one hand, the code was rooted in the ancient Roman and Germanic laws and, on the other, it was inspired by the liberal and democratic ideas of the Enlightenment. ${ }^{136}$ Traditionally women were subordinated to their family's overall interests, and it was not until the Enlightenment that the concept of family began to lose its political and economic implications to be seen primarily as a community of affection. However, as far as women were concerned, the hopes raised by the French Revolution were quashed, and even though the Napoleonic Code subsequently structured the family in a more modern fashion, it still centred the authority on father and husband. Woman did, however, acquire greater patrimonial rights with respect to her original family, but these became limited upon marriage when she would be subject to her husband's authority. The Restoration codes showed even greater indifference towards the innovative thinking of the Enlightenment and subordinated women to their father's authority (up to the age of thirty or forty, or for the whole life) and upon marriage to the authority of the husband. ${ }^{137}$ Women could do very little with their property and, even when widowed, they would not have patria potestas $^{138}$ over their children. The most liberal rules were those of the Lombard provinces which, originating from the Austrian Civil Code, did not require marital authorization for the wife's juridical acts.

\section{Women in Liberal and Fascist Italy}

\section{$\underline{\text { Legal Status }}$}

In the preparatory work for the 1865 Civil Code there were two major areas of disagreement, namely, patria potestas and women's property rights. In the eyes of the more conservative legislators, the family constituted a miniature monarchy with the father wielding the powers of a king: quilibet in domo sua dicitur rex. ${ }^{139}$ However, as Sarogni observes, some innovative thinking had found its way into the draft, in the form of bestowing patria potestas on both parents and granting women the right to administer

\footnotetext{
135 Anna Maria Mozzoni responds to the new civil code with the publication of La donna in faccia al progetto del nuovo codice civile italiano, Milano, Tipografia Sociale, 1865, comparing discrimination against women to racism. The treatise is reprinted in Anna Maria Mozzoni, La liberazione della donna, a cura di Franca Pieroni Bortolotti, Milano, Gabriele Mazzotta, 1975, pp. 91-99.

${ }^{136}$ Emilia Sarogni, La donna italiana 1861-2000. Il lungo cammino verso i diritti, 2. edizione, Milano, NET, 2004, p. 9.

${ }^{137}$ Ibid., pp. 14-15.

${ }^{138}$ Patria potestas means the power of a father over his children and descendants.

${ }^{139}$ Sarogni, La donna italiana, cit., p. 15.
} 
their own property. Later the Minister of Justice, Giuseppe Pisanelli, compromised on the issue of patria potestas by interpreting it as belonging to the father during marriage and to the mother only if the father was incapacitated or upon his death. In the final version of the code even women's right to administer their own property was withdrawn, and the only limitation to the husband's powers over his wife's property was its inalienability. Pisanelli himself expressed regret for this outcome:

È indubitato che la donna ha e deve avere la capacità di amministrare e disporre della propria fortuna, ed è parimenti certo che il matrimonio non può avere per se stesso l'efficacia di privare i coniugi della disponibilità dei loro beni... ${ }^{140}$

There was one area, however, where the Pisanelli Civil Code of 1865 brought an improvement for women. The law stipulated that both sexes attained majority at twenty-one, and women no longer required paternal consent for matrimony. However, in a situation in which women had limited juridical capacity and no economic independence, strong parental pressure could be applied to daughters, limiting their freedom of choice. ${ }^{141}$

Apart from restrictions imposed on the exercise of patria potestas and the exclusion of women from the administration of their dowry, the civil code contained further limitations which decreed that the wife would be obliged to follow her husband anywhere he wished to set up his residence; would assume the husband's name and civil status; would be subject to the husband's authority; would not be able to perform on her own any important juridical act even with regard to her own property; would not be able to testify; and would not be part of the family council.

There was a host of other disadvantages which the law inflicted on women. According to the 1889 penal code a woman would be punished for adultery with imprisonment between three and thirty months while her husband would receive a similar punishment - for what would appear a much graver offence - for keeping a lover in the conjugal house (una concubina nella casa) or notoriously elsewhere (notoriamente altrove). ${ }^{142}$ A woman's adultery would endanger the certainty of paternity of the offspring and the honour of the family. For this reason, in the case of adultery, the husband had the right to ask for legal separation whereas the wife could do so only if the husband forced her

${ }^{140}$ Ibid., p. 19.
${ }^{141}$ Ibid., p. 21.
${ }^{142}$ Ibid., p. 97. 
to live with his lover. ${ }^{143}$ Women could be accused of adultery on the flimsiest of evidence and the interpretation of the law could at times produce astonishing outcomes. For instance, in 1903 the Supreme Court of Cassation ruled that adultery could only be committed by a woman, and this would be the case even if the man "lacked, through amputation, his male organ”, ${ }^{144}$ since for a married woman, “any encounter with a man other than her husband" could be regarded as adultery. ${ }^{145}$

Divorce and acknowledgment of natural children were two family law issues which generated a great deal of public interest and debate in the early years of the twentieth century. Women were uncertain as to the benefits they would derive from the legalization of divorce, and most were opposed to it. Attempts by Socialist parliamentarians to enact divorce legislation proved unsuccessful. According to Liberal parliamentarians Scalini and Salandra, public opinion in Italy was not yet ready for that reform and predictably the Catholic Church was opposed to it. On the other hand, proposals to enforce paternity tests had won Catholic support but pertinent legislation never saw the light. ${ }^{146}$

Under Mussolini women appeared to be punished relatively leniently for adultery, since heavier penalties were to be imposed on adulterous husbands than wives. In the royal decree of 19 October 1930 punishment was doubled for men in cases of adultery albeit for crimes committed in somewhat different circumstances. Whereas women would be punished by imprisonment for up to one year for a single act of adultery, men would be punished for up to two years for stable, extra-marital relationships which involved keeping a lover in the home or "notoriously elsewhere". ${ }^{147}$ In the same year the regime also introduced a new category of crime into the penal code, which was crime committed for an honour motive. It would be punishable by a relatively lenient sentence ranging from three to seven years for anyone who reacted violently causing death on the discovery of an illegitimate carnal relationship of wife, daughter or sister. $^{148}$

\footnotetext{
${ }^{143}$ Mariolina Graziosi, La donna e la storia, Napoli, Liguori, 2000, p. 11.

${ }^{144}$ Quoted in Clark, Modern Italy 1871-1995, cit., p. 164.

145 Zappi, If Eight Hours Seem Too Few, cit., p. 249.

${ }^{146}$ Sarogni, La donna italiana, cit., p. 99.

${ }^{147}$ Ibid., p. 147.

${ }^{148}$ Ibid., p. 148. Sarogni points out that the concept of "crime committed for an honour motive” remained in the Italian penal code until 5 August 1981.
} 
The key indicator of women's lack of juridical independence remained the requirement for marital authorization. Under the law a married woman needed her husband's authorization for any commercial decision or for any "public act”, be it only taking out a subscription to a newspaper. ${ }^{149}$ In an attempt to remove this obnoxious law from the statute books, two bills were presented to parliament, one by Deputy Carlo Gallini in 1910 and the other by Senator Scialoja in 1912. Of the two proposals Gallini's was more far-reaching, concerning not only marital authorization but also a number of other women's issues, including the vote for women in administrative (local) elections, and admission of women to all public service positions and the liberal professions. ${ }^{150}$ It would take a few more years before women were granted these rights, except for the vote in local elections, in recognition of the role they had played during World War I when they had taken upon themselves responsibilities outside the family and substituted for men in various jobs. Finally, on 17 July 1919, the rights foreshadowed by Gallini's proposal were granted to women by the so-called Sacchi law. However, scarcely half a year later, on 4 January 1920, the regulations governing the enforcement of the act listed numerous higher level public service positions for which employment of women was precluded. ${ }^{151}$ Subsequently, in 1923, the Mussolini regime decreed that, with the exception of war widows who had not remarried and sisters of the fallen, all women appointed to public service positions during the war were to be dismissed. ${ }^{152}$ Ultimately also the rights which women had gained in the family law would be lost in 1931 when Mussolini reinstated patria potestas, marital authorization, and the total subordination of women to men. ${ }^{153}$ In November 1933 a royal decree laid down that women were to be excluded from or employed only in limited numbers in the State public service, ${ }^{154}$ and in September 1938 another royal decree ruled that in public administrations (pubbliche amministrazioni) and in private businesses (aziende private) which had less

\footnotetext{
149 Clark, Modern Italy 1871-1995, cit., p. 248.

${ }^{150}$ Sarogni, La donna italiana, cit., pp. 100-101.

151 On pp. 108-109 of ibid. Sarogni writes: "Il regolamento per l'esecuzione della legge sulla capacità giuridica della donna (regio decreto 4 gennaio 1920, n. 39) escludeva le donne dai pubblici impieghi di grado superiore a direttore generale, di ragioniere generale dello Stato, di prefetto, di ministro plenipotenziario di seconda classe e console di prima, di direttore generale delle ferrovie, di commissario e vice commissario generale per l'emigrazione. Ancora nel 1919 le donne erano escluse dal Consiglio di Stato, dalla Corte dei conti, dalla Magistratura, compresi gli impieghi minori, dalla prima categoria dell'amministrazione del ministero dell'Interno, dalla pubblica sicurezza, dall'attività di agenti di custodia, dal personale - anche solo amministrativo - del dicastero per le colonie e dagli altri impieghi a questo collegati, dalla diplomazia, dalle guardie di finanza, dalle forze armate, dal corpo forestale, dal personale navigante delle ferrovie, dai gradi più alti degli impieghi bancari, da gran parte dell'attività ispettiva e dai pubblici impieghi riservati a coloro che possedessero la dignità di grande ufficiale.”

${ }^{152}$ Il Novecento delle italiane. Una storia ancora da raccontare, Roma, Editori Riuniti, 2001, p. 71.

153 Ibid., p. 97: "Vengono ribadite patria potestà, potestà maritale e totale subalternità della donna all'uomo".

${ }^{154}$ Sarogni, La donna italiana, cit., p. 144.
} 
than ten employees no women should be employed in office jobs, while in public offices (uffici pubblici) the proportion of female staff should not exceed 10 per cent. ${ }^{155}$ Women's employment prospects were further restricted by the royal decree in 1939 which contained norms for their recruitment to particular positions in government and private enterprises. ${ }^{156}$

The law imposed special controls on women in the area of prostitution which was rife in Liberal Italy as a corollary to major changes in demography, employment and in the family. As Mary Gibson observes, the lower mortality rate due to improvements in living standards led to a population increase and, as a consequence, to rural unemployment. People seeking employment moved out of their familiar rural communities, and "lacking the outlet of emigration, women competed fiercely for the available jobs in the Italian cities”. ${ }^{157}$ Whereas women and girls had previously worked as members of close-knit peasant and artisan households, they now found themselves without the psychological and financial support of their families. From the outset they came close to being identified with "the dangerous classes", that is, the criminal elements of society:

To middle- and upper-class observers, they were prostitutes - or potential prostitutes - because they did not fit any of the traditional female categories: daughter, mother, wife, or perhaps, nun. ${ }^{158}$

Control of prostitution was one of the earliest priorities of the Italian government, and even before Unification, seeing the debilitating effects of venereal disease on the soldiers in the Turin garrison, Cavour, on 15 February 1860, promulgated a law on prostitution which replaced the existing multitudinous laws and customs with a single statute applicable throughout Italy and which made regulation, instead of prohibition or decriminalization, the official policy. Rather than a crime to be prosecuted by the penal code, prostitution was regarded as a morally and hygienically dangerous vice. The Cavour Regulation legalized prostitution with strict controls imposed on women working in brothels, requiring them to register with police, undergo biweekly health checks and, if necessary, report to special hospitals for treatment for venereal disease.

\footnotetext{
155 Ibid., pp. 144-145.

156 Ibid., p. 145.

${ }^{157}$ Mary Gibson, Prostitution and the State in Italy, 1860-1915, New Brunswick, N.J., Rutgers University Press, 1986, p. 18.

${ }^{158}$ Ibid., p. 20.
} 
Similar restrictions were imposed on brothels, known as case chiuse, since they were closed off from the outside world:

To seal off these brothels, the law stipulated that their windows remain shut, covered with smoked glass in winter and persian blinds in the summer, "fixed and closed to the height of two meters measured from the floor of the room". To prevent communication between outside and inside, prostitutes were forbidden to stand in the windows or doorways of their houses. ${ }^{159}$

Based on the argument that the regulation of prostitution deprived women of their civil rights, there were calls for the "abolition” of prostitution from, among others, Garibaldi, Mazzini, Salvatore Morelli and women from the Mazzinian left: Anna Maria Mozzoni, Sara Nathan, Jessie White Mario, Kate Crawford and Giorgina Crawford Saffi. ${ }^{160}$ Support was also enlisted among lower-class men who saw the virtue of their family under attack by both the Liberal State and middle-class men. ${ }^{161}$ The editor of $L a$ Donna, Gualberta Alaide Beccari, claimed in 1876 that she had obtained signatures from three thousand women calling for the decriminalization of prostitution, while the following year the leading Italian feminist, Anna Maria Mozzoni, attended an international abolitionist congress in Geneva representing two hundred workers' societies spread across Italy. ${ }^{162}$

When, in response to the wide publicity given to the prostitution issue, the new Crispi Regulation came into force on 26 July 1888, it fell short of the demands of the abolitionists. Whereas under the new law the names of individual women could not be recorded, police had the power to keep a register of "places" of prostitution for surveillance reasons. The principle of identifying places and not persons was compromised in the same law by obliging brothel keepers to "supply police with the names and other identifying information about their employees”. ${ }^{163}$ On the other hand, while previously, “any lower-class woman, especially one found alone on city streets in the evening”, ${ }^{164}$ might be arrested on the slightest of evidence, isolated prostitutes could now be arrested only for infringements of the penal code. Furthermore, the new law made treatment for venereal disease free and equal for both sexes, and made it binding

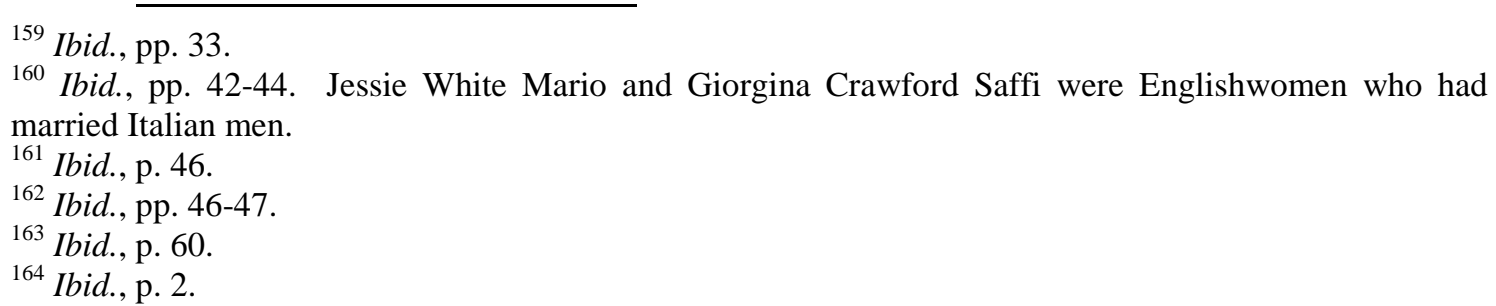


on police to protect women working in brothels and to facilitate their rehabilitation should they wish to leave the brothel. ${ }^{165}$

Inconsistencies in the Crispi law led to confusion in its administration. There was passive resistance on the part of police to its rigorous enforcement, and subordinates directly contravened it. Health Offices found themselves incapable of servicing both the male and female population. Hence very soon, on 27 October 1891, the Crispi law was replaced by the Nicotera Regulation which again legalized the surveillance of single women. The Crispi provision of free and equal treatment for both sexes for venereal disease was retained, with additional resources provided for police to control its spread. ${ }^{166}$ In the 1890s "the innovative and forceful director of public health”, Rocco Santoliquado, a committed abolitionist, campaigned for the separation of police and health functions, which he achieved with the regulation of 27 July 1905, whereby municipal doctors were required to "provide free treatment and drugs for the poor suffering from venereal diseases, just as for poor with other diseases". ${ }^{167}$ However, even though it was no longer possible to arrest prostitutes solely for the purpose of compulsory health checks, police powers remained uncurtailed in other respects. ${ }^{168}$

The abolitionist movement scored its greatest successes when the Italian government became a signatory to two international accords, drafted in 1904 and 1910, to cooperate in the fight against international trafficking in women, through "the exchange of information, immediate extradition of suspected procurers, and free transportation for victims to their country of origin”. ${ }^{169}$ It is interesting to note that at the same time as Italy signed the international accords to alleviate concerns about migrant women, the Liberal government still continued to regard prostitution in the African colonies of Italy as a "necessary public service" rather than an anomaly which should be condemned. ${ }^{170}$

The 1923 Mussolini Regulation returned to the provisions of the Cavour law by obviating the distinction between registering "persons" and "places" and reversed the

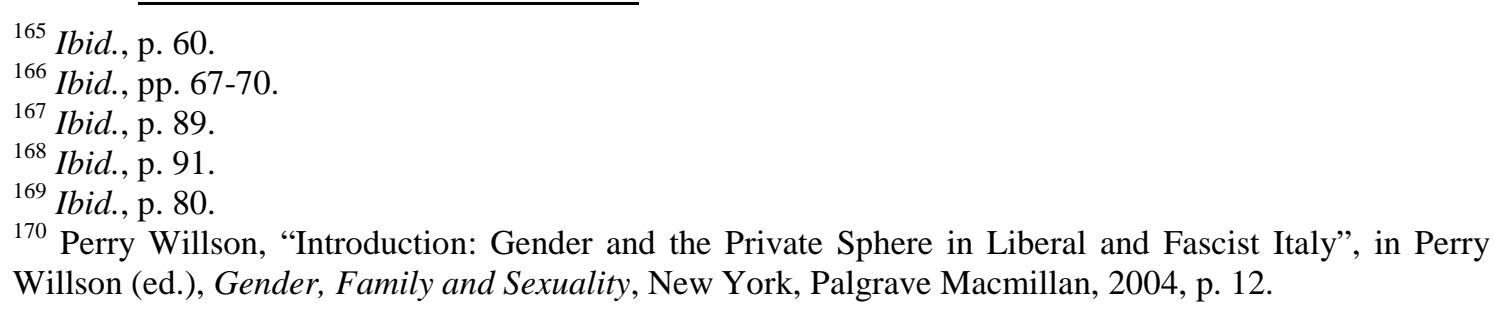


separation of police and health functions. ${ }^{171}$ Italian women would be protected by the law up to the age of twenty-one against being kidnapped and sent to prostitution, while in the case of indigenous women in colonies protection would be up to the age of sixteen. Except by police permission, operation of brothels would be forbidden. “Independent" prostitutes would be required to carry a health certificate or else they would be considered infected and would not be allowed to practise their trade. ${ }^{172}$ Officially, of course, prostitution was not an issue in Mussolini's Italy. Replying to an inquiry by the League of Nations in 1923, Mussolini asserted that "regulated prostitution does not exist in Italy". ${ }^{173}$

\section{Education}

Discrimination against women in the statute books extended to every aspect of their lives. Restricted access to education ensured that they would never occupy an important position in society. As previously discussed, one of the major problems facing the country at Unification was illiteracy and, according to Daniele Marchesini, comparison of the illiteracy rates for 1861 and 1901 shows that, while overall illiteracy declined, a gap of 13 per cent between the male and female illiteracy levels remained constant. ${ }^{174}$ Moreover, even though the Casati Law (1859) decreed that instruction should be equal for both males and females ${ }^{175}$, the educational needs of the two genders were perceived differently:

Le nozioni che si porgono nelle scuole elementari ai fanciulli sono destinate ad essere fondamento degli studi classici e preparazione alle diverse professioni sociali. Ma per il maggior numero delle donne, la cultura intellettuale deve aver quasi unico fine la vita domestica e l'acquisto di quelle cognizioni che si richieggino al buon governo della famiglia, della quale esse deggiono formare l'aiuto e l'ornamento. ${ }^{176}$

The 1877 and 1888 laws, ${ }^{177}$ which, as previously stated, made primary school attendance compulsory for two and three years respectively, were not seriously enforced

\footnotetext{
${ }^{171}$ Gibson, Prostitution and the State in Italy, 1860-1915, cit., p.226.

${ }^{172}$ Il Novecento delle italiane, cit., p.71.

${ }^{173}$ Gibson, Prostitution and the State in Italy, 1860-1915, cit., p .229.

174 Daniele Marchesini, “L'analfabetismo femminile nell'Italia dell'Ottocento: caratteristiche e dinamiche”, in Simonetta Soldani (a cura di), L'educazione delle donne. Scuole e modelli di vita femminile nell'Italia dell'Ottocento, 2. edizione, Milano, Franco Angeli, 1991, p. 41.

${ }_{175}$ Michela De Giorgio, Le italiane dall’Unità a oggi, Roma, Laterza, 1993, p. 411.

${ }^{176}$ Quoted from Istruzioni ai maestri delle scuole primarie sul modo di svolgere i programmi approvati con R.D. 15 settembre 1860, in Marchesini, “L'analfabetismo femminile nell'Italia dell'Ottocento”, cit., p. 45.

${ }^{177}$ Clark, Modern Italy 1871-1995, cit., p. 37.
} 
because, especially in poorer families, children were often needed at home to look after their younger siblings when their mothers were at work. Even after 1904 when the Minister of Education raised the upper age limit for compulsory primary education to twelve years, many children remained at home. Frequently parents hired female children to wealthy families with salaries paid directly to the father and with the children subject to malnutrition, long hours of work, and sexual abuse. ${ }^{178}$

Only a small number of children, less than ten per cent around $1900,{ }^{179}$ received any secondary education at all, and it was common for girls even with middle-class backgrounds to finish school at ten or eleven. Were girls to proceed to secondary education, in most cases they enrolled in convent schools. At State secondary schools the "classical" and "technical” streams were almost exclusively intended for male students. A third stream, the so-called normal schools which trained primary school teachers, was open also for female students, and thus provided women with one of the few opportunities to enter a middle-class occupation. Even after girls' right to enrol at licei (State upper secondary schools) had been legally recognized in 1883, their attendance continued to be an exception: in the academic year of 1901-1902 there was still only one female enrolment to every forty male students. ${ }^{180}$ Nevertheless, especially at lower levels, girls' access to education kept improving. In May 1914, the Minister for Public Education announced at the International Women's Congress that the number of female students at lower secondary schools had reached a hundred thousand. ${ }^{181}$

Many girls, however, received education outside the State school system. In aristocratic and upper middle-class families it was customary for girls to be tutored at home. Quite popular also were boarding schools, educandati, which were in most cases run by Catholic nuns. There was an enormous variation not only in fees but also in academic standards so that while two top schools in Rome enrolled daughters of aristocratic families and, because of their high reputation, even of leftist politicians, others could barely meet the minimum standards of State schools. Since the general purpose of boarding schools was to prepare young ladies for marriage, housekeeping and related skills featured in the syllabus which was also larded with "ornamental” subjects such as piano and harp practice, drawing, dance, French, and sometimes even English and

${ }^{178}$ Il Novecento delle italiane, cit., p. 13.

${ }^{179}$ Clark, Modern Italy 1871-1995, cit., p. 39.

${ }^{180}$ De Giorgio, Le italiane dall'Unità a oggi, cit., p. 435.

${ }^{181}$ Ibid., p. 480. 
German - all these taught and learnt in a dilettante fashion. ${ }^{182}$ The continued domination of convent schools in girls' secondary education was evidenced by the statistics compiled in 1900 by the Ministry of Public Education which showed that while there were 394 convent schools, there were only 149 private non-Catholic and 62 public secondary girls' schools. ${ }^{183}$ The importance of convent schools is highlighted even more cogently by the numbers enrolled in the different categories of secondary education. In 1898 there was a total of 24,335 students enrolled in normal schools, gymnasiums, upper secondary and technical schools, and technical institutions, whereas in convent schools there was by contrast a staggering 95,404 students. ${ }^{184}$

Attendance at liceo, technical school, or acquisition of an equivalent qualification at a non-government school, was essential should a student aspire to tertiary study, but in the case of female students the completion of the lower secondary school did not automatically qualify them for entry into a liceo. Attempts also failed to establish special licei for girls. ${ }^{185}$ Women were admitted to universities from $1874,{ }^{186}$ and between 1877 and 1900, the year when the Ministry of Public Education issued the first statistical compilation of female university graduates, a total of 224 women received degrees. ${ }^{187}$ A large percentage was made up of foreigners and, with one quarter of the total graduates, Turin proved the most popular destination for study. ${ }^{188}$ Very often women who went on to study at university were only children or came from small families, receiving strong support from their fathers, elder brothers, or uncles. ${ }^{189}$ In the early years it was commonly accepted practice for women to attend courses solely as auditors, in which case they did not have any prospects of graduating but only the possibility of acquiring a certificate of attendance, which had no legal validity. ${ }^{190}$ Increasingly, however, women began to enrol with the expectation to graduate, and in the 1915-16 academic year there were 756 female enrolments in arts and philosophy, 36

\footnotetext{
182 Silvia Franchini, “Gli educandati nell’Italia postunitaria”, in Soldani (a cura di), L'educazione delle donne, cit., p. 76.

${ }^{183}$ De Giorgio, Le italiane dall'Unità a oggi, cit., pp. 417-418.

${ }^{184}$ De Giorgio quotes on p. 418 of ibid. from R. Furlani, L'educazione delle donne presso i popoli più civili, Roma, Società Editrice Dante Alighieri, 1903, p. 135: "Infatti mentre nelle scuole Normali avevamo nel 1898 alunne 19.193; nei ginnasi 1.207; nei licei 253; nelle Scuole tecniche 3.577; negli Istituti tecnici 105, cioè un totale di 24.335 alunne, nei monasteri avevamo nell'anno 1899 (...) 95.404 scolare”.

185 Marino Raicich, "Liceo, università, professioni: un percorso difficile”, in Soldani (a cura di), L'educazione delle donne, cit., p. 162.

${ }^{186}$ Zappi, If Eight Hours Seem Too Few, cit., p. 249.

${ }^{187}$ De Giorgio, Le italiane dall'Unità a oggi, cit., p. 462.

188 Ibid.

${ }^{189}$ Ibid., p. 467.

${ }^{190}$ Ibid., p.166.
} 
in law, 593 in the physical, mathematical and natural sciences, 104 in pharmacy, 86 in medicine and surgery, and 35 in engineering. ${ }^{191}$ Notably, despite the fact that women's demands for better education were viewed with suspicion by the Church, Catholic nuns were in the forefront of female education in Italy, being among the first Italian women to obtain university degrees and the first to establish secondary (convent) schools for girls. $^{192}$

Under Mussolini women's access to education, which had gradually improved under Liberal governments, went into reverse. Fascist educators envisaged separate streams for male and female students, with reduced intellectual content for girls whose primary future role was to be a mother. In 1924 the Gentile Reform outlined a special liceo for girls who did not endeavour to proceed to higher studies or to acquire a professional diploma. Since the number of such licei was to be limited to twenty, they were clearly intended for the social élite. ${ }^{193}$ Systemic bias against women meant, as Victoria De Grazia observes, that in 1935 only one out of four students at higher secondary schools (liceo-ginnasi) was a female; one out of seven at scientific licei; one out of ten at industrial schools; and one out of four in commercial and artistic institutes. ${ }^{194}$ Yet women still dominated teaching training institutes, with three out of four students being females. Higher university fees for women, on the other hand, meant tertiary education was available only to female students from wealthy backgrounds. In 1938, observes De Grazia, "four-fifths of all women graduating from the university were crowded into letters and philosophy, the magistero or teachers' college, pharmacy, and to a lesser degree, mathematics and natural sciences”. There were only very few women enrolled in subjects which qualified them for the liberal professions or for positions in government. ${ }^{195}$

\section{Employment}

Entry into professional employment represented another obstacle race. Teaching was the area in which educated women most readily found employment. They were well

\footnotetext{
191 Ibid., p. 480.

${ }^{192}$ Lucetta Scaraffia, “'Christianity Has Liberated Her and Placed Her alongside Man in the Family': From 1850 to 1988 (Mulieris Dignitatem)”, in Lucetta Scaraffia and Gabriella Zarri (eds.), Women and Faith, Cambridge, Mass., Harvard University Press, 1999, p. 261.

${ }^{193}$ Il Novecento delle italiane, cit., p. 75.

194 Victoria de Grazia, How Fascism Ruled Women: Italy, 1922-1945, Berkeley, Calif., University o California Press, 1992, p. 155.

${ }^{195}$ Ibid., pp. 155-156.
} 
represented in primary teaching: by the early 1870s they already made up the bulk of the 45,000 teachers, and by 1901 they constituted two thirds of a total of 97,000 teachers. ${ }^{196}$ The life of female teachers, however, was unenviable since they frequently worked in distant locations without the support of their family; as single women had to put up with the prejudice of the local people; in many cases had to manage classes of a hundred or more students; and were poorly paid. Women's employment prospects in education were widened in 1905 when they were admitted to teaching positions at lower secondary schools and, by the 1920-21 academic year, their number had risen to 7,133 out of a total of 20,742 lower secondary teachers. ${ }^{197}$ Besides, by this time women had become the dominant force in training primary school teachers in normal schools. Including all categories of teaching, in the decade 1911-1921 the number of female teachers increased from 75,251 to 128,266, or from 59 per cent to 70.5 per cent of those employed in teaching. ${ }^{198}$ Under fascism, despite preferment of men, women always made up at least 70 per cent of teachers at lower schools. ${ }^{199}$

Of female university graduates, many hoped to become upper secondary school teachers. However, with their employment restricted to schools with special classes for girls, women working at State upper secondary schools were totally marginalized until World War I. Then the conscription of their male colleagues necessitated women's employment in positions normally occupied by male teachers. After the war, the previously mentioned Sacchi law threw all teaching positions open to women. Nevertheless, with the tightening employment market, women in all walks of life would soon be asked to hand over their jobs to returned soldiers. So in the 1920-21 academic year there were only 136 women (as opposed to 1,076 men) teaching in top professional positions at licei, and the situation was even less encouraging for women at

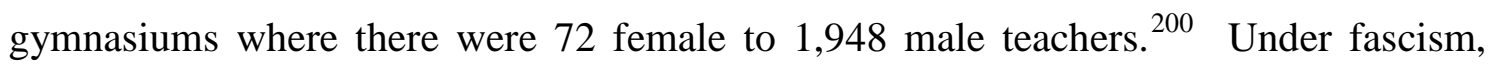
from November 1926, women were barred from teaching Italian, classics, history and philosophy at licei and upper levels at technical schools. There was a compensatory trend to employ women in private teaching, in which, between 1931 and 1936, the total

\footnotetext{
${ }^{196}$ Clark, Modern Italy 1871-1995, cit., p. 34.

${ }^{197}$ De Giorgio, Le italiane dall’Unità a oggi, cit., p. 469.

198 Franca Pieroni Bortolotti, “Osservazioni sull'occupazione femminile durante il fascismo”, in eadem, Sul movimento politico delle donne. Scritti inediti, a cura di Annarita Buttafuoco, Roma, Utopia, 1987, p. 182.

${ }^{199}$ De Grazia, How Fascism Ruled Women, cit., p. 197.

${ }^{200}$ Ibid., pp. 469-470.
} 
number employed increased from 12,587 to 68,176 and the respective percentages for women from 65 per cent to 73.7 per cent. ${ }^{201}$

During the first two decades of the twentieth century women had very few opportunities to enter the liberal professions. Examples of the difficulty women experienced in finding professional employment are the first Italian woman lawyer, Lidia Poët, who was able to exercise her profession only after the previously mentioned Sacchi law of 1919 admitted women to public service positions, and the socialist feminist Anna Kuliscioff, who, being rejected by the Ospedale maggiore di Milano, practised privately for a period as dottora dei poveri. ${ }^{202}$ Another frequently quoted example is that of Teresa Labriola, a graduate in jurisprudence and a university teacher in Rome, who in 1912 was admitted to the Rolls but was struck off a month later on appeal. ${ }^{203}$ The impact of World War I and the Sacchi legislation in 1919 led to an increase of women in higher level professional positions, as shown by census data for the decade 19111921 when the number of women in the category Lettere e scienze applicate rose from 1,053 to $2,212 .^{204}$

Under Mussolini, opportunities for women to reach high ranking professional positions were reduced due to restrictions imposed on their employment. Commenting on women’s employment statistics for 1931, Franca Pieroni Bortolotti observes the paucity of women working at high levels of specialization. The figures below show the restricted access women had to top professional positions:

\footnotetext{
${ }^{201}$ Pieroni Bortolotti, “Osservazioni sull’occupazione femminile durante il fascismo”, cit., pp. 191-192. The writer does not indicate whether the figures quoted relate to primary or secondary teaching, or both. 202 On p. 74 of Diventare storiche dell'arte. Una storia di formazione e professionalizzazione in Italia e in Francia (1900-40), Roma, Carocci, 2009, Maria Mignoni writes: "Resta emblematico il caso della valdese Lydia Poët, prima laureata in giurisprudenza che, dal conseguimento del titolo nel 1881 dovrà attendere il 1920 per ottenere l'iscrizione all'albo degli avvocati torinesi; o quello di Anna Kuliscioff che, respinta dall'Ospedale Maggiore di Milano, si dovette fare per qualche tempo privata 'dottora dei poveri'”,

${ }^{203}$ Il Novecento delle italiane, cit., p. 33.

204 On p. 182 of “Osservazioni sull'occupazione femminile durante il fascismo”, cit., Pieroni Bortolotti writes: "Nel culto, professioni, arti liberali si passa da 150.416 donne su 443.216 addetti nel 1911 (34\%) a 222.791 su 520.212 (poco meno del 43\%) nel 1921. In particolare: vi è aumentato nel culto, discordante con quello dei maschi (si tratta delle suore negli ospedali? O in generale la crisi delle vocazioni nei conventi orientò il clero a una maggiore larghezza nell'accettare le vocazioni femminili?); un aumento percentualmente molto forte nelle 'lettere e scienze applicate', dove le donne passano dal 2,8\% (1.053 in assoluto) del 1911, al 4,15\% nel 1921 (2.212). Il più forte balzo però si riscontra nell'insegnamento, dove si rileva una maggioranza crescente di donne (dal 59\% del 1911 al 70,5\% nel 1921: da 75.251 a 128.266)”.
} 
Writers and literary people $\quad 391$

Journalists $\quad 182$

Publicists $\quad 52$

Translators and interpreters $\quad 56$

Engineers, doctors in chemistry, physics and

the natural sciences (liberal professions) 195

Architects

Doctors in agricultural science, agronomists,

and land surveyors

Doctors in the commercial sciences

Medical practitioners, surgeons etc.

Dentists

Lawyers and solicitors

Barristers

Notaries
13

13

51

795

30

180

7
1,111

2,659

1,252

448

11,897

1,093

1,845

1,886

32,950

891

28,131

1,042

$4,445^{205}$

With the fascist welfare state, however, new "helping” professions, such as nursing and social work, emerged. These had traditionally been the province of Catholic women's volunteer organizations and nursing orders and, in this vein, Pope Pius $\mathrm{X}$ had inaugurated the first professional nursing school in Rome in $1905 .^{206}$ In Fascist Italy, nursing was acknowledged as a profession in 1925 with the government publishing "statutes regulating the training of nurses and their status relative to other professions”. ${ }^{207}$ Outside the Catholic system there were 27,264 nurses in 1921, and their number rose to 39,646 in $1936 .^{208}$ In social work, too, there was a shift away from volunteer, benevolent organizations and, by the late 1930s, the fascist regime had introduced a system of party social workers, visitatrici, who were graduates from courses organized by the Italian Red Cross, wore uniforms, and received salaries. ${ }^{209}$

Another new area of employment for women was work in offices and in retail trade. In the early 1900s, in the wake of technological and industrial developments, there was a demand for women in the clerical and semi-professional fields as typists, switchboard operators, bookkeepers, cashiers, and the like. In fact, already in 1911 there were some 40,000 female office workers, by 1921 their number had risen to 117,000 and 190,000

\footnotetext{
${ }^{205}$ Ibid., p. 189.

${ }^{206}$ Scaraffia, “Christianity Has Liberated Her and Placed Her alongside Man in the Family”, cit., p. 261.

${ }^{207}$ De Grazia, How Fascism Ruled Women, cit., p.196.

${ }^{208}$ Ibid.

${ }^{209}$ Ibid., p. 262.
} 
by $1931 .^{210}$ During the 1930 s, across various industries, office work was increasingly carried out by female staff which in 1936 made up 32.8 per cent $(459,912)$ of a total of 1,406,801. Employment of women in white-collar positions was, however, severely restricted in the state public service with less than a thousand in 1936 while, surprisingly, women made up 42 per cent of managers (1,292 out of 3,080) and 41.7 per cent of office staff $(63,006$ out of 151,529) in local government. Pieroni Bortolotti attributes these relatively high figures to the lack of legislation limiting women's employment in this area and also to the difficulty women experienced in finding suitable positions in the state public service and in the liberal professions. ${ }^{211}$

The vast bulk of women were not employed in the tertiary sector, however, but in the primary and secondary industries. Agriculture continued to be the largest sector of employment, and traditionally women were expected to share fully the workload, or to be equally ready to be hired out. Women's contribution was also important, from early on, in the manufacturing industries. A survey of Italian industry in 1876, which excluded domestic industry, showed that women and girls made up 60 per cent of a total factory workforce of 382,000. ${ }^{212}$ In 1901, the proportion of Italian women participating in the workforce stood at 32.4 per cent, with most women working in the agricultural sector, including seasonal work such as rice weeding, olive or citrus fruit picking, scutching flax, and the like. ${ }^{213}$ Traditionally they made up most of the employees in the textile industries, so that in the 1900-1903 triennium they constituted 70 per cent of the labour in the silk industry, 61 per cent in the cotton industry and 45 per cent in the wool industry. ${ }^{214}$ At 2.5 per cent of the total number of employees, the presence of women was minimal, however, in the metallurgical and mechanical industries which showed strong growth in the Giolittian era. During the second industrial revolution, observes Gloria Chianese, the number of female workers declined and, in the sectors in which they continued to work, the working conditions remained oppressive while the gap between the female and the male salaries increased and the legislative measures to protect female labour were largely ignored by entrepreneurs. ${ }^{215}$ By 1911, the women’s total participation rate had declined to 29.0 per cent. Of those employed, 16.9 per cent

\footnotetext{
${ }^{210}$ De Giorgio, Le italiane dall'Unità a oggi, cit., p. 44.

${ }^{211}$ Pieroni Bortolotti, “Osservazioni sull’occupazione femminile durante il fascismo”, cit., p. 191.

212 Clark, Modern Italy 1871-1995, cit., p. 34.

213 Gloria Chianese, Storia sociale della donna in Italia (1800-1980), Napoli, Guida Editori, 1980, pp. 30, 47.

214 Ibid., p. 29.

${ }^{215}$ Ibid., p. 50.
} 
were in agriculture, 7.9 per cent were in industry and transport, 3.1 per cent in the domestic service, in the liberal professions or in the public service, and 1.1 per cent in commerce, while the great majority of women, 48.6 per cent, were housewives, aristocrats $(400,000)$ or students $(700,000) .{ }^{216}$ With World War I, there was an enormous increase in the demand for female labour, particularly in the armaments industry in which women's employment had, by 1918, increased to 200,000 workers. ${ }^{217}$ After the war, with soldiers returning from the front, female employment declined sharply. It continued to decrease in the textile industries while women's number tended to increase in the tertiary sector, even at higher levels of education. Fewer women were employed as domestics largely because many lower middle-class women carried out their domestic duties themselves. ${ }^{218}$ The pattern of women's employment in the period of 1901 to 1921 can be gauged from the following table which shows the number of women actively employed in different categories, per thousand females aged 10 years or over.

Table 2. Occupational composition of the female population

10 years or over per 1,000 women

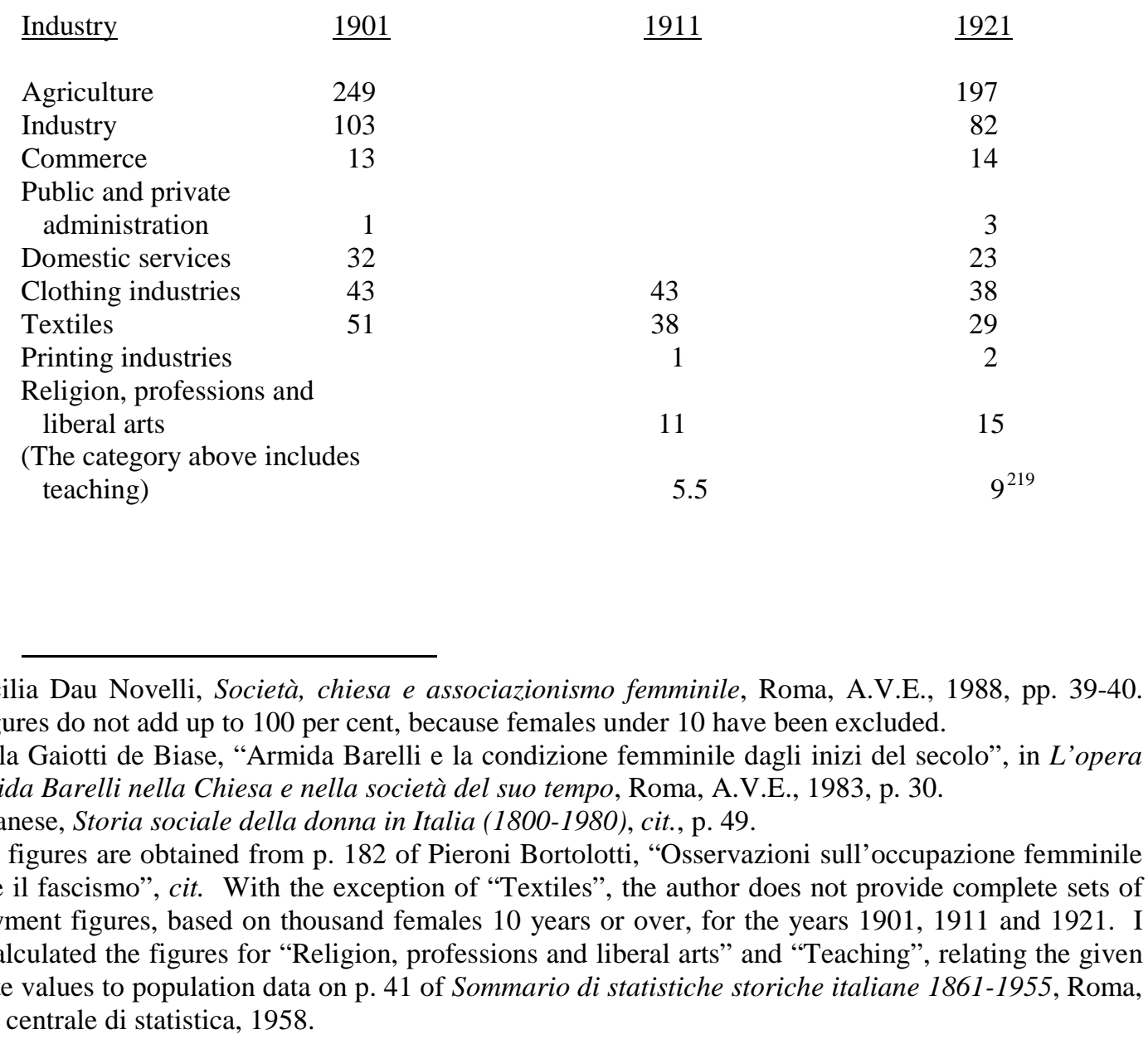

${ }^{216}$ Cecilia Dau Novelli, Società, chiesa e associazionismo femminile, Roma, A.V.E., 1988, pp. 39-40. The figures do not add up to 100 per cent, because females under 10 have been excluded.

${ }^{217}$ Paola Gaiotti de Biase, “Armida Barelli e la condizione femminile dagli inizi del secolo", in L'opera di Armida Barelli nella Chiesa e nella società del suo tempo, Roma, A.V.E., 1983, p. 30.

${ }^{218}$ Chianese, Storia sociale della donna in Italia (1800-1980), cit., p. 49.

${ }^{219}$ The figures are obtained from p. 182 of Pieroni Bortolotti, "Osservazioni sull'occupazione femminile durante il fascismo", cit. With the exception of "Textiles", the author does not provide complete sets of employment figures, based on thousand females 10 years or over, for the years 1901, 1911 and 1921. I have calculated the figures for "Religion, professions and liberal arts" and "Teaching", relating the given absolute values to population data on p. 41 of Sommario di statistiche storiche italiane 1861-1955, Roma, Istituto centrale di statistica, 1958. 
Commenting on trends in the 1921-1936 period, Pieroni Bortolotti notes that there was a continuing decrease of women employed in the agricultural sector. To a minor extent this may have been due to the mechanization of agriculture, and partly to unemployment because of the 1930-1933 economic crisis. Further, many women on farms may have declared themselves housewives (attendenti a casa) to avoid paying obligatory union and social security levies while, owing to an increase in the number of small independent landholdings, a number of women previously classified as agricultural workers would have given their occupation as "housewife". ${ }^{220}$ The Great Depression hit women also in industrial employment. "Industry did not follow an overt program to expel women from jobs”, observes Mariolina Graziosi, but they were among the first to be dismissed in both the industrial and the rural sector. As a result, many unemployed women undertook "clandestine” factory work at home at low pay with no provision for a pension or other benefits. ${ }^{221}$ Over the fifteen-year period, however, there was a notable increase in the number of women employed in secondary industry, with the exception of women employed in the textile and clothing industries. Significant increases in the number of female employees, both salaried and blue-collar, were seen in the chemical, mechanical and food processing industries, leather manufacturing, the processing of non-metallic minerals, roads and transport, the primary processing of metals, and the printing industry. Strong growth was evidenced also in the number of women employed in commerce, banking and insurance as well as public and private administration. A less distinct trend was noticeable in the category "Religion, professions and liberal arts" while the employment of women in domestic service continued to increase. Obviously, despite restrictions imposed by the fascist regime, women continued to be employed and, if anything, they tended to shift toward more skilled positions. One has to keep in mind, however, that employment conditions tended to worsen, especially after the regime decreed on 20 January 1927 that women's remuneration should be cut to half of men's wages, which also had already been reduced. ${ }^{222}$ The table below gives a summary of women employed in different sectors in the period 1921-1936.

\footnotetext{
${ }^{220}$ Ibid., pp. 183-184.

${ }^{221}$ Mariolina Graziosi, "Gender Struggle and the Social Manipulation and Ideological Use of Gender Identity in the Interwar Years”, in Robin Pickering-Iazzi (ed.), Mothers of Invention: Women, Italian Fascism, and Culture, Minneapolis, Minn., University of Minnesota Press, 1995, pp. 36-37.

${ }^{222}$ Chianese, Storia sociale della donna in Italia (1800-1980), cit., p. 72.
} 
Table 3. Women's employment in the different sectors of the Italian economy

between 1911-1936

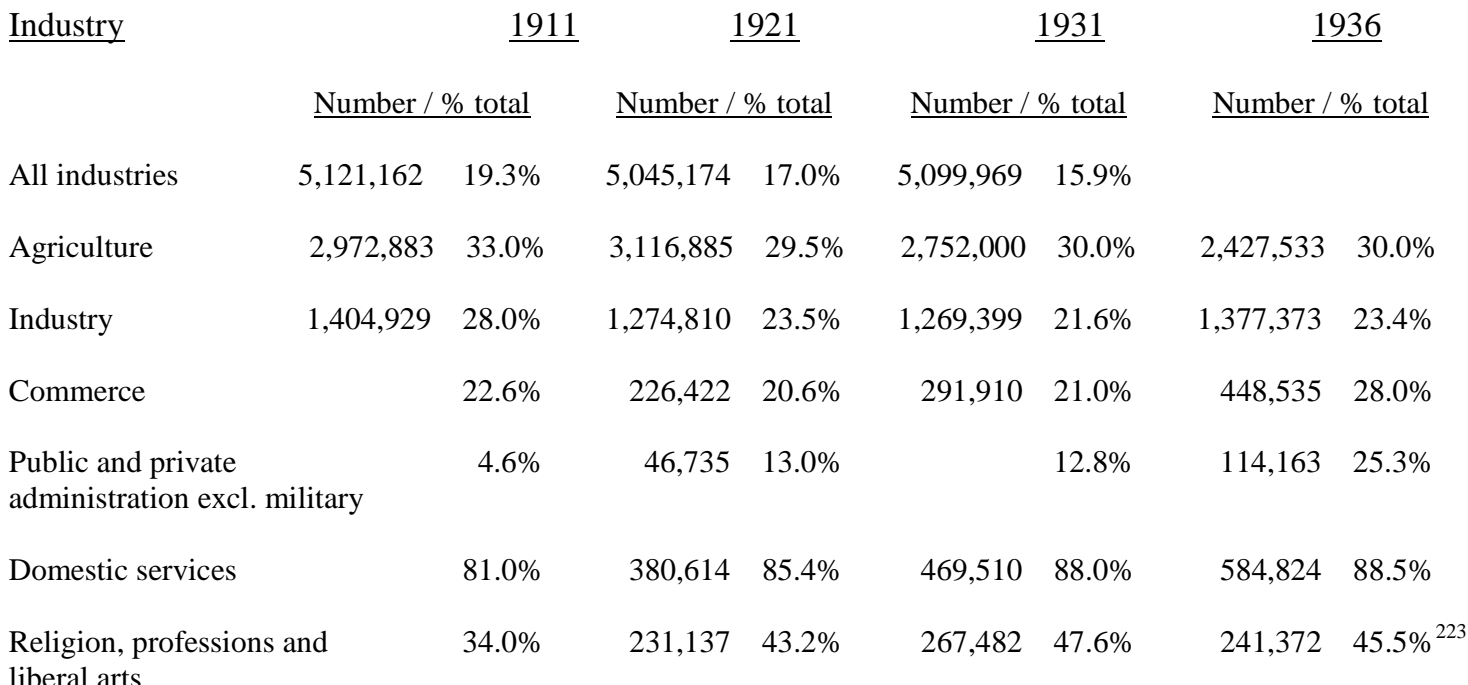

Women's employment conditions remained largely unregulated until 1902 when, as previously mentioned, the Giolitti government introduced some minimum welfare legislation. $^{224}$ The minimum age was raised to twelve for industrial employment and to fifteen years for night work. For women and children, working in mines was prohibited. The working day was limited to twelve hours for women and to eleven hours for minors under sixteen. Additionally the legislation provided for a month's maternity leave after confinement and for the creation of a compulsory maternity fund. $^{225}$ The fund was established in 1910 and was financed by equal annual contributions by employers and workers. ${ }^{226}$ During the fascist period advances were made in legislation on maternity provisions and industrial working conditions. In 1919, Washington had hosted a labour conference which led to drafting several important international conventions on protecting industrial workers. These included restricting

\footnotetext{
223 The figures in the table have been obtained from pp. 180-185 of Pieroni Bortolotti, “Osservazioni sull'occupazione femminile durante il fascismo", cit.

The author has calculated the percentages for "All industries" on the basis of total population of 10 years or over. The percentages for the rest are based on the total number of employees in the respective sectors. The figures represent totals inclusive of blue- and white-collar workers.

The figure of 3,116,885 for female agricultural workers in 1921 is based on new census criteria; applying the criteria used in 1911 would have produced a total of 2,976,590.

The figure of 2,752,000 agricultural workers for 1931 has been obtained from the agricultural census of 19 March 1930 since the 1931 census figure of 1,534,382 appeared unreliable.

In calculating the percentage of women employed in "Agriculture" of the total employed in the sector in 1936, I have used the sum of agricoltori $(3,996,994)$ and lavoratori $(4,096,828)$ as a basis.

In calculating the percentage of women employed in "Industry" of the total employed in the sector, I have based the percentage on the sum of 1,247,778 industriali and 4,629,759 lavoratori in that sector.

224 The Socialist feminist and medical practitioner Anna Kuliscioff was involved in drafting this legislation.

${ }^{225}$ Il Novecento delle italiane, cit., p. 9.

${ }^{226}$ Sarogni, La donna italiana, cit., p. 124.
} 
the working day to eight and the working week to forty-eight hours, unemployment provision, and maternity provision which included leave also prior to confinement. Conditions were also established in relation to the night-time employment of women and children in industry, and the minimum age for industrial employment was set at fourteen. $^{227}$ The fascist regime adopted some of these conditions, especially where they seemed congruent with their requirements for increases in population growth and qualitative improvements of the Italian race. $^{228}$ So the royal decree No. 748 of 15 March 1923 forbade women all night work in factories and industrial laboratories. The act No. 653 of 26 April 1934 raised the minimum working age for women in industrial jobs. It prohibited the employment of females under fifteen in heavy, dangerous or insalubrious jobs; it also regulated in agricultural jobs the employment of women assigned to carrying and lifting loads; it established norms for the protection of pregnant women; tightened the ban on night work for women; decreed the working day to be a maximum of eleven hours for women; introduced an intermediate rest period after six hours of work; laid down provisions for the safeguard of hygiene, safety and morals at work; and made it obligatory for women and minors under twenty-one to submit to controls of their physical suitability for the job by instituting periodic medical visits and introducing the libretto sanitario. ${ }^{229}$ The royal decree No. 2157 of 24 September 1923 consolidated in one text the norms governing the Cassa per la maternità, and the act No. 2277 of 19 December 1925 established the national welfare organization, the Opera nazionale per la protezione della maternità e dell'infanzia (ONMI), to monitor the health of mothers and children. In June 1929 the government introduced legislation, in relation to blue- and white-collar employees in industry and commerce, to provide two months of maternity leave, one month before confinement and another afterwards. A royal decree in the same year made it binding also on employers in businesses to allow pregnant women to retain their jobs and to insure their female employees with the Cassa per la maternità. (Previously such an obligation existed only in the case of female factory workers.) Other positive welfare measures by the fascist regime included the introduction of compulsory insurance schemes for unemployment, invalidity and old age for both men and women in December 1923.

\footnotetext{
${ }^{227}$ Ibid., p. 140.

${ }^{228}$ Ibid., p. 141.

${ }^{229}$ Ibid., pp. 141-142.
} 


\section{$\underline{\text { Suffrage }}$}

In pre-World War II Italy women played practically no part in the enactment of the legislation which affected their legal status, education and employment, and this was so because at every level of society women lacked voting rights in both national and local elections. There were of course occasionally demands for female suffrage but, as Princess Cristina Belgioiso ${ }^{230}$, a famous Risorgimento figure, complained before Unification, Italian women, having lived for centuries without intellectual culture and free from responsibility for business and family affairs, did not have the requisite ambition to demand equal rights, and those women who did, had to contend sometimes with opposition from other women. Mazzini, on the other hand, while he thought highly of women and deplored their lack of access to education, being a committed republican, was convinced that women's emancipation was not possible without the institutional transformation of the State from the monarchy into a republic. ${ }^{231}$ The first advocates for women's suffrage in Italy were the parliamentarian Salvatore Morelli who had spent long periods in Bourbon prisons where he had sketched his book La donna e la scienza, considerate come i soli mezzi atti a risolvere il problema dell'avvenire (first published in 1861, with successive editions in 1862 and 1869) ${ }^{232}$, and the feminist Anna Maria Mozzoni who was only twenty-seven when she published her previously mentioned book La donna e i suoi rapporti sociali (1864). ${ }^{233}$ After release from prison, Morelli devoted the rest of his life to the advocacy of the women's cause, albeit to very little effect. Soon after his election to the Italian Parliament in 1867, Morelli presented a bill which would have recognized women's civil and political rights. Mozzoni, one of his supporters, likened women's emancipation to the Risorgimento, the liberation of the Italian nation. In 1877, encouraged by the electoral victory of Agostino Depretis who during his campaign had promised the vote for women, Mozzoni presented a petition to parliament, which was rejected. Undaunted, she continued to draft new petitions until the matter was taken up by the Republican Deputy Roberto Mirabelli whose proposals, in 1904 and 1907, failed in parliament due to lack of support by the major parties, including the Socialist Party, in which misogynist sentiments were well entrenched. ${ }^{234}$

\footnotetext{
${ }^{230}$ Ibid., p. 45.

${ }^{231}$ Ibid., p. 27.

${ }^{232}$ Ibid., p. 48.

233 Anna Maria Mozzoni, “La donna e i suoi rapporti sociali”, in La liberazione della donna, a cura di Franca Pieroni Bortolotti, Milano, Gabriele Mazzotta, 1975, pp. 33-90.

${ }^{234}$ Zappi, If Eight Hours Seem Too Few, cit., pp. 253-254.
} 
In 1906, together with Maria Montessori, Mozzoni filed yet another petition. ${ }^{235}$ The following year, Prime Minister Giovanni Giolitti appointed an all male committee, nicknamed "the Solons", ${ }^{236}$ to investigate the question of female suffrage, and it became evident that even women themselves were divided on the issue: the Socialists and the Democrats were in favour of granting full voting rights to all women, whereas bourgeois women's associations favoured suffrage based on property and literacy criteria. The committee's deliberations produced a negative verdict for both national and local elections. Defending the committee's negative recommendation, Giolitti argued that it was only "some ladies", remote from women working "in the fields and factories”, who were demanding the vote. ${ }^{237}$ After World War I female suffrage found the acceptance of all major political parties. Then, ultimately, in July 1919, the Chamber of Deputies passed a female suffrage bill by a vast majority of votes. However, just before it was presented to the Senate for approval, parliament was adjourned, and two years later, when the bill was to be reconsidered, the political landscape had changed dramatically. Italian women would not gain voting rights until February 1945 when, with World War II still going on, a legislative decree arising from an agreement between the future Christian Democratic leader Alcide De Gasperi and the Communist leader Palmiro Togliatti, extended universal suffrage to women. Subsequently their right to vote was encoded into the republican constitution in $1948 .^{238}$

Under the fascist regime, one of Mussolini's earliest promises was the vote for women at local elections, and this was fulfilled by the November 1925 legislation. Under the new law certain categories of women, such as mothers who had lost a son in war or women who had received a medal for bravery in war or civil service, automatically qualified for the vote, whereas one distinctive category of women, that is, prostitutes, was explicitly excluded. In more general terms, those eligible to vote had to be twentyfive or over (as opposed to twenty-one for men); had to be enrolled in the communal revenue lists; and had to have completed a minimum of two years of primary education. Mussolini's electoral law therefore restricted the vote to middle-class women, and was duly criticized by Filippo Turati as

una "leggina contagocce", che "favorendo alcune schiere di beniamine - quelle che ne han meno bisogno - ributta la grande massa muliebre, la parte più

\footnotetext{
235 Sarogni, La donna italiana, cit., p. 40.

236 "Wise legislators."

${ }^{237}$ Il Novecento delle italiane, cit., p. 17.

${ }^{238}$ Sarogni, La donna italiana, cit., p. 151.
} 
operosa e dolorosa del sesso femminile nell'anonimato oscuro dei cittadini a metà". 239

The same act limited women's eligibility for senior administrative positions, including that of mayor, in the local government. As it turned out, the reform was short-lived since in the following year, in 1926, the regime replaced the system of elected mayors (sindaci) with appointed podestà, thereby abolishing local elections for the whole electorate, male and female.

As we have seen, the antagonism characterizing the relations between the Italian State and the Vatican gradually gave way to the recognition of the need for Catholics to participate fully in national life and politics and of the need for reconciliation between the two entities. The undemocratic system of government which evolved in the aftermath of Unification disadvantaged the majority of the population; however, the introduction of universal male suffrage engendered political instability, which resulted in the collapse of the Liberal system. Under the succeeding fascist regime women never acquired the vote they had been promised and were anew subjected to restrictions on their education and employment, and to inequality under family law, while at the same time protected in their maternal function. Their emancipation had not been on the agenda of the Risorgimento, and their rights were long ignored by subsequent Liberal lawmakers. Nevertheless, the basic tenets of liberalism in the end prevailed to ensure that women in Liberal Italy would gradually move towards attaining equal rights to education, access to professional employment, and even the right to vote. All these achievements were lost under the fascist regime, although Italian women showed remarkable resilience in following the openings which were left for them. 


\section{CHAPTER TWO: THE CULTURAL, POLITICAL AND IDEOLOGICAL CONTEXT OF FEMMINISMO CRISTIANO}

In the early 1900s the nascent Catholic women's movement in Italy comprised activists whose initial brief was to re-Christianize society and to ameliorate the condition of working-class women, but who then extended their social apostolate to women's civil and political rights. These activists and their like-minded supporters, both male and female, advocated women's issues in journal articles and other publications, and undertook various initiatives, such as union organization, conferences and educational programmes. This early Catholic women's movement is commonly referred to as femminismo cristiano. Promoted by the clergy and the Catholic laity in the final years of Leo XIII's papacy, it fell victim to the modernist campaign during Pius X's papacy and came quickly to an end with the disintegration of the central group.

The unique nature of this movement can be best understood by examining the environment from which it emanated and the influences which shaped it. To begin with, it inherited its militant, missionary quality from the Opera dei congressi e dei comitati cattolici in Italia, under whose auspices it developed. A lay Catholic organization, the Opera dei congressi was, above all, characterized by its intransigent assertiveness towards the Liberal State. The suppression of femminismo cristiano, on the other hand, must be seen in the context of Pius X's anti-modernist campaign. To appreciate the constraints under which Catholic feminists operated, doctrinal limitations to the role of women need to be highlighted. A further perspective on femminismo cristiano is gained by comparing it with contemporary secular feminist movements.

\section{The Origins of femminismo cristiano}

To grasp the special qualities of femminismo cristiano it is necessary to look at the development and characteristics of its parent Catholic lay movement, the Opera dei congressi e dei comitati cattolici in Italia, which was organized, as will become clear from the following, under the administrative framework of annual congresses. In fact, the proceedings of the nineteen Italian Catholic congresses, convened between 1874 and 1903, constitute a primary source of research material on the evolution of femminismo cristiano. They are summarized in Angelo Gambasin's Il movimento sociale 
nell'Opera dei congressi (1874-1904) which contains excerpts from the proceedings of the annual congresses together with material on various other important meetings of the Opera. ${ }^{1}$ The historian Gabriele De Rosa has written widely on the subject, and in Il movimento cattolico in Italia he deals with the history of the lay movement comprehensively and authoritatively. ${ }^{2}$ A number of publications were produced by contemporary writers who were closely associated with the Catholic movement. Don Francesco Olgiati gives a faithful account of the events in his book, La storia dell'Azione cattolica in Italia (1865-1904), which arose from a series of lectures held in the archbishopric of Milan in conjunction with a settimana sociale of the Unione popolare fra i cattolici italiani. ${ }^{3}$ Olgiati's closeness to the conservative side of the Catholic movement, however, sometimes precludes objective assessment of the key players. With his Breve storia del movimento cattolico italiano (1870-1920) ${ }^{4}$ Silvio Fantoni provides another worthwhile introduction to the lay Catholic movement but his writing, too, reflects the attitudes of the conservative clergy. Another author with a great insight into the Catholic world is Ernesto Vercesi, who even before his ordination for the priesthood began writing for L'Osservatore cattolico, which was owned by the intransigent priest Don Davide Albertario. Vercesi’s book, Le origini del movimento cattolico in Italia 1870-1922, shows traces of his journalism and also of his political alignment with Filippo Meda, another writer for L'Osservatore cattolico and later a Liberal politician. ${ }^{5}$ All these works were written by Catholic insiders, and for that reason they are all the more useful despite their biases and lack of detachment.

Catholic lay movements are not an exclusively modern phenomenon, since, for instance, in the eighteenth-century Piedmont members of the Catholic aristocracy had formed amicizie cristiane to compete with freemasonry. ${ }^{6}$ These early movements were notable for their support of both the legitimate secular authority and the papacy. A century later, when the papacy had lost its territorial base to the new Italian State and was immersed in political and cultural battles in Italy and abroad, lay organizations were set up across Europe specifically in defence of the Pope and the Catholic faith.

\footnotetext{
1 Angelo Gambasin, Il movimento sociale nell’Opera dei congressi (1874-1904), Roma, Editrice Università Gregoriana, 1958.

${ }^{2}$ Gabriele De Rosa, Il movimento cattolico in Italia. Dalla Restaurazione all'età giolittiana, 2. edizione, Roma-Bari, Laterza, 1988.

${ }^{3}$ Francesco Olgiati, La storia dell'Azione cattolica (1865-1904), Milano, Vita e Pensiero, 1920.

${ }^{4}$ Silvio Fantoni, Breve storia del movimento cattolico italiano (1870-1920), n.p., Santi Quaranta, n.d.

${ }^{5}$ Ernesto Vercesi, Le origini del movimento cattolico in Italia 1870-1922, Roma, Il Poligno, 1979. The book was originally published by “La Voce” in Florence in 1923.

${ }^{6}$ De Rosa, Il movimento cattolico in Italia, cit., pp. 1-3.
} 
Particularly significant were the Catholic congresses convened in Malines in Belgium in 1863, 1865 and 1867 which were attended by delegates from all over Europe with the purpose of defining the aims and tasks of Catholic lay activity. ${ }^{7}$ In Italy this led to the foundation in Bologna of the first national Catholic association under the name of the Associazione cattolica italiana per la difesa della libertà della Chiesa in Italia. ${ }^{8}$ However, the new national association, acknowledged by a papal brief in April 1866, was short-lived. Connections between the local branches were soon severed because the national president, Giulio Cesare Fangarezzi, was forced to go into exile and another leader, Giambattista Casoni, had to flee Bologna as a result of the government's legislative measures on the eve of the Third War of Independence against Austria. ${ }^{9}$ Nevertheless, despite government hostility toward Catholic organizations, already in the following year Catholic youth circles were founded in Bologna and Viterbo by Dr. Giovanni Acquaderni and Count Mario Fani respectively. Subsequently Acquaderni and Fani joined forces to set up a national organization under the name of Società della gioventù cattolica italiana. ${ }^{10}$ In October 1871, in commemoration of the third centenary anniversary of the Battle of Lepanto and the defeat of the Turks, the Gioventù cattolica held a meeting in Venice where an announcement was made of the intention to organize a Catholic congress on a national scale. ${ }^{11}$ This promise was fulfilled in June 1874 when the first national Catholic congress was convened in Venice.

The inaugural gathering, blessed by the Pope through a brief, was attended by the most important representatives of the Italian militant Catholic laity. This meeting would be followed by further, mostly annual, congresses until the nineteenth congress in Bologna in November 1903. After that, annual congresses would cease as a result of the disbanding of the central organizing body, the Opera dei congressi e dei comitati cattolici in Italia, by Pius X on 28 July $1904 .{ }^{12}$ Comparing themselves to the first Christians, the Catholic militants attending the first congress saw their task as reclaiming contemporary society for Catholicism. Believing in the infallibility of the Pope and having no intention of becoming embroiled in purely doctrinal matters, they

\footnotetext{
${ }^{7}$ Olgiati, La storia dell'Azione cattolica in Italia (1865-1904), cit., p. 13.

${ }^{8}$ De Rosa, Il movimento cattolico in Italia, cit., p. 36.

${ }^{9}$ Ibid., p.37.

${ }^{10}$ Fani and Acquaderni wanted to demonstrate that they were not afraid of openly professing their faith in the aftermath of the assassination attempt on the president of the Reggio Emilia section of the Associazione cattolica italiana per la difesa della libertà della Chiesa in Italia and in protest against the police search of the Neapolitan section of the Associazione. Fantoni, Breve storia del movimento cattolico italiano (1870-1920), cit., pp.20-21.

${ }^{11}$ The Battle of Lepanto took place on 7 October 1571.

${ }^{12}$ Gambasin, Il movimento sociale nell'Opera dei congressi (1874-1904), cit., p.552.
} 
wanted to turn their energies towards practical issues in preparation for some future point in time when the Liberal "revolution" had run its course and they could take over.

Militant Catholics called themselves "intransigents" to manifest their absolute loyalty to the Pope, their adherence to the non expedit, and their demand for the restitution of Rome to the papacy. By contrast, those who believed that Catholic interests could be best served by cooperating with the State and by being represented in its political and administrative structures were referred to as "transigents" or "moderates". ${ }^{13}$ Typically, the intransigent battle cry, "Cattolici italiani, preghiamo che la rivoluzione muoia domani, ma poi lavoriamo come essa dovesse vivere sempre”, did not help to ease tensions between Church and State. ${ }^{14}$ Consequently, the Opera was often the target of punitive measures by government. For instance, the third congress in the Church of San Michelino in Bologna in October 1876, attended by up to a thousand delegates, ${ }^{15}$ was disbanded on the prefect's orders, allegedly to maintain public order. Police made only a perfunctory appearance and did little to protect the delegates. Trouble started on the second day when a big hostile crowd gathered outside. The women, showing great fortitude throughout, were permitted to leave the venue unmolested with a patronising remark from one of the protestors: "Le signore possono uscire liberamente, poiché non sanno quel che si fanno", while priests, the Bishop in Ceneda in particular, were spat at, beaten and hit with stones. ${ }^{16}$ In 1886 the Opera was prevented from organizing a congress in Lucca on the pretext that sanitary conditions were inadequate; ${ }^{17}$ and in 1890 the Lodi congress had to be held in the bishop's residence after the sub-prefect threatened to send carabinieri, regular soldiers and a cavalry company to stop the planned meeting in a church. ${ }^{18}$

\footnotetext{
${ }^{13}$ Olgiati, La storia dell'Azione cattolica in Italia (1865-1904), cit., p. 219; Gambasin, Il movimento sociale nell'Opera dei congressi (1874-1904), cit., p. 16. On pp. 31-32 of Il movimento cattolico in Italia, cit., De Rosa mentions that even titles of periodicals gave an indication of political alignment. In Torino, for instance, Il Mediatore was published until 1866 by Padre Passaglia who had collected 9,000 signatures from the clergy in favour of an accord with the new Italian State. With the intransigent clergy in charge, conciliatory priests soon began to lose ground and their publications, such as Il Conciliatore in Milan, were suppressed.

${ }^{14}$ Olgiati, La storia dell'Azione cattolica in Italia (1865-1904), cit., pp. 68-69. The expression was used by Giuseppe Sacchetti, editor of Veneto cattolico, in conclusion of his address at the Venice congress in 1874.

${ }^{15}$ On p. 170 of ibid. Olgiati quotes from the congress documents: "I membri del Congresso, giunti in Bologna prima dell’inaugurazione, erano circa 800, e nei giorni successivi passarono il migliaio”.

${ }^{16}$ Ibid., pp. 80-82.

${ }^{17}$ On p. 173 of ibid. Olgiati writes: "Nel settembre del 1886 stava per aprirsi a Lucca il settimo Congresso; ma una ordinanza ministeriale, sotto il pretesto delle condizioni sanitarie d'Italia, lo proibì”.

${ }^{18}$ Ibid.
} 
Anti-Catholic sentiments also ran high against local organizations. Much publicity was generated by the eviction of some fifty tenant farmers by their landlords in Briosco (Milan), in March 1898, in punishment for the farmers' audacity to join the parish committee. ${ }^{19}$ This incident occurred only a couple of months before the "bread riots" in May 1898 which first broke out in southern Italy but then engulfed the major cities in the north. Organizations suspected of fomenting the unrest and their ringleaders were severely punished. Classed together with socialist and anarchist organizations, the Opera dei congressi was dissolved; Catholic mutual aid societies and much of the Catholic press were suppressed; Don Davide Albertario, editor of L'Osservatore cattolico in Milan, was arrested; and some Catholic activists had to go into exile. ${ }^{20}$ Condemnation by the Vatican of these measures was relatively muted, and a moderate policy toward the State was adopted with the outcome that the Opera dei congressi and most other Catholic organizations were permitted to resume their activities.

The second congress in Florence in 1875 had ended with the declaration of the continuity of congresses and with the establishment of a permanent committee at the national level and local parish committees. These were recognized in a papal brief on 25 September $1876 .{ }^{21}$ Later on, diocesan and regional committees would be included in the organization structure. The central body was divided into five Sections (from 1902 to be called Groups): Organizzazione ed azione cattolica; Carità; Istruzione ed educazione; Stampa; and Arte cristiana. Of these, the Second Section grew to be the most important and underwent several changes of title: from the original title Carità to Carità ed economia cattolica (1879) to Economia sociale cristiana (1887), and finally to Azione popolare cristiana o democratico-cristiana (1902), reflecting the gradual shift in the political orientation of this section. ${ }^{22}$ This was also the group to which women's organizations were intended to belong. Increasingly, the Opera dei congressi was brought under ecclesiastical control, and from 1901 its most senior appointment, that of the President of the Opera, would be the Pope's prerogative. ${ }^{23}$ As evidenced by the Bologna congress in 1876, women attended meetings from the earliest times, and

\footnotetext{
${ }^{19}$ Vercesi, Le origini del movimento cattolico in Italia 1870-1922, cit., pp. 36-38. Even the Socialist leader Filippo Turati is known to have sent his contribution (obolo) to an appeal launched on behalf of the evicted.

${ }^{20}$ Olgiati, La storia dellAzione cattolica in Italia (1865-1904), cit., pp. 195-203. The organization was originally known as the Opera dei congressi cattolici but in 1881 the President of the Comitato permanente, Duke Scipione Salviati modified its name to the Opera dei congressi e dei comitati cattolici in Italia. See Fantoni, Breve storia del movimento cattolico italiano (1870-1920), cit., p. 39.

${ }^{21}$ Olgiati, La storia dell'Azione cattolica in Italia (1865-1904), cit., pp. 98-99.

${ }^{22}$ Ibid., p. 117.

${ }^{23}$ De Rosa, Il movimento cattolico in Italia, cit., p. 168.
} 
although not qualifying for direct participation in the Opera's activities, they could support its work as aderenti or partecipanti, and in such capacity had the right to attend national congresses and regional, diocesan and parish meetings. ${ }^{24}$

The activities of the Opera were guided by intransigence against the Liberal State:

Noi subiamo i fatti compiuti, e non li accettiamo, ma protestiamo da veri cattolici col S. Padre contro tutto ciò che si è compiuto di iniquo e di ingiusto. ${ }^{25}$

Much effort was directed towards eliminating the government's monopoly on education and reversing the decision on the closure of seminaries. To assert Catholic presence in society, the Opera collected signatures for a variety of causes, organized pilgrimages, jubilees and other activities, and lent support to the Catholic press. Catholic campaigns proved very effective especially in fighting the enactment of a law legalizing divorce, as demonstrated by the collection of some three million signatures by the Opera against the proposed legislation in $1901 .^{26}$ Another area where local committees especially played an important part was the enforcement of the non expedit. It is reported that at the May 1886 elections in one sezione in Bergamo no-one cast a vote: instead would-be voters attended a meeting organized by the local priest, handing to him the voting slips and Peter's pence (obolo di S. Pietro). ${ }^{27}$

In terms of membership, the Opera was at its peak at the time of the fifteenth congress in Milan in August-September 1897, just before its temporary dissolution in 1898. It had under its umbrella 188 diocesan and 3982 parish committees, 708 youth sections, 17 university circles, 588 rural banks, 688 workers' societies, 116 Gioventù cattolica circles, 24 daily newspapers and 155 periodicals. ${ }^{28}$ Despite this apparent success there was a great deal of unrest and dissension in the ranks, to some extent due to a gradual generational change in the leadership. Until then the Opera had been guided predominantly by conservatives who belonged to either the papal or the landed aristocracy, or the upper middle class. Paternalistic in their outlook, the aristocratic leaders tended to approach social problems from the point of view of Christian charity, that is, from the notion that the rich should, at their discretion, provide for the indigent. Moreover, in their intransigence these leaders ruled out any degree of cooperation with

${ }^{24}$ Olgiati, La storia dell'Azione cattolica in Italia (1865-1904), cit., pp. 144-145.

${ }^{25} \mathrm{Ibid}$., p. 115. Included in the programma d'azione emanating from the Florence congress in 1875.

${ }^{26}$ Ibid., p. 142.

${ }^{27}$ Ibid., p. 136.

${ }^{28}$ De Rosa, Il movimento cattolico in Italia, cit., p. 127. 
the Liberal State. By the late 1880s, however, new groups of Catholic laity and clergy, some with a background in the social sciences, had become active in the Opera and had started looking for new ways to deal with social issues. Leo XIII had already provided a doctrinal basis for their social agenda with his encyclicals Inscrutabili Dei consilio (April 1878) and Quod apostolici muneris (December 1878). ${ }^{29}$ In 1891 the encyclical Rerum novarum gave an added impetus to the aspirations of these Catholic activists who called themselves Christian democrats.

The early Christian democratic movement in Italy came into being under the Second Group of the Opera dei congressi and flourished in the decade between 1894 and 19046. Its supporters were called giovani or larghi as opposed to the more conservative members of the Opera who were known as vecchi or rigidi. The origin of the movement can be traced to spontaneous initiatives and a variety of influences. In 1885, for instance, the Jesuit Carlo Maria Curci, drawing on his experiences in exile in France and Belgium, published a book under the title Un socialismo cristiano nella questione operaia. ${ }^{30}$ In the same year, Leo XIII addressed a group of French workers led by the Christian democrat Léon Harmel, using the term "Christian democracy" to describe a movement worthy of support. ${ }^{31}$ In Italy, the Catholic laity and the clergy alike were turning their attention to peasant problems. In Gambarare (Veneto), for example, a young priest, Luigi Cerutti, was struck by the abject poverty of the peasants in his parish and in 1890 founded a rural bank to help out the neediest. Soon, other priests in the Veneto followed his example, and by the end of 1892 there were already some thirty rural banks in the region. ${ }^{32}$

Organizationally under the control of the Opera dei congressi, early Christian democracy was not a unified movement based on common, clearly defined goals. Initially at least, the term "democracy" simply meant concern for the social problems of the working classes rather than the application of democratic principles as such. Certainly Leo XIII had no “popular government” in mind when he published his encyclical on Christian democracy, Graves de communi re, on 18 January $1901 .^{33}$

\footnotetext{
${ }^{29}$ Gambasin, Il movimento sociale nell'Opera dei congressi (1874-1904), cit., pp. 127-128.

${ }^{30}$ Fantoni, Breve storia del movimento cattolico italiano (1870-1920), cit., p. 46.

31 Ibid.

${ }^{32}$ Ibid., pp.58-59.

${ }^{33}$ Leo XIII, Graves de communi re: Encyclical of Pope Leo XIII on Christian Democracy (18 Jan. 1901) http://www.vatican.va/holy_father_/leo_-xiii_enc_18011901_graves_de_communi-re_en.html $(24 / 04 / 2008)$
} 
The earliest and most influential leader of Christian democracy was the Pisan political economist Giuseppe Toniolo. ${ }^{34}$ While still based on the Christian concept of charity, his sociological theories were moving toward a more modern, institutionalized approach to social issues. His preferred models, relying on predominantly agrarian social structures within the context of the existing class hierarchy were centred on the idea of mutuality as exemplified by medieval guilds; on combining agrarian with artisan labour to solve problems of rural unemployment; and on mixed corporations of workers and employers to preserve social harmony. Unconditionally loyal to the Pope and widely respected in the Catholic circles, Toniolo tried to conciliate the different currents of the Christian democratic movement. After the relaxation of the non expedit, he tended towards conservative Clerical-Moderate politics. When Catholic Action was reorganized in 1905 into three separate streams, he became President of one of them, the Unione popolare. ${ }^{35}$

Toniolo’s ideas found resonance among young Genoese students who attended the meetings of the first convention of the Unione cattolica per gli studi sociali, organized in conjunction with the tenth national congress of the Opera dei congressi in Genoa in 1892. Two years later, at a further meeting of the Unione in Milan, Toniolo launched his social programme, Il programma dei cattolici di fronte al socialismo, which came to be known as the Milan Programme. United under its banner, the same Geneose students made up the nucleus of a group whose members began calling themselves "Christian democrats". ${ }^{36}$ Distancing themselves from socialists, Toniolo and the other signatories to the Milan Programme took giustizia and carità sociale as their guiding principles. In the interests of social stability they wanted to see an increase in the number of small farming properties, and asked for industrial workers to be paid a fair wage, part of which could take the form of profit sharing, even with the possibility of workers acquiring company shares through their savings. While mixed unions of workers and employers were envisaged as the preferred form of industrial organization, the programme also acknowledged that if employers were unwilling to join, workers

\footnotetext{
34 Paolo Pecorari, “Toniolo, Giuseppe”, in Francesco Traniello e Giorgio Campanini (a cura di), Dizionario storico del movimento cattolico in Italia 1860-1980, II: I protagonisti, Torino, Mariotti, 1982, pp. 636-644.

${ }^{35}$ Ibid., p. 642.

${ }^{36}$ Fantoni, Breve storia del movimento cattolico italiano (1870-1920), cit., p. 60.
} 
should be able to create their own associations. ${ }^{37}$ Paternalistic mixed unions were, indeed, no longer a feasible concept for industrial organization in the late nineteenth century and, instead, Catholic unions, known as "white trade unions", began to emerge. ${ }^{38}$

At the opposite end of Christian democracy was the fiery priest Romolo Murri from the Marches who from the outset was as intransigent and as loyal to the papacy as any Catholic. After his ordination as a priest, attendance at lectures on historical materialism and Marxism by Antonio Labriola in Rome propelled him toward commitment to cultural and political issues. ${ }^{39}$ Among the periodicals which he founded or contributed to, La vita nova became a rallying point for students desirous of devoting themselves to Christian revival. Through La vita nova Murri promoted student circles and groups at universities, which led to the establishment of a national body, the Federazione universitaria. Attempts by the Federazione to become an autonomous organization to escape the control of the Opera dei congressi were frustrated at the Fiesole congress in 1896. ${ }^{40}$ In January 1898 Murri launched a new journal, Cultura sociale, which, with focus on political and social studies, was intended as a rival to the Socialists’ Critica sociale. ${ }^{41}$ While pursuing his journalistic activities Murri travelled widely and, as a result of his initiatives, Christian democratic fasci and uffici del lavoro emerged in various locations. In anticipation of the Ferrara congress in 1899, Murri formulated his vision for the establishment of a national party in Propositi di parte cattolica. $^{42}$ From 1900 he dedicated himself in a systematic manner to setting up, especially among the young, Christian democratic groups throughout Italy.

Murri saw the Church as playing the leading role in guiding society by means of entirely new strategies. They included cultural renewal and the foundation of a national party to enable Catholics to participate in national political life. ${ }^{43}$ In his view, their greater autonomous responsibility in the social and political domains would guarantee the Church's more active presence in the modern world. Obedience, as defined by leaders such as the conservative president of the Opera, Count Giambattista Paganuzzi,

\footnotetext{
${ }^{37}$ Olgiati, La storia dell'azione cattolica in Italia (1865-1904), cit., pp. 246-250.

${ }^{38}$ Fantoni, Breve storia del movimento cattolico italiano (1870-1920), cit., p. 64.

${ }^{39}$ Maurilio Guasco, "Murri, Romolo", in Traniello e Campanini (a cura di), Dizionario storico del movimento cattolico in Italia 1860-1980, II: I protagonisti, cit., p. 414.

${ }^{40}$ Ibid., p. 415.

${ }^{41}$ Ibid.

${ }^{42}$ Ibid., pp. 416-417.

${ }^{43}$ Ibid., p. 415.
} 
meant subservience. Moreover, Murri believed, a religion unable to move with the times ran the risk of preventing workers and the poor from attaining Christian freedom. Religion itself would become a hate object and would die if it merely preached the virtue of resignation and docility toward employers. ${ }^{44}$ For Murri, the Opera dei congressi represented "la cittadella di un gruppo ristrettissimo di conservatori che dominavano senza tollerare opposizioni", ${ }^{45}$ while the more conservative leaders of the Opera would, for their part, admit Murri's youth groups only on the basis of their total submission to the Opera. Subsequently Leo XIII, while giving a ringing endorsement to young Christian democratic activists in his brief to the Taranto congress in September 1901, referring to them as "quel drappello di giovani freschi di forze ed alacri di volontà, il quale milita per la democrazia cristiana”, also presented a new statute for the Opera, introducing structural modifications which placed the lay organization totally under ecclesiastical control. ${ }^{46}$ In the aftermath of the congress, the Christian democrats struggled to maintain a degree of autonomy for their groups until their efforts were definitively thwarted by the Pope's instructions in February $1902 .{ }^{47}$ In his weekly publication, Il Domani d'Italia, Murri declared his open rebellion against the new statute of the Opera and the papal instructions, ${ }^{48}$ while his archenemy, Count Paganuzzi, resigned from the presidency despite majority support on the permanent committee. $^{49}$ Soon afterwards, in August 1902, Murri drew the censure of Cardinal Respighi for a speech in which he expressed not only his appreciation for the biblical scholarship of the Irish-born modernist Jesuit scholar George Tyrrell but also his opposition to all those who wanted to separate social issues from biblical, apologetic and philosophical problems. ${ }^{50}$

Murri's political aspirations ran against the express wishes of Leo XIII, who in his encyclical Graves de communi re (1902), while still endorsing Christian democracy, also categorically stated that it should not be a political movement. ${ }^{51}$ After the suppression of the Opera by Leo's successor, Pius X, in July 1904 and with the retention of only its Second Group under the leadership of Count Stanislao Medolago

\footnotetext{
${ }^{44}$ De Rosa, Il movimento cattolico in Italia, cit., p. 146.

${ }^{45}$ Quoted in Olgiati, La storia dell'Azione cattolica in Italia (1865-1904), cit., p. 281. From Murri's Battaglie d'oggi, v. IV, p. 161.

${ }^{46}$ De Rosa, Il movimento cattolico in Italia, cit., pp. 166-168.

${ }^{47}$ Ibid., p. 168.

${ }^{48}$ Olgiati, La storia dell'Azione cattolica in Italia (1865-1904), cit., p. 293.

${ }^{49}$ Gambasin, Il movimento sociale nell'Opera dei congressi 1874-1904), cit., p. 542.

${ }^{50}$ Olgiati, La storia dell'Azione cattolica in Italia (1865-1904), cit., pp. 297-298.

${ }^{51}$ Ibid., p. 288.
} 
Albani, Murri and his supporters founded an autonomous Lega democratica nazionale in Bologna in November $1905 .^{52}$ The organization enjoyed only a limited success, and Murri himself was excommunicated after his election to parliament with leftist support. $^{53}$ While rebelling against official policy in his political aspirations and leanings towards modernism, in his views on women, on the other hand, Murri initially shared the paternalistic values of many of the Catholic clergy at the time, but later saw the need to improve their social status and their access to professional employment. His writings on women and his plans to set up a women's section in the Lega democratica nazionale will be discussed later.

Another major leader in the Christian democratic movement was Don Luigi Sturzo who had become acutely aware of the plight of Sicilian peasants in the period 1893-1894 when the army violently suppressed their revolts. ${ }^{54}$ Actively involved in extending the activities of the Opera to Sicily, Sturzo was also a successful local politician founding an association of Catholic councillors to free municipal politics from clientelism. ${ }^{55}$ Representing the voice of the "other Italy" which had been excluded from the fruits of the protectionist economic policies, but which now no longer wanted to express the opposition of civil society against the State, Sturzo envisaged a reform of the State on a regional basis and with a more genuinely representative political system. Ultimately Sturzo was responsible for upholding the early Christian democratic tradition, and his speech in Caltagirone on 24 December 1905 served as a platform for the Partito popolare italiano when it was founded in 1919. Women, who were part of that "other Italy”, were promised the vote in Sturzo's platform.

Ironically, the crisis within the Opera coincided with the period when the Christian democratic movement showed signs of great vitality, attracting an increasing number of trade unions as it expanded rapidly especially in Lombardy, Liguria, Emilia and Sicily. It even held its first regional congress in Milan in $1901 .^{56}$ When the Catholic lay

\footnotetext{
${ }^{52}$ De Rosa, Il movimento cattolico in Italia, cit., p. 237. In the encyclical Pieni l'animo, Pius X forbade the clergy from giving "their names ... to any society that does not have Episcopal approbation". See Pius X, Pieni l'animo: Encyclical of Pope Pius $X$ on the Clergy in Italy (28 July 1906) http://www.jesus.2000.years.de/holyfather/pius_x/encyclicals/documents/hf_p-x_enc_28071906_pienil’animo_en.html (15/05/2009)

53 See footnote 70 on pp. 64-65 below.

54 De Rosa, Il movimento cattolico in Italia, cit., p. 190. The revolts were caused by organized peasant groups known as Fasci siciliani.

${ }^{55}$ Ibid., p. 197.

${ }^{56}$ Ibid., p. 169.
} 
movement was reconstituted under Pius X's encyclical Il fermo proposito in $1905,{ }^{57}$ it was organized into three separate Unions: the Unione popolare, the Unione economicosociale, and the Unione elettorale. Moreover, as the delegates gathered for a convention in Florence in February 1906 to approve the statutes for the new format of Catholic Action, they were additionally presented with a letter by the Secretary of State, Cardinal Merry del Val, containing "fundamental norms for diocesan Catholic Action” whereby bishops assumed direct control over lay organizations in their dioceses. This also included responsibility for the conduct of Catholic militants in the political and social fields. Rigorous control exercised by diocesan authorities spelt an end to the Christian democratic movement which not only lost its central organization but also any modicum of freedom to act independently. ${ }^{58}$

In the latter half of the nineteenth century, as mentioned in Chapter One, large numbers of women and children were employed in factories. Therefore, as one would expect, related employment issues were discussed at several congresses of the Opera dei congressi. At the fourth congress in Bergamo in 1877, Giuseppe Benincori, Secretary of the Lombard Regional Committee, stated that women should be excluded from factories, where they were worn out from fourteen or more hours of work (affrante da quattordici e più ore di lavoro), since the wage of a father, together with the earnings of his working-age sons, should be sufficient to cover the essential expenses of a family. Women should not be employed in jobs which required a great physical effort, or in jobs which put them in close contact with the opposite sex, while in night work the intermingling of the two sexes should be absolutely forbidden. In case of childbirth, women should receive their wages, as happened abroad, for a certain number of days. Benincori further recommended that employers should not admit children under twelve to their factories; that for women and children the working day should not be longer than nine hours; and that there should be a weekly rest-day. ${ }^{59}$

At the eighth congress in Lodi in 1890 Count Stanislao Medolago Albani declared that, with regard to women's and children's employment in factories, hygiene, working hours, and leave, State intervention was not only legitimate but necessary. Giorgio

\footnotetext{
${ }^{57}$ Pius X, Il fermo proposito: Encyclical of Pope Pius X on Catholic Action in Italy (11 June 1905) http://www.vatican.va/holy_father/pius_x/encyclicals/documents/hf_p-X_enc_11061905_il-fermoproposito_en.html (08/09/2010)

${ }^{58}$ De Rosa, Il movimento cattolico in Italia, cit., pp. 252-254.

${ }^{59}$ Gambasin, Il movimento sociale nell'Opera dei congressi (1874-1904), cit., pp. 148-150.
} 
Gusmini from Bergamo further proposed that the regulation of the work of women and children should be decided by an international convention, "animated" (avvivata) by periodic conferences of interested nations. He went on to express demands similar to those made in Bergamo:

... nelle industrie, il cui esercizio è riconosciuto particolarmente pericoloso alla morale ed all'igiene ... delle donne ne debbano venire assolutamente escluse; ... le donne non debbono lavorare di notte; ... la giornata di lavoro delle donne non debba superare le dieci ore e che sia interrotta almeno da un'ora e mezzo o due di riposo, secondo le stagioni. ${ }^{60}$

The questions of a ten-hour working day, maternity leave and provision for it as well as the pay of female workers were also brought up. The parity of pay with male workers was not even mentioned since the generally held opinion was that a male worker should earn a wage sufficient to support his family, and therefore the wife's wage should only be a "complement” (complemento). ${ }^{61}$ Regarding children's employment, it was decided that they should be excluded from factories (fabbriche) and night work until fifteen; that between fifteen and eighteen they should be admitted only on a doctor's certificate and that they should not work more than eight hours. Children of either sex should not be admitted to workshops (opifici) unless they were aged between twelve and sixteen, and their working day should not exceed ten hours. ${ }^{62}$

The push for women's direct participation in the Opera formed part of the whole complex of social issues taken up by Christian democrats. The matter was initially raised, but with no appreciable results, by Monsignor Giacomo Maria Radini Tedeschi, then Vice-President of the Permanent Committee, at a special meeting of the Second Group in Verona in April 1898 which was convened to discuss social policy and to find “a line of conduct” vis-à-vis Christian democratic groups. ${ }^{63}$ Greater progress was subsequently made at the congresses in Rome in 1900, in Taranto in 1901, and in Bologna in 1903, which went beyond the bread and butter issues of the earlier meetings with the endorsement of the idea of women themselves becoming directly involved in the Opera and in industrial matters. By this stage the clergy had recognized the need for harnessing women in its apostolic mission to combat the forces of liberalism and socialism. As Gabriele De Rosa observes, with the Bologna congress a new stage was reached in attitudes to working-class women who until then had not been deemed

\footnotetext{
${ }^{60}$ Ibid., p. 418.

${ }^{61}$ Ibid., pp. 417-423.

${ }^{62}$ Ibid., p. 421.

${ }^{63}$ Ibid., p. 473.
} 
capable of looking after themselves. They had been subjected to moralising crusades by upper-class women, who showed little concern for juridical parity and the actual problems working women faced in their employment in factories. ${ }^{64}$ As will be discussed in Chapter Three, the Bologna congress led to the nomination of a special commission, or a Nucleo fisso, charged with drafting a constitution for a women's section in the Opera dei congressi.

\section{$\underline{\text { Modernism }}$}

In the meantime the Catholic world had become embroiled in modernist debate. Emerging in the late eighteenth and the early twentieth century, modernism was concerned with finding "different ways of construing the relationship between modern academic work, the theological tradition of the Church, and ecclesiastical authority", ${ }^{6}$ While during the nineteenth century new scientific evidence about the origin of the world came to light, in the Catholic Church most worshippers continued to adhere to the literal interpretation of Genesis. ${ }^{66}$ Besides, among Catholic scholars, analysis of the theory of evolution brought up a host of further issues calling for the reform of the Church itself. Issues of modernism already appeared during Leo XIII’s papacy, but the modernist “crisis” as such began with the papal announcements in 1907, in which Pius $\mathrm{X}$ defined modernism as a heresy. ${ }^{67}$ A man with conservative views and authoritarian temperament, Pius $\mathrm{X}$ was totally opposed to the idea of reconciling the Catholic faith with contemporary scholarship and "traced the roots of modernism to idle curiosity and satanic pride, which combined to elevate human reason and devalue the supernatural”. ${ }^{68}$ The controversy took various forms. Concurring with the leading French modernist writer, Alfred Loisy, who observed that "there are as many modernisms as there are modernists”, Nicholas Atkin and Frank Tallet note that Catholic modernists “did not constitute a party with a discrete corpus of ideas and values". 69 Their appeals for doctrinal revision remained unheeded, and the theologians themselves were severely disciplined or even excommunicated. In Italy, where the problem "lay in a link between

\footnotetext{
${ }^{64}$ De Rosa, Il movimento cattolico in Italia, cit., p. 183.

${ }^{65}$ Harvey Hill, “Leo XIII, Loisy, and the 'Broad School': An Early Round of the Modernist Crisis”, The Catholic Historical Review, v. 89, 2003, p. 39.

${ }^{66}$ Owen Chadwick, A History of the Popes 1830-1914, Oxford, Oxford University Press, 1998, p. 346.

${ }^{67}$ Hill, “Leo XIII, Loisy, and the 'Broad School'”, cit., p. 58.

${ }^{68}$ Frank J. Coppa, The Modern Papacy since 1789, London, Longman, 1998, p. 145.

69 Nicholas Atkin and Frank Tallett, Priests, Prelates and People: A History of European Catholicism since 1750, Oxford, Oxford University Press, 2003, p. 160.
} 
liberal religious thought and radical politics", ${ }^{70}$ the modernist crisis coincided with the emergence of the Christian democratic movement and its offshoot femminismo cristiano. Romolo Murri, the chief exponent of Catholic political radicalism, was condemned not for doctrinal deviations but to discipline him for political reasons. ${ }^{71}$ Pius X's denouncements of modernism included the decree Lamentabili sane (3 July 1907) ${ }^{72}$ and the encyclical Pascendi dominici gregis (8 September 1907). ${ }^{73}$ After the publication of Pascendi, religious polemics became increasingly virulent, and measures taken to curb modernism involved censoring publications and establishing diocesan watch committees to enforce religious orthodoxy, as well as creating an extensive espionage network by the name of the Sodality of St. Pius V, or Sodalium pianum, to pry on clergymen and laymen suspected of heresy. ${ }^{74}$

\section{Catholic Dogma and Women}

Women's involvement formed a necessary element in the overall Catholic strategy to claim society back to Christianity. As a consequence, women came to perform tasks outside their traditional domestic and cloistered confines, but there was no corresponding change in the dichotomy of imagery of woman as either a demon or a redeeming angel.

Augustine and especially Thomas Aquinas were the two Doctors of the Church whose teachings continued to have a profound effect on the status of women. The importance

\footnotetext{
${ }^{70}$ Chadwick, A History of the Popes 1830-1914, cit., p. 353

71 Lorenzo Bedeschi, "Prete degli operai", Vita pastorale, n. 8-9, 1996, p. 35. See also Francesco Turvasi, “Le trattative per la 'Riconciliazione’ di Romolo Murri in un documento di Giuseppe Fuschini”, in Ricerche per la storia religiosa di Roma, v. 1, Roma, Edizioni di Storia e Letteratura, 1977, p. 302: "Il Murri era stato sospeso a divinis il 15 aprile 1907 in seguito alle corrispondenze che egli aveva inviato al 'Corriere della Sera' sulla separazione dello stato dalla Chiesa in Francia. Dopo varie trattative intercorse tra Murri e il vescovo di Fermo C. Castelli, il 22 marzo 1909, Murri veniva colpito dalla scomunica maggiore 'nominatim ac personaliter', con la motivazione di disseminare 'erronea ac seditiosa in Ecclesia Dei scripto et verbo’. Murri rispose con una lettera che anche i suoi amici giudicarono negativamente.

Tre giorni prima della scomunica, il 19 marzo, Murri era stato eletto deputato al parlamento e qualche tempo dopo sposava civilmente la signorina Ragnhild Lund.

La motivazione contenuta nel decreto di scomunica e la messa all'Indice di sei opere, avvenuta poco dopo (6 giugno 1907), non autorizza a pensare che Murri fu scomunicato per errori dottrinali. I capi di accusa, scritti di pugno da Pio X, che gli furono rivolti sono circoscritti al piano puramente disciplinare.” Original italics retained.

${ }^{72}$ Pius X, Lamentabili sane: Syllabus Condemning the Errors of the Modernists (3 July 1907) http://www.papalencyclicals.net/Pius10/p10lamen.htm (20/02/2010)

${ }^{73}$ Pius X, Pascendi dominici gregis: Encyclical of Pope Pius X on the Doctrines of the Modernists (8 Sept. 1907) http://www.vatican.va/holy_father/pius-X_enc_19070908_pascendi-dominici-gregis_en.html (02/02/2008)

${ }^{74}$ Coppa, The Modern Papacy since 1789, cit., p. 147.
} 
the Church placed on Aquinas's writings became evident when Leo XIII, in 1879, reaffirmed them, together with their misogynist components, in his encyclical Aeterni patris as official Catholic doctrine. ${ }^{75}$ The Thomist principles were also reacknowledged by Leo's successors, Pius X and Benedict XV. Since these doctrines shaped men's perception of women, and the image women themselves had of their gender, study of early twentieth-century Catholic women's movements, let alone any form of "Catholic feminism”, would be incomplete without reference to them.

Recourse to ancient theories in modern contexts is beset by problems. In her book Aquinas, Feminism, and the Common Good Susanne M. DeCrane directs attention to the need for Christian theology to "reinterpret its significant doctrines, texts, and symbols for each generation and within each culture in which it emerges". ${ }^{76}$ This is required for several reasons: "on anthropological grounds; ${ }^{77}$ in light of the principle of analogy; ${ }^{78}$ because of the nature of the foundational documents themselves; ${ }^{79}$ and ... in light of the hermeneutics of suspicion”. ${ }^{80}$ Until the proclamation of the encyclical Divino afflante spiritu ${ }^{81}$ by Pius XII in 1943, the need for a fresh interpretation of biblical texts was ignored by the Catholic Church, and Catholic hermeneutics was dominated by "dogmatic and positivistic conceptions of tradition, truth, and meaning of texts". ${ }^{82}$ The positivistic approach meant that a text was understood as "a semantic

${ }^{75}$ Leo XIII, Aeterni patris: Encyclical of Pope Leo XIII on the Restoration of Christian Philosophy (4 Aug. 1879) http://www.vatican.va/holy_father/leo_xiii/encyclicals/documents/hf_leoxiii_enc_04081879_aeterni-patris_en.html (20/02/2010)

76 Susanne M. DeCrane, Aquinas, Feminism, and the Common Good, Washington, D.C., Georgetown University Press, 2004, p. 1.

${ }^{77}$ Ibid.: “Anthropologically, human existence and human knowledge are closely bound to the historical, material, concrete world. For symbols and texts which emerged in specific settings to be meaningful in new contexts, they must be reinterpreted..."

${ }^{78}$ Ibid.: "... the principle of analogy, which points to the fact that all new knowledge is in some way linked to experiences and knowledge we have already had”.

${ }^{79}$ Ibid., pp. 1-2: "Foundational documents in themselves (authentic classic texts) by their nature emerge from particular contexts and historical moments and address particular realities using symbols, images, linguistic structures, and language belonging to a particular time, place, and people”.

80 Ibid., p. 2 “... hermeneutics of suspicion is a legacy of the Enlightenment - most particularly of Nietzsche, Freud, and Marx - who argued that religion alienated people from life in this world by discounting their life reality now". The author further states: "Feminist hermeneutical theology is premised on the need of any theological tradition to be reinterpreted. However, its distinguishing character and many of its distinctive methodological procedures stem from its being a form of liberation theology."

81 Pius XII, Divino afflante spiritu: Encyclical of Pope Pius XII on Promoting Biblical Studies, Commemorating the Fiftieth Anniversary of Providentissimus Deus (30 Sept. 1943)

http://www.vatican.va/holy_father/pius_xii/encyclicals/documents/hf_p-xii_enc_30091943_divino-

afflante-spiritu_en.html (20/02/2010)

${ }^{82}$ DeCrane, Aquinas, Feminism, and the Common Good, cit., p. 4. 
container whose meaning content was definitively established by its author". ${ }^{83}$ Modernism emanated precisely from the recognition of the inadequacy of such an approach, with biblical scholars calling for the reconciliation of the Church with "progress, liberalism and modern society" ${ }^{84}$ Traditional Catholic dogma, as far as women were concerned, arguably still remained fixed in its misogynist bearings. They continued, writes DeCrane, as a consequence of Aquinas's anthropology which was based on "inaccurate biological and physiological information". ${ }^{85}$

While Augustine largely derived his notions of women and heterosexual relationships from Plato, Thomas essentially subscribed to Aristotle’s anthropological theories. ${ }^{86}$ In her book Subordination and Equivalence Kari Elisabeth Børresen provides an analysis of how the two theologians view women. ${ }^{87}$ Both in Augustine and in Thomas, she writes, the sole reason for the creation of woman consists in the preservation of the human race; the priority of Adam's creation is seen as determining Eve's dependence on him; and the image of God can be found only in man, because, according to Thomas, woman is a mas occasionatus, a "misbegotten male". ${ }^{88}$ Woman's imperfection is not limited to her bodily characteristics but also extends to her rational faculties and, as a consequence, man is more perfect in reason and stronger in virtue than woman. After the fall, Eve's subordination was reinforced by the special punishments inflicted on her which included painful childbirth and her domination by Adam.

Because woman was created to be man's helper, her state of life is defined by her relationship to him. Of the three states applying to a woman, marriage, with its dual purpose of propagating offspring and remedying concupiscence, constitutes the lowest level in the hierarchy of states, while widowhood and virginity involve different degrees

${ }^{83}$ Ibid., p. 5. The author quotes from Sandra Schneiders, “Feminist Ideology Criticism”, Biblical Theology Bulletin, v. 19, no. 1989, p. 5.

${ }^{84}$ Anthony Rhodes, The Power of Rome in the Twentieth Century, London, Sidgwick \& Jackson, 1983, p. 193.

${ }^{85}$ DeCrane, Aquinas, Feminism and the Common Good, cit., p. 46.

${ }^{86}$ Mary Briody Mahowald, Philosophy of Woman: Classical to Current Concepts, Indianapolis, Hackett Publishing Company, 1978, pp. 78-88.

${ }^{87}$ Kari Elisabeth Børresen, Subordination and Equivalence: The Nature and Rôle of Women in Augustine and Thomas Aquinas, Washington, D.C., University Press of America, 1981. The work originates from the Department of History of Ideas, the University of Oslo; published in French in 1968 and in Italian in 1979.

Børresen employs the term "equivalence" to mean the identical value of man and woman as human persons, without denying that they differ. See p. xvi of ibid.

${ }^{88}$ Thomas Aquinas, Summa Theologica, Benziger Bros. edition 1947, translated by Fathers of the English Dominican Province, digital file produced by Sandra K. Perry, Perrysburg, Ohio.

http://www.ccel.org./a/aquinas/summa/home.html [Converted to HTML 11.01.1998]

Part I, Question 92, Article 1. 
of continence to "share in the spiritual fruitfulness of the Church" and to "follow the ascetic ideal of combating concupiscence”. ${ }^{89}$

The married state allows concupiscence to be used for procreation, but any sexual act performed outside this specific aim is a sin. Within marriage, contraception of any form is forbidden, because it would be a concession to concupiscence, and would constitute a venial sin. ${ }^{90}$ Not even economic hardship is considered as a reasonable justification for restricting family size. ${ }^{91}$ Therefore Catholic dogma denies woman any right, under any circumstances, to control the reproductive functioning of her body. Since in Augustine's view the sole purpose for a woman's existence is procreation, consequently, as Rosemary Radford Ruether comments, "rightly ordered sex is properly such as to be depersonalized, unfeeling and totally instrumental". ${ }^{92}$ Moreover, while the exercise of sexuality does not possess any value per se, "the strivings of a virtuous man against the temptations of concupiscence" breed misogynist sentiments: "Thus it is characteristic of a good Christian to love in one woman the creature of God whom he desires to be transformed and renewed, but to hate corruptible and mortal intimacy and copulation - that is, to love the human being in her but to hate that which makes her a wife". 93

The great importance the Catholic Church places on the stability of marriage and family becomes apparent from the Augustinian doctrine of three marriage "goods": proles (offspring), fides (fidelity) and sacramentum (sacrament). “Offspring means”, writes Augustine, "that children are to be lovingly received, brought up with tender care, and given a religious education”. ${ }^{44}$ But, also in this respect, by drawing on Aristotle's physiological and sociological theories, Thomas emphasizes the ancillary role of woman. ${ }^{95}$ The hierarchy of functions prevails, because by herself woman is considered as lacking the necessary strength and capacity to discipline and instruct even her own children.

\footnotetext{
${ }^{89}$ Børresen, Subordination and Equivalence, cit., p. 124.

${ }^{90}$ Ibid., p. 289. See also Thomas Aquinas, Summa Theologica, cit., Supplement, Question 49, Article 6.

${ }^{91}$ Børresen, Subordination and Equivalence, cit., p. 115.

92 Rosemary Radford Ruether, "Misogynism and Virginal Feminism in the Fathers of the Church", in Rosemary Radford Ruether (ed.), Religion and Sexism: Images of Women in the Jewish and Christian Traditions, New York, Simon and Schuster, 1974, p. 162.

${ }_{93}$ Augustine, The Lord's Sermon on the Mount, Westminster, Md., Newman Press, 1948, p. 51.

${ }^{94}$ Idem, The Literal Meaning of Genesis, v. II, trans. and annotated by John Hammond Taylor, New York, Newman Press, 1982, Book 9, Chapter 7, p. 78.

${ }^{95}$ Børresen, Subordination and Equivalence, cit., p. 256.
} 
The marriage good of fidelity, "means that there must be no relations with any other person outside the marriage bond", ${ }^{96}$ while "sacrament means that the marriage bond is not to be broken, and that if one partner in a marriage should be abandoned by the other, neither may enter a new marriage even for the sake of having children". ${ }^{97}$ Vouching for monogamous marriage, the marriage goods of fidelity and sacrament introduced a significant improvement to the condition of women, as they represent the one area in Catholic dogma where woman is treated as equal to man. The doctrine of the three marriage goods, writes Børresen, “opens a breach in the subordinate state of women” by teaching conjugal fidelity and the sacramental nature of marriage. ${ }^{98}$

One should also note woman's role in the redemption of mankind. Just as the fall of man was brought about by women, also in the salvation of the human race she is assigned an important part. The Catholic concept of woman rests on the polarity of two images: Eve, the temptress who was instrumental in the fall of mankind, and the Virgin Mary, the incarnation of absolute purity and the Mother of the Saviour. The male element in the fall, Adam, has his redemptive counterpart in the figure of Christ. Augustine stresses the need for both sexes to be represented in the salvation:

But mankind's deliverance had to be evidenced among both sexes. Therefore, since it was needful to become man, which is the more honorable sex, it reasonably followed that the deliverance of the female sex be seen by that man's birth from a woman. ${ }^{99}$

Subordination applies to woman's earthly function but, like man, her soul is renewed through baptism and thus shares equivalence regarding the order of salvation.

Women entering a religious order take a vow of virginity but they have no prospects of advancing in the hierarchy of the ecclesiastical system because, according to Thomas, "it is not possible in the female sex to signify eminence of degree, for a woman is in the state of subjection, it follows that she cannot receive the sacrament of Order." ${ }^{00}$ Further, woman is precluded not only from administering the sacraments but she is also deemed "incapable of exercising the power of jurisdiction", and even though she may receive the gift of "charismatic speech" she will be excluded from public teaching. ${ }^{101}$

\footnotetext{
${ }^{96}$ Augustine, The Literal Meaning of Genesis, cit., p. 78.

${ }^{97}$ Ibid.

${ }^{98}$ Børresen, Subordination and Equivalence, p. cit., p. 123.

${ }_{99}$ Augustine, Eighty-three Different Questions, Washington, D.C., Catholic University of America Press, 1982, p. 42.

100 Aquinas, Summa Theologica, cit., Supplement, Question 39, Article 1.

${ }^{101}$ Børresen, Subordination and equivalence, cit., pp. 238-239.
} 
The only position of authority conceded by Thomas to women is that of an abbess which is "delegated as it were, on the account of the danger of men and women living together". 102

By inference, since woman is "incapable of exercising the power of jurisdiction", the Thomist precept also precludes her from any prominent position in society. Her personal rights were further eroded by the way subsequent theologians applied different standards to the two genders. Here the writings of St. Alphonsus Liguori (1696-1787) are particularly illuminating. Founder of the Redemptorist Congregation and a prolific writer on spirituality and theology, Liguori’s approach to moral decision making is known as "equiprobabilism" which allowed "freedom from obligation where opinions for and against the law were equal or nearly equal”. ${ }^{103}$ Accordingly, in his manual for confessors (L'homo apostolicus, 1759), he outlines a series of cases in which a man can be exonerated from the obligation to marry a woman he has seduced. There are essentially three loopholes: the man can be exonerated if the girl has agreed to the intercourse; there has been no official promise of marriage on his part; or the man and the girl live in different social and economic circumstances. In the last case, "hidden" marriage is suggested as a possible solution to preclude an awkward social situation due to differences in social rank. ${ }^{104}$

In the decades following Unification there was no fundamental change in the Church's attitude to women or to society. Commenting on Pius IX, Leo XIII and Pius X, whose papacies fell into the pre-World War I period, Adriana Valerio notes that the three popes opposed every significant change to the condition of women, by flatly condemning any cultural development concomitant with industrialization because it was essentially overshadowed by liberalism and Marxism, both denounced by the Church as children of the Enlightenment and the French Revolution. ${ }^{105}$ In its official publications it kept on defending its doctrine by mustering the forces of Catholicism against the "anti-Christian" liberal and socialist ideologies and by opposing the civil and political emancipation of non-Catholics (acattolici), the effective advancement of the proletariat,

\footnotetext{
${ }^{102}$ Aquinas, Summa Theologica, cit., Supplement, Question 39, Article 1.

103 Castle, Harold, “St. Alphonsus Liguori”, in The Catholic Encyclopedia, v. I, New York, Robert Appleton, 1907. http://www.newadvent.org/cathen/01334a.htm (24/04/2008)

104 Elisa Vicentini, Una chiesa per le donne: Elisa Salerno e il femminismo cristiano, Napoli, M. D’Auria, 1995, p. 58.

${ }^{105}$ Adriana Valerio, "Pazienza, vigilanza, ritiratezza. La questione femminile nei documenti ufficiali della Chiesa (1848-1914)”, Nuova dwf, v. 16, primavera 1981, p. 71.
} 
the freedom of the press, parliamentary government, and any change to the condition of women. ${ }^{106}$

While Catholic dogma has remained essentially unchanged with respect to women, the Church has always regarded it as its moral right to make pronouncements on issues affecting them. In a period when the Liberal State introduced civil marriage as the only legally binding institution, Leo XIII through the publication of an encyclical on Christian marriage, Arcanum (1880), deemed it necessary to stress the sacramental nature of marriage and its indissolubility. ${ }^{107}$ Typically the encyclical reaffirms the husband's supremacy over his wife noting that "the mutual duties of husband and wife have been defined, and their several rights accurately established" and that "the husband is the chief of the family and the head of the wife". Half a century later, in 1930, through the encyclical Casti connubii, ${ }^{108}$ Pius XI essentially confirmed the validity of Leo's Arcanum while elaborating certain aspects of it in greater detail, proscribing any form of birth control and abortion for any reason, and launching a broadside against women's emancipation, which he regarded as "the debasing of the womanly character and the dignity of motherhood”.

Pius XI's predecessor, Benedict XV, had adopted a similar tone in his letter "Natalis trecentesimi” of 27 December 1917 to the Superior General of the Roman Union of Ursulines (Unione romana delle vergini orsoline), deploring that since the French Revolution "everything possible was done to snatch the woman from the maternal solicitude and the vigilance of the Church” and, as a consequence, many women had taken up "occupations ill-befitting their sex" and abandoned "the duties of the housewife”. 109 Not long afterwards, on 21 October 1919, the Pope’s distaste for post-war liberalizing tendencies was unmistakably conveyed in an allocution to a group of Italian women, in which he emphasized the need for Catholic women to show their

\footnotetext{
${ }^{106}$ Ibid., p. 72.

107 Leo XIII, Arcanum: Encyclical of Pope Leo XIII on Christian Marriage (10 Feb. 1880) http://www.vatican.va/holy_father/leo_xiii/encyclicals/documents/hf_lxiii_enc_10021880_arcanum_en.html (17/04/2008)

${ }^{108}$ Pius XI, Casti connubii: Encyclical of Pope Pius XI on Christian Marriage (31 Dec.1930) http://www.vatican.va/holy_father/pius_xi/encyclicals/documents/hf_p-xi_enc_31121930_casticonnubii_en.html (19/07/2009)

${ }^{109}$ Benedict XV, “Natalis trecentesimi” (27 Dec. 1917), in The Monks of Solesmes (eds.), The Woman in the Modern World, Boston, St. Paul Editions, 1959, p. 27.
} 
irreproachability also in their manner of dress and to set "a good example not only within the home, but also in the public ways". ${ }^{110}$

Appropriate standards for women were also the concern of Pius XI who, apart from his encyclical Casti connubii, issued further prescripts on behaviour befitting women. In a letter “A Lei, Vicario Nostro” of 2 May 1928, he expressed strong disapproval of a planned national gymnastic and athletic competition for women, regarding such competitions "in vivid contrast to the special and delicate needs of womanly education". 111 In 1931, on the fifteenth centenary of the proclamation of the divine maternity of Mary, the Pope included, in his celebratory encyclical Lux veritatis, an admonition to "those mothers who in our day, weary of children and of the marriage bond, have repudiated the duties they voluntarily undertook" to mend their ways and follow the divine example. ${ }^{112}$ In the same vein, in the encyclical Divini Redemptoris in 1937, Pius XI condemned “Communist doctrine” on various grounds and not least because, by proclaiming the emancipation of women as a basic tenet, communism would rupture "any link that binds woman to the family and the home”. ${ }^{113}$

\section{$\underline{\text { Secular Women's Movements in Liberal Italy }}$}

While Catholic women's movements were conditioned and restrained by Catholic dogma, secular women's movements, too, had their particular ideological frames of reference, with bourgeois feminism deriving its impulses from Enlightenment philosophies, and socialist feminism from Marxist doctrine. Inquiry into women's status had its roots in the eighteenth century when the question of the applicability of the principles of liberty, equality and natural rights for both sexes was raised. Inevitably, the issue was touched on during the French Revolution. The woman best known for her feminist writings was the playwright Olympe de Gouges who in parallel to the Déclaration des droits de l'homme et du citoyen (1789), which guaranteed fundamental civil and political rights to all men, demanded similar rights for women in

\footnotetext{
110 Idem, [Allocution to a group of Italian women, 21 Oct. 1919], in ibid., pp. 28-32; "Il discorso del Papa”, Bollettino d'organizzazione dell'Unione femminile cattolica italiana, n. 7, 15 novembre 1919, pp. $1-2$.

${ }^{111}$ Pius XI, “A Lei, Vicario Nostro” (2 May 1928), in The Monks of Solesmes (eds.), The Woman in the Modern World, cit., p. 35.

${ }^{112}$ Idem, Lux veritatis (25 Dec. 1931), quoted in ibid., p. 39.

${ }^{113}$ Idem, Divini Redemptoris (19 March 1937),quoted in ibid., pp. 39-40.
} 
the Déclaration des droits de la femme et de la citoyenne (1791). ${ }^{114}$ Far from finding sympathy for her women's rights campaign, de Gouges was denigrated by her male compatriots and executed by guillotine in $1793 .{ }^{115}$ Like de Gouges, Mary Wollstonecraft in England was also subjected to harsh censure when she wrote a treatise entitled A Vindication of the Rights of Woman in 1792. This publication, above all, demanded equal rights to education because of woman's formative influence as a mother on the family and on society as a whole. Indeed, how else could woman, asks Wollstonecraft, be "the companion of man" and educate her children "to understand the true principle of patriotism” if she was not prepared by education for such a task. ${ }^{116}$

These two works, de Gouges’ Déclaration des droits de la femme et de la citoyenne and Wollstonecraft's A Vindication of the Rights of Woman, are generally seen to characterize the two distinct tendencies of subsequent women's movements: one with an emphasis on women's political rights, and the other focusing on special maternal and affective qualities of women. Based on the idea of "common humanity", the first of these currents - observes Anne-Marie Käppeli - has an egalitarian outlook, whilst the second represents a dualist approach with its emphasis on "the eternal feminine". ${ }^{117}$ Arguably appeal could be made simultaneously to both the notion of equality and that of sexual difference. These precepts were seemingly reconciled in John Stuart Mill's famous treatise The Subjection of Women (1869) in which he demanded that the legal subordination of women "ought to be replaced by a principle of perfect equality" 118 whilst also maintaining that women possessed certain gender specific qualities which made their influence strong "in two of the most marked features of modern European life - its aversion to war, and its addiction to philanthropy". 119

The woman who more than anyone represented the feminist aspirations of the late nineteenth and the early twentieth century in Italy was without doubt Anna Maria

\footnotetext{
${ }^{114}$ Elisabeth G. Sledziewski, “The French Revolution as the Turning Point”, in Geneviève Fraisse and Michelle Perrot (eds), A History of Women in the West, IV. Emerging Feminism from Revolution to World War, Cambridge, Mass., The Belknap Press of Harvard University Press, 1993, pp. 42-44.

${ }^{115}$ Fiorenza Tarozzi, "Olympe de Gouges e la Dichiarazione dei diritti della donna”, in Gabriella Zarri, La memoria di lei. Storia delle donne, storia di genere, Torino, SEI, 1996, p. 118.

${ }^{116}$ Mary Wollstonecraft, A Vindication of the Rights of Woman, ed. with an introd. by Miriam Brody, London, Penguin, 1992, pp.86-87.

117 Anne-Marie Käppeli, "Feminist Scenes", in Fraisse and Perrot (eds.), A History of Women in the West, IV: Emerging Feminism from Revolution to World War, cit., p.483.

118 John Stuart Mill, “The Subjection of Women”, in Three Essays, Oxford, Oxford University Press, 1978, p. 427.

${ }^{119}$ On p. 531 of ibid. Mill criticizes the misguided manner in which these inclinations have often been directed.
} 
Mozzoni (1837-1920) whose life and career Franca Pieroni Bortolotti has described in her books Alle origini del movimento femminile in Italia $1848-1892^{120}$ and Socialismo e questione femminile in Italia 1892-1922, ${ }^{121}$ as well as various other publications, such as the introduction to her compilation of Mozzoni's writings under the title $L a$ liberazione della donna. ${ }^{122}$ Mozzoni was born in Rescaldina near Milan into a relatively prosperous noble family. Yet financing the children's education must have caused problems, because at the age of five, as the youngest of the siblings, Mozzoni entered a convent school for daughters of impoverished noble families. By the time she left school at the age of fourteen, the bigoted, pro-Austrian education at the convent had turned her decidedly against the values the school professed. ${ }^{123}$ The cultural climate at home was in sympathy with the Risorgimento, and Mozzoni was able to further her education using her father's well-stocked library. Influenced from an early age by the French utopian socialist philosophers Claude Henri Saint-Simon and François Fourier, Mozzoni envisaged the abolition of the family, the State, and private property. In her personal life, too, she abandoned the conventions of patriarchal tradition by having four children out of wedlock and by insisting that children belonged exclusively to the mother. ${ }^{124}$ In December 1880 Mozzoni founded, together with Paolina Schiff, the Lega promotrice degli interessi femminili ${ }^{125}$ calling for equal civil and political rights for both sexes:

La Lega promotrice degli interessi femminili ... è convinta che le scuole infeudate ad interessi parziali non possono tendere la mano ai diseredati d'ogni specie se non sotto forma di concessione, nè venir loro in ajuto che con opere pie, respinge ogni alleanza che le si presenti sotto queste forme che ribadiscono la ineguaglianza umana - afferma nessun uomo e nessuna donna maggiore o minore della persona, epperò tutti eguali davanti al diritto del voto, del lavoro, della mercede, della responsabilità - eguali dinanzi alla legge morale, e questa in armonia colle leggi della natura e della scienza. ${ }^{126}$

In her uncompromising crusade for women's emancipation Mozzoni aligned in succession with movements of diverse political orientations - the Mazzinians, the

\footnotetext{
${ }^{120}$ Franca Pieroni Bortolotti, Alle origini del movimento femminile in Italia 1848-1892, Torino, Giulio Einaudi, 1975.

${ }^{121}$ Eadem, Socialismo e questione femminile in Italia 1892-1922, Milano, Gabriele Mazzotta, 1976.

122 Anna Maria Mozzoni, La liberazione della donna, a cura di Franca Pieroni Bortolotti, Milano, Gabriele Mazzotta, 1975.

${ }^{123}$ Pieroni Bortolotti, Alle origini del movimento femminile in Italia 1848-1892, cit., p. 47.

${ }^{124}$ Ibid., p. 12.

125 Annarita Buttafuoco, Questioni di cittadinanza. Donne e diritti sociali nell'Italia liberale, Siena, Protagon, 1997, p. 47.

${ }^{126}$ G.A.B. [Gualberta Alaide Beccari], "Lega promotrice degli interessi femminili”, La Donna, a. XII, serie II, n. 16, 5 febbraio 1881, pp. 241-241.
} 
Radicals and the Socialists. ${ }^{127}$ She was an indefatigable campaigner for women's suffrage and, throughout her life, equally unremitting in her demand for the right of and the need for women to work outside the home and to achieve parity of remuneration with male co-workers. Totally focused on the issue of women's emancipation, Mozzoni was not able to touch the right chord with any of the political parties she courted since they would not regard her demands as anything but secondary to their own overarching goals of establishing a new social order.

More moderate in their approach than Mozzoni in her "intransigence for equal rights" (intransigenza paritaria) were the two nation-wide feminist organizations, the Consiglio nazionale delle donne italiane and the Unione femminile nazionale which were philanthropist organizations but also pursued political rights for women (filantropia politica). ${ }^{128}$ The Consiglio nazionale, representing bourgeois feminism, came into existence following a visit to Rome in 1899 by a delegate of the International Council on Women who had come to invite Italian women to take part in their conference in London. ${ }^{129}$ This led to the foundation, in the same year, of the Federazione romana, with an organizing committee drawn from predominantly upperclass women. One of its first tasks was to set up a circulating library and a reading room for primary school teachers to support them in their task of providing elementary education. It campaigned for a range of welfare and social issues including protection of female and child labour, paternity tests, the abolition of marital authorization, ${ }^{130}$ and the vote for women at local elections. By 1909 the Federazione romana had eightyfour affiliated associations. In the meantime, arising from its activities, a more formal framework at the national level had been created in 1903 in anticipation of an international women's congress in Berlin, to which only national bodies were invited. Led by Countess Gabriella Spalletti Rasponi until her death in 1931, ${ }^{131}$ the Consiglio nazionale delle donne italiane, as this body became known, affiliated many of the existing pro-vote groups. The Consiglio nazionale was instrumental in organizing the

\footnotetext{
${ }^{127}$ Pieroni Bortolotti, “Introduzione”, in Mozzoni, La liberazione della donna, cit., p. 7.

128 Annarita Buttafuoco, “La filantropia come politica”, in Lucia Ferrante e Maura Palazzi (a cura di), Ragnatele di rapporti, Torino, Rosenberg \& Sellier, 1988, p. 167.

${ }_{129}$ Debora Migliucci, Per il voto alle donne. Dieci anni di battaglie suffragiste in Italia (1903-1913), Milano, Bruno Mondadori, 2006, p. 5.

130 The wife could not perform any act with commercial or legal implications without her husband's authorization.

${ }^{131}$ Migliucci, Per il voto alle donne, cit., p. 6.
} 
first National Congress of Italian Women in Rome in 1908 at which one whole day was devoted to the discussion of women's suffrage. ${ }^{132}$

The suffragette movement as such was composed of so-called "pro-vote committees", whose national body, Comitato nazionale per il voto alla donna, based in Rome, proclaimed its independence from political and religious affiliations, and its allegiance to the International Women's Suffrage Alliance. ${ }^{133}$ Active from 1905 to the outbreak of World War I, the pro-vote committees lent their support to petition parliament for women's suffrage, but lacked cohesion and never attracted large memberships. Bourgeois feminism in Italy was, as Gabriella Seveso comments, fragmentary and lacked the extreme radicalism of Anglo-Saxon feminists. ${ }^{134}$ The feminist movement in Italy, writes Ginevra Conti Odorisio, remained politically isolated, since it was viewed with suspicion and held up to ridicule by the middle classes; yet at the same time was branded as "bourgeois" by the Socialist Party and "subversive" by the Catholics. The latter, in fact, considered radical bourgeois feminism as far more dangerous than socialist feminism. ${ }^{135}$

In 1899 a group of socialist women, including Ersilia Majno Bronzini, Ada Negri ${ }^{136}$ and Jole Bersellini Bellini, founded the above mentioned Unione femminile in Milan, which soon had branches in Torino, Florence, Bergamo, Venice and Udine. It campaigned for women's emancipation and suffrage; showed great concern for the problems of working-class women; ran various educational programs; and was famous for its Asilo Mariuccia, a rehabilitation home for deviant young women. ${ }^{137}$ In 1906, together with the Milanese "pro-vote" committee, the Unione femminile collected some 10,000 signatures in support of a petition to parliament for women's suffrage. ${ }^{138}$ As discussed previously, in 1907 the Giolitti government appointed an all-male committee to investigate the matter. With women themselves being divided on the suffrage issue, it

\footnotetext{
${ }^{132}$ Ibid., p. 8.

${ }^{133}$ Ibid., p. 11.

${ }^{134}$ Gabriella Seveso, “Movimenti femministi e partecipazione politica”, in Barbara Malpelli e Gabriella Seveso (a cura di), Una storia imprevista. Femminismi del Novecento ed educazione, Milano, Guerini Studio, 2003, p. 43.

${ }^{135}$ Ginevra Conti Odorisio, Storia dell'idea femminista in Italia, Torino, ERI, 1980, pp. 158-159.

136 This erstwhile socialist poetess would later become a fascist sympathizer. See Victoria de Grazia, How Fascism Ruled Women, Berkeley, Calif., University of California Press, 1992, p. 251.

137 Migliucci, Per il voto alle donne, cit., p. 4. For information on Asilo Mariuccia, see Annarita Buttafuoco, Le Mariuccine. Storia di un'istituzione laica l'Asilo Mariuccia, Milano, Franco Angeli, 1998.

${ }^{138}$ Migliucci, Per il voto alle donne, cit., p. 13.
} 
was inevitable that the outcome of the investigation was negative for both local and national elections. ${ }^{139}$

In founding her Lega promotrice degli interessi femminili, Mozzoni came into conflict with the Milanese orthodox socialist feminist, Anna Kuliscioff, who at the time was not only against the idea of interclass collaboration but also saw no reason to set up an independent women's organization since class struggle would automatically include a fight against "the monopoly of man" (il monopolio dell'uomo). ${ }^{140}$ Kuliscioff was strongly influenced by Marxist theorists, such as Friedrich Engels and August Bebel, who based their doctrines of social development on economic criteria. In primitive communal societies, writes Engels, both men and women "worked to produce goods necessary for livelihood", and there was no distinction "between a public world of men's work and a private world of women's household service". ${ }^{141}$ With the development of agriculture, the old communal kinship group was broken up, communal ownership was undermined, and woman's importance declined in food production. New exploitative relations emerged, the individual family became economically responsible for its members and for rearing the new generation, the female sex was subjugated, and her "socially necessary labour" was transformed into "a private service”. ${ }^{142}$ Monogamy which, strictly speaking, only applied to women ensured that a man's property was bequeathed to his biological heirs. In post-capitalist society the abolition of private property would obviate the monogamous family as the basic economic unit. Women would be liberated from private housekeeping, which would be transformed into "a social industry", and the care and education of children would become “a public affair”. ${ }^{143}$

In laying the groundwork for the anticipated proletarian revolution, orthodox socialist feminists showed no interest in or were even inimical to issues which inspired their middle-class counterparts, that is, women's access to education and professional employment, juridical parity and women's suffrage, all of which were to be reforms in

\footnotetext{
${ }^{139}$ Il Novecento delle italiane, Roma, Editori Riuniti, 2001, p. 21.

${ }^{140}$ Franca Pieroni Bortolotti, “Anna Kuliscioff e la questione femminile”, in Anna Kuliscioff e l'età del riformismo. Atti del Convegno di Milano - dicembre 1976, Roma, Mondo Operaio Edizioni Avanti!, 1978, pp. 105-106. In 1890 Kuliscioff gave a talk entitled "Il monopolio dell'uomo”. See Maria Casalini, La signora del socialism italiano. Vita di Anna Kuliscioff, Roma, Editori Riuniti, 1987, p. 97.

${ }^{141}$ Frederick Engels, The Origin of the Family, Private Property and the State, New York, International Publishers, 1972. Originally published in 1884. Based on the work Ancient Society (1877) by the American anthropologist Lewis Henry Morgan.

${ }^{142}$ Engels, The Origin of the Family, Private Property and the State, cit., p. 40.

${ }^{143}$ Ibid., p.139.
} 
the context of the existing political structures. Instead, socialist feminists concentrated exclusively on bringing out publications and on organizing working-class women to demand better pay and working conditions. A case in point was the 1902 social legislation which, drafted by Anna Kuliscioff, introduced minimum standards for women's and children's industrial employment while relinquishing previous demands for parity with male employees. ${ }^{144}$ By contrast, Anna Maria Mozzoni expressed her opposition to the welfare legislation arguing that it would jeopardize the employment of female factory workers. With the passage of time positions changed and ultimately even Kuliscioff, ${ }^{145}$ by then a Reformist Socialist, made an about-face on the issue of women's suffrage. Bourgeois feminists, Kuliscioff now argued, demanded the vote in order to strike the first blow against "the iniquitous stronghold of masculine egoism and arrogance" in a system in which man and woman were rivals while socialist feminists, on the other hand, saw in the vote a weapon for the economic emancipation of both sexes, toward which goal men and women would fight side by side their common enemy, bourgeois society. ${ }^{146}$ Thus Kuliscioff's doctrinaire Marxism was ultimately conquered by her sense of political pragmatism, but her attitude had contributed "to the fragility of the Italian suffrage movement, which was continually beset with divisions, misunderstandings, contradictions, and mutual distrust”. ${ }^{147}$ Commenting on Kuliscioff's speech "Proletariato femminile e partito socialista” at the National Socialist Congress in Milan in 1910, Annarita Buttafuoco writes:

... la Kuliscioff invitava le socialiste a dissociarsi dal suffragismo borghese: pur indicando una tattica comune ("marciare separate per colpire unite"), criticava il "blocco femminista indistinto" che a suo parere si sarebbe accontentato di obiettivi parziali come il suffragio femminile limitato per censo: "il femminismo borghese bentosto se ne contenterebbe dimenticando volentieri le promesse i propositi di “sorellanza”. Le donne proletarie, quindi, per scongiurare questo pericolo di tradimento avrebbero dovuto organizzarsi in un "vasto ed energico movimento [...] in contrapposto al suffragismo delle femministe”. ${ }^{148}$

So, while the chief concern for middle-class feminists was women's emancipation, Marxist feminists, on the other hand, worked toward their long-term goal of

\footnotetext{
${ }^{144}$ Casalini, La signora del socialismo, cit., pp. 157-8.

${ }^{145}$ Anna Kuliscioff went through various political phases. Starting as an anarchist she moved to orthodox Marxism, and through her partner, Filippo Turati, leader of the Italian Socialist Party, was associated with the Reformist faction of the Socialists.

${ }^{146}$ Pieroni Bortolotti, “Anna Kuliscioff e la questione femminile”, cit. pp. 122-3.

${ }^{147}$ Elda Gentili Zappi, If Eight Hours Seem Too Few: Mobilization of Women Workers in the Italian Rice Fields, Albany, N.Y., State University of New York Press, 1991, p. 254.

148 Annarita Buttafuoco, Cronache femminili. Temi e momenti della stampa emancipazionista in Italia dall'unità al fascismo, Arezzo, Dipartimento di studi storico-sociali e filosofici dell'Universitá di Siena, 1988, p. 220.
} 
overthrowing the capitalist system and, in the meantime, toward ameliorating working conditions in factories. Neither feminist current showed interest in social issues related to women's control over their own bodies, that is, sexuality and human reproduction issues which decades later would be taken up by the women's liberation movement. Nevertheless, the question of birth control was already pursued at the time, for instance, by the American activist Margaret Sanger and the Swedish writer Ellen Key, but all major religions, the Catholic Church predictably among them, were against contraception. As emerges from Klara Zetkin's interview with Lenin, even for Marxists matters of a personal sexual nature were of secondary importance. ${ }^{149}$

While femminismo cristiano had its origins in the Catholic lay movement and its intransigent opposition to the Liberal State, “transigent” women’s groups also emerged which embraced both religion and the Liberal State. As discussed by Roberta Fossati in Élites femminili e nuovi modelli religiosi nell'Italia tra Otto e Novecento, ${ }^{150}$ these groups were centred on the Unione per il bene which, open to both sexes, spread to various northern cities, promoting interdenominational religious, cultural and philanthropic activities in the decade 1895-1905. Organizing salotti and cenacoli, the Unione appealed to the upper- and middle-class intelligentsia; and through its association with people like the writer Antonio Fogazzaro had links with modernism. Its prominent female members included the grand-niece of Rosmini, Antonietta Giacomelli, ${ }^{151}$ who represented "the Catholic Risorgimento tradition”; Dora Melegari who brought along the impulses of "the Mazzinian and evangelical tradition"; 152 the Trent poet and writer Luisa Anzoletti; ${ }^{153}$ and the journalist Sofia Bisi Albini. These women and others were actively involved in publishing and writing for a number of periodicals which included the Ora presente (1895-1897), In cammino (1900-1904), Rivista per le signorine (1894-1913), and Cordelia (1881-1942). Far from being radical feminists, the members of the Unione per il bene nevertheless wanted to see the traditional notions of women, those pertaining to marriage and motherhood, broadened to encompass the positive contributions single women could make through their capacity for manual and intellectual work and through their open-minded attitude to

\footnotetext{
${ }^{149}$ Clara Zetkin, “Lenin on the Women’s Question”, from My Memorandum Book (1920). http://www.marxists.org/archive/zetkin/1920/lenin/zetkin1.htm (27/04/2008)

${ }^{150}$ Roberta Fossati, Élites femminili e nuovi modelli religiosi nell'Italia tra Otto e Novecento, Urbino, QuattroVenti, 1997.

${ }^{151}$ Antonietta Giacomelli was prominent also in the Catholic feminist movement.

${ }^{152}$ Fossati, Élites femminili e nuovi modelli religiosi nell'Italia tra Otto e Novecento, cit., p. 15

${ }^{153}$ Luisa Anzoletti was prominent also in the Catholic feminist movement.
} 
cultural and political matters. Because of their high cultural level and their desire to pursue independent careers, women associated with the Unione per il bene rejected the notions of marriage as the only purpose of existence for adult women, and of education as mere preparation for it. ${ }^{154}$

Italian feminists of a theosophical persuasion are discussed by Lucetta Scaraffia who observes that feminism should not be considered merely as the product of democracy and bourgeois individualism or socialist doctrines since it has its cultural roots also in the contradictory process of rejection and affirmation of modernity. Its ancestry can also be traced to the ideological movements of the first decades of the nineteenth century, such as Saint-Simonianism and Romanticism, which set themselves against the rational barrenness of modernity and the void of a world without God by inventing new religions and recovering forgotten dimensions of traditional ones. ${ }^{155} \mathrm{New}$ intellectual currents pitted themselves against the preponderance of materialism and the increasing pace of industrialization seeing in woman a mixture of religion, sentiment and ideal naturalness in contrast to the rational and scientific world which bourgeois culture affirmed. $^{156}$ Theosophy evolved from the spread of a new form of occultism spiritualism - a "science" which claimed to be able to find concrete and "scientific" proof of the existence of an afterlife. Founded in New York in 1875 by the Russian noblewoman Helena Petrovna Blavatsky and Colonel Henry Steel Olcott, the Theosophical Society aimed to set up a nucleus of universal brotherhood of mankind, without discrimination by race, faith, sex or colour, in order to promote the comparative study of religions, philosophies and the sciences as well as to establish studies on less known laws of nature and on latent faculties of man. ${ }^{157}$ Its later leader, Annie Besant, combined her feminism and leadership of the theosophic movement with a prominent position in freemasonry. In Italy, too, "practical” and "philanthropic" feminism, with affinities to freemasonic philanthropy, formed the basis for the concept of the donna

\footnotetext{
${ }^{154}$ Fossati, Élites femminili e nuovi modelli religiosi nell'Italia tra Otto e Novecento, cit., pp. 35-36.

${ }^{155}$ On p. 9 of "Introduzione”, in Lucetta Scaraffia e Anna Maria Isastia, Donne ottimiste. Femminismo e associazioni borghesi nell'Otto e Novecento, Bologna, Il Mulino, 2002, Lucetta Scaraffia writes: “Il femminismo ha le sue radici culturali proprio in questo processo contraddittorio di repulsione e di avvicinamento alla modernità e non può quindi essere considerato figlio soltanto della democrazia e dell'individualismo borghese, né delle dottrine socialiste. Non c'è dubbio infatti che la sua origine, nei primi decenni dell'Ottocento, viene da quei movimenti ideologici - come i sansimoniani e gli intellettuali romantici - che si contrapponevano all'aridità razionale della modernità e al vuoto di un mondo senza Dio inventando nuove religioni o recuperando dimensioni dimenticate delle religioni tradizionali attraverso l'occultismo e la gnosi."

${ }^{156}$ Lucetta Scaraffia, "Il femminismo fra progetti politici e movimenti religiosi", in Scaraffia e Isastia, Donne ottimiste, cit., p. 22.

${ }^{157}$ Eadem, "Il femminismo teosofico", in ibid., pp. 41-44.
} 
nuova. "Italian scientific feminism" was intent on changing the old conception of charity: "from charity to public health service, from sentiment to scientific method, from heart to reason.” Not by accident the feminist writer Sibilla Aleramo defined the so-called "philanthropists" as the most remarkable figures of the female intelligentsia. ${ }^{158}$ Established in 1901, the Theosophic Society in Italy, reaching the height of its popularity in 1922 with more than 500 members, ${ }^{159}$ was made up of the intellectual and social élite of the country with a large number of women, many occupying important positions. One of the most renowned adherents was the internationally famous pedagogue Maria Montessori who represented Italian women at the feminist congress in London in 1899 - in the same year in which she had joined the European section of the Theosophic Society. Montessori's feminist writings contain distinct traces of theosophy, and her rapid international success was without a doubt due to the support she received from a network of sympathizers in the Society. ${ }^{160}$ Theosophy had commonalities, as Scaraffia points out, with femminismo cristiano whose leaders, although more interested in the modernization of the Catholic Church than in the encounter between religions, also wanted to give a public dimension to their religious experience. ${ }^{161}$

The genesis of Catholic feminism can be traced to Leo XIII's Rerum novarum and the Christian democratic movement within the Opera dei congressi. Recognizing the importance of the female apostolate in re-Christianizing society, progressive clergy called for the establishment of a women's section of the Opera. As we will see, the doctrines of the Church, which relegated women to subordinate status in all aspects of their lives and confined them to either the domesticity of their home or seclusion in cloisters, affected women's expectations and behaviour, and militated against the emergence of a genuine feminist movement among Catholic women. As noted above, Catholic feminism had fundamentally different origins from the various currents of secular feminism which had their antecedents in the Enlightenment, the French Revolution, the intellectual currents of the nineteenth century, and in socialist doctrine. Because of their fragmentary nature, the early secular feminist movements in Italy

\footnotetext{
${ }^{158}$ Ibid., p. 69. Sibilla Aleramo wrote Italy's first feminist novel, La donna, published in 1906. On p. 75 of Italian Women's Writing 1860-1994, London, Athlone, 1995, Sharon Wood comments: “Aleramo dissects the condition specifically of middle-class women, uninformed, unemployed, undefended by common class interest, subject to the prevailing moral and social hegemony of a patriarchal society backed by a strong Catholic Church".

${ }^{159}$ Scaraffia, "Il femminismo teosofico", cit., p. 78.

${ }^{160}$ Eadem, “Teosofe, femministe e moderniste in Italia”, in Scaraffia e Isastia, Donne ottimiste, cit., p. 89.

${ }^{161}$ Ibid., p. 92.
} 
enjoyed only a limited success. While both the Church and the State remained suspicious of their activities, the inability of the different brands of feminism to unite in a fight for common goals was the inevitable outcome of the political and ideological rifts between them. 
The present chapter is divided into three parts which each deal with femminismo cristiano. Part I starts with an overview of the major secondary works written on the subject. This is followed by a section on the development of women's religious orders and the role of women religious in Italian society. Thereafter, Part I traces the evolution of femminismo cristiano from the early Christian democratic movement, and describes its initial phase (1900-1904), as represented by the women's periodical L'Azione muliebre. Part II first highlights the most prosperous phase of femminismo cristiano around the periodical Pensiero e azione (1904-1908), and then delineates its disintegration. The primary focus of Parts I and II is to show the gradual shift in the attitude of femminismo cristiano as it moved away, not only from Catholic intransigence towards purely emancipationist issues, but also from denominational isolationism towards collaboration with secular feminism. Along with these developments Parts I and II will also throw light on the interplay of political and gender issues in femminismo cristiano. Finally, Part III discusses Romolo Murri's attitude to matters central to femminismo cristiano and the role which he had planned for a women's movement in the renewal of Italian society.

\section{PART I}

\section{$\underline{\text { Literature Overview }}$}

Originating from the early Christian democratic movement, femminismo cristiano had essentially different characteristics and objectives from those of secular feminist movements. Struggling to find a suitable term to describe their Christian democratic women's movement, Catholics at first referred to it as a movimento femminile cristiano. The term femminismo cristiano, however, soon became established in the Christian democratic press despite the unpalatable connotations "feminism" had acquired for its perceived tendency to negate womanly qualities and to destroy family and matrimony. ${ }^{1}$ Contrary to secular feminism, which had women's emancipation as its primary motive,

\footnotetext{
${ }^{1}$ Francesco Maria Cecchini (a cura di), Il femminismo cristiano. La questione femminile nella prima democrazia cristiana 1898-1912, Roma, Editori Riuniti, 1979, pp. 23-24.
} 
femminismo cristiano evolved to promote Catholic doctrines and values in a society which after Unification was seen to drift away from Christianity.

With the exception of Adelaide Coari and few others like Luisa Anzoletti, Antonietta Giacomelli and Elisa Salerno, not much is known of the exponents of the early Catholic feminist movement; and similarly, femminismo cristiano as a movement has received relatively little attention. Its evolution has been conveyed to posterity mainly through the writings of Paola Gaiotti de Biase whose seminal work, Le origini del movimento cattolico femminile, was published in $1963 .{ }^{2}$ In the introduction to the 2002 reprint of the original publication, she writes that her aim was not merely to write a history of women in modernism, but also to bring into focus the complex set of circumstances confronting women "in the midst of modernizing processes and their contradictions". Placed at the centre of "the difficult relationship between the Church and the modern world”, women had to reconcile their faith with yearnings for emancipation:

Non si tratta dunque solo di mettere meglio a frutto la storia delle donne nel modernismo. Si tratta ormai di proporre alla ricerca un orizzonte più ambizioso; affrontare il nodo delle modalità in cui le donne siano state, si siano trovate, al centro dei processi di modernizzazione e delle loro contraddizioni, e per questo anche al centro del rapporto difficile fra Chiesa e mondo moderno, fra radicamento cristiano e ragioni della libertà. ${ }^{3}$

Due to the particular qualities of its exponents, femminismo cristiano was bound to be a unique phenomenon from the outset. Compared with secular feminists, the protagonists of femminismo cristiano were mostly unmarried women who belonged to tertiary religious orders. ${ }^{4}$ They were thus able to fulfil, as single women, a social role in secular society in a form sanctioned by the Church. Their activism, observes Gaiotti de Biase in a later work, was born from Catholic intransigence in response to a call to fulfil one's obligations in the encounter of Christianity with modern society. Theoretical reflection on oneself as a woman was barely implicit; social commitment stemmed rather from one's Christian sense of duty. This did not mean, however, that individual women were not already fully involved in active roles:

La spinta delle cattoliche nasce nel solco della intransigenza, intorno alla idea di una chiamata, di un dovere cristiano; risente della contrapposizione fra cristianesimo e società moderna. La teorizzazione di sé come donna è sullo

\footnotetext{
2 Paola Gaiotti de Biase, Le origini del movimento cattolico femminile, Nuova edizione, Brescia, Morcelliana, 2002.

${ }^{3}$ Ibid., p. xxxiii.

${ }^{4}$ Members of tertiary religious orders do not have to take a permanent vow of celibacy and may live in the secular world.
} 
sfondo, appena implicita; si gioca sul dovere di intervenire in quanto cristiani. Ma la soggettività femminile singola vi è già tutta coinvolta. ${ }^{5}$

It is arguable, however, whether the early protagonists controlled of their "feminist" agendas. Their entry into the public arena was certainly novel, but at the same time their activities were constantly supervised by members of the clergy. The homage they paid in their papers to the Pope and other illustrious members of the clergy could perhaps be seen to reflect the need to assure ecclesiastical authorities of their loyalty. The survival of their periodicals, published for the first time by Catholic women expressly for Catholic women, was, after all, dependent on the support provided by the clergy in both disseminating and financing them.

Unquestionably, early Catholic feminists were imbued with a deep sense of personal commitment to reform the world as they set out to engage in areas for which their feminine proclivities seemed to make them well adapted. By stressing their genderspecific qualities, from which they drew strength to uphold Catholic values in the modern world, Gaiotti de Biase indirectly touches on the concept of the duality of humankind underlying Catholic dogma, which shaped the thinking also of the exponents of femminismo cristiano. Arguably, then, by accepting women's dependent status in society, femminismo cristiano from the start had to be self-limiting in its aspirations. Moreover, while today, in modern societies, the notion of gender difference no longer imparts an aura of inferiority to women, it had different connotations a hundred years ago. It was precisely the attribution of special characteristics to the feminine sex which in the minds of contemporaries validated women's intrinsic inferiority and therefore justified their subordination to the male gender.

Secular feminism and femminismo cristiano, observes Gaiotti de Biase, were fundamentally different as to their historical origins and objectives. Secular feminist movements had resulted from transformations brought about by the French Revolution and by the processes of industrialization which had led to demands for equal rights with men. The point of departure for Catholic feminism, on the other hand, was the need to deal with a whole new set of apostolic problems which modern society had posed to the Catholic Church:

\footnotetext{
${ }^{5}$ Paola Gaiotti de Biase, "Introduzione”, in eadem (a cura di), I cattolici e il voto alle donne, Torino, Società Editrice Internazionale, 1996, p. 7.
} 
Mentre il femminismo laico ha il suo punto di partenza storico nella dichiarazione dei diritti e nella nuova struttura della produzione e la sua base logica nella affermazione della uguaglianza con l'uomo, il femminismo cristiano parte dal complesso dei nuovi problemi apostolici posti alla Chiesa dalla società moderna e si fonda logicamente sulla uguaglianza della vocazione soprannaturale dell'uomo e della donna. ${ }^{6}$

Rather than a quest for gender equality, therefore, the principal motive for Catholic feminists consisted in fulfilling new missionary tasks as the Church perceived them. It was in this domain, that is, in the "supernatural vocation" to win Italian society back to Catholicism, that women were recognized as being equal to men. While the central issue for secular feminism, writes Gaiotti de Biase, was the demand (rivendicazione) for equal rights, for femminismo cristiano the primary goal was service (servizio) to others. ${ }^{7}$

Looking back on the genesis of her book, Gaiotti de Biase regrets that at the time of writing she did not recognize the significance of the Italian modernist phenomenon. Her judgment was influenced by Don Giuseppe de Luca, ${ }^{8}$ who, like many others in the Catholic clergy, even decades later denied Italian modernism and modernist leaders such as Romolo Murri any degree of intellectual relevance:

... il modernismo italiano, quello romano in particolare, viveva molto di rigovernature: non un Laberthonnière, non un Loisy, non un Turmel [...] Il nostro modernismo annoverò più preti spretati che idee travolgenti... ${ }^{9}$

Entering the stage when the modernist debate was at its height, Catholic feminists, it is argued, rather than questioning the doctrinal, spiritual or ethical foundations of their Catholic faith, regarded them, instead, as a source of strength. They challenged,

\footnotetext{
${ }^{6}$ Gaiotti de Biase, Le origini del movimento cattolico femminile, cit., p. 22.

Also in her later writings Gaiotti de Biase has analysed the upsurge of feminism in the first decade of the nineteenth century. For instance, on pp. 29-33 of her essay "Armida Barelli e la condizione femminile dagli inizi del secolo”, in L'opera di Armida Barelli nella Chiesa e nella società del suo tempo, Roma, A.V.E., 1983, she writes that women's entry into factories, important as it was, was not the only cause for the upsurge of feminism. In fact, the writer observes that there was a significant psychological continuity and contiguity between women's work on farm and factory work, which weakened the psychological impact and the cultural novelty of industrial employment. In her view, other factors were far more important in women's history. They included the "feminization" of education and the resultant development of middle-level occupations, such as telephonists and shop assistants, while women's admission to universities created a pressure for their entry into professional careers. Gaiotti de Biase sees, however, the primary reason for the change in women's condition in the development of the modern market economy. This meant that goods which had previously been produced at home for direct consumption could now be purchased. The modern urban housewife who was born as a result was different from the mistress of a rural household.

${ }^{7}$ Gaiotti de Biase, Le origini del movimento cattolico femminile, cit., p. 23.

${ }^{8}$ The Catholic historian Giuseppe De Luca (1898-1962) is known, among other things, as the founder of the journal Archivio italiano per la storia della pietà, the first volume of which came out in 1951.

${ }^{9}$ Gaiotti de Biase, Le origini del movimento cattolico femminile, cit., pp. xxvi-xxvii. The quotation comes from A. Roncalli, Il cardinale Cesare Baronio, Roma, Edizioni di Storia e Letteratura, 1961. Angelo Roncalli was to become Pope John XXIII (1958-1963).
} 
nevertheless, the mixture of repetitive traditionalism, the suspicion of the value of the new, the clerical monopoly of the truth, and the subjection of the laity to the clergy, but had little to do with the modernist debate as such:

Le nostre brave maestrine sembrano, in generale indifferenti alle componenti più propriamente teoriche della quérelle modernistica, derivate dallo storicismo e dall'immanentismo moderni, le questioni della critica biblica, della trascendenza, le deviazioni psicologistiche, i simbolismi; sembrano aliene a lasciarsi “intrigare”, per dirla con le parole di Giuseppe De Luca, “da tanto strepito in sacrestia". ${ }^{10}$

But our "brave little school teachers" did show interest in modernist issues, evidenced, for example, by their selection of recommended reading for the religious page in Pensiero e azione, as Gaiotti de Biase herself observes. While such spurious reading matter and the imputed links with Romolo Murri's Lega democratica nazionale must have been among the reasons to suppress femminismo cristiano, far more dangerous from the Catholic Church's point of view must have been the manner in which the exponents of the movement transgressed, in fulfilling their apostolate, the role assigned to women by doctrine and by tradition, whereby they implicitly questioned the validity of Catholic dogma in modern society.

Gaiotti de Biase's chronologically arranged narrative follows the activities of a Catholic women's group based in Milan around the young school teacher Adelaide Coari, starting with the congress of the Opera dei congressi e dei comitati cattolici in Italia organized in Rome in 1900 and concluding with the discontinuation of Coari's periodical Pensiero e azione in 1908. Although the book does not lack detail on the contemporary political ambience, the primary focus is clearly on Coari and the Fascio femminile milanese. The Veronese countess Elena da Persico emerges as an opponent of Coari's style of Catholic feminism and as a fierce upholder of conservative values in the Catholic women's movement.

Valuable insight into the Christian democratic women's group around Pensiero e azione is also provided by Maria Assunta Vertemati's little known tesi di laurea. ${ }^{11}$ Starting with discussion of the evolution of the Catholic women's movement in Milan in 19001908, Vertemati's thoroughly researched thesis concentrates on “certain significant

\footnotetext{
${ }^{10}$ Gaiotti de Biase, Le origini del movimento cattolico femminile, cit., pp. 104-105.

11 Maria Assunta Vertemati, “Pensiero e azione” e il movimento femminile cristiano a Milano (19001908), Milano, Tesi di laurea, Università degli studi di Milano, Facoltà di lettere e filosofia, 1977-1978.
} 
aspects of the woman question”, which the periodical dealt with. They included women's employment outside the home, Catholic women's industrial organization, women's engagement in political and social issues, and women's recreational reading. ${ }^{12}$ All these matters need to be addressed. The primary focus of my chapter, however, is to show, as earlier explained, the development of the early Christian democratic women's movement into a genuine feminist movement.

Isabella Pera’s article “Chiesa, donna e società moderna: don Grugni e il femminismo cristiano", ${ }^{13}$ on the other hand, elaborates the material role which Carlo Grugni (18771910) played in the evolution of the Catholic feminist movement and provides, in addition, essential biographical data on the Milanese priest. It appears that, with Cardinal Ferrari's appointment of Grugni as one of the four cappellani di lavoro soon after his ordination, the ecclesiastical career of this young priest was very early given a decisive thrust. In the years when the diocese of Milan was taking an increasingly active interest in the industrial and everyday problems of the working classes, it became Grugni's task to work among peasants and labourers. While most of his activities were connected with the Fascio democratico cristiano in Milan, he simultaneously also contributed prodigiously to various Christian democratic periodicals, participated in congresses, and acted on the executive committees of numerous organizations, trade unions and cooperatives.

Grugni's natural inclination to take up the fight on behalf of the most disadvantaged may also have been the reason, Pera observes, for his particular commitment to women's issues. $^{14}$ Upon his appointment as ecclesiastical assistant to the Fascio femminile, he was instrumental in the development of an active apostolate with demands for economic, social and juridical improvements in women's condition and in the promotion of an independent Catholic women's movement.

Even though Grugni was not an original thinker, he appears to have had a good grasp of feminist issues and was well read in feminist literature, including foreign publications. In contrast to Murri's more sporadic interest, Grugni gave his constant attention to the woman question, not so much on the theoretical level but in terms of practical strategies

\footnotetext{
${ }^{12}$ Ibid., p. ii.

${ }^{13}$ Isabella Pera, "Chiesa, donna e società moderna: don Grugni e il femminismo cristiano", Storia e problemi contemporanei, a. XIII, n. 26, 2000, pp. 25-47.

${ }^{14}$ Ibid., p. 32.
} 
for action and for articulating demands. Despite his loyalty to the political line of the Milanese Curia and his veneration for Cardinal Ferrari, Grugni’s inevitable links with Murri through the Christian democratic movement, even though tenuous in the later years, brought on him the wrath of the most vociferous anti-modernists. As will be discussed later, Grugni's periodical Tribuna sociale was suppressed by Ferrari in July 1908, and soon afterwards Grugni himself was discharged of every ecclesiastical responsibility.

In the introduction to Il femminismo cristiano. La questione femminile nella prima democrazia cristiana 1898-1912, which contains a selection of articles on the woman question written between 1898 and 1912, Francesco Maria Cecchini observes that while Paola Gaiotti de Biase's work captures an important moment in the history of Catholic feminism, it makes no attempt to identify secular class issues stemming from workers' entry into national society - issues which influenced Romolo Murri and his style of Christian democracy. ${ }^{15}$ Against the backdrop of women's industrial employment, the most burning issue for the Catholic intelligentsia and for Catholic feminine sensitivities (sensibilità femminile cattolica), as Cecchini sees it, was how to redress the dual crisis which occurred when the family had lost both its economic and its educative function. Gaiotti de Biase, too, he goes on to say, regards the woman question as arising from the Industrial Revolution, but rather than attributing it to women's entry into factories, she finds its primary cause in the radical change in the family, that is, the breakup of the connection between domesticity and industry. ${ }^{16}$

In contrast to Gaiotti de Biase, Cecchini views the early Catholic feminist movement in the overall context of early Christian democracy with Romolo Murri at its centre. He sees the emergence of the first organized Christian democratic movement as being a response to capitalism, while he attributes its demise to the political assertiveness of the conservative Clerical-Moderate block. Christian democracy was, writes Cecchini, a complex and at times self-contradictory movement without a proper, unambiguous theoretical basis, yet capable of engendering sentiments and ideologies and, most importantly, of disseminating propaganda, in particular through Murri’s Christian

\footnotetext{
${ }^{15}$ Cecchini, Il femminismo cristiano, cit., p. 33, footnote.

${ }^{16}$ Ibid., p. 13: "La base strutturale della questione femminile - ha scritto Paola Gaiotti De Biase - è sí la rivoluzione industriale, ma piú per il mutamento radicale della famiglia, la rottura del rapporto fra domesticità e industria, che per l’ingresso della donna nella fabbrica”.
} 
democratic press, and of creating a network of various associations. ${ }^{17}$ As viewed by Cecchini, femminismo cristiano, which emerged in this period, received its first stimulus from secular feminist movements but, as shown by women like Luisa Anzoletti and Adelaide Coari, it was deeply rooted in Catholic culture and in the gospel. ${ }^{18}$ It was riven by the disparate nature of its membership, which was made up of a minority of intellectuals, school teachers and office employees, on the one hand, and of a vast majority of workers and artisans, on the other. These women were held together by their common vocation to resolve problems through the medium of religion and the trust in the "cathartic possibilities" of the Catholic Church. ${ }^{19}$ Constituting the weakest links in the battle of the Christian democratic labour movement, women's organizations were the first to fall when the lay movement was dissolved. ${ }^{20}$

Cecchini argues that with the disbandment of the Christian democratic movement, of which Murri was by then the chief exponent, femminismo cristiano could no longer represent the entire Catholic women's movement but, instead, came to stand for a kind of "social Catholicism", which was in contrast with the dominant Clerical-Moderate trend and even with the ecclesiastical authority. ${ }^{21}$ While this is true, one also has to note that femminismo cristiano reached its zenith with Pensiero e azione at a time when Pius X had already banned Murri's Lega democratica nazionale. ${ }^{22}$ The reasons for the ultimate suppression of femminismo cristiano have to be sought not purely in class but, as we will see, even more importantly in gender issues.

Several articles provide biographical information on Coari, including Antonietta Cimini’s article “Adelaide Coari e il movimento femminile cattolico”, which covers her entire life and includes twenty-one items of her correspondence, lists of her articles published in Pensiero e azione and Gruppo d'azione as well as a list of women's groups belonging to the Federazione femminile. ${ }^{23}$ Another valuable source is Cettina Militello’s essay “Tra emancipazione e amicizia: Adelaide Coari (1881-1966)”, which interweaves Coari's biography with the evolution of the early Catholic women's

\footnotetext{
17 Ibid.

${ }^{18}$ Ibid., p. 14.

${ }^{19}$ Ibid., pp. 34-35.

${ }^{20}$ Ibid., p. 18.

${ }^{21}$ Ibid., p. 43

${ }^{22}$ In col. 1534 of “Murri, Romolo”, in Enciclopedia cattolica, v. VIII, Firenze, Sansoni, 1952, Filippo Caraffa writes: “... il Murri ... fondò a Bologna la Lega democratica nazionale, che fu condannata da Pio X, il quale nella lettera Pieni l'animo del 28 luglio 1906 proibì ai sacerdoti di iscriversi ad essa”.

${ }^{23}$ Antonietta Cimini, “Adelaide Coari e il movimento femminile cattolico”, Studia Picena, v. 43, 1975, pp. 132-200.
} 
movement. ${ }^{24}$ Isabella Pera's article "La questione femminile nel mondo cattolico nel primo Novecento" deals with three important themes related to the early Catholic women's movement: Pius X's position on the woman question; Catholic women's presence in society in the early 1900s; and the position of Adelaide Coari and Elena da Persico vis-a-vis the religious authority. Both women were loyal to the papacy, writes Pera, but while da Persico's attitude was characterized by total obedience, for Coari the acceptance of the papal line was a far more critical and difficult choice. ${ }^{25}$

\section{The Role of Women Religious in Italian Society}

If one looks back on the history of the condition of women in Italy over the last two centuries, it is easy to understand why the first Catholic feminists should be found among women religious in tertiary orders. A brief discussion of the system of women religious in Italy is therefore necessary to explain the circumstances under which tertiary religious came to play such a prominent part in femminismo cristiano.

In Italy, as elsewhere in the Catholic world, cloistered communal living for men and women alike had a long history. With minimal contact with the opposite sex and isolated from the rest of the world, monks, friars, and nuns could dedicate themselves to God in an atmosphere which "fostered ... prayer and collective work, away from worldly distractions”. ${ }^{26}$ As Silvia Evangelisti observes, in the Middle Ages enclosure was initially used to protect nuns from the perils of the outside world, but it was then applied to guard women against their own frailty and natural inclination towards $\sin { }^{27}$

\footnotetext{
${ }^{24}$ Cettina Militello, Il volto femminile della storia, 2. edizione, Casale Monferrato, Piemme, 1996, pp. 402-416.

${ }^{25}$ Isabella Pera, "La questione femminile nel mondo cattolico nel primo Novecento", Ricerche di storia sociale e religiosa, v. 30, Jan.-June 2001, pp. 67-89. For information on Coari, see also: Maria Assunta Colombo, "Coari, Adelaide", in Francesco Traniello e Giorgio Campanini (a cura di), Dizionario storico del movimento cattolico in Italia 1860-1980, II: I protagonisti, Torino, Marietti, 1982, pp. 109-112; "Coari, Adelaide”, in Rachele Farina (a cura di), Dizionario biografico delle donne lombarde 568-1968, Milano, Baldini \& Castoldi, 1995, pp. 316-319; S. Gazzola, “Coari Adelaide”, in Dizionario biografico degli italiani, v. XXVI, Roma, Istituto della Enciclopedia italiana, 1982, pp. 421-424; Sandra Zampa, “A.G. Roncalli ed Adelaide Coari: una amicizia spirituale”, in Giuseppe Alberigo (ed.), Giovanni XXIII: transizione del Papato e della Chiesa, Roma, Borla, 1988, pp. 30-50; Sandra Zampa, "Fonti per la storia della chiesa in Italia: il fondo Adelaide Coari”, Cristianesimo nella storia, v. 4, 1983, pp. 173-203; eadem, "Obbedienza e esperienza di fede. Il carteggo Coari-Radini Tedeschi nella crisi del primo Novecento”, Cristianesimo nella storia, v. 6, 1985, pp. 299-380; Adelaide Coari, Nicolò Tommaseo, con prefazione di Antonio Fogazzaro, Milano, Libreria Editrice Milanese, 1909; eadem, Ho cercato la sua scuola, Brescia, "La Scuola”, 1962.

${ }^{26}$ Silvia Evangelisti, Nuns: A History of Convent Life 1400-1700, Oxford, Oxford University Press, 2007, p. 42.

${ }^{27}$ Ibid., pp. 43-44.
} 
The first piece of universal legislation regarding cloistered seclusion of women goes back to 1298 when Pope Boniface VIII published a bull, known by the first word of its Latin text as Periculoso, which made enclosure compulsory for all Catholic nuns. ${ }^{28}$ This requirement was reaffirmed and thoroughly implemented by the Council of Trent in 1563, which also made the ruling "uncompromisingly gender-specific" since the male clergy was not bound by it. ${ }^{29}$

From the earliest times, therefore, the policy of repression which the Catholic Church pursued regarding women in secular society was even more severe with respect of those unmarried women who had chosen or were forced to consecrate their lives to religious contemplation or to active welfare services in the name of God. In the secular world an unmarried adult woman enjoyed a lesser status than a married woman, both, nonetheless, being subject to male authority: spinster to her male relatives and wife to her husband. In order to gain independence from their family, single women especially from noble or wealthy backgrounds could join a religious order or a religious congregation, which meant living in complete or at least partial seclusion from the rest of the world in a manner approved by the Catholic Church and society. On the basis of the choice aut maritus, aut murus, that is, between marriage and cloister, Filippo Lovison identifies three social roles for women in the post-Tridentine world. ${ }^{30}$ The first related to married women and their vocation to generate offspring, the second to that of consecrated virgins and their vocation to pray, and the third to that of spinsters who, thanks to their vocation to teach or to serve in hospitals and confraternities, could lead an uncloistered existence. Efforts were continuously made by the Church to impose enclosure on all categories of women religious and some of them, like Teresa d'Avila, welcomed enclosure as a privileged space of freedom. Others, belonging to orders such as the Barnabites, the Angeliche and the Paoline, actively resisted attempts to confine them to convents. But it was not only the Church which wanted to see consecrated women in cloistered seclusion. Gabriella Zarri notes an increase in the number of monastic institutions in Italy in the period from the fifteenth to the seventeenth century, attributing it to patrilineal practices which favoured the intact passage of patrimony to the first-born male heir by overlooking the material interests of

\footnotetext{
${ }^{28}$ Ibid., p. 45.

${ }^{29}$ Ibid.

${ }^{30}$ Filippo Lovison, "Donne e riforma della Chiesa in epoca moderna. Influssi, richiami, suggestioni”, in Luigi Mezzadri e Maurizio Tagliaferri (a cura di), Le donne nella Chiesa e in Italia, Cinisello Balsamo (Milano), San Paolo, 2007, pp. 101-102.
} 
daughters and younger sons. Such a nexus between monastic institutions and noble families evidenced the shared interest the aristocracy and the Church had in the strict enforcement of enclosure. ${ }^{31}$

A religious calling was therefore just one of the reasons why women entered convents. Apart from catering for the need to provide accommodation to unmarried women, over time convents also came to provide useful services to society, so attempts by the French to suppress convents outright during the revolutionary period proved futile because there were no comparable institutions which could have undertaken the work of women religious. As Giancarlo Rocca points out in his book Donne religiose, two principles were applied in the preservation of religious orders: no-one should be forced to enter a convent against her will, and religious orders should serve a useful purpose. ${ }^{32}$ Convents were therefore retained for a variety of reasons: for instance, to look after the education of girls and young women; to provide hospital and charitable services to the public; to function as retreats for widows and for women abandoned by or separated from their husbands; and to act as reformatories for "fallen" girls. ${ }^{33}$ As in France, in Italy, too, there was a notable decline in the number of nuns from the beginning of the nineteenth century, which was especially striking in regions which had been occupied by the Napoleonic forces. This trend accelerated in post-Unification Italy when the principles of usefulness of postrevolutionary France were applied to suppress religious orders and to confiscate ecclesiastical property.

During the 1800s the class-oriented, hierarchical structure within convents began to weaken. Distinction was traditionally made between well-born coriste, who arrived at a convent with a dowry, and often even with their personal servants, and lower-class converse who did not take permanent vows and worked as servants. The convent began to lose its function as living quarters for unmarried noblewomen, assuming more strictly religious features. For young women from aristocratic families, Rocca observes, career paths other than a life in a convent were opening up, while, on the other hand, senior positions within convents became accessible also for women from more humble backgrounds. $^{34}$ Concurrent with internal transformations within convents was the

\footnotetext{
${ }^{31}$ Gabriella Zarri, "Le donne nella Chiesa in Italia: rassegna storiografica”, in ibid., pp. $28-29$.

${ }^{32}$ Giancarlo Rocca, Donne religiose. Contributo a una storia della condizione femminile in Italia nei secoli XIX-XX, Roma, Paoline, 1992, pp. 32-33.

${ }^{33}$ Ibid., pp. 32-33.

${ }^{35}$ Ibid., p. 144.
} 
feminization of the clergy, first noticeable in France and later in Italy and other Catholic countries. Michela De Giorgio notes that the first census of the Kingdom of Italy in 1861 recorded 42,664 “cloistered nuns” and “sisters” as opposed to 30,632 brothers, with the highest concentration of women religious in Umbria and the Marches, both previously provinces of the Papal States, and in the South. ${ }^{35}$

Various forms of religious institutions emerged which, unlike convents, did not impose strict enclosure and often, but not exclusively, involved communal living, wearing a religious habit, and welfare services to the outside world. Typical representatives of the new women religious were suore or sisters who in most cases were not bound to take permanent vows, but lived together in a religious community, dedicating their lives to social work and belonging to an institution directed by a superior-general. Lucetta Scaraffia comments that these were the types of institutions spared after Unification since they demonstrably "performed some useful function in society". Accordingly, "of the 527 women's houses suppressed, with their 9,700 nuns, almost all were cloistered monasteries". ${ }^{36}$ By the time a new equilibrium was established between the different categories of women's religious institutions, nuns had lost their position as the numerically strongest group, having been overtaken by women religious in new institutions. ${ }^{37}$ The latter category, following a decline in numbers after the 1866 and 1873 suppressions, began to increase steadily after $1881 .^{38}$ This trend accelerated especially in the 1911-1931 period when the number of women religious not only increased in absolute terms but also as a percentage of the population from 0.131 to 0.272 per cent. ${ }^{39}$

Along with women in secular society women religious, too, began to acquire academic qualifications. In 1905 Pius $\mathrm{X}$ inaugurated the first professional nursing school in Rome, and in the same period missionary sisters began to obtain degrees in medicine. ${ }^{40}$

\footnotetext{
${ }^{35}$ Michela De Giorgio, “The Catholic Model”, in Geneviève Fraisse and Michelle Perrot (eds.), A History of Women in the West: IV. Emerging Feminism from Revolution to World War, Cambridge, Mass., The Belknap Press of Harvard University Press, 1993, p. 175. The statistics quoted lumped together all categories of women religious and “did not distinguish between 'cloistered nuns' and 'sisters', or between cloistered convents, convent schools, oblate houses and new centralized institutions”.

${ }^{36}$ Lucetta Scaraffia, "'Christianity Has Liberated Her and Placed Her alongside Man in the Family': From 1850 to 1988 (Mulieris Dignitatem), in Lucetta Scaraffia and Gabriella Zarri (eds.), Women and Faith: Catholic Religious Life in Italy from Late Antiquity to the Present, Cambridge, Mass., Harvard University Press, 1999, p. 259.

${ }^{37}$ Rocca, Donne religiose, cit., p. 38.

${ }^{38}$ Ibid., p. 51.

${ }^{39}$ Ibid., pp. 50-51. The percentages shown include both sisters and nuns.

${ }^{40}$ Scaraffia, “'Christianity Has Liberated Her and Placed Her alongside Man in the Family,”, cit., p. 261.
} 
The Marcellines in Milan, the first to create a secondary school for girls, sent sisters to obtain degrees as soon as universities began to admit women. ${ }^{41}$ Organized on a more professional basis, these schools adopted syllabuses similar to those of state schools, with some catering for infants and children right through to secondary level. While women religious acquired higher qualifications, they were constrained in their professional work by proscriptions to maintain decency and decorum. In health care sisters were prohibited from attending male patients, women at child birth, and leaving the convent at night to provide for out-patients. In children's education, on the other hand, the question of whether sisters should also cater for the education of boys remained perennially a moot point. Yet, despite attempts to curb their activities, sisters in religious congregations began to provide a whole new range of social and welfare services, including crèches to help working mothers, orphanages for children without parents, services to the aged and the mentally and physically disabled, the rehabilitation of women at risk, boarding houses for factory workers, assistance to emigrants, and missionary work abroad. ${ }^{42}$

In the latter part of the nineteenth and the early part of the twentieth century women religious saw their institutions becoming structurally and operationally more rigid and drifting inexorably under the control of the male clergy. Gianpaolo Romanato notes that religious congregations were not canonically recognized until Leo XIII issued their constitution, the Conditae a Cristo, in 1900, and the Sacra congregazione dei vescovi e regolari their regulations, the Normae, in 1901. Although these documents defined also charitable works as the purpose of religious congregations, ${ }^{43}$ they at the same time placed numerous limitations on the functions of the congregations. ${ }^{44}$ Meanwhile the trend to limit convents to a purely religious role continued, with Pope Pius $\mathrm{X}$ declaring in a letter to monasteries of visitation in 1909 that their first and foremost duty was to observe their rule. Such observance should not be relinquished, or its significance diminished, even under the pretext of helping one's neighbour. ${ }^{45}$ This development culminated with an instruction on the enclosure of nuns by the Sacra congregazioni dei

\footnotetext{
41 Ibid.

42 Gianpaolo Romanato, “Un modello di religiosità femminile nell’Ottocento: la suora”, in Anna Maria Calapaj Burlini e Saveria Chemotti (a cura di), Donne in-fedeli. Temi, modelli, interpretazioni della religiosità femminile, Padova, Il Poligrafo, 2005, p. 147.

${ }^{43}$ Ibid., pp. 141-142.

${ }^{44}$ Rocca, Donne religiose, cit., pp. 204-205.

${ }^{45}$ Ibid., pp. 203-204.
} 
religiosi, which decreed that nuns should neither be seen nor should they ever leave the convent premises. ${ }^{46}$

There was a simultaneous tendency to limit the functions available to women within the Church itself. Concerned that women religious were moving closer to the traditional apostolate of the male clergy, Pius X decreed in 1903 that sacred music was a "liturgical office” from which women, including women religious, should be excluded. Similarly, only where no priest was available should sisters be permitted to teach catechism. As Scaraffia points out, the uniformity and regularization imposed on new congregations, as well as the limitation of their activities, demonstrated that the Church law was moving in the opposite direction from the secular State law which in 1919 granted full juridical status to women and granted them full access to any profession. ${ }^{47}$

Parenthetically, one should note that while women religious were becoming increasingly constrained in their activities, there were some singular women whose financial ingenuity enabled them to turn their charitable activities into extremely successful, self-financing operations. In fact they behaved, observes Scaraffia, like the entrepreneurs who were about to launch an industrial revolution in Italy, continuously reinvesting their profits in new initiatives and showing in their decision-making great independence from both the State and the Church authorities. But even these women usually had to operate behind a male priest who was nominally in charge of their projects. The religious women entrepreneurs included, among others, Vincenza Gerosa, founder of the Sisters of Charity of Lovere (Bergamo), who by her death in 1847 had opened twenty-four charitable institutions; Maria Giuseppa Rossello, founder of the congregation of the Daughters of Our Lady of Mercy, which at the time of her death in 1880 had sixty-five branches; and Francesca Cabrini who, after migrating to the United States in 1889, created an organization which at her death in 1917 consisted of 1,500 sisters spread over eight countries in Europe and North and South America. ${ }^{48}$

It becomes clear that, being completely under the control of the male clergy and having only limited contact with the outside world, neither nuns (monache) nor sisters (suore)

\footnotetext{
${ }^{46}$ Ibid., p. 240.

${ }^{47}$ Scaraffia, “'Christianity Has Liberated Her and Placed Her alongside Man in the Family'”, cit., p. 265.

${ }^{48}$ Lucetta Scaraffia, "Dalle fondatrici ottocentesche all'ideologia del 'gender'”, in Mezzadri e Tagliaferri (a cura di), Le donne nella Chiesa e in Italia, cit., pp. 331-333. See also Gabriella Zarri, "Francesca Cabrini, patrona degli emigranti”, in eadem, La memoria di lei, Torino, Società Editrice Internazionale, 1996, pp. 85-88.
} 
would have been able to play a prominent part in the Catholic feminist movement. This role was taken up by lay sisters or tertiaries who, too, had long been part of the overall network of women religious. In contrast to nuns and sisters, however, tertiaries did not have to live in a community or take permanent vows. Since they were not members of regular clergy, they could not be seen to pose any challenge to the authority of the ecclesiastical hierarchy of the Church. Isabella Pera characterizes these women who, instead of dedicating their lives to their family, took upon themselves the apostolate of social work for the benefit of society and their own sex as follows:

La tipologia femminile che si affermò in tale contesto fu quindi quella della donna nubile e vergine, che godeva però di una pressoché assoluta libertà di azione e trascorreva gran parte della propria vita a scrivere, viaggiare, fare conferenze, partecipare a convegni e riunioni politiche e/o sindacali; essa, diversamente dalle femministe laiche, possedeva una profonda motivazione spirituale originata da un intenso rapporto con Dio, (pur non essendo religiose consacrate queste donne dedicavono molto tempo alle attività spirituali, preghiere, funzioni, esercizi) che per molte rappresentava l'origine, la legittimazione e la meta di una scelta alternativa o perlomeno assai innovativa. ${ }^{49}$

With married women restricted to domesticity and consecrated women religious to their institutions, it therefore fell on women in tertiary orders and the like to become progressively involved in the implementation of the Church's social programme.

\section{$\underline{\text { L'Azione muliebre }}$}

By the end of the nineteenth century the Catholic Church had recognized that in order to maintain its social relevance it needed to engage women in the alleviation of social problems and inequities. Within the Opera dei congressi one of the most ardent advocates for women's involvement in the social field was Monsignor Giacomo Radini Tedeschi. He was born in 1857 into a noble Piacenza family, and after graduation in canon law and ordination to the priesthood he taught at seminaries in his home town until 1890. In that year he was called to Rome by Leo XIII to take up a position in the Secretariat of the State. ${ }^{50}$ He was soon given the task of unifying the operations of the various Catholic associations in Rome. ${ }^{51}$ Committed to the idea of a totally united Catholic movement centred on the Pope, Radini Tedeschi succeeded in bringing the

\footnotetext{
${ }^{49}$ Isabella Pera, "La questione femminile nel mondo cattolico nel primo Novecento", Ricerche di storia sociale e religiosa, v. 30, Jan-Jun 2001, p. 77.

${ }^{50}$ Franco Molinari, "Radini Tedeschi, Giacomo", in Traniello e Campanini (a cura di), Dizionario storico del movimento cattolico in Italia 1860-1980, II: I protagonisti, cit., p. 527.

51 Mario Casella, “Mons. Giacomo Radini Tedeschi, l’Opera dei congressi e il movimento cattolico romano (1890-1900)”, Rivista di storia della Chiesa in Italia, v. 24, 1970, p. 130.
} 
Roman organizations as well as those in Lazio, the Marches and Umbria under the umbrella of the Opera dei congressi. Being offered a post as papal nuncio to Belgium, he declined it, preferring pastoral work in Rome where he remained until his appointment as Bishop of Bergamo in $1905 .^{52}$

Carlo Radini Tedeschi, Giacomo's intransigent father, was the second president of the local Piacenza branch of the Opera dei congressi. The young Radini Tedeschi became a member in $1883,{ }^{53}$ and formed a close friendship with Giambattista Paganuzzi, the long-standing, aristocratic President of the Permanent Committee, ${ }^{54}$ and, by the time the organization was disbanded by Pius $\mathrm{X}$, had advanced to the Vice-Presidency of the Permanent Committee. ${ }^{55}$

While fully embracing Giuseppe Toniolo's social and economic theories, ${ }^{56}$ Giacomo Radini Tedeschi showed less equanimity towards Romolo Murri. His initial cordiality gave way to a bitter criticism of Murri's fiery polemics and insubordination to ecclesiastical authority. ${ }^{57}$ While both shared an awareness of the gravity of social issues and of the need for an apostolate based on Christian democracy, they disagreed on how their mission should be accomplished. In Radini Tedeschi's view, social problems should be dealt with gradually within the framework of the Opera dei congressi, while Murri, on the other hand, regarding with impatience the immobility he encountered in the Catholic ranks, wanted, if necessary, to operate also outside the Opera, and even act against it. $^{58}$

Although during the modernist crisis Radini Tedeschi vigilantly observed the official policy, he never implemented it with inquisitorial severity. ${ }^{59}$ He remained sensitive to social issues demonstrating his solidarity with workers in his diocese when they went on strike over the right of a co-worker to become vice-president of a Catholic workers'

\footnotetext{
${ }^{52}$ Ibid., p.178.

${ }^{53}$ Molinari, "Radini Tedeschi, Giacomo”, cit., p. 527.

${ }_{54}$ Casella, "Mons. Giacomo Radini Tedeschi, l’Opera dei congressi e il movimento cattolico romano (1890-1900)", cit., p. 134.

${ }^{55}$ Molinari, "Radini Tedeschi, Giacomo”, cit., p. 529.

56 Agostino Vian, "Radini Tedeschi, Giacomo”, in Enciclopedia cattolica, v. X, Firenze, Sansoni, 1953, col. 463.

${ }^{57}$ Molinari, “Radini Tedeschi, Giacomo”, cit., p. 529.

58 Casella, "Mons. Giacomo Radini Tedeschi, l’Opera dei congressi e il movimento cattolico romano (1890-1900)", cit., p. 176.

${ }^{59}$ Molinari, “Radini Tedeschi, Giacomo”, cit., p. 530.
} 
league. ${ }^{60}$ Among the young clergy to whom he offered inspirational guidance and who was influenced by him was his secretary, Angelo Roncalli. ${ }^{61}$

Radini Tedeschi saw the theological basis for women's apostolate in the biblical phrase adiutorium simile sibi (“a helper comparable to him”, Genesis, 2, 18). ${ }^{62} \mathrm{He}$ spearheaded a push to form a separate women's section within the Opera dei congressi in recognition of the need for a more coordinated approach to women's activities and for extending the scope of such activities beyond devotional practice and charitable works. In anticipation of the Rome congress in 1900, Radini Tedeschi carried out a survey of women's involvement in the religious, charitable, economic and social fields, which he published as Azione femminile cattolica in Italia. ${ }^{63}$ He saw the existing religious associations as being isolated, poorly organized, and as lacking apostolic zeal. Similarly he found that the multifarious charitable associations had a local character, were independent of each other with no disciplined structure. He discovered, moreover, that there was no cooperation between men's and women's sections. In the economic field women's organizations, such as women's mutual aid societies, were relatively few in number. The most important area, it seemed to him, were women's associations dealing with social issues, and among them he identified three types which he regarded as worthy of examination in order to derive a basis "not for a secular, sectarian and disastrous feminist movement, but a movement for Christian women". ${ }^{64}$ As he envisaged them, such associations would not limit their scope of activity to their own membership but, together with men's organizations, would function for the renewal of society and for the benefit of its weakest members, including protection of women from prostitution:

Sì, la donna deve essere cooperatrice forte ed efficace dell'uomo nella restaurazione sociale; nella protezione dei deboli; nella previdenza per i poveri, per i fanciulli, per gli operai, per le operaie; nelle rivendicazioni dei doveri e dei diritti del popolo; nel rialzamento cristiano del proletariato femminile, e di patronato sopratutto delle fanciulle, perchè non si abbia la più turpe delle tratte, quella delle schiave bianche del piacere e delle sette, che anche nella donna odiano la religione e la imagine di Cristo, e di conveniente e giusto organamento di classe. ${ }^{65}$

\footnotetext{
${ }^{60}$ Ibid.

${ }^{61}$ Ibid., p. 531. Angelo Roncalli wrote a biography of Radini Tedeschi, In memoria di mons. Giacomo Maria R.T. vescovo di Bergamo, Bergamo, 1916.

${ }^{62}$ Molinari, "Radini Tedeschi, Giacomo", cit., p. 528.

63 Radini Tedeschi, G., Opera dei congressi e comitati cattolici in Italia. Sezione femminile. Documenti, Roma Tipografia degli Artigianelli di S. Giuseppe, 1903.

${ }^{64}$ Ibid., p. 9.

${ }^{65}$ Ibid., p. 22.
} 
He believed that under the exceptional contemporary circumstances women in their traditional role as regine della casa were not able to fulfil the new demands placed on them, and therefore had to adopt a wider social mission. Directing his appeal to wives, mothers and, in particular, to those unmarried women who had consecrated their lives to God, ${ }^{66}$ Radini Tedeschi envisaged a militant nation-wide Christian women's movement under the umbrella of the Opera, with "emphasis on popular Christian action or Christian democracy”. ${ }^{67}$

In the first part of his paper Radini Tedeschi noted that three kinds of organizations, already in existence, had moved beyond a purely local character. The first was the Unione delle donne cattoliche per gli interessi cattolici, which had emerged in Rome in 1870 and had subsequently gained ground also in Venice, Padova, Vicenza and Modena $^{68}$. It was composed predominantly of diocesan associations, and the only common element linking them was the uniformity of their constitutions and participation in the spiritual prerogatives of the Roman diocese. ${ }^{69}$ The second kind, the Unione cattolica italiana, which was also based in Rome, consisted of women's sections loosely connected to parochial committees. The third kind was the Opera internazionale cattolica per la protezione delle giovani figlie which had been founded in Freiburg in 1897 in competition with the existing Protestant organization to save young women from prostitution. ${ }^{70}$ The second part of Radini Tedeschi's document contained a draft constitution for a women's organization, and he acknowledged that in large part his draft derived from the constitutions of two organizations of the first kind, the Unione pia delle donne cattoliche in Rome and the Società delle donne cattoliche per gli interessi cattolici in the Veneto. ${ }^{71}$

As a result of the Rome congress, and of the Taranto congress the following year, impetus was given to forming Catholic women's groups to address social problems. Catholic men's fasci already existed in a number of locations under the auspices of the Opera dei congressi, and now parallel women's fasci were expected to appear. Although social activism was by no means limited to the Milan area, for several reasons

\footnotetext{
${ }^{66}$ Ibid., p. 19.

${ }^{67}$ Ibid.

${ }^{68}$ Ibid., p. 10.

${ }^{69}$ Ibid.

${ }^{70}$ Ibid., pp. 12-13.

${ }^{71}$ Ibid., p. 25.
} 
this city became the focal point for the nascent Catholic feminist movement. As explained by Gaiotti de Biase in Le origini del movimento cattolico femminile, Milan was the most modern city in Italy; one could say its "moral capital”. It was the city which most palpably embodied not only the contradictions and perils of modern life but also its more appealing positive aspects. In this typically capitalist setting one could note the increasing number of women in industrial employment as well as their presence at schools and in further study. Also in evidence were the new social problems caused by urbanization, which contrasted starkly with the ostentatious show of wealth and the vibrancy of cultural interchange. All these elements combined to create a challenging environment for the emergent Catholic women's movement, which had a profound awareness of its social mission. After all, the same city had also seen the evolution of the first secular feminist organization, and was the seat of the most modern brand of socialism. $^{72}$

The earliest manifestation of Catholic feminism was the birth of the periodical L'Azione muliebre. ${ }^{73}$ This was the first Catholic women's periodical in Italy and, according to its later editor, Elena da Persico, in Europe. ${ }^{74}$ In its initial period L'Azione muliebre described itself as organo del femminismo cristiano in Italia, but this would soon mutate to the more acceptable organo del movimento femminile cristiano. ${ }^{75}$ The journal which was aimed at middle-class women was created through the initiative of Padre Antonio Bosio da Trobaso. It had the financial backing of a group of upper-class Franciscan tertiary ladies, who remained in close contact with it and contributed articles. Subsequently L'Azione muliebre also relied on the financial support of the clergy, including the Archbishop of Milan, Cardinal Andrea Carlo Ferrari. ${ }^{76}$ The first issue of

\footnotetext{
${ }^{72}$ Gaiotti de Biase, Le origini del movimento cattolico femminile, cit., p. 28.

${ }^{73}$ Ibid., p. 31.

${ }^{74}$ On p. 19 of Elena da Persico. Una donna nella storia, Roma, A.V.E., 1991, Adolfo Passoni writes: “'L’Azione Muliebre’ è il primo giornale femminista cattolico in Italia, la da Persico nel 1915 dirà che fu il primo in Europa ...”

${ }^{75}$ Liviana Gazzetta, Elena da Persico, Verona, Cierre, 2005, p. 29.

${ }^{76}$ From a humble background, Andrea Carlo Ferrari (1850-1921) was appointed bishop of Guastalla and then of Como, before Leo XIII made him a cardinal and transferred him to Milan. A supporter of Christian democracy, he distanced himself from Romolo Murri and adopted a more moderate stance. He was committed to promoting women's and youth movements, and gave his backing for the founding of the Università cattolica del Sacro Cuore. Despite his doctrinal adherence to Thomism, Ferrari and his diocese experienced the full brunt of the modernist crisis, and he and his seminary received three disciplinary apostolic visits. On Ferrari see Antonio Rimoldi, "Ferrari, Andrea Carlo", in Traniello e Campanini (a cura di), Dizionario storico del movimento cattolico in Italia, II: I protagonisti, cit., pp. 196-201; Carlo Castiglioni, "Noterelle sul Card. Ferrari”, in Memorie storiche della diocesi di Milano, v. X, Milano, 1963, pp. 9-20.
} 
the periodical in January 1901 gives an account of the events leading up to its publication:

A Milano - un gruppo di Signore appartenenti alla Congregazione Terziario [sic] Francescana di S. Maria Immacolata fuori Porta Volta, da parecchi mesi si costituirono in Comitato per concorrere colle forze loro a mettere un argine ai mali che ci travagliano. E istituirono prima una conferenza di S. Vincenzo de' Paoli; poi gettarono le basi di una Biblioteca circolante che presto si spera verrà aperta al pubblico; poi promossero ed organizzarono il Catechismo pei bambini e pel popolo nella medesima Chiesa, in attesa di stabilirvi una scuola superiore di Religione agli studenti ed al ceto colto; da ultimo escogitarono la pubblicazione di un doppio giornale indirizzato alle donne. Questa è senz'altro l'opera più ardua a cui si accinsero, e ne furono taluna volta spaventate a cagione delle innumerevoli difficoltà d'ogni natura sorte per via. Ma per la divina mercè le difficoltà vennero superate trionfalmente; al primo invito lanciato alle donne italiane, moltissime risposero con vero trasporto, si trovarono generose offerenti, si formò la redazione di valenti scrittrici, ed ora i due giornali veggono la luce. $^{77}$

Apart from L'Azione muliebre, the same group was also behind the publication of two other women's periodicals, La Vita sociale and its supplement for working-class women, La Donna del popolo. ${ }^{78}$ The latter changed its name to La Donna in January 1902 and became the journal of the Fascio femminile di Milano. ${ }^{79}$

After only a few months on L'Azione muliebre, its founder, Antonio da Trobaso, disappeared without a trace leaving the editor, Maria Maggioni Baldo, to deplore the vacuum created by the departure of the very man who had offered her the post of editor. $^{80}$ A noblewoman from Rovigo (Venezia) and a member of the society of $S$. Vincenzo de' Paoli, Baldo was with L'azione muliebre for the first three and half years of its existence, describing herself as representative of the extreme right. ${ }^{81}$ Even before

\footnotetext{
77 “Movimento muliebre”, L’Azione muliebre, a. I, gennaio 1901, pp. 49-50. Original bold face retained.

${ }^{78}$ In the masthead of La Donna del popolo, a. I, n. 2, 26 gennaio 1901, we can read:

"Il Giornale $\mathfrak{I} \mathfrak{a}$ domma del popolo tratterà:

1. Di Religione e di Morale in brevi, ma succosi articoli, richiamando alla mente delle operaie le grandi verità della Dottrina Cattolica e le massime del Divino Evangelio.

2. Dei Doveri della donna verso di sè, verso la famiglia e verso la società.

3. Dei Diritti della donna in casa e nel laboratorio.

4. Di Educazione morale e civile.

5. Di Igiene della casa, della persona, dell'allevamento dei bambini, pulizia, cure degli ammalati, etc.

6. Di Economia domestica.

7. Notizie e varietà.”

Original fonts retained.

${ }^{79}$ La Donna continued publication until 22 May 1904 when it was absorbed into Il Domani d'Italia. See Gaiotti de Biase, Le origini del movimento cattolico femminile, cit., p. 56.

${ }^{80}$ Baldo’s letter to Radini Tedeschi, 16 Apr. 1901, FAC 9727, fol. 5-7. See also Adolfo Passoni, Elena da Persico, cit., pp. 19-20.

81 Baldo's letter to Radini Tedeschi, 30 Dec. 1903, FAC 9726, fol. 38-39: “Ad ogni modo se io rappresenterò tra le sig. [signore] l'estrema destra non sarà male che sia rappresentata anche quella”. In
} 
the Rome congress she had expressed her support for the burgeoning Catholic women's movement and had written articles for the periodical La Difesa di Venezia on women's issues. Acquainted with Radini Tedeschi, she corresponded with him frequently from 1900 to $1904 .^{82}$ Upon meeting him for the first time at the Rome Congress, Baldo wrote to Radini Tedeschi about her desire to found a "serious" Catholic women's journal:

Ammesso dunque in massima il principio che anche la donna possa e debba lavorare per la patria e per la Chiesa parmi sarebbe necessario anzitutto che un giornale speciale diventasse l'organo di questo movimento femminista, che ha bisogno prima di tutto d'essere spiegato, bandito ed inteso nel suo vero senso per portare buoni frutti. Un giornale per signore che non parli solo di mode e di letteratura spicciola, una rivista seria veramente cattolica per i principi e gli intendimenti ... Il giornale che io sogno fosse anche soltanto una rivista mensile, potrebbe avere per articolo di fondo una conferenza di questo genere, il cui autore sarebbe facile trovare, Lei per es. Monsignore che con i larghi criteri e con tanta eloquenza sa parlare dei doveri e dei diritti sociali-cristiani della donna. $^{83}$

A widow with four daughters and managing the paper from a distance, Baldo experienced perennial problems in covering the costs and finding eminent contributors for it. As becomes clear from her correspondence with Radini Tedeschi, she often had great difficulty keeping in touch with what was happening in Milan and complained that staff made decisions without consulting her:

Della Co. penso che è una ragazza equilibrata, una testina giusta la sola che intenda lo scopo del giornale e sappia e voglia occuparsene con efficacia. - Ma è certo che è una vera derisione che io mi chiami direttrice e se pur voglio spiegare il contegno loro verso di me devo pensare non sappiano più come regolarsi, che siano a mio riguardo imbarazzati e vergognosi perchè stante il disordine che regna negli uffici di redazione non possono fare nei miei riguardi il loro dovere. E il disordine massimo è questo: che dopo tre anni siamo peggio che in principio. ${ }^{84}$

As a solution to the persistent problems facing L'Azione muliebre, Baldo even suggested, in the above cited letter, that the paper should become a supplement to some respectable Catholic periodical, such as L'Osservatore cattolico. Were this to happen,

the same letter Baldo complained about the insubordination of “young” Christian democrats, which made them forget the spirit of the gospel. The signore, on the other hand, were "stupid" (sciocche), "frivolous" (frivole), and "haughty" (superbe), not caring for women workers but looking down on them. The solution to harmonious relations between the social classes lay not in speaking to the poor about their rights but to the rich about their duties. Moreover, Baldo did not find it appropriate that female workers should set up their own organizations except in special cases, and then with representation from the upper classes.

${ }^{82}$ Antonietta Cimini, “Adelaide Coari e il movimento femminile”, cit., pp. 135-136, footnote 13.

${ }^{83}$ Baldo’s letter to Radini Tedeschi, 25 Sep. 1900, FAC 9727, fol. 1-3.

${ }^{84}$ Baldo’s letter to Radini Tedeschi, 10 Oct. 1903, FAC 9725, fol. 32. 
L'Azione muliebre would be able to elicit contributions from the Catholic women's intellectual elite and even attract someone of the calibre of the Trent poetess and feminist Luisa Anzoletti to become its editor. While she would willingly surrender her post for Anzoletti, Baldo wondered in a letter to Radini Tedeschi whether Anzoletti and the ecclesiastical assistant would get along:

Non le pare che il nostro periodico avrebbe ben più solide basi se si appoggiasse quasi a guisa di supplemento, ad un accreditato giornale; con patti speciali da destinarsi? L’Osservatore Cattolico di Milano è giornale fatto magnificamente di idee larghe e moderne mentre è anche devotissimo alla Chiesa ... Col suo appoggio colle sue aderenze convergerebbe pure a noi una élite femminile e questa volta mediante la collaborazione di brave scrittrici cattoliche che certo non devono mancare, ma che noi non abbiamo sputo [saputo] trovare o conservare. E per cominciare io ne additerei subito una, la quale per il suo valore riconosciuto e incontestabile, per la sua coltura eminente e per il suo carattere e per la sua posizione indipendente sarebbe disegnata, a prendere il mio posto, cioè il vero posto di direttrice ... Il solo diritto che vorrei riservare a me sarebbe di cedere io stessa il mio posto a Lei e io stessa pregarla di accettare ... Devo io o non devo di ciò far parola con De-G. [de Giorgi] e l'Anzoletti (mi accorgo ora di non averla nominata ma che volevo parlare giusto di lei Luisa Anzoletti) non sono in buonissimi rapporti fra loro e credo indovinare il perchè ... il De-G. non è fatto forse per attirare le persone: fatto sta che io trovo strano che l'Anzoletti non scriva per noi e sono altrettanto convinta che se il De-G. avesse saputo fare lei avrebbe scritto. ${ }^{85}$

Of a more far-reaching significance than Baldo's editorial role, however, was the employment of young Adelaide Coari as secretary to the editorial office. Born in Milan in 1881, Coari came from a relatively humble social background. Originally from Rovegno (Genoa), her father was a wood trader while her mother, also from Rovegno, had lost both her parents at an early age and was subsequently brought up in the house of an uncle who was a priest. A Franciscan tertiary in her adult life, Coari was a devout Catholic from childhood and already taught catechism when she was fifteen. Attendance at state school where religion was not part of the syllabus turned her into a fierce advocate for religious instruction at all schools. The 1898 riots in Milan awakened in her an interest in social and political issues. ${ }^{86}$ After qualifying as a primary teacher in 1899, Coari obtained a position at a public school in October 1901 and found herself in charge of a class of 105 students. Only a month later she was appointed secretary to the editorial office of L'Azione muliebre, and continued to hold both

\footnotetext{
${ }^{85}$ Ibid, fol. 33.

${ }^{86}$ The riots, which broke out in Milan in May 1898 because of high food prices, were suppressed by the army. According to official figures 80 were killed and 450 wounded - most of them rioters. Those arrested included the intransigent priest Davide Albertario. See Martin Clark, Modern Italy 1871-1995, $2^{\text {nd }}$ ed., London, Longman, 1997, p. 104.
} 
positions simultaneously. In 1903, with her increasing commitment to social issues, Coari relinquished teaching for approximately two years. By then she had become involved with the women's Christian democratic Fascio in Milan, which showed leanings towards Romolo Murri and received encouragement from the progressive Don Carlo Grugni. Founded towards in October 1901 by Coari and her friends, the Fascio was made up of some fifty young and enthusiastic teachers and students. ${ }^{87}$ Apart from Coari, the most prominent among them were Adele Colombo, ${ }^{88}$ Angiolina Dotti and Pierina Corbetta. ${ }^{89}$ For seven years they represented the avant-garde of the Milanese and Italian Catholic women's movement. As previously mentioned, the periodical $\mathrm{La}$ Donna was the official organ of the Fascio. ${ }^{90}$

For these women, the Bologna congress of the Opera dei congressi in November 1903 was an important occasion, with Don Carlo Grugni presenting a paper entitled Organizzazione femminile which provided a basis for the subsequent resolutions to found a women's section of the Opera. Referring to the discussions at the Rome and Taranto congresses, Grugni reiterated the idea that

... anche per la donna è possible, è conveniente, è utile, è necessario" l'interessarsi e lavorare nella vita cattolica esteriore. ${ }^{91}$

He pointed out that the poetic image of la donna al focolare domestico was already outdated since many women were forced to make a living outside the home, and urged the formation of a women's organization which would be strong, autonomous and

\footnotetext{
${ }^{87}$ In the first issue of La Donna, 18 January 1902, we can read:

"Alle donne Cattoliche

Circa tre mesi fa si è costituita la sezione femminile del Fascio democratico Cristiano Milanese; è questo in Italia il primo esempio di donne che ardentemente innamorate, dell'idea Democratica Cristiana si siano unite per lavorare concordi al benessere sociale ...

Era necessario che di contro al movimento femminista dei socialisti sorgesse il nostro a dimostrare che la religione di Cristo nello stesso tempo che diede alla donna l'aureola d'angelo della famiglia, ispirò S. Caterina, guidò Giovanna d'Arco non proibisce di scendere nel campo sociale a combattere per la causa santa del proletariato ...

Per questo dunque è nata la sezione femminile del Fascio Milanese ... per cooperare alla rivendicazione sociale della donna operaia e per affermare il movimento femminista Cristiano di contro a quello socialista."

${ }^{88}$ A founding member of the Fascio democratico cristiano femminile, Adele Colombo (1881-1904) was a textile worker and union organizer, and was among the seven women appointed by Msgr Radini Tedeschi to write a constitution for the proposed women' section of the Opera. She died from tuberculosis at twenty-three. See "Colombo, Adele”, in Farina (a cura di.), Dizionario biografico delle donne lombarde 568-1968, cit., pp. 330-331.

${ }^{89}$ A founding member of the Fascio democratico cristiano femminile, Pierina Corbetta (1880-1905) was a primary school teacher, and wrote articles for La Donna (Milan), L'Azione muliebre, Il Domani d'Italia, and Pensiero e azione. See "Corbetta, Pierina”, in ibid., pp. 341-342.

${ }^{90}$ Gaiotti de Biase, Le origini del movimento cattolico femminile, cit., p. 36.

${ }^{91}$ Carlo Grugni, “Organizzazione femminile”, in Opera dei congressi e dei comitati cattolici in Italia, Atti del XIX congresso cattolico italiano, Bologna 10, 11, 12, 13 novembre 1903, Ferrara, Stab. Tip. S. Giorgio, 1903, pp. 25-26.
} 
vibrant, and capable of using modern strategies to highlight important issues. He envisaged the future women's section as having the same characteristics as the men's section, albeit with fewer organizational components. Functioning independently, it would be coordinated with the men's section through ecclesiastical assistants. With Radini Tedeschi's draft constitution already in existence, the appointment of a commission to revise it would bring the matter to a speedy conclusion. ${ }^{92}$ Grugni praised the Fascio milanese for its work and its assistance to a women's trade union (Lega femminile), also noting the success of two Milanese feminist periodicals, L'Azione muliebre for the cultured and La Donna for the more common readership. ${ }^{93}$ School teachers and female labourers were the two groups of women who in particular needed to be drawn into the Opera. Since it was anticipated that ultimately all children up to a certain age would be taught by female teachers, Catholics should take the opportunity of organizing women teachers before the initiative was seized by their adversaries. It is clear, therefore, that one of the primary tasks for the proposed organization was to compete for the hearts and minds of women workers. Echoing Romolo Murri's platform, Grugni stressed that Catholics should aim to facilitate women's cooperation in the reconstruction of society on its natural foundations, to develop in women a true sense of class consciousness, and to adopt a "proletarian policy" which would assign to the woman worker the position which was rightfully hers. Since the Lega femminile del lavoro already existed around the country, all that was needed now was to breathe life into the existing organization. ${ }^{94}$

As Grugni had proposed, the congress moved for the establishment of a general women's section and for the appointment of a commission to compile a constitution. The congress further invited Catholics and the committees of the Opera dei congressi to establish a women's association in every centre under ecclesiastical supervision, and to promote the women's press. In the immediate period, women's professional and trade union organizations would carry out their activities following the aims of the existing Second and Third Groups of the Opera. ${ }^{95}$

L'Azione muliebre naturally followed the Bologna congress with great interest, and published Grugni's proposal for a women's organization even before the event in its

\footnotetext{
92 Ibid.

${ }^{93}$ Ibid., p. 27.

${ }^{94}$ Ibid., p. 29.

${ }^{95}$ Ibid., p. 30.
} 
October issue which also contained a commentary on it by the ecclesiastical assistant associated with the periodical, Don Francesco Mariani. The latter emphasized the need for women to remain always docile and submissive to ecclesiastical authority as well as to cooperate with the men's section. Before organizing women, Mariani stressed, priority should be given to their education in the basic principles of Catholicism through study circles and the press: "Basta organizzarle? no; dobbiamo formarle". ${ }^{96}$

The November-December issue published after the congress carries the impressions of "Costanza”, who was altogether pleased both at the number of women attending, which was around sixty, and at the calibre of the attendees, composed of both "simple women" and "distinguished ladies". 97 Above all, these women knew how to conduct themselves and not to speak out of turn when attending men's business:

E questo tono modesto ed il loro stesso numero - una sessantina circa - nè esiguo, nè imponente, dava alla loro presenza colà il vero carattere che le aspettava, quello di una assistenza discreta all'azione maschile, che sapeva non oltrepassare il limite imposto dalla loro condizione di donne, e da quel riserbo femminile quasi pudico che sarebbe deplorevolissimo andasse perduto, quando le donne entrassero maggiormente nella vita pubblica. ${ }^{98}$

Perhaps the women attending were not all quite as meek and submissive as the above passage suggests. Three and a half years later, on the occasion of the Convegno femminile in Milan, Don Cavallanti, a journalist on the staff of L'Unità cattolica, recalled, with some misgivings, Coari's audacious insistence on taking the floor several times at the Bologna congress. ${ }^{99}$

Costanza was also pleased, and almost moved, by the behaviour of the men attending the congress. While treating the women neither as intruders nor as equals they were both chivalrous and protective towards them:

E se le donne seppero rimanere al loro posto, gli uomini ve le lasciarono, trattandole non da intruse nè da eguali, ma secondo usanze cavalleresche che non erano fatue e servili, ma nobilmente protettrici. ${ }^{100}$

\footnotetext{
${ }^{96}$ Francesco M. Mariani, “Commento”, L’Azione muliebre, a. III, fasc. 10, ottobre 1903, pp. 175-184.

97“Costanza”, "Il congresso cattolico di Bologna”, ibid., a. III, fasc. 11-2, novembre-dicembre 1903, p. 263. “Costanza” was Maria Baldo’s nom de plume.

98 Ibid.

99 S.A. Cavallanti wrote in "Modernismo femminile. I centri di propaganda”, L'Unità cattolica, a. XLV, n. 56, 8 marzo 1907, p. 1: "Per chi non sapesse facciamo notare che la Coari è quella signorina che al famoso congresso nazionale di Bologna prese più volte, fra applausi, la parola: noi lo ricordiamo benissimo: sedevamo al banco della presidenza: e la Coari ci era poco distante”.

100 “Costanza”, “Il congresso cattolico di Bologna”, cit., p. 263.
} 
Importantly, the same November-December issue also contained a circular written by Radini Tedeschi nominating a commission to write a constitution for the women's organization and stating its terms of reference. ${ }^{101}$ Because Carlo Grugni, the speaker in Bologna on the subject, lived in Milan and because this city was one of the major centres, it was decided that for the time being the commission was to convene in Milan. Those nominated to the commission, or Nucleo fisso, included: Maria Baldo, editor of L'Azione muliebre; Adelaide Coari, Adele Colombo and Pierina Corbetta from the Fascio femminile milanese; Principessa Gonzaga, Milanese president of the Protezione della giovane; and two women known only by their surname: Mauri from Monza and Palumbo from Venice. The nominated members came from diverse backgrounds, and included two working-class women. ${ }^{102}$ Also on the commission were Giacomo Radini Tedeschi and Carlo Grugni, and an invitation to join was issued, in addition, to Don Francesco Mariani, ecclesiastical assistant to L'Azione muliebre. ${ }^{103}$ By July 1904 the commission had completed a draft constitution for diocesan women's committees, which were intended to form the basis of a nation-wide organization. The proposed diocesan committees would be part of the Opera dei congressi e comitati cattolici in Italia, and their purpose was to promote, federate and supervise diocesan women's associations in religious, educational, social and economic matters for the benefit of the working classes and female workers. Initial appointments to the committees would be made by ecclesiastical authorities, and members would thereafter be elected subject to ecclesiastical approval. Each committee would include an ecclesiastical assistant. ${ }^{104}$

In the meantime, in January 1904, L'Azione muliebre was nominated as the official organ of the planned Catholic women's organization. ${ }^{105}$ This was additional to the role it already played since 1901 as the organ of the Lega cattolica femminile per la rigenerazione del lavoro which was founded by Franciscan tertiaries in Milan in 1900. The periodical had also given its full support for the setting up of the Milanese branch of the Opera della protezione della giovane in May-June $1902 .^{106}$

\footnotetext{
${ }^{101}$ G. Radini-Tedeschi, “Sezione femminile dell’Opera dei congressi in Italia”, L'Azione muliebre, a. III, fasc. 11-12, novembre-dicembre 1903, pp. 271-273.

102 Ibid., p. 273.

103 Gaiotti de Biase, Le origini del movimento cattolico femminile, cit., pp. 79-80.

104 “Movimento femminile in Italia”, L'Azione muliebre, a. IV, fasc. 7, luglio 1904, pp. 432-434.

105 “Notizie varie. Per lo statuto”, ibid., a. IV, fasc. 2, febbraio 1904, p. 120.

${ }^{106}$ Passoni, Elena da Persico, cit., pp. 23-24.
} 
From the very first, it was clear that L'Azione muliebre was meant to be a serious publication. Gaiotti de Biase writes:

L'Azione Muliebre è fin dai primi numeri un giornale molto dignitoso, ben scritto, di buon livello culturale. Il formato è piu caratteristico di una rivista culturale che di un giornale divulgativo, gli articoli sono in genere pochi ma lunghi e documentati, senza concessioni al leggero e al divertente. La narrativa vi ha una parte molto ridotta. Si occupa piuttosto di questioni teologiche e culturali, di pagine della Bibbia e del Vangelo, di vite di santi accanto a piccoli saggi letterari, a problemi educativi e indagini sociali. La critica al costume corrente vi è esplicita. Senza indulgere al tono femminista l'analisi della condizione femminile vi è svolta in termini seri, obiettivi, coraggiosi. ${ }^{107}$

Liviana Gazzetta comments that the underlying objective of the publishers of L'Azione muliebre was to produce a periodical of good standard to serve as a medium of religious and cultural education as well as a medium for the exchange of ideas among Catholic women from the middle and upper classes. In the initial period, however, the uncertainty of the editorial programme evidenced a lack of homogeneity among the editorial staff due to differences in their ideological and political orientations. ${ }^{108}$

Various contributions to the periodical demonstrate how it on occasion served as a vehicle for Catholic indoctrination in conditioning women to accept willingly and unquestioningly their subordinate status. Unlike secular feminists, writers for this periodical did not perceive patriarchal society and its unfair laws and practices as their principal enemies but, instead, liberalism and its endorsement of laissez-faire capitalism and, in the same vein, socialism and its potential to overturn the social order. In dealing with social issues, therefore, $L$ 'Azione muliebre played on the anxieties of its upper- and middle-class readers who came from intransigent Catholic backgrounds. This becomes evident, for example, from an article in the August 1901 issue in which the writer Costanza attributed the prevailing economic disequilibrium to capitalist industrial development. ${ }^{109}$ This was regarded as a passing ill, however, and as rectifiable without upsetting the social order, since Christianity could offer all the necessary means for mitigating the damage caused by the concentration of wealth in the hands of a few. It would be "barbarous" and "absurd", however, to render the populace rebellious by teaching a [socialist] doctrine which had not practical meaning. Remedies could, instead, be sought in Catholic doctrine which through charity (beneficenza) and forbearance (rassegnazione) offered means whereby the effects of poverty could be

\footnotetext{
${ }^{107}$ Gaiotti de Biase, Le origini del movimento cattolico femminile, cit., pp. 31-32.

${ }^{108}$ Gazzetta, Elena da Persico, cit., pp. 29-30.

109 “Costanza”, “Il socialismo e la morale cristiana”, L’Azione muliebre, a. I, n. 8, agosto 1901, pp. 4-12.
} 
alleviated. Upward social mobility, too, was reprehensible, since it would create both a moral and a material "gap” between one's desires and one’s capacity to realize them. ${ }^{110}$

As a women's magazine, L'azione muliebre also dispensed advice consonant with the social profile of its readers. In its regular monthly column Buona tenuta della casa, in February 1902, it exhorts the mistress to keep a close eye on the servants about the house. ${ }^{111}$ Servants could cheat their employers, the writer comments, by wasting time (perdendo tempo) in attending to their own affairs while they should be working for their masters, by colluding (mettendosi d'accordo) with suppliers to overcharge their masters in order to share the spoils, by gluttony (ghiottoneria) in consuming a good part of the food intended for their masters, by misplaced charity (per carità male intesa) in giving excessively to the poor, by passing on the leftovers to their own relatives, and by giving to others what was meant for their patrons' exclusive use. ${ }^{112}$

In a period when voting rights were demanded for women world-wide, L'Azione muliebre could not remain neutral on the subject. It became a hotly debated issue also among Italian Catholics after Belgian Catholics had expressed the view that the right to vote was a natural right which could not be denied to women. When Coari arranged for a supporting article to appear in the L'Azione muliebre in March 1902, it inadvertently revealed one of the many fault lines within the journal's ranks. The editorial line of the paper did not endorse the vote for women, even though some well-known Christian democrats, including Carlo Grugni from the Fascio democratico cristiano, were in favour of it. ${ }^{113}$ In the article, which presumably represented the viewpoint of the Fascio femminile, the writer discusses Catholic women's campaign for the vote in Belgium, declaring first that it would be futile and foolish to express any hopes for Italian women to obtain the vote since, for the time being, due to the Roman Question, Catholic men were also denied it. ${ }^{114}$ Nonetheless, even though circumstances differed, it was

\footnotetext{
${ }^{110}$ Ibid., p. 9: "Il contadino potrebbe vivere senza stenti nella sua condizione, ma suo figlio la sdegna e si fa operaio; l'operaio avrebbe di che mantenere la sua famiglia, ma egli è ambizioso e spingerà suo figlio a diventare impiegato; il figlio dell’impiegato farà il professionista; il figlio del professionista aspirerà alla politica e magari alla diplomazia e così con questa mania di salire tutti si spostano, tutti sembrano cercare il modo di porre un deficit morale fra quello che desiderano e quello che possono ottenere e mettono poi quasi sempre un deficit materiale fra i bisogni che crea la loro posizione o la loro ambizione, e le risorse sempre relativamente meschine del loro impiego. Nell'interno delle famiglie pochi son quelli che non sentano [sic] qualche strettezza, ma al di fuori non c’è quasi più differenza di classi.” Original italics retained.

111 This column was run by Elena da Persico.

112 “Buona tenuta della casa”, ibid., a. II, n. 2, febbraio 1902, pp.134-135.

${ }^{113}$ Gaiotti de Biase, Le origini del movimento cattolico femminile, cit., pp. 44-46.

${ }^{114}$ Luigia van des Plas, "Nel Belgio“, L’Azione muliebre, a. II, n. 3, marzo 1902, p. 213.
} 
legitimate to follow the agitation of Belgian women. ${ }^{115}$ In principle, the article was solidly in favour of female suffrage, since universal suffrage was a matter of "truth" and "justice", and it would be neither correct nor fair to exclude women. ${ }^{116}$ It was published without the endorsement of Baldo, who, without knowing who was to blame, lamented the incident in a letter to Radini Tedeschi:

A proposito del numero di marzo ebbi una sgradita sorpresa vedendo pubblicato qualcosa che io non avevo letto prima e a cui non avrei apposto il visto. Si tratta del voto alle donne nel Belgio (Cronaca femm. pag. 213-219). Mi hanno sciupato sei pagine di giornale per dei principi, che non sono affatto i miei e per approvare cose che io non approvo affatto. Il movimento che io dirigo lo intendo in ben altro senso, che non sia una rivendicazione di diritti sociali e di pareggiamento agli uomini, che secondo il mio modo di vedere, mi sembra urtare contro i disegni della Provvidenza riguardo ai due sessi. ${ }^{117}$

Inevitably also the passage by the Chamber of Deputies of a bill authorizing women to practise law generated discussion in L'Azione muliebre. Coari vacillated on the issue and turned to Radini Tedeschi for advice:

... in questi giorni si dibatte la spinosa questione dell'avvocatura della donna; secondo il mio debole giudizio sarebbe buona cosa che anche noi donne cattoliche ci pronunciassimo; ma per canto mio diffido molto del mio, che starebbe volentieri per l'opposizione; si desiderebbe di molto conoscere il suo, al quale potremmo uniformarci. ${ }^{118}$

In his response Radini Tedeschi stated that it was a matter so much against Italian custom that it was ridiculous even to discuss it. He was critical of Catholic journals which understood feminism in this manner, thereby destroying feminism and achieving universal equality only in their own crazy heads. ${ }^{119}$ At Coari’s invitation, Professor Dalmazio Minoretti wrote an article, "Femminismo e femminismo. Le donne avvocatesse”, in the April 1904 issue, ${ }^{120}$ which probably reflected the views held by the majority of Catholics at the time. In it Minoretti described the types of activities suitable for Catholic women saying that while man and woman were equal, the two

The phrase “come nota la Sig.na Van des Plas” (p. 214) leads to the assumption that part of the article was written by editorial staff of $L$ 'Azione muliebre.

115 Ibid., p. 215.

${ }^{116}$ Ibid., p. 217.

117 Baldo’s letter to Radini Tedeschi, 2 Mar. 1902, FAC 9727, fol. 24-25.

${ }^{118}$ Coari's letter to Radini Tedeschi, 6 Mar. 1904, FAC 3528.

${ }^{119}$ Radini Tedeschi's letter to Coari, dated 20 Mar.1904, FAC 4673: "Veramente a me pare una cosa tanto fuori dai nostri costumi e di tutti i costumi; tanto lontana dalle qualità della donna; tanto inutile, mentre é una grandissima disgrazia l'aver già un numero infinito di avvocati, asini purtroppo; da ritenere veramente ridicolo l'occuparsi di tale questione. E per me fanno poco buona figura i giornali che di parte nostra intendono il femminismo così. Essi distruggono il femminismo, e fanno l'uguaglianza universale... nella loro testa pazza." Original underlining retained.

${ }^{120}$ D. Minoretti, “Femminismo e femminismo. Le donne avvocatesse”, L'Azione muliebre, a. IV, fasc. 4, aprile 1904, pp. 195-200. 
sexes had different missions and consequently, as in the family, in public life too there were certain tasks for which men were better suited, just as women were adapted for motherhood. There were many women, however, who renounced private motherhood in order to fulfil a maternal function in the big human community. No-one, wrote Minoretti, could object to this kind of charitable feminism practised by such women. While steering clear of discussing the contentious issue of political feminism and the vote for women, Minoretti gave his endorsement to educational feminism recognizing the need for women's upper secondary schools to enable mothers to function better as educators in their family. As regards professional feminism, being companions for, but not superior to men, women would not be suited for occupations, such as the legal and engineering professions, in which they would exercise authority over men. Only if there were no suitably qualified men should women be entrusted with public office provided it did not interfere with their family life and did not overtax them physically or intellectually. By comparison, the same criteria did not seem to apply to more menial jobs. It was recognized that women's employment in factories was deplorable, but it could be ameliorated through legislation, workers' organizations, and the charitable work of "good and intelligent ladies".

L'Azione muliebre could offer only a supine response to the Pope's decision to ban women from sacred music. In February 1904 the periodical commented on Pius X's encyclical Tra le sollecitudini of 22 November 1903, which stated that since "singers in church have a real liturgical office”, "women, being incapable of exercising such office, cannot be admitted to form part of the choir". ${ }^{21}$ While the writer, "Ida. T.”, deplored that the Holy Shepherd had made sacred song disappear for women "as if by magic", she tried to justify the decision by pointing to feminine weaknesses which rendered women unfit for such a role. ${ }^{122}$

One of the most notable successes of L'azione muliebre was the fight against the legalization of divorce. The December 1901 issue devoted several pages to the matter, expressing the view that divorce would mean legalizing adultery and would spell the end of the family which “destructive” (irrompente) socialism wanted to annihilate at all costs. $^{123}$ It also published a public appeal signed by a number of Catholic associations

\footnotetext{
${ }^{121}$ Pius X, Tra le sollecitudini: Instruction on Sacred Music (22 Nov. 1903). http://www.adoremus.org/MotuProprio.html (24/11/2008)

${ }^{122}$ Ida. T., "La donna e il canto in chiesa”, L'Azione muliebre, a. IV, fasc. 2, febbraio 1904, pp. 87-88.

123 “Divorzio", ibid., a. I, n. 12, dicembre 1901, pp. 7-12.
} 
in response to a public rally in Milan in favour of divorce. ${ }^{124}$ L'Azione muliebre launched its own campaign headed "Le donne italiane contro il divorzio" aimed at collecting signatures from women. ${ }^{125}$ In January 1902 the periodical reported on the allocution which the Pope had held against divorce the previous month and in which he had referred to the sacramental nature and indissolubility of marriage. ${ }^{126}$ In the meantime the Opera dei congressi, too, had initiated a drive for signatures but, in order to retain the "special character" of its campaign, L'Azione muliebre continued to collect signatures which would later be presented to parliament together with those gathered by the Opera. ${ }^{127}$ Luisa Anzoletti was sponsored to speak on the topic in January 1902, and her speech was published in full in the February issue. ${ }^{128}$ In January 1903 L'Azione muliebre could report that as a result of its efforts three volumes of signatures could be added to the volumes for parliament. ${ }^{129}$ Altogether three and a half million signatures were obtained in nation-wide appeals against the proposed legislation. ${ }^{130}$

It is not possible to provide here an analysis of the complete range of issues which L'Azione muliebre dealt with. It is clear, however, that the paper took its role as a Catholic women's periodical very seriously. It conscientiously reported on women's meetings and conferences in Italy and abroad; took an active interest in schools and matters related to Catholic women's education; promoted Catholic women's unionization and industrial safety regulation; published and sometimes commented on official announcements by the Vatican; and campaigned against prostitution. It was also instrumental, as mentioned previously, in setting up the Milan branch of Il comitato italiano per la protezione della giovane, ${ }^{131}$ an organization which gave practical assistance to girls leaving their home in search of employment in Italy or abroad, and protected them from prostitution. Thus the periodical tended to reflect the whole gamut of different, and sometimes discordant, orientations within the Christian democratic movement, and promoted a range of initiatives spanning from traditional philanthropy to encouraging working-class women to speak out for themselves in industrial matters. Despite occasional glimpses of a desire to embrace emancipationist issues, the tightly guided “feminism” of L'Azione muliebre - which mostly embraced traditional middle-

\footnotetext{
${ }^{124}$ Ibid., pp. 10-12.

125 "Le donne italiane contro il divorzio, ibid., pp. 12-13.

126 “L’allocuzione del Papa contro il divorzio”, ibid., a. II, n. 1, gennaio 1902, pp. 40-41.

127 "La sottoscrizione - protesta delle donne italiane contro il divorzio", ibid., p. 44.

${ }^{128}$ Luisa Anzoletti, “Conferenza sul divorzio”, ibid., a. II, n. 2, febbraio 1902, pp. 140-162.

129 “La nostra bandiera e le nostre speranze”, ibid., a. III, n. 1, gennaio 1903, p. 1.

${ }^{130}$ Clark, Modern Italy 1871-1995, cit., p. 164.

131 "La nostra bandiera e le nostre speranze”, cit., p. 1.
} 
class values - did not espouse causes which would have empowered women either in their home, in the Church or in society.

L'Azione muliebre published articles from a number of sources. From the very first issues, among its contributors was the Veronese countess Elena da Persico who would occupy the editorial post of the periodical from 1904 to 1948 . Born in 1869 as the eldest of the three children of Count Carlo III da Persico and Countess Maria Barbavara di Gravellona at Affi near Verona, Elena was at first privately tutored at Affi but then moved to Milan to study at the Ghislanzoni schools. She then stayed with the Ursuline sisters to concentrate on the study of the main European languages, and obtained a teaching qualification in Como in 1890 and a French teaching diploma the following year. ${ }^{132}$ Because of her family's straitened financial circumstances, Elena had to earn a living but, instead of teaching, she turned to writing for predominantly religious and educational purposes. She became a contributor to the periodical Vittoria Colonna in 1899 and from 1901 she wrote for L'Azione muliebre while simultaneously composing short stories, sketches, novels and hagiographies and producing translations from German and French. Apart from the short stories and translations published in L'Azione muliebre under the nom de plume of Carola da Sabbioneta, da Persico was responsible for two regular columns in that periodical: Convenienze sociali and Buona tenuta della casa. $^{133}$ Adolfo Passoni attributes da Persico’s growing interest in social issues to her association with L'Azione muliebre, ${ }^{134}$ while Dora Castenetto sees her journalism as being directed toward "awakening" the feminine conscience for issues of common concern. ${ }^{135}$ Attracted from a young age to religious and spiritual matters, da Persico took a temporary vow of virginity in 1903 and a permanent vow the following year, ${ }^{136}$ and later established one of Italy's first secular institutions for women, Figlie della Regina degli Apostoli. While her family would have preferred her to marry and showed hostility toward her devotion to religious matters, da Persico from early on in her literary and journalistic career found support among important Catholic figures such as Don Achille Ratti, prefect of the Ambrosian Library who later became Pope Pius XI, the Archbishop of Milan, Cardinal Andrea Ferrari, and Cardinal Rampolla del Tindaro,

\footnotetext{
${ }^{132}$ Dora Castenetto, Elena da Persico. Una intuizione spirituale, Milano, Centro Ambrosiano, 2006, p. 7. Also: Domenenico Mondrone, “Una donna laica moderna. Elena da Persico”, La Civiltà cattolica, v. 136, n. 1, febbraio 1985, p. 355.

133 Gazzetta, Elena da Persico, cit., p. 30.

${ }^{134}$ Passoni, Elena da Persico, cit., p. 19.

${ }^{135}$ Castenetto, Elena da Persico, cit., p. 13.

${ }^{136}$ Mondrone, “Una donna laica moderna”, cit., p. 356.
} 
Leo XIII's powerful Secretary of State. ${ }^{137}$ With such an impressive array of ecclesiastical connections, da Persico could not but promote the orthodox Catholic line and, accordingly, even in the midst of the modernist debate, she would "never take a false step". 138

In the wider Catholic world, the death of Pope Leo XIII, and the election, in August 1903, of Giuseppe Sarto as the new pope under the name of Pius X, ushered in a new era. His decision to disband the Opera dei congressi in July 1904 was motivated by a desire to put an end to the seemingly irresolvable internal conflicts within the lay movement and to bring it simultaneously under tighter ecclesiastical control. The move was triggered by the circulation within the Opera of new directives by the President of the General Committee, Count Giovanni Grosoli. The document, drafted incidentally by Radini Tedeschi and Filippo Meda, ${ }^{139}$ injudiciously not only stressed the Christian democratic nature of the Opera's programme but also alluded to the still open Roman question by saying that "in national consciousness the work of the living should not be hampered by dead issues“. ${ }^{140}$ When the official organ of the Vatican, L'Osservatore romano, refused to publish the circular, Grosoli, and with him, Radini Tedeschi and Meda resigned their positions in the Opera. ${ }^{141}$

The break-up of the Opera dei congressi was foreshadowed by a number of measures which both Leo XIII and Pius X had taken to limit the independence and the scope of activities of the Christian democratic movement. Just half a year earlier, on 18 December 1903, Pius X had published his first encyclical, Fin dalla prima nostra, in which he reiterated the principles laid down by his predecessor in Graves de communi re, on 18 January 1901, on Christian democracy. Basically both pontiffs decreed that "Christian Democracy must have nothing to do with politics, and never be able to serve political ends or parties"; that "in performing its functions, Christian Democracy is bound most strictly to depend upon ecclesiastical authority"; and that "the Christian Democratic movement in Italy ... must be under the direction of the Association of

\footnotetext{
${ }^{137}$ Gazzetta, Elena da Persico, cit., p. 27.

${ }^{138}$ Ibid., p. 32: “... non mise mai il piede in fallo”.

139 Alessandro Albertazzi, “Grosoli Pironi, Giovanni”, in Traniello e Campanini (a cura di), Dizionario storico del movimento cattolico in Italia 1860-1980, II: I protagonisti, cit., p. 277.

${ }^{140}$ Gabriele De Rosa, Il movimento cattolico in Italia. Dalla Restaurazione all'età giolittiana, Roma-Bari, Laterza, 1988, p. 206: “... non venga intralciata l’opera dei viventi da questioni morte nella coscienza nazionale".

141 Ibid, p.207; Alfredo Canavero, “Meda, Filippo”, in Traniello e Campanini (a cura di), Dizionario storico del movimento cattolico in Italia 1860-1980, II: I protagonisti, cit., p. 356.
} 
Catholic Congresses and Committees”. ${ }^{142}$ Pius X's move to dissolve the Opera, therefore, meant dismantling the whole national base of Christian democracy.

These events were also echoed in L'Azione muliebre, which in its September 1904 issue published a circular by the papal Secretary of State, Cardinal Raffaele Merry del Val, which officially announced the disbandment of the Opera. For the burgeoning women's movement the cardinal's directive carried sinister overtones:

... non si conceda mai la parola alle signore, benchè rispettabili e pie. Se alcuna volta i vescovi crederanno opportuno di permettere un'adunanza di sole signore, queste parleranno sotto la presidenza e la sorveglianza di gravi persone ecclesiastiche ... ${ }^{143}$

As in the Opera dei congressi, in L'Azione muliebre too the uneasy association of middle- and upper-class conservatives with progressive Christian democratic elements was beset by fundamental differences. Maria Baldo, the editor, had misgivings about Coari's membership of the Fascio femminile but on the personal level was fond of the young secretary. ${ }^{144}$ The two were diametrically opposed on the question of industrial organization of women; while Baldo held the view that female labour should be guided by bourgeois women, Coari believed that working women would be capable of acting independently, an attitude she had in common with Radini Tedeschi. ${ }^{145}$ Besides, despite being a member of the Nucleo fisso herself, Baldo did not share Coari's enthusiasm for the proposed women's movement:

... sarei molto più contenta e quieta se "L'Azione Muliebre” piuttosto che essere l'organo del movimento femminile fosse un buon giornale semplicemente per la formazione intellettuale e morale delle signore. ${ }^{146}$

Radini Tedeschi, for his part, noted that Baldo’s conservative views showed little evidence of "sane Christian democracy" and were redolent of the fears held by the upper classes in the Veneto. ${ }^{147}$

\footnotetext{
${ }^{142}$ Pius X, "Motu proprio": Fin dalla prima nostra: On Popular Catholic Action by Pope St. Pius X (18 Dec. 1903). http://www.sspxasia.com/Documents/Catholic_Doctrine/Fin_Dalla_Prima_Nostra.htm $(9 / 12 / 2008)$

${ }^{143}$ R. Merry del Val, “Per l’Azione cattolica in Italia. Circolare ai Rev. Ordinari”, L'Azione muliebre, a. IV, fasc. 9, settembre 1904, p. 515.

${ }^{144}$ Baldo writes to Coari on 30 December 1903: "E il Fascio democratico mi piace altrettanto poco". Cimini, “Adelaide Coari e il movimento femminile”, cit., p. 175.

${ }^{145}$ Gaiotti de Biase, Le origini del movimento cattolico femminile, cit., p. 65.

146 Baldo’s letter to Coari, 30 Dec. 1903, in Cimini, “Adelaide Coari e il movimento femminile”, cit., p. 176.

${ }^{147}$ Radini Tedeschi’s letter to Baldo, 22 Jan. 1904, FAC 9739: “Ieri si è letto il suo lavoro; ed io vi ho dovuto notare sinceramente un po' di conservatorismo, se mi permette la parola, e poco di sana democrazia cristiana. Esso risente del Veneto e forse del carattere e dei timori eccessivi della Regione.
} 
Like Baldo, the signore on the committee of L'azione muliebre and the deputy ecclesiastical assistant, Francesco Mariani, looked askance at Coari's links with the Fascio femminile ${ }^{148}$ and were equally averse to turning L'Azione muliebre into the official organ of the women's movement. Coari, on the other hand, had concerns about the unwillingness of the signore to support Christian democracy at grassroots, about their outdated approach to social issues, and about their uncomprehending disdain for the advanced, frightening, and well funded "sectarian” feminist movement in Milan which was campaigning for the legalization of divorce:

Le signore, che non possono conoscere tutti i bisogni delle operaie, non vogliono riconoscere ed appoggiare quel movimento che viene dal basso; intendono che tutto s'inizi da loro, ma sgraziatamente con concetti moderni nulla intraprendono. E poi a Milano abbiamo un movimento settario che spaventa, movimento che à già esteso le sue figliali a Roma e a Torino, movimento a cui fanno capo donne d'intelligenza, donne che per sostenere la campagna per il divorzio e il loro giornale offrono delle migliaia di lire. Le nostre signore non lo prendono in considerazione, lo disprezzano, invece di veder di conquistare terreno con gli stessi mezzi, posto che questi si possano adottare per la diffusione di bene. ${ }^{149}$

The dissonances within the journal were brought into the open when the position of the chief ecclesiastical assistant fell vacant upon the appointment of the incumbent Filippo de Giorgi as a parish priest outside Milan in November $1903 .{ }^{150}$ Alongside de Giorgi, L'Azione muliebre had as deputy ecclesiastical assistant Francesco Mariani, who additionally worked as an assistant for the Protezione della giovane. Since L'Azione muliebre was to become official organ of the proposed women's movement the selection of the ecclesiastical assistant must have been of keen interest also to Radini Tedeschi. Coari's letter to him of 13 December 1903 shows her uncertainty regarding the individuals canvassed for the ecclesiastical vacancies on L'Azione muliebre:

Tengo una lettera della Signora Baldo che le unisco, e approfitto dell'occasione per esprimerle un giudizio che forse, diversamente, non le avrei manifestato per timore di soverchio ardimento. La Signora Baldo in una delle ultime sue lettere mi dava un giudizio poco favorevole su Don C. G. [Carlo Grugni], nel quale non vedeva tutte quelle doti che sono necessarie ad un sacerdote perchè possa assumersi la responsabilità di guidare i primi passi di donne che si danno alla azione pubblica. Il suo giudizio veniva a confermare pianamente il mio. Per

\footnotetext{
Esso accentua un po’ troppo lo spirito di insubordinazione e forse dimentica la lunga e giuridica oppressione onde le classi superiori gravano sulle inferiori contro l'ordine cristiano sociale.”

${ }^{148}$ Mariani had forbidden Coari to continue her activities in the Fascio femminile. See Coari's letter to Radini Tedeschi, 19 June 1904, FAC 3536.

${ }^{149}$ Coari's letter to Radini Tedeschi, 12 Feb. 1904, FAC 3525.

${ }^{150}$ Passoni, Elena da Persico, cit., p. 28.
} 
rassicurarmi ieri ne parlai col prof. De-Giorgi, sacerdote di grande prudenza e bontà, il prof. De-Giorgi mi consigliava a scriverle direttamente esponendo a nome anche suo il mio giudizio su Don C., il quale in Milano si è già inimicato la maggior parte delle Signore e sarebbe proprio per la sua inesperienza e poca prudenza il meno indicato per l'opera nostra. E De-Giorgi mi consigliava anche a farle nomi: il prof. Minoretti del nostro Seminario e Mariani. Minoretti appoggia il nostro movimento e vi darebbe un sicuro indirizzo, è già molto occupato ma se l'invito gli venisse dal Cardinale e avesse al suo fianco un aiuto secondo le sue idee potremmo vincerlo alla causa nostra. Mariani sa conciliare molto bene le parti, sa stare nella giusta via di mezzo, è prudente e di spirito sicuro; così io vengo presentando ciò che mi fu consigliato. Uno dei motivi che proprio in questi ultimi giorni venne a confermarci nel nostro giudizio fu questo: Don Carlo sperava di poter formulare uno statuto a linee così larghe da potervi insediare anche quelle associazioni che non vogliono professare esplicitamente sudditanza alla S. Sede. Da ciò ne venne la mia dichiarazione fatta in seduta, dichiarazione che, a chi non conosceva l'antefatto, poteva apparire assurda o almeno ovvia.

Grugni può far molto per noi, ma non lo si crede capace di un indirizzo sicuro. Perdoni il mio ardire, e creda che sono giunta fino a questo passo perché consigliata e appoggiata. ${ }^{151}$

Just in a matter of few months, however, Coari would have a totally different opinion about the respective suitabilities of Mariano and Grugni for the ecclesiastical positions on L'Azione muliebre. Baldo, for her part, thought her ecclesiastical assistants were overreaching their brief yet showed little competence in their own area:

Inoltre i nostri assistenti non fanno da assistenti (e forse non sono adatti neanche per questo), ma (parlo del giornale) da direttori. Esorbitano dal loro ufficio e fanno male. ${ }^{152}$

In March 1904 Don Dalmazio Minoretti was nominated as ecclesiastical assistant and Carlo Grugni, convenor of the Nucleo fisso and assistant to the Milan Fascio, as deputy assistant. Baldo and Coari supported these nominations, which also accorded with the wishes of De Giorgi and Radini Tedeschi, but meant overlooking Mariani, the incumbent deputy assistant. ${ }^{153}$ At the end of the month, Elena da Persico, in the name of the signore, composed a petition to nominate Mariani, which he was to present to Archbishop Ferrari. This never happened, however. Meanwhile Radini Tedeschi, on a pilgrimage to Palestine, could not play an active part in the selection process, but in a

\footnotetext{
${ }^{151}$ Coari’s letter to Radini Tedeschi, 13 Dec. 1903, FAC 3524.

152 Baldo’s letter to Coari, 30 Dec. 1903, in Cimini, “Adelaide Coari e il movimento femminile”, cit., p. 175.

${ }^{153}$ Passoni, Elena da Persico, cit., p. 29: “Don Mariani dice che l'invito a don Minoretti fu iniziativa personale della Baldo e della Coari; tanto piú si può pensarlo per don Grugni, che era l'assistente del Fascio Femminile della Coari. Questa però era anche la proposta di mons. De Giorgi e la soluzione desiderata da mons. Radini Tedeschi.”
} 
letter to Coari expressed his support for Minoretti. ${ }^{154}$ With Minoretti declaring that he was too busy to consider accepting the position, Mariani was appointed as ecclesiastical assistant by the Archbishop in April 1904, while Minoretti was given the possibly less onerous task of authorizing the issues of L'Azione muliebre for the imprimatur. ${ }^{155}$

Another contentious issue related to the drafting of a new set of internal regulations defining respective duties and responsibilities within L'Azione muliebre. The need for this arose from internal rivalries and divisions within the periodical and also from its anticipated role as official organ of the Catholic women's movement. In the compilation of monthly issues the committee of signore as well as the ecclesiastical assistants played an influential part. The essential features of each issue were determined at a meeting and contributors then attended to drafting individual articles. Some of the signore worked gratis while the committee provided for those requiring remuneration. Since Baldo lived outside Milan, the day to day coordination of activities fell on Coari, who was criticized for using her private address as the official address for the periodical. ${ }^{156}$

Ultimately four separate sets of regulations were produced. The first set, which was drafted by da Persico in agreement with Mariani and the signore, was ready in April, but met with criticism from Baldo and Coari. On his return from Palestine, Radini Tedeschi asked Coari to provide a new draft by June. Da Persico promptly criticized Coari's version since it seemed to concentrate all power in the hands of the editor and the secretary, while the other stakeholders would merely serve as "trimming":

Esso propone una Redazione e un'Amministrazione che ànno solo una Cassa di maneggio e di potere nel giornale, mentre in realtà tutto il potere e tutto il maneggio sono accentrati nella Direttrice e nella Segretaria. Queste divengono sotto tutti i rapporti materiali e morali le vere padrone del giornale, il resto serve solo di contorno per accontentare chi non amasse questo governo assoluto. ${ }^{157}$

\footnotetext{
${ }^{154}$ Radini Tedeschi's note to Coari, 9 Apr. 1904, FAC 4674: "Bisogna insistere anche a mio nome per avere il Prof. Minoretti”. A day later Radini Tedeschi declares his support for both Minoretti and Grugni and asks for the appointments to be delayed: "Prego però lei, a mio nome, scusandomi se l'enorme lavoro di questi giorni mi impedisce di scrivere direttamente, perchè si rechi da Sua Eminenza e lo preghi di voler per ora lasciare le cose some erano rispetto all'Azione Muliebre ed al suo Assistente. Il periodo di transizione e il lavoro di organizzazione, principalmente affidato al Prof. Minoretti con Don Grugni, di piena intesa con Sua Eminenza, esige che questi due principalmente entrino a sostenere l'organo ufficiale della sezione femminile istituenda.” Radini Tedeschi’s letter to Coari, dated 10 Apr. 1904, FAC 4675.

${ }^{155}$ Passoni, Elena da Persico, cit., p. 31.

${ }^{156}$ Ibid., p. 29.

${ }^{157}$ Elena da Persico, “Osservazioni sul regolamento proposto dalla Sig. Coari per il giornale 'L'Azione muliebre’”, 4 June 1904, FAC 1108.
} 
Shortly afterwards, Mariani wrote in an undated memorandum to Baldo that Coari's draft regulation had been rejected by the signore because, he argued, it made no mention of the position of the ecclesiastical assistant, only that of an ecclesiastical censor. Furthermore, Coari's draft relegated the signore to more boring and laborious tasks, such as looking after subscriptions and the payment of debts and, while the signore were called on to become a part of the Consiglio di amministrazione, the management of the periodical in its totality was assigned to the editorial office and, within it, mostly to the editor and the secretary. The draft also indicated, the memorandum claimed, that should the Consiglio di amministrazione fail to perform its duties, the editorial office would take over. ${ }^{158}$ Baldo was requested to provide a new and more detailed set of rules, which Mariani duly received. In his view, Baldo's regulation did not substantially differ from Coari's, only that it was presented in a clearer and much more organized fashion. There were major differences, however. In Coari's design, the editorial council was to consist of the editor and the contributors living in Milan while the administrative council was to be made up of a president and signore interested in supporting the periodical, with the ecclesiastical assistant and the censor being listed among the office holders but not among the members of either council. $^{159}$ Baldo's regulation, on the other hand, envisaged an editorial council consisting of the editor, ecclesiastical censor, ecclesiastical assistant, secretary and a representative of the administrative council. It emphasized that the function of the ecclesiastical assistant was indeed to provide moral and material assistance. ${ }^{160}$ It is obvious that the reason why Coari's and Baldo's drafts did not please the signore was their intention to separate the editorial and administrative functions of the paper. Mariani's plan, contained in his memorandum, did not anticipate splitting the editorial and administrative duties but provided for a council composed of signore and the ecclesiastical assistant, who had the responsibility of appointing the editor, the chairperson of meetings, the administrator, and the secretary. From a note scribbled for Baldo on the last page of the memorandum it appears that Mariani had presented his observations together with Baldo's and Coari's draft regulations to the Archbishop who

\footnotetext{
${ }^{158}$ Mariani’s undated memorandum, FAC 1111.

159 “Regolamento interno del Consiglio dell’Azione muliebre”, FAC 1113.

${ }^{160}$ Ibid., "Funzioni ed obblighi particolari”.
} 
thus became the final arbiter on the subject of the internal organization of L'Azione muliebre. ${ }^{161}$

Eg. Sig. Baldo, addolorato per l'impressione penosa ricevuta prima dal regolamento proposto dalla Sig. Coari e poi dalla Sig. Baldo, ò voluto rifletterci sopra con calma, domandare consiglio e presentare ambedue i regolamenti all'Eminentiss. che mi fece chiamare. Dopo d'averli letti attentamente, à approvato queste mie osservazioni dicendomi espressamente che non può accettare né l'uno né l'altro regolamento, che aderire a quello proposto da me, dicendomi che ogni tentativo mosso per ostacolare l'opera dell'ass. l'avrebbe considerato come uno sfregio, fatto alla profana autorità. Certo che come figlia devota alla S Chiesa ella vorrà fedelmente aderire al desiderio di Sua Eminenza e accettare il regolamento qui incluso. ${ }^{162}$

To ensure the adoption of his own version of the regulation Mariani appears have acted against what had previously been agreed upon between him, Radini Tedeschi, Baldo and Coari. Radini Tedeschi wrote to Coari on 17 June 1904:

Ho avuto la sua e pochi dì dopo una lettera di Don Mariani in cui mi dice che il regolamento proposto da lei e dalla Sig.a Baldo non è accettato, e che Sua Eminenza ne impone un altro.

Veramente io credo che eravamo intesi dovesse essere mandato a me anche il suo per esprimere il mio avviso; e non so come ciò non sia stato. ${ }^{163}$

On the same day Baldo, on her part, wrote to Radini Tedeschi deploring not only Mariani's ruse but also da Persico's complicity in the matter. As things stood, the only option left to her was to resign. ${ }^{164}$ Having her draft regulation rejected by the highest

\footnotetext{
${ }^{161}$ In view of the extremely low circulation of L'Azione muliebre (120 subscriptions), the attention paid to it seems disproportionate. See Coari’s letter to Radini Tedeschi, 19 June 1904, FAC 3536: “... mancano affatto gli abbonamenti - sono appena 120 - si è sempre fatto così ...”

162 Mariani’s undated memorandum, cit., FAC 1111.

163 Radini Tedeschi's letter to Coari, 17 June 1904, FAC 9740.

164 Baldo's letter to Radini Tedeschi, 17 June 1904, FAC 9724, folios 42-43: “Conforme si era rimasti d'accordo il regolamento non doveva essere veduto, discusso che da Lei, da Mariani, dalla Coari e da me. - Io avevo proposto a Mariani per semplificare - di cercare prima di mettersi d'accordo noi tre per mandare poi a Lei il regolamento insieme accettato.

Egli non fece così ed invece credette doverlo mandare al Cardinale.

A quel che egli dice S.E. non approvò il regolamento steso dalla Coari e modificato da me, ma accolse invece tutti gli emendementi di Mar. Inoltre S.E. mi manda a dire, sempre a quanto dice Mar. che qualunque tentativo per ostacolare l'opera dell'Ass. l'avrebbe considerato come uno sfregio fatto alla sua autorità. Ora a mio avviso cominciamo subito ad andare fuori di strada.

Certo noi non abbiamo voluto escludere il Cardinale, ma se non fu detto esplicitamente che Egli pure avesse diritto di vedere e sanzionare il regolamento ciò voleva dire che non si riteneva necessario, anzi che neppure si era pensato a Lui, ritenendo con ragione che una volta accettato dall'Assistente nominato dal Car. questi intendesse lasciare a Lui certa responsabilità senza occuparsi direttamente d'ogni passo o provvedimento da farsi ...

Ma davvero che chi ha dei diritti sopra un giornale è chi lo dirige e lo scrive. Così è per tutti i giornali, io credo fuori che per il nostro, che ha avuto la disgrazia di dover subire un comitato protettore.

Ma non basta qui veniamo a un colmo Mar. ha sottoposto il regolamento al giudizio di persona lontana, estranea per la cui indelicata ingerenza nacquero tutti i guai ...
} 
authority, and with control over L'Azione muliebre being placed in the hands of the conservative lobby and the ecclesiastical assistant, resignation was indeed the only course left for Baldo, while Coari was not invited to join the newly organized editorial office. ${ }^{165}$ In only a matter of days Elena da Persico was installed as the new editor of L'Azione muliebre.

From then on, L'Azione muliebre would even more docilely adhere to the ecclesiastical line, as manifested by a statement in the September 1904 issue, "Due parole della direzione del periodico”. It said that the periodical had refrained from mentioning the crisis in the Opera dei congressi in the previous issue because amidst so much despair, doubt and disagreement women's duty was to remain silent. ${ }^{166}$ The Secretary of State's virtual banishment of women from public life was accepted with humility, reaffirming that woman's duty was indeed at home and that her work should not degenerate into a reckless race which would pervert her feminine character. ${ }^{167}$

\section{PART II}

\section{$\underline{\text { Pensiero e Azione }}$}

With the disbandment of the Opera dei congressi the plans for a national women's organization were left up in the air. Even though Giacomo Radini Tedeschi had resigned from the Opera and, as a corollary, also vacated the presidency of the Nucleo fisso, Adelaide Coari continued to defer to him for advice. Writing to Coari on 31 July 1904, Radini Tedeschi affirmed that the Nucleo fisso had not been dissolved and prompted her to approach Count Stanislao Medolago Albani, president of the residual Second Group of the Opera, to remind him that a draft statute for women's diocesan

\footnotetext{
Ho risposto brevemente a Don Mar. dando le mie dimissioni è l'unica cosa che mi resto a fare e mi ci vuole del coraggio a farla come ad abbandonare una cosa cara, tanto tanto amata. Ma io non ho rimosso ed agisco con perfetta serenità d'animo accettando anche questo dal Signore.”

Original underlining retained.

165 Coari’s letter to Radini Tedeschi, 19 June 1904, FAC 3536: “Credo che la Redazione non si formerà forse vorranno la collaborazione - se mi si chiederà o verrà accettato io per obbedienza a Lei, e perchè è necessario potrò mandare, quando gli altri miei impieghi me lo permetteranno qualche articolo.

Certamente si verrà alla nomina della segretaria (la Direttrice sarà la Carola da Sabbioneta) e supponendo cosa impossibile che fossi nominato io, non potrò accettare in vista di un altro impegno che molto più davvicino riguarda la volontà di Dio e la mia vocazione.”

166 “Due parole della direzione del periodico”, L'Azione muliebre, a. IV, fasc. 9, settembre 1904, p. 517.

${ }^{167}$ Ibid., p. 518.
} 
organizations had been completed and presented to the Holy See. Radini Tedeschi advised Coari to stress that the draft constitution primarily concerned "popular Christian action" and that the Pope's approval was needed to enable women's societies to function as part of the Second Group. ${ }^{168}$ Only a few days later, however, on 3 August, Radini Tedeschi suggested to Coari that as far as “women's action” was concerned there was no urgency since the Nucleo fisso had completed the constitution which it was commissioned to write and that he would himself provide for the rest in a measured way. Nevertheless, he still urged the Fascio femminile to ask Medolago Albani to act on the draft constitution which, after all, had been unanimously approved by the Permanent Committee of the Opera and was now before the Holy See. The matter could then be presented to the Cardinal to gain his support. ${ }^{169}$ It appears, however, that in the aftermath of dismantling the Opera, despite Radini Tedeschi's efforts, the work carried out by the Nucleo fisso never came to fruition.

In the overall confusion which prevailed in the Catholic movement, it was sometimes difficult to know which line to follow at the local level. Having lost her job on L'Azione muliebre, Coari worked for Il Domani d'Italia, a periodical founded by Romolo Murri and now the official organ of the Fascio femminile. The conflict in the Catholic world was also reflected in the editorial office where the male staff wanted to back Murri and resign from the Opera to form an independent political organization, while the women were opposed to such a move. Coari herself wanted to remain loyal to the Pope, never questioning the validity of papal policy or the advice which she received from Radini Tedeschi. The latter counselled Coari to resign from Il Domani, should the paper not abandon its erroneous quest for independence. ${ }^{170}$ In the meantime she had declined an invitation by Countess Sabina Parravicino di Revel to help found

\footnotetext{
168 Radini Tedeschi's letter to Coari, 31 July 1904, FAC 4681: “La via pratica sarà questa semplicemente: Il nucleo fisso, che non è punto sciolto, si rivolga al Conte Medolago per dirgli: $1^{\circ}$ Uno statuto per le Opere e Società femminili diocesane è stato fatto e presentato alla S. Sede; $2^{\circ}$ Tale statuto riguarda principalmente le opere di azione popolare cristiana; $3^{\circ}$ Preghiamo la S.V. a voler procurare con sollecitudine la superiore e suprema approvazione della S. Sede per darci all'opera secondo il programma voluto dal S. Padre, e in adesione e dipendenza da codesto gruppo.”

169 Radini Tedeschi's letter to Coari, 3 Aug. 1904, FAC 4682: "Per l'azione femminile generale aspettiamo un momento. Intanto il Nucleo fisso, che aveva mandato di preparare lo Statuto, ha esaurito il suo mandato. Vedrò io di provvedere per il resto ma con calma, per fare una cosa alla volta.

Invece faccia il fascio femminile di Milano una domanda al Conte Medolago per prendere l'iniziativa del Com. Dioc. Mil. con lo Statuto approvato già ad unanimità dal Com. Gen. Perm., ed ora presentato alla S. Sede. Si potrà presentare poi la cosa al Cardinale e domandare il suo appoggio.” Original underlining retained.

${ }^{170}$ Ibid.: "E se il Domani non lascia la via errata della indipendenza, io la consiglierei di ritirarsi. Invece può chiedere alla Azione Popolare di Bergamo di collaborare.” Original underlining retained.
} 
jointly an independent movement for working-class women. ${ }^{171}$ At the instigation of Radini Tedeschi, the Fascio femminile di Milano continued its membership of the Second Group of the now defunct Opera dei congressi, and even organized a conference for Catholic women's associations in September 1904. After the futile efforts of the Nucleo fisso to set up a national women's organization, it is notable that this conference succeeded in laying down the groundwork for a federation of women's associations which would be established the following year. ${ }^{172}$

For his part, Radini Tedeschi, a member of the clergy and well-connected in the Church hierarchy, endeavoured to adhere to the official line without muddying the waters and taking great pains to stress that his resignation from the Opera should not be followed by others and should not be interpreted as an act of insubordination. On the contrary, he stated, it had been motivated by his desire to put an end to discord within the Opera, by his grief at the continuation of "irritating polemics" forbidden by the Pope and the Secretary of State, and by his desire not to stand in the way when the new leader selected his counsellors. He expounded the reasons for his resignation to Coari in a letter dated 28 July 1904:

Non si tiri in esempio il fatto delle mie dimissioni, che le ho detto motivate: $1^{\circ}$ dal proposito di finire lotte che mi fanno male troppo $=2^{\circ}$ dal dolore di vedere che si continuano le irritanti polemiche vietate dal Papa e dal Card. di Stato anche nella lettera recente $=3^{\circ}$ da un delicato riguardo verso chi sarà chiamato a dirigere l'opera, affinchè sia libero di proporre i consiglieri che li parranno atti ad avere l'omogeinità necessaria. Non è un ritiro, non è una insubordinazione: è

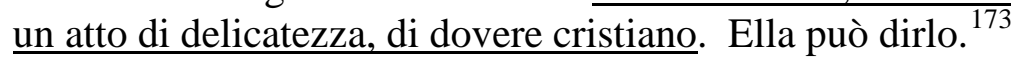

Just as he himself would refrain from criticizing papal announcements, he would also expect Coari to submit obediently to the Secretary of State's directive that women should not speak at men's congresses. Wasn't this, after all, what women wanted themselves:

Le ultime decisioni della S. Sede non dicono punto che le donne non abbiano nulla a fare, ma che non parlino nei Congressi maschili, e che se si riuniscono debbono essere presiedute da gravi ecclesiastici. Non è quello che esse vogliono ${ }^{174}$

\footnotetext{
171 Coari’s letter to Radini Tedeschi, 31 July 1904, FAC 3531: “Oggi ci fu offerto l'appoggio della Contessa Parravicini di Revel, che desidererebbe iniziare un movimento femminile a pro delle classi operaie, ma autonomo. Non accettammo. Desideriamo, vogliamo serbarci pure, intere colla S. Sede, lontane dalle morbosità della Lega Lombarda, con un programma schiettamente papale. Saremo in poche."

172 “Convegno femminile”, Pensiero e azione, a I, n. 8, 5 aprile 1905, pp. 4-7.

${ }^{173}$ Radini Tedeschi's letter to Coari, 28 July 1904, FAC 4679. Original underlining retained.

${ }^{174}$ Radini Tedeschi's letter to Coari, 31 July 1904, FAC 4681. Original underlining retained.
} 
It also emerged that even though L'Azione muliebre was more and more becoming the mouthpiece of conservative interests and even though he had lost control over it, Radini Tedeschi was not going to withdraw his support from it. When sending a letter to the journal for publication, he justified it to Coari by remarking that "evil can be overcome with good":

Vedrà una mia lettera sull'A.M. Fui dubbioso, ma poi la scrissi per mostrare generosità d'animo e plaudire e promuovere dovunque si fa il bene. Vince in bono malum. ${ }^{175}$

In the prevailing political climate, considering the generally ambivalent attitudes of many Catholics towards Christian democracy in general and women's movements in particular, and Radini Tedeschi's own circumspection in sensitive matters, it was remarkable that he should be willing to sponsor a new Christian democratic semimonthly women's periodical, Pensiero e azione, of which Adelaide Coari was to be editor. However, as Isabella Pera remarks, not the entire clergy held Pius X's conservative views on women, so that, for example, in Lombardy due to pressing social problems priests and bishops, including Giacomo Maria Radini Tedeschi, Cardinal Andrea Carlo Ferrari, Padre Antonio da Trobaso and Don Carlo Grugni, supported and promoted women's initiatives. ${ }^{176}$

In the meantime Coari had written to Radini Tedeschi saying that “a women's journal was absolutely necessary for the middle class”, and that she and her friends had in mind “a small monthly periodical”, to commence publication with the feast of the Immaculate Conception. ${ }^{177}$ Around the same period Coari and her friend Angiolina Dotti penned another letter to Radini Tedeschi, which conveyed the unmistakable sense of submissiveness with expressions such as "conviction of our nothingness", "poverty of our words" and "we weak women”. In their letter Coari and Dotti stated that, despite having been educated in public schools, they had been, by the grace of God, surrounded by good people and had been invigorated by the Sacraments. They had therefore a clear understanding of contemporary needs and, even though young, they felt the urgent need for women to cooperate, with love and intelligence, in the restoration of society. It was necessary, they wrote, for a group of young women to respond to the special call by

\footnotetext{
${ }^{175}$ Radini Tedeschi's letter to Coari, 19 Sept.1904, FAC 4683. Original underlining retained.

${ }^{176}$ Pera, “La questione femminile nel mondo cattolico nel primo novecento”, cit., pp. 73-74.

177 Coari’s letter to Radini Tedeschi, 19 June 1904, FAC 3536: “Un giornale femminile è assolutamente necessario per la classe media - per tutti abbiamo pensato a un minuscolo periodico mensile che potrà uscire per l'Immacolata”.
} 
Christ and to work in the social field. There appears to have no immediate reason for writing the letter, except that by submitting their thoughts to Christ and Mary Immaculate, they said, they hoped to receive counsel from Radini Tedeschi. ${ }^{178}$

The inaugural issue of Pensiero e azione on 8 December 1904 carried Radini Tedeschi's felicitations and blessings together with those of two other eminent Catholic leaders, Cardinal Andrea Carlo Ferrari, Archbishop of Milan, and Professor Giuseppe Toniolo. Just one week earlier members of the Fascio femminile had visited the Archbishop to receive his blessings for the new project:

"Brave figliuole!... coraggio e avanti” così ci salutava benevolmente una settimana fa S. Em. il nostro amatissimo Card. Arcivescovo dopo una visita da noi fattagli per chiedere la sua approvazione ad un'opera nostra. E di questo incoraggiamento che il nostro superiore rivolgeva a tutto il Fascio democratico Cristiano femminile, noi ci sentimmo così felici con le nostre sorelle di idea, che nessun sacrificio fatto per proseguire nella via difficile non ci sarebbe parso grave. $^{179}$

In the first issue the archbishop stated that he very much liked the proofs shown to him, because he saw in them "Pensiero e Azione" (thought and action) and because it was "well made”, "well organized” and, most important of all, it was "abundant in sound doctrine". 180

Radini Tedeschi, on the other hand, was deeply touched by the allusion of the Fascio to the coincidence of the commencement of publication with the twenty-fifth anniversary

\footnotetext{
${ }^{178}$ Letter by Coari and Dotti to Radini Tedeschi, 1904 (no exact date known), FAC 3520: "La persuasione della nostra nullità e la comprensione degli ideali sublimi, che ci seduce, ci hanno trattenute sino ad ora dal manifestargliele: anche in questo momento, in cui dopo aver pregato, abbiamo risolutamente deciso di sottometterle al Suo giudizio, affidando tutto all'Immacolata, non ci è estraneo il timore d'essere soverchiamente ardite ...

Sentiamo la povertà delle nostre parole, esse non riflettono l'ardore, l'amore, la forza con cui Cristo ci attira, e però la stessa nostra pochezza ci incoraggia; nella manifestazione del pensiero veda tutto l'amore grande del Maestro Divino: Cristo modifichi il nostro scritto ...

Forse perchè cresciute, educate, istruite nelle nostre pubbliche scuole, e nello stesso tempo per grazia di Dio, circondate da buone persone, vivificate assai spesso dai Sacramenti, si è fatto in noi una più lucida comprensione del bisogno dei nostri tempi, e, per quanto giovani, abbiamo con tutta l'anima sentito la necessità che anche la donna deve portare la sua cooperazione d'intelligenza e d'amore di restaurazione sociale ...

Lavorare nel campo sociale è difficile cosa, tanto più difficile per noi donne deboli, create più per la pace che per la lotta. Solo una chiamata imperiosa di Cristo può lanciarci e mantenerci sulla breccia ...”

179 "La pagina del Fascio. Studio - azione - propaganda”, Pensiero e azione, a. I, n. 1, 8 dicembre 1904, p. 2.

${ }^{180}$ Andrea Carlo Ferrari, [Benedizione], ibid., p. 3: "Io ho veduto nelle bozze il Pensiero e Azione e mi piace assai: è ben fatto, ben ordinato; e quel che maggiormente importa è ricco di sana dottrina, e vi spira il sentimento religioso così schietto che richiama salutarmente il lettore a Dio, a Gesù salvatore, all’Immacolata Madre divina.

Mi rallegro adunque con queste buone figlie, e valenti scrittrici e le benedico." The bold type of the original has been retained..
} 
of his ordination to the priesthood, and complimented the Fascio on its "prudence", “tact” and "discipline” in difficult times. ${ }^{181}$ Toniolo, too, expressed his full approval of the programme announced in the pre-publication circular praising it for its serious nature and lofty ideas. ${ }^{182}$

Pensiero e azione was the mouthpiece of the Fascio democratico femminile milanese and declared in the inaugural issue that its aim was to develop in women an "awareness of their duties and their rights in society", "prudently and duly subject to superior authority”. It would take on issues of religious, social and civil nature, in particular issues concerning proletarian women. It wanted to make an active contribution to society by tackling difficult problems which needed dedicated research. To this end the Fascio had set up a study circle which at the time dealt with Rerum novarum with the objective of turning the members of the Fascio into good propagandists for the encyclical. Research would proceed concurrently with propaganda aimed in particular at women workers through meetings and the press, and by the setting up of financial entities to look after their economic interests. Following in the footsteps of Nucleo fisso, which just few months earlier had written a constitution for diocesan women's organizations, the Fascio was intent on forming the first diocesan group which would bring all women's activities of a social or economic nature under one umbrella. Special mention was made of the problem of prostitution which the Fascio had in mind to combat seriously and compassionately.

Pensiero e azione, which carried the subtitle Rivista femminile italiana, was a modest 16-page fortnightly publication. Its serious orientation did not allow for levity either in subject matter or presentation, and from the very first issue it contained items which remained regular features for the three and a half year span of its life. They included columns such as Istruzione which dealt with educational issues ranging from teacher training to combating illiteracy; Lavoro which discussed various aspects of women's employment; Cronaca and Nella vita e fra i giornali which focussed on current events; and Movimento femminile which provided round-ups of news about women's

\footnotetext{
181 "La pagina del fascio", ibid., p. 2: "Il pensiero del Fascio d. c. f. milanese in occasione del mio XXV mi ha commosso vivamente, ed io ne esprimo sentita riconoscienza a lei (consigliera delegata in occasione della messa d'argento di Radini Tedeschi) e per suo mezzo a tutte e a ciascuna che lo compongono".

${ }^{182}$ G. Toniolo, [Approvazione], ibid., p. 3: "L’Apostolo della Democrazia Cristiana il prof. Toniolo a cui mandammo la circolare-programma ci scriveva: '... il programma del giornale approvo pienamente per serietà ed altezza di concetti. Con tanti incoraggiamenti autorevoli le buone signorine si abbandonino nelle braccia di Dio e procedano all'assalto!'” Original italics retained.
} 
organizations and feminist issues in Italy and abroad. The column Arte, on the other hand, was meant to cultivate the "sentiment of harmony" in women, while articles such as "Questioni filosofiche” introduced them to more fundamental issues. ${ }^{183}$ Piccola posta contained messages received or those needed to be passed on, whereas In biblioteca kept readers informed about current acquisitions for the periodical's library, or recommended items for reading. In addition, Pensiero e azione had taken on the task of disseminating information about forthcoming meetings, new legislation affecting women, union activities, places to which women could turn for advice or recreation, and educational and vocational courses. True to its mission as a Catholic women's periodical, Pensiero e azione announced in the first issue that La pagina religiosa would be a regular feature; however, in the first half of the second year it began to appear irregularly, to vanish totally in the second half. Even though this half-column had added a spiritual dimension, its disappearance did not lessen the paper's entrenched religiosity. Then, in the second year, Pensiero e azione was in effect split into two parts since, starting with the second issue, a four-page insert, Le pagine dell'operaia, ${ }^{184}$ was produced to which women workers could subscribe separately. It is obvious that Pensiero e azione operated on a tight budget, and therefore had to limit its publishing to what the editorial staff considered to be the most vital and essential pieces of information. In the third issue of its third year the paper promised to introduce a column for readers' correspondence, Pagina delle lettrici, as well as reading material of a lighter or more diverting nature in the form of a Pagina romantica. It was only partially able to fulfil its promise, since there is little evidence of it becoming more entertaining except that Le pagine dell'operaia tended to contain a few more stories. If anything, Pensiero e azione would become even more unrelenting in its earnest concentration on important issues concerning women, especially in the final six issues which came out as three double issues.

The feminism of Pensiero e azione was based on a deep sense of religious commitment. In an article entitled Alcuni nostri principi one reads:

Siamo religiose: e sentiamo tutta la poderosa energia di Gesù e della sua Chiesa e dell'unione degli animi; ma è la stessa nostra religiosità che ci rende libere e ci fa cercare, ci rende particolarmente simpatizzanti tutti quegli animi che sdegnano le mezze comparse; è la nostra religiosità che dà valore ed energia di fede a un cumulo di rivendicazioni che chiediamo per noi e per l'umanità: è la

\footnotetext{
183 Adelaide Coari, “In cammino. Rubriche della rivista”, ibid., a. III, n. 1, 5 gennaio 1907, p .3.

${ }^{184}$ Ibid., a. IV, n. 3, 10 febbraio 1908. From this issue on Le pagine dell'operaia was renamed L'operaia which appeared at the end of the main periodical with continuous pagination.
} 
nostra religiosità che non ci può dividere dalle buone volontà, ma anzi ce le fa cercare e desiderare. $^{185}$

The writer felt that women were not giving morally and intellectually all that they could, and that she and her friends suffered from constraints imposed on their freedom and personality. It was this suffering which pushed them along, and made social as well as women's issues the entire focus of their lives. As regards the women's movement, the writer made a distinction between dilettantes (dilettanti) and do-gooders (benevoli), on the one hand, and true priestesses (vere sacerdoti), on the other. For the latter, the movement did not merely provide a focus for social activism, but also had a highly personal dimension to it. With no family of their own, and with no desire to live in a convent, these women had the right to choose the whole of humanity as their spiritual family and to dedicate all their energies to it. ${ }^{186}$ Two years earlier, in a talk sponsored by the Fascio democratico cristiano in Bergamo, Adelaide Coari had spoken about “spiritual filiation” whereby woman's apostolate acquired "the quality of priesthood in the name of Christ, by virtue of those prerogatives which sublimated her to the role of co-redeemer of humankind”. ${ }^{187}$ Arguing that it was egotistical and even naïve to leave one's talents unused, or to surrender one's rights, Coari stressed that women had the right to formulate their own feminist doctrine. ${ }^{188}$ She went on to say that femminismo cristiano, by rejecting the false notion of gender relations, which led the two genders to a perennial struggle, and, by admitting the validity of the "integrative principle" (principio d'integramento), that is, the idea of complementarity of man and woman, was positioned to be guided by justice and progress. Thus the Catholic precept of the dual nature of humankind lay at the very core of femminismo cristiano.

So, not unlike other Catholic publications, such as L'Azione muliebre, Pensiero e azione argued that, while woman's primary purpose in life related to her maternal role in the family, social transformations now necessitated extending this traditional function to the whole of society. In 1906 Grugni discussed the new tasks imposed on women in a

\footnotetext{
185 “Alcuni nostri principi”, ibid., a. III, n. 5-6, 13 aprile 1907, p. 3.

${ }^{186}$ Ibid., p. 4.

187 “Orizzonti nuovi”, ibid., a. I, n. 5, 20 febbraio 1905, p. 4: “Spirituale filiazione per cui l'azione della donna acquista un carattere di sacerdozio compiuto per Cristo, in forza di quelle prerogative che la sublimò ad essere corredentrice del genere umano!”

${ }^{188}$ Ibid., p. 3: "È umiltà riconoscere che ciò che abbiamo lo dobbiamo a Dio, ed è anche egoismo, dabenaggime [sic], puerilità, colpa grave lasciare infruttuose tante energie, cedere i nostri diritti. Ed il femminismo cristiano rifiutando quella falsa concezione delle relazioni fra i due sessi che ce li fa scorgere in perenne lotta, ed ammettendo il principio d'integramento per cui i due esseri si completano a vicenda, si pone sulle basi volute da giustizia e da progresso."
} 
series of six articles entitled "Rivendicazioni femminili", based on a lecture given by him in the bishopric of Milan in the presence of Cardinal Ferrari. At the Bologna congress in 1903 Grugni had outlined reasons why women should participate in public life. Once again, he stressed that it was necessary for women to fulfil their educative mission also outside their home and that the expansion of the scope of their activities would be useful also for women themselves, since it would enable them to utilize their talents in the public arena. Moreover, by reason of elementary distributive justice this major part of humankind should not remain ignored and despised. Grugni went on to say that, due to women's maternal qualities, many of the functions they performed in society tended to be in the educational field. Since female labour constituted a substantial portion of the total industrial and agricultural workforce, women could also play an important part in harmonizing labour relations. In the contemporary democratic setting, Grugni went on, exclusion of women from political life could no longer be justified. Adding that the type of feminism which men had promoted in the past had often been flawed, he stressed that there was a need for women to become active in the promotion of their own cause, and that such feminist action needed to be based on wellgrounded research. $^{189}$

Exponents of femminismo cristiano saw in education a means of improving women's social condition. In "Il programma minimo femminista", Pensiero e azione declared that its principal objective was to educate women to fulfil their social obligations (doveri sociali). Some changes were necessary before this could happen. Deep-rooted customs had inflicted a sense of social inferiority on women, and in order to overcome it, a general renewal of society was called for. Appropriate legislation, once in place, would enable the feminist programme to be reduced to two essential points, that is: the demand that women should be able to make full use of their energie, their mental and physical resources, on the one hand, and the demand for necessary reforms to enable this to happen, on the other. ${ }^{190}$ In the article "La questione fondamentale" the unnamed writer argued that the woman question had emerged almost spontaneously when, in the wake of industrialization, women found themselves thrown into a life in crowded quarters without proper sanitation, without moral guidance, and without adequate compensation for work. In spite of all this - and here the writer seems to take on

189 “Rivendicazioni femminili, ibid., a. II, n. 4, 15 febbraio 1906, pp. 4-5: ”Il lavoro dev'essere presidiato dallo studio. Quanti immani problemi si presenteranno alla soluzione? Sarà ricercato molto dal cuore, ma più dell'intelligenza, sussidiata dalla società e dal sacrificio.”

190 “Il programma minimo femminista, ibid., a. II, n. 2, 5 gennaio 1906, p. 3. 
socialist feminists - it would be as one-sided as it would be unjust to make the woman question a purely economic issue. ${ }^{191}$ A dispassionate search for a solution to the economic problem would, almost brutally, force one to face another, even graver, problem which concerned the moral and spiritual education of the feminine soul. ${ }^{192}$ The first and most fundamental issue of the feminist debate related, therefore, to women's education and methods of education. Although the writer does not clearly state what "the education of the feminine soul" implied, or how it should be accomplished, it becomes obvious, nevertheless, that she understood it to be much more fundamental than a grounding in academic disciplines or training for employment. It could mean nothing other than the instilment of Catholic values in women's minds. In fact, she points out, a new phalanx of militant women had emerged in the Catholic ranks to address this very aspect of the woman question, that is, the moral and religious education of women ${ }^{193}$ - which basically meant their indoctrination in Catholic principles. The stance adopted here by Pensiero e azione showed little variation from the generally held intransigent attitudes, and while its discussion of educational matters ranged from illiteracy to elementary schools, normal schools, and occupational training, it did not tackle the issue of women's access to higher education.

Although there was essentially no difference in the intransigence of L'Azione muliebre and Pensiero e azione towards the Italian State, and in their desire to improve the condition of the lower classes, there were issues on which their views were polarized, and one of the most crucial ones was the question of patronati. ${ }^{194}$ The signore

\footnotetext{
${ }^{191}$ Anna Kuliscioff wrote in "Il sentimentalismo nella questione femminile", Critica sociale, n. 9, 1892: "La questione della donna non è dunque una questione di etica né di questa o quella forma matrimoniale, ma è puramente una questione economica; è questa che la spinge nel campo della produzione, delle professioni e della politica ed è questa che la emanciperà anche nei suoi rapporti intimi coll'altro sesso". Reprinted in Filippo Turati e Anna Kuliscioff, Carteggio II: 1900-1909, v. 1, raccolto da Alessandro Schiavi, a cura di Franco Pedone, Torino, Einaudi, 1977, p. 207.

192 “La questione fondamentale, Pensiero e azione, a. III, n. 15, 5 novembre 1907, pp. 2-3.

193 Ibid., p. 3

${ }^{194}$ Patronati were private welfare institutions with the purpose of providing assistance to economically, socially and culturally disadvantaged people.

The attitude of L'Azione muliebre to labour relations becomes obvious, for example, from the article “Quindici maggio” by “Fmm.” in the May 1905 issue, pp. 292-299. She writes: "La sua [Gesù Cristo] dottrina insegna che disuguaglianze fra gli uomini vengono dalla natura medesima, e tornano in bene della società stessa; che il lavoro, dolce e leggiero nello stato di innocenza, divenne arduo e spinoso dopo la colpa; che gli altri dolori della vita presente non si possono abolire mai del tutto; che le due classi di ricchi e poveri, di padroni ed operai son volute da natura, non perchè abbiano lotta fra loro, ma perchè cooperino armonicamente al bene loro vicendevolmente ... In secondo luogo debbono cooperare i padroni e gli operai stessi. E un mezzo efficacissimo sono le Società o Corporazioni, sia semplici, come miste di operai e padroni ... A istituire queste associazioni professionali devono mirare i cattolici, devono adoperarsi le donne. E noi pensiamo che oltre che pei principi e pel fine, i patronati cattolici femminili devono distinguersi dai liberali anche in questo, nell'unire le giovani operaie in queste leghe o assicuarazioni professionali.” The bold type of the original has been retained.
} 
associated with L'Azione muliebre saw the scope of their welfare activities as extending to active involvement in labour relations, whereas Pensiero e azione was adamant that workers themselves and their trade unions should have direct responsibility for negotiating wages and working conditions. Such differences in approach are understandable considering that, in contrast to wealthy signore, women around Pensiero $e$ azione had working-class or lower middle-class origins, and that as maestre or office workers (impiegate) they themselves often belonged to a "professional” union. Since they depended on themselves for a livelihood and since their own employment in many cases was conditional on them remaining single, they were particularly sensitive to industrial issues and could therefore empathize with female labour. They were also of the opinion that working-class women could and should take responsibility for their own economic affairs.

The immediate trigger for discussing the issue of patronati in Pensiero e azione in May 1905 was the recent establishment of the Milan branch of the Patronato per la protezione della giovane operaia, which was a nation-wide organization under the patronage of the Queen of Italy, with headquarters in Turin. Grugni thought it "absurd" that this charitable institution should in its constitution include activities normally performed by trade unions. Arguably signore, belonging to the ruling classes, would have a potential conflict of interest in representing working-class women. Since industrial disputes could not always be resolved by arbitration, Grugni wondered what signore would do in the case of a strike. Even though patronati could ameliorate class differences, he maintained, they could not, by their very nature, be the bases of strong labour organizations. ${ }^{195}$ While Grugni praised the admirable work eminent ladies and various charitable organizations performed and enlisted himself as their ardent supporter, he insisted that the scope of a patronato should be limited to areas such as charity, moral guardianship, popular education, services to the disabled, and the organization of the managerial class. Workers' organizations, by contrast, especially those of women, were formed essentially to promote the interests of workers and, even though it could not be the only strategy, “class struggle” was at times necessary to gain the most fundamental rights. In Grugni's view, the so-called mixed professional associations and corporations were a historical anachronism. This was demonstrated to be the case by a recent incident in Rome where seamstresses had switched their allegiance from a Catholic patronato to a socialist camera del lavoro to obtain proper

195 “C.G.”, “Lavoro. Patronato femminile”, Pensiero e azione, a. I, n. 5, 20 febbraio 1905, pp. 8-9. 
representation of their claims. ${ }^{196}$ A letter to the periodical by the president of the Patronato femminile bolognese pro-operaie, on the other hand, was meant to draw readers' attention to the positive aspects of patronati. In Bologna some signore had taken upon themselves the task of policing the implementation of the recently passed labour laws by visiting all local tailoring establishments. The same patronato also prided itself on organizing recreational activities for female labour, and considered instituting month-long respites in the country for "some of the most anaemic women workers”. 197

In various articles Grugni spoke of lotta di classe, or class struggle, without exactly stating what he meant by it. Since the Catholic Church endeavoured to harmonize the relations between the social classes, it certainly did not regard political revolution as a solution to social and economic problems. As a member of the clergy, Grugni presumably meant by class struggle the recourse to non-violent strikes to achieve a fairer distribution of wealth and remuneration between the social classes. Such views would have been contrary to the concept of patronato held by many middle-class Catholics who, while intent on ameliorating the social ills caused by large-scale industrialization, urbanization and migration, essentially wanted to retain the social and political status-quo. It is not clear, either, what Grugni meant by "elementary distributive justice”, which he claimed on women's behalf. Was this to imply the redistribution of political power and economic assets between capital and labour or was it also to imply the redistribution of power between the two genders? Such aims could, presumably, ultimately be satisfied through universal suffrage, which included voting rights for both genders.

Pensiero e azione followed with keen interest the debate on women's suffrage and participated in it, stating in one of its articles that the notion of universal suffrage applying exclusively to men went against the most elementary principles of familybased social organization and was simply a carry-over from the past. ${ }^{198}$ While recognizing that men and women had been assigned different social functions, the principle of integramento, the complementary nature of the two genders, nevertheless required that for every function to be carried out perfectly both sexes had to be

\footnotetext{
196 “C.G.”, “Lavoro. Patronato femminile”, ibid., a. I, n. 6, 4 marzo 1905, p. 8.

197 "Patronato femminile, ibid., a. I, n. 12, 5 giugno 1905, p. 5.

198 "Il suffragio universale”, ibid., a. I, n. 23, 20 novembre 1905, p. 2.
} 
involved. ${ }^{199}$ The same principle also applied to electoral matters. It was argued, further, that giving the vote to the family as a whole, as had been suggested, rather than individuals, would not take into account single men without a family and would discriminate against women performing “sacred” social functions in society. ${ }^{200}$

In early 1906 the Fascio femminile milanese called an extraordinary meeting of its members, which was attended also by other women's associations in Milan, to discuss women's suffrage. The meeting tabled resolutions declaring that the right to vote corresponded with women's nature and faculties; that the extension of the vote to women corresponded with the concept of women representatives in government; that women's new condition as factory workers and professionals required the protection and representation of their interests; that even though written into their platform, there was socialist opposition to women's suffrage for fear of clerical influence; and that women's suffrage was only a matter of time. The Fascio was therefore resolved to continue its campaign for women's suffrage by raising public awareness of the issue as well as preparing women, especially organized workers, for the vote, by fighting the socialist tendency to turn suffrage into an anti-religious issue, and by mounting a series of pro-vote demonstrations. ${ }^{201}$

The issue of female suffrage divided the Catholic community. In the issue of Pensiero e azione of 5 August 1905, for example, the writer of the article "Il voto alla donna" challenged the notion that suffrage would alienate woman from her family and would create situations fomenting her passions (creerebbe occasioni fomentatrici di sue passioni). ${ }^{202}$ Statistics, she pointed out, eloquently proved that women were employed in factories in equal numbers with men, so why this concern about the vote? Would not direct women's participation in government bring a sense of order (nota d'ordine) in consonance with her duties in the family? ${ }^{203}$ The 21 August issue reported on three different views on the matter. Filippo Crispolti was against the vote for women on the grounds that men and women had different tasks in society and that women in general

\footnotetext{
199 "Il voto alla donna. Il giudizio di Filippo Crispolti - di Max Turmann - Lino Torriani”, ibid., a. I, n. 17, 21 agosto 1905, p. 5.

${ }^{200}$ Ibid., pp. 5-6.

201 “Il voto alla donna”, ibid., a. II, n. 6, 5 marzo, 1906, p. 9.

202 "Il voto alla donna”, ibid., a. I, n. 16, 5 agosto 1905, p. 2.

${ }^{203}$ Ibid: "La statistica - quanto sono eloquenti le cifre! - afferma che nelle fabbriche la donna è impiegata numericamente quanto l'uomo, dunque? ... La sua diretta partecipazione al governo non potrebbe portare una nota d'ordine in armonia a suoi doveri con la famiglia?” Original italics retained.
} 
lacked the intelligence (ingegno) to be voters. ${ }^{204}$ The French writer Max Turmann, on the other hand, had declared that, from the social and religious point of view, women's suffrage would bring more practical advantages than disadvantages, ${ }^{205}$ while Lino Ferriani, with some sarcasm, wrote in Il Giornale di Sicilia that it would be a mistake to grant the vote to all women:

Ora, date le condizioni speciali della donna italiana moderna - che bisogna essere positivi e non lasciarsi mai trascinare dal sentimentalismo, sia pure materiato di sensi generosi - sarebbe errore accordare il diritto di voto a tutte le donne. Sarebbe una mistificazione, un diritto di nome e non di fatto, che l'intrigo maschile avrebbe il sopravvento, ma dico, che si dovrebbe accordare a quelle donne, che appartengono alla categoria ricordata, a quante sono munite di diplomi, che documentano, e largamente, la loro squisita idoneità. E questo sarà femminismo sano perchè ispirato da vera giustizia distributiva. Alle donne, che sanno e possono, tutte le vie debbono essere chiuse onde si esplichino le loro nobili energie morali e intellettuali. ${ }^{206}$

The frequently raised argument against the vote was women's lack of preparation for it. Indeed, the enfranchisement of women would have been a problem for the Catholic Church, since having thwarted Romolo Murri's attempts to establish a secular Catholic party there was no broad-based national party which would have been able to absorb the Catholic vote, either male or female. Even Murri's party would have been highly unlikely to appeal to all Catholics across the class divide.

While Pensioro e azione openly advocated voting rights for women, the supporters of L'Azione muliebre cautiously fashioned their approach according to the Pope's announcements, which were distinctly against women's suffrage. In the spring of 1906 Camilla Theimer and Elena da Persico were granted papal audiences during which the matter came under discussion. When asked by Theimer about his attitude to feminism, the Pope responded:

Certamente che io lo gradisco, purchè non esca da quei limiti, oltre ai quali ogni organizzazione sociale, che sorge con bontà di mezzi e di scopi, degenera in una forma esiziale al progresso dell'umanità: restando ossequiente alla morale cristiana, può benissimo la donna elevare il suo livello intellettuale, pur utilizzando le sue forze a vantaggio proprio ed altrui. ${ }^{207}$

\footnotetext{
204 “Il voto alla donna. Il giudizio Filippo Crispolti - di Max Turmann - di Lino Torriani”, cit., p. 5-6.

${ }^{205}$ Ibid., p. 6: "Quanto a noi siamo disposti ad ammettere che la concessione del diritto di voto alle figlie di Eva potrebbe attualmente, dal punto di vista sociale e religioso presentare più vantaggi pratici che inconvenienti”.

${ }^{206}$ Ibid., pp. 6-7.

207 “Il voto alla donna”, ibid., a. II, n. 12, 5 giugno 1906, p. 11.
} 
The Pope regarded the various welfare and charitable activities as an extension of the concept of motherhood, but shunned the notion of women voters and deputies since, after all, men already created too much confusion in parliament:

Questo sì che è per la donna un sublime apostolato, ma non elettrici, non deputatesse, perchè è anche troppo la confusione che fanno gli uomini in Parlamento! ${ }^{208}$

During da Persico's audience, too, the Pope reiterated the sentiments he had already expressed to Theimer, approving of educated women and of women's welfare work but not of women voters:

Egli mi confermò ciò che già una letterata tedesca pubblicò un mese fa su tutti i giornali, che Egli approva cioè la donna colta, quella che sa di latino, perfino la dottoressa, non però la donna elettrice, nelle nostre condizioni attuali. Approva anche che la donna si dedichi a quelle opere sociali... ${ }^{209}$

As Pensiero e azione stated in the inaugural issue, it wanted to continue the work of the Nucleo fisso to create a national women's organization. The first step towards this goal was taken when a supporter group, the Circolo femminile di Milano, organized a convention on 25 and 26 April 1905 to "intensify" the work of Pensiero e azione. The paper noted that this was not the first time that the Circolo femminile had held such a convention in Milan. What was remarkable, however, was that whereas the two earlier meetings, in 1903 and 1904, had taken place in conjunction with the Lombard "professional” congresses, this time the convention was organized independently from men by women themselves, because it had become clear that a separate organization was needed to represent women. The 1905 convention gave rise to a new women's federation which would, however, cooperate with men and would draw on their experience. At the start of the convention, telegrams were sent to Pius X, Cardinal Ferrari, Monsignor Radini Tedeschi, and the President of the Second Group of the now defunct Opera dei congressi, Count Medolago Albani. ${ }^{210}$ In response, the Secretary of the Second Group, Vasco Restori, stated that the Second Group would be happy to lend its support for women's social action whenever necessary. ${ }^{211}$ Adelaide Coari was voted to be president of the convention, which represented approximately 20,000 organized women and was attended by delegates from different social backgrounds, including countrywomen (campagnole), factory workers (operaie), professional women (professioniste), and signore. The women's federation would not be restricted to Milan

\footnotetext{
${ }^{208}$ Ibid.

209 "Venti minuti ai piedi del S. Padre”, L'Azione muliebre, a. VI, fasc. 6, giugno 1906, p. 323.

210 “Impressioni”, Pensiero e azione, a. I, n. 8, 5 aprile 1905, pp. 3-4.

${ }^{211}$ Restori, Vasco, "Una lettera del II Gruppo”, ibid., pp. 7-8.
} 
but would welcome both associations and individual members also from outside the Milan diocese. Pensiero e azione would be the depository of its proceedings, and the periodical would be sent to every member association. The convention acknowledged the teaching of catechism and women's support at election campaigns as being matters of great importance in future activities. ${ }^{212}$

Referring to the efforts Radini Tedeschi had made, rather unsuccessfully, to compile statistics on women's associations in 1900, Pensiero e azione announced a renewed attempt at the same task in June 1905. The paper noted the proliferation of women's organizations in the north of Italy and their absence in the southern parts of the country. It found the organizations to consist of three types: study circles, professional (or trade) unions and associations with economic objectives (opere economiche.) ${ }^{213}$ Just two years later, in April 1907, Pensiero e azione could confidently say that the Federazione femminile would be able to field any questions regarding mutual aid societies (casse di mutuo soccorso), credit unions (casse di depositi e prestiti), financial institutions in general (istituzioni economiche in genere), schools for dress-making and tailoring (scuole di lavoro di taglio), home economics (economia domestica) and illiterates (analfabete), evening and Sunday schools (scuole serali e festive), study circles (circoli di studi), lecture series (corsi di conferenze), committees for public morality (comitati per la pubblica moralità), and labour leagues (leghe di lavoro). ${ }^{214} \mathrm{~A}$ month later the periodical reported that the Federazione femminile had set up its own labour exchange (ufficio del lavoro) in response to the inquiries it had received, and in order to better fulfil its tasks. ${ }^{215}$ The Federazione femminile would continue to operate independently from the Second Group of the Opera and also from the Unione popolare, another remnant of the Opera, which subsequently under Giuseppe Toniolo’s leadership sought to unite women's associations into a national body. In fact, in January 1907, Pensiero e azione reported on a meeting in the Milan bishopric where none other than Elena da Persico encouraged women to join the Unione popolare. Don Carlo Grugni was named as the person to whom inquiries should be directed concerning membership. ${ }^{216}$

\footnotetext{
212 “Convegno femminile”, ibid., pp. 4-7.

213 “L’organizzazione femminile”, ibid., a. I, n. 13, 20 giugno 1905, p. 5.

214 “Federazione femminile”, ibid., a. III, n. 5-6, 13 aprile 1907, p. 8.

215 “Federazione femminile”, ibid., a. III, n. 9, 18 maggio 1907, p. 5.

216 “Per l’Unione popolare”, ibid., a. III, n. 2, 21 gennaio 1907, p. 7.
} 
The capacity of the Federazione femminile to organize, jointly with its driving force, Pensiero e azione, a national women's congress (Convegno femminile) in April 1907 gave proof of its vitality and of its aspirations to become a national body. This was an amazing achievement by any standard. With the support of the Archbishop of Milan, the conference took place at the Villa reale, made available by the King of Italy, and Count Gori presented the greetings of the Mayor and the citizens of Milan. The sevenmember organizing committee included Adelaide Coari, Countess Sabina Parravicino di Revel, President of the Federazione lombarda delle opera di attività femminile, and Princess Castelbarco Albani della Somalia, President of the Milan branch of the Società di patronato e M. S. per le operaie. ${ }^{217}$ A total of 450 registrations, a number from nonCatholic individuals and organizations, had been received. ${ }^{218}$

Apart from the good ecclesiastical turnout, two national parliamentarians, a sprinkling of academics and other professional men were also present. But the women by far outnumbered the men. If at the Bologna Congress of the Opera dei congressi three and a half years earlier women were barely given leave to speak, now it was clearly a women's conference at which women confidently discussed women's issues. Numerous aristocratic ladies were in attendance, including an assortment of princesses, duchesses, marchionesses, countesses, and noblewomen. The attendees included two important Catholic conservative figures, Countess Elena da Persico, editor of L'Azione muliebre, and Donna Cristina Giustiniani Bandini, future leader of the yet to be founded Unione fra le donne cattoliche d'Italia, as well as the Catholic journalist and writer Antonietta Giacomelli and Luisa Anzoletti, who was keynote speaker. Secular bodies, such as the Consiglio nazionale delle donne italiane, the Lega per la tutela degli interessi femminili and the Federazione abolizionista had sent delegates. ${ }^{219}$ The presence of representatives from the Unione femminile nazionale, especially of Ersilia Majno and Linda Malnati, illustrated how femminismo cristiano had opened up to influences from the very feminist organization Coari had found so frightening three years earlier. Registrations had also come from the modernist writer Antonio Fogazzaro, the Catholic feminist journalist Elisa Salerno, and Romolo Murri's Lega democratica nazionale. While patronati were well represented, there were also block

\footnotetext{
${ }^{217}$ Princess Castelbarco resigned her position during the planning period and was replaced by Donna Maria Crawen, Vice-President of the Società di patronato e M. S. per le operaie in Milan. See Atti del Convegno femminile, Milano, 25-26-27-28 aprile 1907, Milano, "La Benefica”, 1907, p. 7.

218 Ibid., 1907, pp. 19, 29.

${ }^{219}$ As discussed in Chapter One, "abolitionists" wanted to decriminalize prostitution. The Federazione abolizionista was based in Geneva.
} 
registrations for women workers from various leghe femminili. Organizations of the latter type were rapidly growing in numbers, and the confidence women workers were beginning to have in themselves was demonstrated by the courageous participation of some of them in the discussion. The largest number of registrations had come from Milan, while the rest was made up, almost exclusively, of registrations from other northern cities and locations, and from Rome.

A further important characteristic of the conference was that, strictly speaking, it could no longer be regarded as a purely "Catholic" conference, since contributions by delegates from other faiths were also welcome, as becomes clear from the opening address of the member of the organizing committee, Countess Sabina Parravicino di Revel:

Questo saluto riafferma il nostro programma di ordine e di rispetto alle credenze, ciò che non c'impedirà di accogliere e discutere le buone proposte che ci fossero presentate da persone di altra fede. ${ }^{220}$

The congress agenda showed, how far, in a short span of time, femminismo cristiano had moved to approximate the avant-garde positions of contemporary secular feminists, while simultaneously its strident intransigence vis-a-vis secular institutions had mellowed. In the Programma minimo femminista, Adelaide Coari grouped her claims into four major categories, including the fields of employment, education, social activity, and the law:

I. In the field of employment:

a) Equal pay for equal work;

b) Freedom for women to enter the occupations best suited to their aptitudes;

c) The right of women to defend and safeguard their interests in all those institutions of a social nature which protect and organize the duties and the rights of workers.

II. In the field of education:

a) A more practical orientation for women's schools; and the introduction

of special schools for women in farming and those working in factories;

b) Giving mothers the opportunity to influence more directly the general running of public schools.

III. In the field of social activity:

a) Recognition of the right of women to be involved with public institutions, especially those of an educational and a charitable nature.

\footnotetext{
${ }^{220}$ Atti del Convegno femminile, cit., p. 19.
} 
IV. In the legislative field:

a) Freedom for married women to administer their own property;

b) Legalization of paternity investigation;

c) Extension of the legal liability of the seducer until the seduced woman has reached the age of twenty-one;

d) The creation of salaried female inspectors to enforce the labour law regarding women and children;

e) Women's right to vote at local elections. ${ }^{221}$

Before presenting her log of claims, Coari professed her Catholic faith outlining her core beliefs, highlighting the need for women to take part in the general renewal of society, and expressing the hope of finding common ground with women from other confessions. Women's maternal qualities as well as the principle of integramento were stressed by Coari, as was also her aversion to any kind of gender struggle. She also stated that the formation of woman's personality, distinct from that of man's, but equal to it, was to be achieved through spontaneous development of her unsullied, virginal energies, on the basis of the principle of freedom. Profound harmony between the spirit of freedom (libertà) and love (amore) in its noblest sense, she argued, would lead not to a gender struggle, but to an intelligent, loving cooperation. ${ }^{222}$

In many respects femminismo cristiano approximated the position of moderate socialist feminism represented by the Unione femminile. During the discussion on women's

${ }^{221}$ Ibid., pp. 36-8.

I. Nel campo del lavoro:

a) Uguale mercede per uguale lavoro;

b) Libertà alla donna di accedere là dove è chiamata dalle sue attitudini;

c) Diritto di difendere e tutelare i propri interessi in tutte quelle istituzioni di carattere sociale, che tutelano e ordinano i doveri e i diritti dei lavoratori.

II. Nel campo della scuola:

a) Un indirizzo più pratico alle scuole femminili; e l'inizio di scuole speciali per le contadine e operaie;

b) Dare la possibilità alla madre di influire più direttamente sull'andamento generale delle pubbliche scuole.

III. Nel campo sociale:

a) Riconoscere di diritto alla donna l'interessamento per tutte le istituzioni pubbliche di carattere specialmente educativo o benefico.

IV. Nel campo legislativo rivendicare:

a) Libertà di amministrazione dei beni appartenenti alla donna maritata;

b) Ricerca della paternità;

c) Estendere la responsibilità penale del seduttore finchè la sedotta non abbia raggiunti i 21 anni;

d) Istituzione d'ispettrici stipendiate per l'osservanza della legge sul lavoro delle donne e dei fanciulli;

e) Voto amministrativo.

${ }^{222}$ Ibid., p. 34: "Dalla profonda armonia dello spirito di libertà con l'amore inteso nel più nobile significato scaturisce viva e feconda non già la lotta di sesso per la lotta di sesso; ma l'intelligente, amorosa cooperazione, per mantenere e rivendicare la quale bisogna tenersi ben viva nell'anima la coscienza della propria dignità”. 
property rights, Coari declared that women, especially working-class women, should be free to administer their own property, because marital authorization could cause so much harm to the family. ${ }^{223}$ Ersilia Majno, for her part, remarked that the paragraphs in the statutes, in which woman was equated with minors, idiots, and the disabled, were embarrassing and compromised her authority and her educative work with children. ${ }^{224}$ Many, among them Coari herself, were in favour of demanding women's suffrage at both local and national elections, but, recognizing that it would be unachievable, thought it prudent to remain with the "minimum" demand for the vote at local elections only. The socialist Linda Malnati’s attempt to amend the resolution to claim voting rights at both elections was not accepted. ${ }^{225}$ The women's conference coincided with the Prime Minister Giovanni Giolitti appointment of a commission to explore the question of women's suffrage, and Countess Parravicino di Revel thought it would be appropriate to send a telegram to the government to express approval. ${ }^{226}$

In industrial relations, mixed unions and patronati seemed superseded notions, with the speakers generally expressing themselves in favour of workers setting up their own unions. The conference voted to demand employers to provide insurance cover not only for industrial accidents, as was already the case, but also for sickness, old age and maternity. ${ }^{227}$ With Signora Schiff from the Lega per la tutela degli interessi femminili pointing out that many Italian Camere di commercio had expressed their support for granting the active and the passive vote in their organizations to businesswomen, it was decided to campaign for the admission of businesswomen to the Camera di commercio in Milan and in other cities. ${ }^{228}$

Women's absence from all decision-making bodies impacting on not only their employment but also on their welfare work was palpably evident. In view of the large

\footnotetext{
${ }^{223}$ Ibid., p. 51: "Noi vogliamo che la donna, specialmente la donna operaia sia libera di amministrare i propri beni, libera perchè troppe volte, e molti buoni lo possono comprovare, da questo legame ne vengono tanti mali alla famiglia ...”

${ }^{224}$ Ibid., pp. 50-51.

${ }^{225} \mathrm{Ibid}$., pp. 53-55. Two polls were taken: first Coari's proposal which received 39 votes with two abstentions, then Malnati's proposal which received 30 votes. Of those abstaining from voting for Coari's proposal, Signora Celestina Annoni recommended an affirmation for or against "diritto di voto", while Signora Albini Crosta stated that in her view "il voto politico distrugge la femminilità e quindi si oppone". The quoted phrases are italicized in the original.

${ }^{226}$ Ibid., p. 73: “... [La Contessa Parravicino di Revel] comunica che avendo letto sui giornali essere stata nominata dal Parlamento una commissione inerente alla concessione del voto amministrativo alle donne, parrebbe opportuno alla Presidenza di mandare a nome del Convegno un voto di plauso al Governo ...”

${ }_{227}$ Ibid., p. 72.

${ }^{228}$ Ibid., pp. 66, 71.
} 
numbers of textile workers and rice-weeders, Adelina Meletti stressed the need for women's representation on national labour relations bodies, such as the Ufficio nazionale del lavoro and the Consiglio superiore del lavoro. ${ }^{229}$ Women's participation, she believed, would pave the way toward achieving the eight-hour workday, the establishment of a national maternity fund, improved labour legislation on women and children, better policing of and adherence to the labour laws, and an increase in women's unionization. ${ }^{230}$ Signora Luraschi, in turn, sought women's admission to the administrative bodies of the organizational centres for public welfare activities, Congregazioni di carità. The conference recognized the need for women to receive both practical and theoretical training in social work, and be by right nominated to the administration of every charitable body. Moreover, Italian women needed to unite their efforts towards coordinating public and private welfare work. ${ }^{231}$

Throughout, goodwill was evident between the organizers and the secular feminists and, as voting proved, Coari's program found broad acceptance. As the conference proceeded, however, the division within Catholic ranks, polarized by L'Azione muliebre and Pensiero e azione, became evident. Unchanged in its strident intransigence and its avowed adherence to Merry del Val's circular of 1904, L'Azione muliebre had counselled its readers not to attend the conference because, without an ecclesiastical assistant, there could be no guarantee that it would be conducted in the Catholic spirit. $^{232}$ At the conference, which da Persico had been persuaded to attend after all, the

\footnotetext{
${ }^{229}$ According to Martin Clark, Modern Italy 1871-1995, cit., p. 138, the Consiglio superiore del lavoro, or the Supreme Council of Labour, was founded in 1902 "as an advisory body to examine labour issues and to give its opinion on proposed legislation. It contained employers, civil servants, parliamentarians, various experts, and representatives of various reformist-Socialist bodies like the National League of Cooperatives and the Italian Federation of Mutual-Aid Societies.”

Linda Malnati pointed out that Argentina Altobelli had already been invited to become a member of the Consiglio, an invitation which she had declined. Meletti observed that in Altobelli's case the invitation was due to personal merit; however, women should be entitled to membership irrespective of personal factors. Atti del Convegno femminile, cit., p. 79.

${ }^{230}$ Ibid., p. 77.

${ }^{231}$ Ibid., pp. 81-87.

232 Da Persico wrote in “Il convegno femminile d'Aprile”, L'Azione muliebre, a. VII, fasc. 3, marzo 1907, p. 173: “Abbiamo sotto gli occhi la lettera del Card. Merry del Val del 1904 'Quando i Vescovi credano [sic] dover permettere alle donne di radunarsi a convegno queste non parleranno se non sotto la presidenza di gravi persone ecclesiastiche.' Questa presidenza manca affatto al Convegno d'Aprile, che non ha Assistente ecclesiastico e che quando pure lo chiedesse all'ultimo momento, fece ormai tutto senza di lui: sedute preparatorie, elaborazione di relazioni ecc. Prescindendo anche dall'irregolarità della cosa, quale garanzia abbiamo che in questi preparativi tutto si sia condotto assennatamente secondo lo spirito cattolico?”

Da Persico did not know that Sabina Parravicino di Revel, with the Cardinal's permission, had requested that conference invitations should be sent out without Carlo Grugni's name on them. In Parravicino's view, a priest's signature would have given the conference a denominational aura making it less attractive to many women. Grugni himself, Parravicino thought, would be happier not to be the only male among
} 
split in the Catholic women's movement became clear to everyone present. ${ }^{233}$ She considered the phrase "to give women freedom to choose their occupation" too subjective, arguing that rather than action being guided by personal aptitude, sound morals suggested that aptitude should conform to an external law and to established principles. ${ }^{234}$ Expressing her dissatisfaction for not having received an explanation for Coari's use of the terms "freedom" and "love" and for the principles on which the conference was based, da Persico declared that henceforth (from the morning of the third day of the conference) she would not participate either in the discussions or in the voting. ${ }^{235}$ The major showdown came with Maria Nedrato’s paper entitled "Stampa femminile”, in which she nominated early childhood education, morality and pacifism as areas in which women could make a valuable contribution to mainstream newspapers. She stated that it would be desirable to educate women in Italy so that they too would become dominant in journalism, like in the United States, and play a bigger role in editorial offices, improving the quality of journalism. After criticizing the superficiality of many women's publications, Nedrato singled out Rivista delle signorine, Pensiero e azione, L'Azione muliebre, and Vita femminile as really good women's periodicals, and then named Vita femminile and Pensiero e azione as those best adapted to the requirements of the Catholic women's movement. Interpreting the speaker's criticism of women's periodicals as applying to L'Azione muliebre, da Persico seized on the opportunity to defend her paper's credentials. Like ladies who did not share her faith but had been permitted to argue their case consistently according to their beliefs, she now demanded that she, too, should be permitted to make her case logically in conformity with her principles. These principles called, above all, for total compliance with the announcements of the Pope who in his latest address to new

so many women: "Se vuol dunque seguire il consiglio mio corroborato dal parere di S.E. tolga dal manifesto il nome di D. Carlo Grugni. Sono persuasa che egli pure, sarà contentissimo di non fare la figura di un gallo in un pollaio”. Original underlining retained. See Parravicino di Revel's letter to Coari, 19 Dec. 1906, FAC 5206.

${ }^{233}$ In the end, Princess Cristina Giustiniani Bandini must have persuaded da Persico to attend. Giustiniani Bandini writes in an open letter meant for publication in L'Azione muliebre: "Ho avuto fra le mani il N: 3 del pregiato giornale da Lei diretto 'L'Azione Muliebre' e mi permetto di dirLe francamente la penosa impressione suscitata dalle poche righe riguardanti il prossimo 'Convegno femminile', inserite in questo fascicolo ... Se invece di ostacolare un movimento che può dare buoni frutti ' $L$ 'Azione Muliebre' (lasciamo da parte la questione dell'Assistente Ecclesiastico, che spetta solo al Vescovo di definire come rilevasi dalla stessa circolare citata) volesse portarci tutto il suo contributo d'intelligenza e di energia, forse allontanerebbe quei pericoli che sembra temere e assicurerebbe quei risultati che tutte abbiamo ragione di sperare e che molte sue lettrici invocano." Cristina Giustiniani Bandini, "Alcuni appunti sulla storia della nostra ‘Unione’ 1907-1917”, manuscript, AGOP XIV.950 GIB.1.

${ }^{234}$ Atti del Convegno femminile, cit., p. 41: “'Libertà alla donna di accedere là dove è chiamata dalle sue attitudini' è una frase troppo soggettiva, perchè secondo la sana morale ciò che deve guidare l'azione non è l'attitudine individuale, ma quest'attitudine deve conformarsi ad una legge esterna e a dei principii stabiliti”.

${ }^{235}$ Ibid., p. 73. 
cardinals had labelled as rebels all those Catholics who deviously disseminated monstrous errors and who, by speaking and writing, and by preaching charity without faith, opened the road to eternal ruin for everyone. ${ }^{236}$

Since Pensiero e azione took special interest in problems associated with prostitution, it is not surprising that the final session was devoted to this topic, with Felicita Büchner from Munich presenting a paper entitled "La pubblica moralità e la donna”. As a Catholic periodical, Pensiero e azione took an abolitionist stand on the issue. Stating, “Non vi è che una sola morale per i due sessi”, Büchner criticized the double standards which were generally followed by society. ${ }^{237}$ Prostitution enabled the coexistence of two seemingly irreconcilable social norms: Acceptance of men's right to satisfy their allegedly unrestrainable sexual appetites, on the one hand, and the imposition of strict standards of purity on women, on the other. Hence prostitution was a necessary prop for the institution of marriage:

Ed ecco la prostituzione, eretta ad istituzione di prima necessità, palladio del focolare domestico, del pudore e della castità. ${ }^{238}$

Unwittingly, honest women became accomplices in the debasement of their own gender not only by tolerating prostitution but even approving it, and through their attitude played into the hands of its perpetrators. Viewed by the authorities as un male necessario, prostitution was regulated primarily to control the spread of venereal disease. Professional secrecy, however, to which the medical profession was sworn, could be instrumental in the spreading of venereal disease within the family since doctors were reluctant to disclose to the husband's infected wife the nature of her illness. $^{239}$ Abolitionists demanded that appropriate authorities should carry out a dispassionate, scientific investigation into the problem and introduce reforms so that prostitution would not have to be the inevitable outcome of social conditions. ${ }^{240}$ Moreover, with a large number of young women migrating overseas, the question of white slave trade was also of topical interest in Italy. The speaker deplored that the various committees established to combat the trade in women had not yet managed to

\footnotetext{
${ }^{236}$ Ibid., p. 106: "Ora i cattolici per essere logicamente coerenti ai loro principii devono agire in tutto secondo la direzione che loro viene dal Capo della Chiesa e il Papa proprio ultimamente all'indirizzo dei nuovi Cardinali chiamava ribelli 'quei cattolici che professano e diffondono sotto forme subdole gli errori mostruosi ... Sull'adattamento ai tempi in tutto nel parlare, nello scrivere e nel predicare una carità senza fede che apre a tutti la via all'eterna rovina'." Original italics retained.

${ }^{237}$ Ibid., p. 120.

${ }^{238}$ Ibid., p. 128.

${ }^{239}$ Ibid., pp. 133-134.

${ }^{240}$ Ibid., p. 132.
} 
put the matter on the agenda of international congresses. ${ }^{241}$ Like previous speakers who had touched on the need for women to be employed in government instrumentalities to take care of women's issues, Büchner strongly recommended the employment of welleducated female social workers by the police to help turn around the lives of women and children who had been arrested. ${ }^{242}$ Her address was rapturously received, with the recognition that even though she had spoken about regulation in Germany, the situation was similar in Italy despite the decriminalization of prostitution under the Crispi Regulation of 1888. The conference ended with Sabina Parravicino di Revel's announcement, in the name of the Consiglio nazionale delle donne italiane, that the Second National Women's Conference would take place in Rome the following year. ${ }^{243}$

In the next fortnightly issue of Pensiero e azione, on 11 May 1907, Carlo Grugni could triumphantly assert that the conference had been a success. On the whole, it had received favourable press coverage; the calibre of the delegates themselves had been impressive; and the conference had marked the end of men's domination over feminist debate. In approaching their new mission women had provided evidence of many positive feminine qualities, and full agreement had been reached on the immediacy and practicability of the minimum feminist programme. ${ }^{244}$ A week later Pensiero e azione could proudly announce that not only had the Catholic feminist Luisa Anzoletti decided to join the Federazione femminile, ${ }^{245}$ but also that, noting the total lack of local women's organizations in the diocese, the management of the Como diocese had decided to promote the establishment of sections of the Federazione femminile. ${ }^{246}$ Commenting on Archbishop Ferrari's approval of the conference, Bishop Radini Tedeschi expressed his own satisfaction with it in a letter dated 27 May, in which he enclosed a monetary gift towards the costs. ${ }^{247}$

Shortly afterwards, however, the Archbishop of Milan had to defend the good work the Federazione femminile, and the need for it, at a monthly meeting of clerics. ${ }^{248}$ Among

\footnotetext{
${ }^{241}$ Ibid., p. 156.

${ }^{242}$ Ibid., p. 159.

${ }^{243}$ Ibid., p. 162.

${ }^{244}$ C.G., "Il trionfo", Pensiero e azione, a. III, n. 8, 11 maggio, 1907, p. 6.

245 “Federazione femminile, ibid., a. III, n. 9, 18 maggio 18, 1907, p. 5.

${ }^{246}$ Ibid., pp. 5-6.

${ }^{247}$ Radini Tedeschi's letter to the Presidenza del Convegno femminile, 27 May 1907, FAC 3485.

248 “Conclusioni e polemiche”, Pensiero e azione, a. III, n. 11, 25 giugno, 1907, p. 2: “Autorizzate dall'Eminentissimo Cardinale Arcivescovo, facciamo noto a chi s’è interessato delle polemiche nostre, che Sua Eminenza ha difeso nell'adunanza mensile del Clero, il nostro lavoro, affermandone la bontà e la necessità”.
} 
the harshest critics were the periodicals L'Unità cattolica and Il Berico. S.A. Cavallanti, writing in the first-named journal, labelled the conference "modernist" even before it was convened, ${ }^{249}$ and afterwards found that it was a second, "worsened" edition of the 1903 Bologna congress of the Opera dei congressi. While Murri had dominated in Bologna, the Milan congress was a triumph for Majno:

Poichè a Bologna fu festeggiato, festeggiatissimo, anzi, il re della festa, Romolo Murri; ma esso, benchè modernista bacato fin d'allora, era però un cattolico, un sacerdote, mentre a Milano trionfò pienamente la Maino socialista. ${ }^{250}$

Il Berico devoted two articles to the conference, the first on 9 March by the same S.A. Cavallanti, before the conference had taken place, and the second afterwards, on 4 May, by "an observer" under the heading "Modernismo su tutta la linea". 251 Conservative journals, such as L'Unità cattolica and La Difesa, writes Antonietta Cimini, tended to indentify feminism with modernism and to regard Pensiero $e$ azione as a nest of heretics. ${ }^{252}$ Elena da Persico produced her version of the conference in a supplement to L'Azione muliebre, reiterating her disapproval at the absence of an ecclesiastical assistant and criticizing the religious "neutrality" of the conference as well as commenting on various other points of contention. ${ }^{253}$ Professor Leone Donaldoni who, like Cavallanti, did not attend it, wrote a disparaging pamphlet about it and about Coari's Pensiero e azione. ${ }^{254}$ Pensiero e azione responded by bringing out a special supplement to Issue 9 of 18 May, in which the criticisms of da Persico and Cavallanti were rebutted point by point. $^{255}$

A year later Pensiero e azione was a target for further criticism because of Coari's attendance at the First National Congress of Italian Women convened in Rome from 24

\footnotetext{
${ }^{249}$ S.A. Cavallanti, “Modernismo femminile: i centri di propaganda”, L’Unità cattolica, v. XLV, n. 56, 8 marzo 1907, p. 1 and "Modernismo femminile: il prossimo convegno", in ibid., v. XLV, n. 57, 9 marzo 1907, p. 1.

${ }^{250}$ S.A. Cavallanti, “A Milano: convegno modernista”, ibid., v. XLV, n. 102, n. 102, 4 maggio 1907, p. 1. 251 S.A. Cavallanti, “Moderniste a convegno”, Il Berico, 9 marzo 1907, pp. 2-3. The writer has dark forebodings about the outcome of the conference: "La donna uscirà dal Convegno eletta ed elettrice, avvocatessa e professoressa nell’arte medica e nella politica”. Original italics retained.

"Un osservatore" writes in "Modernismo su tutta la linea”, ibid., 4 maggio 1907, p. 1: "Si entrò coll'impronta cattolica, si uscì col sorriso a tutti i nemici della religione ... Tutto il programma femminista il più avariato ed inopportuno, che anzi non era nemmeno all'ordine del giorno, a Milano venne approvato.”

${ }^{252}$ Cimini, “Adelaide Coari e il movimento femminile cattolico”, cit., p. 143.

253 "Relazione delle discussioni più salienti durante il Congresso femminile nazionale”, L'Azione muliebre, aprile 1907, Supplemento. See also "Risposta al supplemento del Pensiero e azione”, ibid., a. VII, fasc. 6, giugno 1907, pp. 321-322.

254 Leone Donaldoni, Femminismo cristiano? Risposta documentata del Dott. Leone Donaldoni a proposito del Convegno femminile tenutosi in Milano nei giorni 22-28 aprile 1907, Milano, 1907.

255 “'Per la verita.' Correzioni ed aggiunte necessarie agli opuscoli del Prof. Leone Donaldoni e della Contessa da Persico”, Pensiero e azione, Supplemento al n. 9 [18 maggio 1907].
} 
to 30 April. With numerous renowned speakers, representation from over ninety women's organizations, registrations from more than 1,200 delegates, and with the Queen in attendance at the opening ceremony, it was an epoch-making occasion. Asked beforehand whether Catholic women should attend the congress, Pius X's advice was equivocal:

Ne [del Convegno femminile] siete uscite dal rotto della cuffia: se volete un consiglio vi dirò: è più prudente che non andiate, peraltro non lo proibisco. ${ }^{256}$

Pensiero e azione for its part, in the issue of 25 April, extended cordial greetings to the women attending:

Alle donne che in Roma si sono riunite per l'affermazione dei sacrosanti diritti femminili e dell'operosità che a prò delle sorelle e della collettività, il loro cuore e la loro intelligenza suggerisce: che insieme si pongono allo studio e alla discussione di quei problemi che affannano l'animo di ogni generoso che sente pulsare la propria vita nella felicità e nella bontà dell'umanità, il nostro saluto cordiale, il nostro augurio fervido. ${ }^{257}$

Coari had been invited to present a paper on unemployment in the morning session of 29 April, which was chaired by Linda Malnati from the Unione femminile. ${ }^{258}$ This would have been harmless enough in itself had not the congress the day before carried Malnati's “surprise” motion calling for total religious neutrality at primary schools and for objective study of religions at secondary schools. ${ }^{259}$ It was accepted by “unanimous” vote, whereas an alternative motion formulated by Adelaide Coari, Maria Roesler Franz and Elisabetta Venturelli was rejected. ${ }^{260}$ In the afternoon of the

256 The pope was interviewed by Princess Cristina Giustiniani Bandini. See Maria Cristina Giustiniani Bandini, Il beato Pio X e l'associazione cattolica femminile, Roma, 1951, p. 8.

${ }^{257}$ Pensiero e azione, a. IV, n. 8, 25 aprile 1908, p. 2.

${ }^{258}$ Maria Roesler Franz, Secretary of the Sezione Assistenza e Previdenza, had invited Coari to give a paper on unemployment. In her letter of 6 Jan. 1908, FAC 5216, Roesler Franz's writes to Coari: “A noi è nota la sua preziosa attività e a Lei ci rivolgiamo con fiducia perchè accetti d'essere relatrice generale per il IIIo tema proposto dalla nostra sezione sotto il nome di problema della disoccupazione. A lei non può sfuggire l'importanza della questione che desideriamo trattare con criteri obbiettivi e con larghe vedute e dalla discussione che seguirà speriamo sorga qualche idea, che in pratica possa rimediare almeno in minima parte alla terribile piaga della disoccupazione.” Original underlining retained.

${ }^{259}$ Atti del I Congresso nazionale delle donne italiane, Roma, 24-30 aprile 1908, Roma, Stabilimento Tipografico della Società Editrice Laziale, 1912, p. 643: "Il Congresso delle donne italiane, rispettoso di tutte le convinzioni politiche e religiose degli adulti, ma rispettoso anche della libertà di coscienza del fanciullo perchè nell'avvenire possa meglio orientarsi ai liberi principi individuali nella sua condotta morale, fa voti:

1) che la scuola elementare sia assolutamente aconfessionale;

2) che nelle scuole secondarie superiori sia introdotto lo studio interamente obbiettivo delle religioni in relazione alle loro finalità e alle loro conseguenze sociali.”

260 Ibid.: "Il Congresso delle donne italiane, affermato che il principio religioso nella educazione individuale e sociale è potente energia etica, fa voti:

perchè l'insegnamento religioso, migliorato nel modo d'impartirlo, ispiri ancora l'opera educativa.”

L'unità cattolica, a. XLVI, n. 96, 1 maggio, 1908, p. 1, reported that more than 200 women had voted in favour of religious instruction at schools: "Siccome varii giornali hanno pubblicato che il voto contro 
following day (29 April) the convenor, Countess Gabriella Spalletti Rasponi, read out a letter she had sent to newspapers justifying her decision to support Malnati’s motion by stating that, even though she was deeply religious and convinced of the need for religious instruction to children, she nonetheless thought that enormous harm could be done if religion was taught badly or was given by atheist teachers. ${ }^{261}$ There were claims that Catholic women had been prevented from casting their vote, ${ }^{262}$ while Pensiero $e$ azione wrote that Rasponi Spalletti had "illegally" put forward the two motions in the afternoon plenary session. ${ }^{263}$ Since Catholic women had been advised against attendance at the congress, the paper stated, the resolution passed did not represent the majority view of women. ${ }^{264}$ But it had a devastating effect on the incipient cooperation between Catholic and secular feminism. It ruptured, argues Lucetta Scaraffia, the alliances between socialists and Catholic modernists, while moderate secular feminists with "theosophic sympathies" "timidly" put forward their alternative of nonconfessional religious instruction. Their proposal, however, did not proceed and they found themselves voting with the socialists. ${ }^{265}$

A month later Pensiero e azione drew further criticism for publishing the resolutions of the congress organized by the Unione femminile in Milan on 24 and 25 May. While expressing its disagreement on the issues of divorce and religious instruction, it counselled its readers to acknowledge those aspects in the Unione's platform, which were “truly good”. ${ }^{266}$ As Cettina Militello observes, “two philosophies” permeated femminismo cristiano. The first, “dialogic”, considered a dialogue with its socialist

l'insegnamento religiosa, fu adottato all'unanimità, oggi alla stampa è stata comunicata la seguente dichiarazione firmata da oltre duecento congressiste:

'Per la serietà o l'equità del primo Congresso nazionale delle donne italiane le sottoscritte - avendo aderito nella seduta di ieri all'ordine del giorno Coari-Roesler Franz-Venturelli, favorevole all'insegnamento religioso migliorato nel modo di impartirlo - dichiarano che il voto per l'aconfessionalità della scuola, se fu approvato in maggioranza, non lo fu ad unanimità'.” Original italics retained.

${ }^{261}$ Atti del I Congresso nazionale delle donne italiane, Roma, 24-30 aprile 1908, cit., p. 663.

${ }^{262}$ A Catholic version of the event was given by Princess di Cassano Zunica, née Contessa De Courte, in “La votazione religiosa intorno all'insegnamento religioso nel Congresso delle donne italiane”, Unione fra le donne cattoliche d'Italia, n. VIII-IX, gennaio-febbraio 1911, pp. 2-3. According to di Cassano Zunica, Malnati's motion was put first. At that point, there was a sudden influx of men who noisily prevented Catholic women from presenting their case. Amid the tumultuous proceedings the vote was delayed. The Catholics were informed by Rasponi Spalletti that the meeting would be reconvened at 4 p.m. but this in fact occurred an hour earlier. A number of Catholics arrived too late to vote. There was insufficient seating, and those standing were counted as being in favour of Malnati's motion.

263 “Il Congresso femminile di Roma”, Pensiero e azione, v. IV, n. 9-10, 10-25 maggio 1908, p. 6. Afternoon sessions were only meant to report resolutions of sectional meetings.

${ }^{264}$ Ibid., p. 3.

${ }^{265}$ Lucetta Scaraffia, “Teosofe, femministe e moderniste in Italia”, in Lucetta Scaraffia e Anna Maria Isastia, Donne ottimiste, Bologna, Il Mulino, 2002, p. 101.

${ }^{266}$ Congresso femminile”, in Pensiero e azione, a. IV, n. 11-12, 10-25 giugno, 1908, p. 17. 
counterpart absolutely necessary and the reasons compelling, while the second, representing the "intransigent” tradition, wanted to dissociate itself from dialogue at any cost. The first current, sharing the egalitarian goals of socialist feminism, exposed femminismo cristiano to accusations of modernism. ${ }^{267}$

Demands for equal rights for women and for the enfranchisement of the masses, now clearly enunciated in the Catholic feminist platform, challenged not only contemporary patriarchal values, but also the distribution of political power and wealth in society. Murri's Lega democratica nazionale, which had aspired to provide a means for social and political reform, had been condemned together with its exponents. Because of their connection with the network of fasci and leghe which Murri had promoted, Coari and Grugni, in particular, were never able to dispel imputations about their links with the banned Lega democratica nazionale. Although Coari had some correspondence with Murri, and approached him with a very personal letter in July 1903, there is no evidence of any strong link between the two. ${ }^{268}$ Moreover, after his excommunication in 1906, it would have been extremely unwise to maintain any relations with him. In December 1907, the Bishop of Bergamo, Radini Tedeschi, who had supported Pensiero e azione financially, needed to be reassured that Coari had no contact with the Lega:

Il Vescovo di Bergamo ha ricevuto la lettera dell'ottima Signorina Coari e compiega £.20 perché possa prendere ella, se vuole e quel premio che vuole per la sua lotteria. Era ben persuaso che non aveva rapporti con la Democrazia cosidetta autonoma: solo ha voluto avere la prova provata. Conviene che il lavoro femminile debba essere distinto dal maschile, e che si possa valersi dell'aiuto di chi si crede; ma vi sono quanto a questo ultimo delle cautele che è bene non dimenticare. Della persona di cui parla ha stima senza dubbio, e non pronuncia nessuna condanna di ostracismo. Solo segue quella via che o intrinsecamente o per ragione riflessa giudica la migliore; ammettendo il buono, ma ponendo mente che questo non valga a far passare il non buono.

Piace sopratutto la rinnovata espressione di docilità fatta al Cardinale. La via è questa, e bisogna non cedere a tentazioni. ${ }^{269}$

\footnotetext{
${ }^{267}$ Militello, Il volto femminile della storia, cit., p. 406.

${ }^{268}$ Coari wrote to Murri on 4 July 1903: "Ho letto le sue ultime parole, la riposta a Toniolo: ò pianto, l'ho ammirata: è documento che rivela tutta la sua generosità, la grandezza dell'animo suo. Non so spiegare a me stessa come mai io a Lei sconosciuta, debole donnicciola, non abbia saputo ritenermi dal manifestarle tutta la mia riconoscenza, dal dirle che proprio in questi giorni d'angoscia e di lotta per Lei la ricordo al Signore, ed al Signore offro le mie poche sofferenze: fratello per la lotta, che le si muove. Prima di scriverle mi sono gettata ai piedi di Cristo, non ho cercato la pace ma la forza, la costanza: mi alzai con la convinzione ch'Ella ha bisogno di sentire che i cattolici credano che la sua missione è da Dio, l'assistino a mantenersi forte nelle avversità e a sentire che perchè da Dio le viene questa santa missione dove compiersi sempre nella sua Chiesa divina. È troppo grande la sua generosità, troppo necessaria la sua opera perchè neghi all'Opera dei Congressi il comodo della sua energia. L'adesione sincera dei giovani con Lei militanti. Pensi, quanto se ne potrebbe fare - pensi che chi la dirige è interamente con Lei, e che moltissimi fra i cattolici l'ammirano.” Coari's letter to Murri, 4 July 1903, ARM.

${ }^{269}$ Radini Tedeschi’s letter to Coari, 11 Dec. 1907, FAC 9732. Original underlining retained.
} 
Just a few months later, Coari could no longer count on Radini Tedeschi's unstinting support. In May 1908 Radini Tedeschi declined to meet Coari and, while still prepared to counsel her, found it prudent not to be directly connected with her activities, especially because they were outside his jurisdiction. ${ }^{270}$

Murri and the Lega democratica nazionale were not, of course, the only potential source of modernist contamination. Among the contributors to Pensiero e azione were writers such as Giovanni Semeria who would later be persecuted as a modernist, and in 1905 the book reviews included a generally favourable discussion of Antonio Fogazzaro's internationally renowned book, Il santo, ${ }^{271}$ to be banned two years later. An elenco di libri in the Coari archives, compiled in or after 1905, consisting of over two hundred books, suggests that Coari and her friends were familiar with a range of modernist writing, since the list includes works by Loisy, Tyrell, Batiffol, Duchesne, Sabatier, Newman, Houton, Bonomelli, Gabba, Semeria and Murri, as well as five periodicals, together with information about libraries which held the material. ${ }^{272}$ When Pensiero $e$ azione was suppressed in July 1908, one of the reasons was the inclusion, in the June issue, of the socialist August Bebel in a list of recommended holiday reading for school teachers. ${ }^{273}$ This was unacceptable to Catholic leaders, such as Giuseppe Toniolo, who in a letter to Coari also criticized her coverage of the above-mentioned May congress of the Unione femminile. The letter begins, however, with Toniolo's praise of Coari's courageous defence of religious instruction at the Rome congress:

Ma ora debbo dichiararle che la lettura dell'ultimo fascicolo Pensiero e azione mi fece male. Come mai, chi ebbe il coraggio di levarsi in pieno congresso e protestare contro la scuola laica e di farsi propagandista abilissima di una rivendicazione dei diritti di Gesù Cristo sulle intelligenze e sui cuori, e chi rispose a telegrammi dell'arcivescovo di Bologna ${ }^{274}$ (e se vogliamo aggiungere anche al mio) con assicurazioni di prudenza e di disciplina, in quello stesso fascicolo in cui era riportata parte di una elevata sua conferenza cristiana tenuta a Bergamo, ha poi il coraggio di inserire le deliberazioni del convegno di

\footnotetext{
${ }^{270}$ Radini Tedeschi’s letter to Coari, 16 May 1908, FAC 9733: "Ricevo la sua sul punto ti allontanarmi di qui per una decina di giorni; laonde duolmi di non poterle dare indicazione di un giorno, come ella desidera.

E poi, pur rimanendo convinto del bene che può risultare da una azione seria e corretta dell'elemento femminile, e come reazione e come azione, giudico prudente per me rimanere alquanto in riserva, e con consigli e con aiuti ancora.

Non prenda argomento da ciò di scoraggiarsi; anzi ne tragga titolo di perfezionare un movimento da cui, se saviamente diretto, può venire molto bene.

Ma io, non essendo fornito dell’Autorità in luogo, non posso uscire dai limiti d'una grande prudenza.”

${ }^{271}$ Rita Zaimi, “Il Santo”, in Pensiero e azione, a. I, n. 23, 20 novembre 1905, pp. 11-13.

${ }^{272}$ FAC 3325.

273 A. C., “Alcune proposte”, Pensiero e azione, anno IV, n. 11-12, 10-25 giugno 1908, p. 7.

274 The archbishop of Bologna was Giacomo Della Chiesa, the future pope Benedict XV.
} 
maggio a Milano, nelle quali sono condensate in forma di voto, proposizioni che sono un continuo insulto ed una sfacciata ribellione a tutto ciò che è cristiano, nella fede, nella morale, nelle tradizioni, nelle istituzioni della Chiesa, e di quella civiltà uscita dal suo seno materno, di cui primo frutto fu la rigenerazione e la sublimazione della donna?!

... Contraddizione ribadita vieppiù da quel saggio di bibliografia femministica che dalle iniziali sembrerebbe proprio suo (ma ciò non è decisivo) nel quale accanto al Vangelo, messo proprio in coda all'elenco, addita come libro di consultazione, fra altri cattivi e equivoci, anche La donna di Bebel! Spero veramente, per il suo decoro, che ella non lo abbia mai conosciuto, ma certo chi potè suggerircelo sarà informatissimo del "libero amore", del socialismo, non già della santità dell’amore cristiano! ${ }^{275}$

In her reply of 5 August to Toniolo, Coari stated that she had read Bebel's book four years earlier in order to understand better the thinking of adversaries and that for the same reason, for the benefit of her readers, she had published the resolutions of the Unione femminile. ${ }^{276}$

In the meantime, the conservative Catholic press continued its relentless campaign against Pensiero e azione and Adelaide Coari. So, for example, the issue of 13 May of L'Unità cattolica contained an article listing Coari alongside nineteen other alleged modernists planning to found a national modernist organization by the name of Parola fraterna. ${ }^{277}$ Against this background, the suppression of Pensiero e azione could only be a matter of time. Its discontinuation was almost simultaneous with that of Grugni's Tribuna sociale, which published its final issue on 4 July 1908. In it Grugni gives an account of the meeting of the Milanese anti-modernist vigilance council, chaired by Cardinal Ferrari, which led to the termination of his paper. Repudiating the claim of

275 Giuseppe Toniolo, Lettere III 1904-1918, Città del Vaticano, Edizione del Comitato Opera Omnia di G. Toniolo, 1953, pp. 165-166.

${ }^{276}$ Coari's letter to Toniolo, dated 5 August 1908, FAC: "Ella mi rimprovera di aver consigliato Bebel, ch'io lessi quattro anni or sono; badi che la rivista non corre in mano ad operaie, badi che questo libro ci dà la chiave di volta per conoscere il fondo di certo femminismo socialista. Io so che sofferenza che mi ha dato si è tradotto in tanto entusiasmo per la causa buona. Se vogliamo formare delle donne forti bisogna che conoscano quali mali debbono combattere. Il liberalismo e il socialismo hanno preso in seria considerazione le condizioni della donna, noi cattolici ancora non possediamo un'opera che ne parli secondo il bisogno.

Mi rimprovera di aver dato gli ordini del giorno del Congresso di Milano. Professore, li ho dati integralmente perchè le lettrici nostre abbiano idea di quanto lavorano ...; tante volte la visione dell'azione altrui determina in noi forza di maggior volontà. Professore, è male far conoscere quello che vogliono e che compiono gli avversari dell'idea?"

277 “È tempo di parlar chiaro: 'Parola fraterna'”, L’Unità cattolica, a. XLVI, n. 105, 13 maggio 1908, p. 1. Floated at the initiative of Antonietta Giacomelli, Parola fraterna never materialized due to a campaign against the project by conservative hardliners and by the Roman Curia. See "Carteggio GiacomelliSabatier”, a cura di Camillo Brezzi, in Centro studi per la storia del modernismo, Fonti e documenti, 2, Urbino, Istituto di storia dell’Università di Urbino, 1973, p. 306: “Questa nuova associazione si sarebbe impegnata a propagandare una serie di pubblicazioni a basso prezzo utili alla 'formazione di coscienze', senonché il grande lavoro preparatorio rimase fine a se stesso in quanto oramai si era in pieno periodo post-Pascendi”. 
membership of Murri's Lega, Grugni writes that even though he and his friends maintained relations with the Lega over a whole range of activities, they had distanced themselves from it, not because it was condemned by the Ecclesiastical Authority but, because to be effective, Christian democracy needed to be "grafted into the Catholic masses". 278

As we have seen, femminismo cristiano had its origins in early Christian democracy, and was promoted by progressive clergy in order to reintroduce Catholic values into Italian society and to alleviate social problems. Mirroring the political rift in the parent movement, it developed different approaches to women's issues, as shown by the periodicals L'Azione muliebre and Pensiero e azione. With the unavoidable split in the women's movement, the leftist elements moved well beyond the original platform of philanthropy to embrace the most avant-garde positions of secular feminism. In a short time the tightly controlled "feminism” of the conservative L'Azione muliebre unravelled in Pensiero e azione with demands for full civil and political rights regardless of class and gender. Since it was now regarded as "modernist" and disquietingly close to secular feminism, Pensiero e azione was unacceptable to conservative antifeminist ecclesiastics, and had to be silenced. Its suppression signalled the end of the early Catholic feminist movement in Italy.

\section{PART III}

\section{$\underline{\text { Romolo Murri, the Lega democratica nazionale and femminismo cristiano }}$}

In reflecting on contemporary social issues Romolo Murri, the influential Christian democratic leader, could not avoid getting embroiled in the woman question. He and other Christian democratic writers, such as Alessandro Cantono, Luigi Stirati, Edoardo Soderini and Vicenzo Bianchi-Cagliesi, dealt with the matter in articles published in Murri's periodical Cultura sociale between 1898 and 1906. In this span of time Murri's typically antifeminist Catholic views underwent a change as he began to think of the

\footnotetext{
278 “Sospendiamo le pubblicazioni!”, Tribuna sociale, a. II, n. 27, 4 luglio 1908, p. 1: “Sebbene avessimo relazioni larghe e sincere con tutto il programma della Lega democratica Nazionale, pure da questa ci tenemmo sempre separati, non perchè essa fosse sconfessata dall'Autorità Ecclesiastica, ma perchè noi siamo convinti che l'opera democratica cristiana cessa d'avere un'efficacia se non viene innestata nelle masse cattoliche”.
} 
woman question as a corollary to the structural transformation of Italian society. As Giovanni Sale points out, the originality of Murri’s thought consisted in the recognition that moral and spiritual restoration could not take place separately from economic and social reform:

In realtà, la vera originalità del pensiero di Murri consistette nel fatto che egli considerò il rinnovamento religioso e culturale non scorporato o "autonomo" da quello sociale e politico, ma intimamente legato ad esso. ${ }^{279}$

Consequently Murri began to look for solutions to contemporary problems outside the Catholic system. By the time he delivered his landmark speech Libertà e cristianesimo on Catholicism and the State in San Marino on 24 August 1902, Murri had liberated himself from the limitations of a purely ecclesiastical vision. ${ }^{280}$ By relinquishing its narrow perspective he was able to canvass the intricacy of the Catholic presence in Italian society in the overall context of religious and civic renewal. At this juncture Murri also "discovered" the woman question. He became aware of it when contemplating the difficulties and incongruities of contemporary Italian society along with the tensions which were evident in a transition from a traditional peasant community to modern society. ${ }^{281}$

Lorenzo Bedeschi's succinct article, La novità di don Romolo Murri, ${ }^{282}$ provides a useful introduction to the ideological framework from which Murri approached the woman question. The singular in the title is misleading, because Bedeschi speaks, in fact, of Murri's four “novelties”, not mentioned here before. The first was his realization that social structures and the manner in which they operated changed over time. This meant, among other things, that the distribution of wealth between the social classes did not follow an immutable pattern. Secondly, in order for the Christian message to reach people with its full vigour, Murri urged Catholics to leave the social isolation imposed on them by the Roman Question and to live in the present century by embracing new social institutions and by reforming old ones. Thirdly, Murri’s initial

${ }^{279}$ Giovanni Sale, "Romolo Murri tra impegno politico e protesta religiosa, La Civiltà cattolica, v. 151, pt. 3, July 2000, p. 35.

${ }_{280}$ Bruno Brogi, La lega democratica nazionale, Roma, Edizione 5 Lune, 1959, pp. 85-90. Brogi quotes from Murri on p. 87: “... il nostro programma guelfo non è confusione di Cristianesimo e di politica, esso non cerca l'esaltamento della Chiesa nella umiliazione dello stato moderno; nè vuole compiacenti accordi dell'uno e dell'altra, inutile sogno: è un programma di libertà civili ed ecclesiastiche ..."

${ }^{281}$ Italo De Curtis, "La questione femminile agli inizi del secolo: l'approccio di Romolo Murri, Civitas, v. 28, n. 5, 1977, p. 27.

${ }^{282}$ Lorenzo Bedeschi, "La novità di don Romolo Murri”, in Ilaria Biagioli, Alfonso Botti e Rocco Cerrato (a cura di), Romolo Murri e i murrismi in Italia e in Europa cent'anni dopo, Urbino, QuattroVenti, 2004, pp. 619-625. 
grasp of the concept of "social democracy" was modelled on Leo XIII's teachings which combined the notions of democracy and Christian charity. Murri realized, however, that successful implementation of "social Christianity” required new measures such as the industrial organization of workers. As a result, the static structure of society which underpinned the Catholic worldview no longer seemed an unshakeable certainty because democracy was bound to bring about changes to the existing power relations between the social classes (and the genders). As agents of transformation, Murri's young Christian democratic followers, referred to as the giovani, had joined in a struggle to claim social and civil rights for the disinherited classes, while the vecchi, or the "moderate" Catholic elements on the right of the political spectrum, still continued to regard Christian democracy merely as a vehicle for charitable activities. Murri's fourth novelty was the demand for the right of Catholics to participate freely and fully in national political life. Moreover, in exercising their electoral rights, although guided by the precepts of their faith, Catholics ought not to be bound by obedience to the Church.

While the lectures of the Marxist philosopher Arturo Labriola exerted a decisive influence on shaping Murri's social and political attitudes, for his theological orientation, on the other hand, he got his bearings from the teachings of Thomas Aquinas. $^{283}$ Thus the rupture of Murri's relations with the Church hierarchy after 1905 had more to do with its unyielding opposition to his idea of setting up of an independent political party than any doctrinal differences he might have had with it. In the aftermath of the disbandment of the Opera dei congressi and of the relaxation of the non expedit decree, Murri's political ambitions were at odds with the Clerical-Moderate elements of the Catholic system which were beginning to exploit the discretionary lifting of the non expedit as a means of negotiating mutually advantageous electoral deals with the Liberals.

Murri's Thomist beliefs, by contrast, became apparent from his initial approach to the woman question. In a series of articles entitled "Movimento femminile cristiano", published in 1902, Murri spoke of the female sex as being the weaker and in a greater need of help. ${ }^{284}$ Woman's normal function in society was to be a spouse and a mother,

\footnotetext{
283 Maurilio Guasco, "Murri, Romolo", in Traniello e Campanini (a cura di), Dizionario storico del movimento cattolico in Italia 1860-1980, II: I protagonisti, cit., pp. 414-415.

${ }^{284}$ A condensed version of the three articles is included in Cecchini, Il femminismo cristiano, cit., pp. 127-138.
} 
and therefore her social elevation would derive from a stable and intact family. He condemned the feminist movement for its tendency to destroy the juridical unity of the family and the indissolubility of marriage, and for its advocacy of excessive and perilous liberties for women. Such a movement, in his view, was guided by two notions which, on the one hand, would selfishly endeavour to bestow on women the rights of citizenship in order to enable them to exercise legal and economic functions preserved to men, and, on the other, would give women a free rein to pursue sensuous pleasures. In fact, Murri could foresee the emergence of a third sex, that is, spinsters who, in exchange for what to them seemed doubtful joys of motherhood, would seek recompense in noisy masculine pastimes and pursuits. This was in a sharp contrast with the kind of existence the Church traditionally assigned to unmarried women, that is, a spiritual, saintly life in cloisters, devoid of any covetousness. Such a secluded life, Murri argued, contributed to woman's inner growth by compensating her for weakness and natural inferiority in relation to man.

In the early years of its publication, Cultura sociale had a dual preoccupation in that, while it stressed that Christianity had elevated woman from pagan abjection to a place of dignity within the family, it also endeavoured to sensitize young Catholics to make a trenchant contribution to the debate on the woman question. ${ }^{285}$ The first articles on this topic revealed an essentially circumspect attitude as they aired problems related to women working in factories and their often harsh working conditions. Murri's periodical, therefore, did not differ from the position taken, for example, by the contemporary L'Azione muliebre. This becomes obvious also from his speech at the first regional Lombard textile workers' congress which was convened in Milan in May 1902 and attended by some six thousand delegates including representatives from female textile workers' unions. ${ }^{286}$ Murri pledged his support for women's demands for fairer pay, for safeguards of hygiene and morals in factories, and for women's endeavours to form trade union federations. Delighted that in the quest for their economic goals the women had not forsaken their faith and yielded to socialist temptations, Murri stressed that a measure of economic prosperity was a prerequisite for preserving the modesty of girls and for allowing wives and mothers to perform their domestic and educative functions. He could envisage women trade unionists as playing an important role as useful propagandists in the Christian democratic movement.

\footnotetext{
${ }^{285}$ De Curtis, “La questione femminile agli inizi del secolo: l’approccio di Romolo Murri”, cit., p. 26.

${ }^{286}$ Cecchini, Il femminismo cristiano, cit., pp. 99-101.
} 
Murri's scathing article Donne vane, published in the same year under the pseudonym P. Averri, showed how his thinking had advanced on the issue. ${ }^{287}$ While accusing Catholics of complicity in the progressive diminution of the social usefulness of women, he also acknowledged that it was women's right and duty to be instrumental in their own elevation. Moreover, the woman question was not a problem which could be resolved inside the Catholic system, but required solutions of a social, political and educational nature transcending religious boundaries.

Three years later, in 1905, Murri conducted a survey on the woman question in Cultura sociale by eliciting his readers' opinions on the matter. ${ }^{288}$ By then he had begun to see the feminist phenomenon as part of a structural change taking place in Italian society. The survey pinpointed a shift in focus from issues of "proletarian" to those of "bourgeois" feminism. In the introductory article Murri enumerated reasons for commonly held prejudices against feminism. At the top of his list was the customary dislike of any new idea. Another reason for antifeminist prejudice arose from the assumption that, by abandoning the traditional approach to gender relations, feminism was an essentially pagan concept since it not only advocated a greater freedom for women but strengthened their means of seduction. Moreover, by alienating woman from her domestic duties, feminism was also an attack on the life of the family.

Murri then reflected on whether those seeking to address contemporary social evils should look for their causes in women's education as well as in women's intellectual and moral condition, and find remedies in dealing with deficiencies in those areas. ${ }^{289}$ The questionnaire design suggests that Murri considered women's education as central to the problems of contemporary society. Feminism, as Murri conceived it, would seek to promote women's economic and moral wellbeing on the basis of a careful study of their present condition as regards their income, their reduced opportunities to marry because of demographic changes, and their increasing needs for sustenance and education. In Murri’s view, woman was able fully to realize her feminine propensities

\footnotetext{
${ }^{287}$ P. Averri [Romolo Murri], “Donne vane”, Cultura sociale, a. V, n. 22, 1 dicembre 1902, pp. 349-351.

${ }^{288}$ In all, nine articles were published in Cultura sociale in conjunction with Murri’s survey. The introductory article entitled "La questione feminile" [sic] appeared on 16 January 1905, pp. 17-19. The responses and the concluding article appeared under the heading "La nostra inchiesta sul feminismo" [sic] on 16 February 1905, pp. 59-60; 1 March 1905, pp. 69-70; 1 April 1905, pp. 104-105; 16 April 1905, pp. 117-119; 1 May 1905, pp. 134-135; 16 May 1905, pp.147-149; 16 June 1905, pp. 181-183, and 1 August 1905, pp. 225-227.

${ }^{289}$ Romolo Murri, “La questione feminile” [sic], ibid., a. VIII, n. 169, 16 gennaio 1905, p. 17.
} 
only in marriage, whereas a single woman remained merely a fragment, a germ of a potential family. However, not all women were able to marry. As a result of an increase in nuptial age and in the number of single women, finding a husband had become a desperate hunt. In contemporary circumstances, Murri argued, women not only needed to be better trained for domestic duties but also for professional employment. The differential treatment of the two sexes by a law, which was a relic from the feudal past, could no longer be justified from the collective point of view and should be abolished. In spite of his strong support for legal reform, Murri’s Thomist principles would in the end not permit him to endorse totally the parity of the sexes since in marriage, in his view, it would be contrary to the unity of the family and the traditional division of tasks within the family. The final point made by Murri was that feminism should not only look to past mistakes and to ways of rectifying them, but should also direct its thoughts towards the future, since "I'elevazione umana deve essere in grandissima parte elevazione della donna”. ${ }^{290}$

On 1 August Murri expressed his disappointment at the small number of responses he had received to his questionnaire, stating that his introductory article could also have served as a conclusion since the respondents were unanimously in agreement among themselves and with his article. ${ }^{291}$ In his view, the single most divisive issue concerned coeducational schools. In favour of such schools himself, Murri argued that separate secondary schools for girls would weigh heavily on the public purse, and that he could only envisage benefits from bringing boys and girls into closer proximity with each other, provided that the learning environment itself was salubrious and conducive to study.

Contrary to what Murri suggests, however, the twenty-one responses he received showed quite a diversity of opinion. Since the questions were somewhat overlapping, in a number of cases the answers themselves tended to be broadly applicable to more than one question. In addition to fourteen Italian men, the respondents included two Frenchmen and five women, representing writers and newspaper editors, as well as the teaching and the ecclesiastical sectors. ${ }^{292}$ The respondents to Murri's survey were self-

\footnotetext{
${ }^{290}$ Ibid., p. 19.

291 Romolo Murri, “La nostra inchiesta sul feminismo” [sic], ibid., a. VIII, n. 182, 1 agosto 1905, p. 225.

292 Roberta Fossati has provided additional information on the respondents in her article "Romolo Murri e il femminismo cristiano”, in Biagioli, Botti e Cerrato (a cura di), Romolo Murri e i murrismi in Italia e in Europa cent'anni dopo, cit., pp. 221-222: "Risposero all'inchiesta, tra gli altri, personaggi conosciuti,
} 
selecting and, with the exception of the non-Catholic A. Vodoz, came from the narrow margin of educated Catholic laity and clergy. Murri's fellow Christian democrats Alessandro Cantoni, Luigi Stirati and Paolo Mattei Gentili were contributors to Cultura sociale, while G. Molteni was editor of L'Osservatore cattolico in Milan, G. M. Serralunga editor of Lega lombarda and G. F. Cortini editor of Patria in Ancona. Whereas the latter supported equal rights for women including the right to vote, Serralunga thought the existing legislation regarding women did not contain any notable deficiencies, and in general terms it appeared to him prudent and liberal enough. The Vicenza novelist Antonio Fogazzaro was a devout Catholic whose modernist bent resulted in troubled relations with the Church. In his replies Fogazzaro showed a basically conservative, cautious attitude. He was against any sudden changes, however good in theory, if their implementation was premature. A much firmer line on women's rights was taken by Professor Bernardino Lupi, a doctor of letters and theology, who in the strongest terms condemned the iniquitous treatment of women in Calabria, which was manifest not only among peasants but also among the upper class. The five women responding included Marchioness Maria Plattis Majocchi, a writer of popular novels and short stories and, under the nom de plume of Jolanda (or Iolanda), a frequent contributor to several women's periodicals. ${ }^{293}$ Jolanda favoured improvements to women's education, although with soft academic options, and a legislative reform to emancipate woman from man's guardianship. Antonietta Giacomelli, a novelist and editor of the periodical In cammino, was a prominent Catholic feminist figure who, as previously discussed, had connections with the Unione per il bene and modernist circles. In her long response Giacomelli showed her sympathies for Catholic values but rebelled against the notion that the only normal condition for an adult woman was marriage. Single women, too, she argued, could fulfil a personally satisfying and socially useful role. Of the two French intellectuals and writers responding, E. Martin Saint Léon was a Catholic whilst the non-Catholic A. Vodoz was Secretary of the French society Humanité.

come Antonio Fogazzaro, Antonietta Giacomelli e Jolanda (la scrittrice Maria Plattis Majocchi, amatissima da un vasto pubblico di lettrici dell'epoca); risposero anche collaboratori di Murri, come Alessandro Cantono e Luigi Stirati, e poi Paolo Mattei Gentili, G. Molteni, redattore dell'Osservatore Cattolico di Milano, e due intellettuali e scrittori francesi come Martin Saint Léon e il non cattolico Vodoz”. Cultura sociale referred to G. F. Cortini as “direttore della Patria di Ancona”, to Prof. Bernardino Lupi as “dottore in lettere e teologia”, and to G. M. Serralunga as "redattore della Lega Lombarda”.

293 “Iolanda” [Plattis Majocchi, Maria], in Carlo Villani, Stelle feminili. Dizionario bio-bibliografico. Appendice, Napoli-Roma-Milano, Albrighi, Segati \& C., 1916, pp. 125-126. 
In reply to Question 1, "What do you think of feminism?", ${ }^{294}$ many respondents recognized the role it could play in improving women's condition, especially workingclass women's. Even though for some the word "feminism” carried unpleasant connotations, in Professor Lupi's view it would soon triumph as a "cosa nobile e bella e santa” ${ }^{295}$ For P. Mattei Gentili it was essentially a masculine question because it was principally up to men to revise the concept they had of women, while "x.z." noted that God's intention was to create a companion for man, wise yet subordinate to him, and Enrica Grasso thought that "il feminismo sia la cosa più deplorevole di questo mondo". 296

Question 2 asked, "Do you think that the general level of education of women should be equal to that of men of the social class to which they belong, and that therefore secondary education courses should be attended by middle- and upper-class girls in greater numbers?”297 Twelve respondents were in favour of parity in education, with two qualifying their answer by stating the need for separate schools for women and one saying that only few women could profit from a higher-level secondary education. One respondent gave no answer, while the rest (seven) answered "no" to the question, stressing the need for women to receive only religious instruction and training in domestic duties.

As regards Question 3, "Do you accept coeducational secondary schools, or would you like to have special ginnasi and licei for women?”, 298 there were nine negative answers to the coeducational proposition and ten positive ones with four of the latter qualifying their reply by saying that they would find special institutes such as those in America and England preferable but, since they did not exist in Italy, study in coeducational secondary schools was necessary to qualify women for professional careers.

The responses to Question 4, "What kinds of modifications, reductions or substitutions would you regard as necessary with respect to secondary syllabuses?”, 299 stressed the

\footnotetext{
294 “Che cosa pensate del feminismo?”

295 Bernardino Lupi, “La nostra inchiesta sul feminismo/III”, Cultura sociale, a. VIII, n. 172, 1 marzo 1905, p. 69.

${ }^{296}$ Enrica Grasso, “La nostra inchiesta sul feminismo/XX”, ibid., a. VIII, n. 179, 16 giugno 1905, p.182.

297 "Ritenete che in fatto di cultura generale la donna debba essere eguale all'uomo della sua classe, e che quindi i corsi d'istruzione secondaria debbano essere più largamente frequentati dalle giovanette delle classi medie e superiori?”

298 “Accettate la scuola secondaria mista, o vorreste speciali ginnasi e licei per le donne?”

299 “Quali adattamenti, riduzioni e sostituzioni di programmi vi parrebbero necessarii per queste?”
} 
need to prepare women for everyday life through courses in hygiene, home economics, nursing and bringing up children. A sound and morally irreproachable education in religion, history, philosophy and pedagogy would develop in woman a capacity to perform her special role as a mother. Jolanda suggested that the learning of classics, along with mathematics and geometry, should be restricted to a minimum, while a greater emphasis needed to be laid on the teaching of modern languages and literatures and art in general. G.F. Cortini, by contrast, wanted women to have access to all categories of schools and have physical education included in their syllabuses. While most regarded the teaching of domestic science as necessary, the secondary school teacher Anna Evangelisti argued that substituting home economics and hygiene for academic subjects would be a waste of time because such skills should be taught at home.

In Question 5 Murri asked, "How do you think women from different social classes could be properly prepared for fulfilling their special tasks in the family?" ${ }^{300}$ As the responses to the previous questions already indicated, there was a consensus that practical subjects, such as home economics, hygiene, nursing and pedagogy were essential. The value of home tutoring was stressed by some, with one respondent ("Un parroco emiliano") voiced his concern about the unsuitability of graduates for performing their motherly duties. The same respondent idealistically postulated that, in the case of the lower classes, women needed to be liberated from the economic slavery which forced them to do brutalizing jobs. Some also maintained that teaching should be sagacious and frank without leaving students, as Jolanda stated, ignorant of the “mysteries of life”. According to T. Nediani sexual prejudice could be diminished by increasing interaction between the two sexes at school. Anna Evangelisti thought that strict discipline in education would benefit all women, irrespective of class. In Enrica Grasso's view, prudent education would infuse woman with the highest sense of her own dignity and of her own feminine personality so as to make her a companion for man with respect to the family, and a sister with respect to society.

Question 6, “What reforms seem desirable for you with regard to women's a) economic and b) juridical position?”, ${ }^{301}$ produced a list of desirable reforms on which there was a

\footnotetext{
300 “Come credete opportuno provvedere alla migliore educazione della donna delle varie classi al compimento delle sue speciali funzioni nella famiglia?”

301 “Quali riforme vi sembrano desiderabili nella posizione a) economica, b) giuridica della donna?”
} 
general consensus. No replies were given by three ("Sig.na Prof. x”, “x.z.”, "Un parroco emiliano”), while G. M. Serralunga regarded “modern legislation” as "prudent and liberal enough", A. Fogazzaro was not in favour of a "sudden change however good in theory", and "Un antico abbonato fiorentino" deemed the notions of modern feminism too advanced and wanted any reforms to be the outcome of a bargaining process similar to one between vendor and buyer. D. Dragoni, on the other hand, made a facetious reference to the judicial system of an African tribe which had empowered their women to be in charge, in contrast to the Napoleonic Code which was the declared enemy of women. Amendments suggested by various respondents to the existing laws included women's rights to an equal patrimonial share and their rights to administer their own property whether married or single, rights of seduced women, measures to prevent trade in women, abolition of discriminatory treatment of women in adultery cases, protection of working-class women from idle and violent husbands, labour laws to improve pay and working conditions, and equal pay to male and female school teachers.

In Question 7 Murri gauged attitudes to female suffrage by asking, "Do you in principle accept women's suffrage and, if so, within which limits would you like to see it apply immediately in Italy?”302 Of the fourteen Italian men completing the questionnaire, one gave no answer, while three endorsed the idea unconditionally with L. Stirati saying, “... non si può reclamare il suffragio universale... a metà". ${ }^{303}$ Another respondent supported women's suffrage but saw its application as being limited by the mother's domestic role and as being premature in Italy. Someone else regarded it as "a great idea” as long as it did not overwhelm the masculine vote. Of the remaining eight Italian men, one would limit the vote to materfamilias, and five would grant it to widows and to single women meeting one or more of an assortment of qualifications with regard to age, educational level, professional employment, and whether or not woman managed her own property. A further respondent could envisage female suffrage coming only gradually, and yet another would first like to see progress in women's learning and morality. It is worth noting that of the five women responding only one, "Sig.na Prof. x" was in favour of introducing women's suffrage immediately. Jolanda would give the vote to widows always and to single women over the age of thirty, and Antonietta

\footnotetext{
302 "Accettate, in massima, l'elettorato feminile, e, se sì, dentro quali limiti vorreste vederlo applicato subito in Italia?"

${ }^{303}$ L. Stirati, "La nostra inchiesta sul feminismo/XIV”, Cultura sociale, a. VIII, n. 176, 1 maggio 1905, p. 134.
} 
Giacomelli to women meeting certain educational and ethical criteria, while Enrica Grasso thought that women were not sufficiently informed about the economic and political situation to be able to cast their vote. Anna Evangelisti considered women's franchise utopian and, because of the complementary nature of man and woman, an unnecessary duplication. Furthermore, even though Question 7 did not bring up the issue of women's candidature, three raised the point, with no-one, including "Sig.na Prof. x”, wanting to field female candidates in the immediate future.

Finally, Question 8 asked, "Which field would you recommend for women's public activities, and which forms should they take?”304 All Italian respondents, male and female, agreed that in the public arena the focus of women's activities should be on the various forms of social work and private and public welfare. Other areas specifically mentioned included education, women's press, the guardianship of morals, founding women's associations for good works, organizing female labour, and even practising medicine and law.

This small survey demonstrated that there was some discrepancy between men's and women's attitudes to the woman question. The responses from the five women were disappointingly conservative. Basically, most male and female respondents approached the questions from the viewpoint of the God ordained differentiation of gender roles. The vote for women, with its implications for their real empowerment, produced a variety of responses with only four (three men and one woman) unequivocally in favour of its immediate implementation. Women's place was regarded as first and foremost at home, and the most natural extension of their domain was to welfare and charity. Women's education needed to be reformed but many respondents wanted to see women's syllabuses diluted with “practical” subjects or softer academic options. It was recognized by the majority, on the other hand, that the civil and penal codes were out of date and that professional employment needed to be made more accessible for unmarried middle-class women. Again, the type of employment suggested for women was predicated on gender with the exclusion of more prestigious professions and occupations. There was a general endorsement of "proletarian feminism" since the need to improve the condition of female labour was universally recognized.

304 “Quale campo suggerite di preferenza all’azione pubblica della donna, e quali forme?” 
While both agreeing on women's right to vote, the two French respondents differed on every other point. E. Martin Sain Léon thought that women were intellectually and morally different from men and consequently had lesser educational requirements and different social roles to play. The only juridical reforms regarding women which he would welcome were related to the protection of young girls from seduction and to adequate compensation for consequences of seduction. A. Vodoz, on the other hand, emphasized that the same programmes of education should be available to both male and female students while a special complementary course should be provided to girls to familiarize them in household duties. He demanded the abolition of the restrictions which the Napoleonic Code imposed on women, and called for women's public role to be extended to equal that of men's.

Murri's political base was in the Christian democratic movement which he intended to develop into an independent party organization. After the demise of Christian democracy in the wake of the disbandment of the Opera dei congressi, Murri established, in December 1905, an organization known as the Lega democratica nazionale which was inspired by Catholic principles but was secular in its intentions. ${ }^{305}$ As Bruno Brogi observes, organizationally and hierarchically independent from the “official Catholic movement”, the Lega represented the last outlet of the Christian democratic movement which had grown within the Opera dei congressi. ${ }^{306}$

Murri's plans regarding, first, the Christian democratic movement and, then, the Lega democratica nazionale can be gleaned from his multifarious publications. The 1902 Almanacco-manuale democratico cristiano, for example, gives an idea of how he perceived the Catholic women's movement as forming part of the overall Christian democratic network. The almanac stated that there was an urgent need for a federated women's organization which should be based on a two-tiered structure. It was intended to consist, on the one hand, of a "movement" or a "party" made up of groups or fasci and, on the other hand, of a network of trade unions or leghe. Both types were envisaged as functioning alongside similarly structured men’s organizations:

Come per il sesso così detto forte, così per quello così detto debole l'organizzazione deve essere: $1^{\circ}$ di movimento o di partito; $2^{\circ}$ professionale.

\footnotetext{
305 Maurilio Guasco, "Murri, Romolo", in Traniello e Campanini (a cura di), Dizionario storico del movimento cattolico in Italia 1860-1980, II: I protagonisti, cit., p. 418.

${ }^{306}$ Brogi, La lega democratica nazionale, cit., p. 9.
} 
Gruppi o Fasci d. c. femminili, da una parte, di fianco di quelli maschili; Leghe o sezioni di Leghe femminili, dall'altra, di fianco a quelle maschili. ${ }^{307}$

The Fascio femminile milanese represented the first of the women's fasci expected to be established across Italy, while of the second type of leghe, there were many already in existence. In fact, in the case of the 8,000 braiders (trecciaiole) in the province of Florence and of the 6,000 rice weeders in the diocese of Novara, women's unionization had preceded men's. One of the underlying principles of industrial organization was that, once unions were in place, activities should be left to the workers themselves:

“... non fate voi, promotore o consigliere, ma fate fare alle operaie, specialmente alle giovani operaie.”308

Apart from offering advice to working-class women on how to get their unions started, the almanac anticipated that educated women would be active in the party organization in which they would enjoy the same rights as men:

Ci sono invece donne più colte, più facoltose, non logorate dalla fatica quotidiana, non pareggiate allo stato di proletarie? Esortatele, mediante la formazione delle loro coscienze, ad aiutare l'organizzazione professionale delle proprie sorelle e ad interessarsi davvicino dei problemi sociali e del nostro programma di rinnovamento.

Questo ceto di donne più, al pari e meglio delle operaie può dare aderenti alla nostra organizzazione di partito, con eguali diritti degli uomini. ${ }^{309}$

Two years later, however, Almanacco della Lega democratica nazionale per l'anno 1907, expressed its disappointment that the Lega had not succeeded in elaborating and implementing its social and educational reform programme for women. ${ }^{310}$ The almanac called on educated women (signore e signorine veramente colte) to take upon themselves the task of organizing study circles for the intellectual awakening and the development of moral and social consciousness among working-class women, while leghe, on the other hand, were exhorted to set themselves the task of gradual liberation of women from economic slavery and juridical bondage. ${ }^{311}$

One highly educated woman who heeded to Murri's call to join the Lega democratica nazionale was Antonietta Giacomelli. Like Romolo Murri and other youthful leaders of

\footnotetext{
307 Almanacco-manuale democratico cristiano, Anno III 1902, Roma, Società Italiana Cattolica di Cultura, 1902, p. 17.

${ }^{308}$ Ibid.

${ }^{309}$ Almanacco democratico cristiano, Firenze, Azienda Giornalistica Fiorentina, 1905, p. 26.

${ }^{310}$ Almanacco della Lega democratica nazionale per l'anno 1907, Firenze, Società Editrice "La Giustizia Sociale”, 1907, p. 81.

${ }^{311}$ Ibid., p. 83.
} 
this organization, Giacomelli was inspired by the notion of "democratic dynamism", independent from the ecclesiastical hierarchy, which would destroy the privileges of the few to improve the standard of wellbeing of the working poor:

Il concetto di democrazia dinamica, autonoma dalla gerarchia ecclesiastica, a cui si ispirarono questi giovani ribelli, tra cui spiccano Romolo Murri, Tommaso Gallarati-Scotti, Giuseppe Fuschini, Eligio Cacciaguerra, Giuseppe Donati e la stessa Giacomelli, si trasformava in azione tesa a distruggere "tutte le forme parassitarie di oppressione di classe, di egoismi di casta, tutti i privilegi accumulati dalla storia a vantaggio di pochi uomini“" per portare "il popolo, la plebe dei lavoratori, ad un livello di benessere migliore e più giusto”. ${ }^{312}$

Following the promulgation of Pius X's encyclical Pascendi dominici gregis (1907), modernist persecutions went ahead with unrelenting vigour and resulted in the excommunication of figures close to the Catholic reform movement, including the Barnabite priest Semeria, Don Casciola, the writer Fogazzaro, and, in 1909, Romolo Murri after his election to parliament. Antonietta Giacomelli experienced an equally hard time, since the Bishop of Treviso was pressured by the Pope to refuse her communion on account of her links with Murri. Ultimately Giacomelli decided to relocate to Rovereto with her mother, to the Pope's obvious satisfaction:

Ho letto con piacere che la signorina Giacomelli abbia [sic] deciso di abbandonare Treviso; è tanto di guadagnato e preghiamo Iddio che raddrizzi quella povera testolina. ${ }^{313}$

The official disapproval of her modernist connections did not deter Giacomelli from following the reformist course she had chosen, earning her the appellative Signora murrista. ${ }^{314}$ In 1909 she went on to draft a "manifesto" sending it to a number of friends in anticipation of a conference, never actually convened, to set up a programme for all those who felt that the time had come to choose between "the Vatican and Christ”. Giacomelli in fact had the intention to found a new independent evangelical church (Chiesa cattolica apostolica evangelica). ${ }^{315}$ In January 1912 her three-volume work Adveniat regnum tuum was condemned by the Church, and in November 1913 another publication by her, Per la riscossa cristiana, suffered the same fate. ${ }^{316}$ Until 1910 a loyal supporter of Murri, Giacomelli attended meetings of the Lega democratica nazionale and contributed to its official publication Azione. After her relations with

\footnotetext{
${ }^{312}$ Saveria Chemotti, "Verso una nuova presenza femminile: Antonietta Giacomelli”, in Anna-Maria Calapaj Burlini e Saveria Chemotti (a cura di), Donne in-fedeli, Padova, Il Poligrafo, 2005, p. 201.

${ }^{313}$ Quoted in Ibid., p. 202.

${ }^{314}$ Brezzi (a cura di), “Carteggio Giacomelli-Sabatier”, cit., p. 307.

${ }^{315}$ Ibid., p. 309.

${ }^{316}$ Ibid., p. 320.
} 
Murri soured, she channelled her energies towards blending elements of Christianity and democracy in a plan for a modern political party, the short-lived Partito democratico cristiano italiano, which Giuseppe Donati founded in opposition to Luigi Sturzo's and Giuseppe Semeria’s Partito popolare italiano. ${ }^{317}$

Before its dismantlement in 1904, the early Christian democratic movement had succeeded in setting up an impressive network of trade union organizations across Italy from Piedmont to Sicily. According to a list provided by Francesco Cecchini, there were a total of 135 unions for men and 38 for women. Catholic women's unions existed in Piedmont (9), Lombardy (9), Veneto (1), Liguria (2), Toscana (15), Umbria (1) and Calabria (1). ${ }^{318}$ The Lega democratica nazionale, by contrast, never reached the levels of success of the early Christian democratic movement. In February 1906 the Lega democratica nazionale had a total membership of only 800 and consisted of less than 80 sections. ${ }^{319}$ After its membership was banned to the clergy, it never stood a chance of developing into a strong Catholic lay movement.

It was inevitable that the paths of Murri and the Milanese feminist group would cross from time to time. After all, the establishment of the Fascio milanese and of the Fascio femminile milanese was inspired by Murri, and both Carlo Grugni and Adelaide Coari contributed to Murri's press. Initially, until the breakup of the Opera dei congressi in 1904, the unions which Adelaide Coari and others helped to found were part of the Christian democratic network which Murri was setting up. Relations with Murri and his organization were not completely severed even after the proscription of the Lega democratica nazionale. The Convegno femminile in 1907 had the enrolments of two representatives from it, while a female delegate Coari attended its first national congress in Milan in September 1906. Happening as it did only months after Pius X's ban on the clergy to join this organization, and even though the prohibition did not apply to Coari as a layperson, her attendance was nonetheless a courageous act, since it had every chance of alienating some of her ecclesiastical supporters.

It was clear, however, that, unlike Murri, the feminist movement which Pensiero $e$ azione was promoting was committed to remain within the Catholic Church. As

\footnotetext{
${ }^{317}$ Chemotti, "Verso una nuova presenza femminile: Antonietta Giacomelli”, cit., p. 202.

${ }^{318}$ Cecchini, Femminismo cristiano, cit., pp. 261-269.

${ }^{319}$ Brogi, La lega democratica nazionale, cit., p. 168.
} 
previously discussed, in the uncertain days after the breakup of the Opera, when working on Il Domani d'Italia, Adelaide Coari had rejected the idea of joining an independent group of Christian democrats. Evidence of her determination to remain loyal to the Pope appears in Coari’s correspondence to Giacomo Radini Tedeschi, for instance, in a letter dated 1 August 1904:

... ho sete di schiacciarmi per un programma schiettamente papale, di lavorare con intelligenza e amore, ma ubbidendo alla direzione pontificia. Saremo in poche, ma vogliamo portare questa nota eminentemente papale. ${ }^{320}$

Similarly, Carlo Grugni wrote on 20 March 1905, on the eve of the foundation of the Federazione femminile in Milan, that as far as feminism was concerned it would be preferable if nothing was done if it was not distinctly Catholic in nature, and if it was uncertain whether the Church would appreciate it:

Nel campo femminile qualora mancasse il distintivo di confessionalità spiccata noi preferiremmo si facesse nulla, o per lo meno, non si osasse asserire che l'azione che si compie può essere cara alla Chiesa. ${ }^{321}$

In its regular column Nella vita e fra i giornali, Pensiero e azione announced, on 5 February 1905, Murri's survey on the woman question. ${ }^{322}$ In the following issue it stated that it reserved its judgment on the survey and the replies already received, and listed without comment Murri's eight questions. ${ }^{323}$ On 5 May it observed that Cultura sociale, which in its survey had printed many absurd opinions, should take notice of the eighteenth-century author Gaspare Gozzi. He found that if raised as men were, women, too, would be capable of study and great deeds; on the other hand, if boys in the first years of their lives were put to work at a loom, they, too, would gradually be entangled in threads, spools and shuttles, and would not know how to live otherwise. ${ }^{324}$ Pensiero $e$ azione therefore basically agreed with the tenor of Murri's articles if not with all of the submissions. The suppression of Murri's periodical, ${ }^{325}$ on the other hand, was noted with regret and kind words about the sincerity of the man who was well liked even by his political adversaries:

La Coltura [sic] Sociale cessa le sue pubblicazioni. Le parole scritte da Romolo Murri nell'ultimo numero della rivista sono dolorose e hanno un fondo di verità. "La via, grande via dell'azione e della vita pubblica qui finisce per noi. Ci

\footnotetext{
${ }^{320}$ Coari’s letter to Radini Tedeschi, 1 Aug. 1904, FAC 3532.

${ }^{321}$ G.C. [Carlo Grugni], “Federazione femminile”, Pensiero e azione, a. I, n. 7, 20 marzo 1905, p. 4.

322 “Nella vita e fra i giornali”, ibid., a. I, n. 4, 5 febbraio 1905, p. 16.

323 “Nella vita e fra i giornali”, ibid., a. I, n. 5, 20 febbraio 1905, pp. 14-15.

324 "Per l'inchiesta sul femminismo”, ibid., a. I, n. 10, 5 maggio 1905, pp. 9-10.

325 The political and social orientation of Cultura sociale was unacceptable to the Ecclesiastical Authority, which asked bishops to prohibit clergy from reading it. This led to Murri's decision to discontinue the periodical. Brogi, La lega democratica nazionale, cit., p. 177.
} 
mettiamo fuori e prendiamo i sentieri montagnosi della scienza.” Perchè tanto affanno si prova dinanzi al ritiro d'un animo libero?

La sincerità dell'uomo, gli ha attirato la simpatia degli avversari. Anche l'ultimo numero della Critica Sociale ne parlava, con manifesta simpatia. ${ }^{326}$

The cessation of Cultura sociale in 1906 did not put an end to Murri's journalistic career, since thereafter until his death in 1944 he wrote hundreds of articles for numerous periodicals and published dozens of books. ${ }^{327}$ The declining fortunes of the Lega democratica nazionale, however, meant that it would never serve as a vehicle for Murri’s ambitions to rebuild and revitalize Italian society.

With the disbandment of the early Christian democratic movement, both Romolo Murri and Adelaide Coari had to make choices about their future allegiances. By founding the Lega democratica nazionale, Murri opted for a movement outside the official hierarchy, and anticipated a women's movement which would be part of his independent organization. By contrast, Adelaide Coari and Carlo Grugni at various times expressed their loyalty to the papacy and their desire to remain within the Catholic system. Arguably, Coari's extensive Federazione femminile belonged to the officially sponsored lay movement since it was supported by a no lesser person than Archbishop Carlo Ferrari. The fate of the Lega democratica nationale shows how negligible the chances of survival were for a "Catholic" organization without the support of the official hierarchy. In the end, the political conservatism of important sections of the clergy and the Catholic laity as well as the prevailing anti-modernist campaign brought about also the dissolution of femminismo cristiano whose uncompromising stance on women's issues was at odds with the official line.

\footnotetext{
326 “Nella vita e fra i giornali”, Pensiero e azione, a. II, n. 12, 5 giugno 1906, p. 12.

${ }^{327}$ For Murri’s public life and politics in his later years, see Alfonso Botti e Rocco Cerrato, "Gli esiti del murrismo”, in Biagioli, Botti e Cerrato (a cura di), Romolo Murri e i murrismi in Italia e in Europa cent'anni dopo, cit., pp. 627-660, here p. 634.
} 


\section{CHAPTER FOUR: ELISA SALERNO’S CONTRIBUTION TO FEMMINISMO CRISTIANO}

After the suppression of the early Christian democratic women's movement in 1908, one of the few remaining exponents of femminismo cristiano was the independent Vicenza journalist and writer Elisa Salerno. While embracing the avant-garde feminism of the Milanese periodical Pensiero e azione, Salerno came to regard Catholic dogma as the primary source of antifeminist attitudes in the Church and contemporary society. She showed enthusiasm for the prospect of a national organization for Catholic women, yet refrained from active participation in the Unione fra le donne cattoliche d'Italia after it was founded in 1909. Salerno's journalistic career began in 1905, at a time when the first wave of Christian democracy was abating, and continued until 1927 when her second periodical, Problemi femminili, ceased publication. Her writings after World War II are beyond the period covered by this thesis.

In her essay "Dall'ago alla penna”, Antonia Arslan discusses the rich, varied, and at times praiseworthy, literary production by Venetian women writers in the eighteenth and nineteenth centuries. Most of their work is now forgotten, even though in their day many of them were popular writers earning a living from their literary production. ${ }^{1}$ Oblivion would undoubtedly also have been the fate of the writings of their later colleague Elisa Salerno, had not her nieces Giulia and Elisabetta Andolfato, in the late 1970s, donated her personal library and archives to the Suore Orsoline del Sacro Cuore di Maria, Vicenza, who since then have promoted awareness of the work of this remarkable woman. ${ }^{2}$

Through the activities of the Centro documentazione e studi "Presenza Donna" Salerno's major writings are now available to the public together with an increasing body of secondary literature on the various aspects of her feminist works. Elisa Vicentini's Una chiesa per le donne. Elisa Salerno e il femminismo cristiano (1995) discusses Salerno first in the context of her time and then with reference to femminismo

\footnotetext{
${ }^{1}$ Antonia Arslan, “Dall'ago alla penna: scritture femminili nel Veneto tra Ottocento e Novecento”, in Elisa Salerno, Al bivio/ Elisa Salerno oltre il bivio: tra giornalismo e romanzo, Vicenza, Centro documentazione e studi “Presenza Donna”, 1998, pp. 133-152.

2 “Sulla strada difficile del femminismo cristiano”, La Voce dei Berici, 8 dicembre 1991, Chiesa locale/9.
} 
cristiano, her feminist theology, her social activity, and her ideas on education. ${ }^{3}$ The book also includes a selection of Salerno’s correspondence with eminent personalities of her day. Another useful publication is Gianni A. Cisotto's study, Elisa Salerno e la promozione della donna (1996), which provides a chronological introduction to Salerno's life and works and contains copious, scholarly endnotes. ${ }^{4}$ Her selected correspondence has been collated in Una penna inquieta: Lettere scelte di Elisa Salerno (2002). ${ }^{5}$ In addition, frequent conferences and meetings organized by the Centro documentazione, often to commemorate an anniversary of one of her publications, have contributed to the secondary literature. An example of this stream is the three essays on Salerno in La donna e il lavoro published in 2009 to celebrate the centenary of the launch of her first periodical under the same title. ${ }^{6}$ Further evidence of her significance in the early Catholic feminist movement is given by a growing number of dissertations on different aspects of her life and work, including a recent doctoral thesis by Michela Vaccari, entitled Il pensiero e l'azione di Elisa Salerno. Una lettura teologica. ${ }^{7}$

In the context of these studies, my approach to Salerno will be first to explore her criticism of those elements of Catholic dogma which she found to be the primary cause of antifeminism in the Catholic Church and in wider society. I will then examine how she dealt with the feminist issues which she took over from femminismo cristiano. In the light of the radical nature of her journalism and her attacks on Catholic dogma, her relations with the Catholic women's movement as well as the ecclesiastical and the secular authorities of the day will also be examined.

The external aspects of Salerno's life are well documented in the secondary literature and in her own autobiographical novels, Un piccolo mondo cattolico (1908), Al bivio (1921), and Due sorelle-Due nature-Due sistemi (1948). Nonetheless, a brief account of her life is necessary to provide a background to the evolution of her feminism. Elisabetta, or Elisa as she was mostly known, was born in Vicenza on 16 June 1873 to Antonio Salerno and Giulia Menegazzi as the sixth of their nine children who, with the exception of the elder sister Maria Luigia Teresa and Elisa herself, died at an early age.

\footnotetext{
${ }^{3}$ Elisa Vicentini, Una chiesa per le donne. Elisa Salerno e il femminismo cristiano, Napoli, M. D’Auria Editore, 1995.

${ }^{4}$ Gianni A. Cisotto, Elisa Salerno e la promozione della donna, Roma, Edizioni Studium, 1996.

${ }^{5}$ Centro documentazione e studi "Presenza Donna”, Una penna inquieta. Lettere scelte di Elisa Salerno, Padova, Edizioni Messaggero, 2002. Hereafter referred to as "Una penna inquieta".

${ }^{6}$ La donna e il lavoro. Ieri e oggi, Vicenza, Cooperativa tipografica degli operai, 2009.

${ }^{7}$ Michela Vaccari, Il pensiero e l'azione di Elisa Salerno. Una lettura teologica, Tesi di dottorato, Roma, Pontificia università lateranense, 2007.
} 
Originating from a family of prosperous tenant farmers in the Berici Hills, her father Antonio Salerno had left for the city to earn a living as a grain merchant, and later acquired a flour mill. Her mother Giulia Menegazzi came from an established Vicenza family and, before marriage, was an assistant in an elementary school for girls and a teacher of catechism in the Araceli (Vicenza) parish. ${ }^{8}$ Together the parents opened a bakery and a pasta factory on premises which Giulia had inherited. ${ }^{9}$ The devout and industrious family was well-off through their hard work, as Alba Grazia Lazzaretto Zanolo points out, ${ }^{10}$ and until the outbreak of World War I, could afford to employ two domestic servants. ${ }^{11}$ Elisa always remembered her parents with affection, especially her father, whom she described as religious, charitable, honest and diligent. ${ }^{12}$ Surprisingly, despite the seemingly comfortable economic circumstances of her family, in the novel Un piccolo mondo cattolico Salerno’s fictitious double, Maria Alma, describes herself as being of humble social origins (bassa condizione). ${ }^{13}$ Some six years later, however, Salerno appraised her social position quite differently considering herself "well-to-do" and “free”, as she wrote to Bishop Rodolfi’s secretary, Giuseppe Stocchiero:

Ella sa, Rev.mo Signore, che essendo di condizione agiata e libera, potrei godermi la vita senza il giornale. ${ }^{14}$

Salerno had a minimum of formal education. In 1877 the government of Agostino Depretis had made two years' primary education compulsory in Italy, ${ }^{15}$ and four years later, at the age of eight, Salerno was belatedly enrolled at the primary school run by the Sisters of Santa Dorotea. By then she had also begun to help her parents in their business, in which she continued to work for the next thirteen years. Poor health forced her to leave school in the third year but she continued to study privately under the guidance of Don Giuseppe Fogazzaro, re-enrolling in the fifth primary class in Contrà Santi Apostoli and completing her primary education at sixteen in $1889 .^{16}$ Despite her

\footnotetext{
${ }^{8}$ Monica Cisco, “Elisa Salerno”, in La donna e il lavoro, cit., pp. 19-20.

${ }^{9}$ Ibid., p. 20.

${ }^{10}$ On p. 28 of "Per la causa santa della donna", in Centro documentazione e studi "Presenza Donna", Nata troppo presto/Elisa Salerno, Pro muliere, Vicenza, 2007, Alba Grazia Lazzaretto Zanolo writes: "Era nata - sesta di nove fratelli - in una famiglia di piccola borghesia; pur senza essere di origine nobile e nemmeno particolarmente ricca, la famiglia possedeva una agiatezza da lavoro: il padre gestiva un forno con pastificio, aveva un molino e qualche immobile”. The publication henceforth referred to as Nata troppo presto.

${ }^{11}$ Cisotto, Elisa Salerno e la promozione della donna, cit., 1996, p. 97.

12 Elisa Salerno (pseud. Lucilla Arderns), Un piccolo mondo cattolico, Mirano (Venezia), Eidos, 1996, p. 19.

${ }^{13}$ Ibid., p. 111-112.

${ }^{14}$ Salerno’s letter to Giuseppe Stocchiero, 11 July 1914, in Una penna inquieta, cit., p. 221.

${ }^{15}$ Martin Clark, Modern Italy 1871-1995, $2^{\text {nd }}$ ed., London, Longman, 1997, p. 37.

${ }^{16}$ Don Giuseppe Fogazzaro was an uncle of the novelist Antonio. See Elisa Vicentini, Una chiesa per le donne, cit., p. 7.
} 
desire to become a teacher and the encouragement she received from her parents, Elisa gave up school to help out in the family's two shops, which at the time were unexpectedly moving towards bankruptcy. ${ }^{17}$

Apart from participation in the devotional and associative activities of her parish in Araceli, her teenage years saw Salerno steeped in meditation and analysis of biblical texts as well as reading biographies of saints, Christian apologist literature, and books on spirituality and religious culture. Her primary interest, however, lay in philosophy, and her quest for knowledge showed an amazing breadth as she delved into general history, church history, literature, sociology, pedagogy, and even into the study of French, Latin and German. ${ }^{18}$ At twenty, to her disappointment, Salerno saw her application to enter the Santa Chiara convent rejected since, on the grounds of her precarious health, she was not considered suitable for a missionary or any other order. In 1896 her interest in social issues led her to become an honorary member of the first female Catholic mutual aid society in Vicenza, the Società cattolica operaia femminile di mutuo soccorso. ${ }^{19}$ Salerno's social activism lessened, however, after she became a member of the Franciscan Tertiary Order and adopted their inward-looking moral code with the maxim attende tibi. ${ }^{20}$ For some five years she abandoned her studies, withdrew from involvement in social activities, and dedicated herself exclusively to care for her family and to religious practice. Recovering from a prolonged illness, she gradually realized that, for her, Christian perfection was inseparable from a social apostolate:

Ma un anno dopo, l'Attende tibi perdette tutta la forza, ed ella giunse a persuadersi che per lei perfezione cristiana e apostolato sociale erano inseparabili; e si tolse senz'altro da quello stato di segregazione, dal quale s'era figurata di non uscire giammai. ${ }^{21}$

Years later, in 1920, Salerno established her own tertiary order, Unione delle vergini di nostra Signora della Mercede, which had only two other members, her nieces Giulia and Elisabetta, who had lived with her since early childhood. ${ }^{22}$

\footnotetext{
${ }^{17}$ Cisco, "Elisa Salerno”, in La donna e il lavoro, cit., pp. 20-21.

${ }^{18}$ Monica Cisco, Elisa Salerno e "Un piccolo mondo cattolico", Tesi di laurea, Padova, Università degli studi di Padova, 1995-96, pp. 9-10.

${ }^{19}$ Cisotto, Elisa Salerno e la promozione della donna, cit., p.11.

${ }^{20}$ Elisabetta Rita Periotto, La personalità della donna nel pensiero di Elisa Salerno, Tesi di laurea, Padova, Università degli studi di Padova, 1975-76, pp. 66-67.

${ }^{21}$ Salerno, Un piccolo mondo cattolico, cit., p. 6. Original italics retained.

${ }^{22}$ Vicentini, Una chiesa per le donne, cit., pp. 9-10.
} 
At the turn of the twentieth century Vicenza was a deeply Catholic provincial city which was experiencing an early spate of entrepreneurship and industrialization. The promulgation of Rerum novarum and the choice of Vicenza as the venue for the ninth annual congress of the Opera dei congressi in 1891 gave impetus to the establishment of workers' associations, mutual aid societies, and professional organizations with male and female sections. In evidence also were the rifts which existed in the Catholic lay movement, which were reflected in the political alignment of the local newspapers. Of these, Il Berico and La Riscossa represented the intransigent, arch-conservative viewpoint, whereas Il Vessillo bianco was the organ of the "professional" unions leaning towards Christian democracy. ${ }^{23}$ In Vicenza, the disbandment of the Opera dei congressi in 1904 resulted in the breakup of the Catholic professional unions, as described in Salerno's autobiographical novel, Un piccolo mondo cattolico, and in irregularities in the publishing of Il Vessillo bianco. Until then, declares Salerno through the protagonist of the novel, the union movement had shown a vigorous growth, and the circulation of Popolo cattolico (Il Vessillo bianco) had increased week by week. Then suddenly the protagonist finds no outlet for publishing her commemorative article on Rerum novarum and, even worse, the Catholic unions were in disarray:

Ma la presidentessa le disse che s'era dimessa, come pure il presidente, che le Unioni erano osteggiate, la loro azione malamente intralciata ... per il che sarebbero certamente cadute. $^{24}$

Another contemporary phenomenon reflected in the novel was the anti-modernist campaign, whose full fury was also felt in Vicenza. After all, it was the home town of the famous Catholic writer Antonio Fogazzaro whose novels Il santo (1905) and Leila (1910) were placed on the index of blacklisted books. ${ }^{25}$ With most of her journalistic activity taking place after the vehemence of the anti-modernist witch-hunt had diminished, Salerno did not in any profound manner concern herself with the modernist debate. Yet later her first periodical, La Donna e il lavoro, was denounced for its alleged modernism. She lacked awareness, or was unwilling to admit, that her exposure of the antifeminist components of Catholic dogma could make her own writings susceptible to modernist accusations.

\footnotetext{
${ }^{23}$ Il Vessillo bianco was founded by Don Attilio Caldana in 1903 as the organ of the Unioni professionali. It expressed the views of the young generation of "Social Catholics", both lay and ecclesiastic. Apart from Caldana, the clergy on Il Vessillo bianco included Tomaso Tomasi, Leone Zarantonello, Tiziano Veggian and Giuseppe Arena. Arena took over the editorship of Il Vessillo bianco in November 1908. See Stefania Fiocchi, "Introduzione”, in Salerno, Un piccolo mondo cattolico, cit., pp. xiii-xiv.

${ }^{24}$ Salerno, Un piccolo mondo cattolico, cit., p. 13.

${ }^{25}$ L. Strappini, "Fogazzaro, Antonio", in Dizionario biografico degli italiani, v. 7, Roma, Enciclopedia italiana, 1997, pp. 420-429.
} 
Salerno's journalistic career was launched in Il Vessillo bianco on 2 September 1905, with a column entitled Cronaca femminile. ${ }^{26}$ Her writings dealt with women's, especially working-class women's, educational requirements as well as their need to form a Catholic union in order to secure their rights in the workplace. With equal commitment, she campaigned for women's suffrage which was debated in the Catholic press at the time. She wrote articles on women's issues also for Il Berico and L'Osservatore cattolico. ${ }^{27}$ As Stefania Fiocchi observes, Salerno's intensive reading of Pensiero $e$ azione gave her a starting point in elaborating her feminist goals. ${ }^{28}$ For instance, in a talk she gave at a women's conference in the parish of Araceli, Vicenza, in November $1905,{ }^{29}$ she noted the miserable condition of women who were despised, ignorant and economically exploited by industrialists. A religious conscience no longer sufficed, she insisted, but it was necessary to have also a social conscience, since there could not be one without the other. As far as women's economic rights were concerned, for anyone to renounce them would be to compromise the cause of so many other workers. In the pursuit of economic claims, the most honest, legitimate and effective means was to join forces in professional unions with the objective of regulating conditions on wages, working hours, the hygiene of the workplace, the treatment of workers, weekly rest-days and so on.

Her feminist articles soon drew the fire of the conservative Catholic clergy who branded her a femminetta scomoda, indesiderata ed esaltata. ${ }^{30}$ Salerno, however, saw her feminism as stemming from her Christianity, as becomes apparent from an article in L'Osservatore cattolico on 13 October 1905 in which she declared: siamo cristiani, perciò democratici, quindi femministi. ${ }^{31}$ No less important was for her to stress that she was, first and foremost, a Catholic and then a feminist: prima cattolica e poi femminista. $^{32}$

\footnotetext{
${ }^{26}$ Cisco, Elisa Salerno e "Un piccolo mondo cattolico", cit., p. 31.

${ }^{27}$ Ibid., p. 32.

${ }^{28}$ Fiocchi, "Introduzione”, cit., p. xiii.

29 “Conferenze alle Figlie di Maria”, L’Azione muliebre, a. VI, fasc. 1, gennaio 1906, pp. 53-56.

${ }^{30}$ Cisco, Elisa Salerno e "Un piccolo mondo cattolico”, cit., p. 33.

${ }^{31}$ Giuseppina Lugo, “Quella povera testa ... L'utopia femminista di Elisa Salerno”, in Venetica, n. 9, gennaio-giugno 1988, p. 136.

32 "Prima cattolica e poi femminista”, La Donna e il lavoro, a. 8, n. 18, 24 agosto 1917, p. 1. Salerno writes that feminism is not opposed to any moral argument (qualche punto della morale) or any argument regarding the Catholic faith (o della fede cattolica), but is opposed to false and harmful prejudices circulating in society, including the Catholic domain.
} 
Since Il Vessillo bianco had ceased publication for the time being, Salerno had to offer her articles instead to the conservative local paper, Il Berico. These events are narrated in detail in her above-mentioned autobiographical novel Un piccolo mondo cattolico, published under the nom de plume of Lucilla Ardens. In it, the protagonist's father renounces his purchase of a hydraulic power plant adjoining his flour mill in favour of the proprietor of the neighbouring printing press, who produces the local newspaper, $L a$ Spada (Il Berico). In return, the printer pledges to have the articles of his daughter, Maria Alma, published. Since the political inclinations of Maria Alma and the editor of La Spada are quite divergent, after only a couple of articles, Maria’s aspirations are frustrated through delays, modifications and editorial notes disowning the contents of her articles. In the end she decides not to submit further articles to La Spada while the idea of founding her own periodical matures in her mind.

No literary masterpiece, Un piccolo mondo cattolico shows the limitations of Salerno as a writer. Stefania Fiocchi comments:

In quest'opera sono evidenti i limiti della formazione letteraria dell'autodidatta Salerno: l'espressione è spesso goffa o prevedibile, manca un calibrato uso dei registri linguistici, spesso prevale la tonalità colloquiale che risente di inevitabili venetismi e che cozza con alcuni picchi di aulica veemenza. L'impressione che suscita la lettura è a tratti quella di una certa naiveté, riscattata dalla forza espressiva di alcune pagine di piglio giornalistico e polemico. ${ }^{33}$

The novel is historically accurate, however, exposing the narrow-mindedness of the contemporary conservative Catholic establishment, its complicity in the breakup of the professional unions, and its obstructionism to democracy and to femminismo cristiano. The views of the owner of the printing press, Primo Franchi, on women's suffrage exemplify the widely held conservative attitudes, which Maria Alma finds indefensible on rational grounds. ${ }^{34}$

As one would expect, Un piccolo mondo cattolico and its author were subjected to harsh criticism and even ridicule. Among the mildest critics was Giuseppe Toniolo, with whom Salerno exchanged letters between October 1905 and May 1909. ${ }^{35}$ Toniolo had previously advised Salerno against writing a book based on real-life figures and especially against giving it the title La santa, which would have been an obvious

\footnotetext{
${ }^{33}$ Fiocchi, "Introduzione”, cit., p. xxix. Original italics retained.

${ }^{34}$ Salerno, Un piccolo mondo cattolico, cit., pp. 51-53.

${ }^{35}$ Cisotto, Elisa Salerno e la promozione della donna, cit., p. 19.
} 
reference to Fogazzaro’s banned novel Il santo. ${ }^{36}$ In a letter dated 7 May 1908, Toniolo reminded Salerno that he had counselled her against writing the novel, and went on to say that, in his view, it was neither orthodox, nor disciplined, nor Christian to denigrate publicly everything and everyone:

Mi lasci, egregia signorina, pensare che non è nè ortodosso, nè disciplinato, nè informato a spirito cristiano, quest'abito del denigrare anche pubblicamente tutto e tutti, che insinuò in parecchi da qualche tempo l'atmosfera ammorbata e burrascosa che respiriamo. ${ }^{37}$

A few days later, on 13 May, responding to a letter Salerno had sent to him in the meantime, Toniolo wrote to her saying that the setting of her novel was far too local and domestic (disegno di romanzo troppo locale e domestico), and that the reactions to it by some of his friends in the Unione popolare had been charged with recrimination and repugnance (recriminazione disgustosa). ${ }^{38}$ On the other hand, seeing its leading journalists likened to "quattro Don Rodrigo", 39 the reaction of the local newspaper, Il Berico, could only be venomous. ${ }^{40}$ The paper could hardly contain its schadenfreude when Francesco Magri, a well-known Christian democrat and feminist, published a scathing review in L'Avvenire d'Italia which was subsequently reproduced in full in $I l$ Berico. Magri wrote:

Lucilla Ardens [nom de plume of Salerno] - oh! meravigliosa fioritura di pseudonimi - ha voluto commettere anch'essa il suo bravo peccato ... con le migliori intenzioni e si è scusata nella prefazione dichiarando - l'ingenua - che non la pretende a scrittrice. L'artifizio non è una novità: ma sarebbe desiderabile che per fare le cose sul serio non si scrivesse ... addirittura!

Il Piccolo Mondo Cattolico, di trecento pagine di questa che mi pare una ... lavoratrice della penna, assai novellina, vorrebbe essere una battaglia combattuta pro democrazia-cristiana s'intende, e pro femminismo ...

Un paio di questi libri ogni mese e il critico va a finire ruzzoloni sotto il tavolo e la "Unita Cattolica” può ridere in tutta serenità. ${ }^{41}$

Since Il Berico was reluctant to publish her articles, Salerno, calling herself a lavoratrice del pensiero, turned to her father in a letter of 15 October 1906 to ask him to purchase a printing press for the publication of a "popular" journal (giornale popolare):

\footnotetext{
${ }^{36}$ Toniolo writes to Salerno in a letter dated 21 November 1906: "Non lo farei in particolare sotto quel titolo La santa e dopo d'aver sottoposto lo scritto al Fogazzaro”. Giuseppe Toniolo, Lettere III 19041918, Città del Vaticano, Comitato Opera omnia di G. Toniolo, 1953, p. 90.

${ }^{37}$ Toniolo’s letter to Salerno, 7 May 1908, in ibid., p. 154.

38 Toniolo's letter to Salerno, 13 May 1908, in ibid., p. 158.

39 A reference to Alessandro Manzoni’s I promessi sposi.

40 Salerno writes on p. 127 of Un piccolo mondo cattolico, cit.: "Il suo caso era di una gravità eccessionale! Don Rodrigo era glorificato nei suoi posteri! e lei, simile a Renzo Tramaglino, dovea dire alla sua promessa, alla causa femminile che ardentemente avea abbracciata: Per oggi tutto è a monte, $e$ Dio sa quando la Spada farà largo ai volenterosi che bramano di servirlo nella persona del prossimo!”

See also "Era un pettegolezzo ... di sapor locale!”, Il Berico, 12 May 1908, pp. 3-4.

41 “Un piccolo mondo cattolico”, ibid., 24 May 1908, pp. 3-4. Original italics retained.
} 
... tu sai bene che in questa terra vi sono due sorta di affari: quelli materiali e quelli morali: quelli privati e quelli pubblici. Vi sono i lavoratori delle braccia ed i lavoratori del pensiero. Tutti secondo i doni di Dio, secondo la condizione e secondo i mezzi. Ebbene; io nella mia pochezza sento di appartenere ai lavoratori del pensiero, a coloro cioè che si occupano delle cose morali e sociali. Questa mia inclinazione, diletto papà, e le noie che mi fa soffrire "Il Berico", e la caduta delle unioni professionali, tutto questo mi fece nascere un ideale veramente grande, e che potrebbe (se effettuato) essere la risurrezione di tante coscienze, e darebbe vita all'azione cattolica popolare, la sola che sia necessaria oggidì ...

Il mio ideale è questo: Possedere una stamperia per la pubblicazione d'un giornale popolare. ${ }^{42}$

Salerno's dream was realized in December 1909 when she launched the periodical $\mathrm{La}$ Donna $e$ il lavoro which was intended to fill the gap left by the breakup of the professional unions and the discontinuation of their organ, Il Vessillo bianco. ${ }^{43}$ Like Coari's now defunct periodical Pensiero e azione, Salerno's paper targeted women workers with the aim of educating them, instilling in them a sense of Christian awareness, and helping them to look after own their interests. The paper's declared purpose was also to plead the cause of female labour with public authorities, entrepreneurs and industrialists, and to sensitize the public to women's problems. Interestingly, most of the contributors to La Donna e il lavoro were men and included several priests.

Despite her family's wealth, Salerno's correspondence gives the impression of a continuous struggle to finance the paper. So from the very first year of publication she approached the clergy and laypersons alike to solicit them for contributions. ${ }^{44}$ Moreover, due to the dishonest behaviour of her printer during the first four years, she was forced to mortgage the house she and her sister had inherited from their mother. ${ }^{45}$ Her editorial freedom, on the other hand, was restricted owing to the presence of an ecclesiastical assistant and an ecclesiastical censor to whom she had to submit her paper in order to have it accepted in the register of Catholic publications.

\footnotetext{
42 Salerno's letter to Antonio Salerno, 15 Oct. 1906, in Una penna inquieta, cit., p. 159.

${ }^{43}$ Salerno's letter to Coari, 15 Oct. 1906, FES 5.

${ }^{44}$ Cisotto, Elisa Salerno e la promozione della donna, cit., p. 74, footnote 24.

45 Ibid, p. 43. Salerno writes to her grandniece, Maria Andolfato in 1944: "Ebbi la sfortuna d'incappare in una tipografia di marca cattolica, ma poco onesta, la quale, invece di favorire l'incremento del periodico, la dava a sfruttarmi; per la qual cosa, in un termine di tempo (1909-1913, dopo il quale cambiai tipografia) in cui avrei raggiunto almeno il pareggio, dovetti fare un mutuo di L. 5.000, cinquemila, sulla casa lasciatami, in parte con mia sorella, dalla mia venerata mamma”.
} 
Around 1915 Salerno began her study of The Summa Theologica and The Summa contra gentiles of St. Thomas Aquinas as well as the works of St. Alphonsus Liguori, which revealed to her the underlying antifeminist bias of Catholic dogma. To deal with the issue, she wrote a treatise on the subject under the title Per la riabilitazione della donna which she completed in March 1916 and dedicated to Pope Benedict XV, in the hope that the Pope would take steps to purge Catholic dogma of antifeminist theories. A vellum bound copy was presented to the Bishop of Vicenza, Monsignor Ferdinando Rodolfi, with a request to forward it to the Pope. In response, Rodolfi asked Salerno to remove from her treatise the whole of a section dealing with St. Thomas and the scholastics. It appears that, despite Salerno's refusal to revise her document, it reached Rome but was never submitted to the Pope. Failing to gain the attention of the Pontiff, but convinced of the importance of her cause, Salerno proceeded to publish the treatise the following year.

When released, Salerno's pamphlet Per la riabilitazione della donna provoked a violent reaction among both the clergy and lay Catholics. Typically the Bishop of Treviso, in a letter to Rodolfi, did not contest the substance of Salerno's arguments, choosing to belittle her for being an unmarried woman. His vehement outburst was illustrative of the attitudes Salerno was fighting in the Catholic Church:

... che razza di scritto! Verrebbe la tentazione di dire all'autrice, probabilmente zitellona, che se san Tommaso avesse avuto bisogno di una conferma ... la Salerno gliela esibiva! ${ }^{46}$

In Vicenza, averred Rodolfi for his part, no one took Salerno's pamphlet seriously, but he was still concerned that outside the diocese it could generate false ideas of the doctrine of the Church. In retaliation for Salerno's attack on Catholic dogma, the Episcopal Chancellor, Dr Antonio de Manchi, issued a statement, on 30 June 1917, declaring that the paper published in Vicenza under the title La Donna e il lavoro had ceased to form part of the Catholic press, and on 15 July 1917 the bishop himself wrote to the Pope:

Ritengo mio dovere di rendere noto alla E. V. che oggi sul "BOLLETTINO ECCLESIASTICO” della diocesi ho inserito questa dichiarazione:

"Dichiariamo che il foglio che si pubblica in Vicenza col titolo: 'La donna e il lavoro, quindicinale delle classi lavoratrici d'Italia', ha cessato di appartenere alla stampa cattolica”.

Il motivo del provvedimento sta nell'ostinazione con la quale la Direttrice vuol trattare argomenti teologici, in cui è incompetente. ${ }^{47}$

\footnotetext{
${ }^{46}$ Bishop of Treviso’s letter to Rodolfi, 17 May 1917, ACV, Busta E. Salerno.
} 
Salerno's periodical was subsequently readmitted to the Catholic press but after a few months it changed its title to Problemi femminili. When relaunched in December 1918, the periodical had broadened its target readership to include, not only manual workers, but also office workers and professional women. Nine out of the eighteen contributors were priests living outside the Vicenza diocese. ${ }^{48}$

Salerno's periodical may have changed its name, but her fight against the perceived antifeminism in the Catholic Church did not lose any of its fervour. In 1924 her pamphlet Dottrina cristiana sulla donna took up the arguments of 1917, but in a more radical manner, even questioning the ministry of the bishops and the Pope. ${ }^{49}$ Between September 1923 and January 1925, she wrote a series of articles under the title Commenti critici alle note bibliche antifemministe, criticizing Mons. Antonio Martini’s commentary of the Bible; and in February 1925 she published, under the provocative heading of Dottrina infetta, a critique of Bishop Rodolfi's Catechismo ministeriale ad uso delle scuole elementari. ${ }^{50}$ The bishop's response was prompt: on 10 March 1925 he decreed that Problemi femminili was prohibited by the Catholic Church, and could neither be printed, nor sold, nor read. ${ }^{51}$ Salerno's periodical survived, under great duress, until March 1927, when its ultimate closure was brought about by obstructions caused by Fascist authorities and censorship.

After World War II, Salerno began to publish again under the pseudonym Maria Pasini but her work remained largely unnoticed. Living from 1932 with her two nieces in Contrà S. Rocco in Vicenza, in the house she had inherited from her mother, she continued to be preoccupied in an increasingly puritanical manner with the doctrine of

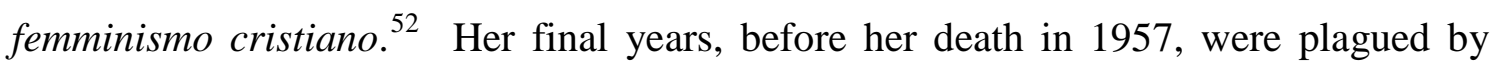
poor health and isolation, with little acknowledgement given to her life's work as a feminist. ${ }^{53}$

\footnotetext{
${ }^{47}$ Rodolfi's letter to Benedict XV, 15 July 1917, ACV, Busta E. Salerno. Original capital letters retained. ${ }^{48}$ Maria LuigiaBertuzzo, La donna e la Chiesa: appunti per una biografia di Elisa Salerno, Tesi di laurea, Roma, "Maria SS. Assunta”, 1986-87, p. 137.

${ }^{49}$ Cisotto, Elisa Salerno e la promozione della donna, cit., p. 133.

${ }^{50}$ Ibid., pp.134-135.

${ }^{51}$ Ibid., p. 133.

${ }^{52}$ Sonia Residori, "Elisa Salerno e la sua utopia femminista: 'Bisognerebbe che io fossi nata nell'epoca futura ...”, Il Giornale di Vicenza, 27 maggio 2004, p. 33.

53 Giuseppina Lugo, “Elisa Salerno”, in A. Arslan, C. Chemello e G. Pizzamiglio (a cura di), Le stanze ritrovate: antologia di scrittrici venete dal Quattrocento al Novecento, Mirano, Eidos, 1991, p. 235.
} 


\section{Criticism of Catholic Dogma}

In Chapter Three we saw how femminismo cristiano progressed from welfare activism to demands for full civil and political rights for women. It was only natural that sooner or later someone should ask for reasons why women were considered inferior to men. The first person to do so in the Italian Catholic context was Elisa Salerno. In trying to get to the root of the problem of antifeminism she made her most daring and original contribution to femmismo cristiano. Her arguments were summarized in Per la riabilitazione della donna, in which she revealed the doctrinal foundations of misogyny in the Church. Subjecting the teachings of Catholic dogma to her unremitting scrutiny for signs of antifeminism in it Salerno formulated, in a unique way, her approach to the woman question. At the same time, she reworked the influences she had received from the Christian democratic women's movement. Since her critique of Catholic dogma underpins her feminist position, her main arguments need to be examined before addressing other aspects of her work.

The literary precedents of Per la riabilitazione della donna can be traced to a series a articles published under the collective title of Trattazione sulla donna in La Donna e il lavoro from 2 August 1912 to 20 June 1913. They appeared under the headings of Agli antifemministi, Una questione di libertà, Quid est mulier, Educazione fisica, Istruzione, La donna nella famiglia e nella società, and Maria e la donna. The radical quality of these articles engendered perplexity among prominent Catholics, such as Giuseppe Toniolo, who conveyed his unease on reading Salerno's treatise in a letter to Bishop Rodolfi in Lent $1913 .^{54}$ Criticism came also from Don Giacomo Dalla Vecchia, ecclesiastical censor of Salerno's periodical, who condemned Salerno's articles for their aggressive tone, their exaggerated claims, and for their, at times, inexact and aprioristic evidence. ${ }^{55}$ Salerno, in turn, continued to make unsuccessful appeals to Rodolfi for exemption from ecclesiastical censorship. ${ }^{56}$ Ultimately, in November 1915, Dalla Vecchia forbade Salerno altogether from publishing further "philosophical” articles on women. ${ }^{57}$

\footnotetext{
${ }^{54}$ Toniolo’s letter to Rodolfi, 1a Quaresima 1913, ACV, Carteggio Rodolfi.

${ }^{55}$ Dalla Vecchia's letter to Rodolfi, 25 Mar. 1913, ACV, Busta E. Salerno: "Il lavoro però si presenta aggressivo nella forma; esagerato nei postulati; talora inesatto ed aprioristico nelle prove”.

${ }^{56}$ Salerno's letter to Rodolfi, 8 Aug. 1914, ACV, Busta E. Salerno.

${ }^{57}$ Dalla Vecchia's letter to Rodolfi, 29 Nov. 1915, ACV, Busta E. Salerno: "Riguardo a 'La donna e il lavoro', ho dovuto prendere la decisione di non permettere più a la Sig.na Salerno di stendere articoli, che ella chiama filosofici, intorno a la donna”.
} 
Despite the objections raised by the ecclesiastical censor and prominent figures of the Catholic establishment to her theological and philosophical articles, Salerno resolutely persisted in her promotion of the "holy cause of women"; doing so even more undeterred when she commenced, in 1915, the year when Italy entered World War I, a serious study of the works of St. Thomas Aquinas and St. Alphonsus Liguori. The perusal of these writings, which she understood literally, temporarily caused a deep crisis in her faith, as she wrote to Don Giuseppe Arena in May 1944:

Dopo letto ed esaminato le opere di san Tommaso d'Aquino e di sant'Alfonso de Liguori, nel loro testo latino originale, compresi le cause del dilagare del malcostume, di tante prevaricazioni e irreligiosità nel popolo cristiano. Soffersi una violenta crisi di Fede, per più giorni, che, con la grazia di Dio, superai nettamente. ${ }^{58}$

Writing Per la riabilitazione della donna against the backdrop of World War I, as she did, suggests the urgency Salerno must have felt for striking a lethal blow against antifeminism at its very epicentre. Michela Vaccari suggests that for its contents and its style the treatise could be described as Summa muliere, as Salerno's response to Thomas's Summa theologica and Summa contra gentiles. ${ }^{59}$ Structural similarities to Aquinas's work are discernible in its "three-part structure" as well as in its "argumentative-demonstrative", "typically scholastic" method. ${ }^{60}$

In her condemnation of the antifeminist components of dogma, Salerno accused scholastics of perpetuating and lending credibility to the pagan philosophy of Aristotle, instead of drawing on the sublime philosophy of the gospel which would restore to woman her rights:

La donna avrà giustizia quando trionferanno la verità ed il diritto. Nel Cattolicesimo l'avrebbe già avuta se fosse stata adottata, a suo riguardo, invece della filosofia di Aristotle, la sublime, perfettissima filosofia del Vangelo. ${ }^{61}$

Salerno herself, having studied Thomist as well as contemporary neo-scholastic philosophy, frequently took recourse to the Bible to validate her statements while also drawing extensively on the scientific data available to her at the time.

\footnotetext{
${ }^{58}$ Salerno’s letter to Arena, 18 May 1944, in Una penna inquieta, cit., pp. 31-32.

${ }^{59}$ Michela Vaccari, "Prefazione", in Elisa Salerno, Per la riabilitazione della donna / Donne e Chiesa, Vicenza, Centro documentazione e studi "Presenza Donna”, 2006, p. 8.

${ }^{60}$ Ibid., p. 9. In Part I, entitled Accuse ed errori, the author identifies the causes of antifeminism and the errors she has discovered in the Summae; in Part II, entitled Origine e conseguenze degli errori ed ingiustizie contro la donna, she deals, as the title suggests, with the origin and the consequences of antifeminism; and in Part III, entitled Le difese, she lists a series of arguments to refute antifeminist theories.

${ }^{61}$ Elisa Salerno, Per la riabilitazione della donna, Vicenza, Fratelli Pastorio, 1917, p. 28.
} 
Part One of Per la riabilitazione della donna begins with a reference to a passage (Part I, Question 92) in The Summa theologica, in which one reads that woman is a mas occasionatus, a misbegotten male, naturally of less dignity and virtue than man, useful only in the act of generation, since in any other work man can be helped more efficiently by another man. ${ }^{62}$ Salerno then provides further evidence of misogyny in Thomas by referring to a passage (Part I, Question 93) which states that, in some secondary sense, God's image is found in man, whereas that relationship does not exist in woman. ${ }^{63}$ In truth, according to Thomas, the divine operation could just as easily have created a horse from Adam's rib (Supplement, Question 54, Article III) ${ }^{64}$ - a statement which, in Salerno's view, negates the existence of an immortal soul in woman. To counter arguments about female deficiency Salerno refers to the use of the verb aedificavit (built) in the Latin version of the Bible, which describes the care and the skill God exercised in the creation of woman.

Salerno notes that in several passages of the Summae Thomas asserts that the Son preexists in the Father, stressing the importance of the active principle or the form, that is, of the male, in the generative act, while contrasting it with the imperfection of the matter, that is, of the female, to which the progeny bears no likeness. ${ }^{65}$ Such denial of woman's genetic role, Salerno points out, is not supported by scientific evidence. She later refers to some other, even more perplexing, scholastic theories, such as the belief that the movement of celestial bodies was sufficient to generate certain animals, and that some other species were born from putrefaction. ${ }^{66}$ In her insistence on the acknowledgement of woman's contribution to genetic heredity, Salerno herself overstates the part played by woman:

La madre perciò trasmette, in due modi, sè stessa alla prole: in virtu del suo seme attivo germinale, e in virtù della materia che le somministra.

Questo spiega, perchè i figli, anche maschi assomiglino spesso più alla madre che al padre. $^{67}$

Salerno was attracted to the writings of Cardinal Desiré Mercier who in his Traité élémentaire de philosophie speaks of the superiority of the intellective moment as

\footnotetext{
${ }^{62}$ Ibid., pp. 5-6.

${ }^{63}$ Ibid., p. 7.

${ }^{64}$ Ibid., p. 8.

${ }^{65}$ Ibid., p. 8.

${ }^{66}$ Ibid., p. 52.

${ }^{67}$ Ibid., p. 54.
} 
regards the human soul. Since abstract thinking capability conferred on man his perfection, neglect of woman's intelligence would, wrote Salerno, mean precluding her from the path to perfection. ${ }^{68}$ But in contemporary society, the Thomist notion of woman's lesser capacity for rational thinking still prevailed, ${ }^{69}$ as demonstrated by Padre Biederlack who in a lecture, a few years earlier, at the Scuola sociale cattolica, had openly claimed that women were incapable of abstract thinking. ${ }^{70}$ Salerno ridiculed the use by scientists of cranial measurements as proof of women's intellectual inferiority arguing that the weight of the brain alone did not accurately measure intelligence since it would prove many animal species more intelligent than man. ${ }^{71}$ Quoting from Paul Topinard, one of the most famous French anthropologists at the time, Salerno maintained that no gender difference was shown in the development of the brain, and suggested woman's brain could even be regarded as more advanced than man's. ${ }^{72}$

Woman's mental deficiency, in Thomist theory, justified her treatment as a thing rather than a person, as something useful only in the act of generation and as a mere chattel in the inventory of man's necessities of life:

È considerata più cosa che persona, uno strumento dell'uomo ad uso generazione, è annoverata, in più parti, insieme con i cibi, le vestimenta, le altre cose, di cui ha bisogno l'uomo ... ${ }^{73}$

Holding the view that woman becomes man's property by marriage, Thomas wondered (Supplement, Question 55, Article IV), in an equally disconcerting manner, whether the relatives of a deceased husband should inherit his wife together with his other possessions:

Certe questioni sulla donna neppure avrebbero dovuto essere poste, come per esempio quella: se i parenti del defunto marito possano succedere nella moglie, come succedono nelle cose di lui, considerato che la donna diventa pel matrimonio, qualche cosa dell'uomo. ${ }^{74}$

Salerno's basic conviction of gender equality is reflected in her version of the theory of the Trinitarian processions, a doctrine deriving, inter alia, from the teachings of St Augustine and St. Thomas. Both man and woman, says Salerno, have been created in

\footnotetext{
${ }^{68}$ Vicentini, Una chiesa per le donne, cit., p. 135.

${ }^{69}$ Salerno, Per la riabilitazione della donna, cit., p. 6.

${ }^{70}$ Ibid., p. 23.

${ }^{71}$ Ibid., p. 63.

${ }^{72}$ Quoted in ibid., p. 65: "Non vi è differenza di sesso, quanto allo sviluppo cerebrale, e si potrebbe perfino sostenere, tenuto conto di quello che l'anatomia comparata dà come vero progresso dell'encefalo, che, nell'evoluzione cerebrale, la donna è più avanzata dell'uomo”.

${ }^{73}$ Ibid., p. 15.

${ }^{74}$ Ibid., pp. 17-18.
} 
the image of God, the Triune God, and the image of the Holiest Trinity is also found in the human couple. Just as the Father is the origin of the Son and the Holy Ghost, whereby it is not legitimate to attribute any inferiority or diminution to them, so man is head of woman, because woman was created from him, but this does not imply her inferiority in relation to him. Woman was not created for the sole purpose of generation. Whereas she has the generative function in common with females of the animal species, she also has the moral and educative mission in common with the Angels and God himself. ${ }^{75}$

However, by emphasizing woman's special moral and educative mission and by attributing to her a deeper moral sense and more subtle affective qualities, Salerno reveals her personal prejudice. ${ }^{76}$ Highlighting woman's special educative mission is not unique to Salerno since it often occurs in the Catholic teaching and literature of the period. According to Salerno, certain qualities emanate from primary and secondary gender characteristics so that motherhood makes tenderness a dominant quality in woman, while in man greater muscularity brings forth hardness:

La maternità fa prevalere nella donna la tenerezza, la muscolosità, maggiore dell'uomo, fa prevalere la durezza. ${ }^{77}$

Yet man and woman are fundamentally equal, argues Salerno, since the spiritual soul is the essential characteristic of both. They are equal as to their volitive, ratiocinating and intellectual potential; they are equal in generating actions based on reason and will; they are equal in their capacity to feel, want, and think; they are subject to the same laws, and similarly moved by the passions of irascibility and concupiscence. ${ }^{78}$

\footnotetext{
${ }^{75}$ Ibid., pp. 47-48: “Infatti, nella divina Trinità, si scorge la processione, la uguaglianza, la necessità delle tre divine Persone, e anche sotto questi rispetti, la divina immagine rifulge nella coppia umana: Come il Padre è principio del Figlio e dello Spirito Santo, senza che sia lecito attribuire a Costoro alcuna inferiorità o diminuzione, così l'uomo è capo della donna, come colui da cui la donna fu tratta, ma la donna non è inferiore a lui, per l'essere completo ed eccellente che Iddio le ha dato formandola dalla costa di Adamo; tanto più che non è necessario che Eva fosse tratta da Adamo, e lo fu per divina operazione, non per operazione naturale. Comunque c'è processione e uguaglianza ... La donna è necessaria, e non solamente per l'opera di generazione, come dicono gli Scolastici. Chè, sebbene, la donna, in detta opera, abbia la parte principale, pure questa sta alla missione morale come la terra al cielo, perchè quella funzione, considerata unicamente dal punto di vista fisiologico, l'ha in comune con le femmine degli animali, e la missione morale, educatrice, l'ha in comune con gli Angeli e con lo stesso Dio, mentre per essa tiene rivolto l'uomo verso il suo ultimo fine e lo aiuta a raggiungerlo.” Original italics retained.

${ }^{76}$ Ibid., p. 17.

${ }^{77}$ Ibid., p. 70.

${ }^{78} \mathrm{Ibid}$.
} 
Salerno is keen to point out that as equal human beings, men and women are equally responsible and culpable for their actions. She therefore objects to the scholastic notion that, when sin is committed, greater blame will attach to man than to woman because only man has the perfect use of reason. ${ }^{79}$ Having no rights, even the sin woman commits has the character of usurpation, since the treatment meted out to her is a matter of a greater concern for the man, who holds her in custody and whose property she is, than for herself. ${ }^{80}$ Equal culpability, argues Salerno, also applies in the case of original sin. According to Thomas, who dismissed Eve as a foolish and evil figure, Adam alone passed the original sin to mankind. Rejecting Thomas's notion, Salerno maintains that, due to her genetic role, Eve would have passed, together with Adam, the original sin to mankind, and would have done so even if Adam had not sinned:

Eva ... non potè non trasmettere il peccato originale alla posterità insieme con Adamo, e lo avrebbe trasmesso anche se Adamo non avesse peccato. ${ }^{81}$

Furthermore, the serpent gave preference to woman, writes Salerno, in the knowledge of her natural mission, that is, the moral influence she was destined to exert on man, who is thus lost but also saved through her. ${ }^{82}$ Eve's transgression appears to have a greater number of mitigating circumstances than Adam's, because she was tempted and seduced by the demon himself, and because she offered Adam part of the fruit out of love. ${ }^{83}$ Adam, on the other hand, even though so ready to accept the fruit, was prompt to blame Eve. Since then, Salerno points out, scholastics and so many other men have followed suit. It seems that rather than his affection for Eve it was his inner passion that exposed Adam to sin. ${ }^{84}$

On the basis of selective quotations from the Bible, writes Salerno, scholastics portrayed the female gender as morally weak and inconstant. Women should remain sober, it was argued, because they did not possess sufficient mental strength to resist concupiscence. ${ }^{85}$ On the other hand, while the scattering of seed by man is passed over

\footnotetext{
${ }^{79}$ Ibid., p. 17.

${ }^{80}$ Ibid., p. 10.

${ }^{81}$ Ibid., p. 55.

${ }^{82}$ Ibid., p. 49.

${ }^{83}$ Ibid., pp. 49-50: "La colpa di Eva mostra d'avere maggiori attenuanti di quella di Adamo, perchè Eva fu sedotta, la tentazione fu più suggestiva, più forte, essendo venuta direttamente dal demonio ... mentre ad Adamo bastò che la compagna gli porgesse il frutto vietato. Eva fu la prima a peccare, ma non perchè l'abbia voluto lei, porse ad Adamo parte del frutto, per affetto ... È ammissibilile che Adamo abbia mangiato il frutto vietato, anche per far piacere ad Eva, ma l'attenuante dell'amore da parte di Eva, è delle più fondate, perchè l'amore è più da presumere in colui che offre, che in colui che riceve, e perchè si vede d’ordinario nella donna uno spiccato altruismo.” Original italics retained.

${ }^{84}$ Ibid., p. 50.

${ }^{85}$ Ibid., p. 12.
} 
by Thomas with a neutral comment, ${ }^{86}$ menses by contrast are considered as something so unclean that new mirrors would draw impurities from a menstruating woman. ${ }^{87}$ Consequently, due to the natural frailty of her body and her soul, woman needed to be subject to man. (Supplement, Question 81, Article III).

Woman's subjection conferred on the husband authority over her life, and defined her status and role in marriage. Salerno's questioning of such unlimited powers was in parallel with secular feminists' fight to have "marital authorization" banned from the statutes. In her treatise, Salerno pointed out that the husband's authority derived from his duty to maintain and protect the family. While it was based on his economic contribution, the services the wife rendered to the family were also, even though not expressible in monetary terms, equal in value. Should the wife work outside the home, she should be entitled to keep her wages and contribute, according to her own judgment, to the maintenance of the household, or, alternatively, if she had no income, the husband should not only provide for the family but also for her personal expenses. But Salerno went further than purely material arguments. Referring to the words of the Apostle Paul, "mulieres viris suis subditae sint", she emphasized that this dictum only implied woman's subordination to her husband, not to all other men and not to them as men. ${ }^{88}$ Moreover, the wife's dependence should not be harmful and detrimental to her personality, for which intelligence, conscience and freedom were as sacred as they were for her husband's. In defining the status of a wife vis-a-vis her husband, Salerno resorted to the phrase "adjutorium simile sibi" 89 - frequently used by exponents of femminismo cristiano as a premise for woman's social apostolate. Within the institution of marriage, Salerno recognized the husband's authority, but solely for the purpose of promoting common interests and protecting motherhood. ${ }^{90}$

As discussed in Chapter Two, Thomas effectively banished woman from any significant role in the hierarchy of the Catholic Church, making it patently clear that woman was not suited to the sacrament of ordination because the feminine gender could not occupy

\footnotetext{
${ }^{86}$ Ibid., p. 11.

${ }^{87}$ Ibid., p. 9.

${ }^{88}$ Ibid., p. 77.

${ }^{89}$ Ibid., p. 79.

${ }^{90}$ Ibid., p. 77: “Ogni autorità ha i suoi limiti imposti dagli scopi di essa, e quindi anche quella maritale ha limiti fissati dagli scopi, per i quali è voluta, che sono: l'unita d'indirizzo famigliare e la difesa della maternità. La donna quindi deve obbedire, sempre che, nelle disposizioni del marito non vi sia offesa di Dio, aperta e grave imprudenza, danno per i figliuoli, e nelle cose che concernono l'indirizzo dell'azienda domestica, fuori delle quali l'uomo non ha autorità sulla moglie, la quale perciò ha completa libertà di coscienza ed è padrona dei suoi atti.” Original italics retained.
} 
any exalted rank (Supplement, Question 39, Article I). ${ }^{91}$ Even worse, he denied woman any kind of office and intellectual occupation (Book II, Part II, Question 102, Article IV). ${ }^{92}$ Ordination of women to the priesthood would be shameful, not only because of the resulting promiscuity of the two sexes, but because it would be against "the law". 93 The only position Thomas grudgingly conceded to women within the Church - that of an abbess - was an authority “delegated” merely to preclude men and women from residing together. ${ }^{94}$ While presumed defects of intellect (intelletto) and will (volontà), writes Salerno, would be reasonable arguments for excluding women from the priesthood, denying them ordination for their alleged stupidity (imbellicità) and lust (lussuria) proved how the Church had implicitly cultivated and fomented male egoism and gender jealousy. ${ }^{95}$ As Elisa Vicentini observes, ${ }^{96}$ Salerno did not campaign for women's ordination to the "official” priesthood since, in her view, they were already, by their very nature, promoters of the spiritual good. Therefore the official priesthood of women would duplicate this function. ${ }^{97}$ Although their ordination was not on her agenda, Salerno nevertheless demanded a greater religious and educational role for women within the Church. Because of their alleged incapacity, she wrote, women were unable to "partake in the gift and grace of the Word", as if it would only belong to someone who officially taught in the Church. ${ }^{98}$ In her view, woman's role was equal to that of the Mother of God who gave the Apostles themselves lessons full of wisdom, counsel and knowledge:

Parmi ... lecito supporre che la Benedetta fra le donne, dopo essere stata la Madre di Dio, abbia dovuto esserlo ancor della Chiesa, impartendo agli Apostoli lezioni piene di sapienza, e di consiglio, e di scienza. ${ }^{99}$

Any kind of reform introduced by the Church, Salerno noted, would leave women worse off. As an example she quoted Pius X's reform of sacred music in 1903, which

\footnotetext{
${ }^{91}$ Ibid., p. 19.

92 Ibid., p. 14.

93 Ibid., pp. 20-21.

${ }^{94}$ Ibid., p. 19.

${ }^{95}$ Ibid., p. 29.

${ }^{96}$ Vicentini, Una chiesa per le donne, cit., p. 57.

${ }^{97}$ Salerno, Per la riabilitazione della donna, cit., p. 81: ”Al sacerdozio ufficiale, accedono soltanto gli uomini, perchè la santità del divino ministero richiedeva che i sacerdoti fossero scelti tra le persone d'un solo sesso, e perchè la donna è naturalmente zelatrice del bene spirituale, promotrice della religione e sarebbe un bis in idem se ella, al sacerdozio naturale, unisse i compiti del sacerdozio ufficiale”. Original italics retained.

98 Ibid., p. 20: “Alla donna, in base all'incapacità, onde è colpita dalla Chiesa, si nega che possa appartenere il dono o grazia della parola, quasi mettendo limite alla liberalità divina, e come se il dono della parola fosse dovuto soltanto a chi insegna ufficialmente nella Chiesa, mentre esso può aversi indifferentemente dall'uomo e dalla donna e può essere efficacemente usato in varie guise dall'uno e dall'altra, a bene della religione e della civiltà".

99 Ibid.
} 
excluded women from participation. ${ }^{100}$ Her criticism of the ban on women in sacred music was in contrast to the docile manner in which L'Azione muliebre accepted the papal decree at the time.

It is noteworthy that Salerno regarded the doctrine of the Immaculate Conception of Virgin Mary, which was promulgated by Pius IX in 1854, as having been directly inspired by the Holy Ghost. ${ }^{101}$ As she elaborated, for example, in Dottrina cristiana sulla donna (1924), Mary’s “pure” femininity, instead of setting her apart from other women, served them as a model - not because it embodied the traditional womanly virtues of obedience, silence and patience - but as a source of inspiration for the emancipation and elevation of womanhood. ${ }^{102}$ In Per la riabilitazione della donna, she pointed out that immaculate conception contradicted science and the laws of nature, and that it was distressing (penoso) to resort to it to explain Mary's motherhood (maternità) which in itself demonstrated the biological importance of woman. ${ }^{103}$

Salerno could not remain blind to questions of sexual morality. She saw the unequal status of men and women reflected in the application of double standards in moral issues, such as in cases of adultery, so that while woman's failings were always judged very harshly, the attitude toward man tended to be more indulgent. In an inequitable manner, the moral code bestowed rights on men but imposed duties on women. In Per la reabilitazione della donna, Salerno briefly dealt with moral issues, writing that the erroneous tenets of the Church had given encouragement to the trade in human flesh. ${ }^{104}$ Like other Catholic feminists, Salerno argued for the "abolition" of prostitution, while also recognizing that its eradication necessitated the introduction of certain minimum welfare standards, such as the provision of various types of pension and leave,

\footnotetext{
${ }^{100}$ Ibid., p. 22.

${ }^{101}$ On p. 86 of Una chiesa per le donne, cit., Vicentini writes: "In rapporto alla storia della Chiesa, il dogma dell’Immacolata Concezione proclamato nel 1854 da Pio IX, è un dogma in cui la Salerno riconosce l'assistenza dello Spirito alla Chiesa e la sua presenza stessa . È uno di quei dogmi, insomma, proclamati ex cathedra in cui si può riconoscere l’infallibilità pontificia e che la Salerno porta ad esempio." Original italics retained.

102 Elisa Vicentini, “Elisa Salerno e l’’eresia antifemminista’”, Bailamme, n. 5/6, pp. 149-150.

103 Salerno, Per la riabilitazione della donna, cit., pp. 8-9: "Quelle teorie se erano contro la evidenza dei fatti nei tempi antichi, a leggerle oggidì, con tanta luce fatta dalla scienza, appaiono ancor più stridenti con le regole manifeste della natura, e fa pena vederle usate per ispiegare la divina maternità di Maria, che è tale fatto che basta da solo a provare tutta l’importanza biologica della donna”.

104 Ibid., p. 16: "Parmi di non essere lontana dal vero pensando che di cotali erronei principi, molti possano essersi sentiti incoraggiati al turpe mercato di carne umana, alla tratta delle bianche, persuasi che sia poco male sfruttare il corpo della donna. Mercato o tratta che sono il cancro della civiltà, e contro cui i cattolici purtroppo non ispiegano uno zelo soverchio.” Original italics retained.
} 
unemployment benefits, maternity pay, etc. ${ }^{105}$ She called for a change in social attitudes so that, for instance, a young woman, who had been seduced and abandoned by her lover, would not be victimized by her family as well, and be forced into the street. ${ }^{106}$ Dealing in her later work, Le tradite (1952), with the application of different moral standards to the two sexes, Salerno typically sought reasons for it in Catholic dogma, especially in the writings of St. Alphonsus Liguori. ${ }^{107}$

\section{$\underline{\text { Women and Education }}$}

From the time she began her doctrinal studies, Salerno's preoccupation with antifeminism in the Church increasingly informed her writing. This is also evident in how she dealt with issues which she had "inherited" from femminismo cristiano, such as women's education, their rights in the workplace, and their juridical and political rights. Here a significant paradigm shift is noticeable. In comparison with other feminists, Salerno does not merely ask for equal rights for women, but often turns the tables by questioning social practices which assigned the male sex its privileged position. To Salerno antifeminism was a form of paganism, and for this reason it was not secular feminism but femminismo cristiano which would have the necessary weapons to overcome it. In departing from sane Catholic morals secular feminism was by its very nature "pure paganism”:

Il femminismo ... è una dottrina ed un movimento ed un movimento che tende a rivendicare alla donna il suo posto nella famiglia e nella società, negatole, nella misura in cui il paganesimo rimase o seppe infiltrarsi nei costumi privati e pubblici; per cui, a propriamente parlare non vi è che un solo femminismo, il femminismo cristiano, sia perchè questo solo ha forza e virtù di vincere il paganesimo, e sia perchè il femminismo d'ogni altra scuola, in quanto che si dilunga dalla dottrina cristiana e si oppone alla sana feconda morale cattolica, è esso pure paganesimo. ${ }^{108}$

On many social issues, however, Salerno's attitude was not very different from that of secular feminism. Both recognized the key role which education played in women's emancipation, even though Salerno, like other Catholic feminists, differed from secular feminists by emphasizing the importance of religious education.

\footnotetext{
105 Elisa Vicentini, "Elisa Salerno e i problemi sociali”, in Centro documentazione e studi "Presenza Donna”, Il femminismo cristiano di Elisa Salerno e le sue prospettive, Vicenza, 1988, p. 91. The publication henceforth referred to as Il femminismo cristiano di Elisa Salerno e le sue prospettive.

${ }^{106}$ Ibid., p. 92.

${ }^{107}$ For a brief discussion of St. Alphonsus Liguori, see Chapter Two, p. 74.

108 “Trattazione sulla donna. Parte I. - Agli antifemministi”, in La Donna e il lavoro, a. 3, n. 32, 9 agosto 1912, p. 3. Original italics retained.
} 
Regardless of social class, argues Salerno, women should study for their own benefit at a level suited to their cultural background, to enable them to fulfil their educative mission, to promote religion, to satisfy their own financial needs, to overcome adversities, and to contribute to the salvation of society and to the progress of civilisation. ${ }^{109}$ In terms of intellect, Salerno compares woman to a miraculous machine, which, with the help of God, manufactures products of optimum quality and, despite being held idle by relentless and unreasonable (antifeminist) competition, manages to provide many wonderful goods:

A questo punto noi possiamo paragonare la donna, nel suo valore intellettuale, ad una macchina, vicino alla quale sta, da un lato, il suo sapiente Inventore e Costruttore (Dio e la divina rivelazione) per dirci e garantirci ch'essa è capace di dare un'ottima produzione, e dall'altro lato sta una quantità di merce scelta (esperienza e storia) prodotta dalla macchina la quale, nonostante fosse tenuta inoperosa, da uno sfrenato ed irragionevole spirito di concorrenza, ebbe tanta potenza da riuscire a darci mirabili frutti. ${ }^{110}$

As Elisa Vicentini points out, Salerno did not produce a single publication on educational issues but, instead, commented on them throughout her entire work. ${ }^{111}$ She shared with other Catholic feminists a belief in women's moral and educative mission in the family and in society, as well as a belief in women's equal rights to education. Her fundamental position was that, irrespective of gender, children should be educated according to their aptitudes to be eligible for a variety of occupations. Nevertheless, owing to the generally held expectation of women fulfilling their social role as mothers, and also to her personal ideas of women's predominant aptitudes, Salerno laid emphasis on women's study of theology, philosophy and pedagogy, but campaigned less vigorously for women's entry into the scientific field. This was not to deny women's suitability for the liberal professions or for institutions of higher learning, even though in such cases Salerno, in line with contemporary Catholic thinking, envisaged women's employment chiefly in teaching, welfare related activities, and in redressing social ills. $^{112}$ Professional employment, as pointed out previously, was regarded by many Catholics as conflicting with the maternal role of women, although the same concern did not seem to apply to women performing manual tasks. Not impervious to this apparent contradiction, Salerno reasoned that reconciling parenting with an outside job

\footnotetext{
109 “Trattazione sulla donna. Parte V. - Istruzione”, ibid., a. 4, n. 7, 14 febbraio 1913, p. 3.

110 “Trattazione sulla donna. Parte III. - Quid est mulier?”, ibid., a. 3, n. 51, 20 dicembre 1912, p. 3.

${ }^{111}$ Vicentini, Una chiesa per le donne, cit., p. 131.

112 Salerno, “Trattazione sulla donna. Parte VI. - La donna nella famiglia e nella società”, La Donna e il lavoro, a. 4, n. 14, 4 aprile 1913, p. 3.
} 
was much harder for working-class women who often had to combine arduous physical work with nurturing a large family, while middle-class professional women, less stressed physically and on higher salaries, were better equipped to provide for their family and for unforeseen adversities. ${ }^{113}$

Salerno took up a number of issues which had been only fleetingly, if at all, dealt with by the contemporary feminist movements. They included the inculcation in children, from early on, of gender roles and of traditional attitudes toward academic learning and physical education; the failure of the Catholic education system to provide for women; the intrinsic value of higher education, that is, the notion that education is valuable for its own sake; and gender discrimination in education regarding women religious.

Remarkably, Salerno's criticism of the patterning of children's behaviour to conform to preconceived gender norms happened at a time when, especially in the official Catholic women's movement, women were urged to return to their traditional roles. She noted that from an early age children were educated for particular tasks, depending on their gender, through customary attitudes and gestures which were then reinforced by formal education. Salerno's writings abound in phrases which provide examples of gender bias in everyday living. A child's future was already determined at the time of birth:

È venuta al mondo una bimba? sarà una massaia. È un bimbo? sarà un fannullone fino all'adolescenza, età in cui comincierà ad imparare un'arte qualsiasi. $^{114}$

During childhood, while girls had to stay at home to help their mothers, boys were permitted to roam about freely, and would, as a matter of course, have their torn clothes mended by their sisters whom they would learn to regard as their subordinates:

... le fanciulle devono stare a casa, devono aiutare la mamma, devono imparare a cucire, perché i fratelli strapazzano i vestiti senza misericordia, e guai se lei non sapesse rammendare ... Sicché noi vediamo la sorella, punto bisognosa di svago, intenta a rammendare i calzoni strappati del fratello, e questi, chi sa dove, a logorarne anzitempo un altro paio. ${ }^{115}$

To prepare a girl for her future role as wife and mother, she was given a doll to play with, which would neither develop her intellect nor encourage her to physical activity. Thus gender prejudice could thwart even her physical development, because it was

${ }_{113}$ Ibid., a. 4, n. 15, 11 aprile 1913, p. 3.
${ }^{114}$ Salerno, Un piccolo mondo cattolico, cit., p. 99.
${ }^{115}$ Bianca (Elisa Salerno), “L'autunno operaio”, Il Berico, a. XXXI, n. 218, 27 settembre 1906. 
feared that fresh air, the sun and the exercise of her body would foster an independent spirit in her:

Si teme che l'aria ossigenata, la luce, il calore del sole, la ginnastica delle membra sveglino, nella giovane, lo spirito d'indipendenza perciò la donna deve star sempre ritirata, fin dall'età infantile, priva di spazio e di moto. ${ }^{116}$

Very often the most inveterate antifeminists were the mothers themselves:

Esse, le madri, adoperano una morale educativa a due tagli, e ben diversa a seconda del sesso: quello che trovano perdonabile e perfino legittimo nei maschi, condannano rigorosamente nelle fanciulle ... Così è che per opera delle madri i fanciulli crescono con idee storte riguardo alla donna ed ai problemi sociali. $^{117}$

Enforcement of gender roles continued through a binary education system, which in the case of girls focused on preparing them for marriage and motherhood, whereby academic learning was discouraged. This accorded with the official policy of the Church, which saw the purpose of women's education solely in the acquisition of domestic skills:

Non importerà nulla se non sa il francese e non conosce l'ultimo romanzo o l'ultima moda; ma sarà apprezzata se conosce e sa eseguire anche i più umili, o almeno i più indispensabili doveri di una buona massaia, di una sposa e di una madre accurata e saggia. ${ }^{118}$

Without incentives and economic means to further their education, in a society which idealized the ignorant woman while ridiculing the educated one, women were encouraged to devote their energies to fashion and other vain pursuits which, argued Salerno, were callously promoted by men for financial gain and for sexist reasons. Adele Cinzia, Salerno's alter ego in Al bivio, puts it succinctly:

Non è di moda, cara signora, che le donne studino e molto meno che mostrino di tenere a certi studi. ${ }^{119}$

Salerno was scathing in her criticism of Catholic education for women, finding Catholic colleges, educandati, superficial in the treatment of academic subjects and harmful in their outcomes. In Al bivio Salerno lets the male protagonist, the idealized Count Arnaldo Lorini, express her own censure of Catholic women's education. Before starting school, his two sisters, says Lorini, were physically strong (forti di membra)

\footnotetext{
${ }^{116}$ Salerno, Per la riabilitazione della donna, cit., p. 38.

117 Salerno, “Trattazione sulla donna. Parte VI. - La donna nella famiglia e nella società”, La Donna e il lavoro, a. 4, n. 18, 2 maggio 1913, p. 3.

${ }^{118}$ Giuseppe Stocchiero, Pratica pastorale, 5. edizione, Vicenza, Società anonima tipografica, 1936, p. 577.

${ }^{119}$ Salerno, Al bivio / Elisa Salerno oltre il bivio: tra giornalismo e romanzo, cit., 1998, p. 99.
} 
and clever (belle d'ingegno), but ten years there had turned them into idiots. ${ }^{120}$ What school had done to them was to sap their energy, to blunt the sharpness of their intellect, and to weaken their mind. It had instilled in them the idea that women must not know anything, and apparently every day at school had removed a bit of brain from their cranium. Physical activity, which exerted a beneficial moral and psychological influence on a child, was banished in all its forms, as illustrated by an incident where a girl, bathing in the sea on the doctor's advice, was expelled from college because of the alleged corruptive effects of such a cure. There were, in addition, environmental factors which were unfavourable for women's education, as exemplified by a casual comment by a friend of Arnaldo's:

Al diavolo tutte le donne sapienti, ragionanti, pensanti, disputanti! a me piacciono le donne che restano donne. ${ }^{121}$

Such negative influences were reinforced by parents' protective and lenient attitudes to their daughters as well as readiness to cater for their every need, which prevented young women from learning to care for themselves.

Furthermore, Al bivio highlights the notion of the intrinsic value of education. In it, the heroine of the novel, Lucia Roselna, has to make a choice between a lucrative marriage proposal and her personal inclination toward study and social commitment. In the unrealistic setting of Salerno's novel, no parental pressure is exerted on the daughter to accept the seemingly excellent suit; while the prospective groom, Count Lorini, is prepared to wait for years to enable his future wife to complete studies in theology and philosophy in order to qualify for her social apostolate. Far from being a romanzo rosa, however, and apart from dealing with the inadequacy of traditional education for women, the novel also puts forward the idea that women have the right to be educated, even if the benefits may not be economic or immediately apparent. The uncle Gustavo, a university teacher, represents conventional wisdom with his concerns about higher education being wasted on women, who, if single, might not find suitable employment; or, in case of marriage, might discontinue their study prematurely. The uncle's negative views are juxtaposed with the enlightened attitude of Lucia's father who acknowledges the value of education, even when it is not directly linked to employment prospects. The father, a lawyer, has never exercised the legal profession, but has found the grounding in that discipline of great value in his work in other fields. In his eyes, it was

\footnotetext{
${ }^{120}$ Ibid., pp. 42-43.

${ }^{121}$ Ibid., p. 70.
} 
a crime to starve women's minds by imposing restrictions on their learning, and it was immoral if their only occupation was to wait for husbands. ${ }^{122}$

The binary education system extended to religious orders, in which men had almost unlimited intellectual opportunities, while women religious were condemned to ignorance, being inferior to lay women, lacking even the worldly experience of the latter:

... la grande diversità tra lo stato d'animo dei religiosi e quello delle religiose: I primi sono posti si può dire in faccia al sole, per la perfezione della conoscenza che raggiungono nell'Ordine religioso da essi abbracciato, ove vanno avanzando nelle luminose vie della verità, rendendosi intellettualmente superiori al comune degli uomini che vivono nel secolo; mentre, all'opposto, la religiosa è condannata a vivere nell'oscurità, e, dal punto di vista intellettuale, è inferiore alle donne secolari, perchè queste sono almeno forzate ad aprire gli occhi dalle esperienze della vita. ${ }^{123}$

In comparison with men's preparation for the Catholic ministry, nothing of a similar quality, deplores Salerno, was available in the Church for Catholic women religious who, if they wanted higher education, had to acquire it in secular institutions. To further their studies they had to enrol at secular licei and universities where they would study together with male students and would receive instruction from atheist or excommunicated professors:

Non vi sono scuole superiori per le donne, nella Chiesa; gli istituti femminili, per lo più, possono dirsi dei reclusorii. Se la donna vuole istruirsi, bisogna che vada, insieme con i maschi, nelle università, nei licei laici, da professori atei, o scomunicati. $^{124}$

On the other hand, as Salerno discovered, antifeminist attitudes were fostered and encouraged in young men entering Catholic seminaries by the way they were taught:

Anni fa, ho domandato al Direttore spirituale del Seminario di Vicenza, perchè denigrava le donne davanti ai ragazzi di quell’istituto ... Egli mi rispose: "Perchè imparino a star lontani dalle donne." 125

To elucidate problems confronting women religious trying to educate themselves as well as be recognized for their intellectual contributions, Salerno refers to St. Catherine of Siena (1347-1380) and St. Theresa of Avila (1515-1582), both important figures in the history of the Catholic Church. Even though both women left behind mystical and doctrinal treatises, because of their sex they were denied the title of Doctor of the

\footnotetext{
${ }^{122}$ Ibid., pp. 71-83.

${ }^{123}$ Salerno, Per la riabilitazione della donna, cit., p. 42.

${ }^{124}$ Ibid., p. 83.

${ }^{125}$ Ibid., p. 24.
} 
Church. ${ }^{126}$ Because of her lack of education, Theresa in particular was conscious of her inability to communicate her experiences adequately and, turning to God, spoke of the blindness and disorientation of an ignorant woman:

... Ciò che c'inganna - scrive la Santa - è, che immaginando noi nostra unica scienza dover essere di pensar a Voi (a Dio), neppur sappiamo interrogare quelli che sanno, nè crediamo che vi sia cosa da domandare, e, per non conoscere noi stesse, passiamo terribili travagli; ciò che è bene ci sembra male, e teniamo come colpa cose che non sono colpa altrimenti. ${ }^{127}$

Parenthetically, one may note that the autodidact Salerno must have felt particular empathy towards Theresa. In her case, too, the attitudes of the Church hierarchy were conditioned by the fact that she was a woman and had received little formal education, as becomes apparent from Bishop Rodolfi's letter to Cardinal De Lai on 18 February 1915 concerning Salerno’s activities as a journalist:

... la mancanza di sufficiente cultura nella Direttrice, la quale si impanca in scienze sociali, in filosofia, in teologia, in Sacra Scrittura, senza competenza e spropositando talora grossolanamente: alienandosi così la parte seria dei lettori e procurandosi anche gravi critiche. ${ }^{128}$

\section{Labour Issues}

With equal ardour Salerno dedicated herself to employment issues, and had a lot to say about women's rights at work. As with education, her discussion of labour issues did not take the form of a special publication but occurred principally through her periodicals La Donna e il lavoro and Problemi femminili. But even before launching her first periodical, Salerno had already dealt with labour problems in other journals, mainly in Il Vessillo bianco, in which she had run a regular column Cronaca femminile from the end of 1905 to June 1909. ${ }^{129}$

Both of Salerno's periodicals were modest four-page publications. As regards $\mathrm{La}$ Donna e il lavoro, which had the subtitle Giornale delle classi lavoratrici femminili, every issue was dominated by topics related to female labour. Salerno's periodical regularly included features such as the current affairs bulletin In settimana, lists or reviews of new publications under the heading Pubblicazioni; and Piccola corrispondenza. It also carried a variety of advertisements which - with the exception

\footnotetext{
${ }^{126}$ The title of "Doctor of the Church" was later conferred upon St. Teresa and St. Catherine of Siena by Pope Paul VI.

${ }^{127}$ Salerno, Per la riabilitazione della donna, cit., p. 62.

${ }^{128}$ Quoted in Cisco, Elisa Salerno e "Un piccolo mondo cattolico”, cit., pp. 62-63.

${ }^{129}$ Gianni A. Cisotto, “Femminismo sociale a Vicenza”, Civitas, v. XXXVI, n. 2, 1985, p. 52.
} 
of La Donna, organ of the Fascio femminile milanese - were generally absent from other Catholic women's periodicals. Her articles covered a wide range: women's employment in industry and agriculture, arbitration in labour disputes, gender-related matters, women's pay, social change, the maternity fund, employment of minors, problems of urban living, emigration, women's congresses, women's unions, the papacy, and prostitution. The activities of the Unione fra le donne cattoliche d'Italia were followed, and later, of course, issues related to World War I were taken up. While still reporting on these matters, but with an increasing emphasis on gender and doctrinal issues, Salerno's second periodical, Problemi femminili, carrying the subtitle Periodico nazionale delle operaie, impiegate, professioniste, turned to some new topics, such as the Catholic Partito popolare italiano and the emergent Catholic women's youth organization, the Gioventù femminile.

It is difficult to estimate to what extent Salerno's journals reached their declared target readership, that is, women workers. Any shortcomings in this respect would not have been due to a lack of entrepreneurial flair on her part. Considering that for all their ecclesiastical backing, L'Azione muliebre could barely muster 120 subscriptions and La Donna, the organ of the Fascio femminile di Milano, some 400 in the fourth year of their operations, ${ }^{130}$ it is remarkable that within a year of its inauguration La Donna e il lavoro was budgeting for 3,000 standard annual subscriptions at 2.50 lire each to enable half-price subscriptions to female workers on the basis of bulk deliveries of ten copies. $^{131}$ Moreover, as regards content and circulation, Salerno did not intend to restrict her paper to a purely local market. In its third issue one reads that it was for sale ... in tutti i Comuni e Città del Veneto, a Mantova, a Firenze, a Reggio Emilia, Lodi, Macerata, Rimini, Crema e Bari. ${ }^{132}$

Salerno's ambitious projections could not be easily met, however. On 11 March 1910, for example, she wrote to Antonio Fogazzaro asking for a financial contribution, obviously finding it hard to meet the weekly printing costs with a mere 200 subscriptions. $^{133}$ Despite all her efforts, Salerno was not breaking even, and had to dip into her own pocket to keep her paper going:

Riguardo al bilancio finanziario, diremo che siamo un po' in deficit, a motivo che abbiamo dato il periodico a lire 1.30 all'anno alle operaie. L'aumento di queste abbonate ci rallegra, perciò preghiamo i nostri amici di voler rinnovare

\footnotetext{
${ }^{130}$ Coari's letter to Radini Tedeschi, 19 June 1904, FAC 3536.

131 “Condizioni di abbonamento”, La Donna e il lavoro, a. 2, n. 53, 23 dicembre 1910, p. 1.

${ }^{132}$ Ibid., a. 1, n. 3, 7 gennaio 1910, p. 3.

133 Salerno’s letter to Fogazzaro, 11 marzo 1910, BCB, Busta E. Salerno 1b.
} 
presto l'abbonamento e di trovarci ciascuno un nuovo abbonato, nella certezza che la loro azione sarà ultimamente meritoria, mentre ci offre la possibilità di diffondere sempre più La Donna e il Lavoro fra le masse lavoratrici femminili. ${ }^{134}$

Bearing in mind the large numbers of women working in industry, Salerno lamented in April 1914 that, after five years of publication, the demand for her paper had not yet reached even 10,000 copies, while noting the increasing circulation of the rival socialist paper, La Difesa delle lavoratrici. ${ }^{135}$ The latter had been launched two years previously at the initiative of Anna Kuliscioff with the aim of reaching women in industrial and agricultural employment. The first official organ of Italian socialist women, it achieved, in its inaugural year, a respectable 14,000 subscriptions. ${ }^{136}$ In both cases, however, one would have to argue that reaching a high circulation rate among female labour was wellnigh impossible. Illiteracy was still a problem. Moreover, as Tamara Ermini observes, after fulfilling their work and family commitments, working-class women had little time left for reading or for taking interest in industrial matters:

Le condizioni di vita delle lavoratrici della terra erano ancora più problematiche, se possibile, di quelle delle operaie delle fabbriche, ma vi era un dato condiviso. Per entrambe, terminato il lavoro, mai inferiore alle dieci ore sia per il campo sia per lo stabilimento, incominciava un nuovo impegno, non meno duro e faticoso del primo, nella famiglia. La donna operaia o contadina non conosceva il riposo festivo perché essa, nei giorni liberi, lavorava sempre intensamente per svolgere le faccende della casa. In queste condizioni di vita era difficile pensare che le donne trovassero anche il tempo per leggere il giornale, istruirsi ed interessarsi delle questioni che agitavano le organizzazioni economiche. ${ }^{137}$

Despite problems of reaching large numbers of working-class women, La Donna e il lavoro, especially in the first years of its publication, never lost sight of its perceived responsibility to inform its target readership. The paper was characterized, above all, by the concreteness of the data it provided. Salerno writes in December 1911:

Infatti, tutta l'importanza del periodico dipende dal suo carattere professionale nel quale perciò è tutta la sua ragione di essere.

Per questo, nell'anno che sta per finire, abbiamo curato maggiormente la trattazione dei problemi del lavoro, e l'anno venturo seguiremo più davvicino il movimento sindacalista italiano ed estero, pubblicheremo di preferenza dati statistici, informazioni, sull'organizzazione di classe, sull'emigrazione, sulle scuole menagère, e professionali, sì da farne il vade-mecum dell'operaia che desidera la propria elevazione ed il miglioramento della propria classe, come

\footnotetext{
134 “’La donna e il lavoro’ nel 1912”, La Donna e il lavoro, a. 2, n. 50, 15 dicembre 1911, p. 1. Original italics retained.

135 “Rivelazioni e appelli”, ibid., a. 5, n. 8, 24 aprile 1914, p. 1.

136 Tamara Ermini, "La difesa delle lavoratrici”. Un giornale di lotta e coscienza (1912-1925), Firenze, Centro editoriale toscano, 2005, pp. 9-12.

${ }^{137}$ Ibid., pp. 49-50.
} 
delle esimie signore, dei giovani fervidi, che a quella elevazione multiforme intendono di dare le loro preziose energie. ${ }^{138}$

To obtain facts and figures, Salerno carried out surveys on the condition of women workers and reported on surveys undertaken by others. Even Pensiero e azione, which was instrumental in setting up study circles to research social problems, did not, by contrast, publish facts and figures to the same extent as Salerno's papers did. In June 1907 the Milanese periodical announced that the Federazione femminile would commence a survey on the condition of female textile workers with a view to founding a national union and asked readers to send their responses to the ten questions which it published. ${ }^{139}$ Like Murri's survey on the woman question, discussed earlier, this was a survey based on a self-selecting sample. The next issue of Pensiero e azione printed two responses, both of which were in sympathy with the idea of founding a union, but neither attempted to answer any of the questions let alone provide quantitative data. ${ }^{140}$ After the publication of these two responses the periodical fell silent on the survey.

La donna e il lavoro, on the other hand, contained articles and ample statistics on the status quo of women workers. From its very first issues in 1909 to 1912 the paper carried out, in a series of articles, a survey on factories and trades employing women in Vicenza. Sergio Spiller, who in his article "La condizione materiale della donna al lavoro” analyzes Salerno's survey in great detail, notes that little is known of her investigative methods, but assumes that she would not have had at her disposal means commensurate with those of the Catholic employment office (Ufficio cattolico del lavoro), which also conducted various labour surveys. It is not known, comments Spiller, whether Salerno undertook her survey entirely by herself or whether she

\footnotetext{
138 “’'La donna e il lavoro’ nel 1912'”, La Donna e il lavoro”, a. 2, n. 50, 15 dicembre 1911, p. 1. Original italics retained.

${ }^{139}$ The questionnaire consisted of ten questions:

"1. Quante operaie vi sono nel vostro stabilimento?

2. Di queste quante sono donne maritate?

3. Quante, ragazze dai 12 ai 16 anni?

4. Lavorate a cottimo o a giornata? Quale modo preferite?

5. Qual'è la paga media per le apprendiste, le filatrici, le tessitrici?

6. Quale orario avete?

7. Ci sono squadre di muta nei lavori di preparazione? Quale orario hanno?

8. Quando avete ottenuto questo orario? Avete avuto scioperi da poco tempo? Perchè? Come terminarono?

9. In complesso come vi trovate nel vostro stabilimento?

10. Quali sono i provvedimenti che più desiderate?”

“Per le tessitrici”, Pensiero e azione, a. III, n. 11, 25 giugno 1907, "Le pagine dell’operaia”, p. 2.

140 "Risposte delle operaie", ibid., a. III, n. 12, 10 luglio1907, "Le pagine dell’operaia”, p. 2.
} 
employed others to complete it. ${ }^{141}$ In Salerno's own view, official surveys left much to be desired because they were usually late in reporting, incomplete, did not consider all relevant factors, and were carried out by people lacking aptitude and interest. ${ }^{142}$

Methodological concerns aside, Salerno's survey was both informative and incisive. In the case of the silk industry, the cotton industry and the metallurgical industry, the examination of the local scene was preceded by an overall summary at the national level. ${ }^{143}$ The survey covered four silk spinning factories and a silk weaving factory, a cotton spinning and weaving factory, an association of fifteen gold workshops, a metal works, and a pasta factory. In addition, there were studies of various trades in which work could be undertaken on the employers' premises or at home. They included quilting, dressmaking, sewing, pearl decoration, and sole attaching in shoemaking. In each case, the survey provided information on work methods and processes, the number of male and female employees, the length of the working day, wages, working conditions and associated problems, and data peculiar to the enterprise.

Salerno went to great lengths to understand the methods of production of every factory or trade included in her investigation, and to obtain information on the production time, the cost and the price of a particular item. She found that working conditions varied from industry to industry, and that within each industry distribution of jobs between male and female employees depended on the skill level, with more expert jobs going to men. Women were sole suppliers of labour in dressmaking, quilting, sewing linen and underwear, pearl decoration, and sole attaching. They dominated the spinning and weaving industries and pasta making, but were in the minority in the gold and the metal industry. Another feature revealed by Salerno’s survey was the extensive use of female migrant labour in silk spinning where they constituted seventy per cent or more of the total female labour. ${ }^{144}$ Apart from wages, the employer provided the migrant women with accommodation either in rooms or dormitories as well as some basic necessities. The number of women employed varied from single-digit numbers in some tailoring

\footnotetext{
${ }^{141}$ Sergio Spiller, "La condizione materiale della donna al lavoro”, in La donna e il lavoro, cit., pp. 41, 38.

142 “Un’altra parola sulle inchieste”, La Donna e il lavoro, a.1, n. 30, 15 luglio 1910, p. 1.

"Inchiesta sul lavoro delle donne. Italia. Il cotone", ibid., a. 1, n. 12, 11 marzo 1910, p. 3.

143،Produzione della seta in Italia”, ibid., a. 1, n. 1, 24 dicembre 1909, p. 3.

"Inchiesta sul lavoro delle donne. Industria metallurgica”, ibid., a. 1, n. 36, 26 agosto 1910, p. 3;

“Industria mineralogica e metallurgica”, ibid., a. 1, n. 37, 1 settembre 1910, p. 3.

144 “Inchiesta sul lavoro delle donne. Vicenza. 'Setificio Schroeder’”, ibid., a. 1, n. 3, 7 gennaio 1910, p. 3; “Setificio Verlato”, ibid., a. 1, n. 6, 28 gennaio 1910, p. 3; “Setificio Sammartin”, ibid., a. 1, n. 7, 4 febbraio 1910, p. 3; “Setificio Gregorina”, ibid., a. 1, n. 9, 18 febbraio 1910, p. 3.
} 
establishments and from twelve in the pasta factory, ${ }^{145}$ to a total of approximately 415 employed by Cotonificio Rossi in cotton spinning and weaving. ${ }^{146}$ As regards the length of the working day, it varied from nine to eleven hours, and was sometimes subject to seasonal variation in starting and finishing times. With the exception of two silk mills, the women were not required to work on Sundays. It is interesting to note that in the spinning department of Cotonificio Rossi, where the length of the working day was eleven hours, the number of days worked had been reduced to five. ${ }^{147}$ Management had adopted a variety of responses to deal with late arrival at work. Some employers tolerated it, others fined the worker, and one employer did not allow late entry after the gate had closed, ${ }^{148}$ while Cotonificio Rossi had set in place an incentive scheme whereby those workers, who had regularly arrived on time, received an extra twenty centesimi per day paid each fortnight. ${ }^{149}$

Regarding remuneration, the labour survey must have heightened Salerno's awareness of the merciless exploitation of women, as she compared it to a form of slavery in an article written just a year later as part of her series Trattazione sulla donna:

La scarcezza del salario dà al lavoro femminile il carattere di schiavitù, spinge la donna alla prostituzione, la affama, la logora, travolgendo insieme la specie umana. $^{150}$

Only rarely, she noted, did women possess the necessary skills to receive a high wage. In general, the amount of pay remained well below two lire per day, and only in very exceptional cases did it exceed that amount. Seamstresses, for example, were extremely lowly paid, because people were unwilling to pay for something that was once made at home at no cost:

Va notato ... che i lavori di biancheria, in tempi non molto remoti, erano eseguiti per conto proprio dalle famiglie, le quali perciò non pensavano a tariffe, a contratti, a concorrenze. Onde, a mano a mano, che per mutamento di tempi, si trovò necessario di rivolgersi a persone estranee alla famiglia, si mantenne rispetto a loro quella, per così esprimerci, mentalità, quei criteri che ispiravano l'azione privata, non considerandosi le cucitrici, come le altre operaie, si credette che bastasse a pagare poco l'esecuzione d'un lavoro che prima si pagava nulla, e

\footnotetext{
145 “Inchiesta sul lavoro delle donne. Vicenza. Pastaie”, ibid., a. 1, n. 47, 11 novembre 1910, p. 3.

146 "Inchiesta sul lavoro delle donne a Vicenza. Trapuntiste in coltroni”, ibid., a. 2, n. 21, 26 maggio 1911, p. 3; "Sarte da donna”, ibid., a. 2, n. 23, 9 giugno 1911, p. 3; a. 2, n. 24, 16 giugno 1911, p. 3; “Cucitrici in bianco”, ibid., a. 2, n. 26, 30 giugno 1911, p. 3; a. 2, n. 28, 14 luglio, p. 3.

147 “Inchiesta sul lavoro delle donne. Vicenza. 'Cotonificio Rossi””, ibid., a. 1, n. 13, 19 marzo 1910, p. 3.

148 “Inchiesta sul lavoro delle donne. Vicenza. 'Setificio Verlato’”, ibid., a. 1, n. 5, 21 gennaio 1910, p. 3.

149 “Inchiesta sul lavoro delle donne. 'Cotonificio Rossi’. Vicenza”, ibid., a. 1, n. 18, 23 aprile 1910, p. 3.

150 “Trattazione sulla donna. Parte II - Una questione di libertà”, ibid., a. 3, n. 45, 8 novembre 1912, p. 3.
} 
la cucitrice in bianco divenne, col progredire dell'industria dell'ago, il tipo dell'operaia sfruttata sia essa ... imprenditrice o giornaliera. ${ }^{151}$

Considering the generally low rate of pay, the cessation of work for four weeks annually, as was the practice with many employers, caused much hardship. There was, of course, a difference in pay between women workers and women overseers (direttrici), but there was an even greater discrepancy between female and male wages, with the wage of the male worker exceeding that of a female overseer. The pay differentials largely reflected the fact that in industries in which men and women worked together women normally performed simpler tasks.

Certain positive aspects also emerge from the survey. Some employers had in place industrial accident insurance, provided nursing rooms for mothers, acknowledged the provisions of the law on the employment of women and children by displaying it, and in a few instances even paid for their employees' annual holidays. Two employers, Stabilimento Orefice and Cotonificio Rossi, gave their long-term female employees a substantial dowry upon their marriage. ${ }^{152}$ The paternalistic Cotonificio Rossi, owned by the Catholic Senator Alessandro Rossi, also made monetary gifts to needy widows annually and to "honest" women at childbirth, sent "anaemic" women and children on holidays in the mountains, and provided facilities in the factory for personal hygiene. ${ }^{153}$

But the negatives far outweighed the positives. In general, women workers were subject to a great deal of discomfort and even illness due to insalubrious working conditions. The worst working environment was to be found in the silk mills which were malodorous with high levels of humidity emanating from the hot water basins in which silk cocoons were unrolled by hand. As a result, women frequently became afflicted with a condition known as malattia delle bacinelle which was characterized by papular and pustular eruptions on hands and arms. ${ }^{154}$ In the silk mills, as elsewhere too, women were often required to work with their bodies and limbs bent in unnatural positions, to stand on their feet for hours, or to carry heavy loads out of proportion to their physical strength. In the cotton mill, on the other hand, women were subject to the

\footnotetext{
151 “Inchiesta sul lavoro delle donne a Vicenza. Cucitrici in bianco”, ibid., a. 2, no. 28, 14 luglio 1911, p. 3.

152 “Inchiesta sul lavoro delle donne. Vicenza. ‘Stabilimento Orefice”, ibid., a. 1, n. 11, 4 marzo 1910, p. 3

“Inchiesta sul lavoro delle donne. Vicenza. ‘Cotonificio Rossi’”, ibid., a.1, n. 19, 30 aprile 1910, p. 3.

${ }^{153}$ Ibid.

154 “Inchiesta sul lavoro delle donne. Vicenza. 'Setificio Schroeder”, ibid., a. 1, n. 4, 14 gennaio 1910, p. 3.
} 
deafening noise of the machines and the fibrous dust from cotton roves. ${ }^{155}$ The unsanitary work practices resulted in the occurrence of anaemia, tuberculosis, miscarriages, swollen legs, circulatory problems, and various other ailments.

While giving her unconditional support for Catholic trade unions, Salerno clearly disliked socialist unions. She even relates a case history of the gold industry in Vicenza, which went through turbulent times after a socialist cooperative tried to seize all the work by poaching employees from its rivals in the industry by offering superior pay and conditions. The cooperative soon foundered because of the lavish style of its socialist experimentation. Subsequently, fifteen local workshops joined to set up a Società anonima delle oreficerie vicentine, which was one of the enterprises included in Salerno’s survey. ${ }^{156}$

Altogether, as Spiller points out, Salerno’s survey makes a significant contribution to the understanding of the life of women workers in Vicenza at the beginning of the twentieth century. Salerno took upon herself to campaign for women's issues, not in the sense of a vague, cultural fad, but to work directly towards a positive solution:

Complessivamente "l'inchiesta sul lavoro delle donne a Vicenza" dà un grande contributo alla ricostruzione dell'universo lavoro nei primi anni del '900; fa emergere i problemi, le fatiche, i passi in avanti e le contraddizioni di quanti come la Salerno si facevano carico della promozione dei problemi femminili e non si limitavono ad una generica azione promozionale e culturale, ma intervenivano direttamente per dare una soluzione positiva. ${ }^{157}$

\section{Women's Rights}

The question of women's rights in the workplace was just one component of a whole complex of issues related to women's civil and political rights. The French Revolution had acknowledged the principles of liberty, equality and natural rights as applying to all men irrespective of their backgrounds. ${ }^{158}$ In the second half of the nineteenth century, philosophers and feminists began to demand similar rights for women, while the Catholic Church continued to regard women's subordination as natural and immutable. Then, with the burgeoning of the Christian democratic movement, Catholic women

\footnotetext{
155 “Inchiesta sul lavoro delle donne. 'Cotonificio Rossi’. Vicenza”, ibid., a. 1., n. 18, 23 aprile 1910, p. 3.

156 “Inchiesta sul lavoro delle donne. Vicenza. Industria dell’oro”, ibid., a. 1, n. 31, 22 luglio 1910, p. 3; a.

1, n. 32, 28 luglio 1910, p. 3; a. 1, n. 33, 5 agosto 1910, p. 3; a. 1, n. 34, 12 agosto 1910, p. 3.

${ }^{157}$ Spiller, "La condizione materiale della donna al lavoro”, cit., pp. 68-69.

${ }^{158}$ See Chapter Two, p. 76.
} 
were encouraged to become men's "helpmates" in the envisaged regeneration of society. The exponents of femminismo cristiano stressed the complementary nature of the two genders, and the need for the involvement of both sexes for any function to be performed in a perfect manner. This ultimately meant that, as complementary partners, women, too, needed civil and political rights.

In Salerno, likewise, the notion of the complementary nature of the two genders is apparent, as she writes:

L'uomo e la donna sono creati a immagine di Dio, Uno e Trino; sulla fronte di entrambi è impresso un raggio della divina maestà e grandezza. Ma l'immagine della Santissima Trinità si rinviene anche nella coppia umana, considerata come un tutto. ${ }^{159}$

But she went further. While recognizing the influence of gender characteristics on "the higher functions of the soul”, she stressed the essential equality of the two genders:

La donna è fondamentalmente eguale all'uomo: l'anima spirituale è la forma sostanziale di entrambi, l'elemento determinatore della loro nobiltà ed eccellenza, il principio operatore dei loro atti, la sorgente originale di tutte le loro perfezioni. L'uomo e la donna sono eguali nelle potenze volitive, raziocinative, intellettive, nella produzione, dirò così, degli atti di ragione, di volontà, nella capacità di sentire, di volere, di pensare, soggetti alle stesse leggi, mossi dalle stesse passioni irascibili, concupiscibili.

Ma le caratteristiche primarie e secondarie del sesso, senza impedire, nè diminuire le funzioni superiori dell'anima, ne colorano, quasi dirò, le operazioni, vi mettono alcunchè delle loro disposizioni ... ${ }^{160}$

Not unlike John Stuart Mill, Salerno acknowledged the principle of the common humanity of the two genders while simultaneously affirming gender-specific attributes. This was the premise of her campaign for equal rights for women.

Salerno addresses the question of women's rights, for example, in five articles entitled "Una questione di libertà", which form part of her series Trattazione sulla donna. Like Maria Baldo in her article "Il socialismo e la morale cristiana” in L'Azione muliebre, ${ }^{161}$ Salerno, regards the advantages enjoyed by women in civilized countries as stemming from the teachings of Christianity, and holds the view that, because of the inherent respect for human beings and their rights implied in Catholic morality, the Church could offer the best solution to the woman question. She goes on to say that, by contrast, civil

\footnotetext{
${ }^{159}$ Salerno, Per la riabilitazione della donna, cit., p. 46.

${ }^{160}$ Ibid., pp. 69-70.

${ }^{161}$ Maria Baldo [pseud. Costanza], “Il socialismo e la morale cristiana”, L'Azione muliebre, a. I, n. 8, agosto 1901, pp. 4-12.
} 
legislation by the State was often the outcome of human egoism, and showed traces of the influence of the class and the gender which had enacted it. ${ }^{162}$ Women should have the right, she claims, to participate in drafting legislation and in governing the nation. In order to prevent brutal excesses, she stresses the need for laws to protect life and property and, in the case of women, also maternity. ${ }^{163}$ The topical issues of women's right to administer their inherited property, to decide how their wage was spent, and to take recourse to the law in paternity disputes, as well as their right to share parental authority over children, were all taken up by Salerno.

Salerno recognized that disenfranchisement was the surest way to disempower women. Her public support for women's suffrage can be traced back to 1906 when she was involved in a polemic on the issue in the columns of Il Vessillo bianco. With her opponents holding the view that women were not yet socially or culturally prepared for the vote, Salerno argued that, as female suffrage would not be granted immediately, women would have time to prepare for it:

È vero che la donna ha bisogno di prepararsi alla vita sociale, ma essendo vero altresì che l'elettorato non sarà concesso immediatamente, nel tempo istesso che esso viene propugnato, la donna di buon senso è stimolata a prepararvisi. ${ }^{164}$

With the passage of the universal manhood suffrage bill in 1912, the question of women's electoral rights became topical again. By this time the entire feminist movement, including bourgeois women and the various currents of socialist feminism, advocated the extension of full voting rights to all women, but the attitude of Catholic women and their official organization remained ambiguous. This equivocation was reflected in Elena da Persico's article in the June 1912 issue of L'Azione muliebre, ${ }^{165}$ eliciting a terse response from Salerno, who could not find one single valid argument against giving women the vote. ${ }^{166}$

Da Persico discussed arguments for and against women's suffrage in the form of an open letter to a young mother. Although the countess refused to state her paper's stance on the issue, she soon made it clear by asking her readers to consult back issues of her periodical. In them she had made her opposition to women's suffrage abundantly clear.

\footnotetext{
162 Salerno, “Trattazione sulla donna. Parte II - Una questione di libertà”, La Donna e il lavoro, a. 3, n. 42, 18 ottobre 1912, p. 3.

${ }^{163}$ Ibid.

${ }^{164}$ Quoted in Il femminismo cristiano di Elisa Salerno e le sue prospettive, cit., p. 86.

165 Elena da Persico, “Suffragio femminile?”, L’Azione muliebre, a. XII, n. 6, giugno 1912, pp. 401-410.

166 “Immaginazioni e false premesse”, La Donna e il lavoro, a. 3, n. 23, 21 giugno 1912, pp. 3-4.
} 
Ostensibly to show her neutrality she listed arguments in favour of the vote after making the observation, however, that the advocacy of female suffrage drew its maximum support from the socialist camp which in every respect wanted to promote the absolute equality of men and women. Responding to this, Salerno argued that, to say that the supporters of the vote were socialists, or any other anti-Christian party, was to prejudice people's minds, even though the fact that socialists demanded it, did not detract from the validity of the claim.

Resorting to the standard arsenal of conservative Catholics, da Persico maintained that, in the Catholic camp, the perception of society rested wholly on the concept of an organism whose primary cell was the family. In it, the decorum of woman was jealously guarded as one of the highest cultural possessions and, therefore, the idea of exposing her to the quagmire of politics was repugnant. To support her case, da Persico referred to the "three giants" of Catholic sociology, Biederlack, Cathrein and Rösler. The question of rights, Rösler had said in his study Die Frauenfrage, was approached from the false premise that every individual had equal rights and duties with regard to everything. Women had the same human rights as men, but then the two sexes also had their particular, different rights depending on their different missions, and among those was the right to elect legislators and to make laws. Paying taxes gave people the right to enjoy public amenities financed by public money, but not the right to regulate the expenditure or to elect those who made regulations. Having to obey laws did not bestow on one the right to make them, unless one believed - like the exponents of the French Revolution did - that only the laws we made ourselves were binding. It was a false syllogism, Rösler went on, to equate those without voting rights to idiots and delinquents who lacked such rights by saying:

... gli idioti e i delinquenti non eleggono, io non eleggo; dunque io per lo Stato sono un idiota o un delinquente ... ${ }^{167}$

For Salerno, not only the syllogism, but also Rösler's reasoning was faulty. She revised the syllogism to say instead:

Gli idioti, i delinquenti, non hanno diritto di voto, io sono stato escluso, o cancellato dalle liste elettorali, dunque io sono considerato delinquente $\mathrm{o}$ idiota. $^{168}$

\footnotetext{
${ }^{167}$ Da Persico, “Suffragio femminile?”, cit., p. 404.

168 "Immaginazioni e false premesse”, cit., p. 3.
} 
Da Persico wondered whether the vote in fact was the best means by which women could defend the family, justice, moral standards, religion, and their economic interests. After all, the abbot Sertillanges, an ardent feminist, had written, with reference to Bernadin de Saint Pierre, that there was perhaps no other country in which women would be as badly treated by the law as France, yet there was no other in which they would have as much power. Sertillanges went on to elaborate the idea further by saying that customs carry greater weight than laws and that women shape customs. Rösler, for his part, asserted that women's direct participation in politics, the goal which feminists hankered after, would in fact damage, or even undo, the sway women held over customs and the way of life. Following the same line of reasoning, da Persico reiterated the vital role women - be they daughters, wives, sisters, or mothers - had in forming the characters of men who then made laws:

Non siamo noi, proprio noi donne, che dobbiamo formare gli uomini? Non sono le figlie, le spose, le sorelle, le madri, che formano quegli uomini, i quali poi fanno le leggi? ${ }^{169}$

Salerno, on the other hand, doubted whether the multitude of women lived in circumstances which permitted them to influence the masculine character and way of life, and further doubted whether the customs and moral standards instilled by women would be sufficiently entrenched to countervail political forces:

Ella [Elena da Persico] si figura che le donne sieno tutte nella condizione di formare i buoni costumi degli uomini e che la loro azione sia così potente che ogni tentativo di violentare, colla forza politica, i costumi fatti penetrare da lei nella vita, debba sempre naufragare. ${ }^{170}$

While the vote was not the only means available to men and women to defend their interests, it was, among many others, a means, and those deprived of it carried the stigma of inferiority and impotence:

Nè per l'uomo, nè per la donna il voto elettorale è l'unico mezzo ecc. ma UN mezzo come tanti altri, un mezzo, la privazione del quale imprime su chi ne è oggetto, un grado d'inferiorità e d'impotenza. ${ }^{171}$

With the conclusion of World War I, as previously discussed, attitudes to women's suffrage changed. By then, the majority of Catholics endorsed the idea, and it was also a plank in the platform of the Partito popolare italiano when it made its debut in the political arena in 1919.

\footnotetext{
${ }^{169}$ Da Persico, “Suffragio femminile?”, cit., p. 406.

170 "Immaginazioni e false premesse”, cit., p. 3.

${ }^{171}$ Ibid., p. 4. Original italics and capital letters retained.
} 


\section{$\underline{\text { Modernism }}$}

Through her feminism Salerno was unwittingly caught up the in the modernist crisis. After all, she lived in a city which was one of the centres of anti-modernist agitation. Religious bigotry was fomented, in particular, by the periodical La riscossa, which was published by the three intransigent Scotton brothers, all priests. They pursued members of the clergy, including Bishop Andrea Ferrari in Milano, for their alleged unorthodoxy until, in 1915, the Bishop of Vicenza, Ferdinando Rodolfi, suppressed their journal. ${ }^{172}$ On the other side of the divide was the internationally acclaimed writer Antonio Fogazzaro whose final two novels, Il santo and Leila, were put on the index of forbidden publications because they alluded to the need for reform within the Catholic Church. Not all Catholics took notice of Fogazzaro's proscription. Adelaide Coari appears to have been unconcerned about Fogazzaro’s fall from grace, as she invited him to supply a preface to her publication on Nicolò Tommaseo in 1909. A copy sent to Bishop Radini Tedeschi elicited a terse letter of reply. ${ }^{173}$ Elisa Salerno, as mentioned already, first intended to name her own fledgling novel "La santa", in homage to Fogazzaro’s banned publication, but was persuaded by Professor Toniolo to give up the idea. There was also a brief period, from 11 March to 26 May 1910, when Salerno was in a relatively frequent contact with Fogazzaro, not to discuss, however, intellectual or political issues, but to ask for his assistance in financing her paper.

Anti-modernist persecutions in Vicenza, as elsewhere, played havoc with people's lives. The prevailing confusion, comments Monsignor Gerani in Un piccolo mondo cattolico, was such that even perfectly unobjectionable Catholic projects were made to appear questionable. The modernist controversy, much feared by the bishop, was exploited by the ultra-conservative elements. It could jeopardize the plans of Maria Alma, Salerno's fictitious double in the novel, to set up a printing press for her proposed journal, because the bishop might not grant the placet for her project:

Un'altra difficoltà agli intenti di Maria era il modernismo, tanto temuto da Mons. Vescovo, tanto sfruttato dai cattolici vecchi. - Oggidì ... è una confusione generale; vengono osteggiate anche opere schiettamente cattoliche, con la scusa di combattere il modernismo, e non hanno ragione che i più retrivi conservatori. Nessuno può discutere neppure per tracciare la linea che dovrebbe segnare dove

\footnotetext{
172 Ermenegildo Reato, "Scotton Jacopo; Scotton Andrea; Scotton Gottardo", in Francesco Traniello e Giorgio Campanini (a cura di), Dizionario storico del movimento cattolico in Italia 1860-1980, II: I protagonisti, Torino, Marietti, 1982, pp. 591-593.

${ }^{173}$ Radini Tedeschi's letter to Coari, 6 Apr. 1909, FAC 3488.
} 
cominci e fin dove arrivi il modernismo. Sicché per l'impianto di cui ella mi parla ci vorrebbe il placet di Mons. Vescovo, e Mons. Vescovo certamente glielo negherebbe. ${ }^{174}$

For her political and religious views Salerno can hardly be classed as a modernist. Although endeavouring to promote the establishment of Catholic women's labour unions, she had no intention to play a part in an independent political organization of the type promoted by Romolo Murri. In religious matters extraneous to gender issues, she strictly followed the orthodox line, as shown by her letter to Bishop Rodolfi in April 1925:

Sarò fedele in tutto alla religione cattolica, eccetto che all'antifemminismo. Non scriverò mai niente che possa meritare una legittima riprensione da parte delle autorità ecclesiastiche, perché l'ortodossia della Chiesa di Gesù Cristo mi è cara più della mia vita. ${ }^{175}$

Salerno was not receptive to any notions of reinterpreting Scripture in the light of modern scientific thought, hinting, instead, in Al bivio, at the danger of exposing the young to the bewitching allurements of modernity and progress which, by perpetrating error, purported to supersede the most sacred and most imperative truths. ${ }^{176}$

It is ironic that while Salerno considered herself an orthodox Catholic, the Church censured her for her alleged modernism because loose application of the modernist slur could easily accommodate Salerno's feminism. After all, she cast doubt on the validity of essential parts of Catholic dogma, attacked the distribution of power between the genders, and impugned the premises which entrenched patriarchal society. The condemnation of Per la riabilitazione della donna and the exclusion of La Donna e il lavoro from the list of authorized Catholic periodicals were made for their alleged “exaggerated, ultra-feminist theories”, since they were seen as belated manifestations of the modernist phenomenon. In fact, La Donna e il lavoro, claimed the Veronese journal Arena, was the only "modernist” periodical which was ever condemned on the Pope's explicit orders, and this occurred when modernism had already subsided. It believed that this little, modernist, almost anachronistic incident would have no sequel:

... si ritiene pertanto che il piccolo incidente modernistico, tanto in ritardo che appare quasi anacronistico, non avrà alcun seguito. ${ }^{177}$

\footnotetext{
${ }^{174}$ Salerno, Un piccolo mondo cattolico, cit., p. 159. Original italics retained.

175 “A Ferdinando Rodolfi, 25 aprile 1925”, in Nata troppo presto, cit., pp.12-13.

${ }^{176}$ Salerno, Al bivio, cit., p. 114.

177 “Note Vaticane. Il piccolo episodio ‘modernistico', di Vicenza”, Arena, 29 luglio 1917, p. 3.
} 
Despite the condemnation of La Donna e il lavoro, Salerno continued to pursue feminist issues with her customary fervour also in her second periodical, Problemi femminili, as she promised when announcing the change of title of her periodical: "Il programma del periodico ... sarà allargato, ma resterà immutato nella sostanza.”178

\section{Relations with the Catholic Lay Movement}

Living in Vicenza, Elisa Salerno was geographically isolated from the main centres of the Catholic women's movement and therefore lacked regular, personal contact with its exponents. Many of the Catholic women's intellectual élite, such as Elena da Persico, Antonietta Giacomelli, Luisa Anzoletti and Felicita Büchner, had left the Venetia region to settle in Milan, which at the time was the centre of attraction for the different currents of feminism. ${ }^{179}$

A conservative, provincial city, Vicenza was not a natural base for feminist activity. Writing in Il Vessillo bianco, Salerno lamented her thankless struggle against apathy, conservatism, disdain, and backwardness which kept women passive and neglected:

Fare del femminismo a Vicenza è lo stesso come voler a forza di unghie scavar terra e terra onde trovare una vena d'acqua per dissetarsi. Qui l'apatia, là il conservatismo, altrove il disprezzo, ovunque l'atavismo mantengono le donne nella passività e nell'abbandono. ${ }^{180}$

Nevertheless, in the wake of Rerum novarum some efforts had been made to mitigate the pitiful condition of the female labour force. They included setting up mutual aid societies for women, the first of which came into being, in 1892, at Arzignano, Vicenza, as a section of a men's society. The first mutual aid society specifically for women, $S$. Anna di Mutuo Soccorso di Vicenza, was founded in 1896, and was followed, in 1903, by another women's society, Società cattolica femminile di Mutuo Soccorso S. Felicissima di Schio. ${ }^{181}$ Showing a marked lack of interest in organizing women workers, the local Catholic lay movement became active in this field only to avoid poaching by socialist unions. Consequently, in the first years of the new century,

\footnotetext{
178 “Problemi femminili”, La Donna e il lavoro, a. 9, n. 16, 29 novembre 1918, p. 1. Original italics retained.

${ }^{179}$ Giuseppina Lugo, “Quella povera testa”, cit., p. 139.

180 Elisa Salerno, “Un lamento”, Il Vessillo bianco, 5 maggio 1906. Quoted in Gianni A. Cisotto, "Il femminismo cristiano di Elisa Salerno”, Bollettino dell'Archivio per la storia del movimento sociale cattolico in Italia, a. XIX, n. 1, gennaio-aprile 1984, p. 36.

${ }^{181}$ Cisotto, "Femminismo sociale a Vicenza", cit., pp. 50-51.
} 
Catholic proto-unions, unioni professionali, were set up in Vicenza for women silk workers, needleworkers and hatters. ${ }^{182}$

In this period Salerno wrote a regular column for Il Vessillo bianco and, in 1905, participated in the first conference of the professional unions in Schio. ${ }^{183}$ Concurrently two primary school teachers, Vittoria Veronese and Maria Bianchini, were active in organizing women workers, but their concern was merely to ameliorate working conditions, not to enhance women's role in society, as was the case with Salerno. All three recognized, however, the need to educate and unionize women, and also shared an aversion toward socialism and class struggle. Like many other Catholics, they viewed strikes with caution, with Bianchini describing them as a "two-edged sword" (arma a doppio taglio). ${ }^{184}$

As a Franciscan tertiary, urging social action, Salerno contributed numerous articles to their regional periodical Terz'ordine francescano veneto in the period 1907-08. ${ }^{185}$ With the publication of Un piccolo mondo cattolico, Salerno's relations with the Order reached a breaking point. The tertiary brothers wanted her to disown her book publicly or, at least, by a letter to the provincial superior. At an interview with the latter, as she later wrote to Toniolo, she underwent an hour and a half of torture during which the superior accused her of links with freemasonry, subjected her to a torrent of indignities on women, and likened her to Murri, Thirrel, Loisy, and to the ladies who had held the women's congress in Rome and who, had they known that she was writing such a book, would have invited her and made her president. According to the superior, she deserved to be expelled from the tertiary order, or, at any rate, she should certainly be severely punished. ${ }^{186}$ Despite these threats, Salerno appears to have survived as a member until 1925 when her expulsion came as a result of another of her publications, Dottrina infetta.

Unlike conservative women leaders, such as Countess Elena da Persico and Princess Cristina Giustiniani Bandini, whose aristocratic rank guaranteed them ready access to the highest levels of the clerical and lay hierarchies, or the members of the Fascio

\footnotetext{
${ }^{182}$ Ibid., pp. 194-195.

183 Ibid., p. 195.

${ }^{184}$ Ibid., pp. 196-198.

${ }^{185}$ Giuseppina Lugo, “Quella povera testa”, cit., p. 138.

${ }^{186}$ Salerno’s letter to Toniolo, 18 May 1908, FES, Carteggio Toniolo 12. The consulted copy is in FES; the original is held in the Biblioteca apostolica vaticana in Rome.
} 
femminile in Milan, who operated at the very heart of the Christian democratic movement, Salerno never became one of the driving forces of the Catholic women's movement. Yet, as Giuseppina Lugo observes, she participated actively in the nationwide discussion regarding the reorganization of the Catholic lay movement following the disbandment of the Opera dei congressi, convinced that, in the aftermath of the 1904 strikes, Catholics had to muster their troops to combat socialism. ${ }^{187}$

Salerno was keen to establish contacts with leading figures in the Catholic lay movement, such as Giuseppe Toniolo. As will be discussed in the next chapter, Toniolo strove to set up a national Catholic women's organization under the umbrella of the Unione popolare whose president he was from 1906 to 1910. To his great disappointment, Pius X decided, in April 1909, to create a totally independent association under the presidency of Princess Cristina Giustiniani Bandini. Meanwhile, Salerno eagerly followed developments towards a women's organization. Her initial contact with Toniolo seems to have taken place in September-October 1905, as a result of the publication of her open letter to him in L'Osservatore cattolico, which elicited responses from Toniolo and Elena da Persico in the same journal. ${ }^{188}$ In the letter Salerno expressed to Toniolo her delight at the founding of the Unione popolare as well as her vivid desire to see the emergence of women's unions alongside with men's. Subsequently Salerno attended the first settimana sociale, organized by the Unione popolare in Pistoia in September 1907, where the matter of a women's organization came up, but it appears that she was unable to meet Toniolo personally. ${ }^{189}$

Salerno's correspondence with Toniolo, continued over the difficult period following the publication of Un piccolo mondo cattolico. It appears that some of her articles on women's issues were accepted by him for the periodical Settimana sociale. In January 1909 Salerno wrote to him to express her profound satisfaction with his promotion of a Catholic association for Italian women, Unione cattolica delle donne italiane. ${ }^{190}$ On

\footnotetext{
${ }^{187}$ Lugo, “Quella povera testa”, cit., p. 136.

${ }^{188}$ Ibid, footnote 59, p. 181: Salerno's article "E le donne?” was published in L'Osservatore cattolico on 30 September 1905. Da Persico’s response “E la donna?” followed on 3 October, and Toniolo’s “E la donna?” on 4 October. Salerno reply to both on 13 October was made under the original heading. On 7 March the following year Toniolo sent her the constitution of the Unione popolare, entitled Presentando lo Statuto dell'Unione popolare dei cattolici d'Italia, Pisa, 1906.

L'Azione muliebre published Salerno's first letter and da Persico's and Toniolo's responses together with a commentary under the heading “E le donne?”, a. V, fasc. 11, novembre1905, pp. 669-677.

${ }^{189}$ Salerno's letter to Toniolo, 15 May 1908, FES, Carteggio Toniolo 11. The consulted copy is in FES; the original is in the Biblioteca apostolica vaticana.

190 Salerno's letter to Toniolo, 13 Jan. 1909, in Una penna inquieta, p. 181.
} 
receiving its draft constitution, however, she could not hide her disappointment at the clause which stated that the proposed association would not pursue political issues and would not campaign for women's rights:

La ringrazio infinitamente della Sua squisita deferenza, nel mandarmi le bozze dell'appello e dello Statuto. Quest'ultimo mi soddisfa in tutto; e soltanto vorrei pregare la S.V. Ill.ma di voler spiegarmi un po' il senso delle tre ultime righe dell'articolo 3, il quale finisce: prescindendo dalla politica ed esclusa la pretesa di diritti, che sono in opposizione diretta con la missione provvidenziale della donna. ${ }^{191}$

Nor could Salerno believe that the Pope himself could be in principle against women's suffrage, but surmised, in a letter to Toniolo, that he had spoken against it on the prompting of Giustiniani and da Persico:

Ecco, so che la principessa Giustiniani e la contessa Da-Persico provocarono dal S. Padre delle risposte, ma non credo affatto che il S. Padre, come Papa e per principio, abbia proibito di favorire l'elettorato femminile. ${ }^{192}$

Correspondence with Toniolo continued well into 1910 when he, in an open letter to $L a$ Donna e il lavoro, praised Salerno for her investigations on women workers in Vicenza:

La signorina Elisa Salerno di Vicenza compiva opera modesta eppure preziosissima, dettando le Relazioni che ora, dietro autorevoli indirizzi e incoraggiamenti, vengono pubblicate. Dissi compiva e avrei dovuto dire iniziava: perchè chi rammenti le inchieste private e pubbliche le quali oggi si sono fatte nei vari paesi d'Europa e di America intorno al lavoro femminile, deve compiacersi che anche da noi si comincino questi rilievi di fatto. ${ }^{193}$

A couple of years later, however, by which time correspondence between Salerno and Toniolo had already dried up, another series of articles by her, Trattazione sulla donna, in La Donna e il lavoro, incurred his censure. He wrote to Bishop Rodolfi:

Permetta che io le esponga un dubbio, riguardante il giornale vicentino "La donna e il Lavoro”. Quando io ero presidente dell'Unione Popolare, io vidi nascere, ed anche incoraggiai la direttrice e fondatrice (la Salerno); alla quale non risparmiai tuttavia moniti amichevoli, ma franchi in più occasioni difficili per essa; perché in mezzo alla sua pietà e alle sue virtù, mi parve una testa effervescente e pericolosa. Tuttavia la parte pratica del giornale è ben fatta; e la mia famiglia perciò fu sempre abbonata al giornale stesso. Ma dacché si pose la Salerno sotto il titolo "Trattazione della donna” a passare al campo filosofico (e qualche volta biologico), mi parve superficiale e appassionata, se non talora in

\footnotetext{
${ }^{191}$ Salerno's letter to Toniolo, Jan.-Feb. 1909. FES, Carteggio Toniolo 20. See also “Statuto della Unione fra le donne cattoliche d'Italia”, L'Azione muliebre, a. IX, fasc. 2, febbraio 1909, pp. 69-72. Article 3 of Toniolo's proposed constitution reads: "Potranno ascriversi all’Unione le donne cattoliche senza riserve, disposte ad esplicare sotto la disciplina della Chiesa le loro energie per il perfezionamento proprio e per il bene domestico e pubblico; prescindendo dalla politica ed esclusa la pretesa di diritti, che sono in opposione [sic] diretta colla missione provvidenziale della donna”.

${ }^{192}$ Salerno’s letter to Toniolo, 15 Apr. 1909. FES, Carteggio Toniolo 22.

193 "Una lettera del Prof. Toniolo", La Donna e il lavoro, a. 1, n. 40, 23 settembre 1910, p. 1. Original italics retained.
} 
argomenti delicati per noi cattolici, inesatta. E certe critiche verso persone autorevoli (fossero quelle pur fondate) tradiscono uno spirito aggressivo, che potrebbe purtroppo richiamare l'attenzione sfavorevole di altri ...

Another important contact in the Catholic lay movement was the Veronese Countess Elena da Persico, editor of L'Azione muliebre whom Salerno possibly met at various settimane sociali. ${ }^{195}$ It becomes clear from her correspondence that, before founding her own periodical, Salerno frequently tried to have her articles published in L'Azione muliebre. ${ }^{196}$ Equally, she expressed her willingness to promote da Persico’s paper by having its contents page published in the local Il Berico. ${ }^{197}$ In March 1910, now editor of a periodical herself, Salerno complimented da Persico on her recently delivered, superb conference paper stating that La Donna e il lavoro was prepared to publish it should L'Azione muliebre not do so. Not lacking business acumen, she then mentioned that she had received about six thousand addresses from "some generous persons" to enable her to boost the circulation of her paper. In the same breath, she asked da Persico for a copy of the subscribers' list for L'Azione muliebre. ${ }^{198}$ In May 1910, perhaps unaware of da Persico’s own perennial financial problems, Salerno solicited the countess for a contribution towards the funding of La Donna e il lavoro, urging her also to approach Cardinal Ferrari in Milan on her behalf since, after all, La Donna e il lavoro was widely disseminated in Lombardy. ${ }^{199}$

Relations between the two women were irreparably ruptured with the publication of Per la riabilitazione della donna. To her great regret - wrote the countess to Salerno - she had read her pamphlet which showed insubordination towards her bishop by wanting to judge and discredit St. Thomas by publicly attacking doctrines of the Church. Da Persico was also offended by the way Salerno made shameless references to those physical aspects of womanly life which modesty would dictate not to mention. The countess saw it as her duty to ask Salerno to disown her pamphlet in the next issue of $L a$

\footnotetext{
194 Toniolo’s letter to Rodolfi, 1a Quaresima1913, ACV, Carteggio Rodolfi.

195 Cisotto in Elisa Salerno e la promozione della donna, cit., pp. 41-42, states that Salerno attended the first settima sociale in Pistoia (23.-28.9.1907), the second in Brescia (6.-13.9.1908) and the fourth in Florence (26.9.-3.10.1909). It is not certain whether Salerno attended the first settimana sociale femminile in Torino in 1913. However, La Donna e il lavoro published unsigned, detailed articles on this settimana sociale femminile in its issues of 18 and 25April 1913, which could only have been written by someone attending. On the other hand, in its 25 April issue, La Donna e il lavoro listed "Elisa Salerno, direttrice del giornale La Donna e il Lavoro", under the heading "Con lettere e telegrammi aderirono”.

${ }^{196}$ Salerno’s letter to da Persico, probably written in 1905, AEP 5474. (Copy also in FES.)

Salerno's letter to da Persico, probably written at the end of 1906, AEP 5475. (Copy also in FES.)

${ }^{197}$ Ibid.

198 Salerno's letter to da Persico, 1 Mar. 1910, AEP 5754. (Copy also in FES.)

199 Salerno’s letter to da Persico, 10 May 1910, AEP 5764. (Copy also in FES.)
} 
Donna e il lavoro, otherwise she would have the unpleasant duty of making a public protest. $^{200}$ There was no reply from Salerno. A few months later da Persico turned to Bishop Rodolfi, saying that because of her role as direttrice di una rivista di elevatezza femminile, she felt obliged to comment publicly on Salerno's pamphlet. Before doing so, however, she wanted to have the bishop's endorsement and, if he was contrary to the idea of her publicly expressing her profound disapproval of Salerno's pamphlet, she would desist. ${ }^{201}$

Initially Salerno’s relations with another conservative woman leader, Princess Cristina Giustiniani Bandini, president of the Unione fra le donne cattoliche d'Italia, were amicable so that for a time even the possibility of La Donna e il lavoro playing an important part in the Catholic women's movement was canvassed. In a postcard in September 1910 the princess thanked Salerno for the preparations she had made for a meeting (giornata) ${ }^{202}$ at which she had spoken to Vicenza women about the aims and the funding of the Unione fra le donne cattoliche. As Salerno wrote to Rodolfi a few months later, Giustiniani Bandini had managed to collect some membership subscriptions in Vicenza, but the initiative lapsed because there was no local support. ${ }^{203}$ It appears, however, that a local committee the Unione fra le donne cattoliche was set up in Vicenza in 1911. ${ }^{204}$ Writing to Rodolfi in December 1913, Salerno seemed to be eager to have her paper acknowledged as an organ of the Unione fra le donne cattoliche, which Giustiniani Bandini had been unable to achieve on her visit to Vicenza without local endorsement. Now that a local branch existed, Salerno urged the bishop to convey to it his authoritative interest in her paper. ${ }^{205}$

In October 1911 Salerno had received another postcard from Giustiniani Bandini in which the princess expressed her appreciation of an article published in La Donna e il lavoro under the title "A proposito del femminismo di R.P.B.”, ${ }^{206}$ which refuted the antifeminist statements made by Padre Biederlack in a talk at the Scuola cattolica in

\footnotetext{
${ }^{200}$ Da Persico’s letter to Salerno, 14 Mar. 1917, AEP. (Copy also in FES.)

${ }^{201}$ Da Persico's letter to Salerno, 17 June 1917, AEP. (Copy also in FES.)

${ }^{202}$ Giustiniani Bandini’s postcard to Salerno, 26 Sep. 1910, FES 39.

${ }^{203}$ Salerno’s letter to Rodolfi, 25 Feb. 1911, in Una penna inquieta, cit., p. 267.

${ }^{204}$ Cisotto, Elisa Salerno e la promozione della donna, cit., p.14.

205 Salerno’s letter to Rodolfi, 5 Dec. 1913, in Una penna inquieta , cit., pp. 205-206.

${ }^{206}$ Giustiniani Bandini’s postcard to Salerno, 24 Oct. 1911, FES 50.
} 
Bergamo. $^{207}$ Referring to the praise she had received from Giustiani Bandini regarding Biederlack as well as her articles published under the title Trattazione sulla donna, Salerno wrote to Rodolfi in February 1914 stating that she and Giustiniani Bandini were in agreement about feminist issues. At this point negotiations were still underway to make La Donna e il lavoro an official organ of the Unione fra le donne cattoliche. Salerno had some reservations about the matter because, she feared, the Princess did not understand the justifiable demands of trade unions. She was concerned that, by becoming an organ of the Unione donne, her paper would suffer limitations to its editorial policy regarding labour issues. Reading the most recent Bollettino of the Unione donne, however, had given her confidence in its programme, and she no longer saw any reason not to make her paper its organ. ${ }^{208}$ Salerno's letter of 10 July 1914 to Rodolfi shows that she expected to receive support from the bishop. ${ }^{209}$

Despite these expectations, Salerno's paper never became an organ of the Unione fra le donne cattoliche d'Italia. As appears from Giustiniani Bandini's undated handwritten draft letter to Salerno, the princess had her reservations about La Donna e il lavoro and made it clear that it would be accepted as an organ of the Unione donne, only if Salerno was prepared to adhere to strict rules of censorship:

Ella sa come fin dal suo sorgere io abbia seguito con interesse e simpatia "La Donna e il lavoro" e l'abbia raccomandata ai nostri Comitati. Questo sentimento non è certo venuto meno; ma Ella ben intenderà che il farne l'organo ufficiale delle classi lavoratrici femminili, importerebbe, (a scanso di responsabilità per chi sta a capo del movimento femminile cattolico), necessarie convenzioni con codesta direzione, ch'io, dubito, siano per essere accettate.

Rispettosa delle rette intenzioni di chi lavora nel nostro campo, ho sempre cercato di non ostacolare nessuna iniziativa buona; ma d'altra parte, responsabile dell'integrità del movimento femminile cattolico, ufficialmente riconosciuto dalla S. Sede, debbo vigilare ed insistere, perchè le direttive emanate dalla stessa Santa Sede, siano fedelmente seguite, e non potrei far a meno di richiedere che la direzione del periodico non ammettesse persone che, riguardo al movimento femminile, non conoscano o non seguano queste direttive; e perciò dovrei esigere che s'intendesse col nostro Ufficio di presidenza sulla scelta e l'accettazione degli scrittori e delle scrittrici, o accettasse la revisione degli articoli da persona di nostra fiducia. Più volte la benemerita Donna e il lavoro sull'indirizzo del nostro movimento generale ha seguito criteri incerti - spesso differenti dai nostri, snaturandone perfino il concetto fondamentale. Ho taciuto, non avendo la responsabilità della pubblicazione; ma ora non potrei raccomandarla ai nostri Comitati, come organo ufficiale, senza essere

\footnotetext{
207 Articles entitled "La donna. A proposito delle opinioni sul femminismo del R. P. Biederback [sic]" appeared in three successive issues of La Donna e il lavoro, a. 2, n. 42, 20 ottobre 1911, p. 1; a. 2, n. 43, 27 ottobre 1911, pp. 1-2; a. 2, n. 44, 3 novembre 1911, pp. 1-2.

${ }^{208}$ Salerno’s letter to Rodolfi, 1 Feb. 1914, in Una penna inquieta, cit., pp. 270-273.

${ }^{209}$ Salerno’s letter to Rodolfi, 10 July 1914, in ibid., pp. 222-223.
} 
moralmente sicura che gli scrittori e le scrittrici conoscano a fondo il nostro programma, e propugnino soltanto il nostro indirizzo. Per la parte amministrativa poi, l'Unione non assumerebbe nessun impiego, almeno per ora. Se questi preliminari non la spaventano, potremo forse venire ad un'intesa, perchè non sono certo aliena dal vedere questo collegamento di forze che mentre gioverebbe al periodico, potrebbe anche giovare allo sviluppo della nostra azione, ecc. ${ }^{210}$

Subsequently Salerno turned the Unione donne, which Giustiniani Bandini led, into an object of her unrestrained criticism and ridicule. In Per la riabilitazione della donna Salerno lamented the chilling and suffocating atmosphere which prevailed in the national Catholic unions and the Catholic movement in general. The Unione donne was so pitiful that it was even trying to excuse its own existence:

Dal punto di vista femminile, nelle unioni cattoliche nazionali, ed in genere nel movimento cattolico, è diffuso alcunchè di agghiacciante e d'irrespirabile. L'Unione fra le Donne Cattoliche, poi, fa pietà. Essa sembra intenta a farsi perdonare d'esser sorta, intuendo che se ne farebbe a meno volentieri. ${ }^{211}$

Later, Salerno was in contact also with Giustiniani Bandini's successor, Marchesa Maddalena Patrizi Gondi. In February 1919 the marchesa complained about an article in Problemi femminili which had made an adverse observation about the Gioventù femminile, the nascent Catholic organization for young women which she was promoting. In reply, Salerno stated that she had found the tone of Patrizi Gondi's letter "unpleasant" (increscioso), and had no intention of passing on her comments to the writer of the article who was "young”, "well-meaning" and "intelligent". ${ }^{212}$ The latter had argued that instead of the intended division of Gioventù femminile's membership along class lines, it should be based on the principles of "true democracy". ${ }^{213}$ As a gesture of appeasement, Salerno drew Patrizi Gondi's attention to her own glowing article about the new organization, published earlier, in which she had expressed her delight in the young women's movement. ${ }^{214}$ Six months later, in September 1919, Salerno responded to a postcard from Patrizi Gondi which had called for an assessment of a number of books listed for women's cultural edification in an issue of Bollettino

\footnotetext{
${ }^{210}$ Giustiniani Bandini’s undated draft letter to Salerno, AGOP XIV.950 GIB.1. Original underlining retained.

${ }^{211}$ Salerno, Per la riabilitazione della donna, cit., p. 23.

212 Salerno's undated letter to Patrizi Gondi, FES 4.

213 On p. 2 of "Per un programma di organizzazione giovanile femminile", Problemi femminili, a. 1, n. 4, 21 febbraio 1919, “E.P.” writes: “... credo fermamente che l'organizzazione giovanile femminile dovrebbe avere principii di vera democrazia, ed essere quindi senza barriere, anche solo apparenti, che separino la signora dall'operaia, studente da studente, ragazza da ragazza, ed ispirarsi a solidarietà, a fratellanza, all'amore, che genera l'unione e la reciproca simpatia, dando così l'esempio, davanti alla nuova era che sorge, di quella confidente amicizia che sarà la base della 'Società di Nazioni'”.

214 “Verso la vita”, La Donna e il lavoro, a. 9, n. 8, 14 giugno 1918, p. 1.
} 
dell'Unione femminile cattolica italiana. Stating that she knew only some of the items, Salerno did not single out any title for praise but dismissed, instead, many for their antifeminism, including an edition of the Holy Bible with Antonio Martini's commentary. ${ }^{215}$ As becomes apparent from the following notice in Bollettino dell'Unione femminile cattolica italiana of 15 June 1923, she was in the end totally ostracized by the officially recognized Catholic movement:

Da varie parti ci giungono espressioni di biasimo e di meraviglia per alcuni articoli pubblicati dal periodico Problemi femminili, di Vicenza, quasi che si trattrasse di un organo dell'U.F.C.I. in contrasto con le direttive della nostra azione culturale.

Dichiariamo che quel periodico non appartiene a nessuna organizzazione cattolica; anzi, da informazioni assunte e che crediamo esatte, esso non ha neppure l'approvazione della locale Autorità ecclesiastica.

Se, quindi, qualcuno vuol entrare in polemiche con quella redazione, si rivolga ad essa direttamente e non a noi. ${ }^{216}$

Salerno showed a natural affinity to the group of young Catholic feminists around Pensiero e azione with some of whom she had personal contact, but there is no evidence of a close friendship. In November 1905 she complimented, in Il Vessillo bianco, the Milanese journal on its articles, finding them appealing and interesting, as they dealt with women's issues in a style which was easy to read, were based on valid criteria, and showed diversity, a modern approach and grace. A week later she praised Adelaide Coari personally in another article in Il vessillo bianco, and in January 1906 included the contents page of the latest issue of Pensiero e azione (6 January 1906) in the Vicenza paper. ${ }^{217}$ On 14 November 1905 Salerno wrote a highly commendatory letter to Coari with regard to her periodical:

Non posso esprimere la consolazione e l'entusiasmo che provo alla lettura della Sua rivista, e penso che i fervidi sentimenti ch'Ella e tutte le altre signorine che formano il Comitato del "Pensiero e Azione" provano in ordine alla questione morale e specificatamente alla questione femminista, a quelli che tengono in moto la mia anima sieno identici e certamente non inferiori; così che si potrebbe scrivere una pagina intitolata “Anime che s'incontrano". ${ }^{218}$

Salerno's name appeared among those registered for the 1907 Convegno femminile, sponsored by Pensiero e azione, but Gianni A. Cisotto doubts whether she actually attended the meeting, since her conference badge, stored among her personal papers,

\footnotetext{
${ }^{215}$ Salerno’s letter to Patrizi Gondi, 9 Sep. 1919, in Una penna inquieta, cit., pp. 86-88.

216 “Il periodico 'Problemi Femminili'”, Bollettino dell'U.F.C.I., a. IV, n. 12, 15 giugno 1923, p. 2.

${ }^{217}$ Cisotto, Elisa Salerno e la promozione della donna, cit., pp. 51-52, p. 85, footnotes 121-125.

${ }^{218}$ Salerno's letter to Coari, 14 Nov. 1905, FES 2.
} 
has no stamp to indicate that it was used to obtain a concessional rail ticket. ${ }^{219}$ Moreover, had Salerno been at the conference she would have witnessed at first hand the split in the Catholic women's movement. She would have been less surprised at not seeing Coari later in the year at the settima sociale in Pistoia, ${ }^{220}$ at which Elena da Persico gave a speech on the proposed women's section of the Unione popolare. ${ }^{221}$ Salerno's own impressions of the gathering in Pistoia were conveyed in an article published in Pensiero e azione on 26 October 1907, in which she stated that the settima sociale had not pleased her, leaving her wondering if society was made up of men only:’

Femminista spassionata e convinta dico subito: la settima sociale di Pistoia non mi ha soddisfatto ... Mentre udivo le lezioni svoltesi a Pistoia, mi veniva di pensare se la società era formata di soli uomini, o almeno se proprio le donne nulla avessero da fare o da conseguire. ${ }^{222}$

Since the issue of unfair pay to women was not touched at all, Salerno felt compelled to speak out to say that women were unwilling to join Catholic unions because such unions did not press their claims. Although submission was a necessary virtue, she argued, it did not right wrongs. She was pleased to have her comments subsequently corroborated by Toniolo's wide-ranging discussion of women's economic exploitation. $^{223}$

In her correspondence Salerno intimated to Coari that she intended to found a "popular" periodical in Vicenza to cover the "dreadful” gap left by the suspension of Il Vessillo bianco, asking Coari to show her the operation of her press on her next visit to Milan. ${ }^{224}$ A few weeks later, in another letter, Salerno revealed to Coari her intention to write "a diary of a Catholic”, a book about her life, canvassing Coari’s opinion as to whether it was legitimate to include personal correspondence in a published work, albeit without revealing the identities of the characters and the city. ${ }^{225}$ Salerno tried, in vain it seems, to obtain a copy of the 1907 Convegno femminile, and in December 1908, by which time Pensiero e azione had ceased publication, she wanted to know what the paper's future was going to be and what would happen to the labour unions founded by Coari:

\footnotetext{
${ }^{219}$ Cisotto, Elisa Salerno e la promozione della donna, cit., pp. 42, 72, footnote 16.

${ }^{220}$ Salerno’s letter to Coari, 25 Sep. 1907, FES 8.

${ }^{221}$ See Chapter Five, p. 249.

222 Elisa Salerno, "Il femminismo e la settimana sociale”, Pensiero e azione, a. III, no. 14, 26 ottobre 1907, p. 6.

${ }^{223}$ Ibid.

${ }^{224}$ Salerno's letter to Coari, 15 Oct. 1906, FES 5.

225 Salerno's letter to Coari, 18 Nov. 1906, FES 7.
} 
Che ne è del "Pensiero e Azione"? ... Ora La prego di dirmi se il Pensiero e Azione ha sospeso le sue pubblicazioni, essendo da vari mesi che non lo ricevo ... Mi scriva anche, se, per mala sorte, si sieno sfasciate le Unioni delle lavoratrici, ch'Ella aveva fondate. ${ }^{226}$

Salerno shared common goals with the Fascio femminile milanese regarding women's education, civil and political rights, and a special concern for female labour. In parallel to Carlo Grugni and Coari, who argued that women themselves should be in charge of their feminist agenda, Salerno held the view that the woman question should be resolved by women. ${ }^{227}$ On the other hand, she did not agree with Grugni's radical notion of class struggle as a means of improving workers' lives, nor did she endorse Murri's idea of setting up an independent Catholic organization. Although initially attracted to Toniolo's style of Christian democracy, Salerno never endorsed the idea of mixed trade unions. She first welcomed both the Unione fra le donne cattoliche d'Italia and the Gioventù femminile, but then recognized the fundamentally antifeminist nature of both organizations which were instrumental in mobilizing women to help preserve the status quo of the social and political structures. By accepting their conservative programme Salerno would have been welcomed into the fold of the mainstream Catholic women's movement, but given the choice, she remained loyal to her Christian democratic principles.

\section{$\underline{\text { Relations with Ecclesiastical and Secular Authorities }}$}

Intent on pleading "the holy cause" of women at the highest levels, Salerno wrote numerous letters to secular and ecclesiastical dignitaries, including Queens Margherita and Elena, Prime Ministers Orlando and Nitti, Mussolini, and Popes Benedict XV, Pius XI and Pius XII. As Dacia Maraini observes, Salerno’s “touching” desire to converse with the authorities manifested the confidence of a woman who firmly believed in the rights of all human beings whether male or female. ${ }^{228}$ Usually Salerno's letters to important public figures were written to convey her concern about a particular issue, so

\footnotetext{
${ }^{226}$ Salerno's letter to Coari, Dec. 1908, FES 17.

${ }^{227}$ Cisotto, Elisa Salerno e la promozione della donna, cit., p. 61. Salerno wrote in Il Vessillo bianco on 21 April 1906: “... la questione delle donne non può essere risolta che per opera delle donne”.

${ }^{228}$ On p. 20 of “Scrivere: per comunicare, suscitare, lottare ...”, in Nata troppo presto, cit., Dacia Maraini writes: "Commovente era il suo desiderio di dialogare con le autorità. Non metteva mai in dubbio l'importanza della rappresentanza politica e religiosa, non era un'anarchica che vuole uccidere il re o il principe o il monsignore. No: Elisa Salerno voleva colloquiare con il re, con il principe, con il monsignore. E qui emerge tutta la sicurezza di una donna che crede fermamente nei diritti degli esseri umani, che siano donne e uomini."
} 
in a letter to Prime Minister Vittorio Emanuele Orlando in March 1919 she took exception to the statement of principles by Christian trade unions convened in Paris, which postulated, among other things, that the natural order of the world and social convention demanded that woman should be prevented, as far as possible, from moving away from home and family. Salerno found that these words offended woman since they regarded her as being harmful to society from which she therefore had to be kept distant. $^{229}$ By contrast, in September the same year, Salerno expressed her satisfaction to another Prime Minister, Francesco Saverio Nitti, for the passing by the lower house of parliament of a law to extend suffrage to women. ${ }^{230}$

To Mussolini Salerno wrote numerous letters. In November 1922, when he had taken over the reins of government, she reminded him of the patriotism of Italian women, and hoped that fascism, having restored the honour of the Italian soldier, would now render justice to Italian women:

Al Fascismo, che ha rivendicato i diritti della nostra Vittoria, che i partiti sovversivi avevano sabotata, e che ha ristabilito l'onore del soldato italiano, rimane ora il compito di rendere giustizia alle Donne italiane, che, nella loro profonda comprensione, e schietto patriottismo, tutto diedero, tutto fecero, perché il Paese realizzasse i suoi alti destini ... Soltanto le Donne italiane, queste artefici della Vittoria, non udirono ancora da Vostra Eccellenza parole riparatrici di quel vergognoso oblio che le offende da troppo tempo, collocando l'Italia che si dice: maestra del Diritto, culla della Civiltà, quasi al livello delle terre musulmane, in cui costumi iniqui regolano il trattamento della donna. ${ }^{231}$

Accompanying Salerno's letter was a copy of Problemi femminili. As tokens of her appreciation of Mussolini’s “courage” and "sincerity” she later sent him also copies of her pamphlets, Per la riabilitazione della donna and La dottrina cristiana della donna. $^{232}$ In February 1926, furthermore, Salerno turned to Mussolini to say that the title of signorina in the case of professional women was a diminutive and disrespectful term. It would be far more courteous to apply the title signora to all categories of

\footnotetext{
${ }^{229}$ Salerno’s letter to Orlando, 26 Mar. 1919, in Una penna inquieta, cit., p. 274: "Nella dichiarazione di principi, si legge: 'I delegati dei Sindacati cristiani ... riuniti in Parigi, dichiarano: ... che l'ordine della natura e le esigenze della Società vogliono che la donna sia messa in grado di allontanarsi il meno possibile dalla casa e dalla famiglia...'

Queste parole offendono la donna quasi essa fosse un essere nocivo alla società, da cui perciò è da tenere lontana."

${ }^{230}$ Salerno’s letter to Nitti, 22 Sep. 1919, in ibid., p. 276.

231 Salerno’s letter to Mussolini, 24 Nov. 1922, in ibid., pp. 280-282.

232 Salerno’s letter to Mussolini, 16 May 1924, in ibid., pp. 282-283.
} 
teaching staff, because making a distinction among students between married and unmarried women ran against the principles of education. ${ }^{233}$

Salerno's letter to Benedict XV in September 1914 was an indirect appeal for financial assistance, revealing her financial problems as a result of a printers' strike and the outbreak of the war, ${ }^{234}$ while in September 1917, in order to have the ban on La Donna e il lavoro lifted, she implored the Pope to read the letter she had sent him, together with the treatise Per la riabilitazione della donna, eighteen months earlier. ${ }^{235}$ By contrast, writing to Pius XI in February 1922, Salerno addressed the problem of Catholic women's access to education and the shortcomings of the existing Catholic women's organization. She pointed out that as opposed to non-Catholic women, very few Catholic women attended courses in the natural sciences and philosophy, being "studiously prevented" from developing their identity and applying their intellectual and moral faculties. By comparison, non-Catholic women were free to organize and defend their professional, moral, social and political interests. Taking into account experience and expertise, Catholic women were therefore less eligible for municipal positions and committees. It was, she argued, at the instigation of Satan that Catholic women were held back, and such a vicious trend had emerged as a result of the failure of the existing Catholic women's organization to produce satisfactory outcomes. Instead of being an association of rational human beings it was a gaggle of non-thinking and blinkered women. Attached to Salerno's letter was a pamphlet Pro muliere which contained her prototype constitution for Catholic women's associations. ${ }^{236}$

At the local level, Salerno's connection to the ecclesiastical hierarchy was through the local bishop. At the start of her journalistic career, the incumbent in Vicenza was Antonio Feruglio (1841-1910) who occupied the position from 1893 to $1910 .^{237}$ By nature hesitant and uncertain, Feruglio sought to steer a middle course between the vecchi and the nuovi of the Christian democratic movement, and insisted that every Catholic organization needed to be approved by the religious authority. Dissidents were marginalized while the keenest social activists persevered in the ranks and continued

\footnotetext{
${ }^{233}$ Salerno’s letter to Mussolini, 19 Feb. 1926, FES L n 31: “Sarebbe infatti altamente civile introdurre l'uso di rivolgere il titolo di Signora alle Maestre, alle assistenti, alle Professoresse, alle Direttrici di tutte le scuole, dagli Asili alle Università, perchè l'uso di dire: Signora, alle maritate e signorina alle nubili, tra gli allievi ed allieve di qualunque classe, è singolarmente antieducativo”. Original underlining retained.

${ }^{234}$ Salerno’s letter to Benedict XV, 14 Sep. 1914, in Una penna inquieta, cit., pp. 234-235.

${ }^{235}$ Salerno’s letter to Benedict XV, 18 Sep. 1917, in ibid., pp. 85-86.

${ }^{236}$ Salerno's letter to Pius XI, 16 Feb. 1922, in ibid., pp. 278-280.

${ }^{237}$ Ibid., p. 171, footnote 40.
} 
their campaign in Il vessillo bianco, which resumed publication in 1908 after being suspended in 1906. ${ }^{238}$ The publication of Salerno's local novel, Un piccolo mondo cattolico, occurred in the period of Feruglio's episcopacy.

It was Feruglio's successor, Ferdinando Rodolfi (1866-1943) who figured most prominently in Salerno's battles with ecclesiastical authorities. A teacher of mathematics, physics and the natural sciences in the seminary of his home town Pavia, as well as ecclesiastical assistant for the Circolo universitaria San Boezio and theologian for the cathedral, Rodolfi was elected Bishop of Vicenza in 1911, and henceforth administered his diocese with sagacity and courage. ${ }^{239}$ Coming from the liberal-conciliatory school of Geremia Bonomelli in Lombardy, he was dismayed at the diatribes traded between intransigents and their modernist opponents:

È noto che egli, giunto nel lontano 1911 nel "prunaio" di Vicenza sconvolto dalle diatribe tra le "vestali” dell'intransigenza cattolica e i "pretoriani” del nuovo corso spesso e volentieri accusati di modernismo - cresciuto com'era alla scuola liberal-conciliatorista lombarda di Geremia Bonomelli, il correspondente e amico di Antonio Fogazzaro, e dei cardinali Ferrari e Maffi - si era guardato bene dallo sposare la causa intransigente. ${ }^{240}$

Rodolfi was instrumental in founding the Vicenza committee of the Donne cattoliche and parents' associations for the Christian education of the youth. After the war he drafted a programme for social regeneration through the medium of unions, cooperatives and mutual aid societies. A supporter of the Partito popolare, he revitalized Catholic Action, founded the local branch of the Gioventù femminile, and various bodies for Catholic university graduates and students. ${ }^{241}$

Eager to establish contact with the new bishop and be reassured of his support, Salerno began correspondence with Rodolfi even before his arrival from Pavia. In March 1911 she solicited Rodolfi for a commendation of La Donna e il lavoro, ${ }^{242}$ which duly appeared in the periodical:

Invoco dal Signore le più elette benedizioni sul periodico La donna e il Lavoro, giornale delle classi lavoratrici, sulla Onorevole Direzione, sulla Amministrazione, sui Lettori e Sostenitori del giornale, ed in modo particolare, sulla eletta schiera di Collaboratrici e Collaboratori, oltrechè su tutte le operaie.

\footnotetext{
${ }^{238}$ Cisotto, Elisa Salerno e la promozione della donna, cit., p. 14.

${ }^{239}$ Una penna inquieta, cit., p. 43, footnote 1.

240 Ermenegildo Reato, "Il Vescovo Rodolfi e il fascismo vicentino", in Tullio Motterle (a cura di), Tradizione e innovazione nella pastoralità di Ferdinando Rodolfi Vescovo di Vicenza 1911-1943, Vicenza, Rumor, 1996, p. 90.

${ }^{241}$ Una penna inquieta, cit., p. 43, footnote 1.

${ }^{242}$ Salerno’s letter to Rodolfi, 5 Mar. 1911, in ibid., pp. 191-192.
} 
Possa il giornale recare un poco di bene alla benemerita e modesta classe delle donne lavoratrici; possa conseguire quei nobilissimi scopi di difesa e di elevazione della classe operaia femminile, alla quale intende.

Ella voglia intanto raccomandare al Signore il nuovo Vescovo, perchè possa fare un poco di bene. ${ }^{243}$

While Rodolfi was determined to deal with the social problems of industrial workers and peasants, he also was adamant in putting an end to acrimony in his diocese. ${ }^{244} \mathrm{He}$ had the intention to renew various aspects of religious life and education, including the revision of catechisms for adults and children, to increase the congregation's participation in Church activities and sacred song, as well as to develop the administrative systems of parishes and other religious organizations. ${ }^{245}$ He wanted his authority as a bishop to be indisputable, as becomes clear from his letter in 1912 to Catholic journals, including Salerno's La Donna e il lavoro, which stated in no uncertain terms:

Niuno, che abbia impugnato la penna per la difesa dei diritti di Dio, niuno mai, per nessun titolo, può arrogarsi il mandato di entrare nel campo riservato ai Vescovi ... Voi, che avete assunto il nobile mandato di difendere la Religione, ricordate sempre ... in ogni circostanza, per quanto delicata del vostro ufficio, che tale mandato non può in nessuna guisa spingersi oltre i limiti fissati dalle leggi e dalla disciplina ecclesiastica. Il che, se mai talvolta da alcuno si faccia, è altamente da deplorarsi e da sconfessarsi. ${ }^{246}$

Salerno's association with Rodolfi was initially cordial enough. She frequently approached the bishop to solicit words of encouragement to publish in her periodical, to advise him of its finances and to ask him for a subsidy. Relations, however, soon became brittle. They started with Salerno publishing a series of articles under the title Trattazione sulla donna. Their publication led to disagreements with her ecclesiastical censor, as mentioned above, and to accusations of disobedience by the bishop. Nevertheless, as late as mid-1914, Salerno still hoped to be able to count on Rodolfi's support in her quest to have her paper made an organ of the Unione fra le donne cattoliche. ${ }^{247}$ But things got worse. The publication of her treatise Per la riabilitazione della donna led to the suspension of her periodical La Donna e il lavoro. As a result, she made numerous appeals to the bishop to have it reinstated, offering successively different formulas for making a submission. Yet, while she was seeking readmission to

\footnotetext{
243 “Consolantissimo riscontro”, La Donna e il lavoro, a. 2, n. 14, 7 aprile 1911, p. 1.

${ }^{244}$ Chiara Magaraggia, "Scheda biografica”, in Una penna inquieta, cit., p. 23.

245 Elisa Cengia, Elisa Salerno. La paladina della donna, Dissertazione, Vicenza, Diocesi di Vicenza, Istituto di Scienze Religiose, 2002/03, p. 27.

${ }^{246}$ Alba Lazzaretto Zanolo, "Le associazioni vicentine del primo Novecento", in Il femminismo cristiano di Elisa Salerno e le sue prospettive, cit., pp. 38-39.

${ }^{247}$ Salerno’s letter to Rodolfi, 29 June 1914, in Una penna inquieta, cit., pp. 217-220.
} 
the Catholic press, she did not hold back her criticism of either her ecclesiastical assistant, Professor Tiziano Veggan, whom she described as being filled with antifeminist spirit, or her ecclesiastical censor, Don Giacomo Dalla Vecchia who, she wrote to the bishop, treated her like a despot. ${ }^{248}$ Then, in June 1918, eleven months from the issue of the ban on her periodical, Salerno suggested to the bishop that she should simply be readmitted to the Catholic press without a public submission on her part. $^{249}$ This is, in fact, was what happened. On 12 September 1918 she received a note inviting her to an interview with the bishop next day, with the outcome that La Donna e il lavoro was reinstated. Since the paper had not notified its readers of the ban, which was probably not known to working-class subscribers, Salerno reasoned it would be better not to publish her personal submission or to announce the paper's readmission. Agreeing to hand over all remaining copies of Per la riabilitazione della donna to the ecclesiastical authority, Salerno received a pastoral benediction. Rodolfi, however, refused to publish a notification about Salerno's readmission in the Bollettino ecclesiastico. $^{250}$

Controversy with ecclesiastical authorities was rekindled with Salerno's publication, in 1924, of Dottrina cristiana sulla donna in which she took up again the arguments of 1917, but in a more radical manner, even raising doubts about the ministry of the bishops and the Pope. ${ }^{251}$ Between September 1923 and January 1925 Salerno wrote a series of articles, Commenti critici alle note bibliche antifemministe, in which she criticized Monsignor Antonio Martini’s commentary on the Bible; and in February 1925 she wrote an article, under the provocative title of Dottrina infetta, in which she criticized the catechism published by Bishop Rodolfi in 1921 for use by schools. ${ }^{252}$ This article occupied the entire issue of 13 February 1925 of Problemi femminili. In it Salerno summarized her doctrinal criticism of Rodolfi's catechism under four headings: prevarication of truth regarding the true nature of woman; denial and rejection of woman's mission; repudiation of woman's importance in the generation of the human species; and disdain and concealment of woman's merits. ${ }^{253}$ Her points did not

\footnotetext{
${ }^{248}$ Salerno's letter to Rodolfi, 11 May 1918, in ibid., p. 246.

${ }^{249}$ Salerno’s letter to Rodolfi, 3 June 1918, in ibid., p. 248.

${ }^{250}$ Cisotto, Elisa Salerno e la promozione della donna, cit., pp. 108-109.

251 Ibid., p. 133.

${ }^{252}$ Ibid., pp. 134-135.

253 "Dottrina infetta”, Problemi femminili, a. 7, n. 3, 13 febbraio 1925, p. 1:

"I quattro vizi capitali di questa dottrina
} 
substantially differ from the arguments in Per la riabilitazione della donna, but in this case were even more provocative since they were directly aimed at a publication by her local bishop. The immediate response by the latter was to announce, in March 1925, a ban on Problemi femminili, which henceforth should neither be printed, nor read, nor sold. $^{254}$ In April 1926 the Congregazione del Santo Uffizio confirmed Rodolfi's proscription on the basis of "errors of a social and religious character contained in said periodical”. ${ }^{255}$ Despite the condemnation Salerno continued publishing. Seeing that Salerno distributed copies to almost all bishops in Italy, the Vicenza curia found it necessary to reissue the earlier proscription in mid-1926. ${ }^{256}$

A fortnight after the imposition of the ban, Rodolfi approached Salerno asking her to make a submission lest she be deprived of the sacraments. She refused to retract her criticism questioning in her unpublished notes the validity of an excommunication not emanating from the Pope. Moreover, she continued to receive the sacraments in the local churches which administered them to her indiscriminately (indifferentemente). ${ }^{257}$ With the condemnation came great suffering, however, and while Salerno refused to yield to the pressures to retract her statements, her health deteriorated. Her subsequent appeals to Rodolfi remained unanswered.

If Salerno had hoped to have the Pope and the bishop seriously consider removing the misogynist components from Catholic dogma - which was highly unlikely in any case then the timing of her pleas made it even less likely, since, unavoidably, external circumstances took precedence. By all accounts Bishop Rodolfi was an authoritarian yet well respected figure. In 1917, when Per la riabilitazione della donna was published, Vicenza was in the front line of World War I battles on the Italian front. Hostile invasion, famine, and the flight of the civilian population into distant provinces absorbed the bishop's attention. His letters to parish priests became civilian bulletins

\footnotetext{
In complesso, questo nuovo catechismo: I. Trafuga la verità circa la natura della donna; II. Misconosce e rigetta la missione della donna; III. Nega l'importanza della donna nella generazione della specie umana; IV. Disprezza e nasconde i meriti della donna."

${ }^{254}$ Cisotto, Elisa Salerno e la promozione della donna, cit., p. 133.

The ban on Problemi femminili was notified also in "Per un periodico femminile", Bollettino dell'Unione femminile cattolica italiana, a. VI, n. 9, 1 maggio 1925, p.1: "Tutte le nostre dirigenti sono avvisate che il periodico Problemi femminili che si stampa in Vicenza, tipografia Arti Grafiche G. Rossi e C., è incorso nella proibizione della chiesa. Il Vescovo di Vicenza ne pubblicava il decreto il 10 marzo sul Bollettino della Diocesi. Si vigili perchè nelle nostre file non circoli questa pubblicazione, che sotto colore di difendere i diritti della donna, fa scempio della dottrina di Cristo.”

${ }^{255}$ Cisotto, Elisa Salerno e la promozione della donna, cit., p. 165.

${ }^{256}$ Ibid.

${ }^{257}$ Bertuzzo, La donna e la Chiesa, cit., p. 150.
} 
regarding procedures to follow in case of evacuation, instructions for warding off epidemics and contagious diseases and, especially after Caporetto, appeals for duty and courage. In his relief efforts Rodolfi did his utmost to help civilians and the clergy, and actively cooperated with the civilian and the military authorities, while he also protected his priests from accusations of defeatism. ${ }^{258}$

In 1925 the bishop would have been insensitive to Salerno's feminist arguments for a different reason. After the March on Rome on 28 October 1922, in the Vicenza diocese, too, priests became targets of fascist violence. Initially cautious in his responses, Rodolfi protested vigorously against the intimidation accompanying the April 1924 elections (which incidentally the local popolari almost won) and excommunicated those involved in beating up local priests. Tensions lessened with the visit Mussolini paid to Vicenza in 1925, but the situation worsened again after a failed attempt on Mussolini's life in November 1926, with the mayor walking out of a thanksgiving service when the bishop in his speech admonished the parishioners that it was now time for reflection so that no further excesses, no further violence would be perpetrated. Disturbances continued, with Rodolfi receiving little support from the Vatican which at the time was preoccupied with the settlement of the Roman Question. ${ }^{259}$

Throughout her life Salerno was more interested in feminist issues than practical politics. Apart from her support of the Christian democratic movement and its syndicalist activities, she was decidedly anti-socialist, refusing to align with any other political movement. With a concern for the improvement of women's social and economic position, she applauded those policies which she perceived as furthering such goals. When the Partito popolare italiano, which under Luigi Sturzo had drawn together the still remaining Christian democratic elements, was founded in 1919, Salerno reviewed its programme in Problemi femminili. ${ }^{260}$ She started her assessment with extracts from an "authoritative letter" which ostensibly had reached her office. The new party, the letter stated, although deriving its principles from the Catholic faith, was independent from the ecclesiastical authority. In a situation in which the nation was threatened by bolshevism, anti-Christian sectarianism, and political parties stirring up social disruption, Catholics had the duty to adhere to the Partito popolare, whereby

\footnotetext{
${ }^{258}$ Alba Lazzaretto Zanolo, Vescovo clero parocchia. Ferdinando Rodolfi e la diocesi di Vicenza 19111943, Vicenza, Neri Pozza, 1993, p. 33.

${ }^{259}$ Reato, "Il vescovo Rodolfi e il fascismo vicentino", cit., pp. 90-93.

260 “Il Partito popolare italiano e il suo programma”, Problemi femminili, a. 1, n. 4, 21 febbraio 1919, p. 2.
} 
they would not have to sacrifice their Christian principles. Salerno was in agreement with Article 1 of the party's programme which promoted the integrity of the family and its protection against breakup and corruption, as well as public morality, welfare and protection of children, and women's right to take recourse to law to prove paternity. While generally agreeing on the text of the programme, Salerno noted one major item missing from it, and that was an abolitionist policy on prostitution. Finally, although expressing her delight in Article 10 of the programme postulating the vote for women, Salerno warned that Italy should not commit the same injustice as England, which had restricted female suffrage to women over thirty. ${ }^{261}$

By the time Mussolini, in 1925, granted women the vote at local elections Salerno had retreated from her earlier, more rigorous views, which demanded full voting rights for women at both national and local elections, and greeted the news with satisfaction. Since the vote was qualified by property ownership and educational criteria, it was strangely at odds with her long-held democratic principles:

In esso la Salerno non coglieva gli elementi discutibili in ordine a questioni giuridiche e l'intrinseca antidemocracità, ma vedeva semplicemente il raggiungimento di un parziale diritto femminile. ${ }^{262}$

Her letter to the President of the Senate indicates that she found "partial” electoral rights satisfactory, and was also impressed by the respectful and dignified way in which discussions had taken place:

Noi ci auguriamo che detto disegno di legge sia approvato senza difficoltà dal Senato, tanto più trattandosi soltanto d'un parziale riconoscimento dei diritti elettorali delle donne.

Facciamo voti altresì che le discussioni siano improntate a nobiltà di criteri, siano rispettose, dignitose, nei riguardi del sesso muliebre. ${ }^{263}$

Until October 1926 Salerno was able to publish her periodical without interference from fascist authorities. She attributed her persecution, when it came, to the agency of the ecclesiastical authority, as becomes obvious from her letter of 15 November to Mussolini. ${ }^{264}$ Yet no evidence has come to light to prove this imputation. The rough treatment she received from fascists came to her as a surprise, because, she was, after

\footnotetext{
261 Ibid.

${ }^{262}$ Cisotto, Elisa Salerno e la promozione della donna, cit., p. 61.

${ }^{263}$ Salerno's letter to Tommaso Tittoni, President of the Senate, 2 June 1925, in Una penna inquieta, cit., p. 284.

${ }^{264}$ Salerno’s letter to Mussolini, 15 Nov. 1926, in ibid., p. 254: “L’Autorità di Pubblica Sicurezza mi perseguita, soltanto da circa due mesi, mossa dall'Autorità Ecclesiastica, per dare soddisfazione alla quale s’è assunta il compito di farmi duri trattamenti”.
} 
all, a model citizen who responded, for example, to Mussolini's appeals for subscriptions of money, ${ }^{265}$ and sent obsequious letters to new appointees to high office. $^{266}$ Salerno's harassment by fascists came a year and a half after her excommunication and the condemnation of her periodical by Bishop Rodolfi. As noted before, the latter at the time had his own difficulties with paramilitary fascist squads. In the wider context, the top echelons in the Vatican were by then confident that Mussolini was going to stay in power. Squabbles at the local level did not interest either party higher up in their respective hierarchies. ${ }^{267}$

Trouble for Salerno began when she was ordered to submit the pre-publication proofs of her periodical to the secretary of the police chief, Capo Gabinetto Dr. D’Alessandro. ${ }^{268}$ In her above-mentioned letter of 15 November to Mussolini, Salerno wrote that D'Alessandro had approached the printer directly to obtain the proofs, and had cancelled some material. Not wanting to see her articles mutilated, Salerno had then asked Mayor Lucciardi to examine the material concerned. Receiving no response, Salerno assumed she could go ahead with publication. Seeing the cancelled material in print, D’Alessandro invited Salerno to Questura, police headquarters, threatening to have her arrested. ${ }^{269}$ From then on she appears to have been subject to continuous harassment, even though the subject matter of her articles had not even remotely anything to do with political issues but, instead, contained sustained attacks on the Church on doctrinal grounds. Hers was not, of course, the only Catholic journal which was experiencing problems. In 1926 four papers were affected: Il Cittadino in Brescia,

\footnotetext{
${ }^{265}$ Salerno’s letter to Mussolini, 16 Dec. 1926, FES ES 47: “... ascoltando, come sempre, l’appello della Patria, nonostante le mie difficoltà, ho sottoscritto L:500, cinquecento, al Prestito del Littorio”.

${ }^{266}$ Salerno’s letter to R. Prefetto di Vicenza, Podestà Lucciardi, 19 Oct. 1926, FES L. n. 39: “... la sottoscritta, nel presentarsi alla S. V., sente il gradito dovere di esprimerle il suo devoto benvenuto, con l'augurio che il nuovo campo d'azione affidatole, Le sia fecondo di alte soddisfazioni”.

${ }^{267}$ Clark, Modern Italy 1871-1995, cit., p. 254.

${ }^{268}$ Salerno’s letter to Comm. Cavalieri, R. Prefetto di Vicenza, 9 Oct. 1926, FES L. n. 38: "Senza giuste ragioni, senza alcuna legalità, il Capo Gabinetto Dott. D’Alessandro m’ha chiamata alla sua presenza, m'ha rampognata, m'ha offesa, ed esige che gli faccia avere tutte le bozze di stampa del periodico 'Problemi femminili' da me diretto, per la censura preventiva".

On 17 June 1926 Salerno had written directly to D’Alessandro after being denigrated by another Vicenza journal: “... mi permetto di presentarle copia degli opuscoli: Per la riabilitazione della donna; - Dottrina cristiana sulla Donna; - Commenti critici alle note bibliche antifemministe - con la speranza che la S.V. vorrà vederli benevolmente. Unisco un foglio di 'Problemi femminili', in cui è ritratta la questione muliebre, di fronte alla Chiesa (o viceversa), con l'articolo in III e IV pagina, intitolato: L'Atteggiamento degli uomini della Chiesa di fronte al femminismo ed all'antifemminismo.

Non so se, alla S. V., sieno sfuggite le denigrazioni, di cui mi gratificò, mercoledì 9 c.m., il 'Corriere Veneto'. In quei giorni, m'era anzi venuto in mente di rivolgermi al Signor Prefetto, per invocare da Lui un opportuno richiamo al Direttore di quel giornale.” In Una penna inquieta, cit., pp. 251-252. Original italics retained.

${ }^{269}$ Ibid.
} 
Il Nuovo trentino of De Gasperi, and Il Messaggero toscano as well as Il Corriere vicentino, which changed its title to Corriere veneto. ${ }^{270}$

In the meantime, Salerno was requested to become a member of the Sindacato fascista dei giornalisti veneti which was formed in April 1926. Writing to the management of the Sindacato in December 1926, Salerno indicated that while she was previously disposed to join the organization, she now wanted more information. Further, Problemi femminili dealt with matters related to the elevation of women according to the laws of God, and therefore wanted to remain outside any political party, yet remain respectful of and obedient to public authorities:

... il periodico "Problemi Femminili", svolgendo la dottrina cristiana sulla donna, propugnando l'elevazione di questa, secondo le Leggi di Dio e della natura umana, si tiene sopra e fuori d'ogni Partito, senza mai immischiarsi nelle competizioni politiche, sente non meno vivamente il gravissimo obbligo di essere, in ogni suo atto, riverente, docile, come fece fin qui, ai pubblici Poteri, legittimamente costituiti e conseguentemente al presente Regime. ${ }^{271}$

In her final appeal to the Under-Secretary of State in March 1927, Salerno indicated that she had reorientated her paper from being an organ for women workers, as reflected in its earlier subtitle Periodico nazionale delle operaie, impiegate e professioniste, to a publication for the clergy and the cultured with a new subtitle, Rivista di scienze religiose e morali. ${ }^{272}$

One would like to be able to describe Salerno's stand in the final six months of her publication as noble and principled. This was not the case. By 1926 she had made her paper an instrument of strident anti-doctrinal propaganda. In her letters, moreover, she warned Mussolini against giving too many liberties to the Church, claiming that, despite appearances, it was treacherous and nurtured hostile attitudes towards the regime. ${ }^{273}$ She also alerted local police to her Catholic adversaries. ${ }^{274}$ All that mattered to her was to continue publishing articles on antifeminist errors in Catholic dogma in a periodical

\footnotetext{
${ }^{270}$ Ibid., p. 258 footnote.

${ }^{271}$ Salerno’s letter to Direzione del Sindacato fascista dei giornalisti veneti, 20 Dec. 1926, in ibid., p. 259.

${ }^{272}$ Salerno's letter to the On. Sottosegretario di Stato, 24 Mar. 1927, FES L. n. 55.

273 Salerno's letter to Mussolini, 15 Nov. 1926, in Una penna inquieta, cit., p. 253: "Voglia l’Eccellenza Vostra lasciare che Le esprima, in proposito, un pensiero: Il Fascismo, nell'accordare tante libertà alla Chiesa, si è ben assicurato che, sotto le parvenze di essa, non fossero tesi lacci, non fossero nutriti spiriti, ostili al Regime”.

${ }^{274}$ Salerno’s letter to D’Alessandro, 17 June 1926, in ibid., pp. 251-252.
} 
for which she found no readers. ${ }^{275}$ To keep it alive, she was even prepared to abandon her core constituency, the operaie, who probably were never really hers.

Yet Salerno's contribution to femminismo cristiano was significant. In her early years she experienced the lively excitement created by the promulgation of Leo XIII's Rerum novarum, and came to see her social apostolate on behalf of the disadvantaged as a path to Christian perfection. Her attraction to Christian democracy and her empathy with women workers provided the underpinnings of her social activism. Calling herself a lavoratrice del pensiero, she found her preferred medium in journalism. Initially writing for a number of journals but experiencing difficulty in publishing her articles, Salerno came into her own with the founding of La Donna e il lavoro. While concurring with the avant-garde feminism of the Milanese paper Pensiero e azione, she found it increasingly difficult, as time went on, to accept the conservative programme of the succeeding women's movement, the Unione fra le donne cattoliche d'Italia. Never an insider of the Milanese feminist group, she remained even more an outsider from the conservative women's movement. As a writer she took over a number of women's issues from femminismo cristiano elaborating them further in her own singular way. Not content merely in demanding equal rights, she turned around the argument by challenging the privileges enjoyed by the male gender. Looking for reasons for the subjection of women, she began more and more to see them in the antifeminist teachings of the Catholic Church, and it is in this area that Salerno made her most original contribution to femminismo cristiano. In the hope of having Catholic dogma expunged of its antifeminist components, she turned to the top echelons of the Church hierarchy.

One wonders if Salerno really believed that her petition would move the clergy. More than ever the Church in this period saw the need to enforce its patriarchal values and to see women remain in their traditional domestic roles. It was not willing to accommodate any form of feminism within its ranks, let alone her demands for revision of its doctrine. Salerno herself did not regard her writings as either modernist or political. Yet they were both. Her pleas for the deletion of antifeminist references from Catholic dogma were parallel with modernists' demands for the reinterpretation of the

${ }^{275}$ On p. 165 of Elisa Salerno e la promozione della donna, cit., Cisotto writes: “... la curia vicentina si sentì in dovere, a metà del 1926, di ripubblicare il decreto di proibizione del 1925: 'anche per norma dei confratelli d'episcopato, ai quali viene spedito il foglio malgrado l'abbiano ripetutamente respinto'”. 
Biblical text. Her quest for equal rights for women, on the other hand, had there been any chance of success, would have resulted in redistributing economic, social and political power between the genders. By the time Mussolini came to power in 1922, it must have been clear to Salerno that the Church was not going to consider her demands. Unable to perceive that Church and State had almost identical platforms on women, she now pinned her hopes on Mussolini in the expectation that he would listen to her. Moving towards reconciliation with the Church, however, the Fascist regime would have no truck with Salerno's denunciations of Catholic dogma. In the end her obsessive dedication to doctrinal matters saw her forget her Christian democratic roots and shift her priorities away from her previously prized social activism on behalf of workingclass women. With no-one willing to listen to her, Salerno’s feminist message was ultimately consumed in the corrosive vortex of anti-doctrinal sentiment. But this does not cancel out the contribution which she had made to femminismo cristiano by exploring the roots of antifeminism in the Church. Nor would anyone doubt her courage in the advocacy of women's rights. 
In this chapter we will look at Catholic women's movements in the period from 1909 to the late 1930s. Part I deals with the evolution and the operation of the conservative Catholic women's organization, the Unione fra le donne cattoliche d'Italia, and Part II with the young women's organization, the Gioventù femminile cattolica italiana (later known as the Gioventù femminile di Azione cattolica), while Part III focuses on the contemporary fascist women's movement for the purpose of comparison with the Catholic women's organizations.

\section{PART I}

\section{The Unione fra le donne cattoliche d'Italia}

The First National Congress of Italian Women in Rome in April 1908 had alerted the Church to the need to create a nationwide organization for Catholic women to combat the advance of secular feminism. Adelaide Coari's Federazione femminile, although still in existence, was unsuitable for the task because of its affinity with secular feminism, its leftist political orientation, and its alleged modernist links. It was also evident that the diverse Catholic women's associations lacked coordination and that a greater number of women had to be mobilized in order to promote the Church's agenda. The new organization would be a means whereby the Church could exert a controlling influence over Italian women as well as provide not only for their religious but also for their cultural and social requirements and aspirations. This would assure the Church of women's loyalty in confronting its liberal, socialist, and, later, fascist adversaries, while protecting the women themselves from contamination by secular feminism.

The first of these organizations, the Unione fra le donne cattoliche d'Italia, was founded as a direct response to the Rome congress. The first president, Princess Maria Cristina Giustiniani Bandini, has recorded its genesis in various unpublished documents and in a printed pamphlet entitled Il beato Pio X e l'associazione cattolica femminile. ${ }^{1}$

\footnotetext{
${ }^{1}$ Maria Cristina Giustiniani Bandini, Il beato Pio X e l'associazione cattolica femminile, Roma, 1951.
} 
In addition, Paola Gaiotti de Biase gives useful background information on the birth of the Unione donne in her article "La nascita dell'organizzazione cattolica femminile nelle lettere di Cristina Giustiniani Bandini al Toniolo”, which includes copies of Giustiniani Bandini’s letters to Giuseppe Toniolo. ${ }^{2}$ Cecilia Dau Novelli’s authoritative book Società, chiesa e associazionismo femminile ${ }^{3}$ and her various articles on the subject provide more than the narration of the origins of the Unione donne because they highlight not only its chief characteristics and ideological context but also its economic and social environment. While Dau Novelli's coverage extends only as far as 1919, Paola Di Cori sketches the developments of the Catholic women's movements over a period of four decades, first in her article "Storia, sentimenti, solidarietà nelle organizzazioni femminili cattoliche dall'età giolittiana al fascismo”, ${ }^{4}$ and then in an essay written jointly with Michela De Giorgio, "Politica e sentimenti: le organizazzioni femminili cattoliche dall'età giolittiana al fascismo”. ${ }^{5}$ For factual information on the history of the Unione donne, two books stand out: Magnificat, ${ }^{6}$ compiled to commemorate the twenty-fifth anniversary of its foundation, and Giovanni Canuti's Cinquant'anni di vita dell'Unione donne di A.C.I., which was published to coincide with its fiftieth anniversary. ${ }^{7}$

In her introductory chapter Dau Novelli compares secular feminism with the officially sponsored Unione donne, pointing to the spectacular success of the latter in relation to both the bourgeois and the socialist feminist movements. While secular feminism could attract only a very small number of women, the Catholic women's movement was more widely accepted because it was better attuned to the way in which the majority of women approached everyday realities. Feminist organizations, argues Dau Novelli, had little appeal to the numerous housewives whose cultural needs were fulfilled by reading love stories and by attending religious ceremonies. ${ }^{8}$ In this environment, the Unione donne played a major, positive role. Even though never abjuring the principal traits of

\footnotetext{
${ }^{2}$ Paola Gaiotti de Biase, "La nascita dell’organizzazione cattolica femminile nelle lettere di Cristina Giustiniani Bandini al Toniolo”, Ricerche per la storia religiosa di Roma, v. 2, 1978, pp. 225-271.

${ }^{3}$ Cecilia Dau Novelli, Società, chiesa e associazionismo femminile. L'Unione fra le donne cattoliche d'Italia (1902-1919), Roma, A.V.E., 1988.

${ }^{4}$ Paola Di Cori, “Storia, sentimenti, solidarietà nelle organizzazioni femminili cattoliche dall'età giolittiana al fascismo”, Nuova dwf, n. 10-11, gennaio-giugno 1979, pp. 80-124.

${ }^{5}$ Michela De Giorgio e Paola Di Cori, "Politica e sentimenti: le organizzazioni femminili cattoliche dall'età giolittiana al fascismo”, Rivista di storia contemporanea, fasc. 3, 1980, pp. 337-371.

${ }^{6}$ Consiglio superiore Unione donne di Azione cattolica italiana, Magnificat, Roma, 1934. Henceforth referred to as Magnificat.

${ }^{7}$ Giovanna Canuti, Cinquant'anni di vita dell'Unione di A.C.I., Roma, S.A.L.E.S., 1959.

${ }^{8}$ Dau Novelli, Società, chiesa e associazionismo femminile, cit., p. 6.
} 
feminine nature, the Catholic women's movement made an arduous effort to bring women out of their world of fantasies, dreams and feelings by introducing them into the realm of rationality, judgment and study. ${ }^{9}$

Citing Jean-Jacques Rousseau and Alexis de Tocqueville to explain how the perception of alleged incompatibility of intelligence and piety in the feminine sex had taken hold, Dau Novelli traces the social and psychological origins of the subjection of women to eighteenth-century society. She finds that women's subordination was attributable to influences external to the Church since the most wide-spread Catholic women's association, the Unione donne, could not have developed had there been dogmatic prejudice in the Church. ${ }^{10}$ While accepting that misogynist secular writings had contributed to the negative view on women, we cannot completely overlook the influence Catholic doctrine had exerted on the general population in perpetuating the image of women as anthropologically and socially inferior to the male sex. It could be said that the denigration of women in eighteenth-century literature paralleled the way in which the underlying misogyny of Catholic dogma had permeated society. Moreover, the reason why the Unione donne was allowed to prosper in the bosom of the Church could be sought in its complete docility in doctrinal and political matters. Indeed, the Church had every reason to promote an organization which was totally under its control and furthered its aims.

Dau Novelli goes on to say that the Catholic women's movement tried to achieve precisely what Rousseau considered impossible - coupling rationality with devotion in women's minds. Thus, she argues, the women's movement strove to create an organization in consonance with the faith while taking care "not to corrupt traditional feminine inclinations but to render them orderly, rational and scientific". ${ }^{11}$ By comparison, the avant-garde feminist platform was too advanced for the mind-set of the average housewife. This aspect, together with the inherent structural weakness of the secular movements and of the Federazione femminile, made these less able than the Unione donne to attract large followings. Regarding the Federazione femminile Dau Novelli writes:

\footnotetext{
${ }^{9}$ Ibid.

${ }^{10}$ Ibid., pp. 3-8.

${ }^{11}$ On p. 8 of Società, chiesa e associazionismo femminile, cit., Dau Novelli writes: "Proprio questo fu il tentativo del movimento femminile: accordare l'organizzazione alla fede, cioè non snaturare le tradizionali tendenze muliebri, ma renderle ordinate, razionali e scientifiche”.
} 
Il gruppo di Adelaide Coari, fondatrice della Federazione, che non riuscí mai a darsi un ordinamento e una struttura efficienti, si spese in un'attività continua di dibattito e di confronto con le altre tendenze emergenti, incontrando perciò l'opposizione della chiesa ufficiale. ${ }^{12}$

But, with a membership of at least twenty thousand, the Federazione femminile, too, was successful in its appeal to Catholic women. It could be argued, alternatively, that the collapse of the Federazione was due less to its organizational weakness or to its dissipation in polemics than to the complete withdrawal of ecclesiastical support. Nor can it be said that the Christian democratic women's movement ever enjoyed a monopoly over Catholic women's associations as the Unione donne did. One should not forget, either, that the Unione donne and the Federazione femminile aimed at different groups of women who had their distinctive needs. Targeting, in the first instance, upper- and middle-class women, the Unione donne concentrated on educational and cultural matters, whereas the Federazione femminile, in addressing the needs of working-class and lower middle-class women, was focused on dealing with industrial problems stemming from the everyday working environment and ultimately with feminist as well as political issues in its search for social justice.

Dau Novelli's book conveys the view that by its nature the Unione donne was best suited to meet the needs of most Italian women at the time. She finds that by the Giolittian years the standard of living in Italy had risen to the extent that the number of women employed in industry and in agriculture had begun to decline. ${ }^{13}$ While fewer women worked outside the home, an increasing number were employed in more highly skilled jobs. At the same time, the vast bulk of Italian women were housewives, who were content to remain at home in order to care for their families. ${ }^{14}$ With minimal interest in feminist or political issues, these women, nonetheless, were willing to make an active contribution to Church and society.

In Paola Di Cori’s article “Storia, sentimenti, solidarietà nelle organizzazioni femminili cattoliche dall'età giolittiana al fascismo”, Catholic women's organizations are examined up to World War II. Contrary to secular feminist groups - she observes - the Catholic women's movement was characterized by intrinsic solidarity among women, which ensured its longevity. Germane to the notion of solidarity, two elements were

\footnotetext{
12 Ibid., p. 17.

${ }^{13}$ For further discussion of women’s employment, see Chapter One, pp. 44-52.

${ }^{14}$ Dau Novelli, Società, chiesa e associazionismo femminile, cit., pp. 39-40.
} 
always present when women reflected on their condition in theoretical and programmatic writings. The first concerned the development of women's historical awareness of the oppression of the feminine sex. The second element was associated with the nature of women's sentiments, and how and to what extent they could be modified. While the strength of solidarity with other women was in direct proportion to the degree of awareness of a common history of oppression, perceptible similarities in feeling and in expressing sentiments demonstrated solidarity with specific aims. ${ }^{15}$ By demanding access to education and the right to vote women became aware of their own history. Despite profound differences in overall objectives, this awareness reinforced and extended bonds of solidarity between various groupings, such as the Consiglio delle donne italiane and the Milan-based Unione femminile. Under fascism this common heritage would vanish once and for all ${ }^{16}$ with the notable exception of the "efficiently structured, active and influential” Catholic women's movement. ${ }^{17}$

In the early 1900s, Di Cori comments, the nascent Catholic women's movement was in disarray, and quotes Elena da Persico, editor of L'Azione muliebre, who deplored the lack of coordination between the various women's associations which operated independently from each other and followed their own agendas. ${ }^{18}$ The contemporary Christian democratic group around Pensiero e azione, argues Di Cori, failed at its 1907 conference to conduct a dialogue with secular feminists and to conciliate the progressive stance of Pensiero e azione with the conservative position of L'Azione muliebre. ${ }^{19}$ The split within the Catholic women's movement became apparent, and a year later at the First National Congress of Italian Women the controversy surrounding religious instruction in effect isolated the Christian democrats from the rest of the feminist movement. Very soon the new conservative Catholic women's organization, the Unione fra le donne cattoliche d'Italia, took firm control over Catholic women's associations, commencing with the task of grooming women's minds by weeding out sentimentalism from their religious life and replacing it with the study of catechism. ${ }^{20}$

\footnotetext{
${ }^{15}$ Di Cori, “Storia, sentimenti, solidarietà nelle organizzazioni femminili dall’età giolittiana al fascismo”, cit., p. 81.

${ }^{16}$ Ibid.

${ }^{17}$ Ibid., p. 83.

${ }^{18}$ Ibid., p. 100.

${ }^{19}$ Ibid., p. 107.

${ }^{20}$ Ibid., p. 110.
} 
According to Di Cori, the success of the Catholic women's organizations from 1909 onwards can be attributed to women's solidarity in the face of their generally unhappy condition and to the skilful manipulation of their sentiments. ${ }^{21}$ No less visible than feminism, yet fundamentally different, Catholic activism, as it evolved, no longer portrayed the choice between the emancipated and the traditional woman. Instead, the woman in Catholic Action was fashioned to suit the times, and was portrayed as someone who was emancipated and participated in a whole range of professional activities in accordance with her Christian apostolate. The model also stressed that employment outside the home was never by personal choice but caused by economic necessity. These notions combined to establish precepts for women's private and everyday lives in which the effects of the transformation of the traditional feminine image were blended with the concept of the naturalness of the domestic role. This provided a basis for an elaborate manipulation of women's sentiments which, in a decidedly anti-sentimental fashion, would perform the ultimate act of psychological depredation by combating everywhere not only objects of fantasy and desire, such as fashion, entertainment, recreational reading and free time, but also outbursts of bad temper, discontent and other undefinable states of mind. ${ }^{22}$

Michela De Giorgio’s and Di Cori’s essay, ”Politica e sentimenti: le organizzazioni femminili cattoliche dall'età giolittiana al fascismo”, is another publication exploring the durability of the Catholic women's movement. In the first years of the twentieth century, they observe, women constituted one of the sections of society which most attracted the interest of the Vatican hierarchy. ${ }^{23}$ Catholic women represented an essential link in the complex relationship between Church and civil society, and stamped on society a Catholic image of womanhood which, in a period ranging from fascism up to and through the 1950s, ultimately merged with the very identity of the Italian woman and came to embody the widespread national ideology on women. ${ }^{24}$ The constant interest of the Vatican hierarchy in nurturing and reinforcing the Catholic women's movement as well as the enormous commitment of the professors of the Università cattolica and the group around Armida Barelli played a part in fostering the fiery dedication of the members of Catholic women's associations. Thus the sense of

\footnotetext{
${ }^{21}$ Ibid., p. 108.

${ }^{22}$ Ibid., p. 87.

${ }^{23}$ De Giorgio e Di Cori, "Politica e sentimenti”, cit., p.339.

${ }^{24}$ Ibid.
} 
belonging was far more "interiorized" in Catholic than in fascist organizations. ${ }^{25}$ The difficulties underlying fascist women's organizations arose from “demobilizing the caparisons of war" (smobilitazione delle bardature di guerra) which the fascist woman had acquired, while transition to the exaltation of reproductive domesticity often came up against the genuinely indifferent attitude which the regime had to the problems of organizing women. ${ }^{26}$ In effect, the regime's frantic insistence on maternal values appeared gross and inadequate when compared with the messages disseminated by Catholic organizations. ${ }^{27}$ In the latter, the promotion of motherhood was perfected throughout the twenties, and was allowed to encompass married women, widows and single women. Especially in the last-named category women were given, in parish groups and circles, an identity denied to them by fascists. ${ }^{28}$ The regime took pains to stress women's “economistic” role, and appealed, in the first place, to the materfamilias who, as mother of a large and thriving family, made up an indispensable cell in the new civilization. Catholics came forth with an organization structure which addressed "new social needs" (nuovi bisogni di socializzazione) and also tried to "solve a political problem”. The feminine model which was produced by Catholic women's organizations with the endorsement of both the regime and the Church in the end became the national prototype:

Dal regime, oltreché dalla Chiesa, e qui sta il connubio, le organizzazioni sono autorizzate a rendere esplicito un modello che, una volta messo a fuoco nei suoi contorni, entra a pieno diritto nel cielo della grande politica, invade inesorabilmente tutto lo spazio delle vite individuali, a questo punto costrette da una doppia legittimazione a proseguire lungo il cammino della continuità e invarianza del modello femminile nazionale. ${ }^{29}$

Since coercion regarding women's natural roles had extended to fill out both the physical and psychological domains, words and deeds were no longer concerned with emancipation, and leisure no longer meant indulging one's fantasies and desires. ${ }^{30}$ After the fall of the regime, the effects of years of mobilizing Catholic women for everyday political issues (mobilitazione sulla politica del quotidiano) became apparent from the ease with which they identified with their new social role and the political

\footnotetext{
${ }^{25}$ Ibid., p. 368.

${ }^{26}$ Ibid., pp. 368-369.

${ }^{27}$ Ibid., p.369.

${ }^{28}$ Ibid., p. 370.

${ }^{29}$ Ibid., p. 371.

${ }^{30}$ Ibid.: “... i luoghi delle parole e del lavoro non sono più luoghi di emancipazione, né il tempo libero è quello in cui si può far spaziare la fantasia o il desiderio, perché la costrizione al rispetto dei ruoli naturali si è allargato fino a occupare e lo spazio fisico e quello psicologico”.
} 
rights it entailed. Not marked by fundamental historical discontinuities, Catholic women's organizations found themselves in a uniquely powerful position:

Svincolate da connivenze troppo pericolose, le organizzazioni femminili cattoliche incarnano a questo punto l'unica morale del tempo, sono la proposta che si arroga tutti i diritti egemonici perché segnata dalla assenza di sostanziali fratture storiche. $^{31}$

All the publications cited above agree on the success of the conservative Catholic women's movement. As will become clear from the following, the initial prosperity of the Unione donne was attributable to the energy, temperament and the organizational talent of its first president, Princess Maria Cristina Giustiniani Bandini (1866-1959), and to her closeness to Pius X. Born into an aristocratic Roman family, she entered the convent of Sacro Cuore at Trinità dei Monti at eighteen after completing her education there. In 1895 she was compelled to leave the cloisters for health reasons; having given her dowry to the convent she could no longer return to her parental home, but had to earn a living by writing. With her religious commitment remaining intact, she became a Dominican tertiary in secular life. ${ }^{32}$ While politically ultra-conservative and antifeminist, she at the same time jealously guarded the independence of the Unione donne from Catholic men's organizations. Basing her organizational concept on the idea of accentramento nel decentramento, Giustiniani Bandini strove towards a centralized structure with a direct reporting relationship to the Pope at the top, but with appointments to the diocesan committees being subject to approval by the respective bishops. To best promote Catholic interests, the Unione donne was intended to be a non-political and antifeminist organization run by aristocratic and upper middle-class women.

In her article 'La nascita dell'organizzazione cattolica nelle lettere di Cristina Giustiniani Bandini al Toniolo”, Paola Gaiotti de Biase identifies three concurrent “initiatives” which provided alternatives for organizing Catholic women in the immediate aftermath of the Rome congress in 1908. First, there was an attempt by Giuseppe Toniolo to bring the women's movement under the umbrella of the Unione popolare as part of the men's movement; then there was Adelaide Coari's Federazione

\footnotetext{
${ }^{31}$ Ibid.

32 Angela Gotelli e Cecilia Dau Novelli, “Giustiniani Bandini, Maria Cristina”, in Francesco Traniello e Giorgio Campanini (a cura di), Dizionario storico del movimento cattolico in Italia 1860-1980, II: I protagonisti, Torino, Mariotti, 1982, pp. 257-259.
} 
lombarda ${ }^{33}$ which was openly aligned with Christian democracy and was in touch with "neutral” feminist groups; and, finally, there was Cristina Giustiniani Bandini’s Unione donne, which in the end carried the day. ${ }^{34}$

Many of the unresolved problems in the lay movement, writes Gaiotti de Biase, were present also in the Federazione femminile. As they moved toward setting up a Christian democratic women's organization, the youthful Christian democratic intransigents increasingly recognized the necessity for independent action. Sometimes they needed to cooperate with other, non-intransigent Catholics and at other times to make contact with socialist and liberal feminists. By taking up feminist demands, such as the vote for women, they anticipated a movement with political ambitions.

... lo scioglimento dell'Opera, consentendo lo sviluppo di presenze locali diversificate ed autonome anche se non sostenute nazionalmente, ha messo in evidenza tutti i problemi irrisolti della fase precedente. L'esperienza lombarda li riflette tutti: la spinta ad una organizzazione femminile cristiana si carica progressivamente di esigenze di autonomia talora saldando l'intransigenza giovanile democratico cristiana con esponenti cattolico-liberali; l'esigenza di un collegamento e di un coordinamento attivo porta a contatti col femminismo socialista e liberale; l'assunzione di posizioni rivendicative, esemplare e discriminante quella del voto alle donne, prefigurano i caratteri di un movimento con ambizioni politiche. ${ }^{35}$

By comparison, Toniolo's aspirations to coordinate all the various forms of the women's movement within the Unione popolare were doomed to failure because of his approach. By not recognizing emerging problems and their causes, he artificially blocked debates and choices which formed part of the everyday experience of femminismo cristiano:

L'aspirazione di Toniolo a coordinare tutte le varie forme di organizzazione femminile entro l'Unione popolare è in realtà destinata a fallire proprio perché muovendosi "al di qua" dei problemi e delle motivazioni emergenti, sembra congelare artificiosamente polemiche e scelte che fanno parte del vissuto quotidiano del femminismo cristiano. ${ }^{36}$

But, arguably, the most convincing reason for the failure of Toniolo's initiative was Giustiniani Bandini's strong determination to create a Catholic women's organization which was not subordinated to the men's movement and was directly under the Pope’s

\footnotetext{
${ }^{33}$ The Federazione lombarda refers here to Adelaide Coari’s Federazione femminile, not to Sabina Parravicino di Revel's Federazione lombarda delle opere di attività femminile.

${ }^{34}$ Gaiotti de Biase, "La nascita dell'organizzazione cattolica femminile nelle lettere di Cristina

Giustiniani Bandini al Toniolo”, cit., p. 228.

${ }^{35}$ Ibid, pp. 230-231.

${ }^{36}$ Ibid, p. 231.
} 
command. This resolve was steeled by the princess's lack of confidence in Toniolo and her dislike of Elena da Persico. The decisive manner in which Giustiniani Bandini acted after the women's congress in Rome had voted against religious instruction at schools earned her the Pope's trust, but even before the Rome congress she had ready access to him. On the occasion of the Convegno femminile in Milan in 1907, which was open also to non-Catholics, Pius X had advised her that, if Catholic principles were somehow to came under fire, Catholics should defend them without reserve. Interestingly, Giustiniani Bandini relates that Catholic women, herself included, had decided to organize the Milan conference with the help of the Federazione lombarda, of which Countess Sabina Parravicino di Revel was president, to test their ability to hold their ground against secular feminists. Giustiniani Bandini never acknowledged the Federazione femminile, the actual organizer of the conference, or its president Adelaide Coari. $^{37}$

A year later, when a vote against religious instruction was taken at the First National Congress of Italian Women, Giustiniani Bandini was among the initiators of the protest action. Already on the evening of the day of the vote, the 28 April, she met with Cardinal Vicar Pietro Respighi and Monsignor Giulio Serafini to formulate a protest declaration which would then be launched by La Civiltà cattolica. The following morning she was called upon early to circulate the text of the declaration to collect a maximum number of signatures from upper-class Roman women. On the very first day she mustered more than three hundred signatures, and very soon more than twenty-four thousand signatures had been collected and were published, as they came in, in Roman newspapers. $^{38}$ She also conducted a lively polemics with Linda Malnati, the socialist delegate, who at the Rome congress was responsible for initiating the motion against

\footnotetext{
${ }^{37}$ Giustiniani Bandini, Il beato Pio X e l'associazione cattolica femminile, cit., p. 7.

${ }^{38}$ Maria Cristina Giustiniani Bandini, “Alcuni appunti sulla storia della nostra ‘Unione’ 1907-1917”, manuscript, AGOP XIV.950 GIB.1.

Liviana Gazzetta’s account of the collection of signatures in Elena da Persico, Verona, Cierre, 2005, p. 70, differs from Giustiniani Bandini’s recollection: "La reazione cattolica fu immediata: furono avviate due raccolte di firme contro l'ordine del giorno votato, la prima promossa dalla principessa Giustiniani Bandini, la seconda dalla Federazione Femminile della Coari, poi confluite in un'unica iniziativa che ottenne oltre 26.000 adesioni; dopo qualche incertezza anche Giuseppe Toniolo fece partire una protesta dell'Unione popolare, come l'aveva sollecitato a fare, tra l'altro, la stessa da Persico".

Pensiero e azione, too, refers to the collection of signatures. Under the heading "Comunicato", it writes on page 19 of the issue of 10-25 maggio 1908, v. 4, n. 9-10: "La Federazione Femminile ... Continua con intenso lavoro le firme della protesta iniziata contro l'ordine del giorno Malnati. Coloro che volessero avere schede ne facciano domanda." The next issue of 10-25 giugno reports on p. 9: "La Federazione Femminile ... Avverte che la relazione delle firme raccolte e che sono più di 100,000 sarà fatto prossimamente”.
} 
religious instruction. ${ }^{39}$ Meanwhile the princess, together with her group of activists, decided to found women's circles all over Italy to promote Catholic cultural activities; and one such circle was set up in Rome on 29 June $1908 .{ }^{40}$

Another important development was a papal audience granted to Giustiniani Bandini and other members of her group Figlie di Maria. During the meeting the Pope vehemently turned on "those miserable wretches" who had prostituted their dignity as women and as Catholics by voting against religious instruction in schools:

Nel discorso tenuto in quella memorabile udienza, Sua Santità si scagliò con zelo veementissimo contro quelle disgraziate che avevano "prostituito la loro dignità di donne e di cattoliche” votando, nel recente Congresso del Consiglio Nazionale, ... per l'aconfessionalità della scuola... ${ }^{41}$

Giustiniani Bandini's Protesta ${ }^{42}$ and the ongoing collection of signatures had given some consolation to the Pope, who gratefully acknowledged her initiative. This prompted her to seek another, private papal audience to discuss the possibility of a new Catholic women's organization. After all, protests were good initially, she maintained, but useless unless followed by some concrete action. In face of an organization which wanted to snatch women from their mission at home and in society, it was necessary to create another organization, based on religious and moral principles, which would recall women to their primary duties:

Beatissimo Padre, di fronte a una organizzazione che tende [a] distogliere la donna dalla sua missione nella famiglia e nella società, conviene far sorgere un'altra organizzazione che la richiami ai suoi precipui doveri, basandosi su i principii religiosi e morali che debbono informare la sua missione muliebre. ${ }^{43}$

Pius X appeared to be opposed to any form of women's organization, since in his opinion the most appropriate thing for women was to stay at home and knit socks, a piece of homespun wisdom which he imparted to the princess in a "sweet" Veneto dialect: “... la donna che la piasa, che la tosa, che la resti in casa”. ${ }^{44}$ In response

\footnotetext{
${ }^{39}$ Giustiniani Bandini, “Alcuni appunti sulla storia della nostra 'Unione’ 1907-1917”, cit.

${ }^{40}$ Eadem, Il beatoPio X e l'associazione cattolica femminile, cit., p. 10.

${ }^{41}$ Ibid., p. 11.

42 “Protesta delle donne romane contro il voto per l'abolizione dell'insegnamento religioso nelle scuole primarie approrovato a Roma dal Congresso delle donne italiane il giorno 28 aprile 1908”, printed document, AGOP XIV.950 GIB.25.

${ }^{43}$ Ibid., p. 12.

${ }^{44}$ Maria Cristina Giustiniani Bandini, "In memoria di Pio X”, typewritten document for publication in the August-November 1913 issue of Azione cattolica femminile, AGOP XIV.950 GIB.53, p. 1. Not understanding the Veneto dialect, Giustiniani Bandini asked the Pope to translate his words for her: "Padre santo, non capisco il veneto”. “Ah, ah, riprese Pio X, non capite? Non volete capire. Ve lo spiego io. Vuol dire che la donna deve restare in casa a fare la calza. Altro che organizzazione femminile!”
} 
Giustiani Bandini stressed the urgency for a women's organization, since it was necessary to defend Catholic principles against new theories imported from Protestant countries as well as deal with threats posed by the feminist movement and freemasonry. ${ }^{45}$ She went on to present the Pope with her draft design for women's circles which the Pontiff returned to her a few days later giving his approval to their foundation. ${ }^{46}$ Giustiniani Bandini regarded 16 July 1908, the date appearing in the Pope's commentary on her draft, as the foundation day for the Unione fra le donne cattoliche d'Italia.

In its opening statement, the document, Circolo femminile di attività e di cultura italiana, stated that Catholic women had often been unjustly accused of not contributing effectively to society. Much work, however, had been done on an individual basis, it maintained, but to maximise its purpose, two major factors had to be present: the spirit of the apostolate and the perfect harmony of ideas. The latter involved renunciation of any form of egoism and self-glory in the task at hand. There was no room for error, nor should any indulgence be shown toward doctrines condemned by the Church. The spirit of the apostolate, on the other hand, was required from those admitted to the membership so that they would be equal to their task. These considerations had already led some ladies to set up a "truly Catholic circle". The members of the proposed circles had to commit themselves, first, to bring all the fecund influence of their religious sentiment to their work; second, to promote the moral and intellectual advancement of women in the different social classes; and, third, to take care of the material well-being of indigent people according to the spirit of the gospel. Each circle was envisaged to consist of three sections dealing, respectively, with religious propaganda, religious and social culture, and welfare activities. It was not intended to initiate new charitable activities but rather coordinate and sustain existing ones. In order to render such activities useful and practical in the highest degree, members were asked to leave the study of any economic and legal issues arising from their work to their governing

\footnotetext{
${ }^{45}$ Ibid., pp. 1-2: “... era dovere per noi cattoliche il difendere i nostri santi principii contro teorie nuove, importate da paesi protestanti; e questo non poteva farsi isolatamente, ma un movimento femminile cattolico doveva sorgere di fronte al nascente movimento femminista per combattere le teorie funeste ed impedire che le donne, pur sempre cattoliche in Italia, ingrossassero ingenue ed incoscenti le file di un esercito agli ordini, più o meno palesi, della Massoneria”.

${ }^{46}$ Giustiniani Bandini, Il beato Pio X e l'associazione cattolica femminile, cit., pp. 13-14: “Approviamo colla massima soddisfazione il Programma del Circolo di attività e di cultura cattolica di cui si fa benemerita iniziatrice la diletta figlia Marchesina Cristina Giustiniani Bandini, e formiamo voti, che tutte le donne veramente cattoliche vi aderiscano; perchè a questa opera di vera carità il Signore accorderà le migliori grazie, delle quali sia caparra la Benedizione Apostolica che a tutte impartiamo di cuore. Li 16 luglio 1908”. "(firmato) Pius PP. X”
} 
council, consiglio direttivo. This would be composed of a president, a vice-president, two councillors, and a secretary, and would meet monthly. ${ }^{47}$

While the establishment of circles modelled on Giustiniani Bandini's proposal was discussed in various cities, competition loomed on the home ground. As Gaiotti de Biase writes, an alternative organization already existed in Rome. In May 1908 Maria Roesler Franz had responded to an appeal initiated by the Federazione femminile with a view of forming a national federation. In fact she had written to Adelaide Coari in order to set up an affiliated group in Rome, asking the latter to send her the constitution of the Federazione speedily together with its social work programme as well as some words of encouragement for prospective members. As becomes clear from Roesler Franz's letter to Coari in May, the new group would pit itself in competition against Giustiani Bandini’s Circolo:

Ora quello che preme è di far sorgere subito il gruppo romano della Federazione. Avendo saputo che la Bandini ha questa sera udienza dal Card. Vicario per trattare le basi di una organizzazione femminile romana, ho subito chiamato a raccolta le amiche mie, per sabato ho indetto una adunanza qui in casa mia e così dar via al nostro gruppo di retto e sincero operare. ${ }^{48}$

Roesler Franz's group called itself Circolo verde and presumably took heart from the views expressed in La Civiltà cattolica by the Jesuit Antonio Pavissich who did not condemn outright the interaction of Catholics with secular feminists. ${ }^{49}$ By coincidence, the same periodical had also been instrumental in printing Giustiniani Bandini's letter of protest. In the face of such competing tendencies, Toniolo's role was ambivalent. He had come to distrust his own teachings as well as Coari’s, writes Gaiotti de Biase, and in his conciliatory attitude was unable to recognize that what was needed was not a new organization but the development of what already existed:

... non si tratta di organizzare ex novo ma di coordinare e di valorizzare quanto esiste. In realtà oggi appare chiaro che questo, e solo questo, era il modo per tener vivo il magistero sociale del Toniolo nel paese, e nel mondo femminile. Ma Toniolo stesso ormai ne diffida, come diffida della Coari, anche se è desiso a "non prendere un atteggiamento aggressivo" e conta, nella sua costante strategia conciliativa, di preparare le condizioni per un superamento delle contrapposizioni ... ${ }^{50}$

\footnotetext{
${ }^{47}$ Eadem, "Circolo femminile di attività e di cultura cattolica”, AGOP XIV.950 GIB.1.

${ }^{48}$ Gaiotti de Biase, “La nascita dell’organizzazione cattolica femminile”, cit., p. 242.

${ }^{49}$ Ibid.: "Il gruppo, che assumerà la denominazione corrente di Circolo verde e che poggia presumibilmente sull’apporto del gesuita Pavissich della 'Civiltà cattolica'...”

${ }^{50}$ Ibid.
} 
In August, in a letter to Giustiniani Bandini, Toniolo lamented the not inconsiderable “confusion of ideas" prevailing in Rome even among the good ladies who had participated in the protest against the resolution passed by the women's congress. Now Coari herself was openly opposing Catholic initiatives. Toniolo, who in the past had always favoured her, could no longer allow any ambiguity in his programme or ignore Coari’s association with Murri, Don Brizio and Grugni - men who had been condemned for their modernism. ${ }^{51}$

In her correspondence to Toniolo and his wife Maria, Giustiniani Bandini, too, was becoming increasingly concerned about the expansion of the Circolo verde. Her letter to Toniolo in December 1908 made reference to the attendance of Toniolo's own daughter, Signora Ferrari, at a meeting of the Circolo verde, ${ }^{52}$ and another letter in January 1909 expressed her dismay that the "solemn inauguration” of the Circolo verde had taken place before the official launch of her own circle. ${ }^{53}$ Writing to Maria Toniolo in February, she conveyed her unease about Toniolo's delay in sending her the necessary documentation (stampe) to enable her to inaugurate her own group officially. $^{54}$

The two contending groups in Rome had different ideological orientations. According to Dau Novelli, the principal difference was that the Circolo verde did not intend to limit its commitment to the Catholic world but wanted to open it up also "for those who were ignorant of Catholic principles”. It did not want to act in a confrontational manner toward “neutral” feminism, as Giustiniani Bandini did, but instead demonstrate its superiority through facts and deeds:

\footnotetext{
51 Toniolo’s letter to Giustiniani Bandini, dated 19 August 1908, in Giuseppe Toniolo, Lettere III 19041918, Città del Vaticano, Comitato Opera Omnia di G. Toniolo, 1953, p. 176: "E per di più la Coari prese ora un contegno di opposizione aperta alle iniziative cattoliche; ed avendola io per lo [sic] passato sempre secondata in ciò che scriveva e faceva di bene (è donna di energia e di talento) per avere il diritto di disapprovarla quando deviasse, ora non posso lasciare equivoco sul programma mio e dell'Unione popolare. Essa in lunghe e frequentissime conferenze col cardinale di Milano finì col dichiarare la propria emancipazione dalle direttive episcopali e papali; e a me pure scrisse cose desolanti, che attestano la sua definitiva decisione di porsi alla sequela del Murri, di don Brizio e del Grugni.”

As it turned out, Coari's group was not officially censured but invited to join the Unione donne. Coari chose to resume teaching while the rest of her group disintegrated. See Dau Novelli, Società, chiesa e associazionismo femminile, cit., p.111. For the discontinuation of Coari's periodical, Pensiero e azione, see Chapter Three, pp.151-155.

${ }^{52}$ Giustiniani Bandini’s letter to Toniolo, dated 7 December 1908, in Gaiotti de Biase, “La nascita dell’organizzazione cattolica”, cit., p. 250: “Le signore del Circolo verde si sono riunite e si riuniranno ancora giovedì prossimo. All'ultima riunione assisteva anche (mi anno detto) la sig.ra Ferrari.”

${ }^{53}$ Giustiniani Bandini’s letter to Toniolo, dated 11 January 1909, in ibid., p. 255.

${ }^{54}$ Giustiniani Bandini’s letters to Maria Toniolo, dated 20 and 25 February 1909, in ibid., pp. 260 and 262.
} 
L'impegno delle donne ... non doveva essere circoscritto al mondo cattolico, ma doveva anche aprirsi a quelli che vivevano nella ignoranza dei principi religiosi. Questa era la radicale differenza con il programma della Bandini. ${ }^{55}$

In 1908, Toniolo's role as president of the Unione popolare made him central to discussions of a new women's organization. He, as well as Elena da Persico, editor of L'Azione muliebre, envisaged such an organization as part of the Unione popolare. Among those who recognized the need for a women's section in the Unione popolare was also Elisa Salerno. As discussed in the previous chapter, her open letter to Toniolo regarding the matter was published in L'Osservatore cattolico on 30 September $1905 .{ }^{56}$ Both Toniolo, who at that stage saw no need for a separate women's section in the Unione popolare, and da Persico, who favoured a separate women's section, responded to Salerno's letter. This was probably the first occasion when Toniolo and da Persico came indirectly into contact with each other. Then, in September 1907, they had an opportunity to meet face to face at the first settimana sociale organized by the Unione popolare in Pistoia. Meanwhile Toniolo, through De Micheli, secretary of the Unione popolare, had asked da Persico to prepare a plan for future action on women. ${ }^{57}$

Da Persico was never able to produce a workable plan for a Catholic women's organization. Her concept, although not entirely clear, was somewhat different from Toniolo’s. Writing to him in August 1908, she proposed “a women’s league in defence of the faith" with a non-federated structure, to deal with religious matters. She was perplexed at Toniolo's intention to create a federation of women's groups without financial independence. Then, at the settimana sociale in Brescia, she indicated that the women's organization had to evolve in conjunction with the Unione popolare and pointed to the complementarity of religious and social initiatives. ${ }^{58}$

\footnotetext{
${ }^{55}$ Dau Novelli, Società, chiesa e associazionismo femminile, cit., p.109.

${ }^{56}$ Salerno’s letter to Toniolo, his and da Persico's replies to Salerno, and a response from the Fascio femminile milanese as well as the editor's commentary were published under the heading "E le donne", L’Azione muliebre, a. V, fasc. 11, novembre 1905, pp. 669-677. See also Chapter Four, p. 216.

${ }^{5}$ Adolfo Passoni, Elena da Persico, Roma, A.V.E., 1991, pp 48-60.

${ }^{58}$ Gazzetta, Elena da Persico, cit., p. 72: "Pur manifestando perplessità, quindi, sull'intenzione di Toniolo di costruire la futura unione come federazione di iniziative e senza autonomia finanziaria, nella conferenza di Brescia la da Persico indica comunque che l'organizzazione doveva nascere in rapporto con l'Unione Popolare e punta alla complementarietà tra iniziative religiose e sociali: 'sorgiamo unite e compatte ad un lavoro più intenso e più ordinato nelle nostre famiglie e nelle nostre opere; sorgiamo unite per la fede e per la donna; sorgiamo accanto a questa Unione popolare, che oggi permise che una voce di donna si levasse tra quelle di tanti uomini, ai quali vorrei far sentire in questo momento quanto del resto nella causa nostra sia implicata la loro'”.
} 
Initially Giustiniani Bandini was prepared to cooperate with Toniolo and, with some reluctance, with da Persico. Toniolo made his first contact with Giustiniani Bandini by a letter dated 29 July 1908, in which he referred to his recent audience with the Pope who had spoken of her initiative for a women's association with great admiration and trust. Discovering that Giustiniani Bandini was presently in Livorno, Toniolo expressed his desire to meet her. Furthermore, he asked her to give a lecture on the organization of Catholic women's associations at the third settimana sociale scheduled to be convened in Palermo in September-October. ${ }^{59}$ The death of her father prevented Giustiniani Bandini from meeting with Toniolo as planned, but she was keen to see him at the settimana sociale in Brescia, which would take place before the Palermo conference. Giving a talk in Palermo did not appeal to her greatly because she believed there was no-one in Palermo who would take on the task of creating a centre of women's activities. Furthermore, she doubted whether settimane sociali would be the right sort of setting for launching the women's movement:

Capisco che le Settimane sociali sono per il popolo mentre il nostro Circolo abbracciando pur tutte le classi della società poggia sull'iniziativa della parte colta e della parte diremo aristocratica. ${ }^{60}$

Toniolo was quick to correct Giustiniani Bandini’s misconception that settimane sociali were for common people. On the contrary, such conferences, and also the Unione popolare itself, were meant for the ruling classes (classi dirigenti). In the same letter Toniolo revealed his vision of a women's federation under the presidency of two women, da Persico and Giustiniani Bandini. Differing fundamentally from Giustiniani Bandini's conception, the women's organization, as he envisaged it, would be promoted by the Unione popolare:

... una Federazione generale femminile (senza nessuno scapito di perfetta autonomia di iniziative locali) veramente cattolica, di cui l’Unione popolare si fa caldeggiatrice. ${ }^{61}$

It was ultimately the incompatibility of personalities rather than variant organizational concepts that caused the scission of Giustiniani Bandini from Toniolo and da Persico. In the immediate future the two women would share responsibilities regarding the proposed settimane sociali. As planned, both duly delivered their talks at the assigned

\footnotetext{
${ }^{59}$ Toniolo’s letter to Giustiniani Bandini, dated 29 July 1908, in Toniolo, Lettere III 1904-1918, cit., pp. 168-170.

${ }^{60}$ Giustiniani Bandini’s letter to Toniolo, dated 11 August 1908, in Gaiotti de Biase, "La nascita dell’organizzazione cattolica femminile nelle lettere di Cristina Giustiniani Bandini al Toniolo”, cit., p. 245 .

61 Toniolo’s letter to Giustiniani Bandini, dated 19 August 1908, in Toniolo, Lettere III 1904-1918, cit., p. 175.
} 
locations, with da Persico giving a talk on La donna cattolica e il suo compito in Italia in Brescia, and Giustiniani Bandini on Il compito della donna nell'ora presente in Palermo. $^{62}$ The idea of having responsibility only for central and southern Italy, while da Persico would look after northern Italy, did not at all appeal to Giustinini Bandini since, in her view, sharing the presidency would destroy the unity of the organization. In her letters to Toniolo she vented her misgivings about da Persico, including her conduct at the Milan congress, her attack on the Gesuits of La Civiltà cattolica for being too chivalrous (troppo cavallereschi) and amiably tolerant (amabilmente tolleranti) in their reporting on the Rome congress as well as her criticism of the views expressed by Padre Sertillanges in his book Féminisme et christianisme (Paris, 1908). ${ }^{63}$ As regards Toniolo himself, Giustiniani Bandini’s willingness to cooperate with him changed when she met him in person in Brescia, in September. Seeing this "venerable old man”, who with his whole essence radiated lofty ideas and intentions, her immediate impulse was to entrust the nascent association to his hands. Little by little, however, it dawned on her that, despite being grandiose and generous, some of his proposals were quite impractical:

Quando vidi quel Venerando vecchio, che da tutto il suo essere spirava elevatezza di concetti e di propositi, il mio primo movimento fu di rimettere nelle sue mani la direzione della nostra nascente Associazione. Però, a poco a poco, nel trattare con lui, mi avvidi che, nonostante la grandezza e generosità delle sue concezioni, certe sue proposte mancavano alquanto di praticità. ${ }^{64}$

The first cracks in the cooperative effort became visible when the three proponents met in Pisa on 5 November to formulate a constitution. It became obvious to the princess that Toniolo was not inclined to cede the necessary independence to her movement. As she recalls, unwilling to give up his concept of a “federation”, Toniolo was not inclined to embrace her idea of individual rather than collective subscriptions, of concentrating on spiritual education instead of bringing up a myriad of initiatives, or of leaving the responsibility for individual activities to local associations which would conjoin solely in matters of a national interest:

Per quanto il Toniolo, rinunciando alla progettata "Federazione", abbracciasse a poco a poco le mie idee riguardo all'organizzazione dell’Unione fra le Donne Cattoliche d'Italia - cioè iscrizioni individuali e non collettive, formazione di coscienze e non moltiplicità di iniziative, autonomia lasciata alle singole opere nel loro campo di azione e solo loro adesione e concorso nelle pubbliche

\footnotetext{
${ }^{62}$ Ibid, footnote.

${ }^{63}$ Giustiniani Bandini’s letters to Toniolo, dated 31 August and 27 October 1908, in Gaiotti de Biase,

“La nascita dell'organizzazione cattolica femminile”, cit., pp. 246-248, pp. 248-249 and footnote 66, p. 249.

${ }^{64}$ Giustiniani Bandini, Il beato Pio X e l'associazione cattolica femminile, cit., p. 17.
} 
manifestazioni d'indole nazionale - pure non ebbi alcun dubbio ch'Egli era poco propenso a riconoscere al nostro movimento quell'autonomia che, una volta organizzata, le era indispensabile. ${ }^{65}$

In Pisa Giustiniani Bandini took exception to two articles of the proposed constitution which stated, first, that the Unione donne was constituted at the initiative of the Unione popolare and, second, that the Unione donne was its filiation. Unwilling to accept the subordination of her organization, she insisted that the Pope had approved its foundation before Toniolo had got in touch with her and that, for this reason, the Unione popolare had not initiated it. ${ }^{66}$

As Giustiniani Bandini reports, in November Toniolo visited Rome twice in order to finalize matters so that on 1 January 1909 a circular could be issued to the bishops announcing the foundation of the Unione donne. Unexpectedly, she had to absent herself from Rome because on 28 December an earthquake devastated the cities on the coastal areas of Calabria and Sicily, and she immediately left as a volunteer nurse for the disaster-stricken south. While in Palermo she fortuitously came across a pamphlet, published without her knowledge, which included three important documents: an appeal to Catholic women signed by Toniolo, President of the Unione popolare; the constitution of the Unione donne; and a letter by the Papal Secretary of State to the President of the Unione popolare. To the princess's dismay the constitution contained the articles to which she had objected in Pisa. Even worse, the letter of the Secretary of State seemed to sanction, in the Pope's name, the dependence of the Unione donne on the Unione popolare. She rushed back to Rome to hear from Cardinal Merry del Val, the Secretary of State, that he had indeed written to Toniolo but in the belief that the constitution had been drawn up with her consent. In a succeeding papal audience Pius $\mathrm{X}$ advised her to found the Unione donne without delay. On the very day of inauguration, he said, the help received from the Unione popolare in the early period would cease, and the Unione donne would get its own independent constitution. ${ }^{67}$

The three protagonists continued their work in their separate ways. Like Giustiniani Bandini, da Persico travelled to various cities in order to set up embryonic women's committees. Her trip to Napoli proved especially successful. On the way back she stopped in Rome in order to meet with Giustiniani Bandini and, if possible, with the

\footnotetext{
${ }^{65}$ Ibid., p. 19.

${ }^{66}$ Ibid., p. 20.

${ }^{67}$ Ibid., p. 21.
} 
Pope. ${ }^{68}$ Da Persico's hopes for a joint reception for all three of them - Toniolo, Giustiniani Bandini, and herself - were dashed because of the Pontiff's illness. Meanwhile Toniolo, too, was waiting in vain for a papal audience to present the constitution for approval. ${ }^{69}$ A corollary issue was the future role of L'Azione muliebre. Seeing da Persico on 6 December, Giustiniani Bandini informed her of the appointment, by Archbishop Ferrari, of Sabina Parravicino di Revel as President of the Milan branch of the Unione donne. On account of Parravicino's distinctly different approach to feminist and political issues, ${ }^{70}$ the choice of her did not please da Persico at all. As local president of the Unione donne, Parravicino could well have become a board member of the Milan-based Azione muliebre, which could easily have happened had the paper become the official organ of the Unione donne, as proposed by Giustiniani Bandini. Even changing the title from L'Azione muliebre to Azione cattolica femminile had been suggested. Da Persico had already agreed to this but then ran into stiff opposition from the paper's board and even from the Archbishop himself. In the end the paper's title did not change nor did it become the organ of the Unione donne. ${ }^{71} \mathrm{Da}$ Persico was finally received by the Pope on 11 December, but their conversation does not appear to have touched on the question of the Unione donne, being limited to the attitudes of the press and to the orientation of her own periodical. ${ }^{72}$

Toniolo, too, was granted a papal audience. On 23 December Maria Toniolo wrote to both da Persico and Giustiniani Bandini stating her husband had returned home from Rome gratified, because everything had been approved. ${ }^{73} 1$ January had been selected as the date for releasing all the pertinent documents, which had each been assigned a “symbolic" date to signify a particular religious feast: 25 December for the constitution; 8 December for Toniolo’s appeal to women; and 26 December for Cardinal Merry del

\footnotetext{
${ }^{68}$ Passoni, Elena da Persico, cit., p. 115.

${ }^{69}$ Ibid., p. 117.

${ }^{70}$ Countess Sabina Parravicino di Revel (1865-1944) was a member of the organizing committee of the Convegno femminile in Milan in 1907. Born in Naples as daughter of General, later Senator, Count Genova Thaon di Revel, she moved to Milan with her parents and married Count E. di Parravicino. She played an important part in the aristocratic and cultured milieu in Lombardy, coming into contact with liberalist Italian, European and American Catholic circles. See O. Confessore Pellegrino, "Parravicino Revel (di), Sabina”, in Dizionario storico del movimento cattolico in Italia, III/2: Le figure rappresentative, Casale Monferrato, 1984, pp. 630-631.

${ }^{71}$ Passoni, Elena da Persico, cit., pp. 118-119. L'Azione muliebre became "an organ of Catholic culture” after the second general congress of the Unione femminile cattolica italiana in September 1922. See alsoGazzetta, Elena da Persico, cit., p. 75.

${ }^{72}$ Passoni, Elena da Persico, cit., p. 120: “... ottenuta per venerdí 11 dicembre l’udienza pontificia, il tema della conversazione ha riguardato gli atteggiamenti dei giornali e l’orientamento della rivista”.

${ }^{73}$ Ibid., p. 121: "Mio marito ritornò stanotte contento; fu tutto approvato e sarà spedita lettera d'incoraggiamento: che si pubblicherà tutto con l'appello e lo statuto subito dopo Natale”.
} 
Val's letter of approval. ${ }^{74}$ Giustiniani Bandini promptly acknowledged Maria Toniolo’s postcard but appears to have been unaware that the constitution still retained the clauses to which she had objected. ${ }^{75}$ The January and February issues of L'Azione muliebre made public all the relevant documentation. It included Toniolo's letter to Catholic women, Alle donne cattoliche d'Italia, which commenced by saying that the Unione popolare, as a representative voice for Italian Catholics regarding the Christian civilization, had already obtained the Pope's approval of the initiative to form a Unione fra le donne cattoliche d'Italia. ${ }^{76}$ The constitution, Statuto della Unione fra le donne cattoliche d'Italia, clearly spelled out, in Articles 1 and 11, the dependence of the women's organization on the Unione popolare. ${ }^{77}$ Furthermore, the Secretary of State's letter to Toniolo implied that the Unione donne was a constituent part of the Unione popolare. $^{78}$ In the meantime, as pointed out earlier, Giustiniani Bandini had received the Pope's assurance that the Unione donne would be constituted as an independent organization. This suggests duplicity, or at the very least incompetence, in the Vatican's handling of the matter. Dau Novelli observes that Pius X was ultimately swayed toward Giustiniani Bandini's concept because the federation hypothesized by Toniolo would not have provided him with the same degree of control over it as did Giustiniani Bandini's model. Pius X feared, too, that modernist thought had penetrated the men's unions and that, without an independent organization, women would have been exposed to modernist contamination. ${ }^{79}$

\footnotetext{
${ }^{74}$ Ibid.: "Tutto sembra procedere ormai linearmente; si fissa la data del $1^{0}$ gennaio per rendere pubblici i documenti, cioè lo statuto con la data, simbolica, del 25 dicembre, l'appello del Toniolo alle donne con la data, pure simbolica, dell'8 dicembre e la lettera di approvazione del card. Merry del Val, indirizzata al Toniolo, con la data del 26 dicembre”.

${ }^{75}$ Giustiniani Bandini’s letter to Toniolo, dated 24 December 1908, in Gaiotti de Biase, "La nascita dell’organizzazione cattolica femminile”, cit., pp. 251-252.

${ }^{76}$ G. Toniolo, “Alle donne cattoliche d'Italia”, L'Azione muliebre, anno IX, fasc. 1, gennaio 1909, p. 7: “L’Unione Popolare interprete e rappresentante dei cattolici d'Italia in ordine a tutti gli interessi della civiltà cristiana, otteneva già dalle labbra venerate di Sua Santità Pio X, e poi con Lettera di S.E. il Cardinale Segretario di Stato (21 e 26 dic. 1908) approvazione solenne della iniziativa d'una Unione fra le donne cattoliche d'Italia ..." Original italics retained.

77 "Statuto della Unione fra le donne cattoliche d'Italia”, L'Azione muliebre, anno IX , fasc. 2, febbraio 1909, pp. 69, 71-72: “Articolo 1 - Per iniziativa dell’Unione Popolare è costituita una Unione fra le donne Cattoliche D'Italia con la sede in Roma”. “Art. 11 - L'Unione fra le donne cattoliche d'Italia è una figliazione dell'Unione Popolare d'Italia; di cui quella estende il numero dei soci, completa e coadiuva il conseguimento degli intenti finali”. Original italics retained.

${ }^{78}$ Merry del Val’s letter to Toniolo, dated 26 December 1908, in ibid., pp. 72: "Sono lieto di parteciparle che l'Augusto Pontefice ne [= dello statuto] ha presa ben volentieri conoscenza e ne ha rilevato con paterna soddisfazione gli alti principii di religione e di cristiana civiltà, che ne costituiscono l'anima e la vita: anima e vita da V.S. saggiamente tradotte nei singoli articoli del ben elaborato Statuto, che pieno di armonica energia, come parte al tutto si unisce al vasto programma dell’Unione Popolare ...” Original italics retained.

${ }^{79}$ Dau Novelli, Società, chiesa e associazionismo femminile, cit., p. 116.
} 
The inauguration of the Unione donne was scheduled to take place on 21 April 1909, the feast of Joan of Arc. At her previous audience with the Pope, Giustiniani Bandini had prepared the ground for creating a Unione internazionale delle Leghe femminili cattoliche. For this purpose, on the eve of the foundation of the Unione donne, two groups of Frenchwomen met with their Roman counterparts, and were invited by Giustiniani Bandini to attend a mass the following morning to celebrate the recent canonization of Joan of Arc. After the mass the Roman group, headed by Giustiniani Bandini, was officially recognized as the Central Committee of the Unione donne, Don Bianchi Cagliesi as its Ecclesiastical Assistant, and Toniolo as President. ${ }^{80}$ Later in the morning the regional representatives met with the Pope, giving accounts of the founding of local committees. Giustiniani Bandini was "unanimously” nominated President General, a title which she refused, accepting provisionally the title of Organizzatrice generale. ${ }^{81}$ Perhaps the vote was not, after all, entirely “unanimous” since da Persico objected to Giustiniani Bandini’s presidency on the grounds that the nomination had to come from the Pope. ${ }^{82}$ The countess herself was offered the Vice-Presidency, which she declined because the President's position was still vacant. ${ }^{83}$ It also became apparent that on Giustiniani Bandini's suggestion da Persico had proceeded to found committees in northern Italy, but in the name of the Unione popolare, which was not how the princess intended it to be. Confusion was intensified when it was discovered that also some delegates of the Unione popolare had on their own initiative gone ahead to set up local committees. ${ }^{84}$

During the second papal audience on the evening of the same day, a sort of coup de main occurred when the question of the financial independence of the Unione donne came up. By then it had become obvious that the Roman group wanted total separation from the Unione popolare. Giustiniani Bandini appears to have been able to assert herself so that both the Pope and the Secretary of State openly lent her their support with the outcome that Toniolo's plan was rejected, necessitating the draft of a new constitution. $^{85}$ This was a humiliating defeat to both Toniolo and da Persico. Presenting the countess's side of the matter, Dora Castenetto writes that when it came to addressing the Pope, Giustiniani Bandini stopped da Persico from delivering her

\footnotetext{
${ }^{80}$ Gazzetta, Elena da Persico, cit., p. 73.

${ }^{81}$ Giustiniani Bandini, Il beato Pio X e l'associazione cattolica femminile, cit., p. 24.

82 Dora Castenetto, Elena da Persico, 2. ed., Milano, Centro Ambrosiano, 2006, p. 34.

${ }^{83}$ Gazzetta, Elena da Persico, cit., pp. 73-74.

${ }^{84}$ Giustiniani Bandini, Il beato Pio e l'associazione cattolica femminile, cit., pp. 22-25.

${ }^{85}$ Gazzetta, Elena da Persico, cit., p. 73.
} 
prepared speech by intervening with her own presentation and blocking the interposition of any explanatory remark by Toniolo or da Persico:

... avendo avuto in precedenza l'incarico di presentare al Santo Padre un indirizzo di gratitudine, con la sintesi del programma dell’Unione nascente, ne è impedita dalla Giustiniani, che pronuncia personalmente il discorso, prevenendo ogni tentativo di spiegazione da parte del Toniolo e della stessa da Persico, per cui riuscirà all'approvazione del nuovo Statuto dell’U.D.C., a farsi ratificare la nomina di prima presidente. ${ }^{86}$

Subsequent documents issued by the Vatican Secretary of State further consolidated Giustiniani Bandini's position at the helm of the Unione donne as well as the independent status of the Unione. These documents confirmed, first, Giustiniani Bandini's position as President of the Unione donne; second, the Pope's prerogative to nominate the President; third, the complete independence of the Unione donne from the Unione popolare; and, fourth, the obligation of all Catholic women's organizations to join the Unione donne.

On 26 June 1909 Giustiniani Bandini received an authority from the Vatican Secretary of State, addressed to the clergy, stating that she alone had the mandate to organize the Unione donne:

"Si attesta ai Rev.mi Ordinari d'Italia che Donna Cristina Giustiniani Bandini latrice del presente biglietto è stata incaricata dal Santo Padre di organizzare l'Unione fra le Donne Cattoliche d'Italia" con cui si autorizzava il mio mandato come sola ed unica organizzatrice. ${ }^{87}$

Soon afterwards, on 18 August 1909, Giustiniani Bandini presented her constitution for papal approval. The Pope returned it to her three days later having made some changes. According to Giustiniani Bandini’s original document, the Central Council would elect the President General who in turn would nominate the Vice-President General, the Secretary General and the Treasurer General. In the final papal version the President was to be nominated by the Pope and the three other office bearers by the Central Council while the number of Councillors was to be limited to eight. The constitution was accepted in this form on 20 August and remained in force for the duration of Giustiniani Bandini’s presidency. ${ }^{88}$

\footnotetext{
${ }^{86}$ Castenetto, Elena da Persico, cit., pp. 34-35.

${ }^{87}$ Giustiniani Bandini, Il beato Pio X e l'associazione cattolica femminile, cit., p. 25.

${ }^{88}$ Ibid., pp. 29-30.
} 
There was a further document from the Secretary of State, dated 1 July 1911, which guaranteed the complete independence of the Unione donne from the men's unions which, moreover, would have no authority to set up women's associations separate from the Unione donne:

Inoltre in data $1^{\circ}$ luglio 1911 un documento, firmato da S.E. il Cardinale Segretario di Stato, è del seguente tenore: “L'art. 2 dello Statuto dell'U.D.C.I. dichiarando perfettamente autonoma l'U.D.C.I. resta evidente che i propagandisti delle altre Unioni non sono autorizzati a formare Associazioni femminili indipendenti dall'Unione fra le Donne Cattoliche d'Italia e anche le Unioni Professionali promosse dall'Unione Economica, debbono essere fatte d'intesa con essa e secondo i criteri già convenuti fra i rispettivi presidenti”. ${ }^{89}$

On 11 July 1911 in yet another document the Secretary of State reaffirmed the independence of the Unione donne from the Unione popolare and also declared the supremacy of the women's union over Catholic women's associations while calling on all Catholic women to join the official movement and declaring that women's associations could be constituted solely under the auspices of the Unione donne :

Allorchè fu promulgata l'Enciclica "Il fermo proposito" in cui si dice che l'Unione Popolare è destinata a raccogliere i cattolici di tutte le classi sociali, non era stata ancora costituita l'Unione fra le Donne Cattoliche d'Italia. Ora che il Sommo Pontefice si è degnato chiamare tutto l'elemento femminile cattolico a far parte del movimento ufficiale cattolico, le Associazioni di donne si fanno soltanto dall'Unione fra le Donne Cattoliche d'Italia per mezzo delle Presidenze dei singoli Comitati. ${ }^{90}$

Having created the central body for the Unione donne, Giustiniani Bandini now needed to enlist the support of the bishops to enable her organization to get off the ground. The concept of accentramento nel decentramento meant that the central body reported directly to the Pope while the local bishops exercised control over the local committees in their dioceses. In order to found such committees in the first place, the bishops' cooperation was essential. Drawing on Giustiniani Bandini's correspondence with the bishops, Cecilia Dau Novelli, in her article "I vescovi e la questione femminile (19001917)”, gives an account of the bishops' attitudes toward the new women's organization. $^{91}$ Chapter 3 of her book, Società, chiesa e associazionismo femminile, entitled "Il ruolo dei vescovi nel rapporto con i comitati locali", also deals with the vital role local bishops had in setting up the Unione donne.

\footnotetext{
${ }^{89}$ Ibid., pp. 25-26.

${ }^{90}$ Ibid., p. 27.

${ }^{91}$ Cecilia Dau Novelli, “I vescovi e la questione femminile (1900-1917)”, Rivista di storia e letteratura religiosa, v. 30, 1984, pp. 429-456.
} 
Only 22 bishops responded positively to Giustiniani Bandini's first circular letter in $1908,{ }^{92}$ but after Pius X's official endorsement of the Unione donne, this number increased to 71 out of a total of 270. As Dau Novelli points out, bishops supported the Unione donne for different reasons: some saw in it a lesser evil than other types of women's organizations, while for others the establishment of a branch of the Unione donne merely meant recognition of local bodies already in existence. ${ }^{93}$ Before the establishment of the Unione donne, while being opposed to anything seeking to alter the traditional position of women, most bishops had expressed minimum concern for the woman question. For the majority of them, woman represented either the angelic custodian of the domestic hearth or a satanic seductress. In their view, woman's natural place was at home, to be mother and wife. Stressing the sacramental nature of the institution of marriage, the prelates were inclined to interpret it in merely functionalist terms: as a means of procreating offspring and of regulating physical desires. ${ }^{94}$

Illustrative of such conservative attitudes was Giovanni Volpi, Bishop of Arezzo, who rebuked his parish priests for showing too much zeal in imparting religious instruction to women. ${ }^{95}$ Those most willing to promote the Unione donne were archbishops in the major cities whose support was, however, more a matter of form than substance since they did not want to be seen to obstruct an organization approved by the Pope. ${ }^{96}$ As regards smaller dioceses, Dau Novelli observes differences between north and south. The predominantly spiritual nature and the unmistakably aristocratic militancy of the Unione donne was of a particular appeal to the sensitivities of the Church in the south,

\footnotetext{
${ }^{92}$ An undated draft copy of Giustiniani Bandini's circular letter to the bishops, "Circolare per comunicare agli Ordinari d'Italia la costituzione definitiva del Comitato Centrale”, AGOP XIV.950 GIB.1, reads as follows: "Mi pregio far consapevole l'E.V.R. che il 21 aprile scorso è stata inaugurata solennemente in Roma, alla presenza stessa di Sua Santità l'Unione fra le Donne Cattoliche d'Italia.

Lo stesso giorno venne pure definitivamente costituito il Comitato Centrale di questa Unione, composto delle delegate delle singole regioni. Voglio quindi pregare l’E.V.R.di favorire nella propria diocesi la formazione di un Comitato locale che promuova questo collegamento delle nostre forze femminili cattoliche: ogni signora di buona volontà, purchè gradita all'E.V., può prenderne l'iniziativa; è d'uopo però (affinchè non si venga meno all'Unità di indirizzo che avvalorerà l'efficacia della nostra unione) che, riunito un primo gruppo di donne cattoliche, si avverta il Comitato centrale che manderà una delle organizzatrici a costituire il Comitato locale secondo i voleri espressi di Sua Santità Pio X.

Parimente per qualunque indicazione o schiarimento in proposito ... preghiamo V.E. di raccomandare veramente alle signore che comporranno il Comitato locale di far capo al nostro Ufficio Centrale in Roma al Palazzo Sanseverino, 518 Corso Umberto 1.

Invochiamo preghiere all’E.V.R onde il soccorso Divino ci sia largo nell'ardua impresa e nel prostrarmi al bacio del Sacro Anello coi sensi della più profonda venerazione, prego umilmente l’E.V.R. di benedirmi ...”

${ }_{93}^{93}$ Dau Novelli, "I vescovi e la questione femminile (1900-1917)”, cit., pp. 432-433.

${ }^{94}$ Eadem, "Il ruolo dei vescovi nel rapporto con i comitati locali”, cit., p. 166.

${ }^{95}$ Eadem, "I vescovi e la questione femminile (1900-1917)", cit., p. 441.

${ }^{96}$ Ibid., p. 444.
} 
whereas bishops in the north were less keen to subscribe to the Unione donne because in their dioceses women were already involved in the Catholic movement and had no time to devote to the new association. ${ }^{97}$ In the majority of cases it was clear that, instead of seeing in the Unione donne an instrument for women's emancipation, the bishops regarded it as a tool to stem the spread of feminism. Thus Monsignor Nasalli Rocca, Bishop of Gubbio, hoped that the Unione donne would become “... un esercito forte, conscio dei suoi grandi doveri sociali e religiosi”. ${ }^{98}$ Some bishops were prepared to found a local association but failed to do so because women were uninterested, while Monsignor Anselmo Evangelista Sansoni, Bishop of Cefalù, laid open the difficulties of establishing a branch in an environment totally hostile to any form of commitment women might have outside their home. So it was not due to a lack of women that he was unable to set up a local committee but rather to women's traditional isolation. ${ }^{99}$ Monsignor Gennaro Trama, Bishop of Lecce, for his part, assigned to Catholic women an important role in reforming modern society, ${ }^{100}$ while Monsignors Zanolini, Morganti, Piovella and Cazzani declared their support for an organization which would have a much wider social programme than the Unione donne. ${ }^{101}$ Monsignor Andrea Giacinto Longhin, Bishop of Treviso, regarded the Unione donne as too elitist; while several years later, in 1917, Nicola Giannattasio, Bishop of Nardò, was equally critical saying that it was unprepared to deal with issues stemming from the entry of the masses into politics, and that its aristocratic leadership lacked the means and the capacity necessary to absorb the new groups of women who worked and were active in society. ${ }^{102}$

The first two articles of the constitution of the Unione donne, states Giovanna Canuti, affirmed its independence from the other unions of Catholic Action. They gave the women's union the same common goals for religious and social activism as the men's unions, while proscribing political and any other form of activity which might contradict the providential nature of women's mission. ${ }^{103}$ In Article 3, the religious objectives of the Unione donne, annotated by Pius $\mathrm{X}$ in the margin in the original draft,

\footnotetext{
97 Ibid., p. 446.

${ }^{98}$ Ibid., p. 448-449.

${ }^{99}$ Dau Novelli, "Il ruolo dei vescovi nel rapporto con i comitati locali”, cit., p. 178.

${ }^{100}$ Ibid., p. 173.

${ }^{101}$ Ibid., pp. 173-177. Pietro Zanolini was Bishop of Fabriano and Matelica, Pasquale Morganti was Bishop of Ravenna, Ernesto Maria Piovella was Archbishop of Oristano, and Giovanni Cazzani was Bishop of Cesena.

102 Ibid, p. 179.

${ }^{103}$ Giovanna Canuti, Cinquant'anni di vita dell'Unione donne di A.C.I., cit., 1959, p.14.
} 
provided for the involvement of Italian women in the profession of the Catholic faith and in the fulfilment of duties to themselves personally, to their families and to society. The article called for women's tasks in the fields of religion, charity and social activities to be made more practical, efficient and responsive to contemporary needs; while a further objective consisted in helping women of all social classes to acquire a sound education in consonance with their Christian mission. ${ }^{104}$ The cardinal points of the platform of the Unione donne were:

I due capisaldi del nostro programma furono: formare interiormente la donna ad una più profonda coscienza cattolica; spronarla con questa sua formazione ad una azione religiosa, sociale di spiccato carattere nazionale. ${ }^{105}$

In tune with this mission statement, the Unione donne had adopted as a motto Fortes in fide, "strong in faith", and as patrons Mary, the mother of Christ, and St Catherine of Siena, a theologian and scholar. ${ }^{106}$ Since the inaugural meeting of the Unione donne had taken place on 21 April 1909, on the day when Joan of Arc was beatified, there was also a special connection to her as a symbol of fortitude and ardour in defending the Church. $^{107}$ So the motto Fortes in fide aptly characterized an association of militant Catholic women:

Araldicamente, militarmente, programmaticamente, questo motto ben conveniva ad una Associazione di Donne Cattoliche militanti. ${ }^{108}$

The Catholic faith, so stated Giustiniani Bandini, was to permeate every single aspect of the Unione donne and its operations:

“L’Unione fra le Donne Cattoliche d’Italia” aveva come suo programma sociale di ritemprare caratteri, di formare coscienze, di richiamare le masse allo esatto concetto e all'osservanza dei principii cattolici, di far penetrare questi medesimi principii nella legislazione e nell'amministrazione civile: noi tutte iscritte all'Unione per vivere di Fede come ci insegna l'Apostolo e trasmettere questa nostra Fede, dovevamo anzitutto umiliare la nostra intelligenza al pensiero e alla parola Divina che doveva essere norma del nostro insegnamento e della nostra azione. $^{109}$

The purpose of the Unione donne was therefore to bring "society back to Christ and the family back to the Church", or, alternatively, to bring "Christ to society and the Church to families". 110 To be equal to this task, it needed to mobilize an army of militants who

\footnotetext{
${ }^{104}$ Ibid.

${ }^{105}$ M.C. Giustiniani Bandini, “In cammino”, in Magnificat, cit., pp. 21-22. Original italics retained.

${ }^{106}$ Canuti, Cinquant'anni di vita dell'Unione donne di A.C.I., cit., p. 14.

${ }^{107}$ Dau Novelli, Società, chiesa e associazionismo femminile, cit., p. 182.

${ }^{108}$ Maria Cristina Giustiniani Bandini, "Fortes in fide”, in Magnificat, cit., p. 9.

${ }^{109}$ Ibid., p. 10.

${ }^{110}$ Dau Novelli, Società,chiesa e associazionismo femminile, cit., p. 181.
} 
were held together by the binding ideology of Catholic doctrine. Keeping in mind the overall objectives of the Unione donne, the religious message had to be simple, orthodox and uniform, so as to leave no room for misinterpretation. For this, instruction in catechism was an ideal strategy, especially as it coincided with Pius X's campaign for the introduction of a single text of catechism as a basis of religious practice. ${ }^{111}$ In order to ensure a maximum degree of dissemination, every local committee had a section devoted to religious propaganda and another to religious education. ${ }^{112}$ The revived interest in the study of religion required a large-scale effort, with every committee opening schools of catechism for boys and girls, for students and housewives. Moreover, in order to promote the acquisition of religious knowledge, competitions were held in the mastery of catechism. ${ }^{113}$ As Paola Di Cori points out, the creation of this confessional political movement (questo movimento politico confessionale), that is, the Unione donne, was carried out by launching a campaign for catechism in order to fight the sentimentalism ensconced in feminine piety. ${ }^{114}$ One may argue that moving away from inchoate, undisciplined private religious thoughts and feelings opened the way for indoctrinating women in a manner apposite to a mass political movement.

On religious issues, but also on other important matters affecting the Unione donne, Giustiniani Bandini could rely on the guidance of her ecclesiastical assistants. In the first years she had at her side Monsignor Vincenzo Bianchi Cagliesi, a sociologist and editor of Rivista internazionale di scienze sociali. It was only natural that Bianchi Cagliesi and Giustiniani Bandini, who lacked the erudition as well as the inside knowledge of the Catholic movement of her ecclesiastical assistant, would hold different views on how to attain overall objectives. While Bianchi Cagliesi was convinced results could be obtained only through a patient educational process, for Giustiniani Bandini the unity of the organization was paramount so that words such as “unity”, “association”, “organization”, and “action” became goals in themselves rather a means to an end. ${ }^{115}$ In November 1915 Giustiniani Bandini received a new ecclesiastical assistant. The appointee was her friend, Monsignor Giulio Serafini, titular Bishop of Lampsaco, ${ }^{116}$ who, after the women's congress in Rome in 1908, had joined

\footnotetext{
${ }^{111}$ Maurilio Guasco, “Pio X, santo”, in Enciclopedia dei papi, v. VIII, Roma, Istituto della Enciclopedia Italiana, 2000, p. 598.

${ }^{112}$ Dau Novelli, Società, chiesa e associazionismo femminile, cit., p. 181.

113 Canuti, Cinquant'anni di vita dell'Unione donne di A.C.I., cit., p. 25.

${ }^{114}$ Di Cori, "Storia, sentimenti, solidarietà”, cit., p. 110.

${ }^{115}$ Dau Novelli, Società, chiesa e associazionismo femminile, cit., pp. 191-192.

116 “Documenti pontifici”, Unione fra le donne cattoliche d'Italia, n. XLV, novembre 1915, p. 1.
} 
Giustiniani Bandini and Cardinal Vicar Pietro Respighi in writing a letter of protest against the resolution to abolish religious instruction.

The disciplined manner in which the Unione donne operated made it ideally suited for the promotion of the Church's social and cultural agenda. From the very first year of its existence, the Unione donne organized women's congresses and conventions on educational and welfare issues. On a more practical level, it was engaged in a myriad of social and charitable initiatives, including the provision of facilities for recreation and after-school activities, the organization of workshops and training courses, the establishment of mutual aid societies and lending libraries, assistance to emigrants, and support for a variety of organizations affiliated with Catholic Action. ${ }^{117}$ Some local committees created their own projects, such as a survey by the Turin Committee in 1911 into the conditions and remuneration of women working at home and the Casa famiglia institution, launched in Venice in 1910, which provided accommodation and rehabilitation for single mothers, ex-prisoners and other categories of women at risk. ${ }^{118}$

The Unione donne gave ample proof of its organizational capacity during World War I. Consisting of some 750 committees and with an approximate membership of 35,000 in $1913,{ }^{119}$ it had already shown its mettle in response to an earthquake in Marsica in December 1914. ${ }^{120}$ Previously, the reaction of Catholic women leaders to colonial wars had been supportive. During the Libyan war in 1911-1912 Giustiniani Bandini typically commented, "[La guerra] uccide dei corpi, ma crea delle anime". ${ }^{121}$ Women, too, had to contribute to warfare and had to transform themselves into "soldiers of Jesus Christ" in order to defend "ideals", "faith" and "souls". 122

At the outbreak of World War I one can assume that Catholic women's attitude to it was not different from that of Italian women in general. Until then - writes the contemporary author Donna Paola Baronchelli Grosson - the majority of Italian women had a clearly neutralist position on foreign policy. But when the inevitable happened in

\footnotetext{
${ }^{117}$ Canuti, Cinquant'anni di vita dell'Unione donne di A.C.I., cit., p. 25.

${ }^{118}$ Magnificat, cit., p. 30.

${ }^{119}$ Canuti, Cinquant'anni di vita dell'Unone donne di A.C.I., cit., p. 27.

${ }^{120}$ Ibid., p. 35. See also "Dopo il terremoto della Marsica”, Unione fra le donne cattoliche d'Italia, n. XLI, 1915, p. 1.

${ }^{121}$ Quoted in Di Cori, “Storia, sentimenti, solidarietà nelle organizzazioni femminili cattoliche dall'età giolittiana al fascismo”, cit., p. 111 .

${ }^{122}$ Ibid.
} 
May 1915, they readily submitted to the will of the fatherland showing, for the first time - as it seemed to her - an awareness of their civic duty:

Fu questa silenziosa, dignitosa, composta sommessione alla volontà della Patria, una prima manifestazione della già educata al civismo anima femminile. ${ }^{123}$

The same attitude was also reflected in the statement issued by the Board of the Unione donne in May 1915:

Ora nessuno ha diritto di spezzare quella grande forza civile che è la disciplina, la concordia, l'unità di tutte le volontà generose: ora una legge suprema, che la morale e la religione sanzionano, si'impone al nostro cuore: il dovere. ${ }^{124}$

Since Italy's involvement in the war had been expected for some time, the ViceSecretary General of the Unione donne, Dr. Giovanni Canuti, gave a talk in January 1915 outlining a programme of action for Catholic women in case of war. ${ }^{125}$ In it she conveyed the palpable sense of the inevitability of a war, and was far from displaying pacifist scruples:

E la Chiesa ha infatti sempre considerata la guerra come un'espiazione, come il ritorno doloroso a un equilibrio morale che veniva a mancare, come la purificazione attraverso al dolore fisico e morale di società guaste e corrotte. ${ }^{126}$

Catholic women's war efforts involved giving religious succour to the members of the army and the navy; moral and social assistance to the families of combatants; assistance to women engaged in the war effort; and preparation for the anticipated crisis in women's employment after the conclusion of hostilities. To facilitate religious worship and practice in the field, the Unione donne asked the armed forces to institute field chaplains, and provided, on a large scale, altars, vestments and other appurtenances necessary to conduct a religious service. It sent large quantities of clothing, foodwarmers, pest killers and other necessities to the front, and set up various kinds of practical and recreational facilities for soldiers in transit or on leave. Jointly with the Red Cross, the Unione donne ran training courses for nurses, and a number of its own members served as nurses at the front. Assistance to families and to women took many forms. Uffici per notizie, for example, manned largely by Catholic women volunteers, apart from being points of contact for the most afflicted families, also gave spiritual

\footnotetext{
${ }^{123}$ Paola Baronchelli Grosson, La donna della nuova Italia, Milano, Stabilimento F. Giussani, 1917, p. 42.

${ }^{124}$ Magnificat, cit., p. 33.

${ }^{125}$ Giovanna Canuti, "Il nostro programma”, Unione fra le donne cattoliche d'Italia, n. XL, 1915, pp. 14.

${ }^{126}$ Ibid., p. 1.
} 
help and comfort. ${ }^{127}$ Crèches, kindergartens, refuges and after school activities were provided to families of soldiers, and in Venice alone some thirty kindergartens catered to two thousand children. In many cities large numbers of women whose husbands were in the army received work through the Catholic distribution system. ${ }^{128}$ Moreover, Catholic women's cooperation also extended to participation in various patriotic campaigns, such as contributing to war loans and economizing on consumption.

While Italian Catholics cooperated in national efforts, in matters of social policy they continued to be at loggerheads with the Liberal government. Contentious issues included, for example, the legalization of divorce, the precedence of civil over Catholic marriage, and the omission of religious affiliation in census data. In the first decade of its existence, the Unione donne waged its most passionate fights against the civil authorities over religious instruction at schools. With the passage of time there had been several changes to the legislation on the teaching of religion. Under the Casati law of 1859 which laid down the basis for the Italian education system, religion was taught at primary schools, but parents could ask for their children to be exempted. In 1877, while not rescinding the previous enactment, the Coppino law provided for the substitution of the teaching of religion by instruction in civic rights and duties. A subsequent regulation in 1888 laid down that municipalities would impart religious instruction only upon parents' specific request. The situation worsened for Catholics in 1908 when the Rava regulation stated that municipalities could refuse to teach religion. In such a case provincial school councils were bound to provide, should parents demand them, school halls for extra-curricular classes in religion after hours. In 1911, under the Daneo-Credaro law, the responsibility for primary school teaching was removed from municipalities and became a State responsibility. ${ }^{129}$ Those allowed to teach at State schools needed a teaching diploma, which automatically disqualified many teachers of catechism. In order to comply with the requirement, the Unione donne introduced accelerated teacher training courses for quick acquisition of the necessary qualification. ${ }^{130}$ Additionally, in many municipalities parents signed public appeals in favour of religious instruction. In Rome the Mayor, Ernesto Nathan, Grand Master of a Masonic lodge, refused to acknowledge fathers' signatures on the pretext that their authenticity could not be guaranteed. What followed gave another example of Catholic

\footnotetext{
${ }^{127}$ Canuti, Cinquant'anni di vita dell'Unione donne di A.C.I., cit., p. 36.

${ }^{128}$ Ibid., p. 37.

${ }^{129}$ Ibid., p. 9.

${ }^{130}$ Ibid., p. 22.
} 
women's tenacity and capability to further their cause. To provide the necessary authentication, they "dragged" public notaries, most of them non-Catholics, into sacristies to certify signatures in long evening sessions sometimes stretching well into midnight. In face of such resolute action, Nathan had to accept defeat. ${ }^{131}$

Meanwhile the campaign against secular feminism continued unabated. In a pamphlet written on the topic of feminism, Giustiniani Bandini categorically stated that no Catholic woman should become a member of a feminist organization. This was because the feminist movement was, in her view, essentially radical and could not be reconciled with a Catholic programme. Calling itself non-denominational, it fomented atheism putting the Catholic religion on a par with other cults, whereby it became non-Catholic. Furthermore, by voting for resolutions contrary to Catholic dogma and morals, it had declared an open war on Catholicism. ${ }^{132}$ An example of Giustiniani Bandini’s unrelenting crusade against feminism was her propaganda against Catholic women's participation in the Second National Congress of Italian Women which was planned by the Consiglio nazionale delle donne italiane to take place in 1911. In view of the divisive vote taken against religious education at the First National Congress, the announcement was not well received in the Catholic world. In order to emphasize the neutrality of the proposed Second National Congress, Countess Gabriella Rasponi Spalletti, President of the Consiglio nazionale, declared that the congress, which was to concentrate on education, would not accept papers of either a political or a denominational nature. She wrote in an open letter, published in Il Giornale d'Italia on 27 February 1911, as follows:

Nemica di ogni polemica, mi sono astenuta fin qui dallo spiegare perchè al Congresso, indetto a Torino per la ventura primavera, non si accetteranno relazioni aventi carattere politico o confessionale ...

Art. 2 [dello statuto del C.N.] - Il C.N. è apolitico e aconfessionale, ciò che gli permette di accogliere persone di ogni tendenza politica, come di ogni fede.

Art. 3 - Esso è aggregato all”International Council of Women” che mira alla organizzazione delle attività femminili per renderle elemento di progresso e di pace nella società, facendovi trionfare la regola d'oro:

"Fate agli altri ciò che vorreste fosse fatto a voi."

L'esperienza ci ha dimostrato a quali pericoli si vada incontro non seguendo rigorosamente le savie norme del Consiglio Internazionale, e riteniamo perciò necessario attenerci ai principi di "aconfessionalità e apoliticità" che soli possono garantire l'ambiente sereno tanto necessario al buon andamento del nostro lavoro.

\footnotetext{
${ }^{131}$ Magnificat, cit., p. 65.

${ }^{132}$ Cristina Giustiniani Bandini, Può una donna cattolica in Italia appartenere al movimento femminista?, n.p., n.d., AGOP XIV.950 GIB.53.
} 
Aconfessionale, del resto, non vuol dire areligioso, e tanto meno antireligoso, come apolitico non implica il disinteresse delle grandi questioni nazionali e sociali.

È puramente un'arena seria di feconda discussione che desideriamo offrire a tutte le madri e a tutte le educatrici italiane, non già un campo di battaglia ove la discussione di problemi pedagogici possa degenerare in lotta religiosa o politica. ${ }^{133}$

Giustiniani Bandini challenged the notion that the planned congress would be nonpolitical and non-sectarian. She pointed out that the previous national congress organized by the Consiglio nazionale had been political because it had voted for women's suffrage, and sectarian because it had voted for the abolition of religious instruction at schools. Besides, it was not fair that Italian women should be required to accept non-sectarianism as a basis for the congress. The International Council of Women, originating in a Protestant country, could well ask its Protestant members to show deference to every religion, she added, but not a women's association in Catholic Italy. Since in Italy the majority confessed the Catholic faith, it seemed to Giustiniani Bandini that non-sectarianism could only mean renouncing the great traditions which made up a significant part of the moral patrimony of the Italian nation. ${ }^{134}$ Moreover, religious neutrality in education was unachievable, because religion was the foundation of any moral education. Had the Consiglio nazionale wanted to deal with less controversial issues, it could have chosen from topics such as the employment and wages of women, internal or external work environments (sale o giardini operai), hygiene of dwellings, and childcare. ${ }^{135}$ As was to be expected, Catholic periodicals, such as L'Azione muliebre, joined in the agitation against the congress, and prominent Catholics, such as Marchese Filippo Crispolti, added their weight to the debate. In the end, the strong Catholic campaign against the congress forced the Consiglio nazionale to cancel it.

Giustiniani Bandini showed filial affection and unconditional loyalty to the Pope, and demanded the same unswerving resolve from others. To her, devotion to the Vicar of

\footnotetext{
133 A reprint of Rasponi Spalletti's letter appeared under the heading “A proposito del Congresso delle 'Donne italiane””, La Donna e il lavoro, a. 2, n. 11, 17 marzo 1911, p. 2.

${ }^{134}$ A reprint of Giustiniani Bandini’s response to Rasponi Spalletti’s letter appeared in ibid., p. 3. She wrote: "Ma è poi lecito a donne cattoliche italiane accettare l'aconfessionalità come base di lavoro? assolutamente no. L'International Council of Women, sorto in paese protestante, poteva domandare alle prime aderenti questa reciproca deferenza per ogni culto, non una associazione femminile dell'Italia cattolica.

In Italia proclamare l'aconfessionalità - peggio, se proprio la donna la proclama - è già una rinunzia alle grandi tradizioni, ad una parte notevolissima del patrimonio morale della Patria”. Original italics retained.

${ }^{135}$ Ibid.
} 
Christ was of greater importance than personal relationships. The dismissal of Countess Sabina Parravicino di Revel, Giustiniani Bandini’s close friend of many years, was a case in point. Apart from demonstrating Parravicino's lack of devotion to the Pope, the incident also harked back to modernist heresies and illustrated Giustiniani Bandini’s propensity to regard the Unione donne as her personal fiefdom. Foundation president of the Milan branch of the Unione donne, Parravicino fell out of favour with the Vatican after publishing some letters she had received from Cardinal Mariano Rampolla in the Florentine paper Rassegna nazionale in January 1914, soon after the prelate's death. The countess had wanted to show that her friend, who was Secretary of State of the Vatican in the latter part of Leo XIII's papacy, was a man of modern ideas, closer to Monsignor Geremia Bonomelli than generally thought. ${ }^{136}$ The correspondence between Parravicino and Rampolla contained opinions of a political and religious nature, which were not favourable to the present government of the Holy See and the members of the present Curia. ${ }^{137}$ The scandal really erupted when a bundle of the countess's own letters to the cardinal was discovered among his papers. In her correspondence she had expressed views which could not but offend the current thinking of the Vatican. ${ }^{138}$ In one letter she had intimated that Archbishop Andrea Ferrari had to follow the intransigent line even when he was privately against it:

Quel povero cardinale Ferrari deve sostenere il “Labaro” mentre poi agli amici egli raccomanda per suo conto l' "Italia”. ${ }^{39}$

Once the news of Parravicino's letters had leaked out, her days as local president of the Unione donne were numbered. Even though there was a degree of uncertainty about who in the end bore the responsibility for removing her from the post, there could be no doubt about Giustiniani Bandini's role in it, as revealed by Parravicino’s letter to the princess after she had been ordered to leave the association:

Signora Presidente Generale,

Ricevetti la sua del 27 marzo, alla quale avrei voluto rispondere subito. Ma riflettendo pensai bene di aspettare; far Pasqua, riavere così la mia calma e non sembrare che la mia risposta venisse ab irato.

Pur prendendo atto del contenuto della sua, non vedrei a dir il vero nello Statuto, nè in nessun altro documento riguardante l'Unione, niuna parola dalla quale possa derivare all’Ufficio Centrale di Presidenza il diritto di dimettere una socia,

\footnotetext{
136 “Una tempesta in Vaticano”, Il Giornale d'Italia, 23 aprile 1914, p. 6. Monsignor Bonomelli had been imputed modernist links.

137 “La corrispondenza di Rampolla con la contessa di Parravicino”, Il Messaggero, 23 aprile 1914.

138 "Una tempesta in Vaticano", cit., p. 5.

${ }^{139}$ Ibid. Labaro and Italia were Milanese Catholic newspapers. The former was noted for its “temporalist intransigence” while the latter had a more modern approach. Il Giornale d'Italia is quoting here the Turin newspaper La Stampa, published the day before.
} 
nè di esonerare una Presidente di Comitato. Tanto più ove si rifletta che da un fatto, che io non voglio qualificare, ma certamente d'indole affatto intima e privata, si è voluto far derivare un altro atto, non solo pubblico, ma anche di una certa solennità.

Altro non aggiungo.

Contessa di Parravicino Thaon di Revel. ${ }^{140}$

Since the constitution of the Unione donne had no provision for the peremptory exoneration of Parravicino from the local presidency, Giustiniani Bandini acted unconstitutionally. In the newspaper reports it was noted that Giustiniani Bandini and Parravicino represented two opposing tendencies in the Catholic women's movement. While the former was "temporalist" and "ultra-conservative”, the latter was described as having "distinctly Italian sentiments" and was identified with the more "modern” and "progressive” current in the movement. To some it seemed that Parravicino's letters to Rampolla only served as an excuse to remove her from her post. Her friends who wanted to mount a lively protest on her behalf were dissuaded from that action by Cardinal Ferrari. ${ }^{141}$

In defining the position of the Unione donne in the Catholic movement, Giustiniani Bandini continually had to clarify its role and functions. Some bishops opposed her on the grounds that the Vatican statutes, Acta apostolicae sedis, did not contain the documents of the Unione donne, nor had they been sent to the bishops. In January 1914 she drew Pius X's attention to this omission, urging him to have the relevant documents published in L'Osservatore romano. ${ }^{142}$ In September of the same year she wrote to Benedict XV that the ambiguities in the relations between the Unione donne and the Unione popolare had even made her offer her resignation from the presidency in February. ${ }^{143}$ In October she wrote to the Pope again asking him to issue a document

\footnotetext{
${ }^{140}$ Parravicino’s letter to Giustiniani Bandini, dated 15 April 1914, AGOP IV.950 GIB.109

141 “Ancora sul carteggio politico fra il cardinale Rampolla e la contessa Parravicino di Revel”, Il Corriere della sera, 23 aprile 1914.

${ }^{142}$ Handwritten copies of two untitled documents to Pius X by Cristina Giustiniani Bandini, dated 20 and 24 January 1914 respectively, AGOP XIV.950 GIB.36.

L'Osservatore romano had not, however, been completely silent on the Unione donne. On 14 September 1912 it had already published an official communication regarding the exclusive right of the Unione donne to form women's associations. See Cristina Giustiniani Bandini, "Pro memoria inviato il 6 settembre 1914”, AGOP XIV.950 GIB.36.

${ }^{143}$ Cristina Giustiniani Bandini, "Pro memoria inviato il 6 settembre 1914”, handwritten copy, AGOP XIV.950 GIB.36. On this occasion Giustiniani Bandini was dissuaded from resigning because, after the successive resignations of Prof. Toniolo, Prof. Boggiano and Dr Necchi in less than three years, her resignation would have added further instability to the Catholic movement.
} 
which would unequivocally affirm the independence of the Unione donne and to include it in Acta apostolicae sedis. ${ }^{144}$

Indeed, time and time again the Unione popolare attempted to assert its supremacy over the Unione donne invoking the encyclical Il fermo proposito. This encyclical urged all militant Catholics to become members of the Unione popolare which would, moreover, supervise the whole of Catholic Action. ${ }^{145}$ Giustiniani Bandini, on her part, insisted on the independence of the Unione donne saying that Il fermo proposito was not binding on it because her organization did not exist at the time of the encyclical's promulgation. She repeatedly asked Pius X to assure her of the independent status of her organization and always received the same answer: "Non voglio un presidente dei presidenti, ogni unione è autonoma per la sua parte di lavoro". ${ }^{146}$

Writing to Benedict XV in the latter part of 1914, Giustiniani Bandini reiterated the reasons for which his predecessor had wanted to grant the Unione donne independent status. Complete separation from the Unione popolare, she wrote, would ensure that women's religious activities would not be jeopardized by any political intrusions; women's organization and education, for all social classes, required different criteria and methods from those applied to men; and in many cases husbands would have been reluctant to see their wives participate in a movement which catered for both sexes. ${ }^{147}$ There was a further reason why the Catholic women's movement had to retain its independence. The Unione donne, if it lost its autonomy, she argued, would be less able to carry out its fight against secular feminism, which derived its prestige and efficiency precisely because it was furthered by women. Therefore, should men be in charge of the Catholic women's movement, the fight against feminism would seem more like a gender struggle than a fight based on convictions. ${ }^{148}$

\footnotetext{
${ }^{144}$ Eadem, "Pro memoria presentato a S.S. Benedetto XV il 9 ottobre 1914”, handwritten copy, AGOP XIV.950 GIB.36.

${ }^{145}$ Pius X, Il fermo proposito: Encyclical of Pope Pius X on Catholic Action in Italy (11June 1905). http://www.vatican.va/holy_father/pius_x/encyclicals/documents/hf_p-X_enc_11061905_il-fermoproposito_en.html (08/09/2010)

${ }_{146}$ Giustiniani Bandini, "Pro memoria inviato il 6 settembre 1914”, cited above, note 143.

147 Eadem, "A Sua Santità Benedetto XV dopo la sua elezione settembre 1914 per rassegnare la mia carica di Presidente Generale dell’Unione fra le donne cattoliche d'Italia”, undated handwritten copy, AGOP XIV.950 GIB.36.

148 “Lettera accompagnativa della domanda del comunicato", undated handwritten copy, probably written in the latter half of 1914, AGOP XIV.950 GIB.36. Original copy signed by Donna Cristina Giustiniani Bandini, Marchesa De Gregorio, Principessa Antici Mattei, Contessa Sanseverino and Monsignor Bianchi Cagliesi.
} 
With her plan to restrict the scope and activities of the Unione donne to religious and social matters, Giustiniani Bandini was reluctant to embrace the issue of women's industrial organization. The matter was raised, for example, at the First Catholic Women's Congress in Modena in November 1910 by Giovannina Ferrari from Como. She voiced the concern that the Catholic women's movement seemed to exclude issues such as the "merits" (meriti) and the "needs" (bisogni) of workers, and lamented the persistence of a certain kind of “distrust” of Christian democracy. Ferrari was quickly stopped in her tracks:

L'assistente del comitato di Modena le replicò seccamente che l'Unione non doveva essere né aristocratica né democratica, ma cattolica. Il "cappello" religioso diveniva cosí un alibi per ignorare qualsiasi elemento oggettivo di analisi sociale. $^{149}$

However, Giustiniani Bandini’s line on industrial relations was not uniformly adhered to. This becomes obvious, for example, from the Turin committee's approach to the matter. Concerned about the difficulty of enforcing the labour law in small- and medium-sized textile and clothing companies, the local committee of the Unione donne was instrumental in helping women workers to report on infringements. ${ }^{150}$ In 1910 a survey carried out by the Turin circle brought to light the appalling conditions under which many worked at home. ${ }^{151}$ Moreover, through their active involvement in founding a union for telephonists $1913,{ }^{152}$ the ladies in Turin showed that they did not intend to distance themselves from labour problems.

Inevitably, the question of union organization was taken up at the first settimana sociale femminile which was organized in Turin between 6 and 11 April 1913. With Giustiniani Bandini not being able to attend, the meeting was chaired by the president of the Turin committee, Marianna Incisa di S. Stefano. In his two speeches Don Alessandro Cantono recognized that women's participation in the workforce as an “objective condition of modern society”, which could possibly be improved but not hindered. He expressed a hope for the State's regulatory intervention in cooperation with women's unions while calling on Catholic women to become involved, in parallel with socialist women, in work-related consultative government agencies. ${ }^{153}$ Bianca Della Croce di Doiola, on the other hand, dealt directly with the issue of industrial

\footnotetext{
${ }^{149}$ Dau Novelli, Società, chiesa e associazionismo femminile, cit., p. 145.

${ }^{150}$ Ibid., pp. 151-152.

${ }^{151}$ Ibid., p. 153.

152 Ibid., p. 154.

${ }^{153}$ Ibid., p. 156.
} 
organization of female workers in the first of her two papers, while her second paper tackled the problems of working at home and emigration. ${ }^{154}$ According to her, it was necessary to reclaim workers' associations, now monopolized by socialists, and bring them back to their original task. While still class-based, such associations, she argued, should not aim to subvert society but instead become a place to resolve industrial conflicts peacefully. Contrary to the attitudes of the First Catholic Women's Congress in Modena, Della Croce called on the Unione donne to become active in union organization. The Settimana sociale in Turin, observes Cecilia Dau Novelli, marked an important moment in the life of the Unione donne in that the policies which emerged there indicated a desire to elaborate "a third way", which blended the essential elements of Christianity with the most valid perceptions (intuizioni) of feminism. ${ }^{155}$

In a discourse published in Azione cattolica femminile in January 1914, Giustiniani Bandini issued a correction to the conclusions reached at the Turin meeting, warning members to be watchful of any weaknesses toward socialism. ${ }^{156}$ She also attacked the men's unions which had moved away from the teachings of the Church by succumbing to "the virus of a misconceived Christian democracy". They, in fact, had strayed from the programme outlined in Rerum novarum and had come near to espousing anticlericalism and Murri's demagoguery. Instead of being an association of workers only, a truly Catholic association should principally address the upper classes which would then have the task of transmitting "sound principles" to the lower classes. ${ }^{157}$ Because of the independence of the local groups, however, Giustiniani Bandini's criticism had in the end little effect. If anything, the influence of the Turin group extended to other committees. ${ }^{158}$

In January 1914 Giustiniani Bandini made a more comprehensive statement on trade unionism in a front-page article entitled “Alle presidenti e socie dell’Unione fra le donne cattoliche d'Italia” in the periodical Unione fra le donne cattoliche. ${ }^{159}$ Reference

\footnotetext{
154 "La prima settimana sociale femminile italiana”, La Donna e il lavoro, a. 4, n. 16, 18 aprile 1913, pp. $1-2$.

${ }^{155}$ On p. 159 of Società, chiesa e associazionismo femminile, cit., Cecilia Dau Novelli writes: “...le linee emerse al convegno di Torino, sembrano ... significare il desiderio di elaborare una terza via originale e diversa, ma nello stesso tempo parallela, in cui fondere gli elementi essenziali del cristianesimo con le intuizioni piú valide del femminismo".

${ }^{156}$ Ibid., p. 160

${ }^{157}$ Ibid., p. 161.

${ }^{158}$ Ibid., pp. 161-162.

${ }^{159}$ L’Ufficio Centrale di Presidenza, “Alle presidenti e socie dell’Unione fra le donne cattoliche d'Italia” [Roma, 20 gennaio 1914], Unione fra le donne cattoliche d'Italia, n. XXXIII, 1914, pp. 1-2.
} 
was made to the previously cited papal document of 1 July 1911 which confirmed the independence of the Unione donne while stating that any "professional unions", promoted by the Unione economica, had to be founded with the agreement of the Unione donne according to mutually accepted criteria. The article went on to say that the two sections had always enjoyed an excellent relationship. The Unione donne had submitted, without failure, the programmes and constitutions of women's unions and mutual aid societies to the Unione economica, while the latter had reciprocated benevolently with help and advice. However, some Catholic propagandists had believed that they would be able to promote organizations for mondine, telephonists and others, independently from the Unione donne and the Unione economica. Such attempts were denounced as "irregular" because they were contrary to papal directives. While these initiatives were taken with the best of intentions, they could not be countenanced since, lacking the efficiency of disciplined and unanimous action, they meant breaking up the women's movement. On the other hand, to qualify for the support of the Unione donne, a women's [industrial] federation needed to have its constitution as well as its directors approved by the board of the Unione donne while the latter would also exercise control over the application of the constitution. ${ }^{160}$ Since various patrionati had become involved in organizing unions, Giustiniani Bandini asked the Pope, in October 1914, to remind the Opera di protezione della giovane, the Patronato di mutuo soccorso, and other similar organizations, of their need to follow their respective constitutions, without arbitrarily substituting themselves for the officially recognized movement. They needed to reach an agreement with the President General of the Unione donne who alone bore the responsibilities for the women's movement. ${ }^{161}$ In the end, she had to admit professional unions into the Unione donne, since she was only too aware of the keenness of the Unione popolare to recruit women into its ranks. In fact, she complained to the Pope in the latter part of 1914 about the tendency of the men's section to organize women, a modo loro, into essentially industrial unions - despite the Pope's prohibition - expressing her own preference for patronati because such institutions enabled the ladies managing them to provide also for the moral and religious needs of workers. ${ }^{162}$

\footnotetext{
160 Ibid.

${ }^{161}$ Giustiniani Bandini, “Pro Memoria presentato a S.S. Benedetto XV il 9 Ottobre 1914”, cited above, note 144.

162 Eadem, "Beatissimo Padre”, undated handwritten copy, AGOP XIV.950 GIB.1.
} 
Industrial organization was just one of the various demarcation disputes between the Unione donne and the Unione popolare. Another clash point between them concerned memberships. While trying to bring all Catholic women's associations under the umbrella of the Unione donne, Giustiniani Bandini felt she had to be on the guard for potential poaching of her members. She complained that she was tired of continuously having to be a "watch-dog" (can di guardia), and wrote letters to both Pius X and Benedict XV in order to alert them to infringements by the Unione popolare of the rules governing respective memberships. ${ }^{163}$ Even before the official inauguration of the Unione donne, as discussed earlier, the Unione popolare had begun recruiting members for the proposed women's association. The recruitment of women did not stop with the foundation of the Unione donne but continued under the successive Presidents of the Unione popolare, Professors Toniolo and Boggiano, Doctor Necchi and Count Dalla Torre. ${ }^{164}$ Even though in Romagna Catholic women had, in several places, succeeded in pacifying industrial and agricultural workers, the Bishop of Ravenna, Monsignor Morgante, did not want the Unione donne to extend its activities to Ravenna on the grounds that it would impede the spread of the Unione popolare. ${ }^{165}$ Also, unbeknownst to the President General of the Unione donne, the Unione popolare had included in its Consiglio direttivo two presidents from the local committees of the Unione donne as well as two presidents from other women's associations. ${ }^{166}$ Moreover, she suspected that the Unione popolare was surreptitiously enlisting female members on the pretext of obtaining their subscriptions for one of its official periodicals, Allarme, which members received free of charge. ${ }^{167}$ Apart from the obfuscation of the boundary between her organization and the Unione popolare, Giustiniani Bandini was also concerned about the integrity of her periodical publications. She was dismayed to find out that, without a previous agreement with the Unione donne, the women's magazine Matelda was made a periodical for young males and females, and the editor, Don Galbriati, was replaced by a woman, Signora Bettazzi Bondi. ${ }^{168}$ The primary reason, she surmised, for the

\footnotetext{
163 Ibid.

${ }^{164}$ Giustinini Bandini, “A Sua Santità Benedetto XV dopo la sua elezione settembre 1914 per rassegnare la mia carica di Presidente Generale dell’Unione fra le donne cattoliche d'Italia, cited above, note 147.

${ }^{165}$ Eadem, "Beatissimo Padre", cited above, note 162. The correct form of the bishop's name is "Morganti”.

${ }^{166}$ L'ufficio centrale di Presidenza dell’U.D.C.I., [Lettera a Benedetto XV], untitled handwritten copy, dated 25 March 1915, AGOP XIV.950 GIB.36.

${ }^{167}$ Giustiniani Bandini, “A Sua Santità Benedetto XV dopo la sua elezione settembre 1914 per rassegnare la mia carica di Presidente Generale dell’Unione fra le donne cattoliche d’Italia”, cited above, note 147.

${ }^{168}$ Eadem, Giustiniani Bandini, “Beatissimo Padre”, cited above, note 162.
} 
Unione popolare not wanting an independent women's movement was economic, because women's contributions had constituted the major share of its total funds. ${ }^{169}$

Another potential danger posed by the Unione popolare to the autonomy of the Unione donne was the proposed leghe dei genitori - "parents' leagues”, which were envisaged for the purpose of religious education of children. Such leagues were promoted, among others, by Luigi Sturzo at a congress organized by the Unione popolare in Genoa in May $1914 .{ }^{170}$ Since they spanned both men's and women's associations, Giustiniani Bandini regarded them as a potential threat to the independence of women's associations, and therefore favoured separate unions for mothers and fathers. The draft constitution provided by the Pro Scuola Secretariat of the Unione popolare in 1912 seemed to confirm her suspicion that the leagues would not limit their functions to the scholastic domain. Besides, collaborative activities involving recourse to family law would put women at a disadvantage because the law recognized only the authority of the paterfamilias. ${ }^{171}$ In this rare instance Giustiniani Bandini almost struck a feminist chord by hinting at the unfairness of the family law as well as the predatory behaviour of the Unione popolare. Leghe dei genitori appeared to her just another attempt to obtain women's contributions of money and work. Moreover, they would make the Unione donne fall apart, alter its programme, and destroy the work it had already carried out:

La più vera e profonda ragione dell'insistenza dell’Unione Popolare per avere leghe di genitori e non leghe separate di padri e madri di famiglia è evidentemente quella di aver modo di riprendere l'organizzazione femminile per averne contributo (dalle donne se non dagli uomini) di lavoro e denaro; e così dire che l'Unione Popolare avrà fatto qualche cosa, avendo disfatto l'Unione fra le Donne Cattoliche. Ma per me la costituzione di leghe di genitori, data la poca sincerità degli opponenti, rappresenterebbe lo sgretolamento dell’Unione nostra,

\footnotetext{
${ }^{169}$ Eadem, "Pro memoria inviato il 6 settembre 1914, cited above, note 143. Giustiniani Bandini writes: “Fin dal suo inizio nel 1908 l’U.D.C.I. ebbe contrasti con l’U.P. per questione economica. L’U.P. non avrebbe voluto che l'U.D.C.I. fosse un'Unione a sè, ma soltanto un ramo dell'U.P. perchè il fondo di cassa dell’U.P. era costituito più da quote femminili che non da quote maschili”. Original underlining retained.

${ }^{170}$ Eadem, "Dopo il Convegno di Genova. Pro memoria inviato il 4 dicembre 1914 a S.S. Benedetto XV”, handwritten copy, dated 4 December 1914, AGOP XIV.950 GIB.36.

171 "Lettera accompagnativa della domanda del comunicato", cited above, note 148: "Ed infatti se si ammette il principio che le donne potranno unirsi in una medesima lega agli uomini per la questione scolastica, domani, per coerenza, bisognerà conceder loro di unirsi agli uomini per i loro interessi professionali di classe, e con tanta maggior ragione perchè di fronte all'autorità governativa l'importanza e il valore di queste leghe professionali è indiscutibile, mentre molto dubbio è quello delle leghe dei Genitori se la legge come i regolamenti scolastici non ammettono che l'autorità del pater familias".
} 
l'alterazione del nostro programma e perciò la distruzione del lavoro fatto fin qui. ${ }^{172}$

Meanwhile, Benedict XV had ascended the papal throne in September 1914. One of the tasks facing the new Pope was to look into the organization of the lay movement. The five unions, Unione popolare fra i cattolici d'Italia, Unione economico-sociale, Unione elettorale, Società della Gioventù cattolica italiana, and Unione fra le donne cattoliche d'Italia, continued their existence also under his new ordinance. Under the previous system, the various presidents had met from time to time to deliberate on matters of general interest under rotating chairmanship. Such meetings were very rare, however, since each union tended to act without recourse to the others, and to guard its autonomy jealously. Now the new ordinance gave the Unione popolare precedence over the other four, and its President the right to chair the monthly meetings of the central directive body, the Giunta, which included all the five presidents. Consultation with respective presidents was obligatory with any action affecting their domain. All Catholic men were required to become members of the Unione popolare and women of the Unione donne, which alone had the mandate to organize Catholic women. ${ }^{173}$

Another important organizational innovation which Benedict XV introduced around 1915 was the institution of parish committees. Their impact on the women's movement was twofold: on the one hand, they started the gradual process of drafting women from all walks of life into the Unione donne and, on the other, their emergence led to a twotiered organizational structure based on parishes and dioceses. ${ }^{174}$ Parish groups subsequently became such a typical feature of Catholic Action that Pius XI later declared: “... la Parrocchia è il primo nucleo della vita religiosa della grande famiglia cattolica". ${ }^{175}$

Differences with the Unione popolare led Giustiniani Bandini to consider resignation several times, but in December 1914 it was her deteriorating health which precipitated her to ask Benedict XV to exonerate her from her post as President General of the

\footnotetext{
${ }^{172}$ Giustiniani Bandini, “Dopo il convegno di Genova. Pro memoria inviato il 4 dicembre 1914 a S.S. Benedetto XV", cited above, note 170.

${ }^{173}$ V.B.C., "Il nuovo ordinamento dell'Azione cattolica in Italia”, Unione fra le donne cattoliche d'Italia, n. XLIII, aprile 1915, p. 1.

${ }^{174}$ Canuti, Cinquant'anni di vita dell’Unione donne di A.C.I., cit., p. 65.

175 "I gruppi e la parrocchialità, in Magnificat, cit., p. 56.
} 
Unione donne. ${ }^{176}$ Her successor was Princess Carlotta Antici-Mattei who was appointed to the position in March $1915 .{ }^{177}$ Having to resign for family reasons after the death of her husband, the new president remained in the post only until November 1915. ${ }^{178}$ Her departure coincided with the resignation of the ecclesiastical assistant, Monsignor Vincenzo Bianchi Cagliesi, who was replaced by Monsignor Giulio Serafini, titular Bishop of Lampsaco. ${ }^{179}$ At this juncture Giustiniani Bandini received a letter from the Secretary of State Gasparri recalling her to the presidency:

Mentre pertanto Sua Santità mi affida il piacevole incarico di farle giungere le paterne Sue felicitazioni, insieme al voto che la sua salute si mantenga durevolmente in condizioni di floridezza e di prosperità, la stessa Santità Sua mi ha commesso di significarle che, non avendo potuto negare il benevolo esaudimento delle dimissioni che l’Ecc.ma Signora Principessa Antici Mattei, provata da recente lutto e circondata da domestiche cure, ha insistentemente rassegnato dell'Ufficio, pur temporaneamente accettato, di Presidente dell'Unione fra le Donne Cattoliche d'Italia, è Suo desiderio che Ella torni all'importante incarico e riassuma la Presidenza del grande Sodalizio femminile, che deve a Lei i suoi inizi e la sua rigogliosa esistenza. ${ }^{180}$

After her return, Giustiniani Bandini found that she still needed to guard the independence of the Unione donne, perhaps now more than before because of the enhanced status of the Unione popolare. Moreover, the internal changes to the Unione donne, such as the admission of professional unions and parish committees, had made it less the elitist organization she wished it to be. Besides, she no longer enjoyed quite the same level of access to the Pope or even to his Secretary of State as under Pius X's papacy, which had enabled her to promote the Unione donne so vigorously. She resigned her position in November 1917, and a month later, in December 1917, Monsignor F. Tedeschini, Sostituto di Segreteria di Stato, appointed Marchioness Maddalena Patrizi as the new President General of the Unione donne. ${ }^{181}$

\footnotetext{
${ }^{176}$ Cristina Giustiniani Bandini, “Lettera di Donna Giustiniani Bandini a S.S. Benedetto XV per dare le dimissioni da Presidente Generale dell’UDCI”, undated handwritten copy, AGOP XIV.950 GIB.36:

“All'esposto del nostro Ufficio di Presidenza io sono obbligata di aggiungere una preghiera fervidissima a Vostra Santità perchè mi esoneri dal mio ufficio di Presidente Generale. Le condizioni di salute me lo impongono. Il Professore che mi cura qui in Roma, in un certificato rilasciatomi, dice testualmente: 'che ha riscontrato una lesione cronica della tonsilla linguale dovuta precipuamente all'eccessivo uso della voce per ragione del mio ufficio ... I caratteri della lesione sono tali da richiedere assolutamente ed urgentemente il riposo completo dell'organo vocale'.” Original underlining retained.

177 “La nuova Presidente Generale”, Unione fra le donne cattoliche d'Italia, n. XLII, marzo 1915, p. 1.

178 “Documenti pontifici”, ibid., n. XLV, novembre 1915, pp. 2-3.

${ }^{179}$ Ibid., p. 1.

${ }^{180}$ Ibid., p. 3. Original italics retained.

181 “Dimissioni della Presidente Generale”, Bollettino dell’Unione fra le donne cattoliche d'Italia, 15 gennaio 1918, p. 1.
} 
Like her predecessor, the new president, Maddalena Patrizi Gondi (1866-1945), came from a patrician family. Interested in the religious and cultural issues of the day, she opened her home in Rome to noblewomen, priests, publishers and writers for weekly “oral critiques” (recensioni parlate) of important books. ${ }^{182}$ Mother of a large family and widowed at a relatively young age in 1908, she devoted herself to charitable activities, was the founder of a mutual aid society for women workers, and during World War I managed a military hospital. ${ }^{183}$ In the eyes of Giustiniani Bandini, whose own favoured candidate was unable to accept the appointment, Patrizi's previous membership of the Consiglio nazionale delle donne italiane made her ill-suited for the position of President General. ${ }^{184}$ Patrizi’s incumbency as president of the Unione donne was only brief, however, since in 1919 she was appointed to head the revamped and expanded Catholic women's movement, the Unione femminile cattolica italiana, which by then encompassed not only the Unione donne but also the young women's movement, the Gioventù femminile cattolica italiana. She remained as President of the Unione femminile until the end of $1933 .{ }^{185}$

With war still ravaging Europe, Patrizi's immediate concerns related to relief operations. In her new role, she aligned the Catholic women's movement decisively against the enemies of Italy. The subsequent cessation of hostilities brought new responsibilities in the form of assistance to refugees and help in the repatriation of soldiers and in prisoner exchange. ${ }^{186}$ Moreover, in the first half of 1919, Catholic women leaders visited the newly "redeemed" cities of Sebenico, Trent and Trieste to deliver aid to the local population and to extend the operation of the Catholic women's movement also to those areas. ${ }^{187}$ Against this backdrop, as will be discussed later in this chapter, the Catholic women's movement underwent a significant change with the

\footnotetext{
${ }^{182}$ Lorenzo Bedeschi, “Circoli modernizzanti a Roma a cavallo del secolo”, Studi romani, v. 18, parte 2, 1970, p. 192.

${ }^{183}$ M.G. Tanara, “Patrizi Gondi, Maddalena”, in Traniello e Campanini (a cura di), Dizionario storico del movimento cattolico in Italia 1860-1980, III/2: Le figure rappresentative, cit., pp. 633-634.

${ }^{184}$ Cristina Giustiniani Bandini, "Pagine di storia dell’Azione cattolica italiana”, typewritten document, AGOP XIV.950 GIB.3, p. 21: "La mia scelta cadde sull’impareggiabile Duchessa di Airola, presidente del Comitato di Napoli, che, durante una mia assenza in Svizzera, mi aveva egregiamente sostituita e si era distinta nell'organizzazione di guerra del proprio Comitato, ma per ragioni di famiglia essa non potè accettare. La marchesa Patrizi chiamata in seguito a presiedere l'Unione, non ne era nemmeno socia, anzi apparteneva tuttora al Consiglio Nazionale delle Donne italiane che nel 1908 aveva votato l'abolizione del Catechismo nelle scuole e aveva provocato il sorgere della nostra Unione. Per questa ragione essa non era al caso di valutarne lo scopo e il programma ..."

${ }^{185}$ Consiglio superiore della Gioventù femminile di A.C.I., Le pietre miliari. Relazione e statistica della Gioventù femminile di Azione cattolica 1934-1936, Milano, 1937, p. 6. Henceforth referred to as Le pietre miliari. Relazione e statistica della Gioventù femminile di Azione cattolica 1934-1936.

${ }^{186}$ Ibid., p. 43.

187 “Propaganda e aiuti alle Terre redente”, in Magnificat, cit., pp. 52-53.
} 
inauguration of a separate branch for young women, the Gioventù femminile cattolica italiana. It was founded as a national movement towards the end of 1918 and, in 1919, became an independent organization with its own specific field of activity, although still linked to the Unione donna via the overarching umbrella organization, the Unione femminile cattolica italiana. ${ }^{188}$ Meanwhile, despite the war, the Unione donne had continued to grow steadily so that, when the first congress of the Unione femminile was convened in October 1919, its membership had risen to 60.000, even after an exodus of some 10,000 young women to the Gioventù femminile. ${ }^{189}$

In the next few years there were frequent changes to the incumbency of President General of the Unione donne. From 1920 to 1922 the position was held by Baroness Camilla Russi Ruggi, from 1922 to 1923 by Signora Emma Lombardi Vallauri, from 1923 to 1924 by Donna Angelina Paternò Castello, who vacated the presidency to join a religious order, and then, for a few months, by Signora Maria Ricci Curbastro. In 1924, Dr. Maria Rimoldi, who had come to the Vice-Presidency of the Unione donne via the Gioventù femminile, was nominated President and remained in her post until 1949. ${ }^{190}$

The next round of major structural changes to the Unione femminile occurred on 21 July 1925 when it was organized into three branches - Donne, Giovani, Universitarie:

Le tre sezioni ... devono essere considerate come Organizzazioni aventi i compiti dell'”azione esterna". All’Unione Donne Cattoliche spetta quanto riguarda le adulte o maritate; alla Gioventù Femminile tutto ciò che riguarda il movimento giovanile; alle Universitarie il movimento universitario secondo gli statuti già approvati. ${ }^{191}$

The women's and the youth branch each had a two-tiered structure anchored in parishes and dioceses. As adjuncts to parish associations, subsections on the basis of occupational groupings also began to be formed. In the Gioventù femminile they proved an enormous success, but less so in the case of the Unione donne. In the latter, from 1922 to 1925, women were divided into categories such as industrial workers, agricultural workers, office employees, graduates, teachers and housewives. Since, however, the vast bulk of women consisted of housewives such categorization was not

\footnotetext{
${ }^{188}$ Canuti, Cinquant'anni di vita dell’Unione di A.C.I., cit., p. 45.

189 Ibid.

${ }^{190}$ Ibid., pp. 50, 55-57.

${ }^{191}$ G. Pizzardo, “Il nuovo ordinamento dell’U.F.C.I.”, Bollettino dell'Unione femminile cattolica italiana, a. VI, n. 15, 15 agosto 1925, p. 1.
} 
useful. $^{192}$ Frequently women’s parish groups were made up of two vastly different types of women:

I due ceti che erano più largamente rappresentati, aristocrazia e popolo, si confondono ora nella massa parrocchiale e il Gruppo rappresenta e vuol essere l’unione, la solidarietà, la fraternità di tutte le classi sociali nell'apostolato. ${ }^{193}$

At no stage in its history did the Unione donne forget the raison d'être of its existence as a bulwark against secular feminism. In her article "Alle presidenti diocesane dell’U.F.C.I.” in May 1928, Patrizi emphasized the important role the Catholic women's organization played in the study of women's problems under their varied and complex aspects, in asserting women's true rights vis-a-vis the authorities and hostile currents (correnti avversarie), and in representing Italian Catholic women in a forum of similar organizations that had emerged in all civilized countries. ${ }^{194}$ It is noteworthy that even at this late stage, when the Italian feminist movement had been totally subdued, she still felt that it was incumbent on her to remind Catholic women leaders of their duty to make the feminine masses aware of the damage secular feminism could inflict on women, the family and society. This was because feminism, in her view, not merely called for the recognition of equal dignity of the two sexes but, in spite of physiological differences, demanded equal rights in all facets of social life. In addressing these issues, the central office of the Unione femminile fulfilled its responsibilities at the national level while diocesan offices adapted and applied them to local requirements:

Osservatorio e baluardo di difesa: ecco che cosa è l’Ufficio Centrale di Presidenza dell'U[nione]F[emminile]C[attolica]I[taliana].

Ecco che cosa sono gli Uffici Diocesani che integrano la sua azione adattando o sviluppando il programma generale alle condizioni locali. ${ }^{195}$

The third branch of the Unione femminile, the Universitarie cattoliche italiane, had its origins in the activities of Luigia (Gina) Tincani who, in her late teens, was drawn into the ranks of the Unione donne. As a student of education in Rome she recognized the great need for the religious instruction of women intellectuals, and in 1914 started her first course in religion for female university students, which then gave impetus to the formation of the first Circolo universitario femminile cattolico. Circoli for university students and staff began to be established also elsewhere to provide courses in religion, biblical exegesis, and languages as well as conferences on a variety of topics. In 1922,

\footnotetext{
${ }^{192}$ Canuti, Cinquant'anni di vita dell'Unione donne di A.C.I., cit., p. 51.

${ }^{193}$ Ibid., p. 65.

${ }^{194}$ Maddalena Patrizi, “Alle presidenti diocesane dell’U.F.C.I.”, Bollettino dell’Unione femminile cattolica italiana, a. IX, n. 5, maggio 1928, p. 1.

${ }^{195}$ Ibid. Original italics retained.
} 
a constitutional change made the women's university circles a branch of the Unione donne, and in 1925, with the reorganization of the Catholic women's movement, of the Unione femminile. ${ }^{196}$

While the membership numbers of the Unione donne were on the increase, further growth came from 1926 onward through the enrolment of Catholic boys (fanciulli) in the women's organization. Special diocesan and parochial delegates were nominated to look after the formation of parish groups (schiere), each consisting of six boys, for instruction in catechism by qualified teachers and for fortnightly social gatherings. ${ }^{197}$ The conclusion of the Lateran Pacts gave another boost with a substantial number of women and boys joining the organization. The tables below show the respective growth in the numbers of members of the Unione donne and of the Fanciulli.

\section{Table 1. Unione Donne}

$\underline{\text { Year }}$

1913

1923

1925

1928

1934

$\underline{\text { Year }}$

1926

1928

1934 $\underline{\text { No. of parish groups }}$

750

2,197

3,162

4,206

8,206

$\underline{\text { Fanciulli }}$

$\underline{\text { No. of parish groups }}$

78

982

4,216
No. of members

$$
\begin{aligned}
& 35,000^{198} \\
& 113,886 \\
& 159,220 \\
& 196,572 \\
& 306,323^{199}
\end{aligned}
$$

$\underline{\text { No. of members }}$

1,715

18,481

$103,696^{200}$

A further change to the constitution of the Unione donne resulted from the confrontation between the Church and the fascists soon after the signing of the Lateran Pacts. While the women's and boys' groups were not directly in the line of fire, the overall situation in Catholic Action was destabilized when, in the spring of 1931, the fascist regime

\footnotetext{
196 "Ricordi di un circolo universitario", in Magnificat, cit., pp. 27-29. On 31 July 1925, there were 610 Catholic university women belonging to the Unione femminile, with 17 circoli and 11 secretariats. See “Relazione dell'azione esterna svolta nelle diocesi”, Bollettino dell'Unione femminile cattolica italiana, a. VI, n. 16, 1 ottobre 1925, p. 14.

197 "I nostri fanciulli cattolici”, ibid., a. VII, n. 11, novembre 1926, p. 3.

${ }^{198}$ Canuti, Cinquant'anni di vita dell’Unione donne di A.C.I., cit., p. 27.

${ }^{199}$ Magnificat, cit., p. 100.

${ }^{200}$ Ibid., p. 86.
} 
temporarily abolished all Catholic youth groups, both male and female. As Albert O'Brien points out, competition between the Catholic Church and the fascists for influence over Italian youth had existed ever since Mussolini came to power in October 1922. ${ }^{201}$ Even though under Article 43 of the Concordat of the Lateran Pacts Catholic youth groups were officially recognized on condition that they were apolitical and under the direction of the ecclesiastical hierarchy, police surveillance of Catholic clubs soon began to intensify. ${ }^{202}$ In early 1931 Catholic sezioni professionali, groups of workers and professional organizations, together with Jesuit-run operations, the Opera dei ritiri operai and the Opera di assistenza religiosa per i militari, were extending their activities. In March the Giunta centrale of Catholic Action decided to create an organized basis for the sezioni in collaboration with ex-members of the Federazione universitaria cattolica italiana. The movement even included, the police discovered, some important former members of the Partito popolare as well as Father Enrico Rosa "who was already under suspicion for his contacts with the anti-fascist Alleanza nazionale". ${ }^{203}$ Stirred up by the fascist press, especially Il Lavoro fascista, the fascists resorted to violence and repressive measures against Catholic Action, including the Federazione universitaria, and the Catholic press, while Mussolini simultaneously accused Catholic Action of having become a refuge for former members of the Partito popolare. On 15 May, on the fortieth anniversary of Rerum novarum, Pius XI promulgated a new encyclical, Quadragesimo anno, which to fascists seemed explicit criticism of the single, State trade union system. ${ }^{204}$ These incidents led to a heightened friction between the Fascist and Catholic youth groups, ${ }^{205}$ which Mussolini used as a pretext to disband the Catholic youth organizations on 29 May 1931. ${ }^{206}$ Appealing to Catholics world-wide, Pius XI issued the encyclical Non abbiamo bisogno, which, although upsetting the fascists through its appeal to the universal Church, also "persuaded Mussolini to negotiate seriously over the youth issue". ${ }^{207}$ The accord of September 1931, while restricting the operation of Catholic Action, nevertheless recognized the right of the Church to organize youth. ${ }^{208}$

\footnotetext{
201 Albert C. O’Brien, “Italian Youth in Conflict: Catholic Action and Fascist Italy, 1929-1931”, The Catholic Historical Review, v. 68, 1982, p. 626.

202 Ibid., p. 627.

203 John F. Pollard, The Vatican and Italian Fascism, 1929-32, Cambridge, Cambridge University Press, 1985, pp. 140-141.

${ }^{204}$ Ibid., p. 139.

${ }^{205}$ O’Brien, “Italian Youth in Conflict”, cit., pp. 629-630.

${ }^{206}$ Ibid., p. 631.

${ }^{207}$ Ibid., p. 634.

${ }^{208}$ Ibid.
} 
The Unione donne did not remain insulated from these events. During the difficult months when the Gioventù femminile had to suspend its operations, the Unione donne opened its heart to the plight of the sister organization and did its best to help it through the troubled period. ${ }^{209}$ The new constitutions of Catholic Action, which were drafted after the confrontation was over, emphasized, above all, the religious nature and the missionary spirit of the Catholic lay movement, making it strictly diocesan and even more dependent on the local bishops. Regarding the Unione donne, as before, bishops nominated the diocesan presidents, eighteen of whom would constitute a Consiglio superiore which also included technical councillors for different areas of activity. The positions of regional delegates were to be abolished, while members of the central organization could only be sent to dioceses at the bishop's request. ${ }^{210}$ It was clear that these measures were aimed at weakening the links of the central organization with the dioceses. The end result could have been a less cohesive Unione donne, which did not prove to be the case.

The Unione donne appealed to women through an ample offering of cultural, recreational and educational activities. National and regional congresses, conventions and settimane sociali as well as pilgrimages to destinations in Italy and abroad were frequent occurrences. For example, on 6 September 1921, a special commemoration ceremony in Ravenna celebrated the six hundredth anniversary of Dante's death. ${ }^{211}$ A procession consisting of up to two thousand Catholic women, from all walks of life, filed through the streets to Dante's tomb:

Ravenna ha visto i cortei dei Fucini, udrà parole di letterati, vedrà rappresentanze governative e della scienza ufficiale. Ma forse solo all’U[unione]F[emminile]C[attolica]I[taliana] era possibile adunare un corteo simile, di masse femminili, in massima parte del popolo, contadine che hanno lasciato per un giorno i campi e le operaie e le casalinghe della laboriosa Romagna, insieme a rappresentanze meno larghe, ma pur numerose, del mondo intellettuale, studentesco, aristocratico e borghese. Crediamo che l'unica vera grande commemorazione popolare che ha fatto palpitare degl'ideali di Dante vivamente e sinceramente gli animi incolti sia e resti la nostra. ${ }^{212}$

This period was also marked with the emergence of the Segretariato centrale di cultura and corresponding diocesan secretariats to look after the foundation of libraries, the

\footnotetext{
${ }^{209}$ Canuti, Cinquant'anni di vita dell'Unione donne di A.C.I., cit., p. 59.

${ }^{210}$ Ibid., pp.72-73.

${ }^{211}$ Dante died in Ravenna on 14 September 1321.

212 “La commemorazione dantesca dell’Unione femminile cattolica italiana”, In alto!, a. 11, n. 8, 1921, p. 1.
} 
formation of study groups and the organization of conventions. ${ }^{213}$ Moreover, women's Catholic Action had a prolific publication programme, with regular periodical issues targeting different sections of the membership. In 1921, for instance, Bollettino d'organizzazione was published for the leaders of the Unione femminile; In alto! for the rank-and-file members of the Unione donne; and Squilli di risurrezione for the members of the Gioventù femminile. There were also two recommended magazines: L'Azione muliebre for women and Fiamma viva for girls, while the weekly comic Corrierino was intended for children. ${ }^{214}$

Social work, which had traditionally been a significant area of activity for Catholic women, under Mussolini was taken over by fasci femminili. Hence the activities of Catholic women's associations in this field became marginal:

Si affievolirà, almeno nella manifestazione esterna, l'accento sociale e civico; la stessa azione sociale sarà più una collaborazione di singole, sia pur formate dall'Associazione, alle opere del tempo anzichè una manifestazione propria dell'organizzazione. $^{215}$

In 1925 the congress of the Unione donne laid down certain constitutional directives regarding the kinds of activities Catholic women should pursue. The principal task of the Unione donne was to address the "Christian and apostolic forming" of its leaders and members, which would in turn naturally translate into apostolic work. Apostolic activity had already been divided into five interconnected, yet largely independent areas: religious work, the family, education, morals, and social work. This division was further studied at the first settimana nazionale in April 1926 when diocesan representatives gathered to find out how each field of activity was related to laws, institutions and customs. ${ }^{216}$ Social work was transformed more and more into the tasks of imparting religious education and of instilling in children and others the observance of Christian principles. For spiritual, educational and social recreation special retreats were organized for mothers as well as industrial and office workers. Women's lives revolved around the family, which as the basic unit of society bestowed on them rights and responsibilities. Over time, the Giornata della madre and later the Settimana della madre became popular events especially in small provincial towns. Signora Emma Lombardi Vallauri, Consigliera dell'azione di moralità, instituted the “Apostolate of the

\footnotetext{
${ }^{213}$ Canuti, Cinquant'anni di vita dell'Unione donne di A.C.I., cit., p. 47.

214 "La nostra stampa nel 1921", Bollettino d'organizzazione dell'Unione femminile cattolica italiana, n. 24, 1 dicembre 1920, p. 1.

${ }^{215}$ Canuti, Cinquant'anni di vita dell'Unione donne di A.C.I., cit., p. 66.

${ }^{216}$ Ibid., p. 57.
} 
Cradle” (Apostolato della culla) to combat the declining birth rate. ${ }^{217}$ On its moral crusade the Unione donne took a special interest in the various categories of women and girls leading a marginal existence, such as delinquent minors, "fallen” women and girls, single mothers, women prisoners and those released from prison, as well as women patients with venereal disease. ${ }^{218}$ The Unione donne continued to fight prostitution, and campaigned against alcoholism and blasphemy. Women's energies were also channelled into support for the Church's missionary activities, in which they could participate through prayer, propaganda and fund raising. ${ }^{219}$

In December 1925, as discussed in Chapter One, the fascist regime had established the Opera nazionale per la maternità e infanzia, which received whole-hearted support from all sides of politics. With its new body, the fascist government sought to address problems associated with the soaring number of illegitimate births and the simultaneous decline in the overall birth rate. ${ }^{220}$ In fact, in June 1922, the Liberal government had already appointed a commission to formulate a plan for such an agency. When the project was later revived by Mussolini's cabinet, the new commission, using the internationally recognized Belgian Oeuvre as a model, recommended a semi-public national body for looking after the welfare of infants and mothers. ${ }^{221}$ Even though its role was limited to religious matters, the Catholic women's movement received the new agency with a great deal of enthusiasm. It was represented at the Consiglio centrale, the highest level of the Opera nazionale, through Princess Isabella Borghese, and locally through various committees of patronage. ${ }^{222}$ However, until its reorganization in 1933, the Opera nazionale was plagued by “confusion about its aims”, "a plethoric committee structure” and “untrained volunteers”. 223

The Unione femminile continued to give spiritual and also practical assistance to migrants who moved to other locations in Italy or headed for overseas destinations in search of work. In this field it cooperated with three affiliated Catholic organizations:

\footnotetext{
${ }^{217}$ Ibid., p. 89.

${ }^{218}$ Ibid., 88-89.

219 “L’U.F.C.I. e l'azione missionaria”, Bollettino dell’Unione femminile cattolica italiana, a. V, n. 20, 1 dicembre 1924, p. 1.

${ }^{220}$ Victoria de Grazia, How Fascism Ruled Women: Italy, 1922-1945, Berkeley, Calif., University of California Press, 1992, p. 60.

${ }^{221}$ Ibid., pp. 60-61.

222 “L’Opera nazionale per la protezione della maternità e dell'infanzia”, Le pagine interne del Bollettino dell'Unione femminile cattolica italiana, n. 4, aprile 1927, pp. 8-9.

${ }^{223}$ De Grazia, How Fascism Ruled Women, cit., p. 61.
} 
Protezione della giovane, Consorzio di emigrazione and Congregazione delle Figlie missionarie dell'Immacolata. Since the late 1800s migration inside Italy and to overseas destinations had taken place in ever growing numbers. By 1928 the seasonal movements of rice weeders alone had risen to an annual figure of around 100,000. ${ }^{224}$ Various measures were taken to ensure the safety and welfare of these women. Parishes from which departure took place had a Segretariato pro risaiole which kept a record of rice weeders, their destinations and their supervisors on location. Then, during the journey to the rice fields, the women could call on the help of religious sisters and ladies at the stations. On location, an important part of the practical assistance consisted in inspecting the dormitories of rice weeders to ensure that the accommodation met the prescribed hygiene and sanitary standards. To look after the women's religious needs, reading material and church services were provided, often in combination with recreational activities.

In a similar way, the Church provided spiritual guidance and practical information to those emigrating abroad. Population movements had taken on massive proportions. From the 1870s to 1927 a total of 9,168,367 Italians had moved aboard - among them 3,319,901 women - to North America $(3,914,416)$, South America $(3,753,714)$, Europe $1,267,841)$, and Africa $(188,702) .{ }^{225}$ Within the Catholic Church assistance to emigrants was under the direction of the Santa congregazione consistoriale. Through its segretariati pro famiglia, the Unione femminile informed parish priests about impending departures, gave emigrants the addresses of the nearest Italian clergy in new locations abroad, and provided them with information about legal matters pertaining to their relocation. After the departure of a relative, the segretariato pro famiglia helped the family to keep in contact with him or her through correspondence. Emigration to foreign countries was, of course, against the fascist regime's population policy. From the late 1920s it sought to restrict it by abolishing certain government bodies which had facilitated it, by limiting shipping companies' promotion of transport, and by making it binding on emigrants to obtain the nulla osta clearance from the Ministry of Foreign Affairs before the issue of a passport. ${ }^{226}$ The real reason, however, for the decline in emigration was the reduction, after 1921, in the admission of Italian immigrants into the

224 “Assistenza religiosa agli emigranti”, Le pagine interne del Bollettino dell'Unione femminile cattolica italiana, serie III, n. 12, dicembre 1928, p. 11.

${ }^{225}$ Ibid., pp. 2-3.

${ }^{226}$ Ibid., p. 5. In the case of the middle classes the government wanted to promote emigration: "Lo Stato invece facilita l'emigrazione delle classi commerciali, dei laureati, dei professionisti, ritenendola benefica per l'espansione italiana all'estero". 
United States. While the Americans had accepted an average of 233,000 Italian immigrants annually between 1901 and 1910, their number dropped to 42,000 per annum in the 1920s and to 11,500 in the 1930s. Emigration to European countries also decreased due to the Depression. ${ }^{227}$

Unfailingly, the Unione donne continued to render its support for the Church's social policies. In the immediate post-war period, for instance, it was instrumental in founding the Opera delle madrine degli orfani di guerra to provide support to mothers of war orphans, and, in order to prevent "illegitimate unions", campaigned for the retention of pensions by war widows upon remarriage. ${ }^{228}$ Until the Lateran Pacts, the perennial thorny questions of religious instruction, legality of religious marriage and divorce resurfaced periodically necessitating the participation of the Unione donne to promote the Catholic line. Divorce became topical once again in 1919 when the socialists Costantino Lazzari and P. Marangoni introduced a bill for its legalization. ${ }^{229}$ Like on similar occasions in the past, Catholic women staged an energetic campaign against it, which involved writing articles in the press, staging public demonstrations and meetings, and putting out leaflets and flyers against the proposed law. The Catholic women's magazine In alto!, for example, raised the topic in several issues, sounding a call to arms for all Italian women:

Sorelle nostre di tutta Italia, l'ora della battaglia è suonata per noi!

Ancora una volta i nemici della religione e della patria, la setta massonica e il socialismo bolscevico, si sono dati la mano per tentare di introdurre nel nostro paese l'infame legge del divorzio, i cui effetti funesti hanno portato alla dissoluzione della famiglia in tutti quegli Stati che ebbero la sfortuna di adottarla. $^{230}$

In public appeals against the passage of the divorce bill, the Unione donne collected some 2,700,000 signatures - all from women - which the President General, Maddalena Patrizi, delivered to Prime Minister Giolitti in fifty-four bound volumes. ${ }^{231}$

There was a constant tendency to regulate members' private lives by setting norms for acceptable behaviour, for example, through the vigorous campaign for decency in dress standards. This theme was taken up intermittently in a variety of Catholic women's periodicals, such as L'Azione muliebre, La Donna e il lavoro, Problemi femminili,

${ }^{227}$ Clark, Modern Italy 1871-1995, cit., pp. 272-275.

228 "Dalla guerra al dopoguerra”, in Magnificat, cit., p. 51.

${ }^{229}$ Il Novecento delle italiane, Roma, Editori Riuniti, 2001, p. 53.

230 “L’ora della battaglia è suonata!!!”, In alto!, a. I, n. 3, 1920, p. 1.

${ }^{231}$ Canuti, Cinquant'anni di vita dell'Unione donne di A.C.I., cit., p. 48. 
Bollettino dell'Unione femminile, and In alto!. Immodest dressing, it was felt, could only bring discredit on young women:

Le giovinette cattoliche hanno norme precise in fatto di moda: non scollature non calze velate color carne, non abiti troppo stretti, nè corti al disopra delle ginocchia, per le beniamine, e al disopra dei polpacci delle gambe, per le altre. Niente belletto, non occhi e labbra tinti, nessuna pettinatura eccentrica: in tutto contegno da vere ragazze cristiane ...

Oh, mamme, queste giovinette sono le sole veramente rispettate dagli uomini guardate con un certo senso di stima e di ammirazione; alle altre che seguono moda indecente, gli uomini sanno fare occhiate sensuali, fare complimenti, ma solo per il piacere di pochi mesi, di pochi giorni, di poche ore forse, mentre nel loro cuore le disprezzano e le considerano come insignificanti pupattole svestite o come civettuole indegne di un amore serio. ${ }^{232}$

The question of fashion was also taken up at the highest levels in the Vatican. Pius XI himself had already discoursed on the harmful effects of fashion as early as October 1919 on the occasion of the first congress of the Unione femminile. ${ }^{233}$ Some ten years later, the Sacra congregazione del concilio, on the Pope's orders, issued norms to combat indecency in fashion. Parish priests, teachers, parents and women's associations were all called on to ensure that young women and girls dressed with proper decorum. Moreover, once a year diocesan vigilance councils were required to convene in order to study the best ways and means of upholding feminine modesty, while every three years bishops and other prelates were to inform the Sacra congregazione on women's dress standards and on measures that had been taken to comply with its instructions. ${ }^{234}$

With equal tenacity, Catholic women's periodicals launched attacks on the related topic of luxury because it was "superfluous”, not a "sign of wellbeing” or “comfort”, but was, particularly in the case of the rich, injurious to their soul and, through the bad example they gave, to the soul of others. ${ }^{235}$ The pursuit of luxury pervaded all strata of society and derailed people’s lifestyle:

Non vedete l'operaia che mangia solo la minestra per pagarsi le calze di seta, non vedete la famiglia d'impiegati che vive alla diavola per concedersi il cinematografo la domenica, la signora che preferisce seppellire una somma in un

\footnotetext{
232 “La moda femminile”, In alto!, a. VIII, n. 11, novembre 1927, p. 2.

233 “Alle donne ed alle giovani dell’U.F.C.I., 21ottobre 1919”, in Tre pontefici e la Gioventù femminile di A.C., Milano, Vita e Pensiero, 1943, pp. 13-18.

234 "La Sacra congregazione del concilio contro la disonestà della moda femminile”, Bollettino dell'Unione femminile cattolica italiana, a. IX, n. 3, marzo 1930, p. 1.

235 "Il lusso", In alto!, a. 1, n. 6, 1920, p. 2.
} 
vestito da sera che dopo quindici giorni sarà passato di moda, invece che abbellire la sua casa come facevano i ricchi nei tempi antichi? ${ }^{236}$

Fashion and luxury not only undermined social mores but were ultimately also pernicious to social order, since the lower classes could overreach themselves by imitating the upper classes in external appearances and cause false levelling of society. In an article published in Bollettino dell'Unione femminile cattolica italiana on 1 November 1924, the writer "G.C" saw luxury and immoral fashions, bonded with fine yet most tenacious ties (avvinti con sottili e tenacissimi legami), as signs of a decline in values underpinning perceptions of love and life. ${ }^{237}$ Moreover, so the writer pointed out, leaving flirtation and immorality aside, the desire to assert equality between the social classes was the reason why luxury was so sought after and widely spread, and why it had infected the whole social environment. People were imbued to excess with egalitarian ideas, not in the Christian sense of fraternal equality, nor in the sense of fundamental equality of all human beings, but in a more material, in a more mistaken, and in a more socialist sense. Social levelling was therefore dangerous:

Livellamento pericoloso per due ragioni: perchè naturalmente impossibile; perchè facile a far deviare, specie le classi lavoratrici, da quella visione di benessere, di dignità, di retribuzione giusta del loro lavoro dalla quale soltanto potrebbe venire ad esse una vera elevazione sociale. Ed esse, come hanno presa l'uguaglianza in senso tutto materiale ed esterno, così tendono purtroppo ad uguagliare il benessere delle altre classi solo in ciò che ha di raffinatezza esteriore, senza rendersi conto come l'elevamento della vita e il benessere dipendano invece da tutto il tono dell'ambiente familiare, dalla formazione dei singoli, dai mezzi d'istruzione e d'educazione di cui dispongono, dallo sfuggire col risparmio e con la previdenza alle strette immediate del bisogno. ${ }^{238}$

Here one gains a glimpse of how the Unione donne served to preserve the interests of its middle-class members rather than promote the cause of working-class women.

Women's suffrage became topical in the aftermath of the war. There was an awareness, among the general public and the major political parties, of the enormous suffering Italian women had undergone and of the substantial contribution they had made to the national economy during the war years. On 30 July 1919 the lower house of parliament passed, with an overwhelming majority, a universal female suffrage bill granting

\footnotetext{
${ }^{236}$ Ibid.

${ }^{237}$ G.C. [Giovanna Canuti], “Conversazioni. Il lusso”, Bollettino dell’Unione femminile cattolica italiana, a. V, n. 18, 1 novembre 1924, p. 4.

${ }^{238}$ Ibid.
} 
women voting rights at both local and national elections. ${ }^{239}$ Yet among Catholic women there were still many who were reluctant to embrace the idea. Elena da Persico's survey on the vote, conducted in the first half of 1919, revealed that the twenty female respondents were evenly divided on the issue. ${ }^{240}$ Catholic women leaders were generally in favour of the vote, after all, Pope Benedict XV had recognized its inevitability. ${ }^{241}$ The question of female suffrage was taken up at the first congress of the Unione femminile in October 1919, at which Marchioness Altoviti spoke in favour of women rights and about the need to prepare Catholic women for voting at local elections. Patrizi, the President General, reminded the audience that the Unione femminile fought for the vote, not in the "unhealthy spirit of modernity", but to carry out its social function fully "in a Christian sense”. Acknowledging that the bill needed to be ratified by the incoming legislature, the congress moved in favour of the resolution to grant women voting rights at both national and local elections:

Il Congresso dell'U.F.C.I. considerando che il rapido riconoscimento effettivo del voto amministrativo e politico della donna è istrumento indispensabile per ritornare cristiana la Nazione, condizione questa, grazie alla quale, sola si potrà condurre la vita nazionale alla grandezza che la sua tradizione esige, fa voti che la Camera nelle prime sedute della nuova legislatura approvi la leggi [sic] sull'elettorato femminile. ${ }^{242}$

With Mussolini's ascendancy the momentum for women's suffrage was lost, although for the next two years he purported to endorse the idea of limited voting rights for women, as becomes clear from his address to the delegates of the ninth congress of the International Alliance for Women's Suffrage, convened in Rome from 14 to 19 May 1923. In the first instance, Mussolini foresaw only certain categories of Italian women as becoming eligible for the vote at local elections while stressing that, apart from the vote, there were also other ways to influence the course of events:

\footnotetext{
${ }^{239}$ The enactment of the bill was stalled by the adjournment of the upper house and, before it could be reconsidered, the fascist regime had taken over.

240 “A proposito di elettorato femminile”, L'Azione muliebre, a. XIX, fasc. 3, 15 marzo 1919, pp. 138154; “A proposito dell'elettorato femminile”, ibid., 15 aprile 1919, pp. 202-207; "Il voto alla donna”, ibid., 15 giugno 1919, pp. 305-313. Da Persico’s sample was small because only very few women responded to her invitation to express their opinion on women's suffrage.

${ }^{241}$ For example, in his address to the delegates of the first congress of the Unione femminile cattolica italiana on 21 October 1919, Benedict XV said: "Le mutate condizioni dei tempi hanno potuto attribuire alla donna funzioni e diritti, che la precedente età non le consentiva”. He also stressed that woman's primary mission remained her own family: "Ma niun mutamento nell’opinione degli uomini, e nessuna novità di cose o di eventi potranno mai allontanare la donna, conscia della sua missione, da quel centro naturale che è per lei la famiglia”. "Il Santo Padre e l’Unione femminile cattolica italiana”, Bollettino d’organizzazione dell'Unione femminile cattolica italina, n. 7, 15 novembre 1919, p. 1.

242 “Il primo congresso dell’Unione femminile cattolica italiana”, ibid., p. 7.
} 
Io penso, che dato lo spirito pubblico italiano e le tendenze del nostro sviluppo politico, la concessione del diritto elettorale alle donne non può incontrare nessuna opposizione pregiudiziale in nessun partito. Per quello che mi riguarda, mi sento autorizzato a dichiarare che il Governo fascista, salvo avvenimenti imprevisti, s’impegna a concedere il voto a parecchie categorie di donne, cominciando dal campo amministrativo. Credo che nessuna, tra voi, si sorprenderà di questo mio procedimento prudenziale in materia di voto, tanto più che questa prudenza è alleata a previsioni ottimistiche. Credo in realtà che la concessione del voto alle donne nelle elezioni amministrative in un primo tempo e nelle elezioni politiche in un secondo tempo non avrà conseguenze catastrofiche.

Permettetemi tuttavia di osservare che con il voto non può esaurirsi nè si esaurisce l'attività politica di un cittadino; in mille altri campi e con molti differenti modi si può influire sul corso degli eventi, e sullo sviluppo delle situazioni politiche. Ma le elezioni non sono che un episodio più o meno clamoroso ed importante: ci sono al di fuori del problema elettorale molti altri problemi la cui risoluzione interessa le donne ed il loro avvenire famigliare e sociale. Avete dunque fatto molto bene a portare questi problemi al vostro ordine del giorno.

In siffatta materia vi dichiaro che tutto ciò che sarà tentato per elevare spiritualmente il mondo femminile troverà il cordial appoggio del Governo fascista. Recentemente questo Governo ha approvato le Convenzioni sociali di Washington che riguardano il lavoro notturno delle donne e dei fanciulli ponendosi in prima linea fra le nazioni civili del mondo ed accogliendo i voti tante volte espressi da tanti Congressi Internazionali. Ha approvato ancora la legge contro la tratta delle donne e dei fanciulli concretando così in precise disposizioni legislative quella protezione effettiva delle donne che era un dovere dei popoli civili, e che da molto tempo era stata interessantemente reclamata da tutti quelli che si erano occupati del grave problema. ${ }^{243}$

The editor of L'Azione muliebre, Elena da Persico, could not but fully agree with Mussolini. Another reporter on the congress, Giovanna Canuti, found that unity was lacking among the multifarious array of feminists ranging from the left-wing of the Italian women's movement to international delegates from forty countries, with AngloSaxon Protestant feminists wielding a major influence:

A proposito di femminismo, dico, non credo che l'unione sia perfetta nel campo dell'Alleanza; l'elemento anglosassone vi prevale e, comunque, la mentalità e la società protestante informano di sè la maggioranza; ad esempio le delegate italiane, che pur rappresentano la sinistra del nostro movimento femminile ci sembravano tutt'altro che consenzienti sulle conclusioni votate. ${ }^{244}$

While agreeing in principle on the female suffrage issue, Catholic women did not whole-heartedly endorse the resolutions on the other topics on the congress agenda: equal pay and equal access to employment; application of the same moral standards to

\footnotetext{
243 “Dal discorso di S.E. Mussolini all’inaugurazione del Congresso dell’Alleanza internazionale per il suffragio”, L'Azione muliebre, a. XXIII, n. 6, giugno 1923, pp. 374-375.

${ }^{244}$ G.C. [Giovanna Canuti], "Il congresso dell’Alleanza internazionale per il suffragio femminile”, Bollettino dell'Unione femminile cattolica italiana, a. IV, n. 11, 1 giugno 1923, p. 4.
} 
both sexes; woman's right to choose nationality upon marriage; and the economic position of married women, mothers, and children, both legitimate and illegitimate. Their reservations were based on the perception that feminists regarded individual rights as being paramount and, therefore, as overriding the rights of the family. The feminist viewpoint was reflected in the resolutions which "affermano la concezione, direi matriarcale, della famiglia e la sete di indipendenza economica della donna". ${ }^{245}$

A few weeks later, on 9 June 1923, the regime introduced to parliament a bill which would grant the right to vote at local elections, but not the right of representation, to seven categories of mostly well-to-do women. This would have meant limiting the franchise to just over a million Italian women out of a total of twelve million. ${ }^{246}$ The Unione femminile welcomed enthusiastically the prospect of a female electorate, even though it was considerably scaled down and did not encompass national elections, and envisaged educating women in their civic duties. ${ }^{247}$ As previously, such preparations proved unnecessary, with the bill being rejected, although not totally buried, since it was put before parliament again in May 1925. On this occasion the Unione femminile sent a message to Mussolini and to all individual deputies:

L’Ufficio centrale di Presidenza dell'Unione Femminile Cattolica Italiana, riferendosi al voto già espresso dalla sua Assemblea generale, in nome delle trecentomila donne iscritte nell'associazione, appartenenti ad ogni regione italiana,

nell'imminenza della discussione parlamentare per la concessione dell'elettorato amministrativo ad alcune categorie di donne

riaffermando l'importanza dell'influenza sociale della donna che, nei presenti ordinamenti, può essere più efficace attraverso il voto

confida che, considerando anche la particolare natura dell'elettorato amministrativo che, per le sue ripercussioni sulla vita cittadina, ha particolari rapporti con la famiglia e con l'attività sociale di cui la donna italiana si è resa altamente benemerita, il Parlamento vorrà riconoscere l'opportunità e la convenienza di concedere alla donna il diritto al voto amministrativo. ${ }^{248}$

The bill was passed in November 1925, but the women who would have been eligible to vote under its restricted covenant never came to exercise their right because in the following year the suffrage law was voided by the institution of a new system of local government which deprived both men and women of the right to vote. ${ }^{249}$

\footnotetext{
245 Ibid.

${ }^{246}$ Il Novecento delle italiane, cit., p. 73.

247 “Elettrici!”, Bollettino dell’Unione femminile cattolica italiana, a. IV, n. 12, 15 giugno 1923, pp. 1-2.

248 "Per il voto amministrativo", ibid., a. VI, n. 10, 15 maggio 1925, p. 1. Original paragraphing retained.

${ }^{249}$ Il Novecento delle italiane, cit., p. 81.
} 
Totally loyal to the Church and accepting its rulings obediently, the Unione femminile remained, as was intended, an "apolitical” organization. Only rarely did its periodicals comment on current affairs, and then mostly when the Church or its institutions were perceived to be under threat. In 1919, for example, the Bollettino delle donne cattoliche d'Italia lamented that anticlericalism was on the increase and that thousands of Giordano Bruno societies had emerged to collect funds for an openly anticlerical newspaper. $^{250}$ In the unstable post-war political climate there were frequent clashes between Catholic and socialist youth. In May 1920, as reported in In alto!, socialist attacks did not only target young Catholic men, but also extended to assaults on suore, priests, women, girls and children. ${ }^{251}$

While the Unione donne was hostile to socialism, it was not prepared, either, to embrace a left-wing party on its own side of the religious divide. In accordance with its leaders' Clerical-Moderate background, the Unione donne distanced itself from the Partito popolare italiano, which during its brief existence received very little, if any, support from the Catholic hierarchy. In February 1920 the Bollettino d'organizzazione stated categorically that the Unione femminile had nothing to do with the party or its women's groups:

Ancora sentiamo far confusioni tra la nostra organizzazione e i Gruppi femminili del P. Pop. It. Ripetiamo per l'ennesima volta che la nostra associazione non ha nulla da vedere col Partito popolare, nè i nostri Gruppi e i nostri Circoli con i Gruppi femminili e le sezioni del Partito. ${ }^{252}$

A few years later, in April 1924, when fascists posed a new threat, the Bollettino dell'Unione femminile felt it necessary to publish the resolutions of Catholic Action regarding fascist violence against Catholic youth groups, including the Gioventù femminile. ${ }^{253}$ But in November 1926 the Bollettino also carried a brief extract from L'Osservatore romano to express abhorrence at an attempt on Mussolini's life. ${ }^{254}$ A

\footnotetext{
250 “Anticlericalismo”, Bollettino dell'Unione fra le donne cattoliche d'Italia, 15 marzo 1919, p. 1. 251 “Infamie rosse”, In alto!, a. 1, n. 2, 1920, pp. 1-2.

252 "La nostra associazione e i gruppi femminili del Partito popolare”, Bollettino d'organizzazione dell'Unione femminile cattolica italiana, n. 5, 30 [sic] febbraio 1920, p. 1. Adelaide Coari was among the first members of the Partito popolare. See "Si è spenta Adelaide Coari", Cronaca di Milano, 18 febbraio 1966. Another prominent woman to join was Elena da Persico who, however, was against the party's policy in favour of women's suffrage, supporting the idea of the family vote. See Passoni, Elena da Persico, cit., p. 47.

253 “Per le violenze contro le associazioni cattoliche”, Bollettino dell'Unione femminile cattolica italiana, a. V, n. 8, 15 aprile 1924, p. 1.

254 “Per l'attentato contro il Capo del Governo”, ibid., a. VII, n. 11, novembre 1926, p. 1.
} 
month later, on the other hand, the Unione femminile quite openly cautioned its parish leaders against surrendering membership lists to the local authorities. ${ }^{255}$ Very seldom, however, can one find any kind of direct criticism of government policy. This occurred when, in November 1926, the government issued a regulation of excluding women from teaching Italian, the classical languages and literature, history, and philosophy in upper secondary schools and from teaching senior classes in technical schools. The Bollettino dell'Unione femminile disapproved of the measure, and found it perplexing because teaching suited the natural inclinations of women better than the liberal professions which women were still allowed to practise:

Se si ammette la donna all'esercizio delle professioni libere dell'avvocatura, del notariato, della medicina, della ingegneria, perchè escluderla dall'insegnamento che è tanto più conforme alle sue naturali attitudini e capacità? ${ }^{256}$

Like the Catholic population at large, Catholic women greeted the signing of the Lateran Pacts, on 11 February 1929, with a great deal of joy and jubilation. Many of the causes they had fought for decades now appeared to have been brought to a satisfactory conclusion, including the resolution of the Roman question with the granting of territorial sovereignty to the Pope over Vatican City, the agreement on religious education in primary and middle schools, and the recognition of church marriages with no allowance for divorce. Moreover, as long as they were immediately subordinate to the ecclesiastical hierarchy and acted independently of any political party, the Catholic Action organizations had their future guaranteed. ${ }^{257}$ On the day following the historic event, a group of students from the Università cattolica del Sacro Cuore in Milan, in a papal audience on their pilgrimage to Rome, heard Pius XI declare Mussolini l'uomo provvidenziale. Soon afterwards, Maria Sticco's comments in Fiamma viva reflected the high expectations many Catholics, including the Pope, had of Mussolini:

Non positivista ieri, non idealista oggi, ma genio d'azione, Benito Mussolini ha compreso l'assurdità dello stato agnostico, come il pericolo dello Stato etico, ha visto nella Religione cattolica l'unità e la forza morale di un popolo; ha visto nella Chiesa di Roma la più grande forza della storia, appunto perché essa stessa è la religione una, necessaria, universale, ed è andato solo incontro a Pio XI solo. E la conciliazione diviene realtà, e il Papa ora può dire la frase storica: “Speriamo di aver dato Dio all'Italia e l'Italia a Dio". ${ }^{258}$

\footnotetext{
255 "Per il caso di abusive pressioni”, ibid., a. VII, n.12, dicembre 1926, p. 1.

${ }^{256}$ Fanny Dalmazzo, “La capacità giuridica della donna”, ibid., a. VIII, n. 2, febbraio 1927, p. 2.

${ }^{257}$ Clark, Modern Italy 1871-1995, cit., p. 255.

${ }^{258}$ Maria Sticco, “Conversazioni intime. L’undici febbraio”, Fiamma viva, marzo 1929, p. 141.
} 
Now acting "faithfully" and "effectively" inside the Italian State, Catholic Action saw its role in society as reinforced, having both the "duty" and the "mandate" to ensure that Catholic values would permeate society:

Ma intanto rimanga ben chiaro che l'Azione Cattolica ha il dovere e il mandato di consolidare nel popolo e di estendere la sincera adesione e la fervente pratica dei principii cattolici; di penetrare ogni istituto sociale del senso di Cristo; di portare la Patria nostra nei suoi nuovi ordinamenti verso il Regno di Cristo. La nosta attività si spiegherà lealmente ed efficacemente dentro lo Stato e le forze che lo compongono, per il pieno raggiungimeno degli scopi ai quali fu ordinata la felice intesa della Chiesa e della Nazione. ${ }^{259}$

By the mid-1930s the Unione donne felt fully integrated into its fascist environment. Always more interested in God's grand designs than politics, it found that with the advent of the fascist regime there was no cause to "change" (mutare), "rectify" (correggere) or "abandon” (abbandonare) anything. On the contrary, the ideal conditions which the regime generated in national politics rendered the spiritual contribution of the Unione donne necessary (necessario), effective (fattivo) and fruitful (fruttuoso). Further still, members of the Unione donne were encouraged to take out cross memberships of the Fasci femminili:

Per la vita politica, le nostre socie che ebbero in animo di viverla più direttamente, furono incoraggiate ad assumere le proprie responsabilità in un movimento adatto alla donna, quale il movimento dei Fasci Femminili dedicati in massima parte alla assistenza sociale. ${ }^{260}$

In the meantime, irrespective of the political environment, the Church's fundamental position on women did not change but, if anything, it hardened in the determination to ensure the prevalence of traditional patriarchal values. Totally submissive to the ecclesiastical hierarchy, the Catholic women's organization blindly accepted any decision and any announcement impacting on its members' status and wellbeing. This was also the case with two encyclicals promulgated by Pius XI, Casti connubii ${ }^{261}$ and Quadragesimo anno, ${ }^{262}$ which both codified the Church’s position on women. On 31 December 1930 Pius XI reaffirmed in Casti connubii the idea of the divine institution of matrimony which underpinned Leo XIII's Arcanum, promulgated fifty years earlier.

\footnotetext{
259 “La soluzione della Questione romana. Un trattato e un concordato”, Bollettino dell’Unione femminile cattolica italia, a. X, n. 3, marzo 1929, p. 1.

260 "La nostra unione nella vita odierna", in Magnificat, p. 106.

${ }^{261}$ Pius XI, Casti connubii: Encyclical of Pope Pius XI on Christian Marriage (31 Dec. 1930). http://www.vatican.va/holy_father/pius_xi/encyclicals/documents/hf_p-xi_enc_31121930_casticonnubii_en.html (19/07/2009)

${ }^{262}$ Pius XI, Quadragesimo anno: Encyclical of Pope Pius XI on Reconstruction of the Social Order (15 May 1931). http://www.vatican.va/holy_father/pius_xi/encyclicals/documents/hf_pxi_enc_19310515_quadragesimo-anno_en.html (03/09/2010)
} 
Marriage arose from "the free consent of each of the spouses", and its principal ends consisted in the propagation of children and in caring and educating them in a religious environment. ${ }^{263}$ It was based on the mutual fidelity of the spouses, and its sacramental aspect generally meant that it was indissoluble except when it was not consummated. While not taking away from woman her dignity as a human person in view of her noble function as wife, mother and companion, and not implying that a wife should be regarded as a minor, it forbade "that exaggerated liberty" which did not consider the good of the family. ${ }^{264}$ It categorically ruled against abortion, eugenics and contraception, and against women's emancipation for either physiological, social, or economic reasons. The encyclical went on to say that the emancipation of woman meant debasing the womanly character and dignity of motherhood, and that the "false liberty and unnatural equality with the husband" were "to the detriment of the woman herself”, 265

By declaring the primacy of the husband with regard to the wife and children, Casti connubii reiterated the patriarchal tenets of the Catholic Church, forbidding women even from controlling the biological functions of their own bodies. The Pope's attitude, it seemed, was in total agreement with fascist policies which gradually eroded the rights women had gained in Liberal Italy. In wanting to see women, almost exclusively, as regine della casa, it converged on fascist perceptions of their role in society. While the encyclical and fascist population policies appeared to have the same aim, write De Giorgio and Di Cori, Casti connubii resonated differently from Mussolini's discourses on cradles and coffins. The propositions through the voice of the spiritual father became personal norms (norme ad personam), and had an infinitely greater effect on behaviour than fascist appeals made in huge town squares through loudspeakers. ${ }^{266}$ Nevertheless, even though the content and the mode of delivery may have been different, the papal and the fascist exhortations all the more clearly demonstrated the collusion of the two ideologies in trampling on the fundamental rights of women. Typically the Bollettino dell'Unione femminile published the lengthy encyclical in its

\footnotetext{
${ }^{263}$ Pius XI, Casti connubii, cit., para. 6.

${ }^{264}$ Ibid., para. 27.

${ }^{265}$ Ibid., para. 75.

${ }^{266}$ De Giorgio e Di Cori, “Politica e sentimenti”, cit., p. 369.
} 
entirety in its February issue in $1931 .^{267}$ There was no commentary, since, in any case, approval would have been superfluous and disapproval unthinkable.

The encyclical Quadragesimo anno, promulgated on 15 May 1931 in commemoration of the fortieth anniversary of Leo XIII' encyclical On the Condition of Workers, dealt with the reconstruction of social order. In paragraph 71 it made a special reference to women, once again enunciating the papal view that ideally women should stay at home to look after their families, assuming that a worker's wage was sufficient to support wife and family:

Mothers, concentrating on household duties, should work primarily in the home or in its immediate vicinity. It is an intolerable abuse, and to be abolished at all cost, for mothers on account the father's low wage to be forced to engage in gainful occupations outside the home to the neglect of their proper cares and duties, especially the training of children. ${ }^{268}$

While this could not be always achieved "in the existing circumstances", the Pope nevertheless hoped that changes would be introduced to enable every workingman to receive an adequate wage. Similar sentiments can also be found in La famiglia, e la sua educazione nella vita sociale, a publication issued by the Unione femminile in November 1929. ${ }^{269}$ By this time it was taken for granted that unmarried women could work outside home provided it did not risk their health or morals, and did not jeopardize their possible future maternal role. In the case of married women, outside work, if it could not be avoided, should only minimally contrast with their duties as wives and mothers. ${ }^{270}$ With the arrival of fascism, the paper noted, labour legislation in Italy had undergone important changes. In Liberal Italy, the absence of state intervention had, among Catholics, given rise to the establishment of workers' unions (organizzazioni di classe) in order to counter the anti-Christian influence of socialist organizations. Now, under the fascist regime, private enterprise was disciplined through direct State intervention, which in itself was "good" and "rightful", and reminiscent of Rerum novarum, which appealed to governments to regulate the relations between employers and workers. ${ }^{271}$ Among the government measures which enhanced the social role of the family the paper mentioned the tax on the unmarried, prizes for large families, reduced

\footnotetext{
267 “Il matrimonio cristiano”, Bollettino dell’Unione femminile cattolica italiana, a. XII, n. 2, febbraio 1931, pp. 3-8.

${ }^{268}$ Pius XI, Quadragesimo anno, cit., para. 71.

269 "La famiglia, e la sua educazione nella vita sociale”, Supplemento al Bollettino dell’Unione femminile cattolica italiana, serie IV, n. 11, novembre 1929.

${ }^{270}$ Ibid., p. 2.

${ }^{271}$ Ibid., p. 7.
} 
military service (ferma) for sons of large families and, for the unmarried, limited career opportunities in the public service and reduced availability of public housing. ${ }^{272}$

\section{PART II}

\section{The Gioventù femminile}

While the Unione donne attracted a large following among a cross-section of Italian women, the growth of the Gioventù femminile cattolica italiana, which started off as a branch of the Unione, would be even more spectacular. As with the Unione, the success derived from the organizational talent and the relentless energy of the founder, who in this case was Armida Barelli.

Born in Milan, Barelli (1882-1952) came from an upper middle-class family which was both cultured and materially well-off. To complete her education, the family sent her to the Institute of the Sacred Heart in Menzingen, Switzerland, where she studied languages from 1895 to 1900. The institute was run by Franciscan sisters, so her stay there gave an early impulse to a lifelong dedication to Franciscan spirituality and to the Sacred Heart. ${ }^{273}$ She first came into contact with "intransigent" Catholicism in 1909 while attending a course on religious culture at the Archbishopric in Milan. Her decision to join the Franciscan Tertiary Order the following year was influenced by her association with Father Agostino Gemelli who, like her, came from a non-religious background but had in young adulthood given up his secular career as a medical practitioner in order to take the vows as a Franciscan. One of the first instances of Barelli's productive cooperation with Gemelli was to provide translations for his Rivista di filosofia neoscolastica. ${ }^{274}$

Barelli was initially drawn into the Catholic women's movement through a project known as the "Enthronement of the Sacred Heart", promoted by the Chilean priest Mateo Crawley Boevey during World War I with the support of Pope Benedict XV and

\footnotetext{
${ }^{272}$ Ibid., p. 5.

${ }^{273}$ M. Casella, "Barelli, Armida”, in Dizionario biografico degli italiani, v. 34, Roma, Istituto della Enciclopedia italiana, 1988, pp. 251.

274 "Barelli, Armida”, in Rachele Farina (a cura di), Dizionario biografico delle donne lombarde 5681968, Milano, Baldini e Castoldi, 1995, p.107.
} 
other highly placed ecclesiastics in Italy as well as the President General of the Unione donne, Cristina Giustiniani Bandini. In essence, the "Enthronement of the Sacred Heart” was

Più che un semplice atto di culto, l’Intronizzazione del Sacro Cuore di Gesù nel focolare domestico, era un riconoscimento sociale dei diritti di Nostro Signore Gesù Cristo sulle famiglie e sulle Nazioni che importava perciò la Consacrazione delle singole famiglie, delle Comunità Religiose, delle Associazioni, delle città, dei Regni etc - L'atto della Intronizzazione non poteva quindi separarsi dall'atto della Consacrazione e viceversa senza venir meno al fine propostoci. ${ }^{275}$

Cristina Giustiniani Bandini accompanied Crawley Boevey to various cities in Italy to promote his initiative, which also meant entering the war zone in order to invite soldiers to pledge themselves to the Sacred Heart. Discovering that Agostino Gemelli already had a similar idea, she was content to leave the project to him. This brought Giustiniani Bandini into contact with Barelli whom Gemelli appointed as secretary to the organizing committee. ${ }^{276}$ The project was completed with some two million soldiers dedicating themselves to the Sacred Heart. Then Barelli's life took an entirely new direction following a request to set up a young women's organization, which came to be known as the Gioventù femminile. In this enormously busy period she was also involved in creating an apostolic fellowship for laywomen: the Pio sodalizio delle missionarie della regalità di Cristo, which would prove of great importance not only for the Gioventù femminile but also for various other projects. ${ }^{277}$ The fellowship gave rise, in 1928, to the Opera della regalità which promoted the recognition of the sovereignty of Christ in society. ${ }^{278}$ In the period 1919-1922, apart from the groundwork for the Gioventù femminile, Barelli also played a vital role in the planning of the Università cattolica del Sacro Cuore. Upon the foundation of the university, she served as its treasurer until her death. She acted in a similar role for Vita e pensiero which was founded in 1918 as a publishing house for the Università cattolica.

\footnotetext{
${ }^{275}$ Cristina Giustiniani Bandini, “Pagine di storia dell’Azione femminile cattolica italiana”, cit., p. 3. 276 Ibid., p. 6.

${ }^{277}$ Casella, “Barelli, Armida”, cit., p. 251: “L’importanza di questo Pio Sodalizio fu enorme non solo per la Gioventù femminile di azione cattolica, ma anche per altre iniziative legate al nome della B.: raccolta di offerte per l'Università cattolica e per le missioni, consacrazione dei soldati al Sacro Cuore, ecc." ${ }^{278}$ On pp. 41-42 of "Dalle carte di Armida Barelli l'’immensa opera' di una donna ambrosiana'”, in Armida Barelli nella società italiana, Milano, Edizioni O.R., 1983, Giorgio Rumi writes: “L’Opera della Regalità si conferma ... lo strumento opportuno per la preparazione pubblica dell'idea-forza dell'universale dipendenza da Cristo ... È il momento di istituzionalizzare questo sforzo in un'opera, dal programma semplice e schietto: 'promuovere il riconoscimento della Regalità di Cristo nella società: a) con la diffusione della dottrina sulla Regalità; b) con la consacrazione al Sacro Cuore delle scuole, fabbriche, uffici, negozi, comunità, collegi, seminari, municipi, prefetture, ecc.; c) promuovere la festa della Regalità, congressi, manifestazioni'.”
} 
Compared to the Unione donne, the Gioventù femminile has generated a higher level of interest among the general public and researchers and, consequently, a greater number of publications. Barelli's own writings provide an insight into the movement, especially her autobiography, La sorella maggiore racconta: storia della GF dal 1918 al 1948, ${ }^{279}$ which was written over a period of one month with the assistance of two typist stenographers, and was first published in $1948 .{ }^{280}$ Barelli's friends and fellow leaders in the Gioventù femminile, Maria Sticco and Irma Corsaro, have also published accounts of her, which have been reprinted in several editions. ${ }^{281}$ The occasion of the one hundredth anniversary of her birth in 1982 saw a renewed, if short-lived, interest in Barelli. As a result of a conference held in Rome in 1983, the organizing body, the Istituto Paolo VI, published a volume of conference papers entitled L'opera di Armida Barelli nella Chiesa e nella società del suo tempo, which presented, as the title suggests, Barelli and her movement in the context of her time. ${ }^{282}$ One of the papers, Armida Barelli e la GF nell'Archivio dell'AC by Mario Casella, provides an overview of research material available in the Istituto Paolo VI, the repository of the historical documents of Catholic Action. ${ }^{283}$ Another useful monograph, emanating from Milan around the same time, is Armida Barelli nella società italiana. ${ }^{284}$ Luciano Caimi’s more recent article, Modelli educativi dell'associazionismo giovanile cattolico nel primo dopoguerra (1919-1939), outlines the Catholic youth movements against the backdrop of Fascist Italy, ${ }^{285}$ while Maria Bocci's article, “Una 'distrazione' storiografica significativa: il caso di Armida Barelli”, discusses various literary sources on Barelli. $^{286}$

The foundation of the Gioventù femminile was not Barelli's own idea but was floated by the Church hierarchy. After Gemelli’s Sacred Heart project had come to an end, Giustiniani Bandini recommended Barelli for the vice-presidency of the Milan

\footnotetext{
${ }^{279}$ Armida Barelli, La sorella maggiore racconta: storia della GF dal 1918 al 1948, Milano, Edizioni O.R., 1981.

${ }^{280}$ Luigi Crippa, "Introduzione”, in ibid., p. XIV.

${ }^{281}$ Maria Sticco, Una donna fra due secoli: Armida Barelli, Milano, Vita e Pensiero, 1967. Irma Corsaro, Armida Barelli, Milano, Vita e Pensiero, 1954.

${ }^{282}$ L'opera di Armida Barelli nella Chiesa e nella società del suo tempo, Roma, A.V.E., 1983.

${ }^{283}$ Mario Casella, “Armida Barelli e la GF nell’Archivio dell’ AC”, in ibid., pp. 49-72.

${ }^{284}$ Armida Barelli nella società italiana, cit.

285 Luciano Caimi, “Modelli educativi dell’associazionismo giovanile cattolico nel primo dopoguerra (1919-1939)”, in Luciano Pazzaglia (a cura di), Chiesa, cultura e educazione in Italia tra le due guerre, Brescia, Editrice La Scuola, 2003, pp. 217-286.

${ }^{286}$ Maria Bocci, “Una 'distrazione’ storiografica significativa: il caso di Armida Barelli”, Annali di storia moderna e contemporanea, v. 9, 2003, pp. 429-443.
} 
Committee of the Unione donne which at the time lacked strong leadership. ${ }^{287}$ Not impressed by the calibre of women on the local committee, Barelli was ready to leave it when Archbishop Ferrari, concerned about socialist penetration in his diocese, asked her to found a new organization for young Catholic women in Milan. She was initially afraid of the prospect of having to talk in public before an audience of strangers, and refused the task. As Barelli reminisces, in the winter 1917-18 the city and the diocese of Milan were being infiltrated by Bolsheviks, who sent their agitators into the countryside in order to entice young women to join red unions and to sever their links with the Church. As a consequence, parish priests were pleading with the archbishop to send young Catholic teachers or ladies to counter the Marxist propaganda. ${ }^{288}$ After declining the job, she heard Ferrari mutter bitterly when she was leaving the archbishopric: “... avrei dovuto essere preparato al suo rifiuto: dai ricchi non si ottiene mai nulla”. 289

A few days later Barelli received a phone call from a priest relating to her how an atheist teacher had surmised in class that none of her students would still be so stupid as to go to a mass. Seven boys belonging to the Gioventù cattolica had stood up to declare their allegiance to the Church while not one girl had done so even though thirty-two of them were known to be practising Catholics. Seized by her conscience, Barelli was tormented by the idea:

Che sarà delle madri di domani se le giovani d'oggi adorano il Signore nella penombra del tempio e lo rinnegano alla luce del sole? Ha ragione l'arcivescovo: bisogna riunirle, istruirle, dare loro la fierezza della loro fede, per farne domani madri capaci di educare cristianamente i figliuoli. ${ }^{290}$

With Barelli installed as leader, the Gioventù femminile cattolica was inaugurated on the first Sunday in Lent of $1918{ }^{291}$ While preparatory work for the Gioventù femminile was in progress in Milan, Barelli was invited to Rome by Marchioness Maddalena Patrizi, President General of the Unione donne, and Commendatore Paolo Pericoli, President of the Società della gioventù cattolica italiana, to brief them on developments

\footnotetext{
${ }^{287}$ Rumi, “Dalle carte di Armida Barelli: l’’immensa opera’ di una donna ambrosiana”, cit., p. 36: “Nel 1918, la vecchia dirigenza [dell’Unione donne] poteva vantare la fondazione di 346 comitati con 46.000 socie. La situazione milanese era esemplare: 700.000 abitanti, solo 800 iscritte: 'le socie erano quasi tutte anziane, la gioventù non era quasi entrata nelle file dell’Unione Donne Cattoliche. Le dirigenti dei Comitati erano quasi tutte della nobiltà'”.

${ }^{288}$ Barelli, La sorella maggiore racconta, cit., pp. 5-6.

${ }^{289}$ Crippa, "Introduzione”, cit., p. XXIII.

${ }^{290}$ Barelli, La sorella maggiore racconta, cit., p. 7.

${ }^{291}$ Ibid., p. 8.
} 
in Milan and to impart to them her views on a national organization for young women. On her second visit to Rome, in September 1918, Patrizi informed her that Benedict XV was eager for her to accept a commission to found the Gioventù femminile in all dioceses in Italy. In an audience with the Pope, Barelli tried to decline the appointment but her suggestions for alternative, worthier leaders went unheeded with the Pope declaring:

No, voglio proprio lei. Non la mando come maestra tra le scolare - i maestri della Chiesa sono i sacerdoti - la mando come sorella tra le sorelle. ${ }^{292}$

Assured of Benedict's help and blessings, Barelli suggested two amendments to the draft constitution which had already been prepared: the first concerned raising the upper membership age limit to thirty-five ${ }^{293}$ and the second choosing St Agnes, Joan of Arc and Rose of Viterbo as the patron saints of the Gioventù femminile - not Catherine of Siena who was already patron saint of the Unione donne. ${ }^{294}$ The selection of patron saints was a matter of finding the most precise and relevant symbols for a young women's organization, whereas the upper age limit of thirty-five, important for Barelli in view of the age gap between herself and future members, was to deprive the Unione donne of the contribution of many competent young women who would be drafted into Gioventù femminile instead. ${ }^{295}$

The Gioventù femminile always regarded Benedict XV and his successors with great affection. It regarded Benedict XV as its benevolent founder, who at the sight of thousands of its members, gathered for a conference, all clad in white, exclaimed: "Voi della Chiesa siete il fiore più bello”. ${ }^{296}$ Relations with Benedict's immediate successor, Pius XI, known as the Papa dell'Azione cattolica ${ }^{297}$ were, if possible, even more cordial. For him, Catholic Action remained forever "the apple of his eye", and his attention to the Gioventù femminile was particularly lavish:

Pio XI guidò ininterrottamente la Gioventù femminile, interessandosi personalmente degli ordinamenti organizzativi, della nomina della presidenza, delle iniziative generali e particolari. Telegrammi, udienze collettive e individuali, lettere, discorsi, autografi, incoraggiamenti, doni eccezionali dissero il suo amore paterno, costante, tenerissimo per la giovane organizzazione. ${ }^{298}$

\footnotetext{
${ }^{292}$ Ibid., p. 14.

${ }^{293}$ Later the upper age limit was reduced to thirty.

${ }^{294}$ Ibid., p. 15.

${ }^{295}$ Giustiniani Bandini, “Pagine di storia dell’Azione cattolica italiana”, cit., p. 22.

296 Tre pontefici e la Gioventù femminile di A.C., cit., p. 4.

${ }^{297}$ Ibid., p. 6.

${ }^{298}$ Barelli, La sorella maggiore racconta, cit., p. 361.
} 
With the exception of the two alterations requested by her, Barelli had no hand in the drafting of the first constitution of the Gioventù femminile, which laid down its nature, its objectives and its composition. Headed by a vice-president and a vice ecclesiastical assistant, it formed part of the Unione donne. ${ }^{299}$ However, in order to grow, writes Barelli, the Gioventù femminile needed independence. Together with Patrizi, she drafted a new constitution in 1919, whereby the women's organization was split into two parallel and independent branches, the Unione fra le donne cattoliche d'Italia and the Gioventù femminile cattolica italiana, headed by their respective vice-presidents and vice-ecclesiastical assistants, and coordinated at the apex by a new body, the Unione femminile cattolica italiana. ${ }^{300}$ Even though the two branches were meant to be independent, in practice they maintained a strong organizational link, since in every diocese the women's group and the youth circle shared the same secretariat for propaganda. $^{301}$ In 1922, the national congress of the Gioventù femminile promulgated a third constitution which further enhanced its independent status. Both for the Unione donne and the Gioventù femminile the titles of the leaders changed from vice-president and vice-ecclesiastical assistant to president and ecclesiastical assistant regarding positions both in the national body, the Consiglio superiore, and in the diocesan councils. Importantly, both branches had henceforth their own separate secretariats for propaganda. $^{302}$ A fourth constitution came into force at the third national congress of the Gioventù femminile in 1925, granting it the monopoly over the organization of the entire population of young Catholic women, whether inside or outside Catholic Action. ${ }^{303}$ The ruling was not categorically enforced, however, since the universitybased women's association, the Universitarie cattoliche, continued to maintain links, albeit tenuous, with the male organization, the Federazione universitaria cattolica italiana - a situation on which Barelli did not look favourably. ${ }^{304}$ As previously

\footnotetext{
${ }^{299}$ Ibid., p. 352

${ }^{300}$ Ibid.

${ }^{301}$ Ibid., p. 353.

${ }^{302}$ Ibid.

303 Ibid.

${ }^{304}$ Caimi, "Modelli educativi dell'associazionismo giovanile cattolico nel primo dopoguerra (19191939)”, cit., p. 239. The Universitarie were interested in maintaining ties with the male university students' association, the Federazione universitaria cattolica italiana, as well as their independent identity within Catholic Action, while the leaders of the Unione femminile and the Gioventù femminile wanted to retain the section in their sphere of influence. Cristina Luccioli writes on p. 231 of “'Lei cucirà le nostre opere'. Il rapporto tra Armida Barelli e Agostino Gemelli”, in Emma Fattorini (a cura di), Dire Dio, Genova-Milano, Marietti, 2005: "Sebbene il processo di assorbimento delle universitarie nell’Unione Femminile avvenne tra il 1922 e il 1924, tentativi di allontanare le studentesse dalla Federazione si erano verificati già in precedenza, quando prima l’Unione Donne e poi la Gioventù Femminile cercarono di far rientrare la gestione delle universitarie nella loro sfera di competenza. Benché fosse stato garantito il mantenimento di legami sostanziali tra le universitarie e la Fuci, nella
} 
discussed, in May 1931 the Fascist regime temporarily abolished all youth associations belonging to Catholic Action, but allowed them to be reconstituted in September of the same year. When promulgated in 1932, the new constitution for the Gioventù femminile precluded any activity of a social, syndicalist or civic nature. It also contained changes of a lesser consequence: the Gioventù femminile had to give up its distinctive badge and to adopt the cross commonly worn by the Unione femminile; it also lost its white flag since only tricolours were allowed; circles were renamed associations; the Consiglio superiore became Centro nazionale; and the association itself assumed the title of Gioventù femminile di Azione Cattolica in place of Gioventù femminile cattolica italiana. $^{305}$

Since its inauguration, the Gioventù femminile continued to grow steadily, as shown by the figures below:

\section{Table 2. Gioventù femminile}

$\begin{array}{rrr}\text { Year } & \text { Number of circoli } & \text { Number of members } \\ & & \\ 1919 & 750 & 50,000 \\ 1922 & 4,363 & 183,000 \\ 1923 & 4,700 & 211,000 \\ 1924 & 5,149 & 225,000 \\ 1925 & 5,817 & 255,734 \\ 1928 & & 500,000^{306}\end{array}$

Number of associazioni

1936

14,409

$862,771^{307}$

realtà questo impegno fu sostanzialmente disatteso...”. She also writes on p. 239, “Le discussioni intorno allo statuto delle universitarie si prolungarono fino al 21 settembre 1923, quando fu firmato dalla marchesa Patrizi, da Maria Carena e da Giacinta Uniarte, segretaria delle universitarie, l'atto di costituzione delle Uci: il documento stabilì i rapporti tra le universitarie e la Fuci, consentendo alle studentesse di condividere con la Federazione l'attività specifica universitaria; limitò la permanenza nella sezione a un massimo di due anni dopo il conseguimento del titolo di studio; permise la partecipazione delle universitarie alla vita della G.F”. She comments further on p. 240: "Nello statuto, pubblicato nel 1924, le relazioni delle universitarie con la Federazione erano ... solo rapidamente accennate, a significare l'esistenza di contatti episodici e privi di reale efficacia operativa".

${ }^{305}$ Barelli, La sorella maggiore racconta, cit., pp. 353-354.

${ }^{306}$ For 1919 the data is obtained from ibid., p. v. For the years 1922-1925 the figures are obtained from p. 12 of Consiglio superiore della Gioventù femminile cattolica italiana, Relazione e statistica della Gioventù femminile cattolica italiana. Triennio 1922-1925, Milano, Vita e Pensiero, n.d. (Henceforth referred to as Relazione e statistica della Gioventù femminile cattolica italiana. Triennio 1922-1925.) The total for 1922 includes the categories effettive and aspiranti, whereas the totals for 1923-1925 additionally include the category beniamine. The total for 1928 comes from p. 463 of Irma Corsaro, "Il IV congresso nazionale della G.F.C.I.”, Fiamma viva, agosto 1928. Corsaro gives the number of circles as 1,800, which appears incorrect. On p. 120 of The Vatican and Italian Fascism, 1929-32,cit., John F. Pollard gives the total membership of the Gioventù femminile in 1928 as 394, 251. 
In membership numbers, the Gioventù femminile quickly outgrew the male Catholic youth organization, the Gioventù cattolica italiana, which in 1928 recorded a total of 206,410 members. ${ }^{308}$

In essence, the Gioventù femminile was initially conceived as an organization which would disseminate Catholicism among young girls and women in the 18-30 age group. As Barelli recounts, very soon there was a request to lower the age limit, which resulted, in 1920, in the foundation of a special section for younger girls. Further junior sections came into being over time, with some variation in the age limit between the different categories until they consolidated at between 6 and 11 years for beniamine, 11 and 14 years for aspiranti, 14 and 18 years for giovanissime, and 18 and 30 for effettive. At the age of 30, a member would enter the Unione donne, as she would also do upon marriage. During the 1930s two further sections were added to the Gioventù femminile: in 1933 a section for piccolissime for girls aged between 4 and 6 years, and in 1937 another section for angioletti receiving infants up to 4 years. ${ }^{309}$ Each age group had its own periodical publication, which for the youngest members included only illustrations and brief verses for memorization. The introduction of the junior sections led to a shift toward a preponderance of younger members so that while in 1925 the members in the most senior category, the effettive, $(145,536)$ constituted approximately 60 per cent of the total membership, by 1936 this component, though it had increased in number, had shrunk to 29 per cent $(252,519){ }^{310}$

The occupational breakdown, provided in the 1922-1925 triennial statistical compilation of the Gioventù femminile, provides an analysis of the make-up of the total membership. For each thousand members, there were:

345 factory workers (operaie), 235 agricultural workers (contadine), 130 girls/women performing home duties (casalinghe), 200 primary students (studenti elementari, mostly beniamine), 35 office workers and shop assistants (impiegate and commesse), 28 primary teachers (maestre),

${ }^{307}$ Le pietre miliari. Relazione e statistica della Gioventù femminile di Azione cattolica 1934-1936, cit., p. 7. Includes categories effettive, aspiranti, beniamine and piccolissime.

${ }^{308}$ Pollard, The Vatican and Italian Fascism, 1929-32, cit., p. 120.

${ }^{309}$ Barelli, La sorella maggiore racconta, cit., pp. 129-143.

310 "Dati statistici riassuntivi ricavati dai 215 questionari rinviati dai Consigli diocesani della G.F.C.I. prima del 15 agosto 1925”, in Relazione e statistica della Gioventù femminile cattolica italiana. Triennio 1922-1925, cit. 
25 middle school students (studenti medie),

3 graduates (laureate), and

1 university student (universitaria). ${ }^{311}$

This profile suggests that entry into the Gioventù femminile was open to every Catholic girl, even though, within the organization, members were streamed by age and occupation. The same triennial compilation also provides data on the origin of the presidenti diocesane, revealing a high proportion of middle-class girls and women otherwise not employed, together with primary teachers, in leading positions, with the numerically largest group, female workers, having only a modest representation as diocesan leaders, and the next largest group, agricultural workers, not being represented at all:

Primary teachers (maestre)

University students/graduates (universitarie)

Graduates (laureate)

Workers (lavoratrici)

Young ladies (signorine)

Office workers (impiegate)

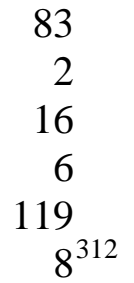

Furthermore, the 1922-1925 statistical data indicated that 70 per cent of members came from the northern regions (Trentino, Venezia Giulia, Veneto, Lombardy, Piedmont, Liguria, Emilia and Romagna), 12 per cent from the central (Tuscany, Umbria, The Marches and Lazio) and 18 per cent from the southern regions (Abruzzo, Campania, Beneventano, Salernitano, Puglia, Basilicata, Calabria, Sicily and Sardinia). ${ }^{313}$ The statistics for the mid-1930s confirmed at 64 per cent the continuing, although declining, predominance of the north, while the numbers had stabilized around 13 per cent for central Italy and had increased to 23 per cent for southern Italy. ${ }^{314}$

Founded as a bulwark against socialism, the Gioventù femminile had the objective of “forming” members and leaders in order to introduce Christianity into society and into everyday life. It was characterized by a religious militancy which was blended with a propensity to asceticism, reminiscent of its founder's Franciscan background. In effect, Barelli embodied the values of the Gioventù femminile and stood as a role model for its members:

\footnotetext{
311 “Relazione G.F.C.I. nel triennio 1922-1925”, in ibid., p. 26.

312 "Dati statistici riassuntivi ricavati dai 215 questionari rinviati dai Consigli diocesani della G.F.C.I. prima del 15 agosto 1925”, in ibid.

${ }^{313}$ Obtained from ibid.

${ }^{314}$ Obtained from p. 7 of Le pietre miliari. Relazione e statistica della Gioventù femminile di Azione cattolica 1934-1936, cit.
} 
... Armida Barelli fu fedele ad una formula di vita francescana che si può sintetizzare nel seguente modo: eliminare i desideri inutili; agire in un’operosità corrispondente alla propria vocazione, cosí compatta e veloce da non lasciare lacune per le fantasticherie ed i sentimentalismi; camminare sempre per le vie maestre, al sole; contentarsi di poco e godere di tutto; vivere giorno per giorno nella povertà liberatrice; aspettare il dolore come un amico; amarlo gelosamente come segno di predestinazione; fidarsi di Dio e volere sempre la sua volontà. ${ }^{315}$

The parallel young men's Catholic organization, the Società della Gioventù cattolica italiana, had been established fifty years earlier with the motto Preghiera, azione, sacrificio. The leaders of the Gioventù femminile found the spirit of the motto suitable also for their own organization, changing, however, the terms to Eucaristia, apostolato, eroismo;

Trovammo l'essenza della preghiera nell'Eucaristia, il valore soprannaturale dell'azione nell'apostolato, la elevazione del sacrificio nell'eroismo. ${ }^{316}$

The motto characterized the missionary quality of the Gioventù femminile. In practice, “apostolate” meant recruitment among equals, on a sister to sister basis, by appealing to potential members by exemplary conduct or by applying more overt forms of proselytizing. A lot of thought went into the design of the membership badge which showed the link between the Gioventù femminile and the Unione femminile. It had the form of three ears of corn on a blue field, held together by a band on which was written Fortes in fide, the motto of the Unione femminile. The three ears of corn represented the triple aspect of the Eucharist: true presence, sacrament and sacrifice; the bundle of corn signified the organization; and the blue field stood for heaven, the fatherland of the soul. $^{317}$

The import of the motto and the symbolism of the badge were reinforced by the fivestanza hymn of the Gioventù femminile which was composed in May $1920 .{ }^{318}$ The last stanza paid tribute to the three patron saints, St Rose of Viterbo, St Agnes and Joan of Arc, who were celebrated for their heroic perseverance and martyrdom:

Avanti! se rude è il cimento, ne incuoran l'apostola Rosa che là da Viterbo fiorì,

\footnotetext{
${ }^{315}$ Agostino Gemelli, "Prefazione”, in Irma Corsaro, Armida Barelli, cit., p. xxxiii.

${ }^{316}$ Barelli, La sorella maggiore racconta, cit., p. 47.

${ }^{317}$ Ibid.: "Prevalse il disegno di tre spighe in campo azzurro legate da un nastro sul quale era scritto:’Fortes in fide’ (motto dell’UFCI) perché nelle tre spighe vedevamo il triplice aspetto dell'Eucaristia: presenza reale, sacramento, sacrificio; nel fascio di spighe vedevamo l'organizzazione, nell'azzurro il cielo, la patria dell'anima".

${ }^{318}$ Ibid., p. 48.
} 
la tenera martire Agnese,

Giovanna, la ognor vittoriosa,

che impavida il rogo salì. ${ }^{319}$

On the occasion of the canonization of Joan of Arc, the Gioventù femminile made a national pilgrimage to Rome in May 1920; two years later there was another national pilgrimage to the tomb of St Rose in Viterbo, who, at three, had resuscitated a dead aunt by prayer, and, at eight, was wounded defending her city against the forces of Emperor Frederick and, after promising to the Virgin to become a Franciscan tertiary, was cured of her terrible afflictions to carry out apostolic work. ${ }^{320}$ There were also pilgrimages to the catacombs of St Agnes, who was the first female martyr to burn at the stake. Like her, the members of the Gioventù femminile were expected to be ready to sacrifice their blood for the sake of faith and virtue while also taking cognizance of her special qualities: fortitude in faith (fortezza nella fede), fraternal charity (carità fraterna), purity (purezza), and otherworldliness (distacco dal mondo). ${ }^{321}$ But, apart from these three saints, there were also more contemporary exemplary figures, former ardent members of the Gioventù femminile, who, after a valiant struggle with illness and physical adversity, had died early. They included Delia Agostini, who at eight had asked of God "virginity and martyrdom”, at fourteen had been the first aspirante desirous of joining the Gioventù femminile, and had died at twenty-three with the words "l'ideale vale più della vita” on her lips. ${ }^{322}$ Another laudable young woman was Argene Fati, the first regional delegate from Lazio and later diocesan president of Rome, who had been stricken with cancer, as had also been the case with Ida Mattei, the first administrative delegate of the Gioventù femminile. ${ }^{323}$ The virtues embodied by these paragons were to be emulated by rank-and-file members, as becomes evident, for example, from the conditions on which new members were accepted. These tightly regimented their spiritual, moral and social lives as well as their lives as members of the Gioventù femminile. ${ }^{324}$

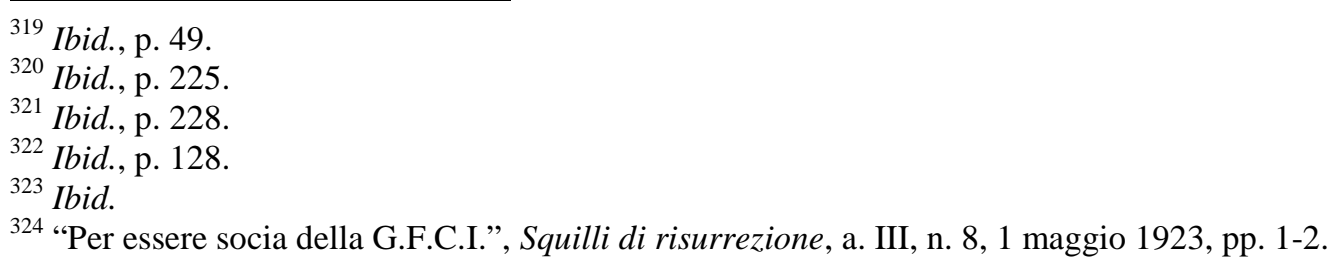

The nature and extent of the commitment expected of members is best conveyed by providing the full text of the form designed for the acceptance of new members, which read as follows:

"Modulo per l'accettazione delle socie...

So che la Gioventù Femminile Cattolica Italiana vuol formare le sue socie all'apostolato sociale perchè il S. Cuore regni nell'Italia nostra e chiedo a codesto Consiglio di Presidenza d'essere ascritta come socia effettiva.

Con ciò intendo impegnarmi:

1. In riguardo alla vita spirituale: 
In order to expand, the Gioventù femminile needed "propagandists" at every level of the organization and a cohesive framework for their instruction. With this objective, it convened regular meetings, first, at the national level, with national and regional propagandists, and then week-long seminars at the regional level between regional delegates and diocesan presidents. Most of the national propagandists and regional delegates were young ladies of independent means, who, often having to overcome the objections of their families, travelled to diocesan centres or to country locations to found new circles or to give organizational help to circles already in existence. ${ }^{325}$ Furthermore, by 1925, there were 105 diocesan schools of propaganda which operated
a) ad adempire tutti i doveri di una buona cristiana;
b) a fare possibilmente ogni giorno una breve meditazione e ad accostarmi almeno mensilmente alla S. Comunione;
c) a frequentare sempre, salvo proporzionati impedimenti, la dottrina domenicale nella mia Parrocchia.

2. In riguardo alla vita morale:

a) contenermi sempre e ovunque in modo esemplare;

b) a vestire correttissimamente (non esclusa l'eleganza) e secondo la mia condizione;

c) a non abbonarmi o leggere riviste, giornali o libri proibiti, immorali o comunque contrari alla nostra religione, ma favorire del mio meglio la buona stampa;

d) a evitare fermamente, anche a prezzo di sacrificio, quelle feste, quelle riunioni, quegli spettacoli o quei divertimenti che, per essi stessi o per l'ambiente, sono dannosi o pericolosi ad una giovane cattolica;

e) a difendere apertamente Dio, la Chiesa cattolica, la Patria e la mia Associazione qualora venissero in mia presenza denigrati e la prudenza non mi vietasse di intervenire.

3. In riguardo alla vita sociale:

a) a essere nella mia famiglia conforto, aiuto, esempio;

b) a sforzarmi di esercitare nell'ambiente in cui vivo (nei campi, in officina, in laboratorio, in ufficio, in salotto, sui banchi di scuola o sulla cattedra) quell'apostolato che è programma specifico della G.F.C.I. e pel quale vogliamo attirare le anime a Gesù;

c) a prepararmi alla missione materna sopranaturale per cui, vivendo secondo lo stato in cui Dio mi vorrà, io possa contribuire a 'render cristiana l'Italia, portar Cristo in ogni cuore, formare le nuove generazioni per preparare un avvenire più lieto e più degno delle nostre splendide tradizioni storiche'.

4. In riguardo alla vita d'organizzazione:

a) a non dare il nome ad associzioni di qualunque genere, professionali, culturali, politiche, di beneficenza, che siano di principi contrari ai nostri o non ispirate dallo spirito cristiano;

b) a pagare annualmente la quota sociale stabilita dal Consiglio diocesano e dal Circolo e ritirare la tessera della G.F.C.I.;

c) a portare il distintivo e leggere il nostro giornale Squilli di Risurrezione;

d) ad intervenire regolarmente alle adunanze e manifestazioni religiose, sociali, ecc., indette dal Circolo, e, in caso di proporzionato impedimento che me lo vietasse, a giustificare la mia assenza e a ripararla il più possibile coll'informarmi su ciò che è stato detto o fatto durante la mia assenza;

e) a considerare come sorelle tutte le socie della G.F.C.I. ed a trattarle con la corrispondente carità;

f) a restituire tessera e distintivo qualora non dovessi più appartenere al Circolo;

g) m'impegno pure ad osservare tutte le norme dello statuto e regolamento della G.F.C.I. e dell'U.F.C.I., nonchè quelle stabilite da codesto Consiglio di Presidenza al quale prometto amore, disciplina e collaborazione”. Original italics retained.

${ }^{325}$ Barelli, La sorella maggiore racconta, cit., pp. 93-100. 
under the guidelines of the central governing body, the Consiglio superiore. ${ }^{326}$ Even though the Gioventù femminile endeavoured to reach the maximum number of girls, it was selective in its recruitment. By the second national congress in 1922, the membership had grown to a total of 228,495 - by any standard a great achievement but it represented only half of what had been projected. ${ }^{327}$ Barelli attributed the shortfall to the so-called "maximum programme" (programma massimo), which involved setting up, initially, “elitist” parish circles in order to maintain the programme of Eucaristia, apostolato, eroismo and excluding girls who would not be able to adhere to it and who would therefore change the character of the circle. ${ }^{328}$

In a span of five to six years, claims Luciano Caimi, the educational programme of the Gioventù femminile had acquired a clear and organic configuration, which, without distancing itself from the traditional Catholic feminine image, had additional new features. They involved imbuing young Catholic girls - who continued to attend to their everyday duties at home, study or work, - with a sense of “apostolic protagonism”, which led them to new evangelizing commitments and turned their attention to ecclesial matters, such as the papacy, missions, clerical vocations, "good press", and the Università cattolica. ${ }^{329}$ In order to ensure the girls' commitment, the Gioventù femminile obviously saw the need to mould their minds in a unitary and disciplined manner. One of the principal tools was its publishing programme, which generated voluminous streams of periodicals and other publications with religious content, each stream crafted to target a particular group of members:

Dunque cultura religiosa e popolare, una cultura cioè capace di far in qualche modo fronte all'ignoranza religiosa allora diffusissima, mostrandosi in grado di personalizzare il messaggio, di arrivare cioè a tutte e a ciascuna delle socie, fossero esse divise per età (piccolissime, beniamine, aspiranti, effettive), fossero esse raggruppate per professione (contadine, casalinghe, lavoratrici, studenti ecc.). ${ }^{330}$

Publishing activities ultimately assumed gigantic proportions and relied on the competently run central administrative system which simultaneously catered for the organizational requirements of the Gioventù femminile:

\footnotetext{
${ }^{326}$ Relazione e statistica della Gioventù femminile cattolica italiana. Triennio 1922-1925, cit., p. 19.

${ }^{327}$ Ibid., pp. 154-155. The figure quoted by Barelli conflicts with the data in Relazione e statistica della Gioventù femminile cattolica italiana. Triennio 1922-1925, cit., p. 12. The total number of card-carrying members (1922) is shown there as 183,000.

${ }^{328}$ Ibid., p. 155.

${ }^{329}$ Caimi, "Modelli educativi dell'associazionismo giovanile cattolico nel primo dopoguerra (19191939)”, cit., p. 231.

${ }^{330}$ Casella, “Armida Barelli e la GF nell’Archivio dell’AC”, cit., p. 64.
} 
Per dare un'idea del lavoro amministrativo dirò che dal solo Segretariato, nel 1925, furono spediti 5007 lettere, 5420 pacchi, decine di migliaia di plichi; ricevuti 7821 vaglia ..., senza contare l'amministrazione di Squilli che nel giro di 30 giorni importava, sempre nel 1925, la spedizione di 291.400 Squilli di risurrezione (quindicinale), 72 mila Squilli d'aurora e 43 mila Squilli argentini (mensile). ${ }^{331}$

The leaders of the Gioventù femminile shared with the Unione donne the periodical Bollettino d'organizzazione dell'Unione femminile cattolica italiana and later Bollettino dell'Unione femminile cattolica italiana, which ran a regular page dedicated to the Gioventù femminile containing administrative and organizational information together with a letter from Barelli (vostra sorella maggiore) and occasionally from Patrizi (vostra mamma di Roma). From 1 January 1921 the rank-and-file members of the Gioventù femminile had their own journal, Squilli di risurrezione. Soon Barelli recognized that, for each member to receive the same uniform message, a membership should automatically entitle to a free subscription, and that it should be to a national rather than diocesan journal:

... il giornale diocesano, per la esigua tiratura, costa molto e non si può imporre; quindi molte socie, in quelle diocesi, resterebbero senza la nostra stampa di organizzazione. In secondo luogo non otterremmo quella formazione unica che manterrà intatta, anzi cementerà l'unità magnifica che ha oggi la nostra GFCI. ${ }^{332}$

Up to the late 1930s, new streams of Squilli came into existence reaching an ever expanding market of readers:

Squilli di apostolato, journal for diocesan leaders (1925)

Squilli parrocchiali, journal for parish leaders (1925)

Squilli di risurrezione (1921), weekly for members; later separate editions for the cultured and workers (1931)

Squilli d'aurora, weekly for aspiranti (1923)

Squilli argentini, fortnightly for beniamine (1924)

Squilli d'innocenza, monthly for piccolissime (1934)

Squilli d'innocenza, monthly edition for angioletti

Squilli studenteschi, fortnightly for students

Squilli di luce, monthly for the blind

Squilli di consolazione, four-monthly for the sick

Squilli delle religiose, monthly for religious sisters involved with the Gioventù femminile

Squilli melodiosi, bimonthly for singers

Squilli dell'assistente, bimonthly for ecclesiastical assistants in parishes

Squilli sacerdotali, bimonthly for diocesan ecclesiastical assistants

\footnotetext{
${ }^{331}$ Barelli, La sorella maggiore racconta, cit., p. 91. As will be explained below, "Squilli” refers to serial publications issued by the Gioventù femminile.

${ }^{332}$ Ibid., pp. 106-107.
} 
Ragazze che lavorano, monthly for factory workers (operaie) ${ }^{333}$

Squilli di risurrezione, which aimed at girls in the most senior category, contained information about organizational matters, such as the constitution and the regulations of the Gioventù femminile, discussions of social problems, for example, school reform in middle school, feminism, and fashion, norms of conduct, questionnaires on a variety of topics, and publicity regarding conferences and educational functions. An issue often carried a letter from Barelli or even from the Pope. Such letters also featured in periodicals meant for the junior sections. Younger members could read simple stories about saints or events from the life of Jesus, while some issues contained poetry, most of them puzzles to solve, and very often a letter from "Don Micio”, un bel gattone nero, to air an everyday problem through fairy tale-like characters. ${ }^{334}$

Apart from Squilli di risurrezione, January 1921 marked the commencement of the magazine Fiamma viva, which was intended for leaders and well-educated middle-class girls. Edited by Maria Sticco, Fiamma viva saw its basic mission as consisting in the entrenchment of Catholic values among young women. It dealt with a number of issues affecting young women, most of whom studied or worked outside the home to earn a living. In the June 1923 issue, for instance, Father Gemelli wrote an article on the physical education of women, noting that for anatomical, physiological and psychological reasons it should be different from men's exercises while stressing the importance of developing girls into healthy and robust mothers. ${ }^{335}$ The magazine rarely touched directly on political issues, but, in August 1925, when certain categories of women were made eligible for the vote at local elections, it found that the vote, far from damaging women spiritually, could perfect them and make them more efficient, ${ }^{336}$ and, in November 1928, after women's right to vote at local elections had been abolished in May, Anna Racca wrote a surprisingly critical article about the matter. ${ }^{337}$

Many articles were dedicated to women's employment issues and career choices. Teaching had remained a profession open to women, and in primary schools they made up the majority of the professional staff, however, in middle schools there was a

\footnotetext{
${ }^{333}$ Ibid., p. 110. For some Squilli Barelli has indicated the starting year in parentheses.

334 "Don Micio” was the pseudonym of Monsignor Francesco Olgiati.

${ }^{335}$ Agostino Gemelli, “La educazione fisica della donna”, Fiamma viva, giugno 1923, pp. 346, 349.

${ }^{336}$ Giovanna Canuti, “A proposito del voto amministrativo alle donne. Madre o elettrice?”, ibid., agosto 1925, p. 459.

337 Anna Racca, “La donna e il voto”, ibid., novembre 1928, pp. 686-688.
} 
growing tendency to replace women with men - a trend which women had to accept without protest:

... dovremo escludere che non potrà essere la donna cristiana ad impedire che l'uomo ritorni all'integrità dei suoi compiti nella vita sociale. ${ }^{338}$

On the other hand, the previously noted ban on female teachers at classical and technical licei led Fiamma viva to comment that even at lower levels of schooling teaching capabilities are important. If, the magazine wondered, women do not know how to educate fifteen- to seventeen-year olds, how could they ever deal with one- to two-year olds? ${ }^{339}$ Its advice on choosing a medical profession was equivocal, since such a profession could ruin the health of a young woman or derail her completely but it could also enable her to become an "beneficial woman” (donna benefica). ${ }^{340}$ Speaking of Doctor Giuseppina Pastori’s appointment as university lecturer in histology in March 1930, the magazine expressed the hope that this would be "una promessa per l'avvenire". 341

In their outlook, the young subscribers to Fiamma viva tended to be conservative and reflected their conditioning to the unquestioning acceptance of Catholic values. In 1925-1926 the magazine carried out a competition to elicit its readers' views on five specific questions:

I. What do modern young women think of the economic, social and moral position which life offers to them, and how do they intend to improve it?

II. What do they think of their preparation for life: should their education be totally free or should it be subject to old-fashioned discipline?

III. What do they think of achieving equality in marriage as a result of the wife having a profession?

IV. What do they think of the so-called feminism and of their own participation in politics?

V. What are their favourite occupations, their preferred books and how do they intend to plan their lives? ${ }^{342}$

\footnotetext{
${ }^{338}$ Giovanna Canuti, “Appunti sociali. La donna insegnante”, ibid., febbraio 1926, p. 111.

339 Anna Maria Penné, “Da riviste e giornali”, ibid., febbraio 1927, p. 115.

${ }^{340}$ Maria Galli, “Vita femminile. Medichesse, farmaciste, infermiere”, ibid., aprile 1930, p. 218.

341 Osanna Monreale, “Attualità. Una libera docenza”, ibid., marzo 1930, p. 185.

342 "I. Che cosa pensano le giovani moderne della posizione materiale, sociale e morale che la vita offre loro, e come intenderebbero di migliorarla?

II. Concepiscono la loro preparazione alla vita, la loro educazione del tutto libera o sottomessa alla disciplina antica?

III. Che cosa pensano dell'uguaglianza conquistata nel matrimonio per mezzo dell'esercizio di una professione?

IV Che cosa pensano del così detto femminismo e della loro partecipazione alla politica?
} 
Fiamma viva summarized the results of its survey in its November 1926 issue. $^{343}$ It had received some two hundred responses of which it had printed nine in its previous issues. The prize was won by “Ala” who had replied adequately to each question and whose answers had the merit of representing the thought of the majority of participants. ${ }^{344}$ The survey found that modern young Italian women were mostly content with their lives. As far as education was concerned no-one wanted go backwards nor, however, did anyone want to free herself from the discipline imposed on her by the family. In marriage the respondents preferred the Christian and the Roman hierarchy of pater- and materfamilias to equality between the spouses. The wife's work outside the home was tolerated as an economic necessity but not as a means of demanding rights vis-a-vis the

\footnotetext{
V. Quali sono le loro occupazioni, i loro libri preferiti e come intendono dirigere la loro vita?” Fiamma viva dealt with the survey in eight issues: novembre 1925, pp. 701-703; dicembre 1925, pp. 760764; gennaio 1926, pp. 58-61; febbraio 1926, pp. 121-124; marzo 1926, pp. 190-192; aprile 1926, pp. 252-254; maggio 1926, pp. 315-316, and novembre 1926, pp. 694-697.

343 "Problemi di vita femminile. Quello che insegna il nostro concorso", Fiamma viva, novembre 1926, pp. 694-697.

344 “Ala”'s responses were published in "Problemi di vita femminile. Il nostro concorso”, gennaio 1926, pp. 58-61. In replying to the five questions, "Ala” writes among other things:

"I. ... non è più possibile per nessuno sottrarre la propria parte alla vita sociale ... oltre che dalle necessità sociali, la donna è spesso e sopratutto portata fuori di casa dalle proprie necessità economiche. Oggi la donna guadagna quasi quanto l'uomo (quando non guadagna di più); e in ogni famiglia che non sia veramente agiata si è abituati a far conto anche di quel che possono produrre e portare in casa le signorine. È un bene? Sì, è certamente un bene che la giovanetta aiuti i fratelli nell'alleviare ai genitori le preoccupazioni economiche. Ma noi abbiamo oggi moltissime fanciulle che vivono nella propria famiglia una vita economicamente indipendente e che della propria indipendenza economica usano per inclinare a tutte le esigenze del lusso e per assicurarsi una emancipazione pratica dall'autorità dei genitori e dalla vita di famiglia... Ricordiamoci che se molti posti e molte mansioni ci aspettano fuori di casa, il nostro primo e naturale posto resta sempre in famiglia;che disertare tale posto è tradire le stesse aspettative della società e della umanità. I nostri primi doveri restano sempre verso coloro che Dio ha più strettamente consegnato ai nostri cuori ed alla nostra missione: voglio dire verso le persone di casa nostra... Nelle aziende, negli studi, nelle organizzazioni, restiamo donne veramente donne: intelligenti, ma discrete collaboratrici degli uomini... a mio avviso, per migliorare le condizioni attuali della giovane donna, bisogna insegnarle a percorrere la maggior ampiezza che oggi le offre il mondo, senza sbarazzarsi della sua anima antica.

II. E perciò io penso che la giovanetta debba prepararsi alla vita non attraverso una educazione completamente libera, ma in una giusta dipendenza, dall'esperienza e dall'autorità dei genitori ... III. Quanto all'uguaglianza che la donna sposata può avere col proprio marito mediante l'esercizio d'una professione, io dico che essa è quasi sempre un male.

IV. Oggi la nostra possibile prossima entrata al Parlamento trova noi donne moderne ancora impreparate; almeno nella massa. Per me, confesso che non desidero il voto; ma quando il voto mi sarà concesso ne [sic] userò (proprio come dice la redazione di “Fiamma”) per uno spinoso dovere di fede e patria.

$\mathrm{V}$. Mi piace tutto quanto è governo della casa; ed ho una particolare simpatia per far cucina. Coltivo con passione i fiori, ho gusto per la vita all'aria libera, ho inclinazione a cogliere la bellezza nei suoi aspetti più semplici. Sono ugualmente innamorata della natura e dell'arte; ed ho tendenze intellettuali. Cerco la compagnia delle persone istruite e mi è sommamente caro visitare i poveri e gli ammalati.

... Non sono una forte lettrice di romanzi, benchè vi sono romanzi come "I Promessi Sposi” e "Piccolo mondo antico" che ho in cuore come cari amici. Prediligo le letture storiche, i libri che raccontano cose ignote di personaggi noti (come i libri di Raffaello Barbiera), gli epistolari, le biografie, le autobiografie, specialmente quando sono libri dell'anima, si chiamino essi 'Le confessioni’ di S. Agostino o ‘Il divino tormento’ di Gianni Verkade.

Amo con passione la poesia, ma la poesia dei grandi poeti. E devo dire di un piccolo libro che è veramente il mio libro: il Vangelo.” Original italics retained.
} 
husband. As regards politics, the respondents were indifferent to the issue of women's suffrage, even though they theoretically considered it as their basic right and not solely as a specious duty. This did not mean that contemporary Italian girls were oldfashioned and copied their mothers; obviously between the young ladies of 1900 and of 1926 there was, the article stated, as much difference as there was between a chignon and long hair (zazzera), but in girls the desire for independence was always less than the desire to have a family, family meaning abnegation and independence loneliness. Of these two alternatives young Italian women preferred abnegation. As for their preferred reading, the respondents as a rule mentioned the gospel and the Imitation of Christ while many, especially office workers, indicated that they read little.

Apart from its abundant publication programme, the Gioventù femminile organized events of various types, congresses, conferences, jubilees, pilgrimages, spiritual exercises, cultural weeks, summer courses, schools for propagandists, and competitions on religious knowledge which took place at the parish, diocesan and national levels, and were instrumental in cementing the organization and in standardizing the "forming" of the members' minds. Standing or marching together with thousands of others was not only inspirational but also reassured the participants of the validity of their religious commitment, while through their very presence the young white-clad girls added to the pageantry of the occasion. After the first national congress, convened together with the Unione femminile in $1919,{ }^{345}$ the Gioventù femminile held further national congresses in 1922, 1925 and 1928. At the third national congress in 1925, the 3,500 girls, together with the delegates of the Unione femminile, created an impressive sight when their procession, headed by a group of the Forza e grazia in elegant uniforms, filed into San Giovanni in Laterano. ${ }^{346}$ At a papal audience, the members of the Consiglio superiore presented gifts to the Pope: a small portable library consisting of seven white-bound volumes made up of folios sent in by circles across Italy, the 1922-1925 statistical compilation, 25,000 lire collected by the girls (on top of the monetary gifts already made that year), and a large quantity of linen for holy ceremonies, handmade by aspiranti and beniamine. ${ }^{347}$ The preparations for the fourth national congress in 1928 , which marked the tenth anniversary of the Gioventù femminile, were in themselves

\footnotetext{
${ }^{345}$ Barelli, La sorella maggiore racconta, cit., pp. 31-32.

${ }^{346}$ Ibid., pp. 159-160.

${ }^{347}$ Ibid., p. 161.
} 
another feat, giving further proof of the organizational talent of the leaders of the Gioventù femminile:

La preparazione del congresso costò un lavoro intenso ... Bisognò provvedere per il vitto e l'alloggio delle seimila iscritte, in cinquantaquattro istituti. E poi stampa, stampa, stampa; otto tipografie erano impegnate per noi; avvisi, programmi, circolari, tessere, immagini, pagelline e specialmente il volume della relazione triennale...

Eravamo in 10 mila nella grande giornata del 15 luglio, e tutto: arrivi, partecipazioni, partenze, tutto si svolse con ordine, con devozione, con attenzione senza il minimo incidente. ${ }^{348}$

The 1928 congress was also the occasion of the first national competition on religious culture, which had been preceded by competitions at the parish, diocesan and regional levels, with the participation of members from 3186 circles in 210 dioceses, and with the national winners and the finalists receiving their prizes from the Pope. ${ }^{349}$ It was obvious that the papal prizes had increased the level of participation and, as a result, had led to a demand for more than a hundred thousand copies of the catechism. ${ }^{350}$ Congresses were often accompanied by pilgrimages, as was, for instance, the case with the first national congress of the junior sections in Bologna in 1927, when the aspiranti and the beniamine visited the tomb of Blessed Imelda (Beata Imelda). ${ }^{351}$ Looking at the ten thousand girls attending the congress, all dressed in white and wearing white veils, the cardinal of Bologna exclaimed: "Pare che in san Domenico sia caduta la neve!" Pilgrimages to destinations in Italy and abroad featured regularly, and reminded members of traditional forms of piety and of the essential nature of life as a pilgrimage:

Valga ... a tenere viva nel cuore della GF la devozione verso le tradizionali forme di pietà tanto frequenti nella Chiesa di Dio, ed a ricordare che la vita cristiana è un pellegrinaggio dalla terra al cielo. ${ }^{352}$

\footnotetext{
${ }^{348}$ Ibid., p. 264.

${ }^{349}$ Ibid., p. 120.

${ }^{350}$ On p. 65 of “Armida Barelli e la GF nell’Archivio dell’AC”, cit., Casella writes: “Quanto ... alla gara di cultura religiosa, essa fu organizzata per la prima volta nel triennio 1925-28. E fu subito un successo, stando ai 121.933 catechismi esauriti in tre mesi e complessivamente stampati in cinque edizioni. Iniziato l'esperimento della gara di cultura nelle diocesi del Veneto (in particolare, Treviso e Padova), l'iniziativa andò man mano estendosi alle altre diocesi italiane. Nel 1936 parteciparono alla gara 289 diocesi, 9644 associazioni, 509.500 socie”.

${ }^{351}$ On p. 374 of “Imelda, Bl.”, in New Catholic Encyclopedia, vol. VII, San Francisco, New Catholic Encyclopedia, 1967, M.J. Finnegan writes: "Born of a noble family, she [Imelda] entered the Dominican cloister of Valdipietra near Bologna. Since she was under 12, then the required age for First Communion, her ardent request for Holy Communion was denied. On Ascension Day 1333, when the nuns received Communion, Imelda, then 11 years old, remained in her place. Suddenly, it was reported, the Sacred Host appeared above her head. The priest gave it to the child, whose First Communion was also her last, for she died in the rapture of her thanksgiving. She was beatified in 1826, and in 1910 was proclaimed the patroness of first communion".

352 Barelli, La sorella maggiore racconta, cit., p. 253.
} 
The Gioventù femminile paid great attention to the development of its leaders. At the Università cattolica thousands of women leaders attended courses designed to teach them techniques in public debate, in conference planning and, to control emotionality, women's true "enemy”, in group psychotherapy. ${ }^{353}$ However, while leaders learnt modern techniques of organization and presentation, the reading material dispensed to them shows a lack of depth. Presidents of parish circles had their own periodical, Squilli parrocchiali, but before it was launched the President General of the Gioventù femminile had dispatched to parish leaders circulars with practical instructions and duty statements, which were subsequently condensed into a single pamphlet. ${ }^{354}$ The cultural preparation recommended by it was restricted to religious and organizational matters, with a total lack of any books which might provoke intellectual curiosity beyond the boundaries of the Gioventù femminile. Apart from the perusal of their regular periodicals and the catechism, parish leaders were to consult:

a) per la vostra formazione religiosa: il Vangelo; il libro "Gesù Re Amore" del P. Matéo; il nostro Manuale "La formazione religiosa della giovane" e i meravigliosi libri di Mons. Olgiati: "Il sillabario del Cristianesimo" e "Sillabario della morale cattolica";

b) per la vostra formazione all'Azione Cattolica: gli Statuti G.F.C.I.; i "Nuovi orizzonti della Gioventù Femminile Cattolica" nella 8 ${ }^{\mathrm{a}}$ edizione; "Ideali e conquiste della G.F.C.I." di Mons. Olgiati; il "Manuale delle Presidenti" cioè i due volumi intitolati: "Aiuti fraterni", il "Vademecum delle Delegate Aspiranti e Beniamine” e la "Parola di Pio XI sull’Azione Cattolica”. 355

As one can see, the training material for Gioventù femminile leaders lacked the intellectual scope and the practical content of the much more ambitious reading programme of the young feminists around Pensiero e azione some twenty years earlier. $^{356}$ The bibliography of recommended holiday reading, published in the Milanese periodical in June 1908, not only comprised religious literature, but its subject coverage also extended to "philosophical studies", "studies of a social character", “educational problems", and "the woman question", with the last-mentioned category including La donna nel passato, nel presente e nell'avvenire by August Bebel and L'assujettisement des femmes by John Stuart Mill. ${ }^{357}$ There was a marked difference in

\footnotetext{
${ }^{353}$ Lucetta Scaraffia, “Teosofe, femministe e moderniste in Italia”, in Lucetta Scaraffia e Anna Maria Isastia, Donne ottimiste. Femminismo e associazioni borghesi nell'Otto e Novecento, Bologna, Il Mulino, 2002, p. 113.

${ }^{354}$ Armida Barelli, Tra sorelle. Istruzioni, direttive e doveri, Milano, U.F.C.I., 1931, p. 1.

${ }^{355}$ Ibid., pp. 21-22.

356 See Chapter Three, p. 68.

357 A.C. [Adelaide Coari], “Alcune proposte”, Pensiero e azione, a. IV, n. 11-12, 10-25 giugno 1908, p. 7. The Fondo A. Coari contains a more comprehensive 8-page handwritten bibliography of 236 books and
} 
attitude between the two groups of women: while early Catholic feminists encouraged their colleagues to expand their mental horizons by reading widely, and even more controversial literature, the Gioventù femminile, by contrast, appears to have been totally inward-looking offering few, if any, incentives to intellectual inquiry. Besides, its leadership failed to grasp, as Paola Gaiotti de Biase points out, the transformation in the feminine image, to remove the contradiction between one based on old, antifeminist precepts and another attuned to new ways of life. It failed, therefore, to update the woman question in practical, theoretical and spiritual terms so that, unlike Catholic women élites before, it did not, for example, deal with syndicalist or political issues. ${ }^{358}$

Year after year the Gioventù femminile collected money for the Università cattolica, and demonstrated its capability to operate with military precision and effectiveness. Because Armida Barelli had played a major part in its establishment, there was a natural link between the two institutions. In the autumn of 1918 the gravely ill Giuseppe Toniolo had expressed to Barelli, and to the other visitors at his sick-bed, his great disappointment at not having been able to found a Catholic university. ${ }^{359}$ He envisaged Father Gemelli, who was among the visitors, to be the right man for the task, and Barelli the person who would make it financially possible:

Non potrebbe darsi, signorina, che il Sacro Cuore l'abbia messa a capo della Gioventù femminile perché ella formi le Marte che raccolgono i mezzi alle Marie del sapere? ${ }^{360}$

Barelli took on the role of Martha and, as we have noted, remained treasurer of the university until her death in 1952. She saw her role as subordinate and secondary to the functions of her male colleagues. There was, therefore, incongruence between her occupancy of a senior position at the university and her lack of intellectual ambition for herself and even for her followers. Despite her undoubted intelligence and competence,

16 periodical titles as well as indications of holding libraries in Turin. Some of the writers listed were modernist, and the reading of their works would have been forbidden at the time. [Elenco di libri], FAC 3325.

${ }^{358}$ On p. 80 of Vissuto religioso e secolarizzazione. Le donne nella “rivoluzione più lunga”, Roma, Studium, 2006, Paola Gaiotti de Biase writes: "Il condizionamento più pesante tuttavia sulla formazione diffusa sarà l'avvento del fascismo. La GF pagherà i costi del venir meno dell'impegno sindacale e politico in cui élites femminili cattoliche erano state coinvolte, e finirà così anche col rimuovere ulteriormente la questione femminile moderna, costruendosi a prescindere da essa. Tarderà ancora la storicizzazione del mutamento della figura femminile, la rimozione della contraddizione fra l'antica precettistica antifemminile, del resto sempre in qualche modo latente, e le nuove pratiche di vita. Tarderà il confronto, in termini spirituali, con il valore teorico della libertà personale, dei diritti, delle responsabilità pubbliche, anche quando, nelle scelte di vita, ci si muoverà in sintonia con essi”. ${ }^{359}$ Barelli, La sorella maggiore racconta, cit., p. 11. ${ }^{360}$ Ibid. 
she was diffident, as a woman, about attending in December 1921 the opening ceremony of the university as a member of the organizing committee:

... a molti è parso strano che una donna facesse parte del comitato promotore dell’Università cattolica; che accanto a tanta scienza e a tanta santità maschile, ci fosse una così evidente incompetenza femminile ... ${ }^{361}$

Barelli first hoped to finance the running costs of the university through annual subscriptions by "Friends" of the university, ${ }^{362}$ but, as this method of raising finance proved inadequate, she was able to persuade Pius XI, in 1924, to institute Passion Sunday as Giornata universitaria to collect money for the university all over Italy. ${ }^{363}$ In the first year of collecting, the contributions added up to a million lire, the amount required annually; they subsequently rose to three million lire; and remained at this level for almost ten years, being sufficient to cover the recurrent costs. ${ }^{364}$ Every section of Catholic Action participated in Giornata universitaria, with the members of the Gioventù femminile being assigned the task of collecting money at the church door. The Università cattolica itself undertook an enormous amount of preparatory work by sending publicity material to all parishes, Catholic associations and companies, seminaries and religious institutions. In light of the total funds required, the amounts collected by the girls were not only impressive but represented the major part of the total needed, since in the 1923-1925 triennium, for example, they collected 512,481 lire, 868,711 lire, and 1,312,966 lire in the respective three years. ${ }^{365}$

In return, the Università cattolica provided the Gioventù femminile with a permanent seat on campus, and in its Marianum college students from the Gioventù femminile and from the students' section of the Unione femminile had priority for accommodation. University professors held special courses and seminars for leaders, and some of the lectures were subsequently published for wider dissemination. Father Gemelli and Monsignor Olgiati, who were especially close to the Gioventù femminile, frequently wrote articles for the various streams of Squilli and for Fiamma viva, and participated in many congresses and pilgrimages. A further important contribution on the part of the

\footnotetext{
${ }^{361}$ Ibid., p. 203.

${ }^{362}$ Ibid., p. 204.

${ }^{363}$ Ibid., pp. 207-208.

${ }^{364}$ Ibid., p. 209.

${ }^{365}$ Relazione e statistica della Gioventù femminile cattolica italiana. Triennio 1922-1925, cit., p. 18. On the basis of the questionnaires received the actual totals for the three years were 274,874 lire (1923), 465,924 lire (1924) and 720,312 lire (1925). Taking the non-responding circles into account, these figures were extrapolated to those quoted in the text. Giornata universitaria had not yet been officially instituted in 1923.
} 
university was the compilation of statistics and books for the congresses of the Gioventù femminile. $^{366}$

Apart from the Università cattolica, there was another area which regularly engaged the Gioventù femminile in money collecting, and this was overseas missions. In 1919 Benedict XV published an encyclical on missions, ${ }^{367}$ which led to the burgeoning of missionary activities. Since the Pope himself maintained a missionary in Shen-Si in China, Barelli, too, was keen to provide a missionary for China and, in December 1920, the Gioventù femminile organized a collection of money for this purpose. ${ }^{368}$ After the death of the Pope, the Gioventù femminile founded, in 1923, the Istituto Benedetto XV for Chinese girls within the existing mission, giving dowries to poor girls interested in a religious vocation, opening an orphanage and a dispensary for the poor, and reviving the mission schools. ${ }^{369}$ The Gioventù femminile readily participated in the annual nationwide collection of funds on Giornata missionaria when it was instituted by Pius XI. ${ }^{370}$

Barelli took, right from the beginning, a firm stand against fascism. ${ }^{371}$ Regarding its upsurge as a reaction against the violence of revolutionary bolshevism, she observed how its impact varied from place to place. In Milan it was anti-clerical to such a degree that Archbishop Ferrari banned Mussolini's journal; while in Bologna, which was subjected to leftist intimidation, fascism was viewed as a legitimate shield against lawlessness. Naturally, where fascism seemingly stood for public order, members of the Gioventù femminile looked upon it favourably. ${ }^{372}$ Barelli's own adverse stance towards fascism could not be mistaken, whereas the President General of the Unione femminile, Maddalena Patrizi, was cautious and equivocal in her attitude. Relatively early it became important for Barelli to communicate to members where the Gioventù femminile stood in regard to fascism. With this in mind, she wrote a clear directive in Bollettino d'organizzazione in May 1921. Before publication, however, she ran into opposition on the part of Patrizi who, perhaps frightened of possible retaliation, suggested that, instead, a circular letter in a sealed envelope should be sent to leaders. Barelli was determined to publish her article but agreed to change the title from "Perché

\footnotetext{
${ }^{366}$ Barelli, La sorella maggiore racconta, cit., p. 200.

${ }^{367}$ Ibid., p. 182.

${ }^{368}$ Ibid., p. 183

${ }^{369}$ Ibid., p. 185.

${ }^{370}$ Ibid., p. 186.

${ }^{371}$ Ibid., p. 59.

${ }^{372}$ Ibid., p. 58.
} 
la G.F.C.I. non può e non deve entrare nei Fasci” to the less confronting “G.F.C.I. e fascismo". ${ }^{373}$ She concluded her article by writing:

Non può la G.F.C.I. schierarsi con nessuno che, dimentico o negatore della legge d'amore predicata dal Vangelo, getta il seme di rinnovate discordie; non può. Ma deve, per la sua missione, nel nome onnipotente di Cristo, sopire le ire, smorzare gli odi, sedar le vendette e affrettare, come ha promesso, come ha giurato, l'avvento del regno di Dio nella Patria nostro [sic] diletta.

Ecco perchè la G.F.C.I. non può e non deve entrare nei Fasci. ${ }^{374}$

The firm line taken by the Gioventù femminile, writes Barelli, effectively reduced the spread of fasci femminili to smaller centres because young women and girls were averse to joining fascist organizations. ${ }^{375}$ Consequently, the Gioventù femminile, together with other Catholic youth organizations, was regarded by fascists as rivals and punished: in 1925 it was forced to disband its section for gymnastics and sports, Forza e grazia; and in 1931 the whole organization was temporarily disbanded. Barelli's anti-fascist position was evidenced by her periodicals. In an analysis of Squilli di risurrezione for the years 1921-1931, Lia Gaggioli provides a summary of articles dealing with fascism. Written to comment on particular contemporary events, their subject matter suggests that for most of this period Barelli and the Gioventù femminile clearly distanced themselves from fascism. ${ }^{376}$

By 1925 Barelli was forced to modify her absolute ban on the membership of fascist organizations, because in many instances employment was conditional on joining a fascist trade union. With casuistic dexterity, as Giorgio Rumi comments, she wrote in a circular to diocesan presidents in June of that year:

Come debbono comportarsi le maestre, le impiegate, le operaie richieste di far parte di sindacati fascisti. Distinguiamo: se è possibile continuare il proprio lavoro senza aderire ai sindacati fascisti, non si aderisce per la semplice ragione che noi dobbiamo aderire alle associazioni o sindacati cristiani ... se non aderire vuol dire mancare del pane, si può prendere la tessera, ma senza vendere la propria anima. $^{377}$

With the passage of time the position of the Gioventù femminile changed even further. By the mid-1930s its leadership, too, was caught up in the general patriotic fervour

\footnotetext{
${ }^{373}$ Ibid., p. 59.

374 “G.F.C.I. e fascismo”, “Le pagine per le dirigenti della Gioventù F.C.I.”, Bollettino d’organizzazione, a. II, n. 8-9, 1-15 maggio 1921, p. 4.

${ }^{375}$ Barelli, La sorella maggiore racconta, cit., p. 60.

${ }^{376}$ Lia Gaggioli, “La stampa della GF dagli inizi”, in L'Opera di Armida Barelli nella Chiesa e nella società del suo tempo, cit., pp. 173-174.

${ }^{377}$ Quoted in Rumi, “Dalle carte di Armida Barelli: l’’immensa opera' di una donna ambrosiana”, cit., pp. 44-45.
} 
which was conveyed in the introductory text of Le pietre miliari, the 1934-1936 statistical compilation of the Gioventù femminile:

L'Italia nostra nell'autunno del 1935 vide i suoi soldati in arme, partire generosi e ardenti per l'Africa Orientale onde preparare "un posto al sole" al nostro popolo generoso e fecondo.

La Gioventù Femminile di A.C. ha vibrato col cuore ardente della giovinezza pura ed ha accettato con entusiasmo l'austerità di vita che il momento esigeva. ${ }^{378}$

Like a growing number of Catholics in general, the Gioventù femminile had by then lowered the "critical threshold" toward the regime which now posed as a defender of the interests of the fatherland against external enemies stirred up by Freemasons, Bolsheviks and Protestants. The bellicose, antifascist stance of the early 1920s had become a memory. ${ }^{379}$

\section{PART III}

\section{Comparison and Relations with the Fascist Women's Movement}

An area of convergence of fascist ideology and Catholicism was their attitude to women. While the Church mobilized women to re-Christianize society in opposition to secularizing influences, the Fascist State looked for their consensus in creating a populous and vigorous warrior nation. Both successfully suppressed femininism within their ranks, with Catholics eradicating femminismo cristiano after the First Congress of Italian Women in 1908, and with fascists, as we will see, gradually purging the Partito fascista of feminist elements. Both the Church and the Fascist State concurred in enunciating the essentially secondary status of women and in centring their lives solely on their maternal function. The thoughts expressed by the fascist academic Giovanni Gentile, an early Education Minister in Mussolini’s cabinet, showed how similar these two ideologies were in this regard. ${ }^{380}$ In his two-part essay La donna e il fanciullo, he declared feminism dead. ${ }^{381}$ This was because where women had obtained equal rights, these had proved to be devoid of anticipated recompenses (soddisfazioni), and the rights

\footnotetext{
378 “Amor di patria”, in Le pietre miliari. Relazione e statistica della Gioventù femminile di Azione cattolica 1934-1936, cit., p. 31.

${ }^{379}$ Caimi, "Modelli educativi dell'associazionismo giovanile cattolico nel primo dopoguerra (19191939)”, cit., p. 264.

${ }^{380}$ G. Sasso, “Gentile, Giovanni”, in Dizionario biografico degli italiani, cit., v. 53, 1999, pp. 196-212.

${ }^{381}$ Giovanni Gentile, La donna e il fanciullo, Firenze, G.C. Sansoni, 1934, p. 3.
} 
had showed themselves to be, to both men and women, more an illusion than a reality, more like a whimsical ideology than a concrete and effective contribution to man's civil and political life. ${ }^{382}$ Gentile argued that women no longer wanted the rights for which they had previously fought. The very polemics had heightened their awareness of their moral dignity and had induced men to recognize the high mission women had in respect of the family and society. Among the beneficial effects of feminist struggles, he noted the fascist regime's legislation for the protection of mothers and infants as well as the enormous progress among civilized nations regarding the education and cultural advancement of women. ${ }^{383}$ Gentile expressed views here that could have emanated from the Catholic hierarchy.

Given this community of beliefs, we should briefly look at the contemporary fascist women's organizations to highlight their relationship to the fascist hierarchy as well as to compare them to their Catholic counterparts. As noted earlier, rivalries existed especially between the Catholic and the fascist youth organizations, but by the mid1930s, in the prevailing patriotic climate, a truce had been reached, and the Unione donne even encouraged its members to cooperate with the fascist women's welfare organization. In contrast to the paucity of coverage of the Unione donne and the Unione femminile, several works exist on the fascist women's movement. Denise Detragiache's article Il fascismo femminile da San Sepolcro all'affare Matteotti (1919-1925) (1983) deals with its early years; ${ }^{384}$ Marina Addis Saba’s essay La donna “muliebre” (1988) explores the fascist regime's policies on women and women's reactions to them; ${ }^{385}$ and Victoria De Grazia gives, in How Fascism Ruled Women (1992), a comprehensive overview of Italian women in the fascist period. More recently, Helga DittrichJohansen has made a further contribution through a detailed analysis of fascist women and their organizations in Le "militi dell'idea" (2002). ${ }^{386}$

Denise Detragiache traces the origins the fascist women's movement to the attendance of nine women at the inaugural meeting of the Fasci di combattimento at San Sepolcro

\footnotetext{
${ }^{382}$ Ibid., pp. 3-4.

${ }^{383}$ Ibid., pp. 4-5.

${ }^{384}$ Denise Detragiache, “Il fascismo femminile da San Sepolcro all’affare Matteotti (1919-1925)”, Storia contemporanea, a. XIV, n. 2, aprile 1983, pp. 211-251.

${ }^{385}$ Marina Addis Saba, "La donna 'muliebre'”, in Marina Addis Saba (a cura di), La corporazione delle donne: ricerche e studi sui modelli nel ventennio fascista, Firenze, Vallecchi Editore, 1988, pp. 1-71.

${ }^{386}$ Helga Dittrich-Johansen, Le "militi dell'idea": Storia delle organizzazioni femminili del Partito nazionale fascista, Firenze, Leo S. Olschki, 2002.
} 
square in Milan on 23 March 1919. ${ }^{387}$ The female participants represented ex-socialists, revolutionary syndicalists and irredentist nationalists from a variety of social backgrounds. Their programme consisted, first and foremost, in the demand for women's right to vote and to stand for parliament. The drama of Gabriele D’Annunzio's occupation of Fiume, then unfolding, found sympathizers among fascist women, including Elisa Majer Rizzioli, one of the attendees at San Sepolcro and founder of the fascist Associazione nazionale delle sorelle dei legionari di Fiume e di Dalmazia. ${ }^{388}$ D’Annunzio's expulsion from Fiume in November 1920, together with the rising socialist militancy and the fears aroused by the good performance of the leftist parties at the recent local elections, kindled passions among nationalists and other elements of the political right. In the general climate of discontent the fascist paramilitary movement - squadrismo - stepped up its activities and involved even some women in its violent raids. Women's participation was never of major importance, however, except for the legendary cult figure it provided in the young Ines Donati, the "Joan of Arc of fascism". ${ }^{389}$ Rent apart by disparate elements, the squadrists and the non-squadrists on the one hand, and the suffragists and the non-suffragists on the other, the fascist women's movement remained weak and lacked cohesion. ${ }^{390}$ In due course, when they were no longer useful to Mussolini, both the squadrist and the suffragist elements would be expelled from the fascist movement.

It becomes evident from even the most cursory glance at the historiography of the fascist women's movement that antifeminism was as ingrained in the fascist hierarchy as it was in society and in the Church. However, in contrast to the Catholic organizations, from the very beginning, fascists treated their women's fasci with arrogance and disdain. Yet, women offered crucial support to Mussolini. For instance, during the crucial May 1921 elections Majer Rizzioli pledged to him the cooperation of her Associazione nazionale delle sorelle dei legionari. ${ }^{391}$ Further, in June 1924, during the Matteotti crisis, she published, in the Popolo d'Italia, a letter assuring Mussolini of the "full and unconditional loyalty" of Lombard fascist women ${ }^{392}$. Her reward came at the end of the year when she was appointed to the Gran consiglio of the Partito

\footnotetext{
${ }^{387}$ Detragiache, “Il fascismo femminile da San Sepolcro all’affare Matteotti (1919-1925)”, cit., pp. 212213.

${ }^{388}$ Ibid., p. 220.

${ }^{389}$ Ibid., pp. 225-230.

${ }^{390}$ Ibid., p.233.

${ }^{391}$ Ibid., pp. 223-224.

${ }^{392}$ Ibid., p. 244.
} 
nazionale fascista and was made Ispettrice generale dei fasci femminili as well as editor of the Rassegna femminile italiana, official bulletin of the women's fasci. ${ }^{393}$ In a matter of only a few months, however, the fascist women's movement suffered a setback. Unlike Catholic women who played a decisive role in drafting their own constitutions and were free to run their organizations, fascist women had to submit totally to the will of the party hierarchy. Typically, in the drafting of a new constitution for the fasci femminili in late 1925, Majer Rizzioli was the only female member of the executive commission, with the other three being men from the Direttorio nazionale. ${ }^{394}$ In its final form the constitution reneged on earlier promises made by Mussolini:

Scomparso del tutto qualsiasi cenno alla "relativa" autonomia amministrativa e d'azione precedentemente ventilata da Mussolini, non solo si asseriva che l'operato delle sezioni femminili doveva risultare "convergente" con quello dei fasci maschili, ma si chiariva anche che a livello provinciale non era contemplata la creazione di alcun organo specifico essendo "i fasci femminili alle dipendenze della Federazione provinciale fascista”. ${ }^{395}$

Majer Rizzioli, who had moderated her feminism to turn into a docile follower of Mussolini, was soon pushed aside from the apex of the fasci femminili. In December 1925, the Rassegna femminile italiana was suppressed and, in January 1926, the inspectorate was abolished. Those feminists who did not agree to keep silent about "the nasty trick played on them" were purged. ${ }^{396}$ After the abolition of the inspectorate, Angiola Moretti, with no feminist or squadrist connections and a loyal follower of the party secretary, Augusto Turati, was given the responsibility for the women's organizations of the party. ${ }^{397}$ But Moretti's tenure, too, as secretary of the women's fasci was rather brief, ending in 1930 with the dismissal of Turati as party secretary. ${ }^{398}$

By the late 1920s, the regime recognized that women were an important "public force" and, in order to fully exploit their potential contribution, the fasci femminili needed to be turned into a mass organization. The first step in this direction was taken by designating, in 1929, the Giornale della donna as their official organ with Paola Benedittini Alferazzi as editor. ${ }^{399}$ There was no change, however, to the high-handed

\footnotetext{
393 Ibid., p. 248.

${ }^{394}$ Dittrich-Johansen, Le “militi dell'idea”, cit., pp. 85-86.

${ }^{395}$ Ibid., p. 87.

${ }^{396}$ Detragiache, “Il fascismo da San Sepolcro all’affare Matteotti (1919-1925)”, cit., p. 251: “...

eliminazione di quelle tra le suffragiste fasciste che, dopo il brutto scherzo giocato loro, non accettano di 'tacere"”.

${ }^{397}$ Dittrich-Johansen, Le “militi dell'idea”, cit., p. 104.

${ }^{398}$ De Grazia, How Fascism Ruled Women, cit., p. 268.

${ }^{399}$ Ibid., p. 247.
} 
manner in which fascist authorities continued to deal with their women's organizations. Nor is there any evidence, finds Victoria De Grazia, of fascist female leaders' advice being sought on many major, or even minor, issues concerning women:

... not in 1929, when the piccole and giovani italiane were handed over to Renato Ricci's ONB [Opera nazionale Balilla], nor in 1930, when the women's dopolavoro was detached from the men's and its 100,000 members were given to the OND [Opera nazionale Dopolavoro]; not in 1933, when it was decided to found the massaie rurali, nor in 1938, when the PNF [Partito nazionale fascista] launched the special sections for Factory and Household Workers (SOLD). The men in charge, first and foremost Starace, dictated the little details as well: from the fabric to be used for uniforms to the stitches designing the banner and flame on the SOLD's neckerchiefs. ${ }^{400}$

After a decade of slow growth, recruitment to the fasci femminili quickened after 1932, especially in the mid-1930s when women were mobilized against the economic sanctions which the League of Nations had imposed after Italy's invasion of Ethiopia. ${ }^{401}$ Women's support was needed not only for the regime's austerity measures but also for its ruralization policies which aimed at creating self-sufficiency in food supply. Like the rival Catholic equivalents, the fascist women's organizations turned into a mass movement, but on an even bigger scale. During the 1920s the Unione donne had outnumbered the fasci femminili, so that, for instance, in 1928 the Unione had 196,572 members as opposed to the 88,006 members of the fasci. In 1934 the Unione $(306,323)$ was still numerically stronger than the fasci $(273,229)$, but consisted only of half the number of the organized fascist women if the figures for the latter were also to include the massaie rurali $(371,658){ }^{402}$ In the case of female youth organizations, in 1928 the Gioventù femminile had half a million members while the Piccole italiane and the Giovani italiane of the fascist female youth organizations made up a combined total of 432,034 members. By 1936 the Gioventù femminile had grown to 862,771 members while the fascist female youth organizations had reached a formidable total of 2,574,302 members. ${ }^{403}$ We should note, however, that the high recruitment figures for the fascist

\footnotetext{
${ }^{400}$ Ibid., p. 268.

${ }^{401}$ Ibid., p. 266. The recruitment drive was further intensified after 1937 when the Partito nazionale fascista commanded that “maximum impulse [be given] to fascism among Italian women”.

${ }^{402}$ The data is obtained from Magnificat, cit., p. 100, and Dittrich-Johansen, Le "militia dell'idea", cit., p. 255.

${ }^{403}$ The data is obtained from Le pietre miliari. Relazione e statistica della Gioventù femminile di Azione cattolica 1934-1936, cit., pp. 7-8, and Dittrich-Johansen, Le “militia dell'idea”, cit., pp. 254-255. The figures quoted enable only approximate comparisons because of differences in categorization: in the case of the Gioventù femminile membership was open to women up to 30 years, whereas the upper age limit for the Giovani fasciste was 21. The total for the Gioventù femminile in 1936 also includes the Piccolissime (116,894 members, aged 4-6 years), which had no corresponding category in the fascist organizations, where the youngest category was the Piccole (8-13 years).
} 
organizations should not be accepted uncritically, because in many categories of employment party membership was compulsory. Considering this, the high enrolment in the Catholic organizations was a remarkable achievement.

The phenomenal growth in the memberships of the fascist organizations reflected not only the regime's concerted effort to recruit women to promote its demographic policies but also the huge popularity which the Duce enjoyed at the time Italy invaded Ethiopia. Through social work and welfare activities, the fasci femminili had a vital role to play in his demographic campaign. The main agency was the above-mentioned state child welfare body Opera Nazionale della Maternità e dell'Infanzia, which in the 1930s began to employ salaried and professionally trained social workers, visitatrici, to replace the old welfare system run by volunteers. ${ }^{404}$ These activities coincided with the regime's 1934 legislation for maternity leave and for a family benefits scheme which started with industrial workers and then extended to the other economic sectors. ${ }^{405}$ Paradoxically, while the women's movement grew rapidly, the regime's endeavours to increase the size of population proved a failure. ${ }^{406}$ The birth-rate declined steadily, and despite the bachelor tax, a substantial number of Italian men stayed unmarried. Moreover, the median marriage age remained relatively high: 28.3 for men and 24.9 for women. ${ }^{407}$

As in the case of Catholic women, fascist women leaders, too, came from aristocratic or middle-class origins but, unlike Catholic women, they never had, or were never permitted to have, a strong national leader of the calibre of Cristina Giustiniani Bandini or Armida Barelli. Notably, while their policies toward the female population at large were repressive, fascists at the same time maintained a galaxy of compliant intellectuals. Not part of the organization hierarchy, these women were seemingly influential and included celebrities such as the first official biographer of Mussolini, Margherita Sarfatti, the poetess Ada Negri, and the novelist Sibilla Aleramo - all in the past known as socialist sympathizers as well as front-line feminists. ${ }^{408}$ These prominent figures stood in stark contrast to working-class women who had effectively been left with no

\footnotetext{
${ }^{404}$ De Grazia, How Fascism Ruled Women, cit., p. 262.

${ }^{405}$ Gloria Chianese, Storia sociale della donna in Italia (1800-1980), Napoli, Guida Editori, 1980, p. 82.

${ }^{406}$ De Grazia, How Fascism Ruled Women, cit., p. 46.

${ }^{407}$ Clark, Modern Italy 1871-1995, cit., p. 275.

${ }^{408}$ Margherita Sarfatti was co-editor of La difesa delle lavoratrici, a journal founded by Anna Kuliscioff; Ada Negri was a member of the socialist feminist organization Unione femminile; and Sibilla Aleramo wrote Italy's first feminist novel, Una donna (1907).
} 
leaders to promote their gender or class interests. "Suppression of peasant and proletarian women", writes Alexander De Grand, "formed a particular aspect of the general repression of the entire working class". ${ }^{409}$ Women in the lower socio-economic classes, enduring the worsening of their condition through the disbandment of their trade unions and their falling real wages, were the prime target of the regime's ruralization and population policies which made publicity or education regarding family planning illegal. ${ }^{410}$

The notions of donna nuova and "Latin feminism" (femminismo latino) provided a clever artifice behind which fascism could hide its inherent antifeminism. ${ }^{411}$ Much of the theoretical groundwork for these concepts was undertaken by two women who came from socialist and liberal backgrounds: the lawyer and university lecturer Teresa Labriola, daughter of the Marxist intellectual Arturo Labriola; and Gina Lombroso, daughter of the criminologist Cesare Lombroso. Denouncing feminism for its tendency to "masculinise" women, Gina Lombroso spoke of women as upholders of maternal values and of "other-directedness" (alterocentrismo), which motivated them to make another person, someone whom one loved and wanted to be loved by, the focus of one's pleasure (piacere) and ambition. ${ }^{412}$ Teresa Labriola, on the other hand, postulated that women should acquire certain "virile" qualities which derived from the awareness that they belonged to their ancestral stock (stirpe) and to their nation. ${ }^{413}$ Not incidentally, therefore, the concept of womanhood had to be updated to include participation in sports as a means of improving women's health and thereby the quality of the Italian race as well as forging women's preparedness for war. ${ }^{414}$ As Addis Saba writes, while the model of the donna nuova preserved traditional feminine roles, it also combined the fascist intent to educate women, with all the conditioning force of an antifeminist dictatorship, in their social and national responsibilities:

Infatti oltre al modello "domestico" fu proposto alle donne un altro modello che, conservando ad esse il ruolo tradizionale, le assumeva però anche nella società a fare la loro parte, subordinata e assistenziale. "Il fascismo vuole conservare alla donna la sua naturale missione, ma educarla affinché la compia con consapevole

\footnotetext{
${ }^{409}$ Alexander De Grand, “Women under Italian Fascism”, The Historical Journal, v. 19, no. 4, 1976, p. 947.

${ }^{410}$ Ibid., p. 958.

${ }^{411}$ The term derives from Paola Barronchelli-Grosson who in her book Io e il mio elettore. Propositi $e$ spropositi di una futura deputata (1910) proposed the adoption of the term feminilismo as a "Latin reaction” against Anglo-Saxon feminism. See De Giorgio, Le italiane dall'Unità a oggi, cit., p. 508.

${ }^{412}$ Dittrich-Johansen, Le "militi dell'idea”, cit., p. 110.

${ }^{413}$ Addis Saba, "La donna 'muliebre'”, cit., p. 30.

${ }^{414}$ Ibid., p. 46.
} 
responsabilità nazionale e sociale": questa frase di Starace è una sintesi "mirabile" delle intenzioni della dittatura: conservare alla donna tutti quei doveri imposti come "naturali" espressioni della sua femminilità, ma insieme educarla con tutta la forza di condizionamento di una dittatura antifemminista a compiti nazionali e sociali. ${ }^{415}$

This new type of feminism was "pure" in the sense that it was untarnished by "the intemperate levelling of socialist reformism" or by "the strident individualism of the Anglo-American equal-rights movement”. It was "Latin” because it championed traditional attitudes "peculiar to Italian womanhood", and was "national" in the recognition of "the need to subordinate feminine aspirations to the higher interests of the Italian state and people". ${ }^{416}$ In its underpinnings, therefore, Latin feminism approximated the values promoted by the Catholic Church, even though here the preeminence of women's maternal role was additionally reinforced by the militaristic requirements of the totalitarian state.

Maria Sticco, editor of Fiamma viva, exemplifies the acceptance of fascist gender policies among Catholic women intellectuals. Even as late as 1946, when looking back on the fascist period, she applauds the restoration, by "the Italian political movement", of women's lives on their traditional foundations:

Nel secondo ventennio del Novecento il movimento politico italiano riconduce decisamente la vita femminile sulla via maestra della tradizione, incoraggiando e premiando le famiglie numerose, onorando la maternità ed assegnando alla donna una parte del tutto benefica nella vita pubblica, mediante le opere assistenziali. Negato il voto amministrativo e politico, limitate le carriere professionali, proibiti gli sbandamenti dei vari femminismi di carattere oltremontano, il titolo piú alto riconosciuto alla donna era quello di madre ed il suo compito doveva essere naturalmente e spiritualmente materno. L'educazione femminile riconquistava cosí quell’ideale di famiglia che le utopie socialiste avevano tentato di strapparle; però non ripeteva gli errori del passato in quanto veniva ritemprata da un energico esercizio dei muscoli e della volontà e da una vigile formazione nazionale, cosí che non erano piú di moda in Italia i languori del romanticismo e nemmeno gli atteggiamenti mascolini delle suffragette. La linea nuova rispondeva all'indole della donna nostra, si accordava con l’ideale cristiano e si perfezionava nelle virtú di purezza e carità che la Chiesa raccomanda. ${ }^{417}$

The Catholic women's movements outlasted in significant numbers their secular counterparts. As discussed, Cecilia Dau Novelli attributes the success of the Unione

\footnotetext{
${ }^{415}$ Ibid., p. 34.

${ }^{416}$ De Grazia, How Fascism Ruled Women, cit., p. 236.

${ }^{417}$ Quoted in Franca Pieroni Bortolotti, Socialismo e questione femminile in Italia 1892-1922, 2. edizione, Torino, Gabriele Mazzotta, 1976, p. 17.
} 
donne to its ability to address the social, cultural and religious needs of conservative Catholic women. Catholic associations offered ordinary housewives, for the first time in history, the opportunity to come out of their family circle and to channel their energies into involvement in various causes outside their private domain. In Paola Di Cori's view, the common awareness of their generally unhappy condition caused women to forge links of solidarity, while at the same time the Church manipulated women's sentiments in order to make their minds receptive to discipline and religious orthodoxy. In both cases, it may be argued, belonging to an organization gave women a set of common objectives and their social activities a sense of purpose, whether it meant discussing the education of their children, organizing conferences, or participating in pilgrimages.

While all this is true, the Catholic women's organizations could not have prospered without the symbiotic relationship which existed between them and the ecclesiastical hierarchy. Women had been given the task of re-Christianizing society and of ensuring the permeation of traditional patriarchal values, which saw the family as the basic building block of society and the mother as religious educator of her offspring. The Church and upper- and middle-class women in the Catholic organizations were averse to feminism and were equally opposed to socialism. With shared political interests, these women were content to follow ecclesiastical rulings on gender and political issues.

It was only natural that Catholic women leaders should come from the upper echelons of society. To begin with, a prominent family background enabled women, such as Cristina Giustiniani Bandini, Maddalena Patrizi and Armida Barelli, to gain ready access to the Pope and other high-ranking prelates, and to play a vital part in decisions affecting their organizations. The relations between the women leaders and the clergy were characterized by mutual loyalty, and it is unimaginable that the Catholic women leaders would have been treated with the arrogance meted out to many of the fascist women leaders.

The Catholic leaders would not have been able to build a viable organization, however, had they not been strong personalities in their own right. In the early years, Giustiniani Bandini had to struggle to enforce the primacy of her Unione donne over all Catholic women's organizations; she fought trade unionism to maintain the unity of her organization; and she did not resile from insisting on the independence of the Unione 
donne from the men's organizations. With all the repugnance she felt towards feminism, she herself exhibited feminist characteristics in her persistent battle against the Unione popolare in order to maintain the independence of the Catholic women's movement and to ensure its survival.

The organizational structure based on the principle of accentramento nel decentramento proved judicious. The direct reporting relationship to the Pope ensured that the central organization remained a strong coordinating element, while decentralization meant not encroaching on the authority of local bishops, who retained control over the functioning of diocesan organizations and were able to select local leaders. At every level, of course, doctrinal compliance was guaranteed through ecclesiastical assistants, while in other respects women were left to themselves to run their organizations. The system welcomed different categories of women, including well-to-do single women, who would otherwise have been unemployed but who could now devote their time to the Gioventù femminile or the Unione donne as propagandists or regional delegates.

It was a system, however, which conditioned women and girls to submit unquestioningly to the authority of their leaders and of the ecclesiastical hierarchy. Beyond religious instruction by rote, very little was offered to encourage intellectual exploration or reflection on contemporary society and on one's role in it.

Undeniably, the promotion of women's organizations produced desired outcomes for the Church. It could rely on women to rally behind its social policy objectives, such as religious instruction at schools and indissolubility of marriage. Even more importantly, feminism became "taboo", not only in the Church, but also in society at large so that no emancipationist traits could be discerned in the image of the donna nuova which embodied the fascist ideal of womanhood. 


\section{CONCLUSION}

The analysis of the Catholic women's movements in Liberal and Fascist Italy has centred on six principal areas of enquiry. In the first place, it has aimed to find out how the clash between the patriarchal values underpinning Catholic women's attitudes and demands for equal rights impacted on the development of the Catholic women's movements. As seen, it proved to be the main cause of the split in the early Catholic women's movement, ultimately bringing about the disintegration of the early Catholic feminist movement, femminismo cristiano, followed by the emergence of two conservative women's organizations. Both these organizations crusaded against women's rights, and did so with unforeseen vehemence, virtually eradicating the support, among middle-class Catholic women, for the moderate feminist organization Consiglio nazionale delle donne italiane.

Another major area of enquiry regarded the attitude of the ecclesiastical hierarchy to the Catholic women's movements and sought to ascertain whether it was able or willing to accommodate any degree of feminism. It was discovered that some sections of the clergy not only accepted feminism, but were directly involved in femminismo cristiano. It was shown how the different levels of the clergy played multi-faceted, and at times contradictory, roles in the emergence of the early Catholic feminist movement, in the development of its avant-garde feminist stand, as well as in its dissolution. Femminismo cristiano changed essentially when its nucleus shifted from the tightly controlled ambience of L'Azione muliebre, which enjoyed the full backing of the ecclesiastical hierarchy, to the feminist activism of Pensiero e azione, which quickly lost its approval. Monsignor Giacomo Radini Tedeschi and Don Carlo Grugni were the two ecclesiastics who in particular exemplified these two stages. While both seriously desired to promote the Catholic women's movement, Radini Tedeschi, close to the higher echelons of the clergy and the Catholic laity, saw in woman an adiutorium simile sibi, with the emphasis on adiutorium, whereas Grugni, close to the grassroots of the early Christian democratic movement, placed the emphasis on simile sibi. From the male-dominated feminism of the Bologna congress (1903) the Catholic women's 
movement very rapidly developed into the more radical feminism of the Convegno femminile of Milan (1907), at which women themselves took the lead on issues which concerned women - a stand not endorsed by conservative members of the clergy.

The thesis also endeavoured to explore how Catholic teachings influenced women's own perceptions of themselves, their social roles and their capabilities. It seemed reasonable to assume that Catholic feminists would have full confidence in themselves and in their gender. This was not necessarily the case. Pensiero e azione frequently referred to the complementary nature of the two genders, not to their equality. Notably, in their letter to Giacomo Radini Tedeschi, in 1904, Adelaide Coari and Angiolina Dotti called themselves "noi donne deboli” - hardly a phrase that one would expect feminists to use as a self-description. Such an attitude is less surprising in the case of Armida Barelli who, despite her undisputed organizational skills, rated herself as having "una così evidente incompetenza femminile" in comparison to her male colleagues. An interesting contrast to these women, in the context of the time, was Elisa Salerno who in her Per la riabilitazione della donna expounded that man and woman were fundamentally equal.

A further area of study concerned the social functions which the Church envisaged for women. The starting point of this enquiry was the roles traditionally assigned by the Church to women, that is, those of wife and mother, or woman religious. Some Catholic leaders, Romolo Murri among them, recognized that the demographic changes which Italian society was undergoing called for an extension to women's social and economic roles. For Catholics, the overriding concern regarding women's participation in social activities or in the workforce was the deleterious effect it might have on the family. Double standards were applied to women's employment: while manual labour was condoned out of economic necessity, professional work was perceived as a threat to the patriarchal order. Yet, with an increasing number of unmarried middle-class women seeking outside employment, there was a need to expand the range of acceptable options. Since these women could be regarded as applying their maternal qualities for the benefit of the whole of society, they, too, it was argued, performed a function similar to motherhood. This sanctioned women's leadership roles in the Unione donne, the Gioventù femminile and the various patronati, as well as their employment in a range of middle-level professional positions such as primary and middle-school teaching, nursing and social work. At the same time, however, women were 
discouraged from pursuing careers in top-level positions, let alone occupying ranks superior to those of their male colleagues.

The thesis also examined whether the Catholic women's movements could cater for both women's interests and those of the Catholic hierarchy. Early in the analysis it clearly emerged that no such community of purpose was possible. One must note, however, that in the fascist period the pursuit of any objective even remotely related to women's rights would have been unrealistic because of the certainty of opposition not only by the ecclesiastical hierarchy but also by the fascist regime. As it turned out, with their unprecedented growth and spread, the Unione donne and the Gioventù femminile became successful organizations which did address the social, cultural and religious needs of a wide cross-section of Italian women of all ages. Thus, with their memberships reaching hundreds of thousands, they provided an alternative to government-sponsored fascist women's organizations.

Finally, the question needed to be raised whether the Catholic women leaders were true "protagonists" setting their own agenda or whether they were directed by the clergy. Adelaide Coari started her feminist career hesitatingly, constantly seeking advice from ecclesiastics around her, but soon matured, with Carlo Grugni's support, to stand her ground independently and confidently, earning the respect of secular feminists. In helping to find solutions that would improve the lives especially of working women, Coari and other Catholic women activists developed new strategies, pioneered new social roles, and acquired political skills to assuage conflicts emanating from class and gender issues. The compliant conservative Catholic women's movements, too, were directed by strong women, who demonstrated their leadership credentials. They did not fight for women's rights, but channelled the energies of their members into socially worthwhile activities. Paradoxically, these Catholic women found fulfilment in the implementation of the patriarchal values of the Church, but in the process cast away any claims for gender equality and for true protagonism on women's issues.

Nonetheless, the conservative Catholic women's movements in pre-World War II Italy left an impressive legacy. Maintaining direct links to the Pope and to every other level of the Church hierarchy, Catholic women built strong autonomous organizations. They penetrated every part of Italy and had members from all walks of life, while sustaining 
vigorous publishing and conference programmes. Even with the fascist government's efforts to exclude Catholic women from their customary beneficent activities, they still managed to retain their involvement in some areas of social work. Their organizations succeeded in bringing out myriads of women from the isolation of their homes and in satisfying their social aspirations. They prospered despite the political, social and religious constraints of the period. The confidence Catholic women gained in their capabilities as leaders and members of the Catholic women's movements would stand them in good stead in their struggles in the postwar period. 


\section{BIBLIOGRAPHY}

\section{PRIMARY SOURCES}

\section{CORRESPONDENCE AND MANUSCRIPTS}

(For resolutions of abbreviations, see Abbreviations at the beginning of the thesis.)

$\underline{\text { Maria Baldo }}$

25.09.1900, to Giacomo Radini Tedeschi, FAC 9727, f. 1-3

16.04.1901, to Giacomo Radini Tedeschi, FAC 9727, f. 5-7

02.03.1902, to Giacomo Radini Tedeschi, FAC 9727, f. 24-25

10.10.1903, to Giacomo Radini Tedeschi, FAC 9725, f. 31-33

30.12.1903, to Giacomo Radini Tedeschi, FAC 9726, f. 38-39

30.12.1903, to Adelaide Coari, Cimini, pp.174-176 ${ }^{1}$

22.01.1904, from Giacomo Radini Tedeschi, FAC 9739

17.06.1904, to Giacomo Radini Tedeschi, FAC 9724, f. $42-43$

\section{$\underline{\text { Adelaide Coari }}$}

04.07,1903, to Romolo Murri, ARM

13.12.1903, to Giacomo Radini Tedeschi, FAC 3524

30.12.1903, from Maria Baldo, Cimini, pp.174-176

12.02.1904, to Giacomo Radini Tedeschi, FAC 3525

06.03.1904, to Giacomo Radini Tedeschi, FAC 3528

20.03.1904, from Giacomo Radini Tedeschi, FAC 4673

09.04.1904, from Giacomo Radini Tedeschi, FAC 4674

10.04.1904, from Giacomo Radini Tedeschi, FAC 4675

17. 06.1904,from Giacomo Radini Tedeschi, FAC 9740

19.06.1904, to Giacomo Radini Tedeschi, FAC 3536

28.07.1904, from Giacomo Radini Tedeschi, FAC 4679

31.07.1904, from Giacomo Radini Tedeschi, FAC 4681

31.07.1904, to Giacomo Radini Tedeschi, FAC 3531

01.08.1904, to Giacomo Radini Tedeschi, FAC 3532

03.08.1904, from Giacomo Radini Tedeschi, FAC 4682

19.09.1904, from Giacomo Radini Tedeschi, FAC 4683

1904, with Angiolina Dotti to Giacomo Radini Tedeschi, FAC 3520

14.11.1905, from Elisa Salerno, FES 2

15.10.1906, from Elisa Salerno, FES 5

18.11.1906, from Elisa Salerno, FES 7

19.12.1906, from Sabina Parravicino di Revel, FAC 5206

25.09.1907, from Elisa Salerno, FES 8

11.12.1907, from Giacomo Radini Tedeschi, FAC 9732

1 “Cimini” refers to Antonietta Cimini, “Adelaide Coari e il movimento femminile cattolico”, Studia Picena, v. 43, 1975, pp. 132-200. 
16.01.1908, from Maria Roesler Franz, FAC 5216

16.05.1908, from Giacomo Radini Tedeschi, FAC 9733

29.07.1908, from Giuseppe Toniolo, Toniolo, ${ }^{2}$ pp. 165-168

05.08.1908, to Giuseppe Toniolo, FAC

12.1908, from Elisa Salerno, FES 17

06.04.1909, from Giacomo Radini Tedeschi, FAC 3488

\section{Giacomo Radini Tedeschi}

25.09.1900, from Maria Baldo, FAC 9727, f. 1-3

16.04.1901, from Maria Baldo, FAC 9727, f. 5-7

02.03.1902, from Maria Baldo, FAC 9727, f. 24-25

10.10.1903, from Maria Baldo, FAC 9725, f. 31-33

13.12.1903, from Adelaide Coari, FAC 3524

30.12.1903, from Maria Baldo, FAC 9726, f. 38-39

22.01.1904, to Maria Baldo, FAC 9739

12.02.1904, from Adelaide Coari, FAC 3525

06.03.1904, from Adelaide Coari, FAC 3528

20.03.1904, to Adelaide Coari, FAC 4673

09.04.1904, to Adelaide Coari, FAC 4674

10.04.1904, to Adelaide Coari, FAC 4675

17.06.1904, to Adelaide Coari, FAC 9740

17.06.1904, from Maria Baldo, FAC 9724, f. 42-43

19.06.1904, from Adelaide Coari, FAC 3536

28.07.1904, to Adelaide Coari, FAC 4679

31.07.1904, to Adelaide Coari, FAC 4681

31.07.1904, from Adelaide Coari, FAC 3531

01.08.1904, from Adelaide Coari, FAC 3532

03.08.1904, to Adelaide Coari, FAC 4682

19.09.1904, to Adelaide Coari, AC 4683

1904, from Adelaide Coari and Angiolina Dotti, FAC 3520

27.05.1907, to the Presidenza del Convegno femminile, FAC 3485

11.12.1907, to Adelaide Coari, FAC 9732

16.05.1908, to Adelaide Coari, FAC 9733

06.04.1909, to Adelaide Coari, FAC 3488

\section{Giuseppe (and Maria) Toniolo}

21.11.1906, to Elisa Salerno, Toniolo, pp. 90-91

07.05.1908, to Elisa Salerno, Toniolo, pp. 152-154

13.05.1908, to Elisa Salerno, Toniolo, pp. 157-158

15.05.1908, from Elisa Salerno, FES, Carteggio Toniolo f. 12

18.05. 1908, from Elisa Salerno, FES

29.07.1908, to Adelaide Coari, Toniolo, pp. 165-168

29.07.1908, to Cristina Giustiniani Bandini, Toniolo, pp. 168-170

05.08.1908, from Adelaide Coari, FAC

11.08.1908, from Cristina Giustiniani Bandini, Gaiotti, ${ }^{3}$ pp. 245-246

2 “Toniolo" refers to Toniolo, Giuseppe, Lettere III 1904-1918, raccolte da Guido Anichini, ordinate e annotate da Nello Vian, Città del Vaticano, Comitato Opera omnia di G. Toniolo, 1953. 
19.08.1908, to Cristina Giustiniani Bandini, Toniolo, pp. 175-177

31.08.1908, from Cristina Giustiniani Bandini, Gaiotti, pp. 246-248

27.10.1908, from Cristinia Giustiniani Banidi, Gaiotti, pp. 248-249

07.12.1908, from Cristina Giustiniani Bandini, Gaiotti, pp. 249-251

23.12.1908, (Maria Toniolo) to Cristina Giustiniani Bandini, Passoni, ${ }^{4}$ p. 121

24.12.1908, from Cristina Giustiniani Bandini, Gaiotti, pp. 251-252

26.12.1908, from R. Merry del Val, $\mathrm{LAM}^{5}$

11.01.1909, from Cristina Giustiniani Bandini, Gaiotti, pp. 255-256

13.01.1909, from Elisa Salerno, UPI, ${ }^{6}$ pp. 181-182

Jan.-Feb. 1909, from Elisa Salerno, FES, Carteggio Toniolo f. 20

20.02.1909, from Cristina Giustiniani Bandini (Maria Toniolo), Gaiotti, pp. 260-261

25.02.1909, from Cristina Giustiniani Bandini (Maria Toniolo), Gaiotti, pp. 261-263

15.04.1909, from Elisa Salerno, FES, Carteggio Toniolo f. 22

1a Quaresima 1913, to Ferdinando Rodolfi, ACV, Carte Rodolfi

Draft regulations for the organization of L'Azione muliebre

no date, Maria Baldo, “Funzioni ed obblighi particolari”, FAC 1113

no date, Adelaide Coari, "Regolamento interno del Consiglio dell’Azione muliebre", FAC 1113

14.06.1904, Elena da Persico, “Osservazioni sul regolamento proposto dalla Sig. Coari per il giornale 'L’Azione muliebre’”, FAC 1108

no date, Francesco Mariani, [Memorandum], FAC 1111

\section{$\underline{\text { Elisa Salerno }}$}

\subsubsection{5, to Adelaide Coari, FES 2}

1905, to Elena da Persico, AEP 5474

15.10.1906, to Antonio Salerno, UPI, pp. 159-160

15.10.1906, to Adelaide Coari, FES 5

18.11.1906, to Adelaide Coari, FES 7

21.11.1906, from Giuseppe Toniolo, Toniolo, pp. 90-91

End 1906, to Elena da Persico, AEP 5475

25.09.1907, to Adelaide Coari, FES 8

07.05.1908, from Giuseppe Toniolo, Toniolo, pp. 152-154

13.05.1908, from Giuseppe Toniolo, Toniolo, pp. 157-158

15.05.1908, to Giuseppe Toniolo, FES, Carteggio Toniolo f. 12

18.05.1908, to Giuseppe Toniolo, FES

12.1908, to Adelaide Coari, FES 17

13.01.1909, to Giuseppe Toniolo, UPI, pp. 181-182

Jan.-Febr. 1909, to Giuseppe Toniolo, FES, Carteggio Toniolo f. 20

15.04.1909, to Giuseppe Toniolo, FES, Carteggio Toniolo f. 22

01.03.1910, to Elena da Persico, AEP 5754

\footnotetext{
3 “Gaiotti” refers to Paola Gaiotti de Biase, "La nascita dell’organizzazione cattolica femminile nelle lettere di Cristina Giustiniani Bandini al Toniolo”, Ricerche per la storia religiosa di Roma, v. 2, 1978, pp. 225-271.

4 "Passoni” refers to Adolfo Passoni, Elena da Persico, Roma, A.V.E., 1991.

5 “LAM” refers to “Ill.mo Sig. Presidente”, L'Azione muliebre, a. IX, fasc. 2, febbraio 1909, pp. 72-73.

6 "UPI” refers to Centro documentazione e studi "Presenza Donna”, Una penna inquieta. Lettere scelte di Elisa Salerno, Padova, Edizioni Messaggero, 2002.
} 
11.03.1910, to Antonio Fogazzaro, BCB, Busta E Salerno 1b

10.05.1910, to Elena da Persico, AEP 5764

26.09.1910, from Cristina Giustiniani Bandini, FES 39

25.02.1911, to Ferdinando Rodolfi, UPI, pp. 266-267

05.03.1911, to Ferdinando Rodolfi, UPI, pp. 191-192

24.10.1911, from Cristina Giustiniani Bandini, FES 50

05.12.1913, to Ferdinando Rodolfi, UPI, pp. 204-206

01.02.1914, to Ferdinando Rodolfi, UPI, pp. 270-273

29.06.1914, to Ferdinando Rodolfi, UPI, pp. 217-220

11.07.1914, to Giuseppe Stocchiero, UPI, p. 221-221

10.07.1914, to Ferdinando Rodolfi, UPI, pp. 222-225

08.08.1914, to Ferdinando Rodolfi, ACV, Busta E. Salerno

14.09.1914, to Benedict XV, UPI, pp. 232-235

14.03.1917, from Elena da Persico, FES

18.09.1917, to Benedict XV, UPI, pp. 85-86

11.05.1918, to Ferdinando Rodolfi, UPI, 245-247

03.06.1918, to Ferdinando Rodolfi, UPI, 247-248

26.03.1919, to Vittorio Emanuele Orlando, UPI, pp. 273-276

09.09.1919, to Maddalena Patrizi Gondi, UPI, pp. 86-88

22.09.1919, to Francesco Saverio Nitti, UPI, pp. 276-277

16.02.1922, to Pius XI, UPI, pp. 278-280

24.11.1922, to Benito Mussolini, UPI, pp. 280-282

16.05.1924, to Benito Mussolini, UPI, pp. 282-283

25.04.1925, to Ferdinando Rodolfi, Nata troppo presto, ${ }^{7}$ pp. 12-13

02.06.1925, to Tommaso Tittoni, UPI, pp. 283-284

19.02.1926, to Benito Mussolini, FES L n 31

17.06.1926, to A. D’Alessandro, UPI, pp. 251-252

09.10.1926, to Comm. Cavalieri, FES L n 38

19.10.1926, to Podestà Lucciardi, FES L n 39

15.11.1926, to Benito Mussolini, UPI, pp. 252-256

16.12.1926, to Benito Mussolini, FES 47

20.12.1926, to the Direzione del Sindacato fascista dei giornalisti veneti, UPI, pp. 258-259

24.03.1927, to the On. Sottosegretario di Stato, FES L n 55

18.05.1944, to Giuseppe Arena, UPI, pp. 29-34

no date, to Maddalena Patrizi Gondi, FES 4

\section{Ferdinando Rodolfi}

25.02.1911, from Elisa Salerno, UPI, pp. 266-267

05.03.1911, from Elisa Salerno, UPI, pp. 191-192

25.03.1913, from Giacomo Dalla Vecchia, ACV, Busta E. Salerno

1a Quaresima 1913, from Giuseppe Toniolo, ACV, Carte Rodolfi

05.12.1913, from Elisa Salerno, UPI, pp. 204-206

01.02.1914, from Elisa Salerno, UPI, pp. 270-273

29.06.1914, from Elisa Salerno, UPI, pp. 217-220

10.07,1914, from Elisa Salerno, UPI, pp. 222-225

08.08.1914, from Elisa Salerno, ACV, Busta E. Salerno

\footnotetext{
7 “Nata troppo presto" refers to Centro documentazione e studi "Presenza Donna”, Nata troppo presto/Elisa Salerno, Pro muliere, Vicenza, 2007.
} 
29.11.1915, from Giacomo Dalla Vecchia, ACV, Busta E. Salerno

17.05.1917, from Bishop of Treviso, ACV, Busta E. Salerno

17.06.1917, from Elena da Persico, FES

15.07.1917, to Benedict XV, ACV, Busta E. Salerno

11. 05.1918, from Elisa Salerno, UPI, pp. 245-247

03.06.1918, from Elisa Salerno, UPI, pp. 247-248

25.04.1925, from Elisa Salerno, Nata troppo presto, pp. 12-13

\section{Cristina Giustiniani Bandini}

March 1907, Letter for publication in L'Azione muliebre, AGOP XIV.950 GIB.1

28.04.1908, "Protesta delle donne romane contro il voto per l'abolizione dell'insegnamento religioso nelle scuole primarie approvato a Roma dal Congresso delle donne italiane il giorno 28 aprile 1908”, AGOP XIV.950 GIB.25

29.06.1908, "Circolo femminile di attività e di cultura cattolica", AGOP XIV.950 GIB.1

29.07.1908, from Giuseppe Toniolo, Toniolo, pp. 168-170

11.08.1908, to Giuseppe Toniolo, Gaiotti, pp. 245-246

19.08.1908, from Giuseppe Toniolo, Toniolo, pp. 175-177

31.08.1908, to Giuseppe Toniolo, Gaiotti, pp. 246-248

27.10.1908, to Giuseppe Toniolo, Gaiotti, pp. pp. 248-249

07.12.1908, to Giuseppe Toniolo, Gaiotti, pp. 249-251

23.12.1908 from Maria Toniolo, Passoni, p. 121

24.12.1908, to Giuseppe Toniolo, Gaiotti, pp. 251-252

11.01.1909, to Giuseppe Toniolo, Gaiotti, pp. 255-256

20.02.1909, to Maria Toniolo, Gaiotti, pp 260-261

25.02.1909, to Maria Toniolo, Gaiotti, pp. 261-263

26.09.1910, postcard to Elisa Salerno, FES 39

24.10.1911, postcard to Elisa Salerno, FES 50

8.-11.1913, "In memoria di Pio X", for publication in Azione femminile cattolica, Aug.-Nov. 1913, AGOP XIV.950 GIB.53

20.01.1914, to Pius X, AGOP XIV.950 GIB.36

24.01.1914, to Pius X, AGOP XIV.950 GIB.36

15.04.1914, from Sabina Parravicino di Revel, AGOP IV.950 GIB.109

06.09.1914, "Pro memoria inviato il 6 settembre 1914", AGOP XIV 950 GIB.36

09.10.1914, "Pro memoria presentato a S.S. Benedetto XV il 9 ottobre 1914", AGOP XIV 950 GIB.36

04.12.1914, "Dopo il Convegno di Genova. Pro memoria inviato il 4 dicembre 1914 a S.S. Benedetto XV”, AGOP XIV.950 GIB.36

1914, "Lettera accompagnativa della domanda del comunicato", AGOP XIV.950 GIB.36

25.03.1915, L’Ufficio centrale di Presidenza dell’U.D.C.I. to Benedict XV, AGOP XIV.950 GIB.36

no date, Letter to Elisa Salerno (draft), AGOP XIV.950 GIB.53

no date, A Sua Santità Benedetto XV dopo la sua elezione settembre 1914 per rassegnare la mia carica di Presidente generale dell Unione fra le donne cattoliche d'Italia”, AGOP XIV.950 GIB.36

no date, “Alcuni appunti sulla storia della nostra 'Unione’ 1907-1917”, AGOP XIV.950 GIB.1

no date, "Beatissimo Padre”, AGOP XIV.950 GIB.36 
no date, “Circolare per comunicare agli Ordinari d'Italia la costituzione definitiva del Comitato Centrale”, AGOP XIV.950 GIB.36

no date, "Lettera di Donna Giustiniani Bandini a S.S. Benedetto XV per dare le dimissioni da Presidente generale dell’U.D.C.I.”, AGOP XIV.950 GIB.36

no date, "Pagine di storia dell’Azione cattolica italiana”, AGOP XIV.950 GIB.3

\section{PUBLISHED PRIMARY WORKS}

Aleramo, Sibilla, La donna, $48^{\text {th }}$ ed., Milano, Feltrinelli, 2005. Originally published in 1906.

Almanacco della Lega democratica nazionale per l'anno 1907, Firenze, Società editrice "La giustizia sociale", 1907.

Almanacco democratico cristiano, Firenze, Azienda giornalistica fiorentina, 1905.

Almanacco-manuale democratico cristiano. Anno III 1902, Roma, Società italiana cattolica di cultura, 1902.

“Amor di patria”, in Consiglio superiore della Gioventù femminile di A.C.I., Le pietre miliari. Relazione e statistica della Gioventù femminile di Azione cattolica 1934-1936, Milano, 1937, p. 31.

Atti del Convegno femminile, Milano, 25-26-27-28 aprile 1907, Milano, “La Benefica”, 1907.

Atti del primo Congresso cattolico italiano tenutosi in Venezia dal 12 al 16 giugno 1874, Bologna, Tipografia Felsinea, 1874.

Atti del XIX congresso cattolico italiano, Bologna, 10, 11, 12, 13 novembre 1903, Ferrara, Stab. Tip. S. Giorgio, 1903.

Atti del I Congresso nazionale delle donne italiane, Roma, 24-30 aprile 1908, Roma, Stabilimento Tipografico della Società Editrice Laziale, 1912.

Barelli, Armida, La sorella maggiore racconta. Storia della GF dal 1918 al 1948, Milano Edizione O.R., 1981.

, Tra sorelle. Istruzioni, direttive e doveri delle presidenti dei circoli della G.F.C.I., Milano, Gioventù femminile cattolica italiana, 1931.

Baronchelli Grosson, Paola, La donna della nuova Italia, Milano, Stabilimento G. Giussani, 1917.

Brezzi, Camillo (a cura di), "Carteggio Giacomelli-Sabatier, in Centro studi per la storia del modernismo, Fonti e documenti, 2, Urbino, Istituto di storia dell’Università di Urbino, 1973, pp 296-473. 
Camera dei deputati, Discorso del deputato Villari sulle relazioni dello Stato colla Chiesa pronunciato nella seduta del 6 maggio 1975, Roma, 1875, pp. 10-13. Reprinted in Storia d'Italia, Volume quarto: Dall'Unità a oggi, 3, Torino, Giulio Einaudi, 1976, pp. 1711-1712.

Canuti, Giovanna, Cinquant'anni di vita dell'Unione donne di A.C.I., Roma, S.A.L.E.S., 1959.

Cecchini, Francesco Maria (a cura di), Il femminismo cristiano. La questione femminile nella prima democrazia cristiana 1898-1912, Roma, Editori Riuniti, 1979.

Coari, Adelaide, Ho cercato la sua scuola, Brescia, “La Scuola”, 1962.

Nicolò Tommaseo, con prefazione di Antonio Fogazzaro, Milano, Libreria Editrice Milanese, 1909.

Consiglio superiore della Gioventù femminile cattolica italiana, Relazione e statistica della Gioventù femminile cattolica italiana. Triennio 1922-1925, Milano, Vita e Pensiero, n. d.

Consiglio superiore della Gioventù femminile di A.C.I., Le pietre miliari. Relazione e statistica della Gioventù femminile di Azione cattolica 1934-1936, Milano, 1937.

Consiglio superiore Unione donne di Azione cattolica italiana, Magnificat. Ricordi di vita. Ideali di azione. Iniziative, Roma, 1934.

"Dalla guerra al dopoguerra", in Consiglio superiore Unione donne di Azione cattolica italiana, Magnificat. Ricordi di vita. Ideali di azione. Iniziative, Roma, 1934, pp. 51-53.

Donaldoni, Leone, Femminismo cristiano? Risposta documentata del Dott. Leone Donaldoni a proposito del Convegno femminile tenutosi in Milano nei giorni 22-28 aprile 1907, Milano, 1907.

Engels, Frederick, The Origin of the Family, Private Property and the State, New York, International Publishers, 1972. Originally published in 1884.

Gaiotti de Biase, Paola (a cura di), I cattolici e il voto alle donne, Torino, Società Editrice Internazionale, 1996. Various documents published between 1901 and 1946.

Gentile, Giovanni, La donna e il fanciullo, Firenze, G.C. Sansoni, 1934.

Giustiniani Bandini, Maria Cristina, Il beato Pio X e l'associazione cattolica femminile, Roma, 1951.

"In cammino", in Consiglio superiore Unione donne di Azione cattolica italiana, Magnificat. Ricordi di vita. Ideali di azione. Iniziative, Roma, 1934, pp. 21-23.

"Fortes in fide", in Consiglio superiore Unione donne di Azione cattolica italiana, Magnificat. Ricordi di vita. Ideali di azione. Iniziative, Roma, Consiglio superiore Unione donne di Azione cattolica italiana, 1934, pp. 9-10. 
Può una donna cattolica in Italia appartenere al movimento femminista?, n.p., n.d., AGOP XIV GIB.53.

Grugni, Carlo, “Organizzazione femminile”, in Opera dei congressi e dei comitati cattolici in Italia, Atti del XIX congresso cattolico italiano, Bologna 10, 11, 12, 13 novembre 1903, Ferrara, Stab. Tip. S. Giorgio, 1903, pp. 25-29.

"I gruppi di parrocchialità”, in Consiglio superiore Unione donne di Azione cattolica italiana, Magnificat. Ricordi di vita. Ideali di azione. Iniziative, Roma, 1934, pp. 56-57.

Locke, John, “Second Treatise”, in Two Treatises of Government, ed. with introd. by P. Laslett, Cambridge, Cambridge University Press, 1967, pp. 283-446.

Mazzini, Giuseppe, Dei doveri dell'uomo/Fede e avvenire, a cura di Paolo Rossi, 2. edizione, Milano, Mursia, 1972. Dei doveri dell'uomo originally published in 1860.

Mill, John Stuart, “The Subjection of Women”, in Three Essays, Oxford, Oxford University Press, 1978. Originally published in 1869.

Morelli, Salvatore, La donna e la scienza considerate come soli mezzi atti a risolvere il problema dell'avvenire, Napoli, Stab. Tip. delle Belle Arti, 1861.

Mozzoni, Anna Maria, La donna e i suoi rapporti sociali, Milano, Tipografia Sociale, 1864.

Reprinted in Anna Maria Mozzoni, La liberazione della donna, a cura di Franca Pieroni Bortolotti, Milano, Gabriele Mazzotta, 1975, pp. 33-90.

, La donna in faccia al progetto del nuovo codice civile italiano, Milano, Tipografia Sociale, 1865. Reprinted in Anna Maria Mozzoni, La liberazione della donna, a cura di Franca Pieroni Bortolotti, Milano, Gabriele Mazzotta, 1975, pp. 91-99.

, La liberazione della donna, a cura di Franca Pieroni Bortolotti, Milano, Gabriele Mazzotta, 1975.

Murri, Romolo, "Proletariato femminile cristiano", in Francesco Maria Cecchini (a cura di), Il femminismo cristiano. La questione femminile nella prima democrazia cristiana 1898-1912, Roma, Editori Riuniti, 1979, pp. 99-101.

“La nostra unione nella vita odierna”, in Consiglio superiore Unione donne di Azione cattolica italiana, Magnificat. Ricordi di vita. Ideali di azione. Iniziative, Roma, 1934, pp. 106-107.

"Propaganda e aiuti alle Terre redente", in Consiglio superiore Unione donne di Azione cattolica italiana, Magnificat. Ricordi di vita. Ideali di azione. Iniziative, Roma, 1934, pp. 52-53.

Radini Tedeschi, Giacomo, Opera dei congressi e comitati cattolici in Italia. Sezione femminile. Documenti, Roma, Tipografia degli Artigianelli di S. Giuseppe, 1903.

"Ricordi di un circolo universitario”, in Consiglio superiore Unione donne di Azione cattolica italiana, Magnificat. Ricordi di vita. Ideali di azione. Iniziative, Roma, 1934, pp. 27-29. 
Salerno, Elisa, Al bivio / Centro documentazione e studi "Presenza Donna”, Elisa Salerno oltre il bivio: tra giornalismo e romanzo. Atti del Convegno di studi, Vicenza, 12 aprile 1997, Vicenza, 1998, pp. 11-121. Al bivio was originally published 1921.

Pastorio, 1917.

Per la riabilitazione della donna, Vicenza, Tip. Editrice Ditta Fratelli

, Per la riabilitazione della donna / Centro documentazione e studi "Presenza Donna”, Donne e Chiesa. Atti del convegno, Vicenza, 29 ottobre 2005, Vicenza, 2006, pp. 73-102.

Pro muliere. Programma di studio e azione / Centro documentazione e studi "Presenza Donna”, Nata troppo presto. Omaggio ad Elisa Salerno nel $50^{\circ}$ anno dalla morte, Vicenza, 2007, pp. 73-102. Pro muliere was originally published in 1921.

Salerno, Elisa (pseud. Lucilla Ardens), Un piccolo mondo cattolico, a cura di Stefania Fiocchi, Mirano (Venezia), Eidos, 1996. Originally published in 1908.

Salerno, Elisa (pseud. Maria Pasini), La donna in san Paolo apostolo, Vicenza, Centro documentazione e studi “Presenza Donna”, 2009. Originally published in 1952.

"Porrò inimicizia fra te e la donna" / Centro documentazione e studi "Presenza Donna”, Comunicazione alle frontiere della profezia, Vicenza, Centro documentazione e studi "Presenza Donna” e Azione cattolica vicentina, 2004, pp. 4560. Originally published in 1954.

Stocchiero, Giuseppe, Pratica pastorale, 5. edizione, Vicenza, Società anonima tipografica, 1936.

Turati, Filippo e Kuliscioff, Anna, Carteggio II: 1900-1909, v. 1, raccolto da Alessandro Schiavi, a cura di Franco Pedone, Torino, Giulio Einaudi, 1977.

Wollstonecraft, Mary, A Vindication of the Rights of Woman, ed. with an introd. by Miriam Brody, London, Penguin, 1992. Originally published in 1792.

Zetkin, Clara, “Lenin on the Woman Question”, from My Memorandum Book (1920). http://www.marxists.org/archive/zetkin/1920/lenin/zetkin1.htm (27/04/2008) 


\section{PERIODICAL AND NEWSPAPER ARTICLES}

\section{L’Azione muliebre}

“A proposito di elettorato femminile”, L'Azione muliebre, a. XIX, n. 3, 15 marzo 1919, pp. 138-154; a. XIX, n. 4, 15 aprile 1919, pp. 202-207.

"L’allocuzione del Papa contro il divorzio", L'Azione muliebre, a. II, n. 1, gennaio 1902, pp. 40-41.

“Antonietta”, “L’enciclica sulla Democrazia cristiana”, L'Azione muliebre, a. I, n. 3, marzo 1901, pp. 13-18.

Anzoletti, Luisa, “Conferenza sul divorzio”, L’Azione muliebre, a. II, n. 2, febbraio 1902, pp. 140-162.

Baldo, Maria (pseud. Costanza), ”Il congresso cattolico di Bologna”, L'Azione muliebre, a. III, fasc. 11-12, novembre-dicembre 1903, pp. 258-264.

1901, pp. 4-12.

" “Il socialismo e la morale cristiana”, L'Azione muliebre, a. I, n. 8, agosto

“Buona tenuta della casa”, L’Azione muliebre, a. II, n. 2, febbraio 1902, pp. 134-135.

“Il convegno femminile d'aprile”, L'Azione muliebre, a. VII, fasc. 3, marzo 1907, p. 173.

“Dal discorso di S.E. Mussolini all'inaugurazione del Congresso dell’Alleanza internazionale per il suffragio”, L'Azione muliebre, a. XXIII, n. 6, giugno 1923, pp. 374-375.

“Divorzio”, L’Azione muliebre, a. I, n. 12, dicembre 1901, pp. 7-12.

"La donna e il canto in chiesa”, L'Azione muliebre, a. IV, fasc. 2, febbraio 1904, pp. 8788.

“Due parole della direzione del periodico”, L'Azione muliebre, a. IV, fasc. 9, settembre 1904, pp. 517-518.

“Le donne italiane contro il dovorzio”, L’Azione muliebre, a. I, n. 12, dicembre 1901, pp. 12-13.

“E le donne?”, L’Azione muliebre, a. V, fasc. 11, novembre 1905, pp. 669-677.

Mariani, Francesco M., “Commento”, L’Azione muliebre, a. III, fasc. 10, Ottobre 1903, pp. 175-184.

Merry del Val, R. "Per l'Azione cattolica in Italia. Circolare ai Rev. Ordinari”, L'Azione muliebre, a. IV., fasc. 9, settembre 1904, pp. 513-517. 
Minoretti, D., “Femminismo e femminismo. Le donne avvocatesse”, L 'Azione muliebre, a. IV, fasc. 4, aprile 1904, pp. 195-200.

“Movimento femminile in Italia”, L'Azione muliebre, a. IV, fasc. 7, luglio 1904, pp. 432-436.

“Movimento muliebre”, L’Azione muliebre, a. I., n. 1, gennaio 1901, pp. 49-50.

“La nostra bandiera e le nostre speranze”, L'Azione muliebre, a. III, n. 1, gennaio 1903, pp. 1-8.

“Notizie varie. Per lo statuto”, L'Azione muliebre, a. IV, fasc. 2, febbraio 1904, pp. 120 121.

“Quindici maggio”, L’Azione muliebre, a. V, fasc. 5, maggio 1905, pp. 292-299.

Radini Tedeschi, G., "Sezione femminile dell’Opera dei congressi in Italia”, L'Azione muliebre, a. III, n. 11-12, novembre-dicembre 1903, pp. 271-273.

"Relazione delle discussioni più salienti durante il Congresso femminile nazionale”, L’Azione muliebre, aprile 1907, Supplemento.

“Risposta al supplemento del Pensiero ed azione”, L'Azione muliebre, a. VII, fasc. 6, giugno 1907, pp. 321-322.

Salerno, Elisa, “Conferenze alle Figlie di Maria”, L 'Azione muliebre, a. VI, fasc. 1, gennaio 1906, pp. 53-56.

“La sottoscrizione - protesta delle donne italiane contro il divorzio”, L'Azione muliebre, a. II, n. 1, gennaio 1902, pp. 41-44.

“Statuto della Unione fra le donne cattoliche d'Italia”, L 'Azione muliebre, a. IX, fasc. 2, febbraio 1909, pp. 69-72.

“Suffragio femminile?”, L’Azione muliebre, a. XII, n. 6, giugno 1912, pp. 401-410.

Toniolo, G., “Alle donne cattoliche d'Italia”, L'Azione muliebre, a. IX, fasc. 1, gennaio 1909, pp. 7-8.

Van des Plas, Luigia, “Nel Belgio”, L’Azione muliebre, a. II, n. 3, marzo 1902, pp. 213219.

“Venti minuti ai piedi del S. Padre”, L'Azione muliebre, a. VI, fasc. 6, giugno 1906, p. 321-324.

“Il voto alla donna”, L'Azione muliebre, a. XIX, n. 6, 15 giugno 1919, pp. 305-313.

\section{$\underline{\text { Pensiero e azione }}$}

“Alcuni nostri principi”, Pensiero e azione, a. III, n. 5-6, 13 aprile 1907, pp. 2-5. 
“Comunicato”, Pensiero e azione, a. 4, nos 9-10, 10-25 maggio 1908, p. 19.

Coari, Adelaide, “Alcune proposte”, Pensiero e azione, a. IV, n. 11-12, 10-25 giugno 1908, pp. 6-8.

1907, pp. 3-4.

“In cammino. Rubriche della rivista”, Pensiero e azione, a. III, n. 1, 5 gennaio

“Conclusioni e polemiche”, Pensiero e azione, a. III, n. 11, 25 giugno 1907, p. 2.

“Congresso femminile”, Pensiero e azione, a. IV, n. 11-12, 10-25 giugno 1908, pp. 1723.

“Il congresso femminile di Roma”, Pensiero e azione, a. IV, n. 9-10, 10-25 maggio 1908, pp. 2-19.

“Convegno femminile”, Pensiero e azione, a. I, n. 8, 5 aprile 1905, pp. 4-7.

“Federazione femminile”, Pensiero e azione, a. III, n. 5-6, 13 aprile 1907, p. 8.

“Federazione femminile”, Pensiero e azione, a. III, n. 9, 18 maggio 1907, pp. 5-6.

“Federazione femminile”, Pensiero e azione, a. IV, 11-12, 10-25 giugno 1908, pp 8-9.

Ferrari, Andrea Carlo, [Benedizione], Pensiero e azione, a. I, n. 1, 8 dicembre 1904, p. 3.

Grugni, Carlo, “Federazione femminile”, Pensiero e azione, a. I, n. 7, 20 marzo 1905, pp. 3-4. 1905, pp. 8-9.

"Lavoro. Patronato femminile", Pensiero e azione, a. I, n. 5, 20 febbraio

pp. 7-8.

“Lavoro. Patronato femminile”, Pensiero e azione, a. I, n. 6, 4 marzo 1905,

— “Il trionfo”, Pensiero e azione, a. III, n. 8, 11 maggio 1907, p. 6.

“Impressioni”, Pensiero e azione, a. I, n. 8, 5 aprile 1905, pp. 3-4.

“Nella vita e fra i giornali [Annuncio dell'Inchiesta sul femminismo ne Cultura sociale], Pensiero e azione, a. I, n. 4, 5 febbraio 1905, p. 16.

“Nella vita e fra i giornali. Un'inchiesta sul femminismo”, Pensiero e azione, a. I, n. 5, 20 febbraio 1905, pp. 14-15.

“Nella vita e fra i giornali. Per una rivista che scompare”, Pensiero e azione, a. II, n. 12, 5 giugno 1906, p. 12.

“L’organizzazione femminile”, Pensiero e azione, a. I, n. 13, 20 giugno 1905, pp. 5-6.

“Orizzonti nuovi”, Pensiero e azione, a. I, n. 5, 20 febbraio 1905, pp. 3-5. 
“La pagina del Fascio. Studio - azione - propaganda”, Pensiero e azione, a. I, n. 1, 8 dicembre 1904, p. 2.

“Patronato femminile”, Pensiero e azione, a. I, n. 12, 5 giugno 1905, pp. 5-6.

“'Per la verita.' Correzioni ed aggiunte necessarie agli opuscoli del Prof. Leone Donaldoni e della Contessa da Persico”, Pensiero e azione, Supplemento al n. 9 [18 maggio 1907].

“Per le tessitrici”, Pensiero e azione, a. III, n. 11, 25 giugno 1907, Le pagine dell'operaia, p. 2.

“Per l'inchiesta sul femminismo”, Pensiero e azione, a. I, n. 10, 5 maggio 1905, pp. 910.

“Per l’Unione popolare”, Pensiero e azione, a. III, n. 2, 21 gennaio 1907, p. 7.

“Il programma minimo femminista”, Pensiero e azione, a. II, n. 2, 5 gennaio 1906, pp. 2-3.

“La questione fondamentale”, Pensiero e azione, a. III, n. 15, 5 novembre 1907, pp. 23.

Restori, Vasco, “Una lettera del II Gruppo”, Pensiero e azione, a. I, n. 8, 5 aprile 1905, pp. 7-8.

“Risposte delle operaie”, Pensiero e azione, a. III, n. 12, luglio 1907, Le pagine dell'operaia, p. 2.

“Rivendicazioni femminili”, Pensiero e azione, a. II, n. 4, 15 febbraio 1906, pp. 3-5.

Salerno, Elisa, “Il femminismo e la settimana sociale”, Pensiero e azione, a. III, n. 14, 26 ottobre 1907, pp. 5-6.

[Saluto alle donne di Roma], Pensiero e azione, a. IV, n. 8, 25 aprile 1908, p. 2.

“Il suffragio universale”, Pensiero e azione, a. I, n. 23, 20 novembre 1905, pp. 2-3.

Toniolo, G., [Approvazione], Pensiero e azione, a. I, n. 1, 8 dicembre 1904, p. 3.

“Il voto alla donna”, Pensiero e azione, a. I, n. 16, 5 agosto 1905, pp. 2-3.

“Il voto alla donna”, Pensiero e azione, a. I, n. 17, 21 agosto 1905, pp. 5-7.

“Il voto alla donna”, Pensiero e azione, a. II, n. 6, 5 marzo 1906, pp. 9-10.

“Il voto alla donna”, Pensiero e azione, a. II. n. 12, 5 giugno 1906, pp. 10-12.

Zaimi, Rita, “Il santo”, Pensiero e azione, a. I, n. 23, 20 novembre 1905, pp. 11-13. 


\section{La Donna (Bologna)}

G.A.B. [Gualberta Alaide Beccari], "Lega promotrice degli interessi femminili”, La Donna, a. XII, serie II, n. 16, 5 febbraio 1881, pp. 241-243.

\section{La Donna del popolo / La Donna (Milano)}

[Testata], La Donna del popolo, a. I, n. 2, 26 gennaio 1901, p. 1.

“Alle donne cattoliche”, La Donna, a. II, n. 3, 18 gennaio 1902, p. 1.

\section{$\underline{\text { L’Unità cattolica }}$}

Cavallanti, S.A., “A Milano: convegno modernista”, L’Unità cattolica, v. XLV, n. 102, 4 maggio 1907, p. 1. "Modernismo femminile. I centri di propaganda”, L'Unità cattolica, a. XLV, n. 56, 8 marzo 1907, p. 1. “Modernismo femminile. Il prossimo convegno”, L’Unità cattolica, a. XLV, n. 57, 9 marzo 1907, p. 1.

“È tempo di parlar chiaro: 'Parola fraterna””, L’Unità cattolica, XLVI, n. 105, 13 maggio 1908, p. 1.

“Il primo congresso femminile italiano”, L’Unità cattolica, a. XLVI, n. 96, 1 maggio 1908, p. 1.

\section{$\underline{\text { Il Berico }}$}

Cavallanti, S.A., “Moderniste a convegno”, Il Berico, 9 marzo 1907, pp. 2-3.

“Era un pettegolezzo ... di sapore locale!”, Il Berico, 12 May 1908, pp. 3-4.

“Modernismo su tutta la linea, Il Berico, 4 maggio 1907, p. 1.

Salerno, Elisa (pseud. Bianca), “L’autunno operaio”, Il Berico, a. XXXI, n. 218, 27 settembre 1906.

\section{Tribuna sociale}

“Sospendiamo le pubblicazioni!”, Tribuna sociale, a. II, n. 27, 4 luglio 1908, p. 1. 


\section{$\underline{\text { Cultura sociale }}$}

Murri, Romolo (pseud. P. Averri), “ Donne vane”, Cultura sociale, a. V, n. 22, 1 dicembre 1902, pp. 349-351.

“La questione feminile” [sic], Cultura sociale, a. VIII, n. 169, 16 gennaio 1905, pp. 1719.

"La nostra inchiesta sul feminismo" [sic], Cultura sociale, a. VIII, n. 171, 16 febbraio 1905, pp. 59-60.

"La nostra inchiesta sul feminismo", Cultura sociale, a. VIII, n. 172, 1 marzo 1905, pp. 69-70.

"La nostra inchiesta sul feminismo", Cultura sociale, a. VIII, n. 174, 1 aprile 1905, pp. 104-105.

“La nostra inchiesta sul feminismo”, Cultura sociale, a. VIII, n. 175, 16 aprile 1905, pp. 117-119.

“La nostra inchiesta sul feminismo”, Cultura sociale, a. VIII, n. 176, 1 maggio 1905, pp. 134-135.

"La nostra inchiesta sul feminismo", Cultura sociale, a. VIII, n. 177, 16 maggio 1905, pp. 147-149.

“La nostra inchiesta sul feminismo”, Cultura sociale, a. VIII, n. 179, 16 giugno 1905, pp. 181-183.

“La nostra inchiesta sul feminismo”, Cultura sociale, a. VIII, n. 182, 1 agosto 1905, pp. 225-227.

\section{La Donna e il lavoro}

“A proposito del Congresso delle 'Donne italiane'”, La Donna e il lavoro, a. 2, n. 11, 17 marzo 1911, pp. 2-3.

“Un altra parola sulle inchieste”, La Donna e il lavoro, a. 1, n. 30, 15 luglio 1910, p. 1.

“Conclusioni dell'inchiesta sulle lavoratrici dell’ago di Firenze”, La Donna e il lavoro, a. 3, n. 6, 9 febbraio 1912, p. 1.

“Condizioni di abbonamento”, La Donna e il lavoro, a. 2, n. 53, 23 dicembre 1910, p. 1.

“Consolantissimo riscontro”, La Donna e il lavoro, a. 2, n. 14, 7 aprile 1911, p. 1.

“La donna. A proposito delle opinioni sul femminismo del R.P. Biederback” [sic], La Donna e il lavoro, a. 2, n. 42, 20 ottobre 1911, p. 1; a. 2, n. 43, 27 ottobre 1911, p. 1; a. 2, n. 44, 3 novembre 1911, p. 1. 
“’La donna e il lavoro’ nel 1912”, La Donna e il lavoro, a. 2, n. 50, 15 dicembre 1911, p. 1.

“Immaginazioni e false premesse”, La Donna e il lavoro, a. 3, n. 23, 21 giugno 1912, pp. 3-4.

"Inchiesta sul lavoro delle donne. Vicenza. 'Setificio Schroeder'”, La Donna e il lavoro, a. I, n. 2, 29 dicembre 1909, p. 3; a. 1, n. 3, 7 gennaio 1910, p. 3; a. n. 4, 14 gennaio 1910, p. 3.

"Inchiesta sul lavoro delle donne. Vicenza. 'Setificio Verlato'”, La Donna e il lavoro, a. 1, n. 5, 21 gennaio 1910, p. 3; a. 1, n. 6, 28 gennaio 1910, p. 3.

“Inchiesta sul lavoro delle donne. Vicenza. 'Setificio Sammartin’”, La Donna e il lavoro, a. 1, n. 7, 4 febbraio 1910, p. 3.

“Inchiesta sul lavoro delle donne. Vicenza. 'Setificio Gregorina'”, La Donna e il lavoro, a. 1, n. 9, 18 febbraio 1910, p. 3.

“Inchiesta sul lavoro delle donne. Vicenza. 'Stabilimento Orefice”, La Donna e il lavoro, a. 1, n. 10, 25 febbraio 1910, p .3; a. 1, n. 11, 4 marzo 1910, p. 3.

“Inchiesta sul lavoro delle donne. Italia. Il cotone”, La Donna e il lavoro, a. 1, n. 12, 11 marzo 1910, p. 3.

"Inchiesta sul lavoro delle donne. Vicenza. 'Cotonificio Rossi'”, La Donna e il lavoro, a. 1, n. 13, 19 marzo 1910, p. 3; a. 1, n. 14, 26 marzo 1910, p. 3; a. 1, n. 15, 1 aprile 1910, p. 3; a. 1, n. 16, 9 aprile 1910, p. 3; a. 1, n. 17, 16 aprile 1910, p. 3; a. 1, n. 18, 23 aprile 1910, p. 3; a. 1, n. 19, 30 aprile 1910, p. 3; a. 1, n. 20, 6 maggio 1910, p. 3; a. 1, n. 21, 13 maggio 1910, p. 3; a. 1, n. 22, 19 maggio 1910, p. 3; a. 1, n. 26, 17 giugno 1910, p. 3; a. 1, n. 27, 24 giugno 1910, p. 3; a. 1, n. 28, 1 luglio 1910, p. 3.

“Inchiesta sul lavoro delle donne. Vicenza. Industria dell’oro”, a. 1, n. 31, 22 luglio 1910, p. 3; a. n. 32, 28 luglio 1910, p. 3; a. 1, n. 33, 5 agosto 1910, p. 3; a. 1, n. 34, 12 agosto 1910, p. 3.

“Inchiesta sul lavoro delle donne. Industria metallurgica”, La Donna e il lavoro, a. 1, n. 36, 26 agosto 1910, p. 3.

“Inchiesta sul lavoro delle donne. Industria mineralogica e metallurgica”, La Donna e il lavoro, a. 1, n. 37, 1 settembre 1910, p. 3.

“Inchiesta sul lavoro delle donne. Industria metallurgica”, La Donna e il lavoro, a. 1, n. 38, 9 settembre 1910, p. 3.

“Inchiesta sul lavoro delle donne. Vicenza. Società anonima metallurgica”, a. 1, no. 39, 16 settembre 1910, p. 3 .

“Inchiesta sul lavoro delle donne. Vicenza. Pastaie”, La Donna e il lavoro, a. 1, n. 47, 11 novembre 1910, p. 3; a. 1, n. 48, 18 novembre 1910, p. 3; a. 1, n. 49, 25 novembre 1910, p. 3. 
“Inchiesta sul lavoro delle donne a Vicenza. Trapuntisti in coltroni”, La Donna e il lavoro, a. 2, n. 21, 26 maggio 1911, p. 3.

“Inchiesta sul lavoro delle donne a Vicenza. Sarte da donna”, La Donna e il lavoro, a. 2, n. 23, 9 giugno 1911, p. 3; a. 2, n. 24, 16 giugno 1911, p. 3.

"Inchiesta sul lavoro delle donne a Vicenza. Cucitrici in bianco", La Donna e il lavoro, a. 2, n. 26, 30 giugno 1911, p. 3; a. 2, n. 28, 14 luglio, p. 3.

“Inchiesta sul lavoro delle donne a Vicenza. Lavoratrici in perle”, La Donna e il lavoro, a. 2, n. 52, 29 dicembre 1911, p. 3.

"Inchiesta sul lavoro delle donne a Vicenza. Aggiuntatore od orlatrici”, La Donna e il lavoro, a. 3, n. 22, 31 maggio 1912, p. 3.

“Prima cattolica e poi femminista”, La Donna e il lavoro, a. 8, n. 18, 24 agosto 1917, p. 1.

“La prima settimana sociale femminile italiana”, La Donna e il lavoro, a. 4, n. 16, 18 aprile 1913, pp. 1-2.

“Problemi femminili”, La Donna e il lavoro, a. 9, n. 16, 29 novembre 1918, p. 1.

"Produzione della seta in Italia”, La Donna e il lavoro, a. 1, n. 1, 24 dicembre 1909, p. 3.

“Rivelazioni e appelli”, La Donna e il lavoro, a. 5, n. 8, 24 aprile 1914, p. 1.

“La settimana sociale femminile”, La Donna e il lavoro, a. 4, n. 17, 25 aprile 1913, p. 1.

“La prima settimana sociale femminile italiana”, La Donna e il lavoro, a. 4, n. 16, 18 aprile 1913, pp. 1-2.

“Trattazione sulla donna. Parte I. - Agli antifemministi”, La Donna e il lavoro, a. 3, n. 31, 2 agosto 1912, p. 3; a. 3, n. 32, 9 agosto 1912, p. 3; a. 3, n. 33, 16 agosto 1912; a. 3, n. 34, 23 agosto 1912, p. 3; a. 3, n. 35, 30 agosto 1912, p. 3; a. 3, n. 36, 6 settembre 1912, p. 3; a. 3, n. 37, 13 settembre 1912, p. 3; a. 3, n. 38, 20 settembre 1912, p. 3; a. 3, n. 39, 27 settembre 1912, p. 3; a. 3, n. 40, 4 ottobre 1912, p. 3.

“Trattazione sulla donna. Parte II. - Una questione di libertà”, La Donna e il lavoro, a. 3, n. 41, 11 ottobre 1912, p. 3; a. 3, n. 42, 18 ottobre 1912, p. 3; a. 3, n. 43, 25 ottobre 1912, p. 3; a. 3, n. 44, 1 novembre 1912 1912, p. 3; a. 3, n. 45, 8 novembre 1912, p. 3.

“Trattazione sulla donna. Parte III. - Quid est mulier?”, La Donna e il lavoro, a. 3, n. 46, 15 novembre 1912, p. 3; a. 3, n. 47, 22 novembre 1912, p. 3; a. 3, n. 48, 29 novembre 1912, pp. 3-4; a. 3, n. 49, 6 dicembre 1912, p. 3; a. 3, n. 50, 13 dicembre 1912, p. 3; a. 3, n. 51, 20 dicembre 1912, p. 3; a. 3, n. 52, 27 dicembre 1912, p. 3; a. 4, n. 1 , 3 gennaio 1913, p. 3.

“Trattazione sulla donna. Parte IV. - Educazione fisica”, La Donna e il lavoro, a. 4, n. 2, 10 gennaio 1913, p. 3; a. 4, n. 3, 17 gennaio 1913, p. 3; a. 4, n. 4, 24 gennaio 1913, p. 3. 
“Trattazione sulla donna. Parte V. - Istruzione”, La Donna e il lavoro, a. 4, n. 5, 31 gennaio 1913, p. 3; a. 4, n. 6, 7 febbraio 1913, p. 3; a. 4, n. 7, 14 febbraio 1913, p 3; a. 4, n. 8, 21 febbraio 1913, p. 3; a. 4, n. 9, 28 febbraio 1913, p. 3; a. 4, n. 10, 7 marzo 1913, p. 3.

“Trattazione sulla donna. Parte VI. - La donna nella famiglia e nella società”, La Donna e il lavoro, a. 4, n. 11, 14 marzo 1913, p. 3; a. 4, n. 12, 21 marzo 1913, p. 3; a. 4, n. 13, 28 marzo 1913, p. 3; a. 4, n. 14, 4 aprile 1913, p. 3; a. 4, n. 15, 11 aprile 1913, p. 3; a. 4, n. 16, 18 aprile 1913, p. 3; a. 4, n. 17, 25 aprile 1913, p. 3; a. 4, n. 18, 2 maggio 1913, p. 3; a. 4, n. 19, 9 maggio 1913, p. 3.

“Trattazione sulla donna. Parte VII - Maria e la donna”, a. 4, n. 20, 16 maggio 1913, p. 3; a. 4, n. 21, 23 maggio 1913, p. 3; a. 4, n. 22, 30 maggio 1913, p. 3; a. 4, n. 23, 6 giugno 1913, p. 3; a. 4, n. 24, 13 giugno 1913, p. 3.

“Trattazione sulla donna. Concludendo”, a 4, n. 25, 20 giugno 1913, p. 3.

“Una lettera del Prof. Toniolo”, La Donna e il lavoro, a. 1, n. 40, 23 settembre 1910, p. 1.

“Verso la vita”, La Donna e il lavoro, a. 9, n. 8, 14 giugno 1918, p. 1.

\section{$\underline{\text { Arena }}$}

“Note vaticane. Il piccolo episodio ‘modernistico’, di Vicenza”, Arena, 29 luglio 1917, p. 3.

\section{$\underline{\text { Problemi femminili }}$}

“Dottrina infetta”, Problemi femminili, a. 7. n. 3, 13 febbraio 1925, pp. 1-3.

“Il Partito popolare italiano e il suo programma”, Problemi femminili, a. 1, n. 4, 21 febbraio 1919, p. 2.

"Per un programma di organizzazione giovanile femminile”, Problemi femminili, a. 1, n. 4, 21 febbraio 1919, p. 2.

\section{Il Corriere della sera}

"Ancora sul carteggio politico fra il cardinale Rampolla e la contessa Parravicino di Revel”, Corriere della sera, 23 aprile 1914.

\section{Il Giornale d'Italia}

“Una tempesta in Vaticano”, Giornale d'Italia, 23 aprile 1914, p. 6. 


\section{$\underline{\text { Il Messaggero }}$}

"La corrispondenza di Rampolla con la contessa di Parravicino”, Messaggero, 23 aprile 1914.

\section{Unione fra le donne cattoliche d'Italia}

Canuti, Giovanna, “Il nostro programma”, Unione fra le donne cattoliche d'Italia, n. XL, 1915, pp. 1-4.

Di Cassano Zunica (née de Courte), “La votazione religiosa intorno all’insegnamento religioso nel Congresso delle donne italiane”, Unione fra le donne cattoliche d'Italia, $\mathrm{n}$. VIII-IX, gennaio-febbraio 1911, pp. 2-3.

“Documenti pontifici”, Unione fra le Donne cattoliche d'Italia, n. XLV, novembre 1915, pp. 1-4.

“Dopo il terremoto della Marsica”, Unione fra le Donne cattoliche d'Italia, n. XLI, dicembre 1915, p. 1.

“La nuova Presidente generale”, Unione fra le donne cattoliche d'Italia, XLII, 1915, p. 1.

"Il nuovo ordinamento dell'Azione cattolica in Italia”, Unione fra le donne cattoliche d'Italia, n. XLIII, 1915, p.1.

L’Ufficio centrale di Presidenza, “Alle presidenti e socie dell’Unione fra le donne cattoliche d’Italia” (Roma 20 gennaio 1914), XXXIII, 1914, pp. 1-2.

\section{Bollettino dell'Unione fra le donne cattoliche d'Italia}

“Anticlericalismo”, Bollettino dell'Unione fra le donne cattoliche d'Italia, 15 marzo 1919, p. 1.

“Dimissioni della Presidente generale”, Bollettino dell'Unione fra le donne cattoliche d'Italia, 15 gennaio 1918, pp. 1-2.

\section{Bollettino d'organizzazione dell'Unione femminile cattolica italiana}

“G.F.C.I. e fascismo”, Bollettino d'organizzazione, Le pagine per le dirigenti della Gioventù F.C.I., a. II, n. 8-9, 1-15 maggio 1921, p. 4.

"La nostra associazione e i gruppi femminili del Partito popolare", Bollettino d'organizzazione dell'Unione femminile cattolica italiana, n. 5, 30 [sic] febbraio 1920, p. 1.

“La nostra stampa nel 1921”, Bollettino d'organizzazione dell’Unione femminile cattolica italiana, n. 24, 1 dicembre 1920, p. 1. 
“Il primo congresso dell’Unione femminile cattolica italiana”, Bollettino

d'organizzazione dell'Unione femminile cattolica italiana, n. 7, 15 novembre 1919, pp. 2-8.

“Il Santo Padre e l’Unione femminile cattolica italiana”, Bollettino d'organizzazione dell'Unione femminile cattolica italiana, n. 7, 15 novembre 1919, pp. 1-2.

\section{$\underline{\text { Bollettino dell'Unione femminile cattolica italiana }}$}

“Alle presidenti diocesane dell'U.F.C.I.”, Bollettino dell'Unione femminile cattolica italiana, a. IX, n. 5, maggio 1928, p. 1.

“Assistenza religiosa agli emigranti”, Le pagine interne del Bollettino dell’Unione femminile cattolica italiana, serie III, n. 12, dicembre 1928, pp. 1-14.

"Il Congresso dell'Alleanza internazionale per il suffragio femminile”, Bollettino dell'Unione femminile cattolica italiana, a. IV, n. 11, 1 giugno 1923, p. 4.

“La capacità giuridica della donna”, Bollettino dell'Unione femminile cattolica italiana, a. VIII, n. 2, febbraio 1927, p. 2.

“Conversazioni. Il lusso”, Bollettino dell'Unione femminile cattolica italiana, a. V., n. 18, 1 novembre 1924, p. 4.

“Elettrici!”, Bollettino dell'Unione femminile cattolica italiana, a. IV, n. 12, 15 giugno 1923, pp. 1-2.

"La famiglia, e la sua educazione nella vita sociale”, Supplemento al Bollettino dell’Unione femminile cattolica italiana, Serie IV, n. 11, novembre 1929, pp. 1-16.

“Il matrimonio cristiano", Bollettino dell'Unione femminile cattolica italiana, a. XII, n. 2, febbraio 1931, pp. 3-8.

“I nostri fanciulli cattolici”, Bollettino dell’Unione femminile cattolica italiana, a. VII, n. 11 , novembre 1926, p. 3.

“Il nuovo ordinamento dell’U.F.C.I.”, Bollettino dell'Unione femminile cattolica italiana, a. VI, n. 15, 15 agosto 1925, p. 1.

“L’Opera nazionale per la protezione della maternità e dell'infanzia”, Bollettino dell'Unione femminile cattolica italiana, Le pagine interne, n. 4, aprile 1927, pp. 1-16.

"Per il caso di abusive pressioni”, Bollettino dell'Unione femminile cattolica italiana, a. VII, n. 12, dicembre 1926, p. 1.

“Per il voto amministrativo", Bollettino dell'Unione femminile cattolica italiana, a. VI, n. 10, 15 maggio 1925, p. 1.

"Per l'attentato contro il Capo del Governo", Bollettino dell'Unione femminile cattolica italiana, a. VII, n. 11, novembre 1926, p. 1. 
“Per le violenze contro le associazioni cattoliche”, Bollettino dell'Unione femminile cattolica italiana, a. V., n. 8, 15 aprile 1924, p. 1.

“Per un periodico femminile”, Bollettino dell'Unione femminile cattolica italiana, a. VI, n. 9, 1 maggio 1925, p. 1.

"Il periodico 'Problemi femminili'”, Bollettino dell'Unione femminile cattolica italiana, a. IV, n. 12, 15 giugno 1923, p. 2.

“Relazione dell'azione esterna svolta nelle diocesi”, Bollettino dell'Unione femminile cattolica italiana, a VI, n. 16, 1 ottobre 1925, p. 14.

"La Sacra congregazione del concilio contro la disonestà della moda femminile", Bollettino dell’Unione femminile cattolica italiana, a. IX, n. 3, marzo 1930, p. 1.

"La soluzione della Questione romana. Un trattato e un concordato", Bollettino dell'Unione femminile cattolica italiana, a. X, n. 3, marzo 1929, p. 1.

“L’U.F.C.I. e l’azione missionaria”, Bollettino dell'Unione femminile cattolica italiana, a. V., n. 20, 1 dicembre 1924, pp. 1-2.

\section{$\underline{\text { In alto! }}$}

“La commemorazione dantesca dell’Unione femminile cattolica italiana a Ravenna - 6 settembre 1921”, In alto!, a. II, n. 8, 1921, p. 1-3.

“Infamie rosse”, In alto!, a. I, n. 2, 1920, pp. 1-2.

“Il lusso”, In alto!, a. I, n. 6, 1920, p. 2.

“La moda femminile, In alto!, a. VIII, n. 11, novembre 1927, p. 2.

“L’ora della battaglia è suonata!!!”, In alto!, a. I. n. 3, 1920, p. 1.

\section{$\underline{\text { Fiamma viva }}$}

Canuti, Giovanna, “A proposito del voto amministrativo alle donne. Madre o elettrice?”, Fiamma viva, agosto 1925, pp. 455-460.

109-111.

“Appunti sociali. La donna insegnante”, Fiamma viva, febbraio 1926, pp.

Galli, Maria, "Vita femminile. Medichesse, farmaciste, infermiere”, Fiamma viva, aprile 1930, pp. 214-218.

Gemelli, Agostino, “La educazione fisica della donna”, Fiamma viva, giugno 1923, pp. 338-351.

Monreale, Osanna, “Attualità. Una libera docenza”, Fiamma viva, marzo 1930, pp. 185186. 
“Il nostro concorso”, Fiamma viva, novembre 1925, pp. 701-703.

Penné, Anna Maria, “Da riviste e giornali”, Fiamma viva, febbraio 1927, pp. 113-117.

“Problemi di vita femminile. Il nostro concorso. Risposta di ‘Ala””, Fiamma viva, gennaio 1926, pp. 58-61.

“Problemi di vita femminile. Il nostro concorso. Risposta di Lux”, Fiamma viva, maggio 1926, pp. 315-316.

“Problemi di vita femminile. Il nostro concorso. Risposta di Maria Devoto”, Fiamma viva, marzo 1926, pp. 190-192.

"Problemi di vita femminile. Il nostro concorso. Risposta di Spes. Risposta di Ussia”, Fiamma viva, febbraio 1926, pp. 121-124.

“Problemi di vita femminile. Il nostro concorso. Risposta di T.B.”, Fiamma viva, aprile 1926, pp. 252-254.

"Problemi di vita femminile. Quello che insegna il nostro concorso”, Fiamma viva, novembre 1926, pp. 694-697.

“Il IV congresso nazionale della G.F.C.I.”, Fiamma viva, agosto 1928, p. 460-465.

Racca, Anna, “La donna e il voto”, Fiamma viva, novembre 1928, pp. 686-688.

Ricci Curbastro, Elisabetta, "Il nostro concorso. Una bella risposta”, Fiamma viva, dicembre 1925, pp. 760-764.

Sticco, Maria, “Conversazioni intime. L’undici febbraio”, Fiamma viva, marzo 1929, pp. 132-141.

\section{Squilli di risurrezione}

“Per essere socia della G.F.C.I.”, Squilli di risurrezione, a. III, n. 8, 1 maggio 1923, pp. $1-2$.

\section{DOCTRINAL AND PAPAL DOCUMENTS}

Augustine, Saint, Eighty-three Different Questions, Washington, D.C., Catholic University of America Press, 1982, p. 42.

The Literal Meaning of Genesis, v. II, trans. and annotated by John Hammond Taylor, New York, Newman Press, 1982.

, The Lord's Sermon on the Mount, Westminster, Md., Newman Press, 1948. 
Thomas, Aquinas, Saint, Summa Theologica, Benziger Bros. ed. 1947, trans. by Fathers of the English Dominican Province, digital file produced by Sandra K. Perry, Perrysburg, Ohio.

http://www.ccel.org./a/aquinas/summa/home.html [Converted to HTML 11.01.1998]

Pius IX, Ubi primum (On The Immaculate Conception) (2 Feb. 1849). http://ewtnkids.net/library/encyc/p9ubipro2.html (10/08/2009)

Quanta cura: Encyclical of Pope Pius IX Condemning Current Errors (8 Dec. 1864). http://www.papalencyclicals.net/Pius09/p9quanta.htm (12/01/2010)

, The Syllabus of Errors Condemned by Pius IX (8 Dec. 1864).

http://www.papalencyclicals.net/Pius09/p9syll.htm (12/01/2010)

Leo XIII, Inscrutabili Dei consilio: Encyclical of Pope Leo XIII on the Evils of Society (21 Apr. 1878). http://www.vatican.va/holy_father/leo_xiii/encyclicals/documents/hf_lxiii_enc_21041878-inscrutabili-dei-consilio_en.html (20/02/2011)

Quod apostolici muneris: Encyclical of Pope Leo XIII on Socialism (28 Dec. 1878). http://www.vatican.va/holy_father/leo_xiii/encyclicals/documents/hf_lxiii_enc_28121878_quod-apostolici-muneris_en.html (20/02/2011)

, Aeterni patris: Encyclical of Pope Leo XIII on the Restoration of Christian Philosophy (4 Aug. 1879).

http://www.vatican.va/holy_father/leo_xiii/encyclicals/documents/hf_leoxiii_enc_04081879_aeterni-patris_en.html (20/02/2010)

Arcanum: Encyclical of Pope Leo XIII on Christian Marriage (10 Feb. 1880). http://www.vatican.va/holy_father/leo_xiii/encyclicals/documents/hf_lxiii_enc_10021880_arcanum_en.html (17/04/2008)

Rerum novarum: Encyclical of Pope Leo XIII on Capital and Labour (15 May 1891). http://www.vatican.va/holy_father/leo_xiii/encyclicals/documents/hf_lxiii_enc_15051891_rerum_novarum_en.html (10/03/2008)

Graves de communi re: Encyclical of Pope Leo XIII on Christian Democracy (18 Jan. 1901). http://www.vatican.va/holy_father/leo_xiii/encyclicals/documents/hf_lxiii_enc_18011901_graves_de_communi_re_en.html (24/04/2008)

Pius X, Tra le sollecitudini: Instruction on Sacred Music (22. Nov. 1903). http://www.adoremus.org/MotuProprio.html (17/04/2008)

"Motu proprio": Fin dalla prima nostra: On Popular Catholic Action by Pope St. Pius $X$ (18 Dec. 1903). http://www.sspxasia.com/Documents/Catholic_Doctrine/Fin_Dalla-Prima_Nostra.htm $(09 / 12 / 2008)$

Il fermo proposito: Encyclical of Pope Pius X on Catholic Action in Italy (11 June 1905). http://sedevacantist.com/encyclicals/Pius10/PIOFERMO.HTM (09.12.2008) 
1906).

, Pieni l'animo: Encyclical of Pope Pius $X$ on the Clergy in Italy (28 July

http://www.jesus.2000.years.de/holy_father/pius_x/encyclicals/documents/hf_p-

x_enc_28071906_pieni_l’animo_en.html (15/05/2009)

, Lamentabili sane: Syllabus Condemning the Errors of the Modernists (3 July 1907). http://www.papalencyclicals.net/Pius/p10lamen.htm (20/02/2011)

Pascendi Dominici gregis: Encyclical of Pope Pius $X$ on the Doctrines of the Modernists (8 Sept. 1907).

http://www.vatican.va/holy_father/pius_x/encyclicals/documents/hf_p-

x_enc_19070908_pascendi-dominici-gregis_en.html (02/02/2008)

Benedict XV, Ad beatissimi apostolarum: Encyclical of Pope Benedict XV Appealing for Peace (1 Nov. 1914).

http://www.vatican.va/holy_father/benedict_xv/encyclicals/documents/hf_benxv_enc_01111914_ad-beatissimi-apostolarum_en.html

Natalis trecentesimi: Letter to the Superior General of the Roman Union of Ursulines (27 Dec. 1917), extract in The Monks of Solesmes, The Woman in the Modern World, Boston, Mass., St. Paul Editions, 1959, p. 27.

, "Il discorso del Papa" (Allocution of the Pope to a Group of Italian Women on 21 Oct. 1919), Bollettino d'organizzazione dell'Unione femminile cattolica italiana, n. 7, 15 novembre 1919, pp. 1-2.

Pius XI, “A Lei, Vicaro Nostro”: Letter to the Cardinal Vicar of Rome (2 May 1928), extract in The Monks of Solesmes, The Woman in the Modern World, Boston, Mass., St. Paul Editions, 1959, p. 35.

1930).

, Casti connubii: Encyclical of Pope Pius XI on Christian Marriage (31 Dec.

http://www.vatican.va/holy_father/pius_xi/encyclicals/documents/hf_p-

xi_enc_31121930_casti-connubii_en.html (19/07/2009)

, Quadragesimo anno: Encyclical of Pope Pius XI on Reconstruction of Social Order (15 May 1931).

http://www.vatican.va/holy_father/pius_xi/encyclicals/documents/hf_pxi_enc_19310515_quadragesimo-anno_en.html (03/092010)

Non abbiamo bisogno: Encyclical of Pope Pius XI on Catholic Action in Italy (29 June 1931).

http://www.vatican.va/holy_father/pius_xi/encyclicals/documents/hf_p-

xi_enc_29061931_non-abbiamo-bisogno_en.html

Lux veritatis: Encyclical on the Council of Ephesus (25 Dec. 1931), extract in The Monks of Solesmes, The Woman in the Modern World, Boston, Mass., St. Paul Editions, 1959, p. 39.

, Divini redemptoris: Encyclical of Pope Pius XI on Atheistic Communism (19 Mar. 1937), extract in The Monks of Solesmes, The Woman in the Modern World, Boston, Mass., St. Paul Editions, 1959, pp. 39-40. 
Pius XII, Divino afflante spiritu: Encyclical of Pope Pius XII on Promoting Biblical Studies, Commemorating the Fiftieth Anniversary of Providentissimus Deus (30 Sept. 1943).

http://www.vatican.va/holy_father/pius_xii/encyclicals/documents/hf_p-

xii_enc_30091943_divino-afflante-spiritu_en.html (20/02/2010)

The Monks of Solesmes (eds.), The Woman in the Modern World, Boston, St. Paul Editions, 1959. Papal documents from Leo XIII to Pius XII.

Tre pontefici e la Gioventù femminile di A.C. Documenti di Benedetto XV, Pio XI e Pio XII alla Gioventù femminile di A.C.I. - 1918-1943, Milano, "Vita e Pensiero”, 1943.

\section{SECONDARY SOURCES}

\section{PUBLISHED BOOKS AND ARTICLES}

Addis Saba, Marina (a cura di), La corporazione delle donne. Ricerche e studi sui modelli nel ventennio fascista, Firenze, Vallecchi Editore, 1988.

"La donna muliebre”, in Marina Addis Saba (a cura di), La corporazione delle donne. Ricerche e studi sui modelli nel ventennio fascista, Firenze, Vallecchi Editore, 1988, pp. 1-71.

Alberigo, Giuseppe (a cura di), Giovanni XXIII: transizione del Papato e della Chiesa, Roma, Borla, 1988.

Albertazzi, Alessandro, “Grosoli Pironi, Giovanni”, in Francesco Traniello e Giorgio Campanini (a cura di), Dizionario storico del movimento cattolico in Italia 1860-1980, II: I protagonisti, Torino, Marietti, 1982, pp. 275-280.

Armida Barelli nella societa italiana, Milano, Edizioni O.R., 1983.

Arslan, Antonia, “Dall'ago alla penna: scritture femminili nel Veneto tra Ottocento e Novecento", in Elisa Salerno, Al bivio / Elisa Salerno oltre il bivio: tra giornalismo e romanzo. Atti del Convegno di studi, Vicenza, 12 aprile 1997, Vicenza, Centro documentazione e studi “Presenza Donna”, 1998, pp. 133-152.

Arslan, Antonia, Chemello, A. and Pizzamiglio, G. (a cura di), Le stanze ritrovate. Antologia di scrittrici venete dal Quattrocento al Novecento, Mirano, Eidos, 1991.

Ascoli, Albert Russell and von Henneberg, Krystyna (eds.), Making and Remaking of Italy, Oxford, Berg, 2001.

Atkin, Nicholas and Tallett, Frank, Priests, Prelates and People: A History of European Catholicism since 1750, Oxford, Oxford University Press, 2003. 
"Barelli, Armida”, in Rachele Farina (a cura di), Dizionario biografico delle donne lombarde 568-1968, Milano Baldini \& Castoldi, 1995, pp. 106-107.

Bedeschi, Lorenzo, “Circoli modernizzanti a Roma a cavallo del secolo”, Studi romani, v. 18, parte 2, 1970, pp. 189-215.

, "La novità di don Romolo Murri”, in Ilaria Biagioli, Alfonso Botti e Rocco Cerrato (a cura di), Romolo Murri e murrismi in Italia e in Europa cent'anni dopo. Atti del Convegno internazionale di Urbino 24-26 settembre 2001, Urbino, Quattro Venti, 2004, pp. 619-625.

, "Prete degli operai”, Vita pastorale, n. 8-9, 1996, pp. 32-35.

Berkin, Carol R. and Lovett, Clara M. (eds.), Women, War, and Revolution, New York, Holmes \& Meyer, 1980.

Biagioli, Ilaria, Botti, Alfonso e Cerrato, Rocco (a cura di), Romolo Murri e i murrismi in Italia e in Europa cent'anni dopo. Atti del Convegno internazionale di Urbino 24-26 settembre 2001, Urbino, Quattro Venti, 2004.

Bocci, Maria, “Una 'distrazione’ storiografica significativa: il caso di Armida Barelli”, Annali di storia moderna e contemporanea, v. 9, 2003, pp. 429-443.

Børresen, Kari Elisabeth, Subordination and Equivalence: The Nature and Rôle of Women in Augustine and Thomas Aquinas, Washington, D.C., University Press of America, 1981.

Bosworth, R.J.B., Mussolini’s Italy, London, Penguin Books, 2006.

Botti, Alfonso e Cerrato, Rocco, "Gli esiti del murrismo", in Ilaria Biagioli, Alfonso Botti e Rocco Cerrato (a cura di), Romolo Murri e i murrismi in Italia e in Europa cent'anni dopo. Atti del Convegno internazionale di Urbino 24-26 settembre 2001, Urbino, Quattro Venti, 2004, pp. 627-660.

Bramsted, E.K. and Melhuish, K.J., "Aspects of Liberalism and Radicalism in France”, in E.K.. Bramsted and K.J. Melhuish (eds.), Western Liberalism: A History in Documents from Locke to Croce, London, Longman, 1978, pp. 52-79.

"The Tyranny of the Majority and the Right to Non-conformity: Introduction", in E.K. Bramsted and K.J. Melhuish (eds.), Western Liberalism: A History in Documents from Locke to Croce, London, Longman, 1978, pp. 577-582.

(eds.), Western Liberalism: A History in Documents from Locke to Croce, London, Longman, 1978.

Brogi, Bruno, La lega democratica nazionale, Roma, Edizione 5 Lune, 1959.

Buttafuoco, Annarita, Cronache femminili. Temi e momenti della stampa emancipazionista in Italia dall'unità al fascism, Arezzo, Dipartimento di studi storicosociali e filosofici dell’Università di Siena, 1988. 
“La filantropia come politica. Esperienze dell'emancipazionismo italiano nel Novecento", in Lucia Ferrante, Maura Palazzi e Gianna Pomata (a cura di), Ragnatele di rapporti, Torino, Rosenberg \& Sellier, 1988, pp. 166-187.

, Le Mariuccine. Storia di un'istituzione laica l'Asilo Mariuccia, Milano, Franco Angeli, 1998.

Questioni di cittadinanza. Donne e diritti sociali nell'Italia liberale, Siena, Protagon, 1997.

Cafagna, Luciano, “The Industrial Revolution in Italy 1830-1914”, in Carlo M. Cipolla (ed.), The Fontana Economic History of Europe: The Emergence of Industrial Societies: Part One, London, Collins/Fontana, 1973, pp. 279-328.

Caimi, Luciano, "Modelli educativi dell’associazianismo giovanile cattolico nel primo dopoguerra (1919-1939)", in Luciano Pazzaglia (a cura di), Chiesa, cultura e educazione in Italia tra le due guerre, Brescia, Editrice La Scuola, 2003, pp. 217-286.

Calapaj Burlini, Anna Maria e Chemotti, Saveria (a cura di), Donne in-fedeli. Temi, modelli, interpretazioni della religiosità femminile, Padova, Il Poligrafo, 2005.

Calogero, Guido, “Church and State in Italy: The Constitutional Issues”, International Affairs, v. 35, no. 1, Jan. 1959, pp. 33-42.

Camp, Richard L., "From Passive Subordination to Complementary Partnership: The Papal Conception of a Woman's Place in Church and Society since 1878”, The Catholic Historical Review, v. 76, 1990, pp. 506-525.

Canavero, Alfredo, “Meda, Filippo”, in Francesco Traniello e Giorgio Campanini (a cura di), Dizionario storico del movimento cattolico in Italia 1860-1980, II: I

protagonisti, Torino, Marietti, 1982, pp. 354-363.

Caraffa, Filippo, “Murri, Romolo”, in Enciclopedia cattolica, v. VIII, Firenze, Sansoni, 1952, colonne 1534-1535.

Casalini, Maria, La signora del socialismo. Vita di Anna Kuliscioff, Roma, Editori Riuniti, 1987.

Casella, Mario, “Armida Barelli e la GF nell'Archivio dell'AC”, in L'opera di Armida Barelli nella Chiesa e nella società del suo tempo, Roma, A.V.E., 1983, pp. 49-72.

, "Barelli, Armida”, in Dizionario biografico degli italiani, v. 34, Roma, Istituto della Enciclopedia italiana, 1988, pp. 250-252.

"Mons. Giacomo Radini Tedeschi, l’Opera dei congressi e il movimento cattolico romano (1890-1900)”, Rivista di storia della Chiesa in Italia, v. 24, 1970, pp. 129-179.

Castenetto, Dora, Elena da Persico. Una intuizione spirituale, 2. edizione, Milano, Centro Ambrosiano, 2000. 
Castiglioni, Carlo, "Noterelle sul Card. Ferrari”, in Memorie storiche della diocesi di Milano, v. X, Milano, 1963, pp. 9-20.

Castle, Harold, “St. Alphonsus Liguori”, in The Catholic Encyclopedia, v. 1, New York, Robert Appleton, 1907.

Catanzaro, Raimondo, "Enforcers, Entrepreneurs, and Survivors: How the Mafia Has Adapted to Change”, The British Journal of Sociology, v. 36, no. 1, Mar. 1985, pp. 3457.

Cecchini, Francesco Maria, "Introduzione”, in Francesco Maria Cecchini (a cura di), Il femminismo cristiano. La questione femminile nella prima democrazia cristiana 18981912, Roma, Editori Riuniti, 1979, pp. 9-46.

Centro documentazione e studi "Presenza Donna”, Attualità di Elisa Salerno a fine millennio. Atti del Convegno di studi, Vicenza, 23 marzo 1996, a cura di Maria Grazia Piazza, Vicenza, 1996.

, Comunicazione: alle frontiere della profezia / Elisa Salerno (pseud. Maria Pasini), "Porrò inimicizia fra te e la donna", Vicenza, Centro documentazione e studi “Presenza Donna” e Azione cattolica vicentina, 2004, pp. 5-44.

pp. 93-126.

, Donne e Chiesa, con Elisa Salerno, Per la riabilitazione della donna, 2006,

, Elisa Salerno oltre il bivio: tra giornalismo e romanzo. Atti del Convegno di studi, Vicenza, 12 aprile 1997 / Elisa Salerno, Al bivio, Vicenza, 1998, pp. 123-161.

Vicenza, 2002.

Elisa Salerno: una penna che inquieta, a cura di Maria Grazia Piazza, , Il femminismo cristiano di Elisa Salerno e le sue prospettive, Vicenza, 1989. , Madri d’Europa. Elisa Salerno tra le voci del suo tempo, Vicenza, 2003.

, Nata troppo presto. Omaggio ad Elisa Salerno nel $50^{\circ}$ anno dalla morte / Elisa Salerno, Pro muliere. Programma di studio e azione, Vicenza, 2007, pp. 5-66. , Una penna inquieta. Lettere scelte di Elisa Salerno, Padova, Edizioni Messaggero, 2002.

Centro studi per la storia del modernismo, Fonti e documenti, 2, Urbino, Istituto di storia dell’Università di Urbino, 1973.

Chadwick, Owen, A History of the Popes 1830-1914, Oxford, Oxford University Press, 1998.

Chemotti, Saveria, "Verso una nuova presenza femminile: Antonietta Giacomelli”, in Anna-Maria Calapaj Burlini e Saveria Chemotti (a cura di), Donne in-fedeli. Testi, modelli, interpretazioni della religiosità femminile, Padova, Il Poligrafo, 2005, pp. 191215. 
Chianese, Gloria, Storia sociale della donna in Italia (1800-1980), Napoli, Guida Editori, 1980.

Cimini, Antonietta, “Adelaide Coari e il movimento femminile cattolico”, Studia Picena, v. 43, 1975, pp. 132-200.

Cipolla, Carlo M. (ed.), The Fontana Economic History of Europe: The Emergence of Industrial Societies: Part One, London, Collins/Fontana, 1973.

Cisco, Monica, "Elisa Salerno”, in La donna e il lavoro. Ieri e oggi, Cooperativa tipografica degli operai, 2009, pp. 18-33.

Cisotto, Gianni A., Elisa Salerno e la promozione della donna, Roma, Edizioni Studium, 1996.

“Il femminismo cristiano di Elisa Salerno”, Bollettino dell'Archivio per la storia del movimento sociale cattolico in Italia, a. XIX, n. 1, gennaio-aprile 1984, pp. 32-48.

_, “Femminismo sociale a Vicenza”, Civitas, v. XXXVI, n. 2, 1985, pp. 49-58.

Clark, Christopher and Kaiser, Wolfram (eds.), Culture Wars: Secular-Catholic Conflict in Nineteenth-Century Europe, Cambridge, Cambridge University Press, 2003.

Clark, Martin, Modern Italy 1871-1995, $2^{\text {nd }}$ ed., London, Longman, 1997.

“Coari, Adelaide”, in Rachele Farina (a cura di), Dizionario biografico delle donne lombarde 568-1968, Milano, Baldini \& Castoldi, 1995, pp. 316-319.

“Colombo, Adele”, in Rachele Farina (a cura di), Dizionario biografico delle donne lombarde 568-1968, Milano, Baldini \& Castoldi, 1995, pp. 330-331.

Colombo, Maria Assunta, “Coari, Adelaide”, in Francesco Traniello e Giorgio Campanini (a cura di), Dizionario storico del movimento cattolico in Italia 1860-1980, II: I protagonisti, Torino, Marietti, 1982, pp. 109-112.

Confessore Pellegrino, O., "Parravicino Revel (di), Sabina”, in Francesco Traniello e Giorgio Campanini (a cura di), Dizionario storico del movimento cattolico in Italia, III/2: Le figure rappresentative, Casale Monferrato, Marietti, 1984, pp. 630-631.

Conti Odorisio, Ginevra, Storia dell'idea femminista in Italia, Torino, ERI, 1980.

Coppa, Frank J., The Modern Papacy since 1789, London, Longman, 1998.

“Corbetta, Pierina”, in Rachele Farina (a cura di), Dizionario biografico delle donne lombarde 568-1968, Milano, Baldini \& Castoldi, 1995, pp. 341-342.

Corsaro, Irma, Armida Barelli, Milano, Vita e Pensiero, 1954.

Crippa, Luigi, “Introduzione”, in Armida Barelli, La sorella maggiore racconta. Storia della GF dal 1918 al 1948, Milano, Edizioni O.R., 1981, pp. v-xxxix. 
Croce, Benedetto, A History of Italy 1871-1915, Oxford, Clarendon, 1929.

Cunsolo, Ronald S., "Nationalists and Catholics in Giolittian Italy: An Uneasy

Collaboration”, The Catholic Historical Review, v. 79, 1993, pp. 22-53.

Daly, Mary, The Church and the Second Sex, Boston, Beacon Press, 1985.

Dau Novelli, Cecilia, “Il Fondo Cristina Giustiniani Bandini”, Bollettino dell'Archivio per la storia del movimento cattolico, n. 1, gennaio-aprile, 1985, pp. 141-152.

, "Note sulla questione femminile nel magistero della Chiesa, da Leone XIII a Pio XI, Orientamenti sociali, v. 3, 1981, pp. 67-79.

"Il ruolo dei vescovi nel rapporto con i comitati locali", in Cecilia Dau

Novelli, Società, chiesa e associazionismo femminile. L'Unione fra le donne cattoliche d'Italia (1902-1919), Roma, A.V.E., 1988, pp. 163-180.

, Società, chiesa e associazionismo femminile. L'Unione fra le donne cattoliche d'Italia (1902-1919), Roma, A.V.E., 1988.

, “I vescovi e la questione femminile (1900-1917)”, Rivista di storia e letteratura religiosa, v. 30, 1984, pp. 429-456.

Davis, John A, “Introduction: Italy’s Difficult Modernization”, in John A. Davis (ed.), Italy in the Nineteenth Century, Oxford, Oxford University Press, 2000, pp. 1-24.

(ed.), Italy in the Nineteenth Century, Oxford, Oxford University Press, 2000.

De Curtis, Italo, “La questione femminile agli inizi del secolo: l'approccio di Romolo Murri, Civitas, v. 28, n. 5, 1977, pp. 21-31.

, "La questione femminile: il pensiero di Murri in una inchiesta di 'Cultura sociale””, Civitas, v. 28, n. 6, 1977, pp. 35-45.

De Giorgio, Michela, "The Catholic Model”, in Geneviève Fraisse and Michelle Perrot (eds.), A History of Women in the West: IV. Emerging Feminism from Revolution to World War, Cambridge, Mass., The Belknap Press of Harvard University Press, 1993, pp. 166-197.

Le italiane dall'Unità a oggi, Roma, Laterza, 1993.

De Giorgio, Michela and Di Cori, Paola, "Politica e sentimenti: le organizzazioni femminili cattoliche dall'età giolittiana al fascismo”, Rivista di storia contemporanea, fasc. 3, 1980, pp. 337-371.

De Grand, Alexander, “Women under Italian Fascism”, The Historical Journal, v. 19, n. 4, 1976, 947-968.

De Grazia, Victoria, How Fascism Ruled Women: Italy 1922-1945, Berkeley, Calif., University of California Press, 1992. 
De Rosa, Gabriele, “Benedetto XV”, in Enciclopedia dei papi, v. 3, Roma, Enciclopedia Italiana, 2000, pp. 608-617.

Il movimento cattolico in Italia. Dalla Restaurazione all'età giolittiana, 2. edizione, Roma-Bari, Laterza, 1988.

De Ruggiero, Guido, The History of European Liberalism, Boston, Beacon, 1959.

DeCrane, Susanne M., Aquinas, Feminism, and the Common Good, Washington, D.C., Georgetown University Press, 2004.

Detragiache, Denise, “Il fascismo femminile da San Sepolcro all'affare Matteotti (19191925)”, Storia contemporanea, a. XIV, n. 2, aprile 1983, pp. 211-251.

Di Cori, Paola, "Storia, sentimenti, solidarietà nelle organizzazioni femminili cattoliche dall'età giolittiana al fascismo”, Nuova dwf/Donnawomanfemme, n. 10-11, gennaiogiugno 1979, pp. 80-124.

Di Scala, Spencer, Dilemmas of Italian Socialism: The Politics of Filippo Turati, Amherst, Mass., University of Massachusetts Press, 1980.

Dittrich-Johansen, Helga, Le "militi dell'idea”. Storia delle organizzazioni femminili del Partito nazionale fascista, Firenze, Leo S. Olschi, 2002.

La donna e il lavoro. Ieri e oggi, Vicenza, Cooperativa tipografica degli operai, 2009.

Elisa Salerno oltre il bivio, in Al bivio/Elisa Salerno oltre in bivio. Atti del Convegno di studi, Vicenza, 12 aprile 1997, Vicenza, Centro documentazione e studi "Presenza Donna”, 1998, pp. 125-161.

Enciclopedia dei papi, v. 3, Roma, Enciclopedia Italiana, 2000.

Ermini, Tamara, "La difesa delle lavoratrici”. Un giornale di lotta e coscienza (19121925), Firenze, Centro editoriale toscano, 2005.

Evangelisti, Silvia, Nuns: A History of Convent Life 1400-1700, Oxford, Oxford University Press, 2007.

Fantoni, Silvio, Breve storia del movimento cattolico italiano (1870-1920), n.p., Santi Quaranta, n.d.

Farina, Rachele (a cura di), Dizionario biografico delle donne lombarde 568-1968, Milano, Baldini \& Castoldi, 1995.

Fattorini, Emma (a cura di), Dire Dio, Genova-Milano, Marietti, 2005.

Ferrante, Lucia, Palazzi, Maura and Pomata, Gianna (eds.), Ragnatele di rapporti, Torino, Rosenberg \& Sellier, 1988.

Finnegan, M.J., “Imelda, Bl.”, in New Catholic Encyclopedia, v. VII, San Francisco, New Catholic Encyclopedia, 1967, p. 374. 
Fiocchi, Stefania, “Introduzione”, in Elisa Salerno (pseud. Lucilla Ardens), Un piccolo mondo cattolico, a cura di Stefania Fiocchi, Mirano (Venezia), Eidos, 1996, pp. ix-xxx.

Fossati, Roberta, Élites femminili e nuovi modelli religiosi nell'Italia tra Otto e Novecento, Urbino, Quattro Venti, 1997.

"Romolo Murri e il femminismo cristiano", in Ilaria Biagioli, Alfonso Botti e Rocco Cerrato (a cura di), Romolo Murri e i murrismi in Italia e Europa cent'anni dopo. Atti del Convegno internazionale di Urbino 24-26 settembre 2001, Urbino, Quattro Venti, 2004, pp. 213-228.

Fraisse, Geneviève and Perrot, Michelle (eds.), A History of Women in the West, IV. Emerging Feminism from Revolution to World War, Cambridge, Mass., The Belknap Press of Harvard University Press, 1993.

Franchini, Silvia, “Gli educandati nell'Italia postunitaria”, in Simonetta Soldani (a cura di), L'educazione delle donne. Scuole e modelli di vita femminile nell'Italia dell'Ottocento, 2. edizione, Milano, Franco Angeli, 1991, pp. 57-86.

Gaggioli, Lia, “La stampa della GF dagli inizi”, in L'opera di Armida Barelli nella chiesa e nella società del suo tempo. Atti dell'Incontro di studio, Roma, 19 marzo 1983, Roma, A.V.E., 1983, pp. 163-177.

Gaiotti de Biase, Paola, “Armida Barelli e la condizione femminile dagli inizi del secolo” in L'opera di Armida Barelli nella Chiesa e nella società del suo tempo. Atti dell'Incontro di studio, Roma, 19 marzo 1983, Roma, A.V.E., 1983, pp. 27-48.

, “Donne, fede e modernità. L'asimmetria di genere nei processi di secolarizzazione”, Bailamme, gennaio-dicembre 2001, pp. 83-109.

, "Introduzione”, in Paola Gaiotti de Biase (a cura di), I cattolici e il voto alle donne, Torino, Società Editrice Internazionale, 1996, pp. 1-26.

"La nascita dell’organizzazione cattolica femminile nelle lettere di Cristina Giustiniani Bandini al Toniolo”, Ricerche per la storia religiosa di Roma, v. 2, 1978, pp. 225-271.

Le origini del movimento cattolico femminile, Nuova edizione, Brescia, Morcelliana, 2002. First published in 1963.

, Vissuto religioso e secolarizzazione. Le donne nella "rivoluzione più lunga", Roma, Edizioni Studium, 2006.

Gambasin, Angelo, Il movimento sociale nell'Opera dei congressi (1874-1904), Roma, Editrice Università Gregoriana, 1958.

Gazzetta, Liviana, Elena da Persico, Verona, Cierre, 2005.

"Tra antifemminismo e antimodernismo: Elena da Persico e la nascita dell'Unione fra le donne cattoliche d'Italia”, in Anna Maria Calapaj Burlini e Saveria Chemotti (a cura di), Donne in-fedeli. Temi, modelli, interpretazioni della religiosità femminile, Padova, Il Poligrafo, 2005, pp. 217-238. 
Gazzola, S., “Coari, Adelaide”, in Dizionario biografico degli italiani, v. XXVI, Roma, Istituto della Enciclopedia italiana, 1982, pp. 421-424.

Gemelli, Agostino, “Prefazione”, in Irma Corsaro, Armida Barelli, Milano, Vita e Pensiero, 1954, pp. vii-xli.

Gherardi, Raffaella, L'arte del compromesso. La politica della mediazione nell'Italia liberale, Bologna, Il Mulino, 1988.

Gibson, Mary, Prostitution and the State in Italy, 1860-1915, New Brunswick, N.J., Rutgers University Press, 1986.

Girvetz, Harry K., From Wealth to Welfare: The Evolution of Liberalism, Stanford, Calif., Stanford University Press, 1950.

Gotelli, Angela e Dau Novelli, Cecilia, “Giustiniani Bandini, Maria Cristina”, in Francesco Traniello e Giorgio Campanini (a cura di), Dizionario storico del movimento cattolico in Italia 1860-1980, II: I protagonisti, Torino, Marietti, 1982, pp. 257-259.

Graziosi, Mariolina, La donna e la storia, Napoli, Liguori, 2000.

, "Gender Struggle and the Social Manipulation and Ideological Use of Gender Identity in the Interwar Years”, in Robin Pickering-Iazzi (ed.), Mothers of Invention: Women, Italian Fascism, and Culture, Minneapolis, Minn., University of Minnesota Press, 1995, pp. 26-51.

Guasco, Maurilio, “Murri, Romolo”, in Francesco Traniello e Giorgio Campanini (a cura di), Dizionario storico del movimento cattolico in Italia 1860-1980, II: I protagonisti, Torino, Mariotti, 1982, pp. 414-422. 2000, pp. 593-608.

"Pio X, santo", in Enciclopedia dei papi, v. 3, Roma, Enciclopedia Italiana,

Hill, Harvey, "Leo XIII, Loisy, and the 'Broad School': An Early Round of the Modernist Crisis”, The Catholic Historical Review, v. 89, 2003, pp. 39-59.

“Iolanda” [Plattis Majocchi, Maria], in Carlo Villani, Stelle feminili. Dizionario biobibliografico. Appendice, Napoli-Roma-Milano, Albrighi, Segati \& C., 1916, pp. 125126.

Istituto centrale di statistica, Sommario di statistiche storiche italiane 1861-1955, Roma, 1958.

Jeffrey Howard, Judith, "Patriot Mothers in the Post-Risorgimento", in Carol R. Berkin and Clara M. Lovett (eds.), Women, War, and Revolution, New York, Holmes \& Meier, 1980, pp. 237-258.

Jemolo, A.C., Church and State in Italy 1850-1950, Oxford, Basil Blackwell, 1960.

Käppeli, Anne-Marie, “Feminist Scenes”, in Geneviève Fraisse and Michelle Perrot (eds.), A History of Women in the West, IV. Emerging Feminism from Revolution to 
World War, Cambridge, Mass., The Belknap Press of Harvard University Press, 1993, pp. 482-514.

Kertzer, David I., Prisoner of the Vatican, Boston, Houghton Mifflin, 2004.

Lazzaretto Zanolo, Alba Grazia, "Le associazioni vicentine del primo Novecento”, in Centro documentaziono e studi "Presenza Donna”, Il femminismo cristiano di Elisa Salerno e le sue prospettive, Vicenza, 1989, pp. 35-49.

"La condizione sociale e giuridica della donna nel primo Novecento", in $L a$ donna e il lavoro. Ieri e oggi, Vicenza, Cooperativa tipografica degli operai, 2009, pp. 70-107.

"Elisa Salerno: 'Per la causa santa della donna'”, in Centro documentazione e studi "Presenza Donna”, Nata troppo presto. Omaggio ad Elisa Salerno nel $50^{\circ}$ anno dalla morte/Elisa Salerno, Pro muliere. Programma di studio e azione, Vicenza, 2007, pp. 28-37.

, Vescovo clero parrocchia. Ferdinando Rodolfi e la diocesi di Vicenza 19111943, Vicenza, Neri Pozza Editore, 1993.

Lovison, Filippo, "Donne e riforma della Chiesa in epoca moderna. Influssi, richiami, suggestioni”, in Luigi Mezzadri e Maurizio Tagliaferri (a cura di), Le donne nella Chiesa e in Italia, Cinisello Balsamo (Milano), San Paolo, 2007, pp. 100-180.

Luccioli, Cristina, “'Lei cucirà le nostre opere’. Il rapporto tra Armida Barelli e Agostino Gemelli”, in Emma Fattorini (a cura di), Dire Dio, Genova-Milano, Marietti, 2005, pp. 223-244.

Lugo, Giuseppina, “Elisa Salerno”, in A. Arslan, A. Chemello e G. Pizzamiglio (a cura di), Le stanze ritrovate: antologia di scrittrici venete dal Quattrocento al Novecento, Mirano, Eidos, 1991, pp. 232-242.

, “Quella povera testa ... L’utopia femminista di Elisa Salerno”, Venetica, n. 9, gennaio-giugno 1988, pp. 126-203.

Mack Smith, Denis, The Making of Italy 1976-1866, $2^{\text {nd }}$ ed., Basingstoke, Hampshire, Macmillan, 1992.

Magaraggia, Chiara, "Scheda biografica”, in Centro documentazione e studi "Presenza Donna”, Una penna inquieta. Lettere scelte di Elisa Salerno, Padova, Edizioni Messaggero, 2002, pp. 20-24.

Mahowald, Mary Briody, Philosophy of Woman: Classical to Current Concepts, Indianapolis, Ind., Hackett Publishing Company, 1978.

Malgeri, Francesco, “Leone XIII”, in Enciclopedia dei papi, v. 3, Roma, Enciclopedia Italiana, 2000, pp. 575-593.

1980.

(a cura di), Storia del movimento cattolico in Italia, v. 2, Roma, Il Poligno, 
Malpelli, Barbara e Seveso, Gabriella (a cura di), Una storia imprevista. Femminismi del Novecento ed educazione, Milano, Guerini Studio, 2003.

Maraini, Dacia, “Scrivere per comunicare, suscitare, lottare ...”, in Centro documentazione e studi "Presenza Donna”, Nata troppo presto. Omaggio ad Elisa Salerno nel $50^{\circ}$ anno dalla morte/Elisa Salerno, Pro muliere. Programma e studio e azione, Vicenza, 2007.

Marchesini, Daniele, “L’analfabetismo femminile nell’Italia dell’Ottocento: caratteristiche e dinamiche”, in Simonetta Soldani (a cura di), L'educazione delle donne. Scuole e modelli di vita femminile nell'Italia dell'Ottocento, 2. edizione, Milano, Franco Angeli, 1991, pp. 37-56.

Margiotta Broglio, Francesco, "Pio XI", in Enciclopedia dei papi, v. 3, Roma, Enciclopedia Italiana, 2000, pp. 617-632.

Mezzadri, Luigi e Tagliaferri, Maurizio (a cura di), Le donne nella Chiesa e in Italia, Cinisello Balsamo (Milano), San Paolo, 2007.

Migliucci, Debora, Per il voto alle donne. Dieci anni di battaglie suffragiste in Italia (1903-1913), Milano, Bruno Mondadori, 2006.

Mignoni, Maria, Diventare storiche dell'arte.Una storia di formazione e professionalizzazione in Italia e in Francia (1900-40), Roma, Carocci, 2009.

Militello, Cettina, Il volto femminile della storia, 2. edizione, Casale Monferrato, Piemme, 1996.

Molinari, Franco, “Radini Tedeschi, Giacomo”, in Francesco Traniello e Giorgio Campanini (a cura di), Dizionario storico del movimento cattolico in Italia 1860-1980, II: I protagonisti, Torino, Marietti, 1982, pp. 527-531.

Mondrone, Domenico, “Una donna laica moderna. Elena da Persico”, La Civiltà cattolica, v. 136, n. 1, febbraio 1985, pp. 354-365.

The Monks of Solesmes (eds.), The Woman in the Modern World, Boston, St. Paul Editions, 1959.

Motterle, Tullio (a cura di), Tradizione e innovazione nella pastoralità di Ferdinando Rodolfi Vescovo di Vicenza 1911-1943. Atti del Convegno di studio, Vicenza, 23-24 aprile 1993, Vicenza, Rumor, 1996.

Neufeld, Maurice F., Italy: School for Awakening Countries, Westport., Conn., Greenwood, 1974.

Il Novecento delle italiane. Una storia ancora da raccontare, Roma, Editori Riuniti, 2001.

O’Brien, Albert C., "Italian Youth in Conflict: Catholic Action and Fascist Italy, 19291931”, The Catholic Historical Review, v. 68, no. 4, Oct. 1982, pp. 625-635. 
Olgiati, Francesco, La storia dell'Azione cattolica (1865-1904), Milano, Vita e Pensiero, 1920.

L'opera di Armida Barelli: nella chiesa e nella società del suo tempo. Atti dell'Incontro di studio, Roma, 19 marzo 1983, Roma, A.V.E., 1983.

Papenheim, Martin, “Roma o morte: Culture Wars in Italy”, in Christopher Clark and Wolfram Kaiser (eds.), Culture Wars: Secular-Catholic Conflict in Nineteenth-Century Europe, Cambridge, Cambridge University Press, 2003, pp. 202-226.

Passoni, Adolfo, Elena da Persico. Una donna nella storia, Roma, A.V.E., 1991.

Pazzaglia, Luciano (a cura di), Chiesa, cultura e educazione in Italia tra le due guerre, Brescia, Editrice La Scuola, 2003.

Pecorari, Paolo, “Toniolo, Giuseppe”, in Francesco Traniello e Giorgio Campanini (a cura di), Dizionario storico del movimento cattolico in Italia 1860-1980, II: I protagonisti, Torino, Marietti, 1982, pp. 636-644.

Pera, Isabella, “Chiesa, donna e società moderna: don Grugni e il femminismo cristiano”, Storia e problemi contemporanei, a XIII, n. 26, 2000, pp. 25-47.

, "La questione femminile nel mondo cattolico nel primo Novecento", Ricerche di storia sociale e religiosa, v. 30, Jan.-June 2001, pp. 67-89.

Pickering-Iazzi, Robin (ed.), Mothers of Invention: Women, Italian Fascism, and Culture, Minneapolis, Minn., University of Minnesota Press, 1995.

Pieroni Bortolotti, Franca, Alle origini del movimento femminile in Italia 1848-1892, Torino, Giulio Einaudi, 1975.

, “Anna Kuliscioff e la questione femminile”, in Anna Kuliscioffe l'età del riformismo. Atti del Convegno di Milano - dicembre 1976, Roma, Mondo Operaio Edizioni Avanti!, 1978, pp. 104-139.

"Introduzione”, in Anna Maria Mozzoni, La liberazione della donna, a cura di Franca Pieroni Bortolotti, Milano, Gabriele Mazzotta, 1975, pp. 7-32.

, "Osservazioni sull’occupazione femminile durante il fascismo", in Franca Pieroni Bortolotti, Sul movimento politico delle donne. Scritti inediti, a cura di Annarita Buttafuoco, Roma, Utopia, 1987, pp. 179-207.

Mazzotta, 1976.

Socialismo e questione femminile in Italia 1892-1922, Milano, Gabriele

, Sul movimento politico delle donne. Scritti inediti, a cura di Annarita Buttafuoco, Roma, Utopia, 1987.

Pisa, Beatrice, Venticinque anni di emancipazionismo femminile in Italia. Gualberta Alaide Beccari e la rivista “La Donna” (1868-1890), Roma, Elengraf, n.d.

Pollard, John F., Catholicism in Modern Italy, London, Routledge, 2008. 
Press, 1985.

The Vatican and Italian Fascism, 1929-32, Cambridge, Cambridge University

Raicich, Marino, “Liceo, università, professioni: un percorso difficile”, in Simonetta Soldani (a cura di), L'educazione delle donne. Scuole e modelli di vita femminile nell'Italia dell'Ottocento, 2. edizione, Milano, Franco Angeli, 1991, pp. 147-181.

Reato, Ermenegildo, "Scotton, Jacopo; Scotton, Andrea; Scotton, Gottardo”, in Francesco Traniello e Giorgio Campanini (a cura di), Dizionario storico del movimento cattolico in Italia 1860-1980, II: I protagonisti, Torino, Marietti, 1982, pp. 591-593.

"Il Vescovo Rodolfi e il fascismo vicentino", in Tullio Motterle (a cura di), Tradizione e innovazione nella pastoralità di Ferdinando Rodolfi Vescovo di Vicenza 1911-1943. Atti del Convegno di studio, Vicenza, 23-24 aprile 1993, Vicenza, Rumor, 1996, pp. 89-106.

Residori, Sonia, “Elisa Salerno e la sua utopia femminista: 'Bisognerebbe che io fossi nata nell’epoca futura ...”, Il Giornale di Vicenza, 27 maggio 2004, p. 33.

Rhodes, Anthony, The Power of Rome in the Twentieth Century, London, Sidgwick \& Jackson, 1983.

Riall, Lucy, The Italian Risorgimento: State, Society and National Unification, London, Routledge, 1994.

, "Progress and Compromise in Liberal Italy", The Historical Journal, v. 38, no. 1, Mar. 1995, pp. 205-213.

Rimoldi, Antonio, “Ferrari, Andrea Carlo”, in Francesco Traniello e Giorgio Campanini (a cura di), Dizionario storico del movimento cattolico in Italia, II: I protagonisti, Torino, Marietti, 1982, pp. 196-201.

Rocca, Giancarlo, Donne religiose. Contributo a una storia della condizione femminile in Italia nei secoli XIX-XX, Roma, Paoline, 1992.

Romanato, Gianpaolo, ‘Un nuovo modello di religiosità femminile nell’Ottocento: la suora”, in Anna Maria Calapaj Burlini e Saveria Chemotti (a cura di), Donne in-fedeli. Temi, modelli, interpretazioni della religiosità femminile, Padova, Il Poligrafo, 2005, pp. 135-149.

Romanelli, Raffaele, L’Italia liberale 1861-1900, Bologna, Il Mulino, 1990.

Roncalli, Angelo, Il cardinale Cesare Baronio, Roma, Edizioni di Storia e Letteratura, 1961.

In memoria di mons. Giacomo Maria Radini Tedeschi vescovo di Bergamo, 3. edizione, Roma, Edizioni di Storia e Letteratura, 1963.

Ruether, Rosemary Radford, "Misogynism and Virginal Feminism in the Fathers of the Church”, in Rosemary Radford Ruether (ed.), Religion and Sexism: Images of Women 
in the Jewish and Christian Traditions, New York, Simon and Schuster, 1974, pp. 150183.

(ed.), Religion and Sexism: Images of Women in the Jewish and Christian Traditions, New York, Simon and Schuster, 1974.

Rumi, Giorgio, “Dalle carte di Armida Barelli. L’'immensa opera' di una donna ambrosiana”, in Armida Barelli nella società italiana, Milano, Edizioni O.R., 1983, pp. 21-53.

Sale, Giovanni, "Romolo Murri tra impegno politico e protesta religiosa”, La Civiltà cattolica, v. 151, pt. 3, July 2000, pp. 34-44.

Salerno, Elisa, Per la riabilitazione della donna/Donne e Chiesa, Vicenza, Centro documenazione e studi “Presenza Donna”, 2006.

Sarogni, Emilia, La donna italiana 1861-2000. Il lungo cammino verso i diritti, 2. edizione, Milano, NET, 2004.

Sasso, G., “Gentile, Giovanni”, in Dizionario biografico degli italiani, v. 53, Roma, Enciclopedia italiana, 1999, pp. 196-212.

Scaraffia, Lucetta, “'Christianity Has Liberated Her and Placed Her alongside Man in the Family’: From 1850 to 1988 (Mulieris Dignitatem)”, in Lucetta Scaraffia and Gabriella Zarri (eds.), Women and Faith, Cambridge, Mass., Harvard University Press, 1999, pp. 249-280.

, "Dalle fondatrici ottocentesche all'ideologia del 'gender'”, in Luigi Mezzadri e Maurizio Tagliaferri (a cura di), Le donne nella Chiesa e in Italia, Cinisello Balsamo (Milano), San Paolo, 2007, pp. 325-348.

, "Il femminismo fra progetti politici e movimenti religiosi”, in Lucetta Scaraffia e Anna Maria Isastia, Donne ottimiste. Femminismo e associazioni borghesi nell'Otto e Novecento, Bologna, Il Mulino, 2002, pp. 19-40.

"Il femminismo teosofico", in Lucetta Scaraffia e Anna Maria Isastia, Donne ottimiste. Femminismo e associazioni borghesi nell'Otto e Novecento, Bologna, Il Mulino, 2002, pp. 41-76.

, "Introduzione”, in Lucetta Scaraffia e Anna Maria Isastia, Donne ottimiste. Femminismo e associazioni borghesi nell'Otto e Novecento, Bologna, Il Mulino, 2002, pp. 7-16.

"Teosofe, femministe e moderniste in Italia”, in Lucetta Scaraffia e Anna Maria Isastia, Donne ottimiste. Femminismo e associazioni borghesi nell'Otto e Novecento, Bologna, Il Mulino, 2002, pp. 77-124.

Scaraffia, Lucetta e Isastia, Anna Maria, Donne ottimiste. Femminismo e associazioni borghesi nell'Otto e Novecento, Bologna, Il Mulino, 2002. 
Scaraffia, Lucetta and Zarri, Gabriella (eds.), Women and Faith: Catholic Religious Life in Italy from Late Antiquity to the Present, Cambridge, Mass., Harvard University Press, 1999.

Seton-Watson, Christopher, Italy from Liberalism to Fascism: 1870-1925, London, Methuen, 1967.

Seveso, Gabriella, "Movimenti femministi e partecipazione politica”, in Barbara Malpelli e Gabriella Seveso (a cura di), Una storia imprevista. Femminismi del Novecento ed educazione, Milano, Guerini Studio, 2003, pp. 40-51.

“Si è spenta Adelaide Coari”, Cronaca di Milano, 18 febbraio 1966.

Sledziewski, Elisabeth G., “The French Revolution as the Turning Point”, in Geneviève Fraisse and Michelle Perrot (eds.), A History of Women in the West, IV. Emerging Feminism from Revolution to World War, Cambridge, Mass., The Belknap Press of Harvard University Press, 1993, pp. 33-47.

Soldani, Simonetta (a cura di), L'educazione delle donne. Scuole e modelli di vita femminile nell'Italia dell'Ottocento, 2. edizione, Milano, Franco Angeli, 1991.

Spiller, Sergio, “La condizione materiale della donna al lavoro”, in La donna e il lavoro. Ieri e oggi, Vicenza, Cooperativa tipografica degli operai, 2009, pp. 34-69.

Spinosa, Antonio, Italiane: il lato segreto del Risorgimento, Milano, Arnoldo Mondadori, 1994.

Sticco, Maria, Una donna fra due secoli: Armida Barelli, Milano, Vita e Pensiero, 1967.

Strappini, L, “Fogazzaro, Antonio”, in Dizionario biografico degli italiani, v. 7, Roma, Enciclopedia italiana, 1997, pp. 420-429.

“Sulla strada difficile del femminismo cristiano”, La Voce dei Berici, 8 dicembre 1991, Chiesa locale/9.

Tanara, M.G., "Patrizi Gondi, Maddalena”, in Francesco Traniello e Giorgio Campanini (a cura di), Dizionario storico del movimento cattolico in Italia 1860-1980, III/2: Le figure rappresentative, Casale Monferrato, Marietti, 1984, pp. 633-634.

Tarozzi, Fiorenza, “Olympe de Gouges e la Dichiarazione dei diritti della donna”, in Gabriella Zarri, La memoria di lei. Storia delle donne, storia di genere, Torino, Società Editrice Internazionale, 1996, pp. 116-118.

Traniello, Francesco e Campanini, Giorgio (a cura di), Dizionario storico del movimento cattolico in Italia 1860-1980, II: I protagonisti, Torino, Marietti, 1982.

Dizionario storico del movimento cattolico in 1talia 1860-1980, III: Le figure rappresentative, Casale Monferrato, Marietti, 1984.

Turvasi, Francesco, “Le trattative per la 'Riconciliazione' di Romolo Murri in un documento di Giuseppe Fuschini”, in Ricerche per la storia religiosa di Roma, v. 1, Roma, Edizioni di Storia e Letteratura, 1977, pp. 301-312. 
Vaccari, Ilva, La donna nel ventennio fascista (1919-1943), Milano, Vangelista, 1978.

Vaccari, Michela, Il pensiero e l'azione di Elisa Salerno. Una lettura teologica, Roma, Pontifica università lateranense, 2007.

, "Prefazione”, in Elisa Salerno, Per la riabilitazione della donna/Donne e

Chiesa, Vicenza, Centro documentazione e studi “Presenza Donna”, 2006, pp. 5-13.

Valerio, Adriana, "Pazienza, vigilanza, ritiratezza. La questione femminile nei documenti ufficiali della Chiesa (1848-1914)”, Nuova dwf, Donnawomanfemme, v. 16, primavera 1981, pp. 60-79.

Valerio, Anthony, Anita Garibaldi, Westport, Conn., Praeger, 2001.

Vercesi, Ernesto, Le origini del movimento cattolico in Italia 1870-1922, Roma, Il Poligno, 1979. Ristampa dell'originale pubblicato dalla "Voce” a Firenze nel 1923.

Vian, Agostino, "Radini Tedeschi, Giacomo”, in Enciclopedia cattolica, v. X, Firenze, Sansoni, 1953, colonna 463.

Vicentini, Elisa, Una chiesa per le donne. Elisa Salerno e il femminismo cristiano, Napoli, M. D’Auria Editore, 1995.

, "Elisa Salerno e i problemi sociali”, in Centro documentazione e studi "Presenza Donna", Il femminismo cristiano di Elisa Salerno e le sue prospettive, Vicenza, 1988, pp. 79-96.

154.

“Elisa Salerno e l’’eresia antifemminista’”, Bailamme, n. 5-6, 1989, pp. 134-

Von Henneberg, Krystyna and Ascoli, Albert Russell, "Introduction: Nationalism and the Uses of Risorgimento Culture”, in Albert Russell Ascoli and Krystyna von Henneberg (eds.), Making and Remaking Italy, Oxford, Berg, 2001, pp. 1-23.

Willson, Perry (ed.), Gender, Family and Sexuality, New York, Palgrave Macmillan, 2004.

, "Introduction: Gender and the Private Sphere in Liberal and Fascist Italy”, in Perry Willson (ed.), Gender, Family and Sexuality, New York, Palgrave Macmillan, 2004, pp. 1-19.

Wood, Sharon, Italian Women’s Writing 1860-1994, London, Athlone, 1995.

Zampa, Sandra, “A.G. Roncalli ed Adelaide Coari: un amicizia spirituale”, in Giuseppe Alberigo (a cura di), Giovanni XXIII: transizione del Papato e della Chiesa, Roma, Borla, 1988, pp. 30-50.

"Fonti per la storia della chiesa in Italia: il fondo Adelaide Coari",

Cristianesimo nella storia, v. 4, 1983, pp. 173-203. 
, "Obbedienza e esperienza di fede. Il carteggio Coari-Radini Tedeschi nella

crisi del primo Novecento”, Cristianesimo nella storia, v. 6, 1985, pp. 299-380.

Zappi, Elda Gentili, If Eight Hours Seem Too Few: Mobilization of Women Workers in the Italian Rice Fields, Albany, N.Y., State University of New York, 1991.

Zarri, Gabriella, "Le donne nella Chiesa in Italia: rassegna storiografica”, in Luigi Mezzadri e Maurizio Tagliaferri (a cura di), Le donne nella Chiesa e in Italia, Cinisello Balsamo (Milano), San Paolo, pp. 13-34.

, “Francesca Cabrini, patrona degli emigranti”, in Gabriella Zarri, La memoria

di lei. Storia delle donne, storia di genere, Torino, Società Editrice Internazionale, 1996, pp. 85-88.

, La memoria di lei. Storia delle donne, storia di genere, Torino, Società

Editrice Internazionale, 1996.

\section{UNPUBLISHED THESES}

Bertuzzo, Maria Luigia, La donna e la Chiesa: appunti per una biografia di Elisa Salerno, Tesi di laurea, Roma, “Maria SS. Assunta”, 1986-87.

Cengia, Elisa, Elisa Salerno. La paladina della donna, Dissertazione, Vicenza, Diocesi di Vicenza, Istituto di Scienze Religiose, 2002/03.

Cisco, Monica, Elisa Salerno e “Un piccolo mondo cattolico”, Tesi di laurea, Padova, Università degli studi di Padova, 1975-76.

Periotto, Elisabetta Rita, La personalità della donna nel pensiero di Elisa Salerno, Laurea in pedagogia, Padova, Università degli studi di Padova, 1975-76.

Vaccari, Michela, Il pensiero e l'azione di Elisa Salerno. Una lettura teologica, Tesi di dottorato, Roma, Pontificia università lateranense, 2007.

Vertemati, Maria Assunta, "Pensiero e azione" e il movimento femminile cristiano a Milano (1900-1908), Tesi di laurea, Milano, Università degli studi di Milano, Facoltà di lettere e filosofia, 1977-1978. 